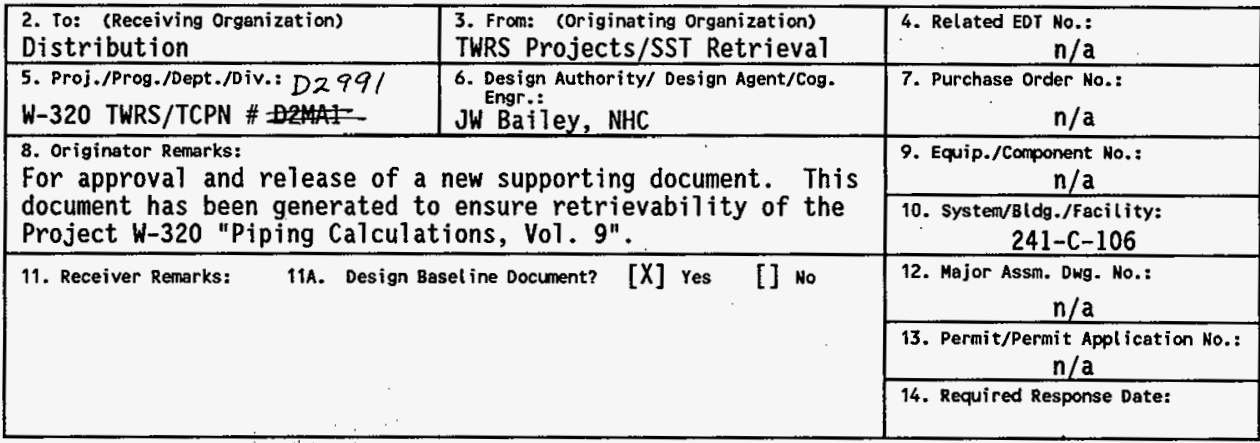

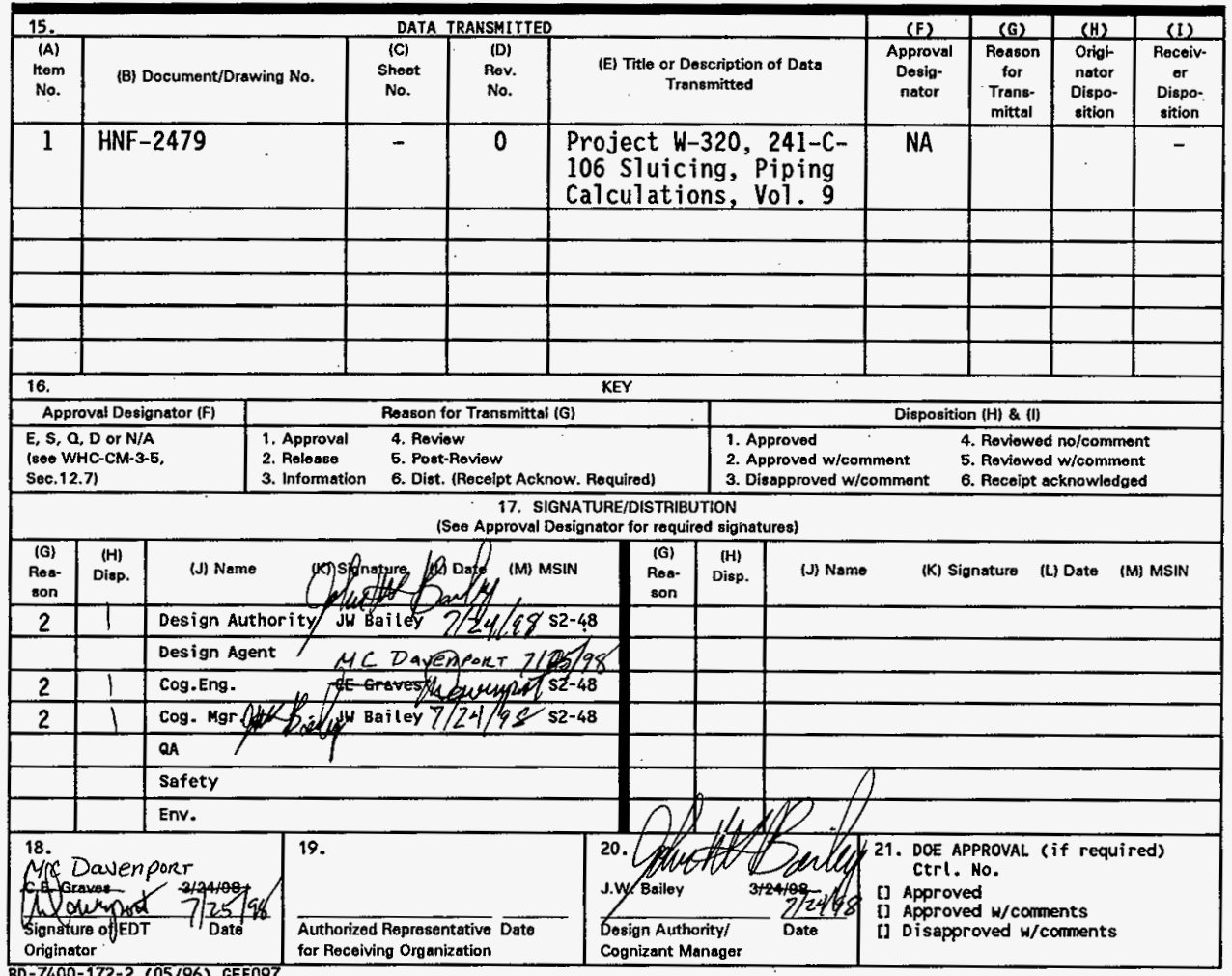

BD-7400-172-2 (05/96) GEF097 


\section{Project W-320, 241-C-106 Sluicing Piping Calculations, Vol. 9}

John W. Bailey

Numatec Hanford Co., Richland, WA 99352

U.S. Department of Energy Contract DE-AC09-96RL13200

EDT/ECN: 622237

UC: $\mathbf{5 0 6}$

Org Code: $8 C 452$

Charge Code: D2991/HANA0600

B\&R Code: EW3130010

Total Pages: 347

Key Words: W-320, Sluicing, Tank 241-C-106, Tank 241-AY-102, WRSS, calculations, piping.

Abstract: This supporting document has been prepared to make the FDNW calculations for Project $W-320$, readily retrievable.

Product cut sheets in this document have been reviewed and are not Copyrighted.

TRADEMARK DISCLAIMER. Reference herein to any specific comercial product, process, or service by trade name, trademark, manufacturer, or otherwise, does not necessarily constitute or imply its endorsement, recommendation, or favoring by the United States Government or any agency thereof or its contractors or subcontractors.

Printed in the United States of America. To obtain copies of this document, contact: Document Control Services, P.0. Box 950, Mailstop H6-08, Richland WA 99352, Phone (509) 372-2420; fax (509) 376-4989.
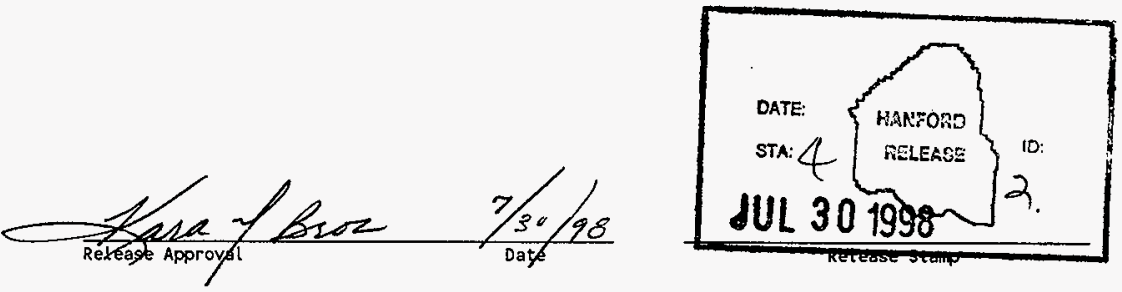

\section{Approved for Public Release}


HNF-2479, Rev. 0

\title{
Project W-320, 241-C-106 Sluicing Piping Calculations, Vol. 9
}

\author{
TABLE OF CONTENTS
}

Calc. No. W320-27-049

W320-27-050

W320-27-051

W320-27-053

W320-27-054

W320-27-055
Title

Sizing of HVAC Duct Flushing System Portabie Exhauster Installation Analys is B-i

Jumper Flushing Supply Head Analysis

New Supernate Jumper Analysis

System Curves for Portable Exhauster Installation

Nozzle Plate \& Encasement Plate Analysis F-i
Page

$A-i$

$c-i$

D- $\mathbf{i}$

$E-\mathbf{i}$ 
HNF-2479, Rev. 0

W320-27-049

Sizing of HVAC Duct Flushing System

A-i 


\section{G FLUOR DANIEL NORTHWEST INC.}

This sheet shows the status and description of the attached Design Analysis sheets.

Discipline: Mechanical Wo/Job No.: W-320

Project No. \& Name: W-320, WASTE RETRIEVAL for TANK 241-C-106.

Calculation Item: Sizing of HVAC Duct Flushing System

These calculations apply to:

Dwg. No.: H-2-818470 Sh. 1, and 2.

Rev. No. 1

Dwg. No.: H-2-818470 Sh. 5

Rev. No. 0

Other (Study, CDR):N/A

Rev. No. N/A

The status of these calculations is:

[] Preliminary Caiculations

[X] Final Calculations

[] Check Calculations (On Calculation Dated)

1] Void Calculation (Reason Voided)

Incorporated in Final Drawings?

This calculation verified by independent "check" calculations?

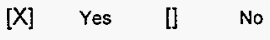

Original and Revised Calculation Approvals:

\begin{tabular}{|c|c|c|c|}
\hline 1. & $\begin{array}{c}\text { Rev. } 0 \\
\text { Signature/Date }\end{array}$ & $\begin{array}{c}\text { Rev. } 1 \\
\text { Signature/Date }\end{array}$ & $\begin{array}{c}\text { Rev. } 2 \\
\text { Signature/Date }\end{array}$ \\
\hline Oríginator & & . & \\
\hline Checked by & & & \\
\hline Approved by & & & \\
\hline $\begin{array}{l}\text { Checked Against } \\
\text { Approved Vendor Data }\end{array}$ & & & \\
\hline
\end{tabular}

\section{INDEX}

Design Analysis Page No.

Description

\begin{tabular}{|c|l|}
\hline I, ii & Calculation Identification and Index \\
\hline iii & Calculation Cross Index \\
\hline 1 & Objectives, Design Inputs and Calculation \\
\hline 2 & Conclusion \\
\hline Appendix A & Technical Data \\
\hline
\end{tabular}




\begin{tabular}{|c|c|c|}
\hline \multirow{2}{*}{$\begin{array}{l}\text { VIEL } \\
N C .\end{array}$} & \multirow{2}{*}{$\begin{array}{l}\text { CALCULATION IDENTIFICATION AND } \\
\text { INDEX } \\
\text { Continuation Sheet }\end{array}$} & Page ii of iii \\
\hline & & Date \\
\hline \multicolumn{2}{|c|}{ Wo/Job No. W-320 } & Calculation No. W-320-27-049 \\
\hline $\begin{array}{c}\text { Rev. } 0 \\
\text { Signature/Date }\end{array}$ & $\begin{array}{c}\text { Rev. } 1 \\
\text { Signature/Date }\end{array}$ & $\begin{array}{c}\text { Rev. } 2 \\
\text { Signature/Date }\end{array}$ \\
\hline \multicolumn{3}{|c|}{ INDEX } \\
\hline \multicolumn{3}{|c|}{ Description } \\
\hline
\end{tabular}

\section{REVISION}

Description 


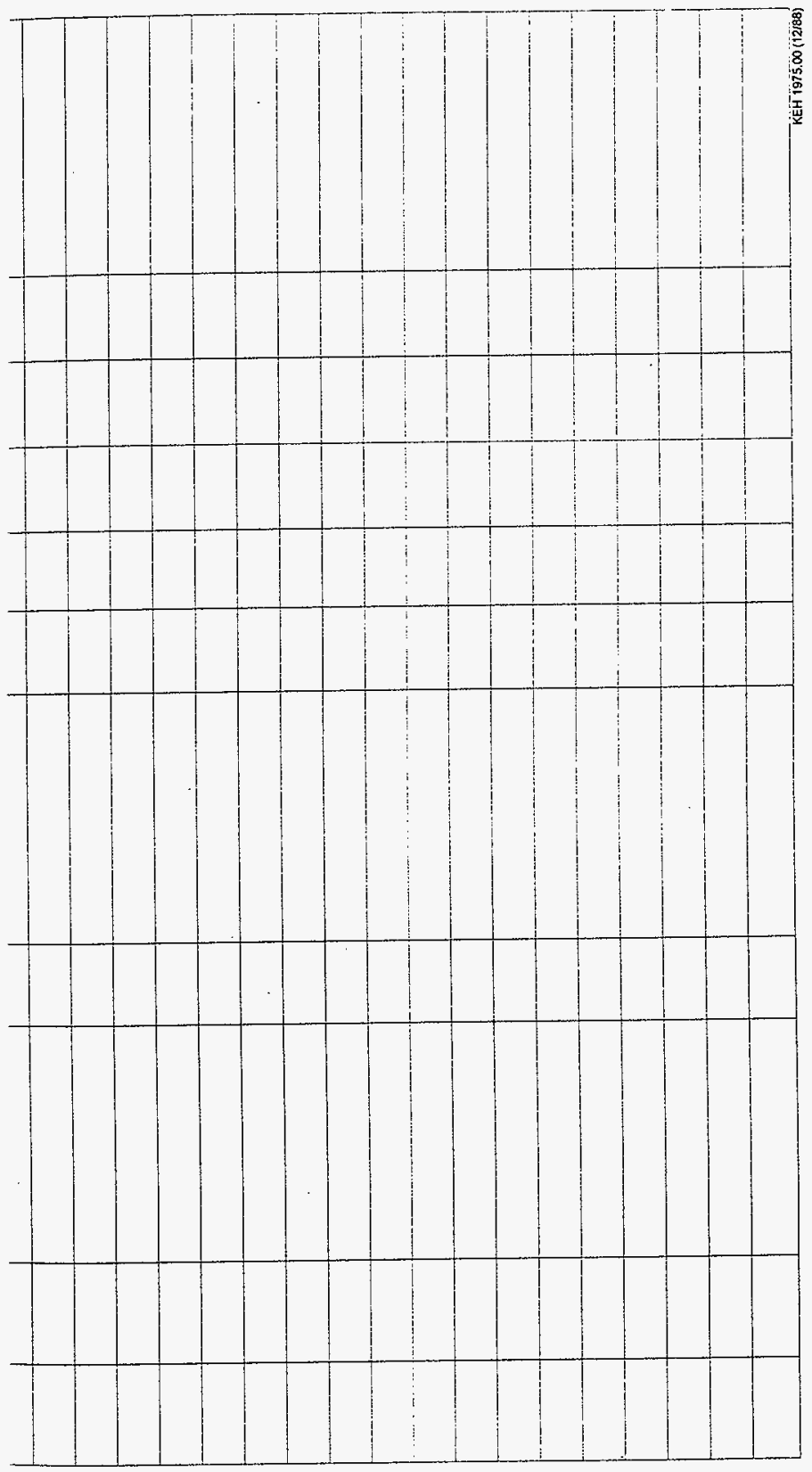


ว.

\section{DESIGN ANALYSIS}

Revision: 0

Page No.: 1 of 2

Wo/Job No.: W-320

poration

-RIEVAL For TANK 241-C-106.

Flushing System

ss Building
Date: $11 / 04 / 97$

Checked: $11 / 6 / 97$

Revised:

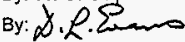

By:
By: N. J. Juplo

$f$ this calculation is to determine the size and capacity of the HVAC duct (10"VT-1010ystem.

TS:

Jocument, Project W-320, Tank 241-C-106 Sluicing, Project Rebaselining Change Scope, HNF-SD-W320-DB-001, Rev. 0.

vS

sed for the calculation of the fiushing system is only based on the full flushing coverage face of the HVAC duct. The effectiveness and frequency of flushing to remove ds that accumulate on the interior walls of the duct (thus reducing radiological dose $\geqslant$ outside surface of the duct) will be determined by field measurements, radiological rm by farm HPs.

\section{: ANALYSIS}

stion.

hing system raw water supply pressure is 60 psig.

size $=10^{\prime \prime}$

Ref. 1.

shing supply line = 1" (1" RAW-601-M5) located in the Process Bldg. Ref. 2.

Es

J-320 Drawing \#H-2-818470, Sh, 1, Rev. 1.

1-320 Drawing \# H-2-818481, Sh. 2, Rev. 1.

chnical Paper \# 410, Flow of Fluids.

jpray Nozzles, Systems and Accessories.

N:

the reasonable liquid flow rate for the existing 1 " supply line:

ne Technical Paper \# 410, Flow of Fluids:

Ref. 3, page B-14. 


\section{DESIGN ANALYSIS}

Page No:: 2 of 2

Numatec Hanford Corporation

zt: W-320, WASTE RETRIEVAL For TANK 241-C-106.

Sizing of HVAC Duct Flushing System

on: C-Tank Farm/Process Building
Wo/Job No: W-320

Date: $11 / 04 / 97$

Checked: "1/6/97

Revised:
By: N. J. Juplo

By:D. $\mathcal{L}$ Enam

By:

A 1" diameter pipe with a reasonable velocity of $5.57 \mathrm{ft} / \mathrm{sec}$. (pressure drop of 6.36 $\mathrm{psi} / 100 \mathrm{ft}$ of pipe), has a discharge of $15 \mathrm{gpm}$.

From Lechler Spray Nozzles, Systems and Accessories:

A $1 / 4$ " spray nozzle, full cone, 90 degree spray at 60 psi pressure will deliver $0.64 \mathrm{gpm}$ (max. $0.8 \mathrm{gpm}$ at $100 \mathrm{psi}$ pressure).

By inspection, the $1 / 4$ " spray nozzle at 60 psi pressure will effectively cover the inner surface of the $10^{\prime \prime}$ duct up to a distance of at least 4 feet from the nozzle.

Per the HVAC duct Drawing (Ref. 1), 8 nozzles at approx. 2'-8" centers will effectively flush the HVAC duct (conservative overlapping spray). With 8 spray nozzles, the maximum total flushing flow requirement of the nozzles is $6.4 \mathrm{gpm}$ (at $100 \mathrm{psi}$ pressure), which is well within the raw water supply availability of $15 \mathrm{gpm}$.

The flush system header is a $1 / 2$ " diameter pipe and is only approximately 20 feet long. At 6.4 maximum gpm the fluid velocity is $6.75 \mathrm{ft} / \mathrm{sec}$. (reasonable) and the pressure drop is about $17 \mathrm{psi} / 100 \mathrm{ft}$. of pipe. The total pressure drop of the $1 / 2^{\prime \prime}$ pipe should not be a significant factor to affect the flushing system, to fully cover the inner surface of the HVAC duct to be flushed.

\subsection{CONCLUSIONS:}

Based on the above analysis, a flushing system consisting of eight (8)1/4" spray nozzles with a maximum flow rate of $0.8 \mathrm{gpm}$ each at $100 \mathrm{psi}$ pressure, will meet the flushing requirement for the $10^{\text {" }} \mathrm{HVAC}$ duct 10 "VT-1010-M5. In addition, an existing 1 " line located in the Process Building can be utilized and can handle the flushing requirement. 


\section{Appendix A}




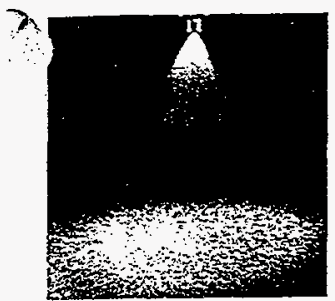

Full Cone Wall Mount Nozzles Lechler axial wall mount full corie nozzles mirror our popular 460 series and ofier the same outstanding performance. All the advantages of this design are available in the wall mount
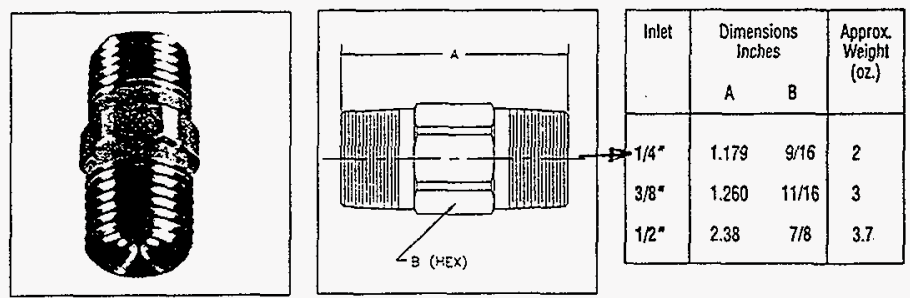

configuration which allows mounting through the side of a pipe, vessel or container.

This configuration uses a male NPT thread on both ends of the nozzle, both the same size.

$\therefore-$ Product Codes tor Ordering

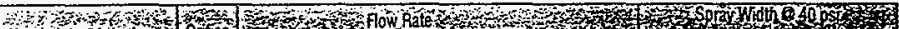
$\therefore$ Nozle Type $\cdots$ Material Code.

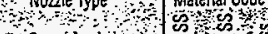
Spray Angle

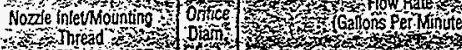
Male NPT X Male WPT $60^{\circ} \div 10 \% 16 \div 30$

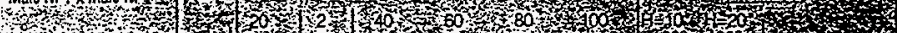

480.404

480.444

480.484

D.

480.504

480.524

480.604

480.644

480.684

480.704

480.724

480.764

480.784

480.804

480.844

490.884

480.88 $90^{\circ}$

480.406

480.446

480.486

480.506

480.526

480.566

480.606

480.646

480.686

480.706

480.726

480.746

480.766

480.786

480.806

in

480.846

480.886

480.926

480.965

480.006

\begin{tabular}{lll|l|l|l|l|llll}
0 & 0 & 0 & $B C / B C$ & .051 & 0.23 & 1.00 & 0.30 & 0.35 & 0.40 & 0.43 \\
0 & 0 & 0 & $B C B C$ & .053 & 0.28 & 1.25 & 0.38 & 0.44 & 0.50 & 0.54 \\
0 & 0 & 0 & BC/BC & .057 & 0.36 & 1.60 & 0.48 & 0.57 & 0.63 & 0.69 \\
\hline
\end{tabular}

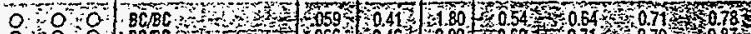

000

$B C B C$.

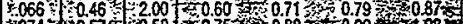

$\begin{array}{lll}0 & 0 & 0 \\ 0 & 0 & 0 \\ 0 & 0 & 0\end{array}$

$B C / B C$

$\begin{array}{llll}0 & 0 & B E / B E\end{array}$

$B E / B E$

$074=57$

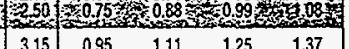

\begin{tabular}{l|l}
.084 & 0.72 \\
.094 & 0.91 \\
.100 & 1.14
\end{tabular}

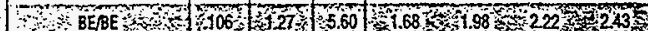

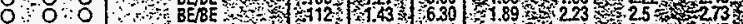

$800 \div 0$

$\because \mathrm{BEBE}, \mathrm{YUZ}$

(11) 6 - 182

3.00

$B E / B$

\begin{tabular}{l|l|l|} 
& .126 & 2.05 \\
.133 & 2.28 \\
.149 & 2.85
\end{tabular}

\begin{tabular}{l|l}
9.00 & 2.70 \\
0.0 & 3.00 \\
\hline
\end{tabular}

\begin{tabular}{l|l}
10.0 & 3.00 \\
12.5 & 3.75
\end{tabular}

$75 \quad 4.42$

$\begin{array}{lll}3.18 & 3.57 & 3.90\end{array}$

$\begin{array}{lll}3.53 & 3.96 & 4.33 \\ 4.42 & 4.55 & 5.42\end{array}$

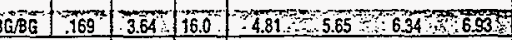

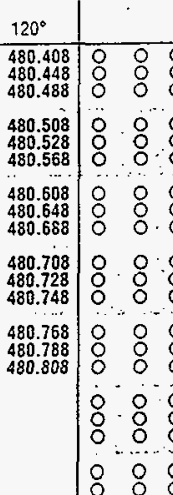

( BGB

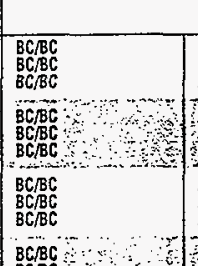

\begin{tabular}{lll|llll}
.047 & 0.23 & 1.00 & 0.30 & 0.35 & 0.40 & 0.43
\end{tabular}

\begin{tabular}{l|l|l|l}
.047 & 0.23 & 1.00 & 0.30 \\
.051 & 0.28 & 1.25 & 0.30 \\
053 & 0.38 & 1.60 & 0.4
\end{tabular}

0570.4101 .80 0.54 0.640 .7100 .78

$=059 \quad 0.46,2.00 \quad 0.60$ \% $0.71 \div 0.79 \times 0.87$

$0060.57 \times 2.50$

0740.72

\begin{tabular}{l|l|l|l}
.074 & 0.72 & 3.15 & 0.95
\end{tabular}

.094

1.14

4.00
5.00

0.75
0.95
1.20
1.50

$1.11 \quad 1.25$

$1.11 \quad 1.25$

1.77

1.98

1.73

100 1.27 $5.60168-1.98,2.22+2.43$

$B C / B C$

$B E / B E$

$106^{2} 1.4$

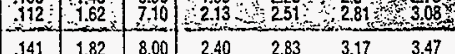

\begin{tabular}{l|l|l}
$B E / B E$ & .141 & 1.8 \\
$B E / B E$ & .145 & 2.05
\end{tabular}

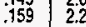

\begin{tabular}{l|lll}
8.00 & 2.40 & 2.83 & 3.17 \\
9.00 & 2.70 & 3.18 & 3.57
\end{tabular}

10.0

$B E / B E-O H$

563

$\mathrm{G} / \mathrm{BG}$

$G / B G$

204.4 .55

12.5
16.0
20.0

3.00

3.53

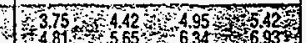

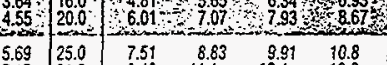

- Nozzles are manufactured to spray performance, not oritice diameter.

Ordering Information:

Type + Material Code + Connector No. = Order No.

480. $608 \quad 30$
480. 608. 30. BC. BC
Material Code:

16303 SS

$17316 \mathrm{SS}$

30 Brass 


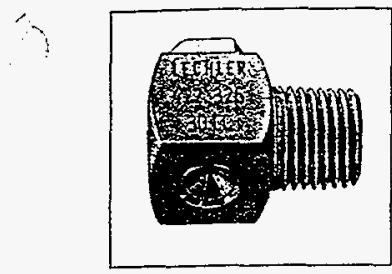

Vaneless Tangential Full Cone Nozzles

Lechler's palented tangential full cone nozzles use no internal inserts or vanes. The unique design generates a precise, uniform spray distribution, for spray performance and reliability that's superior to conventional insert-dependent tangential full cone nozzles. Spray angles are extremely stable, regardless of pressure fluctuation.
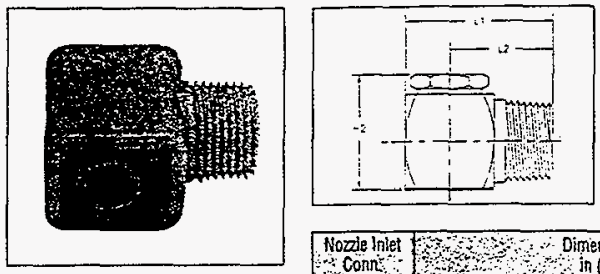

HNF-2479, Rev. 0 Page A-8
Typical Applications: Washing and cleaning Cooling of gas or solid product Surlace spraying improvement of chemical reactions

\begin{tabular}{|c|c|c|c|c|}
\hline 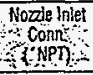 & $\begin{array}{l}0,1 \\
4,41\end{array}$ & $\begin{array}{l}\therefore \text { Dimiensions } \\
\sin (\text { in }) \\
;-12\end{array}$ & 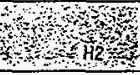 & 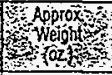 \\
\hline $1 / 4$ & 1.1 & .79 & 81 & 1.5 \\
\hline $\begin{array}{l}3 / 8 \\
1 / 2 \\
3 / 4\end{array}$ & $\begin{array}{l}1.42 \\
1.91 \\
2.30 \\
2.30\end{array}$ & $\begin{array}{r}.98 \\
1.32 \\
1.52\end{array}$ & $\begin{array}{l}1.04 \\
1.52 \\
2.24\end{array}$ & $\begin{array}{l}3.75 \\
8.87 \\
-\end{array}$ \\
\hline$\frac{1}{7 / 4^{\circ}}$ & $\frac{3.00}{3.90}$ & $\frac{1.21}{.79}$ & $\frac{2.60}{.63}$ & \\
\hline $\begin{array}{l}3 / 8^{\circ} \\
1 / 2^{\circ}\end{array}$ & $\begin{array}{l}1.42 \\
1.95\end{array}$ & $\begin{array}{r}98 \\
1.32\end{array}$ & $\begin{array}{r}.90 \\
1.50\end{array}$ & $\bar{z}$ \\
\hline
\end{tabular}

The following sizes are available in molded PVDF:

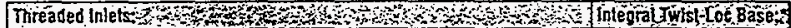

\begin{tabular}{|c|c|c|c|}
\hline $\begin{array}{l}422.406 .5 E . B C \\
422.408 .5 E . B C \\
422.448 .5 E . B C \\
422.486 .5 E . B C \\
422.488 .5 E . B C \\
422.566 .5 E . B C \\
422.568 .5 E . B C\end{array}$ & $\begin{array}{l}422.606 .5 \mathrm{E} . \mathrm{BE} \\
422.646 .5 \mathrm{E} . \mathrm{BE} \\
422.726 .5 \mathrm{E} . \mathrm{BE} \\
422.806 .5 \mathrm{E} . \mathrm{BE} \\
422.846 .5 \mathrm{BE} \\
422.856 .5 \mathrm{BE} \\
422.886 .5 \mathrm{BE} . \mathrm{BE}\end{array}$ & $\begin{array}{l}422.888 .5 E . B E \\
422.896 .5 E . B E \\
422.926 .5 E . B G \\
422.966 .5 E . B G \\
422.968 .5 E . B G \\
422.006 .5 E . B G \\
422.128 .5 E .8 K\end{array}$ & $\begin{array}{l}\text { 422.406.5E.KB } \\
422.528 .5 E . K B \\
422.606 .5 E . K B \\
422.608 .5 E . K B \\
\text { - See page 67. }\end{array}$ \\
\hline
\end{tabular}

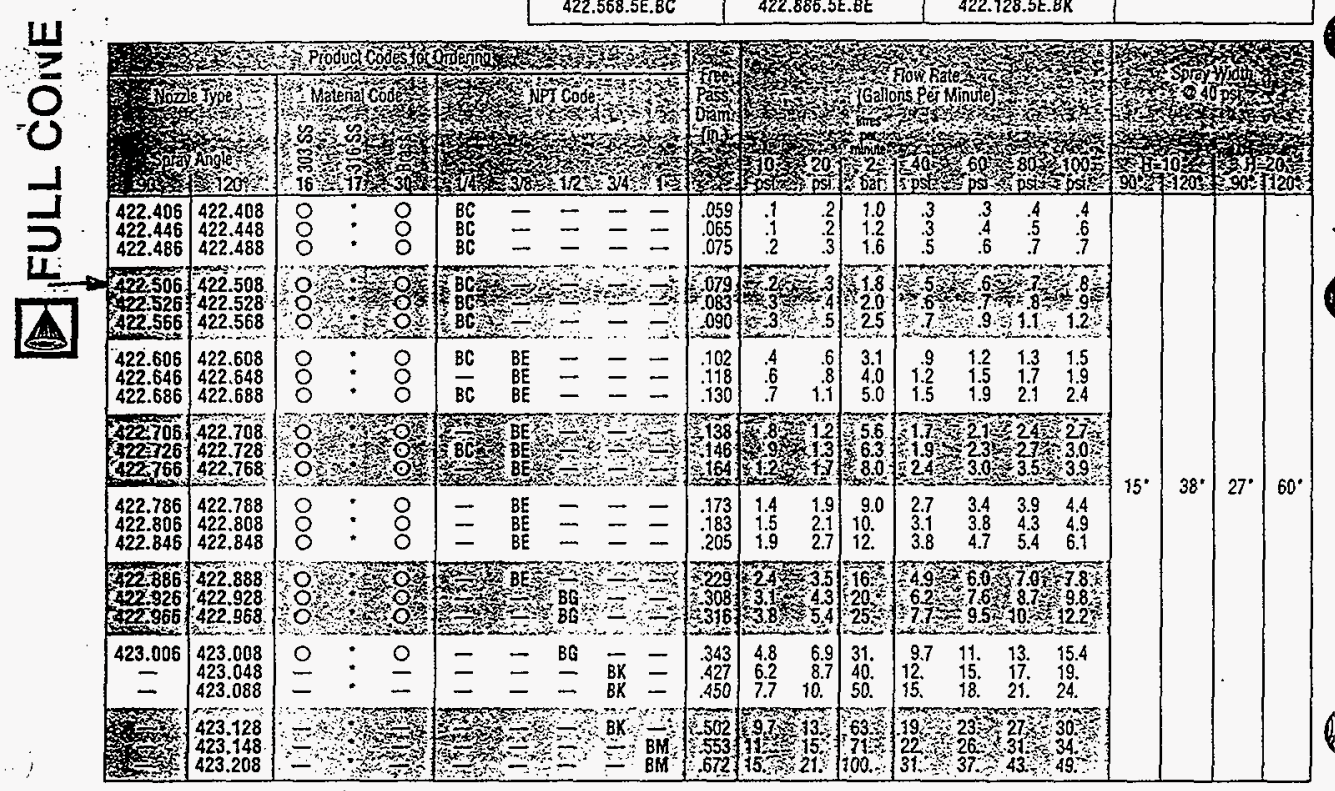

- Available on quote.

- Nozzles are manufactured 10 spray performance, not free passage diameter.

\section{Ordering Information:}

Type + Material Code + NPT Code = Order No.

422. $406 \quad 16 \quad$ BC $422.406 .16 \mathrm{BC}$
Material Code:

16303 SS 30 Brass

17316 SS 5E PVDF 
HNF-2479, Rev. 0

W320-27-050

Portable Exhauster Installation Anatysis

B-i 
This sheet shows the status and description of the attached Design Analysis sheets.

Discipline: (27) Piping Wo/Job No.: ER4319N-320

Calculation No: W320-27-050

Project No. \& Name: W-320 Tank 241-C-106 Waste Retrieval

Calculation Item: Portable Exhauster Installation Analysis

These calculations apply to:

Dwg. No.: See References

Rev. No.

Dwg. No.:

Rev. No.

Other (Study, CDR):

Rev. No.

The status of these calculations is:

[] Preliminary Calculations

[X] Final Calculations

[] Check Calculations (On Calculation Dated)

[] Void Calculation (Reason Voided)

Incorporated in Final Drawings?

This calculation verified by independent "check" calculations?

$\begin{array}{llll}{[X]} & \text { Yes } & {[]} & \text { No } \\ \text { [] } & \text { Yes } & {[X]} & \text { No }\end{array}$

Original and Revised Calculation Approvals:

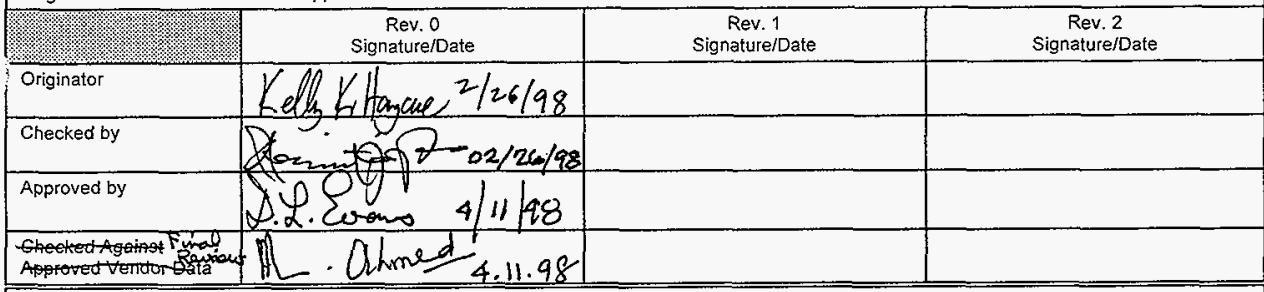

INDEX

Design Analysis Page No.

Description

\begin{tabular}{|c|l|}
\hline $1-3$ & Objective, Design Inputs, References, Conclusions \\
\hline $4-26$ & Calculations \\
\hline A-1 to A-21 & Appendix A - Autopipe Model "PEXCNDS" \\
\hline B-1 to B-36 & Appendix B - Reference Information \\
\hline
\end{tabular}




\begin{tabular}{|c|c|c|c|c|c|c|c|c|c|c|}
\hline \multicolumn{10}{|c|}{$\begin{array}{l}\text { CALCULATION CROSS INDEX (Typical) } \\
\text { Subject Calculation No:: W320-27-050 }\end{array}$} & \multirow{3}{*}{ Page ii of ili } \\
\hline \multirow[t]{2}{*}{\begin{tabular}{l|l} 
Subject \\
Caccication \\
Revilion \\
No.
\end{tabular}} & \multirow[t]{2}{*}{$\begin{array}{l}\text { Superceded } \\
\text { by } \\
\text { Calculation } \\
\text { No. }\end{array}$} & \multicolumn{2}{|c|}{ 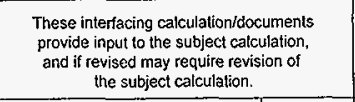 } & \multicolumn{2}{|c|}{$\begin{array}{l}\text { Results and conclusions of the subject } \\
\text { calculatation are used in these interfacing } \\
\text { calculations and/or documents }\end{array}$} & \multicolumn{2}{|c|}{$\begin{array}{l}\text { Does the outuput } \\
\text { interface calculationt } \\
\text { documents require } \\
\text { revision? }\end{array}$} & \multicolumn{2}{|c|}{$\begin{array}{l}\text { Has the outout } \\
\text { interfacecalculation' } \\
\text { documents been } \\
\text { revised? }\end{array}$} & \\
\hline & & Calculation/Document No. & $\begin{array}{c}\text { Revision } \\
\text { No. }\end{array}$ & Calculation/Document No. & $\begin{array}{c}\text { Revision } \\
\text { No. } \\
\end{array}$ & Yes & No & Yes & No & \\
\hline 0 & $\mathrm{NA}$ & H-2-818506, Sheet 1 & $0^{1}$ & NA & & & $r$ & & $\nu$ & $T$ \\
\hline & & H-2-818506, Sheet 2 & $\theta^{\prime}$ & & & & $r$ & & $\gamma$ & \\
\hline & & $\mathrm{H}-2-818506$, Sheet 3 & $\phi^{\prime}$ & & & & $\sim$ & & $\checkmark$ & Depians 719198 \\
\hline & & $\mathrm{H}-2-818507$, Sheet 1 & $\phi^{\prime}$ & & & & r & & N & $f$ \\
\hline & & $\mathrm{H}-2-818507$, Sheet 2 & $e^{1}$ & & & & $\sim$ & & $\sim$ & \\
\hline & & H-2-818507, Sheet 3 & $8^{\prime}$ & & & & $r$ & & $r$ & \\
\hline & & & & & & & & & & \\
\hline & & & & & & & & & & \\
\hline & & & & & & & & & & \\
\hline & & & & & & & & & & \\
\hline & & & & & & & & & & \\
\hline & & & & & & & & & & \\
\hline & & & & & & & & & & \\
\hline & & & & & & & & & & \\
\hline & & & & & & & & & & \\
\hline & & & & & & & & & & \\
\hline & & & & & & & & & & \\
\hline & & & & & & & & & & \\
\hline & & & & & & & & & & \\
\hline
\end{tabular}


Client: Numatec

Subject: Portable Exhauster Installation Analysis

Location: 241-C / 241-AY
WO/Job No.: ER4319N-320

Date: $12 / 15 / 97 \quad$ By: Kelly Hayase

Checked: $12 / 29 / 97$ By: N.S. JUPLO

Revised:

By:

\section{OBJECTIVE:}

The objective of this calculation is to analyze the portable exhauster installation. The analysis includes a pipe stress analysis of the condensate drain piping and miscellaneous structural analyses.

\section{DESIGN INPUTS:}

\section{CRITERIA AND SOURCE:}

1. HNF-SD-W320-FDC-001, Rev. 4

\section{GIVEN OR KNOWN DATA:}

1. The portable exhauster fan is rated for $1000 \mathrm{cfm}$ but will be operated at $500 \mathrm{cfm}$.

2. The portable exhauster installation is a temporary installation for emergency scenarios.

3. The portable exhauster installation is considered Safety Class. Loadings for the analysis of Safety Class systems will be based on Safety Class 1 loadings from Reference \#6.

\section{ASSUMPTIONS:}

1. The portable exhauster installation will not be qualified for the Safety Class 1 missile load. Spare parts (per customer decision) would provide the required redundancy if the flex duct or condensate drain failed as a result of a Safety Class 1 missile impact.

\section{METHODS TO BE USED:}

Autopipe (Ref. \#5) shall be used for the pipe stress analysis. All other analyses shall be performed using standard engineering principles and formulas.

\section{REFERENCES/SOURCES:}

1. ASME B31.3-1996, "Process Pipe" (Appx B-34 and B-35)

2. ASME N509-1989, "Nuclear Power Plant Air-Cleaning Units and Components" (Appx B-36)

3. ASME N510-1989, "Testing of Nuclear Air Treatment Systems"

4. Crane Technical Paper No. 410, "Flow of Fluids"

5. Autopipe Pipe Stress Analysis Program, Version 4.6, by Rebis.

6. FDNW Practice \# 134.215.1217, "Design Loads for Facilities" (Appx B-32 and B-33) 
Client: Numatec

Subject: Portable Exhauster Installation Analysis
WO/Job No: ER4319N-320

Date: $12 / 15 / 97$

Checked: $12 / 29 / 97$

Revised:
By: Kelly Hayase

By: N. J. SUPLO

By:

Location: 241-C / 241-AY

7. ANSI/ASCE 7-88, "Minimum Design Loads for Buildings and Other Structures" (Appx B-1 to B-5)

8. Unistrut General Engineering Catalog No. 12 (Appx B-6 to B-9)

9. Unistrut Seismic Bracing Systems, SBS-1 (Appx B-10)

10. Blodgett, "Design of Welded Structures"

11. SMACNA, "HVAC Systems Duct Design", 1981 ed. (Appx B-29)

12. Duravent Corporation, "Pressure Information for Blue Max and Max-Flyte Flexible Duct/Hose" (Appx B-30)

13. Randolph Austin Co., "Pumpheads and Capacities" (Appx B-11)

14. Duravent Corporation, "Specification Sheet for 8" ID 2PN" (Appx B-31)

15. HNF-SD-WM-DA-230, Rev. 0, "Design Calculations and Methods for 500 CFM Portable Exhauster, VTP-2212A" (Appx B-12)

16. Gaylord, "Structural Engineering Handbook", 4 th Ed. (Appx B-13 to B-17)

17. WRC Bulletin 107, "Local Stresses in Spherical and Cylindrical Shells due to External Loadings" (Appx B-18 to B-28)

18. $1000 \mathrm{CFM}$ Portable Exhauster Vendor Drawings (Farwell and Hendricks, Inc.)

96159-W03, Sheet 1, Rev. 5

96159-W04, Sheet 1, Rev. 4

19. Drawing Numbers:

H-2-818506, Sheets $1-3$, Rev. 0 H-2-818507, Sheets 1-3, Rev. 0
HVAC Alternate Emergency Ventilation Configuration HVAC Altemate Emergency Ventilation Configuration 


\section{(5) FLUOR DANIEL} NORTHWEST INC.

\section{DESIGN ANALYSIS}

Calc. No: W320-27-050

Revision: 0

Page No: 3 of 26
Client: Numatec

Subject: Portable Exhauster Installation Analysis

Location: 241-C / 241-AY
WO/Job No.: ER4319N-320

Date: $12 / 15 / 97$ By: Kelly Hayase

Checked: 1219197 By: H. S. JUPLo

Revised:

By:

\section{CONCLUSIONS:}

Based on the results of the analysis:

1. The portable exhauster installation satisfies the requirements of ASME B31.3 and ASME N509 for the design loads for Safety Class systems.

2. The portable exhauster installation will not be qualified for the Safety Class 1 missile load. Spare parts (per customer decision) would provide the required redundancy if the flex duct or condensate drain failed as a result of a Safety Class 1 missile impact. 
Client: Numatec

Subject: Portable Exhauster Installation Analysis
WO/Job No.: ER4319/W-320

Date: $12 / 15 / 97$

Checked: $12 / 17 / 97$

Revised:
By: Kelly Hayase

By: Lein cest

By:

\section{CALCULATIONS:}

Pipe Stress Analysis (For condensate drain lines)

Autopipe Analysis Input

Pipe: $\quad 1 / 2 "$ sch40S, A312-TP304L, with 1-1/2" thick fiberglass insulation (conservative, actually $1 "$ thk)

Fluid: water

Pressure: $\quad 20 \mathrm{psig}$ (maximum pressure for peristaltic pump on portable exhaust skid)

Min temperature: $\quad 40^{\circ} \mathrm{F}$ (assumed because the pipe is heat traced and insulated during winter)

Max temperature: $\quad 200^{\circ} \mathrm{F}$ (assumed)

Seismic input: Safety Class 1 Spectra, $0.2 \mathrm{~g}, 5 \%$ damping (Ref. \#6)

Wind input: $\quad 90 \mathrm{mph}$ wind speed

Importance factor - 1.0

Exposure category - $\mathrm{C}$

(Ref. \#6)

Gust response factor, $\mathrm{G}_{z}-1.32$ (Ref. \#7, Table 8)

Force coefficient, $C_{f}-0.8$ (Ref. \#7, Table 12)

Seismic displacement of portable exhauster (Ref. \#14)

For 500 CFM Portable Exhauster, $\Delta=0.28$ inch

Assume similar for 1000 CFM Portable Exhauster 
FLUOR DANIEL NORTHWEST, INC.

DESIGN ANALYSIS
Cali. No. $\omega 320 \cdot 27-050$

Revision 0

Page No. 5 of 26

Client Numatec

WO/Job No. ER $4319 /$ w. 320

\begin{tabular}{lll}
\hline Subject Portable Exhausted Installation Analysis & Date 12/15/97 & By Kelly Hayase \\
\hline Location $241-C / 241-A Y$ & Checked 12/12/97 By Kan Coff \\
\hline & Revised & By \\
\hline
\end{tabular}

Autopipe Model "PEXCNDS"

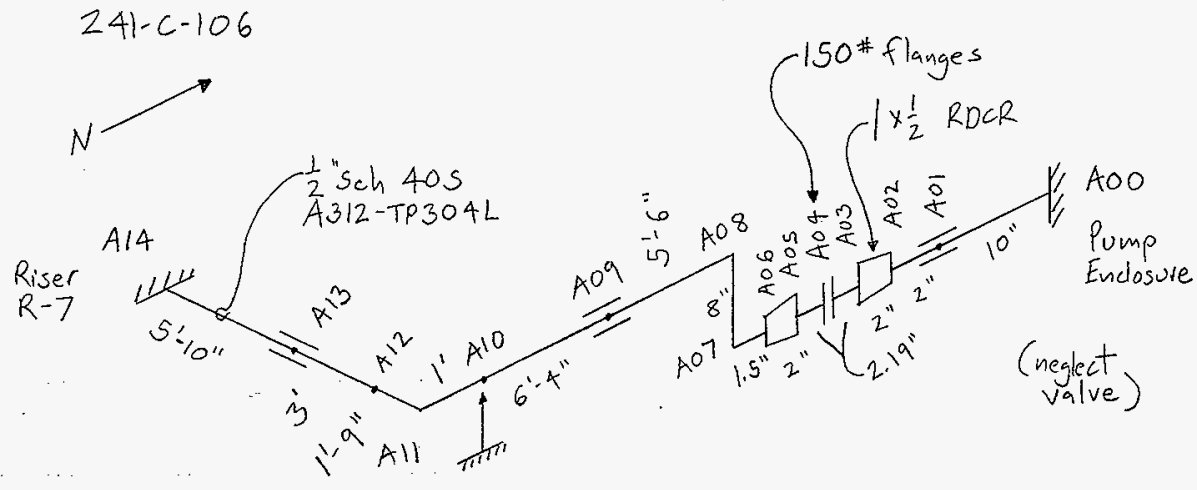

Riser

$15 \mathrm{~K} \quad \mathrm{~B} 12$
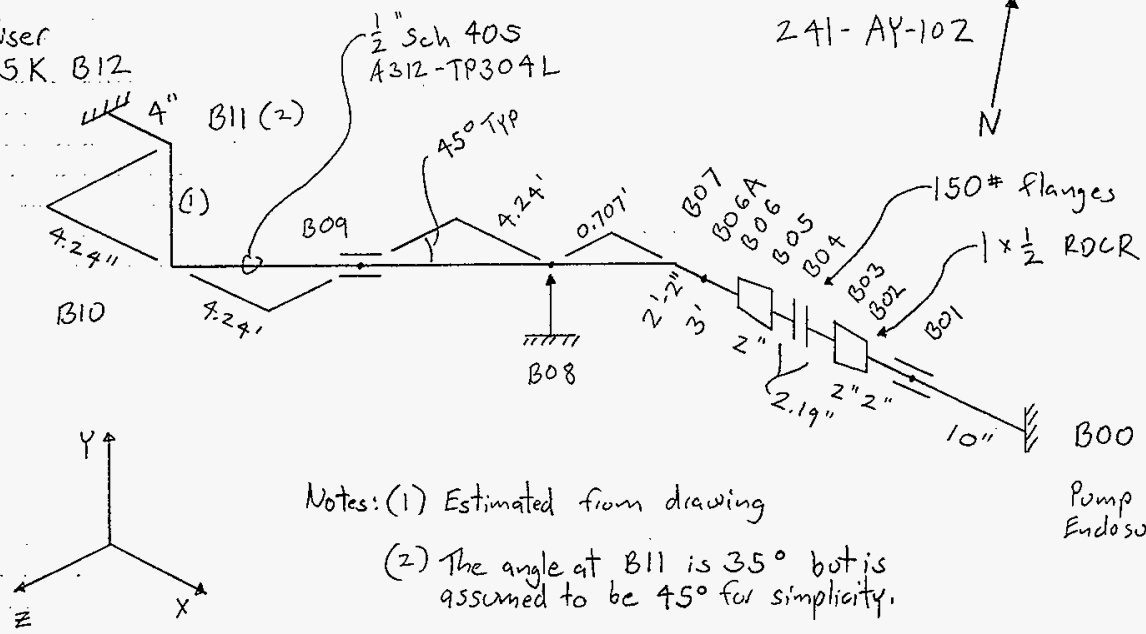

Notes: (1) Estimated from drawing

Pump

(2) The angle at BII is $35^{\circ}$ but is

Endospore assumed to be $45^{\circ}$ for simplicity.

HNF-2479, Rev. 0

Page B-7

$\mathrm{BD}-6002-142(12 / 9$ 
FLUOR DANIEL NORTHWEST, INC.

DESIGN ANALYSIS
Cali. No. $0,320-27 \cdot 050$

Revision $\mathrm{O}$

Page No. 6 of 26

Client Numatec

WO/JOb No. ER $4319 / \omega-320$

Subject Portable Exhausted Installation Analysis Date $12 / 15 / 97$ By Kelly Hayase

Location 241-C/241-AY

Revised

By

Hanging Flex Hose (For condensate drain line)

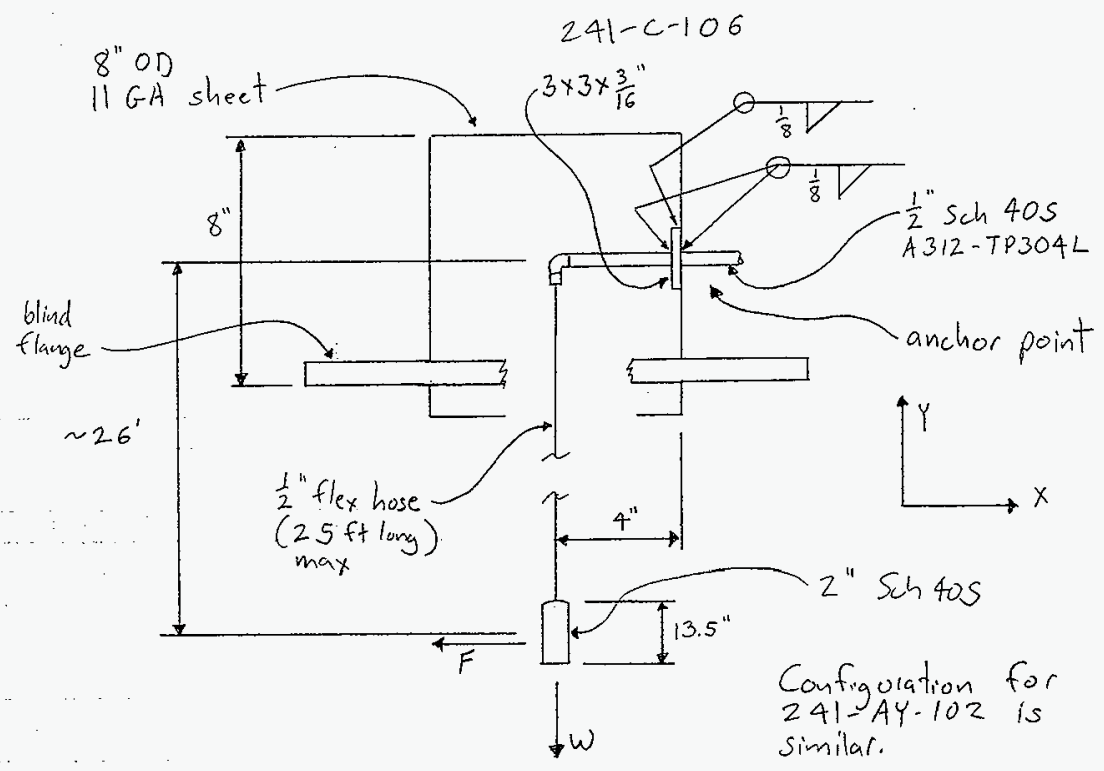

$\frac{1}{2} " \operatorname{sch} 405$

$$
\text { weight }=0.85 \mathrm{lb} / \mathrm{ft} \quad S=0.04069 \mathrm{in}^{3}
$$

$2 " \operatorname{sch} 405$

$$
\text { weight }=3.65^{\mathrm{lb}} / \mathrm{ft}
$$

Assume weight of $\frac{1}{2}$ "flex hose equals weight of $\frac{1}{2}$ "pipe.

Seismic acceleration $=0.42 \mathrm{~g} \quad(\max$ acceleration from SC -1 spectra, Ref. $\# 6$ )

HNF-2479, Rev. 0

Page B-8 
FLUOR DANIEL NORTHWEST, INC.

DESIGN ANALYSIS

Client Numatec

Subject Portable Exhausted Installation Analysis
Location $241-C / 241-A Y$
Hanging Flex Hose (continued)

$$
\begin{aligned}
& \omega=(25 \mathrm{ft})\left(0.85^{16 / \mathrm{ft}}\right)+(13.5 \mathrm{in})\left(\frac{\mathrm{ft}}{12 \mathrm{in}}\right)(3.65 \mathrm{k} / \mathrm{ft}) \\
& \omega=25.4 \mathrm{lb}
\end{aligned}
$$

Calc. No. $w 320-27-0.50$

Revision $\frac{0}{7}$ of 26

Page No. Date $12 / 15 / 97$ By Kelly Hay hs e

Revised

By

$$
26
$$

ing

Forces at anchor point (Due to flex hose)

$$
\begin{aligned}
& F_{x}=(0.42 \mathrm{~g})(25.4 \mathrm{lb})=11 \mathrm{lb} \\
& F_{y}=(1.42 \mathrm{~g})(25.4 \mathrm{lb})=36 \mathrm{lb} \\
& F_{z}=(0.42 \mathrm{~g})(25.4 \mathrm{~kb})=11 \mathrm{lb} \\
& M_{x}=0 \\
& M_{y}=(4 \mathrm{in})(11 \mathrm{lb})=44 \mathrm{in.16} \\
& M_{z}=(4 \mathrm{in})(36 \mathrm{lb})=144 \mathrm{in.16}
\end{aligned}
$$

No moment in flex hose

Bending Stress in $\frac{1}{2}$ " pipe

$$
\begin{aligned}
& \sigma=\frac{M}{S}=\frac{\sqrt{144^{2}+44^{2}}}{0.04069 \mathrm{in}^{3}} \\
& \sigma=3700 \text { psi }<16,700 \text { psi (B31.3 allowable) }
\end{aligned}
$$

HNF-2479, Rev. 0

Page B-9 
FLUOR DANIEL NORTHWEST, INC.

DESIGN ANALYSIS
Talc. No. $14320-27-0.50$

Revision No. $\frac{0}{8 \text { of } 26}$

Client Numatec WO/Job No. ER $4319 / w \cdot 320$

Subject Portable Exhausted Installation Analysis Date $12 / 15 / 97$ By Kelly Hanse

Location $241-C / 241-A Y$

Checked 12/19/97 BV N.2. Sup lo

Condensate drain line "anchor points" at risers

Analyze weld as a line (Ref. \pm 10 )

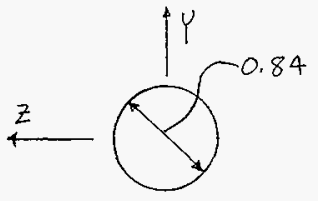

$$
\begin{aligned}
& A_{\omega}=\pi(0.84 \mathrm{in})=2.64 \mathrm{in} \\
& S_{\omega}=\frac{\pi(0.84 \mathrm{in})^{2}}{4}=0.55 \mathrm{in}^{2}
\end{aligned}
$$

Force on weld from Autopipe Node Point $B 12$

$$
\begin{aligned}
& F_{x}=3616 . \quad M_{x}=0 \\
& F_{Y}=6 \mathrm{lb} \quad M_{Y}=65 \mathrm{ft} \cdot 1 \mathrm{~b}=780 \mathrm{im} .16 \\
& F_{z}=6716 \quad M_{z}=7 \mathrm{fl} \cdot 1 \mathrm{~s}=84 \mathrm{in} .16
\end{aligned}
$$

Total force on weld

Add force from hanging flex hose to loads from B12

$$
\begin{aligned}
& F_{x}=11+36=4716 \quad M_{x}=0 \\
& F_{Y}=36+6=4216 \quad M_{Y}=44+780=824 \mathrm{in} \cdot 16 \\
& F_{z}=11+67=7816 \quad M_{z}=144+84=228 \mathrm{in} 16 \\
& f_{\omega}=\sqrt{\left(\frac{47 \text { ib }}{2.64 \text { in }}+\frac{824 \mathrm{in.16}}{0.55 \mathrm{in}^{2}}+\frac{228 \mathrm{in} 13}{0.55 \mathrm{in}^{2}}\right)^{2}+\left(\frac{4213}{2.64 \mathrm{in}}\right)^{2}+\left(\frac{7813}{2.64 \mathrm{in}}\right)^{2}} \\
& f_{\omega}=1931 \mathrm{k} / \mathrm{in}
\end{aligned}
$$

HNF-2479, Rev. 0

Page B. 10 
FLUOR DANIEL NORTHWEST, INC.

DESIGN ANALYSIS
Calk. No. $w 320-27 \cdot 050$

Revision $\mathrm{O}$

Page No. 9 of 26

Client Numatec

WO/Job No. ER $4319 / w-320$

Subject Portable Exhausted Installation Anal sis Date $12 / 15 / 97$ By Kelly House

Location 241-C/241-AY

Revised

By

Condensate drain line "anchor points" at vises (continued)

$$
\begin{aligned}
& t_{\omega}=\frac{f_{w}}{(0.707) \tau_{\text {allow }}}=\frac{1931 \mathrm{~b} / \mathrm{in}}{(0.707)(16700 \mathrm{psi})(0.8)(1.33)} \\
& \text { B31.3 allow }
\end{aligned}
$$

$t_{\omega}=0.154$ in $<2 \times \frac{1}{8} " \quad$ Therefore weld is acceptable.

two sides

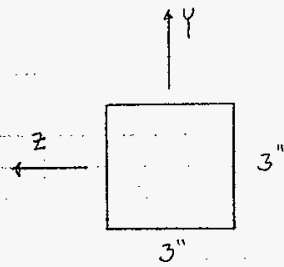

$$
\begin{aligned}
& A_{\omega}=4 \times 3 \text { in }=12 \text { in } \\
& S_{\omega}=(3 \text { in })(3 \text { in })+\frac{(3 \text { in })^{2}}{3}=12 \mathrm{in}^{2}
\end{aligned}
$$

$$
\begin{aligned}
& f_{w}=\sqrt{\left(\frac{47}{12 i n}+\frac{824 i n b}{12 i n^{2}}+\frac{228 i n 1 b}{12 i n^{2}}\right)^{2}+\left(\frac{4216}{12 i n}\right)^{2}+\left(\frac{781 b}{12 i n}\right)^{2}} \\
& f_{\omega}=92 \mathrm{k} / \mathrm{in}
\end{aligned}
$$

$$
t_{\omega}=\frac{92 \mathrm{lb} / \mathrm{in}}{(0.707)(16700 \mathrm{psi})(0.8)(1.33)}=0.01 \text { in }<\frac{1}{8} \text { "Therefore weld }
$$

HNF-2479, Rev. 0

Page B-11 
FLUOR DANIEL NORTHWEST, INC.

DESIGN ANALYSIS

Calc. No. w320-27-050

Revision 0

Page No. 10 of 26

Client Numatec

WO/Job No. ER 4319/w320

\begin{tabular}{lll}
\hline Subject Portable Exhausted Installation Analysis & Date $12 / 15 / 97$ & By Kelly Hay se \\
\hline Location $241-\mathrm{C} / 241-A Y$ & Checked $12 / 19 / 97$ By N. J. JUFLO
\end{tabular}

By

Existing Pipe Support and Anchor on Portable Exhausted

Based on the low support forces, the existing pipe support on the portable exhausted is assumed to be adaquate.

Check weld at pump enclosure (Ref. $\# 18$ )

$\frac{1}{16}{ }^{*}$ think

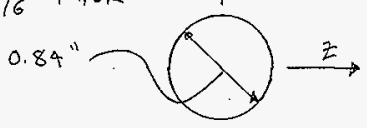

$$
\begin{aligned}
& A_{\omega}=\pi(0.84 \mathrm{in})=2.64 \mathrm{in} \\
& S_{\omega}=\frac{\pi(0.89 \mathrm{in})^{2}}{4}=0.55 \mathrm{in}^{2}
\end{aligned}
$$

Force on weld, Autopipe Node Point BOO

$$
\begin{aligned}
& F_{x}=73 \mathrm{lb} \\
& M_{x}=0 \\
& F_{y}=19 \mathrm{lb} \\
& M_{y}=22 \text { ft. } 13=264 \mathrm{in} \cdot 16 \\
& F_{z}=8116 \\
& M_{z}=5 \mathrm{ft} \cdot \mathrm{b}=60 \mathrm{in} \cdot 1 \mathrm{~s} \\
& f_{w}=\sqrt{\left(\frac{73 \mathrm{ib}}{2.64 \mathrm{in}}+\frac{264 \mathrm{in} \cdot 13}{0.55 \mathrm{in}^{2}}+\frac{60 \mathrm{ind}^{16}}{0.55 \mathrm{in}^{2}}\right)^{2}+\left(\frac{1916}{2.64 \mathrm{in}}\right)^{2}+\left(\frac{81 \mathrm{ib}}{2.64 \mathrm{in}}\right)^{2}} \\
& f_{\omega}=618 \mathrm{k} / \mathrm{in} \\
& t_{w}=\frac{618 \mathrm{lb} / \mathrm{in}}{(0.707)(16700 \mathrm{psi})(0.8)(1.33)}=0.049 \text { in }<\frac{1}{16} " \text { Therefore weld }
\end{aligned}
$$

HNF-2479, Rev. 0

Page $\mathrm{B}-12$ 
FLUOR DANIEL. NORTHWEST, INC.

DESIGN ANALYSIS
Calc. No. $0320.27-050$

Revision 0

Page No. 11 of 26

Client Numatec

WO/Job No. ER 4319/w.320

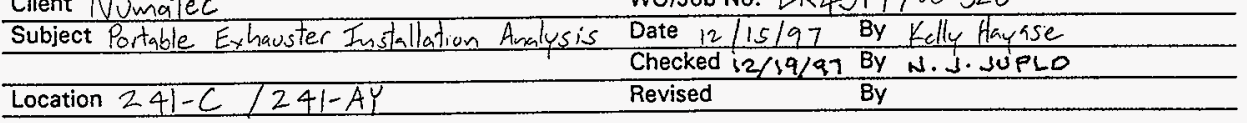

Pipe Support (For condensate drain line)

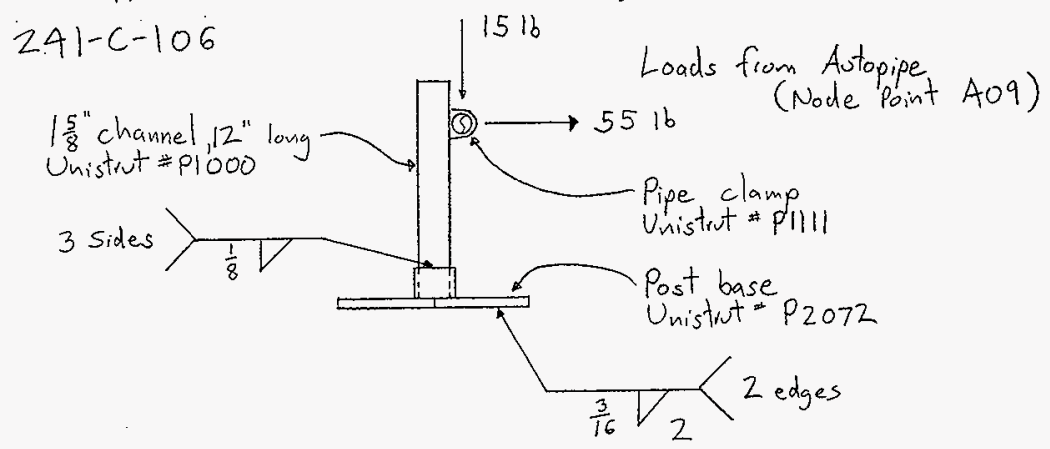

Pipe clamp allowable loads (Ref. $*$ q)

Unistut \#p 1111

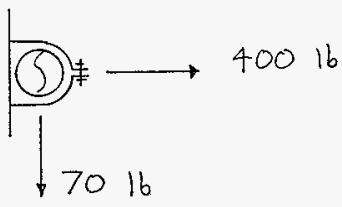

Therefore pipe clamp is acceptable

Channel allowable moment (Ref. $*$ )

Unistrut \#p1000

allowable moment $=5080 \mathrm{in} \cdot \mathrm{lb}$

actual moment $=(12 \mathrm{in})(55 \mathrm{is})=660 \mathrm{in} .16$

Therefore channel is acceptable.

HNF-2479, Rev. 0

Page B-13 
FLUOR DANIEL NORTHWEST, INC.

DESIGN ANALYSIS
Cali. No. W320-27-050

Revision $\frac{0}{12 \text { of } 26}$

Client Numatec

WO/Job No. ER $4319 / \omega-320$

Subject Portable Exhausted Installation Analysis Date $12 / 15 / 97$ By Kelly Hayase

Location $2 4 1 - C \longdiv { 2 4 1 - A 4 }$

Revised

By

Pipe Support (continued)

The weakest link on the post base assembly is the $\frac{3}{16}$ " fillet welds, 2 "long, on 2 edges.

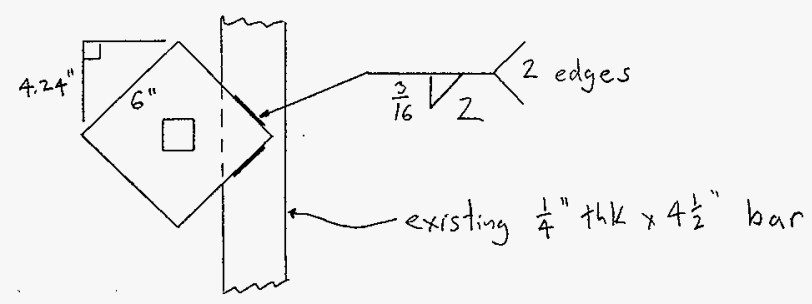

Analyze weld as a line (Ref. $\# 10$ )

$$
\begin{aligned}
& A_{\omega}=2 \times 2 \text { in }=4 \text { in }
\end{aligned}
$$$$
\begin{aligned}
& \text { now assume } \quad=1.41^{11} \\
& \text { as }
\end{aligned}
$$

$$
S_{\omega}=\frac{(1.41 \mathrm{in})^{2}}{3}=0.66 \mathrm{in}^{2}
$$

HNF-2479, Rev. 0

Page B-14 
FLUOR DANIEL NORTHWEST, INC.

DESIGN ANALYSIS
Calc. No. W320-27-050

Revision

Page No. 13 of 26

Client Numatec

WO/Job No. ER $4319 / w-320$

Subject Portable Exhaviter Installation Analysis Date $12 / 15 / 97$ By Kelly Hays

Location $241-C / 24)-A Y$

Revised

By

Pipe Support (continued)

Worst case loadings
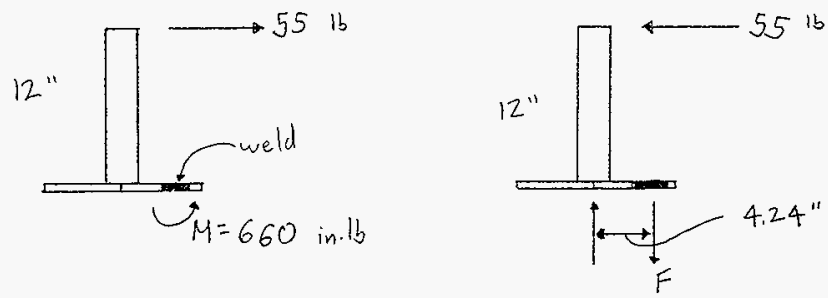

$$
\begin{aligned}
& F=\frac{(12 \mathrm{in})(55 \mathrm{ib})}{4.24^{\prime \prime}} \\
& F=156 \mathrm{ib} \text { (conservative) }
\end{aligned}
$$

For conservatism, assume loads act together

$$
\begin{aligned}
& f_{\omega}=\sqrt{\left(\frac{156: b}{4 i n}+\frac{660 \mathrm{in} \cdot 16}{0.66 \mathrm{in}^{2}}\right)^{2}+\left(\frac{55 \mathrm{ib}}{4 \mathrm{in}}\right)^{2}}=1039 \mathrm{lb} / \mathrm{in} \\
& t_{w}=\frac{f_{w}}{(0.707) \sigma_{\text {allow }}}=\frac{103916 / \mathrm{in}}{(0.707)(17982 \mathrm{psi})}=0.082 \mathrm{in}<\frac{3}{16} \\
& \sigma_{\text {allow }}=(16900 \mathrm{psi})(0.8)(1.33)=17982 \mathrm{psi}
\end{aligned}
$$

HNF-2479, Rev. 0

Page B-15 
FLUOR DANIEL NORTHWEST, INC.

DESIGN ANALYSIS
Calc. No. $\omega 320-27-050$

Revision $O$

Page No. 14 of 26

Client Numatec

WO/JOb No. ER 43/9/W-320

Subject Portable Exhausted Installation Analysis Date $12 / 15 / 97$ By Kelly Hayase Checked $12 / 19 / 97$ By H.J. Juplo

Location $241-C \cdot 1241-A Y$

Revised

By

Pipe Support (continued)

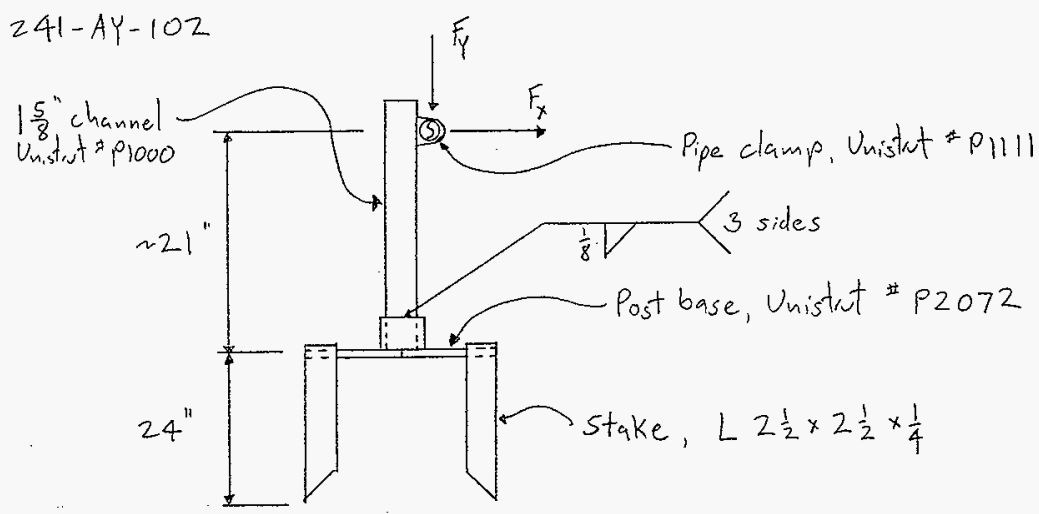

Loads from Autopipe (Node Point Bo q)

$$
F_{y}=15 \mathrm{~kb}
$$

$F_{x}=$ Max of wind or Seismic (Sec note on page 16)

$$
=3016+1116 \quad(W 1+(G R+T 1))
$$

However Autupie used $1 \frac{1}{2}$ "the insulation but actually is only 1 "the.

$$
\begin{gathered}
\frac{0.84 \text { in }+2 \text { in }}{0.84 i n+3 \text { in }}=0.74 \\
F_{x}=(3013)(0.74)+1116=3316
\end{gathered}
$$

Pipe clamp is acceptable.

Moment $=(3313)(21$ in $)=693 \mathrm{in} .16<5080 \mathrm{in} \cdot 16 \therefore$ channel is acceptor is

HNF-2479, Rev. 0

Page B-16 


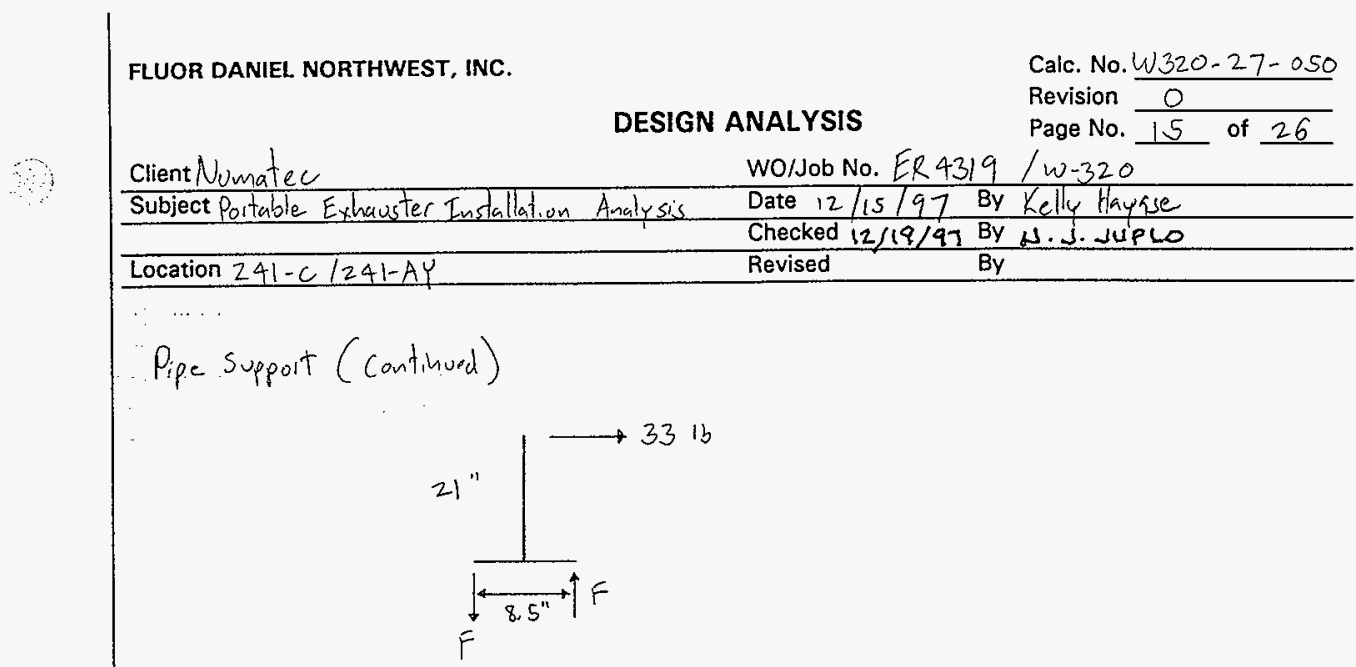

Uplift force $F$

$$
F=\frac{(33 \mathrm{ib})(21 \mathrm{in})}{(8.5 \mathrm{in})}=82 \mathrm{k}
$$

Uplift resistance of stake

$$
\begin{aligned}
& Q=\left(\frac{1}{2} \gamma l^{2}\right) k p \tan \phi_{f} \quad\left(P_{\text {age }} 7-41, R_{c} f_{*} 16\right) \\
& \gamma=130 \frac{\mathrm{b}}{\mathrm{ft}}=0.075 \mathrm{~b} / \mathrm{in}^{3} \quad\left(P_{\text {age }} 7-26, R_{c} f_{.}{ }^{16}\right) \\
& l=24 \mathrm{in} \\
& \left.K=1.0 \text { (Page } 7-41, R_{e} f * 16\right) \\
& P=(2.5 \mathrm{in})(4)=10 \text { in (perimeter of angle) } \\
& \tan \phi_{f}=0.45 \quad\left(P_{\text {age }} 7-42, \operatorname{Re} f^{\# 16}\right) \\
& Q=\frac{1}{2}\left(0.075 \mathrm{k} / \mathrm{in}^{3}\right)(24 \mathrm{in})^{2}(1.0)(10 \mathrm{in})(0.45) \\
& Q=97 \mathrm{lb}>82 \mathrm{lb} \quad \text { OiK. }
\end{aligned}
$$

HNF-2479, Rev. 0

Page B-17 
FLUOR DANIEL NORTHWEST, INC.

DESIGN ANALYSIS
Cali. No. $w 320-27-050$

Revision

Page No. $\frac{0}{16}$ of 26

Client Numatec

WO/Job No. ER $4319 / w-320$

Subject Portable Exhausted Installation Analysis Date $12 / 15 / 97$ By Kelly Hay ese

$$
\text { Location 241-C } / 241-A Y \quad \text { Checked } 12 / 19 / 97 \text { By N. S. Sue lo }
$$

Location $241-C / 241-A Y$

Revised

By

Pipe Support (Continued)

Lateral resistance of stake

$$
\begin{aligned}
& Q=3 B \gamma z\left(\frac{1+\sin \phi}{1-\sin \phi}\right) \\
& B=2,5 \text { in } \\
& \gamma=0.075 \mathrm{H} / \mathrm{in}^{3} \\
& \phi=30^{\circ} \text { (assumed) } \\
& z=12 \text { in (avenge depth) } \\
& \therefore Q=3(2.5 \text { in })(0.075 \mathrm{~B} / \mathrm{in})(12 \mathrm{in})\left(\frac{1+\sin 30}{1-\sin 30}\right) \\
& Q=20 \mathrm{~b} / \mathrm{in} \\
& \text { Resistance }=(20 \mathrm{lb} / \mathrm{in})(24 \mathrm{in})=480 \mathrm{lb}>33 \mathrm{lb}
\end{aligned}
$$

ak.

Note: ASME B31.3 considers all loads acting together for support and anchor analysis. FDNW Practice \#134.215.1217 does not consider wind and seismic loads acting together. Because this is a temporary installation, consider max of wind or seismic loads.

HNF-2479, Rev. 0

Page B-18 
FLUOR DANIEL NORTHWEST, INC.

DESIGN ANALYSIS
Calc. No. W320-27-650

Revision

Page No. 17 of 26

Client Numatec

WO/Job No. ER $4319 / w-320$

Subject Portable Exhausted Installation Analysis Date 12/15/97 By Key Hayride Checked $12 / 19 / 47$ By N. J. LILo

Location $24|-C| 241-A Y$

Revised

By

8" Flex Duct

wind Load on flex duct

$$
\begin{aligned}
& F=q_{z} G_{z} C_{f} A_{f} \\
& \text { (Ref, } \# \text { 7, Table 4) } \\
& G_{z}=1.32 \quad \text { (Table 8) } \\
& C_{f}=1.0 \quad \text { (Table 12) } \quad h / p=1 / 0.67=1.5 \\
& K_{z}=0.8 \quad \text { (Table 6) } \\
& q_{z}=0.00256 k_{z}(\text { IV })^{2} \quad(E q .3) \\
& q_{z}=0.00256(0.8)(1.0 \times 90)^{2}=17 \text { psf } \\
& A_{f}=(0.67 \mathrm{ft})(18 \mathrm{ft})=12 \mathrm{ft}^{2} \\
& F=(17 \text { psf })(1.32)(1.0)\left(12 \mathrm{ft}^{2}\right)=270 \mathrm{lb}
\end{aligned}
$$

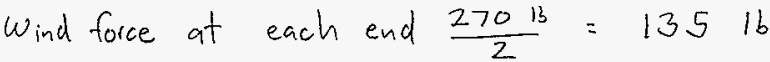

Seismic load on flex duct can be neglected because of the small mass and high flexibility of the flex duct.

The pressure rating of the 8 "flex duct (Dura-vent, Blue Max $\# 2 P N-C)$ is 10 in $\mathrm{Hg}$ vacuum and 11 psi pressure. . (Ref. $* 12, A_{p p} \times$ B-30) This is more than adequate for the operating conditions of the tanks.

HNF-2479, Rev. 0

Page B-19 
FLUOR DANIEL NORTHWEST, INC.

DESIGN ANALYSIS
Calc. No. $1320-27-050$

Revision $\mathrm{O}$

Page No. 18 of 26

Client Numatec WO/Job No. ER $4319 / \omega-320$

Subject Portable Exhausted Installation Analysis Date $12 / 15 / 97$ By Kelly Hay are Location $241-C / 241-A Y$ Checked $12 / 19 / 93$ By N.J. Juplo Revised

$$
\text { By }
$$

8" Flex Duct (continued)

$$
241-c-106
$$

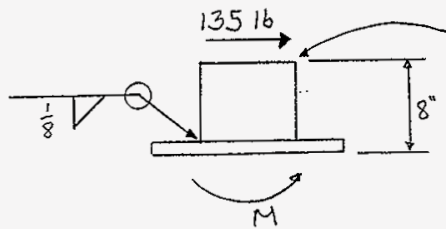

8" OD

I) GA sheet, A $240-304 \mathrm{~L}$ ( 0.1196 inch the)

$0=8 \mathrm{in}$

$d=8 \mathrm{in}-2(0.1196 \mathrm{in})=7.7608 \mathrm{in}$

$$
\begin{aligned}
& S=\frac{\pi}{32}\left(\frac{D^{4}-d^{4}}{D}\right)=\frac{\pi}{32}\left(\frac{8 \mathrm{in}^{4}-7.7608 \mathrm{in}}{8 \mathrm{in}}\right)=5.7 \mathrm{in}^{3} \\
& \sigma=\frac{M}{S}=\frac{(135 \mathrm{ib})(8 \mathrm{in})}{5.7 \mathrm{in}^{3}}=189 \mathrm{psi}<\sigma_{\text {allow }}<. K .
\end{aligned}
$$

(neglect shear)

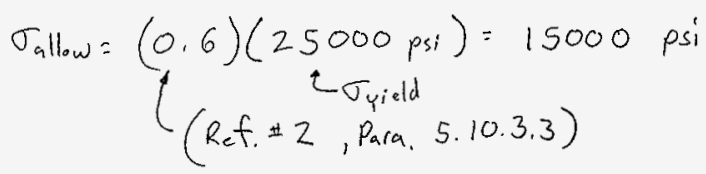

weld

$$
\begin{aligned}
& A_{\omega}=\pi(8 \mathrm{in})=25 \mathrm{in} \\
& S_{w}=\frac{\pi(8 \mathrm{in})^{2}}{4}=50 \mathrm{in}^{2}
\end{aligned}
$$

$$
\begin{aligned}
& f_{\omega}=\sqrt{\left(\frac{(13516)(8 \mathrm{in})}{50 \mathrm{in}^{2}}\right)^{2}+\left(\frac{135 \mathrm{ib}}{25 \mathrm{in}}\right)^{2}}=22 \mathrm{~kb} / \mathrm{in} . \\
& t_{w}=\frac{f_{w}}{(0.707) \tau_{\text {allow }}}=\frac{22 \mathrm{bl} / \mathrm{in}}{(0.707)\left(15000 \rho_{\mathrm{si}}\right)(0.8)}=0.003 \mathrm{in}<\frac{1}{8} " 0 . \mathrm{K} \text {. }
\end{aligned}
$$

HNF-2479, Rev. 0

Page B-20 
FLUOR DANIEL NORTHWEST, INC.

DESIGN ANALYSIS
Calc. No. w320-27-050

Revision

Page No. 19 of 26

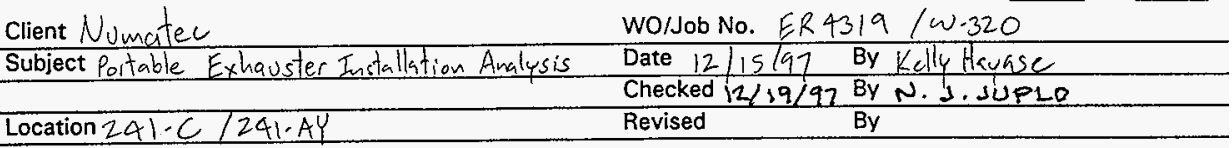

8." Flex. Duct (contused)

$241-A Y-102$

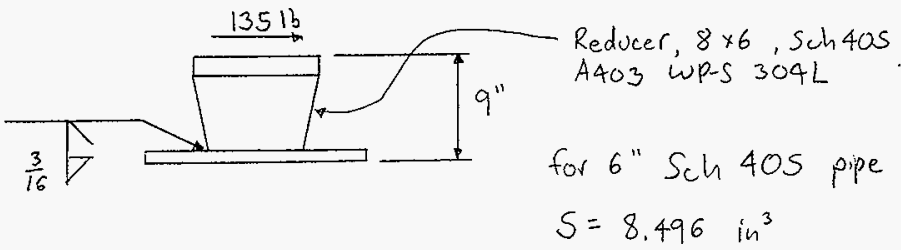

$$
\sigma=\frac{M}{s}=\frac{(135 \mathrm{lb})\left(\mathrm{q}_{\mathrm{in}}\right)}{8.496 \mathrm{in}^{3}}=143 \mathrm{psi}<15000 \mathrm{psi}=\sigma_{\text {allow }} \quad 0 . \mathrm{K} \text {, }
$$

(neglect shear)

Weld

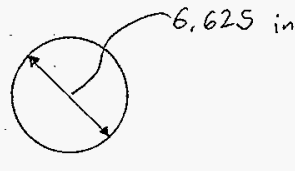

$$
\begin{aligned}
& A_{\omega}=\pi(6.625 \mathrm{in})=20.8 \mathrm{in} \\
& S_{\omega}=\frac{\pi(6.625 \mathrm{in})^{2}}{4}=34.5 \mathrm{in}^{2}
\end{aligned}
$$

$$
\begin{aligned}
& f_{\omega}=\sqrt{\left(\frac{(135 \mathrm{lb})(9 \mathrm{in})}{34.5 \mathrm{in}^{2}}\right)^{2}+\left(\frac{135 \mathrm{lb}}{20.8 \mathrm{in}}\right)^{2}}=36 \mathrm{k} / \mathrm{in} \\
& T_{\omega}=\frac{36 \mathrm{lb} / \mathrm{in}}{(0.707)\left(15000_{\mathrm{psi}}\right)(0.8)}=0.004 \mathrm{in}<\frac{3}{16}{ }^{\prime \prime} \text { o. K. }
\end{aligned}
$$

HNF-2479, Rev. 0

Page B-21 
FLUOR DANIEL NORTHWEST, INC.

DESIGN ANALYSIS
Talc. No. $6320.27-0,50$

Revision $\frac{0}{20}$ of 26

Wo/Job No. ER $4319 / \omega-320$

Client Numgtec

Subject Portable Exhausted Installation Analysis Date $12 / 15 / 97$ By Kelly Hawse Checked $12 / 19 / 97$ By $\mathrm{M}$. 1 . Sup 10

Location $241-C / 241-A Y$

By

Local stresses in 8 "Duct due to Welded Condensate Drain (Ret. $\$ 17$ for method)

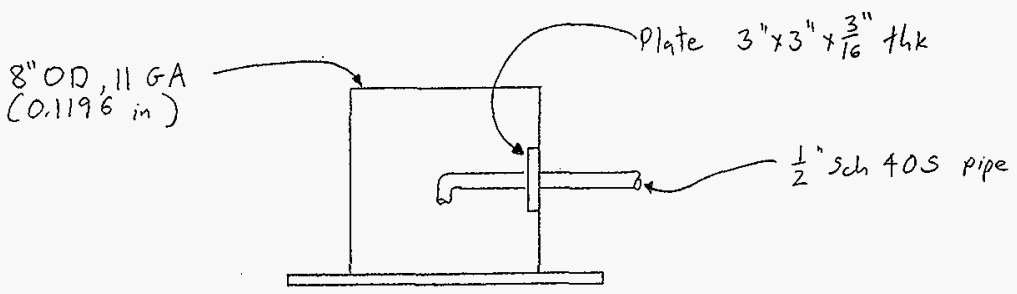

Thickness $t=0.1196 \mathrm{in}$

$$
\begin{aligned}
& r_{0}=0.84 \mathrm{in} / 2=0.42 \mathrm{in} \\
& R_{m}=4 \mathrm{in} \\
& \gamma=\frac{R_{m}}{t}=\frac{4}{0.1196}=33 \\
& \beta=(0.875) \frac{r_{0}}{R_{m}}=(0.875)\left(\frac{0.42}{4}\right)=0.092
\end{aligned}
$$

Total thickness $T=0.1196 \mathrm{in}+0.1875 \mathrm{in}=0.3071 \mathrm{in}$

The thickness of the pad shall only be used in the total thickness in the stress equations and shall not be considered in determining the geometric parameters.

Loads (from page 8)

$$
\begin{array}{llll}
P=4716 & \left(F_{Y}\right) & M_{T}=0 & \left(M_{X}\right) \\
V_{C}=78 \mathrm{~kb} & \left(F_{z}\right) & M_{C}=824 \mathrm{in} \cdot 16 \quad\left(M_{Y}\right) \\
V_{L}=42 \mathrm{~kb} & \left(F_{Y}\right) & M_{L}=228 \mathrm{in} \cdot 16 \quad\left(M_{z}\right)
\end{array}
$$

HNF-2479, Rev. 0

Page $\mathrm{B}-22$ 
Client: Numatec

Subject: Portable Exhauster Installation Analysis

Location: 241-C/ 241-AY

\section{Local Stresses (continued)}

\section{Table 5-Computation Shent for Local Stresses in Cyllndrical Shoils}

*(See App B-18 to B-28 for figures)

i. Applied Loodx"

\begin{tabular}{|c|c|}
\hline 803 & \\
\hline 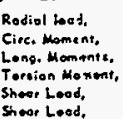 & 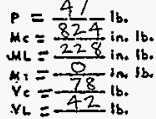 \\
\hline
\end{tabular}

2. Crometry

Vereet thickness, $T=\frac{0,3071}{0.42} \mathrm{in}$.

Atrectomont rudivs, $10=0.42 \mathrm{im}$

Yeutel vodius, $8_{m}=\frac{4}{4}$ in.
Wo/Job No: ER4319/W-320

Date: $)^{2} / 15 / 97$ By: Kelly Hayase

Checked: $12 / 19 / 97$ By: N. J.JUPLO

Revised:

By:

\begin{tabular}{|c|c|c|c|c|c|c|c|c|c|c|}
\hline \multirow{2}{*}{$\begin{array}{l}\text { From } \\
\text { Fip }\end{array}$} & \multirow{2}{*}{$\begin{array}{c}\text { Rood eumes } \\
\text { for }\end{array}$} & \multirow{2}{*}{ 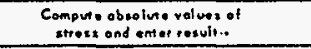 } & \multicolumn{8}{|c|}{ 3TRESSES - il lood is opposile thot she $n$, pererses signs shewn } \\
\hline & & & $\overline{\lambda_{\psi}}$ & $\pi L$ & $\mathrm{Bv}_{\mathrm{v}}$ & BL & $\epsilon_{v}$ & CL & $D_{n}$ & $\overline{D L}$ \\
\hline $\begin{array}{c}30-0 \% \\
4 C\end{array}$ & $\frac{\mu_{0}}{\operatorname{rim}_{m}}=6.4$ & $k_{n}\left(\frac{x \delta}{v_{1} x_{m}}\right) \cdot \frac{p}{x_{m} t}=245$ & 745 & - & $\rightarrow$ & - & $\overline{2} 45$ & - & - & - \\
\hline $\begin{array}{c}1 c \text { or } \\
2 c-1- \\
\end{array}$ & $\frac{m b}{p}=0.14$ & ks $\left(\frac{M p}{P}\right) \cdot \frac{6 P}{T^{2}}=419$ & -419 & + & - & + & -419 & $t$ & $1-$ & 4 \\
\hline 34 & $\frac{\mathrm{N}_{6}}{\mu_{c} / R_{m}^{2} \beta}=0$ & $x_{n}\left(\frac{N \phi}{\mu_{c} k_{m}{ }^{2} \beta}\right) \cdot \frac{\mu_{c}}{R_{m}^{2} \beta t}=164$ & POIOT & Oי & 要 & Y & 7641 & $\infty$ & $t$ & H \\
\hline in & 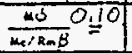 & $x_{0}\left(\frac{M_{C}}{\mu_{c} / R_{-} \beta}\right) \cdot \frac{6 k_{c}}{R_{m} \beta_{T^{2}}}=14$ & ; & & 4 & OY & $\pi 245$ & t & + & - \\
\hline 31 & $\frac{m \omega}{m L / m^{2} \beta}=$ & $K_{n}\left(\frac{N \phi}{\mu_{L} / R_{m}{ }^{2} \beta}\right) \cdot \frac{\mu_{L}}{R_{m}^{2} \beta_{T}}=15 / 3$ & 1513 & - & $t$ & + & & & & \\
\hline $\begin{array}{ll}+16-1 \\
1+-1\end{array}$ & 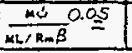 & $x *\left(\frac{m_{\omega}}{\omega_{1} \cdot m_{m} \beta}\right) \cdot \frac{6 m L}{k_{m} \beta T^{2}}=1971$ & -197 & + & + & - & & & & \\
\hline \multicolumn{3}{|c|}{ 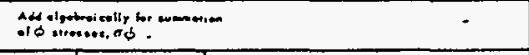 } & 4148 & & & & 16550 & & & \\
\hline$\frac{36-06-}{46}$ & $\frac{k_{s}}{p / R_{m}}=6.4$ & $k_{n}\left(\frac{k_{n}}{p_{12} R_{m}}\right) \cdot \frac{p}{R_{m}}=245$ & 245 & - & - & - & 245 & - & - & - \\
\hline $\begin{array}{l}2 c-1 \\
-2 x-2 c-\end{array}$ & $\frac{\mu_{1}}{r}=0.14$ & $x \cdot\left(\frac{m_{2}}{p}\right) \cdot \frac{6 p}{T_{2}}=419$ & -419 & + & - & + & -419 & + & - & + \\
\hline $4 \mathbf{A}$ & $\frac{M_{1}}{m_{c} / R_{m}^{2} E}=$ & $x_{n}\left(\frac{\omega_{n}}{\mu_{c} / R_{m} \beta \beta}\right) \cdot \frac{\mu_{c}}{R_{m^{2}} \beta_{t}}=2370$ & & M & O & & -2370 & $\rightarrow$ & + & + \\
\hline 21 & $\frac{m_{*}}{M_{s} R_{m} \beta} 0.06$ & $\therefore\left(\frac{M_{0}}{M_{\alpha} / R m}\right) \cdot \frac{\sigma M_{c}}{R_{m} \beta T^{2}}=8$ & & & & & -8547 & $\div$ & + & $1-$ \\
\hline 48 & $\frac{N_{1}}{N_{L} / R_{m}{ }^{2} \beta} 0.90$ & $x_{n}\left(\frac{N_{2}}{M_{L} R_{m} \beta}\right) \cdot \frac{m_{L}}{k_{m^{2} \beta T} \beta_{T}}=454$ & -454 & - & $t$ & + & & & & \\
\hline $28-1$ & $\frac{m=8}{m \cdot \operatorname{Rm} B}=0$ & $x \cdot\left(\frac{M_{z}}{M_{L} \cdot R_{m} \beta}\right) \cdot \frac{6 M_{L} L}{R_{m} A^{2}}=3153$ & -3153 & + & + & - & & & & III \\
\hline \multicolumn{3}{|c|}{ 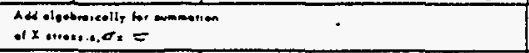 } & 427 & & & $\therefore$ & $|158|$ & & & \\
\hline \multicolumn{2}{|c|}{ 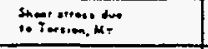 } & $x \cos =T=\phi=\overline{2 \pi} \frac{\bar{\mu}}{r_{0}^{2} T}=$ & + & + & $t$ & $t$ & + & $t$ & t & $t$ \\
\hline \multicolumn{2}{|c|}{ 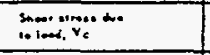 } & $T \times d=\pi \frac{V c}{T}=192$ & +192 & + & - & - & & & & OM. \\
\hline \multicolumn{2}{|c|}{ 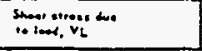 } & $T \times \omega *-\frac{v L}{\pi}$ & eOPo: & YII & & & $\overline{104}$ & - & $t$ & f \\
\hline \multicolumn{3}{|c|}{ 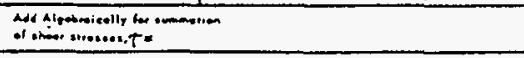 } & 192 & & & & 104 & & & \\
\hline
\end{tabular}

3. Coomnetic Porometers

r $\frac{R_{m}}{r}=33$

B. $\quad(0.375) \frac{1_{0}}{R_{m}}=0.092$

Seress Cencentration due to:

a) membrona loac, $K_{\mathrm{n}}$

b) bending lood, $\mathrm{K}_{\mathrm{B}}$ I

- NOTE: Emen oll toree values in

eceordance with sign canvention

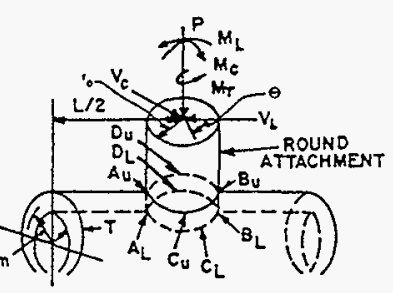

CYLINORICAL SHELL 
FLUOR DANIEL NORTHWEST, INC.

DESIGN ANALYSIS
Talc. No. w320-27-050

Revision 0

Page No. 22 of 26

Client Numatec

WO/Job No. ER 4319/w.320

Subject Portable Exhausted Installation Analysis

Date $12 / 15 / 97$ By Kelly Hayase

Location $241-C / 241-A Y$

Checked 12/19/97 By N.J. DuPLe

Local Stresses (continued)

Combined Stress

$$
\begin{aligned}
& S=\frac{1}{2}\left[\sigma_{x}+\sigma_{\phi}+\sqrt{\left(\sigma_{x}-\sigma_{\phi}\right)^{2}+4 \tau^{2}}\right] \\
& S=\frac{1}{2}[11581 p s i+16550 p s i \\
& \left.+\sqrt{(11581 p s i-16550 p s i)^{2}+4(192 p s i)^{2}}\right] \\
& S=16557 \text { psi } \\
& \text { Total steps }=16557 \text { psi }+189 \text { psi }=16746 \text { psi }<\sigma_{a} l_{0 w} \text { oik. }
\end{aligned}
$$

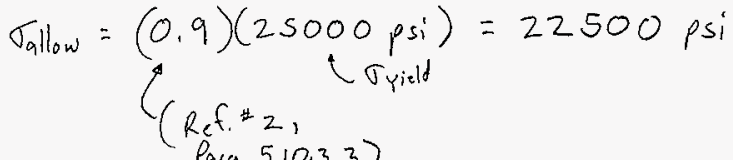

$$
\begin{aligned}
& \text { Para } 5.10 .3 .3)
\end{aligned}
$$

Based on comparison, local stresses in $8 \times 6$ Reducer due to welded condensate drain are acceptable.

HNF-2479, Rev. 0

Page B-24 
FLUOR DANIEL NORTHWEST, INC.

DESIGN ANALYSIS
Calc. No. w320-27-050

Revision $\mathrm{O}$

Page No. 23 of 26

Client Numater

WO/JOb No. ER $4319 / w-320$

Subject Portable Exhausted Installation Analysis Date $12 / 15 / 97$ By Kelly Hanse

Location 2A1-C /241-AY

Revised

By

Flex Duct Support $241-A Y \cdot 102$

Stakes

$22 \frac{1}{2} \times 2 \frac{1}{2} \times \frac{1}{4}$
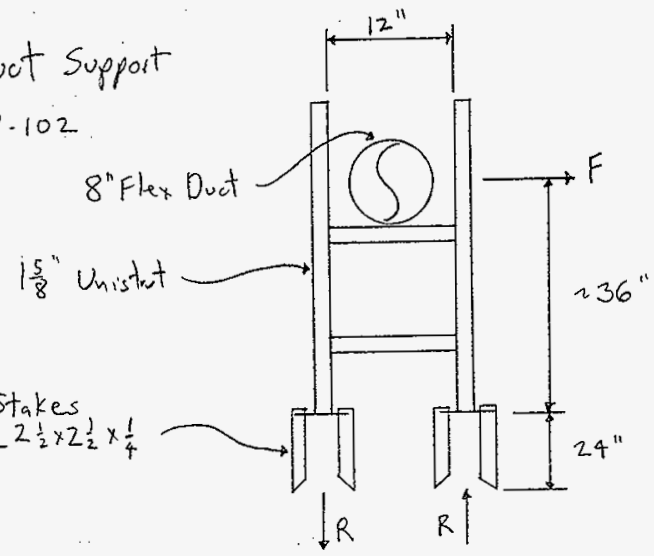

$$
\begin{aligned}
& F=(17 \text { psf })(1.32)(1.0)(0.67 \mathrm{ft})(7 \mathrm{ft})=10.5 \mathrm{lb} \\
& R=\frac{(105 \mathrm{~b})(36 \mathrm{in})}{(12 \mathrm{in})}=315 \mathrm{lb} \\
& \text { Uplift force }=\frac{315 \mathrm{lb}}{4}=79 \mathrm{lb}<97 \mathrm{Bb}=Q \quad \text { uplift resistance }
\end{aligned}
$$

Later resistance is acceptable, 105 b $<480$ b

0.1,

HNF-2479, Rev. 0

Page B-25 
FLUOR DANIEL NORTHWEST, INC.

DESIGN ANALYSIS
Calc. No. W320-27.050

Revision

Page No. 24 of 26

Client Numatec

WO/Job No. ER 4319/w-320

Subject Portable Exhausted Installation Analysis Date $2 / 20 / 98$ By Kelly Hayase

Location $24 \mid - C \longdiv { 2 4 1 - A Y }$ Revised

By

Flex Duct Support (Continued)

$5 \mathrm{ft}$ lengths of 9 \%/16" wide $11 \mathrm{G} A$ sheets will be placed on each duct support to support the flex duct i (to prevent sag)

Determine seismic load of flex duct a sheet

weight of hose $=(1.75 \mathrm{lb} / \mathrm{ft})(7 \mathrm{ft})=12.25 \mathrm{lb}$

weight of sheet $=(60 \mathrm{in})(9.5625 \mathrm{in})(0.1196 \mathrm{in})\left(0.284 \mathrm{lb} / \mathrm{in}^{3}\right)=19.513$

seismic load $=(1.5)(0.42 g)(12.25+19.513)=2016$

This is less than $105 \mathrm{lb}$ wind force $\therefore$ page 23 is $0 . K$.

Determine deflection at end of sheet ( 24 inches out)

$$
\begin{aligned}
& \omega=\left(1.75 \frac{\mathrm{b}}{\mathrm{ft}}\right)\left(\frac{\mathrm{ft}}{12 \mathrm{in}}\right)+(19.5 \mathrm{bb} / 60 \mathrm{in})=0.47 \mathrm{ib} / \mathrm{in} \\
& I=\frac{b \mathrm{~h}^{3}}{12}=\frac{(9.5625 \mathrm{in})(0.1196 \mathrm{in})^{3}}{12}=0.00136 \mathrm{in}^{4} \\
& \Delta=\frac{\omega L^{4}}{8 E I}=\frac{\left(0.47 \frac{13}{\mathrm{in}}\right)(24 \mathrm{in})^{4}}{8\left(30 \times 10^{6} \mathrm{psi}\right)\left(0.00136 \mathrm{in}^{4}\right)} \\
& \Delta=0.48 \mathrm{in} \simeq \frac{1}{2} \text { This is acceptable. }
\end{aligned}
$$

HNF-2479, Rev. 0

Page B-26 
FLUOR DANIEL NORTHWEST, INC.

DESIGN ANALYSIS
Cali. No. w320-27-050

Revision $\frac{0}{25 \text { of } 26}$

Client Numatec

WO/Job No. ER $4319 / \omega-320$

Subject Portable Exhausted Installation Analysis Date $2 / 26 / 98$ By Kelly Hayase

Location $241-C / 241-A Y$ Checked $2 / 26 / 98$ By N.J. JuPLO

Revised

By

Flex Duct Support

$$
241-c-106
$$

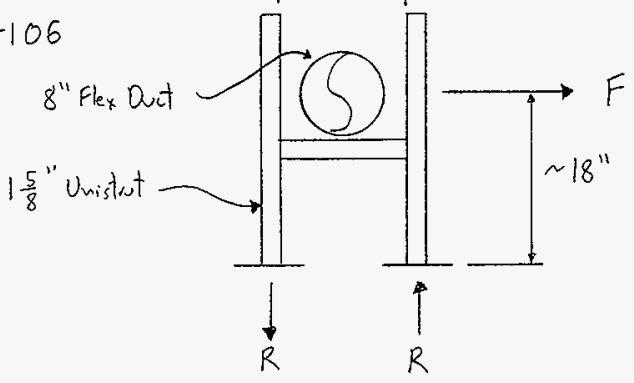

existing $\frac{1}{4}$ the $\times 4 \frac{1}{2}^{\prime \prime}$ bar

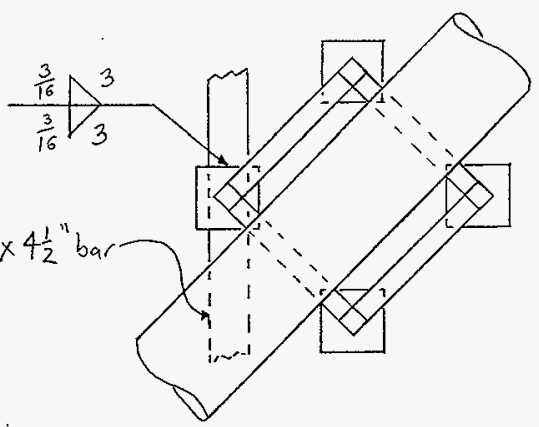

$$
\begin{aligned}
& F=(17 \text { pst })(1.32)(1.0)(0.67 \mathrm{ft})(9 \mathrm{ft})=135 \mathrm{lb} \\
& \left.\begin{array}{l}
R=\frac{(135 \mathrm{~kb})(18 \mathrm{in})}{(12 \mathrm{in})}=203 \mathrm{~kb} \\
M=(135 \mathrm{~kb})(18 \mathrm{in})=2430 \mathrm{in}, 1 \mathrm{~b}
\end{array}\right\} \begin{array}{l}
\text { An uplift force } \\
\text { or a moment will } \\
\text { act on weld, depending } \\
\text { on direction of force. }
\end{array}
\end{aligned}
$$

HNF-2479, Rev. 0

Page B-27 
FLUOR DANIEL NORTHWEST, INC.

DESIGN ANALYSIS
Talc. No. W320-27.050

Revision $\frac{\mathrm{O}}{26}$

Page No. 26 of 26

Client Numatec

WO/Job No. ER 4319/w-320

Subject Portable Exhausted Installation Analysis Date $2 / 26 / 98$ By Kelly Hayase

Location $24|-C| 24 \mid-A_{!}$

Checked or/26/98By N. S. JUPLO

Revised

By

Flex Duct Support (Continued)

Analyze weld as 9 line

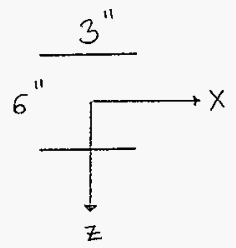

$$
\begin{aligned}
& A_{\omega}=2 \times 3 \text { in }=6 \text { in } \\
& S_{\omega z}=\frac{(3 \mathrm{in})^{2}}{3}=3 \mathrm{in}^{2}
\end{aligned}
$$

Assume weld takes all fores o moment, neglect $45^{\circ}$ rotation

$$
\begin{aligned}
& f_{\omega}=\sqrt{\left(\frac{203 \mathrm{ib}}{6 \mathrm{in}}+\frac{2430 \mathrm{in} \cdot 16}{3 \mathrm{in}^{2}}\right)^{2}+\left(\frac{135 \mathrm{ib}}{6 \mathrm{in}}\right)^{2}}=844 \mathrm{k} / \mathrm{in} \\
& t_{\omega}=\frac{844 \mathrm{lb} / \mathrm{in}}{(0.707)(17982 \mathrm{psi})}=0.066<\frac{3}{16} \quad \begin{array}{l}
\text { Therefore weld } \\
\text { is acceptable }
\end{array}
\end{aligned}
$$

HNF-2479, Rev. 0

Page B-28 


PEXCNDS W-320 TANK $241-\mathrm{C}-106$ WASTE RETRIEVAL $\begin{aligned} & \text { Fluor Daniel Nor thwest } \\ & \text { AUtOPIPE }+4.60 \mathrm{MODEL} \text { PAGE }\end{aligned}$
$12 / 22 / 97$

\section{PEXCNDS W-320 TANK 241-C-106 WASTE RETRIEVAL Fluor Daniel Northwest

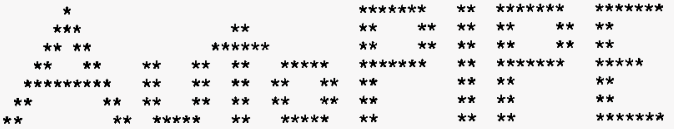

Pipe Stress Analysis and Design Program

Version: 4.60 .03

Edition: Plus-DOS

Developed and Maintained by

Engineering Design Automation, Inc.

1600 Riviera Ave. Suite 300
Walnut Creek, CA 94596

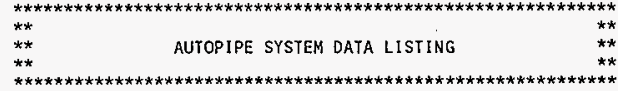

SYSTEM NAME : PEXCNDS

PROJECT ID : W-320 TANK 241-C-106 WASTE RETRIEVAL

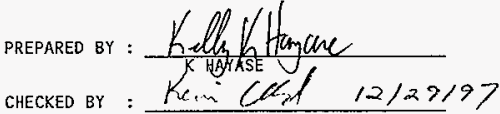

PIPING CODE : B31.3

AMBIENT TEMP. ( deg F ) : 40.0

COMPONENT LIBRARY : AUTOPIPE

MATERIAL LIBRARY : AUTOB313

MODEL REVISION NUMBER : 31 
PEXCNDS W-320 TANK $241-\mathrm{C}-106$ WASTE RETRIEVAL

$12 / 22 / 9$

fluor Daniel Northwest

Daniel Nor thwest

POINT DATA LISTING

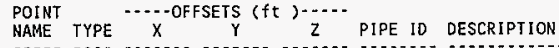

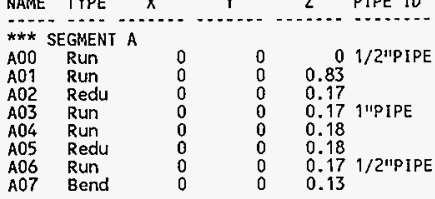

0.13

Long Elbow, Radius $=0.75$ inch Bend angle change $=90.00$ deg Mid point at 50.00 percent SIF $=$ In 1.25
Flex
.

$\begin{array}{lllll}A 08 & B e n d & 0 & 0.67 & 0\end{array}$

Long $E$ lbow, Radius $=0.75$ inch Bend angle change $=90.00$ deg Mid point at 50.00 percent SIF - In 1.25 , Out $=1.04$ Flex $=2.696$

$\begin{array}{lllll}\text { A09 } & \text { Run } & 0 & 0 & 5.50 \\ \text { A10 } & \text { Run } & 0 & 0 & 6.33 \\ \text { A11 } & \text { Bend } & 0 & 0 & 1.00\end{array}$

Long Elbow, Radius $=0.75$ inch Bend angle change $=90.00$ deg Mid point at 50.00 percent Sif - in 1.25, out $=1.04$ $\mathrm{Flex}=2.696$

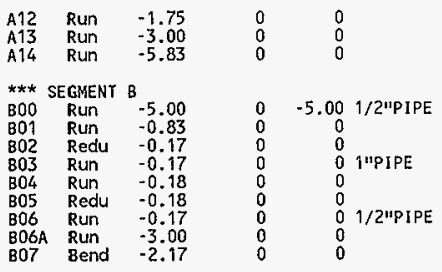

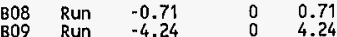

\section{PEXCNDS W-320 TANK 241-C-106 WASTE RETRIEVAL Fluor Daniel Nor thwest}

POINT DATA LISTING

POINT

B10 Bend $-4.24 \quad 0 \quad 4.24 \quad$ Long Elbow, Radius $=0.75$ inch Bend angle change $=90.00$ deg Hid point at 50.00 percent Sif - In 1.25 , out $=1.04$ Flex $=2.696$

B11 Bend $-0.35 \quad 0 \quad-0.35$

Long Elbow, Radius $=0.75$ inch Bend angle change $=45.00 \mathrm{deg}$ Mid point at 50.00 percent Sif - In 1.25 , out $=1.04$ Flex $=2.696$

B12 Run $-0.33 \quad 0 \quad 0$

Total weight of empty pipes : $65 \mathrm{lb}$ 


PEXCNDS W-320 TANK $241-\mathrm{C}-106$ WASTE RETRIEVAL
$12 / 22 / 97$

C OM PONENY DATA LISTING

$\begin{array}{llll}\text { POINT } & \cdots \text { COORDINATESft } & \jmath \cdots & \text { DATA } \\ \text { NAME } & X & \text { DAPE } & \text { DESCRIPTION }\end{array}$

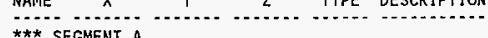

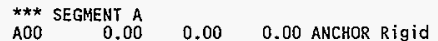

AODermal movements : None

A01 $\quad 0.00 \quad 0.00 \quad 0.83$ GUIDE $10:$ A01 1 , Connected to Ground

Stiffness $=$ RIGID

$\mathrm{A} 02 \quad 0.00 \quad 0.00 \quad 1.00^{\text {DISPL }}$ User 1

$\begin{array}{llll}A 03 & 0.00 & 0.00 & 1.00\end{array}$

AO4 $\quad 0.00 \quad 0.00 \quad 1.35$ fLANGE Weld neck $\quad$ SIF $=1.00$ Rating $=150$, weight $=3$ bif

A05 $\quad 0.00 \quad 0.00 \quad 1.53 \quad$ Rating $=150$, weight $=3 \mathrm{ib}$

$\begin{array}{llll}A 06 & 0.00 & 0.00 & 1.53 \\ A 07 & 0.00 & 0.00 & 1.70\end{array}$

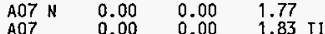

$\begin{array}{llll}A 07 & 0.00 & 0.00 & 1.83 \mathrm{TI}\end{array}$

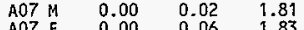

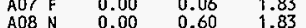

$\begin{array}{llll}\text { A08 N } & 0.00 & 0.60 & 1.83 \\ \text { A08 } & 0.00 & 0.67 & 1.83 \mathrm{TI}\end{array}$

$\begin{array}{llll}A 08 \mathrm{M} & 0.00 & 0.65 & 1.85 \\ \mathrm{~A} 0 \mathrm{~F} & 0.00 & 0.67 & 1.89\end{array}$

$0.67 \quad 1.89 \quad 3$ mass point(s)

A09 $\quad 0.00 \quad 0.67 \quad 7.33$ GUIDE $10=$ mass point(s) ID A A 1 , COnmect Stiffness = RIGID

$\begin{array}{lllll}\text { A10 } & 0.00 & 0.67 & 13.66 \text { Y-STOP ID : A10 } 1 \text {, Connected to Ground }\end{array}$ $\begin{array}{llll}\text { A } 11 \mathrm{~N} & 0.00 & 0.67 & 14.60 \\ & 0.00 & 0.67 & 14.66\end{array}$

$\begin{array}{lrrr}\text { A11 } & 0.00 & 0.67 & 14.66 \mathrm{~T}\end{array}$

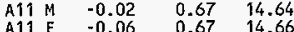

$\begin{array}{llll}A 11 F & -0.06 & 0.67 & 14.66 \\ \text { A12 } & -1.75 & 0.67 & 14.66\end{array}$

1 mass point (s)

A13 $-4.75 \quad 0.67 \quad 14.66$ GUIDE ID : A13 1 , Connected to Ground Stiffness $=$ RIGID

A14 $-10.58 \quad 0.67 \quad 14.66$ ANCHOR Rigid

Thermal movements : None

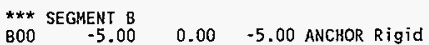

$B 00 \quad-5.00 \quad 0.00 \quad-5.00$ ANCHOR Rigid

$\begin{array}{llll}801-5.83 & 0.00 & -5.00 \mathrm{GLIDE} & \text { User ? }\end{array}$

Stiffness = RIGID DISPL User 1

$\begin{array}{llll}\mathrm{BO2} & -6.00 & 0.00 & -5.00\end{array}$

$\begin{array}{llll}\text { B03 } & -6.17 & 0.00 & -5.00 \\ \text { B04 } & -6.35 & 0.00 & -5.00 \text { FLANGE Weld neck }\end{array}$

$0.00-5.00$ FLANGE Weld neck
Rating $=150$, weight $=3 \mathrm{ib}$

\section{CONPONENT DATA LISTING}

POINT $-\cdots$-COORDINATE $(f t)-\cdots$ DATA

NAME $X$ Y Y $Z$ TYPE DESCRIPIION

$\begin{aligned} & \text { FLANGE Weld neck } \text { siF }=1.00 \\ & \text { Rating }=150 \text {, weight }=3\end{aligned}$

$\begin{array}{lllll}805 & -6.53 & 0.00 & -5.00 & \text { Rating }=150, \text { weigl } \\ \text { B06 } & -6.70 & 0.00 & -5.00 & 1 \text { mass point(s) } \\ \text { B06A } & -9.70 & 0.00 & -5.00 & 1 \text { mass point(s) }\end{array}$

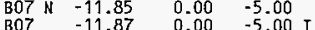

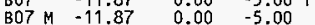

$\begin{array}{llll}B 07 \mathrm{~F} & -11.89 & 0.00 & -4.98\end{array}$

B08 $-12.58 \quad 0.00 \quad-4.29$ Y-STOP $10:$ B08 1, connected to Ground

$809-16.82 \quad 0.00-0.05$ GUIDE 3 mass point(s)

Stiffness = RIGID

$\begin{array}{lllll}B 10 \mathrm{~N} & -21.02 & 0.00 & 4.14 & 3\end{array}$ mass point(s)

$\begin{array}{llll}B 10 & -21.06 & 0.00 & 4.19 \mathrm{TI}\end{array}$

B $10-21.06 \quad 0.00 \quad 4.16$

$\begin{array}{llll}B 11 \mathrm{~N} & -21.39 & 0.00 & 4.14 \\ \mathrm{~B} & -21.00 & 3.85\end{array}$

В11 $-21.41 \quad 0.00 \quad 3.83 \mathrm{TI}$

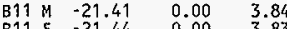

$0.00 \quad 3.83$ ANCHOR Rigid

Thermal movements : None

Number of points in the system : 65 


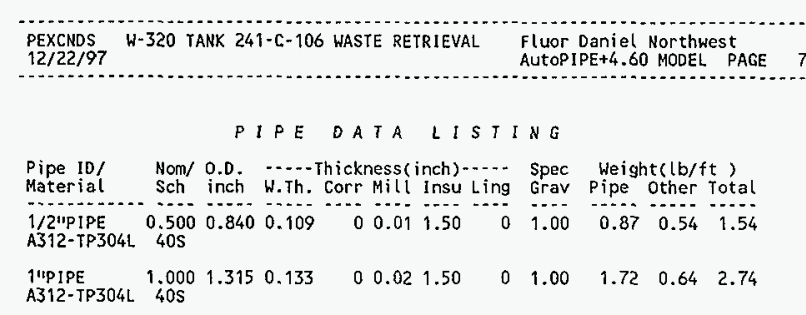

\begin{tabular}{|c|c|c|c|c|c|c|c|}
\hline $\begin{array}{l}\text { PEXCNDS } \\
12 / 22 / 97\end{array}$ & \multicolumn{3}{|c|}{ W-320 TANK $241-C-106$ WASTE } & \multicolumn{4}{|c|}{$\begin{array}{l}\text { Fluor Daniel Northwest } \\
\text { AutoPIPE+4.60 MODEL }\end{array}$} \\
\hline & $M A T$ & $E R I A L$ & $D A$ & $T A$ & ISTII & $N G$ & \\
\hline $\begin{array}{l}\text { Material } \\
\text { Name }\end{array}$ & Pipe ID & $\begin{array}{l}\text { Density } \\
\text { lb/cu.ft }\end{array}$ & $\begin{array}{l}\text { Pois. } \\
\text { Ratio }\end{array}$ & $\begin{array}{l}\text { Temper. } \\
\text { deg } F\end{array}$ & $\begin{array}{l}\text { Modulus } \\
\text { E6 psi }\end{array}$ & $\begin{array}{l}\text { Expans. } \\
\text { in } / 100 \mathrm{ft}\end{array}$ & $\begin{array}{l}\text { Allow. } \\
\text { psi }\end{array}$ \\
\hline A312-TP304L & $1 / 2 " P ! P E$ & 509.0 & 0.30 & $\begin{array}{r}40.0 \\
200.0\end{array}$ & 28.42 & 1.7688 & $\begin{array}{l}16700.0 \\
16700.0\end{array}$ \\
\hline A312-TP304L & 1"PIPE & 501.0 & 0.30 & $\begin{array}{r}40.0 \\
200.0\end{array}$ & 28.42 & 1.7688 & $\begin{array}{l}16700.0 \\
16700.0\end{array}$ \\
\hline
\end{tabular}


PEXCNDS W-320 TANK $241-\mathrm{C}-106$ WASTE RETRIEVAL

PEXCNDS

luor Daniel Northwest

AutoPIPE+4.60 MODEL PAGE

TEMPERATURE AND PRESSURE DATA

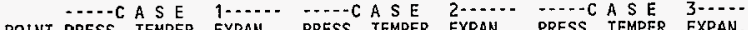
NAME psi deg $F$ in/100ft psi deg $F$ in/100ft psi deg $F$ in/100ft

.............

$\begin{array}{cccc}\star \star \star & \text { SEGMENT A } & & \\ \text { A00 } & 20.00 & 200 & 1.769 \\ \text { A14 } & 20.00 & 200 & 1.769 \\ \star \star \star & \text { SEGMENT B } & & \\ 800 & 20.00 & 200 & 1.769 \\ 812 & 20.00 & 200 & 1.769\end{array}$

$\begin{array}{llll}800 & 20.00 & 200 & 1.769 \\ 812 & 20.00 & 200 & 1.760\end{array}$
W-320 TANK 241-C-106 WASTE RETRIEVAL

Luor Daniel Northwes

AutOPIPE+4.60 MODEL PAGE 10

FORCES AND DISPLACEMENTS

(Force - lb, Moment - $f \mathrm{t}-\mathrm{lb}$, Tran. - in, Rot. - deg, Line - lb/ft

POINT LOAD

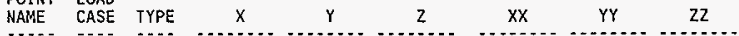

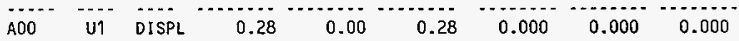

$\begin{array}{lllllllll}\text { A01 U1 DISPL } & 0.28 & 0.00 & 0.28 & 0.000 & 0.000 & 0.000\end{array}$

$\begin{array}{lllllllll}\text { B00 U1 DISPL } & 0.28 & 0.00 & 0.28 & 0.000 & 0.000 & 0.000\end{array}$

$\begin{array}{lllllllll}\text { B01 U1 DISPL } & 0.28 & 0.00 & 0.28 & 0.000 & 0.000 & 0.000\end{array}$


Pipe Stress Analysis and Design Program

\section{Version: 4.60 .03}

Edition: Plus-DOS

Developed and Maintained by

Engineering Design Automation, Inc. 1600 Riviera Ave., Suite 300
ANALYSIS SUMMARY

Current model revision number : 31

Static - Date and rime of analysis Model Revision Number Dec 22, $1997 \quad 2: 47 \mathrm{PM}$ Number of load cases 31 Lod cases analyzed ................ GR I1 W1 W2 U1 Gaps/Friction/Yielding considered ..... No Hanger design run $\ldots \ldots \ldots \ldots \ldots \ldots \ldots$. No Cut short included $\ldots \ldots \ldots \ldots \ldots \ldots \ldots$ No Weight of contents included $\ldots . . \ldots \ldots$.... Yes Number of mass points per span ......... Automatic Pressure stiffening case .............. 0 Water elevation for buoyancy loads .... Not considered Wind analysis method ................. Normal

Modal - Date and Time of analysis .......... Dec 22, 1997 2:47 PM Model Revision Number ............... 31

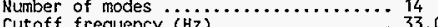
Cutoff frequency ( $\mathrm{Hz}$ ) $\ldots \ldots \ldots \ldots \ldots \ldots . .33 .0$ Weight of contents included ............ Yes Number of mass points per span ......... Automatic Pressure stiffening case .............. 0 Water elevation for buoyancy loads ..... Not considered Wind analysis method ................. Normal

Response - Date and Time of analys is .......... Dec 22, 1997 2:47 PM Model Revision Number ............... 31

Number of load cases $\ldots \ldots \ldots \ldots \ldots \ldots, \ldots, 1$ Load cases analyzed ................. R1 Date and time of modal analysis ....... Dec 22, $1997 \quad 2: 47$ PM

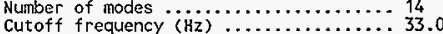
Cutoff frequency (kz) Model revision of modal analysis $\ldots \ldots \ldots . \ldots 31$ Weight of contents included ............ Number of mass points per span ........... Automatic Pressure stiffening case .............. Not considered Wind analysis method .................. Normal 


PEXCNDS W-320 TANK $241-\mathrm{C}-106$ WASTE RETRIEVAL
$12 / 22 / 97$

CODE COMPLIANCE COMBINATIONS

\begin{tabular}{|c|c|c|c|c|c|c|}
\hline Combination & Category & Method & Load & Factor & Al lowable & Renarks \\
\hline$G R+\operatorname{Max} P$ & Sustain & Sum & $\begin{array}{l}\text { Gravity } \\
\text { Max Long }\end{array}$ & $\begin{array}{l}1.00 \\
1.00\end{array}$ & Automat ic & Default \\
\hline Cold to I1 & Expansion & sum & Thermal 1 & 1.00 & Automatic & Default \\
\hline Sus. + W1 & Occasion & Abs sum & $\begin{array}{l}\text { Wind } 1 \\
\text { Max sus }\end{array}$ & $\begin{array}{l}1.00 \\
1.00\end{array}$ & Automatic & Default \\
\hline Sus. + W2 & Occasion & Abs sum & $\begin{array}{l}\text { Wind } 2 \\
\text { Max Sus }\end{array}$ & $\begin{array}{l}1.00 \\
1.00\end{array}$ & Automat ic & Default \\
\hline Sus. + U1 & Occasion & Abs sum & $\begin{array}{l}\text { User } 1 \\
\text { Max Sus }\end{array}$ & $\begin{array}{l}1.00 \\
1.00\end{array}$ & Automatic & Default \\
\hline Sus. + R1 & Occasion & Abs sum & $\begin{array}{l}\text { Response } 1 \\
\text { Max Sus }\end{array}$ & $\begin{array}{l}1.00 \\
1.00\end{array}$ & Automat ic & Default \\
\hline $\operatorname{Max} P$ & Hoop & & Max Hoop & 1.00 & Automatic & Default \\
\hline SUS+WIND & Occasion & Abs sum & $\begin{array}{l}\text { Wind } 1 \\
\text { Wind } 2 \\
\text { Max Sus }\end{array}$ & $\begin{array}{l}1.00 \\
1.00 \\
1.00\end{array}$ & Automat ic & User \\
\hline SUS + & Occasion & Abs sum & $\begin{array}{l}\text { Response } 1 \\
\text { User } 1 \\
\text { Max Sus }\end{array}$ & $\begin{array}{l}1.00 \\
1.00 \\
1.00\end{array}$ & Automat ic & User \\
\hline
\end{tabular}

OTHER USER COMBINATIONS

\begin{tabular}{lllll} 
Combination & Method & Load & Factor & Remarks \\
\hdashline GR & Sum & Gravity & 1.00 & Default \\
$T 1$ & Sum & Thermal 1 & 1.00 & Default \\
W1 & Sum & Wind 1 & 1.00 & Default \\
W2 & Sum & Wind 2 & 1.00 & Default \\
U1 & Sum & User 1 & 1.00 & Default \\
R1 & Sum & Response 1 & 1.00 & Default \\
GR+T1 & Sum & Gravity & 1.00 & User \\
& & Thermal 1 & 1.00 & \\
TOTAL & Abs & GR+T1 & 1.00 & User
\end{tabular}

TOTAL Abs sum GR+T1 1.00 User
PEXCNDS W-320 TANK $241-\mathrm{C}-106$ WASTE RETRIEVAL
$12 / 22 / 97$

CODE COMPLIANCE

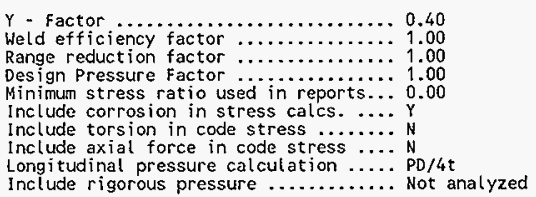

Longitudinal pressure calculation $\ldots \ldots$. PD/4t
include rigorous pressure $\ldots \ldots \ldots$ Not analyzed 
W-320 TANK $241-\mathrm{C}-106$ WASTE RETRIEVAL

AutoPIPE+4.60 RESULT PAGE

\section{WIND LOAD CASES :}

Number of load cases analysed : 2

Wind shape factor : 1.000

Exposure factor for buried pipes : 0.000

Exposure factor for submerged pipes : 0.000

Exposed Segments - A B

Load case 1 - W'

Direction - Global $x$-axis

AMS1 A58.1-82

Basic wind speed at $33 \mathrm{ft}(10 \mathrm{~m}): 90.00 \mathrm{mph}$ Exposure category : $c$

Gust response factor : 1.32

Force coefficient : 0.80

Importance factor : 1.00

\section{PEXCNDS W-320 TANK $241-\mathrm{C}-106$ WASTE RETRIEVAL Fluor Daniel Nor thwes} $12 / 22 / 97$

Load case 2 - W2

Direction - Global z-axis

ANSI A58.1-82

Basic wind speed at $33 \mathrm{ft}(10 \mathrm{~m}): 90.00 \mathrm{mph}$

Exposure category : C

Gust response factor : $\mathbf{1 . 3 2}$

Force coefficient : 0.80

Importance factor : 1.00 
RESPONSE SPECTRUM LOAD CASES :

Number of load cases analysed : 1

Load case 1 - R1

Missing mass : Yes

Combination method : Grouping

X- Spectrum : SC1
Multiplier :

SC1

\begin{tabular}{|c|c|c|c|c|c|}
\hline $\operatorname{ceg}(\mathrm{Hz})$ & ave & Freq $(\mathrm{Hz})$ & Gravs & Freq $(H z)$ & Grave \\
\hline $\begin{array}{r}0.100 \\
0.400 \\
1.640 \\
20.000\end{array}$ & $\begin{array}{l}0.01 \\
0.10 \\
0.42 \\
0.26\end{array}$ & $\begin{array}{r}0.160 \\
0.600 \\
8.000 \\
33.000\end{array}$ & $\begin{array}{l}0.03 \\
0.16 \\
0.42 \\
0.20\end{array}$ & $\begin{array}{r}0.250 \\
1.100 \\
12.000 \\
100.000\end{array}$ & $\begin{array}{l}0.06 \\
0.28 \\
0.34 \\
0.20\end{array}$ \\
\hline
\end{tabular}

$20.000 \quad 0.26$

33.000

0.20

0.34

Y- spectrum:
Multiplier

SCI

Freq(Hz) Grave

$\begin{array}{rr}0.100 & 0.01 \\ 0.400 & 0.10 \\ 1.640 & 0.42 \\ 20.000 & 0.26\end{array}$

Freq(Hz) Grave

\subsection{0}

Grave

Freq(Hz) Grave

0.600

33.000

0.16

0.42
0.20

$\begin{array}{rr}\text { Freq(Hz) } & \text { Grave } \\ 0.250 & 0.06 \\ 1.100 & 0.28 \\ 12.000 & 0.34 \\ 100.000 & 0.20\end{array}$

2- Spectrum : SC1

Muttiplier : 1.00

SC1

Freq( $\mathrm{Hz})$ Grave ) $\begin{array}{ll}0.100 & 0.01 \\ 0.400 & 0.10 \\ 1.640 & 0.42\end{array}$ $20.000 \quad 0.26$

\begin{tabular}{|c|c|c|c|}
\hline $\operatorname{eg}(\mathrm{Hz})$ & Grave & Freq $(\mathrm{Hz})$ & Grave \\
\hline $\begin{array}{r}0.160 \\
0.600 \\
8.000 \\
33.000\end{array}$ & $\begin{array}{l}0.03 \\
0.16 \\
0.42 \\
0.20\end{array}$ & $\begin{array}{r}0.250 \\
1.100 \\
12.000 \\
100.000\end{array}$ & $\begin{array}{l}0.06 \\
0.28 \\
0.34 \\
0.20\end{array}$ \\
\hline
\end{tabular}

FREQUENCIES

\begin{tabular}{crrrrrr}
$\begin{array}{c}\text { Mode } \\
\text { Number }\end{array}$ & $\begin{array}{c}\text { Frequency } \\
\text { (Rads/sec) }\end{array}$ & $\begin{array}{c}\text { Frequency } \\
\text { (Hertz) }\end{array}$ & $\begin{array}{c}\text { Period } \\
\text { (Sec) }\end{array}$ & \multicolumn{3}{c}{ Participation factors } \\
X & & & $Y$ & $Y$ \\
1 & 68.5170 & 10.9048 & 0.092 & -0.070 & 0.002 & 0.001 \\
2 & 70.8816 & 11.2812 & 0.089 & 0.005 & -0.004 & -0.056 \\
3 & 74.4452 & 11.8483 & 0.084 & -0.061 & 0.000 & -0.001 \\
4 & 78.9281 & 12.5618 & 0.080 & 0.000 & -0.052 & 0.000 \\
5 & 100.1454 & 15.9386 & 0.063 & 0.004 & 0.104 & -0.130 \\
6 & 106.4236 & 16.9378 & 0.059 & 0.000 & 0.046 & 0.000 \\
7 & 109.4619 & 17.4214 & 0.057 & 0.182 & -0.001 & 0.002 \\
8 & 109.6878 & 17.4574 & 0.057 & 0.056 & 0.000 & 0.203 \\
9 & 119.7931 & 19.0657 & 0.052 & 0.037 & -0.063 & 0.049 \\
10 & 130.8613 & 20.8272 & 0.048 & -0.032 & 0.000 & 0.155 \\
11 & 131.8344 & 20.9821 & 0.048 & 0.059 & 0.033 & -0.072 \\
12 & 134.0674 & 21.3375 & 0.047 & 0.000 & 0.225 & 0.000 \\
13 & 167.1168 & 26.5975 & 0.038 & -0.004 & 0.185 & -0.075 \\
14 & 183.7632 & 29.2468 & 0.034 & -0.022 & -0.101 & -0.190
\end{tabular}




\begin{tabular}{|c|c|c|c|c|c|c|c|}
\hline $\begin{array}{l}\text { PEXCNDS } \\
12 / 22 / 97\end{array}$ & W-320 TANK & $241-c-106$ & \multicolumn{2}{|c|}{ WASTE RETRIEVAL } & \multicolumn{3}{|c|}{$\begin{array}{l}\text { Fluor Daniel Northwest } \\
\text { AutoPIPE+4.60 RESULT PA }\end{array}$} \\
\hline \multicolumn{8}{|c|}{ DISPLACEMENTS } \\
\hline $\begin{array}{l}\text { Point } \\
\text { name }\end{array}$ & $\begin{array}{l}\text { Load } \\
\text { combination }\end{array}$ & $\underset{X}{\text { TRANSL }}$ & TIONS & ${ }_{2} z^{2}$ & $\begin{array}{l}\text { ROTAT } \\
\mathrm{X}\end{array}$ & ons (deg & ? \\
\hline$* * * s$ & int A beg & & & & & & \\
\hline $\mathrm{A} 00$ & $\begin{array}{l}\text { GR } \\
T 1 \\
\text { W1 } \\
\text { W2 } \\
\text { U1 } \\
\text { R1 } \\
\text { GR+Ti } \\
\text { TOTAL }\end{array}$ & $\begin{array}{l}0.000 \\
0.000 \\
0.000 \\
0.000 \\
0.280 \\
0.000 \\
0.000 \\
0.280\end{array}$ & $\begin{array}{l}0.000 \\
0.000 \\
0.000 \\
0.000 \\
0.000 \\
0.000 \\
0.000 \\
0.000\end{array}$ & $\begin{array}{l}0.000 \\
0.000 \\
0.000 \\
0.000 \\
0.280 \\
0.000 \\
0.000 \\
0.280\end{array}$ & $\begin{array}{l}0.000 \\
0.000 \\
0.000 \\
0.000 \\
0.000 \\
0.000 \\
0.000 \\
0.000\end{array}$ & $\begin{array}{l}0.000 \\
0.000 \\
0.000 \\
0.000 \\
0.000 \\
0.000 \\
0.000 \\
0.000\end{array}$ & $\begin{array}{l}0.000 \\
0.000 \\
0.000 \\
0.000 \\
0.000 \\
0.000 \\
0.000 \\
0.000\end{array}$ \\
\hline $\mathrm{A} 01$ & $\begin{array}{l}\text { GR } \\
\text { I1 } \\
\text { W1 } \\
\text { W2 } \\
\text { U1 } \\
\text { R1 } \\
\text { GR+T1 } 1 \\
\text { TOTAL }\end{array}$ & $\begin{array}{l}0.000 \\
0.000 \\
0.000 \\
0.000 \\
0.280 \\
0.000 \\
0.000 \\
0.280\end{array}$ & $\begin{array}{l}0.000 \\
0.000 \\
0.000 \\
0.000 \\
0.000 \\
0.000 \\
0.000 \\
0.000\end{array}$ & $\begin{array}{l}0.000 \\
0.015 \\
0.000 \\
0.000 \\
0.280 \\
0.000 \\
0.015 \\
0.295\end{array}$ & $\begin{array}{r}0.029 \\
-0.003 \\
0.006 \\
0.018 \\
-0.004 \\
0.008 \\
0.026 \\
0.062\end{array}$ & $\begin{array}{r}0.000 \\
-0.006 \\
0.064 \\
0.001 \\
-0.026 \\
0.007 \\
-0.006 \\
0.105\end{array}$ & $\begin{array}{r}0.003 \\
0.010 \\
-0.137 \\
-0.002 \\
0.023 \\
0.014 \\
0.013 \\
0.190\end{array}$ \\
\hline A02 & $\begin{array}{l}\text { GR } \\
\text { T1 } \\
\text { W1 } \\
\text { W2 } \\
\text { U1 } \\
\text { R1 } \\
\text { GR+T I } \\
\text { TOTAL }\end{array}$ & $\begin{array}{l}0.000 \\
0.000 \\
0.003 \\
0.000 \\
0.279 \\
0.000 \\
0.000 \\
0.283\end{array}$ & $\begin{array}{r}-0.001 \\
0.000 \\
0.000 \\
-0.001 \\
0.000 \\
0.000 \\
-0.001 \\
0.003\end{array}$ & $\begin{array}{l}0.000 \\
0.018 \\
0.000 \\
0.000 \\
0.280 \\
0.000 \\
0.018 \\
0.298\end{array}$ & $\begin{array}{r}0.050 \\
-0.006 \\
0.010 \\
0.032 \\
-0.007 \\
0.015 \\
0.044 \\
0.108\end{array}$ & $\begin{array}{r}0.000 \\
-0.011 \\
0.110 \\
0.003 \\
-0.046 \\
0.012 \\
-0.011 \\
0.182\end{array}$ & $\begin{array}{r}0.004 \\
0.012 \\
-0.164 \\
-0.003 \\
0.027 \\
0.017 \\
0.016 \\
0.227\end{array}$ \\
\hline $\mathrm{A} 03$ & $\begin{array}{l}\text { GR } \\
\text { T1 } \\
\text { W1 } \\
\text { W2 } \\
\text { U1 } \\
\text { R1 } \\
\text { GR+T1 } \\
\text { TOTAL }\end{array}$ & $\begin{array}{r}0.000 \\
-0.001 \\
0.007 \\
0.000 \\
0.277 \\
0.001 \\
-0.001 \\
0.286\end{array}$ & $\begin{array}{r}-0.003 \\
0.000 \\
-0.001 \\
-0.002 \\
0.000 \\
0.001 \\
-0.003 \\
0.007\end{array}$ & $\begin{array}{l}0.000 \\
0.021 \\
0.000 \\
0.000 \\
0.280 \\
0.000 \\
0.021 \\
0.301\end{array}$ & $\begin{array}{r}0.056 \\
-0.007 \\
0.012 \\
0.038 \\
-0.009 \\
0.017 \\
0.049 \\
0.124\end{array}$ & $\begin{array}{r}0.000 \\
-0.013 \\
0.125 \\
0.003 \\
-0.054 \\
0.014 \\
-0.013 \\
0.209\end{array}$ & $\begin{array}{r}0.004 \\
0.013 \\
-0.175 \\
-0.003 \\
0.029 \\
0.019 \\
0.017 \\
0.243\end{array}$ \\
\hline $\mathrm{A} 04$ & $\begin{array}{l}\text { GR } \\
\text { T1 } \\
\text { W1 } \\
\text { W2 } \\
\text { U1 } \\
\text { R1 } \\
\text { GR+II } \\
\text { TOTAL }\end{array}$ & $\begin{array}{r}0.000 \\
-0.001 \\
0.012 \\
0.000 \\
0.275 \\
0.001 \\
-0.001 \\
0.290\end{array}$ & $\begin{array}{r}-0.006 \\
0.001 \\
-0.001 \\
-0.004 \\
0.001 \\
0.002 \\
-0.005 \\
0.012\end{array}$ & $\begin{array}{l}0.000 \\
0.024 \\
0.000 \\
0.000 \\
0.280 \\
0.000 \\
0.024 \\
0.304\end{array}$ & $\begin{array}{r}0.058 \\
-0.007 \\
0.013 \\
0.041 \\
-0.009 \\
0.018 \\
0.051 \\
0.132\end{array}$ & $\begin{array}{r}0.000 \\
-0.014 \\
0.131 \\
0.003 \\
-0.058 \\
0.015 \\
-0.014 \\
0.221\end{array}$ & $\begin{array}{r}0.005 \\
0.013 \\
-0.181 \\
-0.003 \\
0.030 \\
0.019 \\
0.018 \\
0.251\end{array}$ \\
\hline
\end{tabular}

\section{W-320 TANK $241-C-106$ WASTE RETRIEVAI \\ Fluor Daniel Northwest \\ $12 / 22 / 97$ \\ W20 TANK $24 \uparrow-C-106$ WASTE RETRIEV}

D I SP LACEMENTS

\begin{tabular}{|c|c|c|c|c|c|c|c|}
\hline \multirow{2}{*}{$\begin{array}{l}\text { Point } \\
\text { name }\end{array}$} & \multirow{2}{*}{$\begin{array}{l}\text { Load } \\
\text { combination }\end{array}$} & \multicolumn{3}{|c|}{ TRANSLATLONS (in ${ }_{x}^{\prime}$} & \multirow{2}{*}{\multicolumn{3}{|c|}{$\begin{array}{l}\text { ROTATIONS (deg } \\
X\end{array}$}} \\
\hline & & & & & & & \\
\hline A05 & $\begin{array}{l}\text { GR } \\
T 1 \\
W 1 \\
\text { W2 } \\
\text { U1 } \\
\text { R1 } \\
\text { GR+T1 } \\
\text { TOTAL }\end{array}$ & $\begin{array}{r}0.000 \\
-0.002 \\
0.017 \\
0.000 \\
0.273 \\
0.002 \\
-0.002 \\
0.294\end{array}$ & $\begin{array}{r}-0.008 \\
0.001 \\
-0.002 \\
-0.005 \\
0.001 \\
0.002 \\
-0.007 \\
0.017\end{array}$ & $\begin{array}{l}0.000 \\
0.027 \\
0.000 \\
0.000 \\
0.280 \\
0.000 \\
0.027 \\
0.307\end{array}$ & $\begin{array}{r}0.059 \\
-0.008 \\
0.014 \\
0.044 \\
-0.010 \\
0.019 \\
0.051 \\
0.138\end{array}$ & $\begin{array}{r}0.000 \\
-0.014 \\
0.135 \\
0.003 \\
-0.061 \\
0.015 \\
-0.014 \\
0.230\end{array}$ & $\begin{array}{r}0.005 \\
0.013 \\
-0.187 \\
-0.003 \\
0.031 \\
0.020 \\
0.018 \\
0.259\end{array}$ \\
\hline$A 06$ & $\begin{array}{l}\text { GR } \\
\text { T1 } \\
\text { W1 } \\
\text { W2 } \\
\text { U1 } \\
\text { R1 } \\
\text { GR+T1 } \\
\text { TOTAL. }\end{array}$ & $\begin{array}{r}0.000 \\
-0.002 \\
0.022 \\
0.001 \\
0.270 \\
0.002 \\
-0.002 \\
0.298\end{array}$ & $\begin{array}{r}-0.010 \\
0.001 \\
-0.002 \\
-0.007 \\
0.002 \\
0.003 \\
-0.009 \\
0.022\end{array}$ & $\begin{array}{l}0.000 \\
0.030 \\
0.000 \\
0.000 \\
0.280 \\
0.000 \\
0.030 \\
0.310\end{array}$ & $\begin{array}{r}0.061 \\
-0.009 \\
0.016 \\
0.050 \\
-0.011 \\
0.021 \\
0.052 \\
0.150\end{array}$ & $\begin{array}{r}0.000 \\
-0.016 \\
0.140 \\
0.004 \\
-0.068 \\
0.016 \\
-0.016 \\
0.243\end{array}$ & $\begin{array}{r}0.005 \\
0.014 \\
-0.198 \\
-0.004 \\
0.033 \\
0.021 \\
0.019 \\
0.275\end{array}$ \\
\hline $\mathrm{A} 07 \mathrm{~N}$ & $\begin{array}{l}\text { GR } \\
T 1 \\
W 1 \\
\text { W2 } \\
\text { U1 } \\
\text { R1 } \\
\text { GR+T1 } \\
\text { TOTAL }\end{array}$ & $\begin{array}{r}0.000 \\
-0.003 \\
0.024 \\
0.001 \\
0.269 \\
0.003 \\
-0.003 \\
0.299\end{array}$ & $\begin{array}{r}-0.011 \\
0.001 \\
-0.002 \\
-0.008 \\
0.002 \\
0.003 \\
-0.009 \\
0.024\end{array}$ & $\begin{array}{l}0.000 \\
0.031 \\
0.000 \\
0.000 \\
0.280 \\
0.000 \\
0.031 \\
0.311\end{array}$ & $\begin{array}{r}0.061 \\
-0.010 \\
0.018 \\
0.055 \\
-0.013 \\
0.022 \\
0.051 \\
0.159\end{array}$ & $\begin{array}{r}0.000 \\
-0.017 \\
0.142 \\
0.004 \\
-0.074 \\
0.016 \\
-0.017 \\
0.253\end{array}$ & $\begin{array}{r}0.005 \\
0.015 \\
-0.209 \\
-0.004 \\
0.034 \\
0.022 \\
0.020 \\
0.289\end{array}$ \\
\hline $\mathrm{A} 07 \mathrm{M}$ & $\begin{array}{l}\text { GR } \\
T 1 \\
W T \\
W 2 \\
\text { U1 } \\
R 1 \\
\text { GR+T1 } \\
\text { TOTAL }\end{array}$ & $\begin{array}{r}0.000 \\
-0.003 \\
0.026 \\
0.001 \\
0.268 \\
0.003 \\
-0.003 \\
0.301\end{array}$ & $\begin{array}{r}-0.011 \\
0.002 \\
-0.003 \\
-0.008 \\
0.002 \\
0.004 \\
-0.009 \\
0.026\end{array}$ & $\begin{array}{l}0.000 \\
0.032 \\
0.000 \\
0.000 \\
0.280 \\
0.000 \\
0.032 \\
0.313\end{array}$ & $\begin{array}{r}0.063 \\
-0.013 \\
0.021 \\
0.067 \\
-0.016 \\
0.026 \\
0.050 \\
0.180\end{array}$ & $\begin{array}{r}0.000 \\
-0.019 \\
0.148 \\
0.004 \\
-0.085 \\
0.018 \\
-0.019 \\
0.273\end{array}$ & $\begin{array}{r}0.005 \\
0.016 \\
-0.219 \\
-0.004 \\
0.038 \\
0.023 \\
0.021 \\
0.305\end{array}$ \\
\hline $\mathrm{A} 07 \mathrm{~F}$ & $\begin{array}{l}\text { GR } \\
\text { T1 } \\
W 1 \\
W 2 \\
\text { U1 } \\
R 1 \\
\text { GR+T1 } \\
\text { TOTAL }\end{array}$ & $\begin{array}{r}0.000 \\
-0.003 \\
0.029 \\
0.001 \\
0.268 \\
0.003 \\
-0.003 \\
0.304\end{array}$ & $\begin{array}{r}-0.011 \\
0.003 \\
-0.003 \\
-0.008 \\
0.002 \\
0.004 \\
-0.009 \\
0.025\end{array}$ & $\begin{array}{l}0.001 \\
0.032 \\
0.000 \\
0.001 \\
0.280 \\
0.000 \\
0.033 \\
0.314\end{array}$ & $\begin{array}{r}0.063 \\
-0.015 \\
0.025 \\
0.078 \\
-0.018 \\
0.029 \\
0.048 \\
0.198\end{array}$ & $\begin{array}{r}0.000 \\
-0.020 \\
0.152 \\
0.005 \\
-0.092 \\
0.018 \\
-0.020 \\
0.286\end{array}$ & $\begin{array}{r}0.006 \\
0.017 \\
-0.233 \\
-0.004 \\
0.042 \\
0.025 \\
0.023 \\
0.327\end{array}$ \\
\hline
\end{tabular}


D I SPLACEMEN T S

\begin{tabular}{|c|c|c|c|c|c|c|c|}
\hline \multirow{3}{*}{$\begin{array}{l}\text { Point } \\
\text { name } \\
\text { A08 N }\end{array}$} & \multirow{3}{*}{$\begin{array}{l}\text { Load } \\
\text { combination } \\
\text { GR } \\
\text { T1 } \\
\text { W1 } \\
\text { W2 } \\
\text { U1 } \\
\text { R1 } \\
\text { GR+T1 } \\
\text { TOTAL }\end{array}$} & \multicolumn{3}{|c|}{ 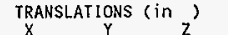 } & \multirow{2}{*}{\multicolumn{3}{|c|}{$\begin{array}{l}\text { ROTATIONS (deg } \\
X\end{array}$}} \\
\hline & & $x$ & & z & & & \\
\hline & & $\begin{array}{r}-0.001 \\
-0.005 \\
0.058 \\
0.001 \\
0.263 \\
0.006 \\
-0.006 \\
0.334\end{array}$ & $\begin{array}{r}-0.011 \\
0.012 \\
-0.003 \\
-0.008 \\
0.002 \\
0.004 \\
0.001 \\
0.017\end{array}$ & $\begin{array}{l}0.008 \\
0.030 \\
0.004 \\
0.011 \\
0.277 \\
0.004 \\
0.038 \\
0.334\end{array}$ & $\begin{array}{r}0.066 \\
-0.016 \\
0.028 \\
0.085 \\
-0.021 \\
0.034 \\
0.051 \\
0.219\end{array}$ & $\begin{array}{r}0.000 \\
-0.030 \\
0.162 \\
0.007 \\
-0.153 \\
0.023 \\
-0.030 \\
0.375\end{array}$ & $\begin{array}{r}0.008 \\
0.020 \\
-0.261 \\
-0.005 \\
0.047 \\
0.028 \\
0.027 \\
0.368\end{array}$ \\
\hline$A 08 \mathrm{M}$ & $\begin{array}{l}\text { GR } \\
\text { T1 } \\
\text { W1 } \\
\text { W2 } \\
\text { U1 } \\
\text { R1 } \\
\text { GR+TI } \\
\text { TOTAL }\end{array}$ & $\begin{array}{r}-0.001 \\
-0.005 \\
0.061 \\
0.001 \\
0.262 \\
0.007 \\
-0.006 \\
0.336\end{array}$ & $\begin{array}{r}-0.012 \\
0.013 \\
-0.003 \\
-0.009 \\
0.002 \\
0.004 \\
0.001 \\
0.019\end{array}$ & $\begin{array}{l}0.009 \\
0.030 \\
0.004 \\
0.012 \\
0.277 \\
0.004 \\
0.039 \\
0.336\end{array}$ & $\begin{array}{r}0.067 \\
-0.014 \\
0.027 \\
0.079 \\
-0.019 \\
0.033 \\
0.053 \\
0.211\end{array}$ & $\begin{array}{r}0.000 \\
-0.031 \\
0.162 \\
0.007 \\
-0.160 \\
0.024 \\
-0.031 \\
0.385\end{array}$ & $\begin{array}{r}0.008 \\
0.020 \\
-0.260 \\
-0.005 \\
0.049 \\
0.028 \\
0.028 \\
0.370\end{array}$ \\
\hline$A 08 F$ & $\begin{array}{l}\text { GR } \\
\text { I1 } \\
\text { W1 } \\
\text { W2 } \\
\text { U1 } \\
\text { R1 } \\
\text { GR+T1 } \\
\text { TOTAL }\end{array}$ & $\begin{array}{r}-0.001 \\
-0.006 \\
0.063 \\
0.001 \\
0.260 \\
0.007 \\
-0.007 \\
0.338\end{array}$ & $\begin{array}{r}-0.012 \\
0.013 \\
-0.003 \\
-0.009 \\
0.002 \\
0.004 \\
0.001 \\
0.020\end{array}$ & $\begin{array}{l}0.009 \\
0.031 \\
0.004 \\
0.012 \\
0.277 \\
0.004 \\
0.040 \\
0.338\end{array}$ & $\begin{array}{r}0.068 \\
-0.012 \\
0.024 \\
0.073 \\
-0.018 \\
0.032 \\
0.056 \\
0.202\end{array}$ & $\begin{array}{r}0.000 \\
-0.033 \\
0.163 \\
0.008 \\
-0.170 \\
0.024 \\
-0.033 \\
0.398\end{array}$ & $\begin{array}{r}0.008 \\
0.020 \\
-0.260 \\
-0.005 \\
0.050 \\
0.028 \\
0.028 \\
0.372\end{array}$ \\
\hline A09 & $\begin{array}{l}\text { GR } \\
\text { T1 } \\
W 1 \\
W 2 \\
\text { U1 } \\
R 1 \\
\text { GR+T1 } \\
\text { TOTAL }\end{array}$ & $\begin{array}{l}0.000 \\
0.000 \\
0.000 \\
0.000 \\
0.000 \\
0.000 \\
0.000 \\
0.000\end{array}$ & $\begin{array}{l}0.000 \\
0.000 \\
0.000 \\
0.000 \\
0.000 \\
0.000 \\
0.000 \\
0.000\end{array}$ & $\begin{array}{l}0.009 \\
0.127 \\
0.004 \\
0.012 \\
0.277 \\
0.005 \\
0.136 \\
0.434\end{array}$ & $\begin{array}{r}-0.001 \\
0.014 \\
-0.011 \\
-0.029 \\
0.007 \\
0.024 \\
0.013 \\
0.085\end{array}$ & $\begin{array}{r}0.002 \\
0.118 \\
0.138 \\
-0.028 \\
-0.112 \\
0.030 \\
0.120 \\
0.428\end{array}$ & $\begin{array}{r}0.030 \\
0.013 \\
-0.159 \\
-0.004 \\
0.031 \\
0.021 \\
0.043 \\
0.258\end{array}$ \\
\hline A10 & $\begin{array}{l}\text { GR } \\
\text { T1 } \\
\text { W1 } \\
\text { W2 } \\
\text { U1 } \\
\text { R1 } \\
\text { GR+T1 } \\
\text { TOTAL }\end{array}$ & $\begin{array}{r}0.001 \\
0.200 \\
0.098 \\
-0.019 \\
0.023 \\
0.006 \\
0.201 \\
0.347\end{array}$ & $\begin{array}{l}0.000 \\
0.000 \\
0.000 \\
0.000 \\
0.000 \\
0.000 \\
0.000 \\
0.000\end{array}$ & $\begin{array}{l}0.009 \\
0.239 \\
0.004 \\
0.012 \\
0.277 \\
0.005 \\
0.248 \\
0.546\end{array}$ & $\begin{array}{r}-0.041 \\
-0.007 \\
0.010 \\
0.013 \\
-0.004 \\
0.038 \\
-0.048 \\
0.113\end{array}$ & $\begin{array}{r}-0.004 \\
-0.001 \\
-0.496 \\
0.064 \\
-0.061 \\
0.031 \\
-0.005 \\
0.658\end{array}$ & $\begin{array}{r}0.056 \\
0.004 \\
-0.042 \\
-0.004 \\
0.009 \\
0.019 \\
0.060 \\
0.132\end{array}$ \\
\hline
\end{tabular}

DI SPLACEMENTS

\begin{tabular}{|c|c|c|c|c|c|c|c|}
\hline \multirow{3}{*}{$\begin{array}{l}\text { Point } \\
\text { name } \\
\text { A11 N }\end{array}$} & Load & \multirow{2}{*}{\multicolumn{3}{|c|}{$\underset{X}{\text { TRANSLATIONS (in }}{ }_{Y}$ ) }} & \multirow{2}{*}{\multicolumn{2}{|c|}{${ }_{X}^{\text {ROTATIONS (deg }}$}} & \multirow{2}{*}{ z } \\
\hline & combination & & & & & & \\
\hline & $\begin{array}{l}\text { GR } \\
\text { T1 } \\
\text { W1 } \\
\text { W2 } \\
\text { U1 } \\
\text { R1 } \\
\text { GR+T1 } \\
\text { TOTAL }\end{array}$ & $\begin{array}{r}0.000 \\
0.189 \\
0.005 \\
-0.002 \\
0.002 \\
0.000 \\
0.189 \\
0.198\end{array}$ & $\begin{array}{r}0.004 \\
0.001 \\
-0.002 \\
-0.002 \\
0.001 \\
0.008 \\
0.006 \\
0.019\end{array}$ & $\begin{array}{l}0.009 \\
0.256 \\
0.004 \\
0.012 \\
0.277 \\
0.005 \\
0.265 \\
0.563\end{array}$ & $\begin{array}{r}-0.012 \\
-0.006 \\
0.011 \\
0.012 \\
-0.004 \\
0.041 \\
-0.019 \\
0.087\end{array}$ & $\begin{array}{r}-0.007 \\
-0.114 \\
-0.403 \\
0.111 \\
-0.159 \\
0.028 \\
-0.120 \\
0.822\end{array}$ & $\begin{array}{r}0.059 \\
0.003 \\
-0.024 \\
-0.003 \\
0.005 \\
0.019 \\
0.063 \\
0.115\end{array}$ \\
\hline A11 M & $\begin{array}{l}\text { GR } \\
T 1 \\
\text { W1 } \\
\text { W2 } \\
\text { U1 } \\
\text { R1 } \\
\text { GR+T1 } \\
\text { TOTAL }\end{array}$ & $\begin{array}{l}0.000 \\
0.187 \\
0.002 \\
0.000 \\
0.001 \\
0.000 \\
0.187 \\
0.190\end{array}$ & $\begin{array}{r}0.004 \\
0.001 \\
-0.002 \\
-0.003 \\
0.001 \\
0.008 \\
0.006 \\
0.019\end{array}$ & $\begin{array}{l}0.009 \\
0.256 \\
0.003 \\
0.013 \\
0.276 \\
0.005 \\
0.265 \\
0.561\end{array}$ & $\begin{array}{r}-0.012 \\
-0.006 \\
0.011 \\
0.012 \\
-0.004 \\
0.041 \\
-0.018 \\
0.087\end{array}$ & $\begin{array}{r}-0.007 \\
-0.131 \\
-0.371 \\
0.118 \\
-0.175 \\
0.027 \\
-0.138 \\
0.830\end{array}$ & $\begin{array}{r}0.060 \\
0.003 \\
-0.023 \\
-0.003 \\
0.005 \\
0.019 \\
0.063 \\
0.113\end{array}$ \\
\hline $\mathrm{A} 11 \mathrm{~F}$ & $\begin{array}{l}\text { GR } \\
\text { T1 } \\
\text { W1 } \\
\text { W2 } \\
\text { U1 } \\
\text { R1 } \\
\text { GR+T } 1 \\
\text { TOTAL }\end{array}$ & $\begin{array}{l}0.000 \\
0.186 \\
0.000 \\
0.000 \\
0.000 \\
0.000 \\
0.186 \\
0.186\end{array}$ & $\begin{array}{r}0.004 \\
0.001 \\
-0.002 \\
-0.003 \\
0.001 \\
0.009 \\
0.005 \\
0.019\end{array}$ & $\begin{array}{r}0.009 \\
0.255 \\
-0.001 \\
0.014 \\
0.275 \\
0.005 \\
0.264 \\
0.558\end{array}$ & $\begin{array}{r}-0.012 \\
-0.006 \\
0.011 \\
0.012 \\
-0.004 \\
0.041 \\
-0.018 \\
0.086\end{array}$ & $\begin{array}{r}-0.007 \\
-0.149 \\
-0.338 \\
0.124 \\
-0.191 \\
0.026 \\
-0.156 \\
0.836\end{array}$ & $\begin{array}{r}0.060 \\
0.003 \\
-0.022 \\
-0.003 \\
0.005 \\
0.019 \\
0.063 \\
0.112\end{array}$ \\
\hline A12 & $\begin{array}{l}\text { GR } \\
\text { T1 } \\
W 1 \\
W 2 \\
\text { W1 } \\
R 1 \\
\text { GR+T1 } \\
\text { TOTAL }\end{array}$ & $\begin{array}{l}0.000 \\
0.156 \\
0.000 \\
0.000 \\
0.000 \\
0.000 \\
0.156 \\
0.157\end{array}$ & $\begin{array}{r}-0.012 \\
0.001 \\
0.002 \\
-0.001 \\
0.000 \\
0.010 \\
-0.011 \\
0.025\end{array}$ & $\begin{array}{r}0.006 \\
0.172 \\
-0.057 \\
0.048 \\
0.181 \\
0.008 \\
0.178 \\
0.472\end{array}$ & $\begin{array}{r}-0.010 \\
-0.005 \\
0.010 \\
0.010 \\
-0.004 \\
0.034 \\
-0.015 \\
0.073\end{array}$ & $\begin{array}{r}-0.010 \\
-0.294 \\
-0.013 \\
0.022 \\
-0.317 \\
0.008 \\
-0.304 \\
0.664\end{array}$ & $\begin{array}{r}0.015 \\
0.002 \\
-0.003 \\
-0.003 \\
0.001 \\
0.009 \\
0.017 \\
0.033\end{array}$ \\
\hline $\mathrm{A} 13$ & $\begin{array}{l}\text { GR } \\
\text { T1 } \\
\text { W1 } \\
\text { W2 } \\
\text { U1 } \\
\text { R1 } \\
\text { GR+T1 } \\
\text { TOTAL }\end{array}$ & $\begin{array}{l}0.000 \\
0.103 \\
0.000 \\
0.000 \\
0.000 \\
0.000 \\
0.103 \\
0.103\end{array}$ & $\begin{array}{l}0.000 \\
0.000 \\
0.000 \\
0.000 \\
0.000 \\
0.000 \\
0.000 \\
0.000\end{array}$ & $\begin{array}{l}0.000 \\
0.000 \\
0.000 \\
0.000 \\
0.000 \\
0.000 \\
0.000 \\
0.000\end{array}$ & $\begin{array}{r}-0.007 \\
-0.003 \\
0.006 \\
0.007 \\
-0.002 \\
0.023 \\
-0.010 \\
0.048\end{array}$ & $\begin{array}{r}-0.006 \\
-0.175 \\
0.094 \\
0.016 \\
-0.180 \\
0.019 \\
-0.180 \\
0.489\end{array}$ & $\begin{array}{r}0.004 \\
0.000 \\
0.004 \\
-0.001 \\
-0.001 \\
0.020 \\
0.004 \\
0.030\end{array}$ \\
\hline
\end{tabular}




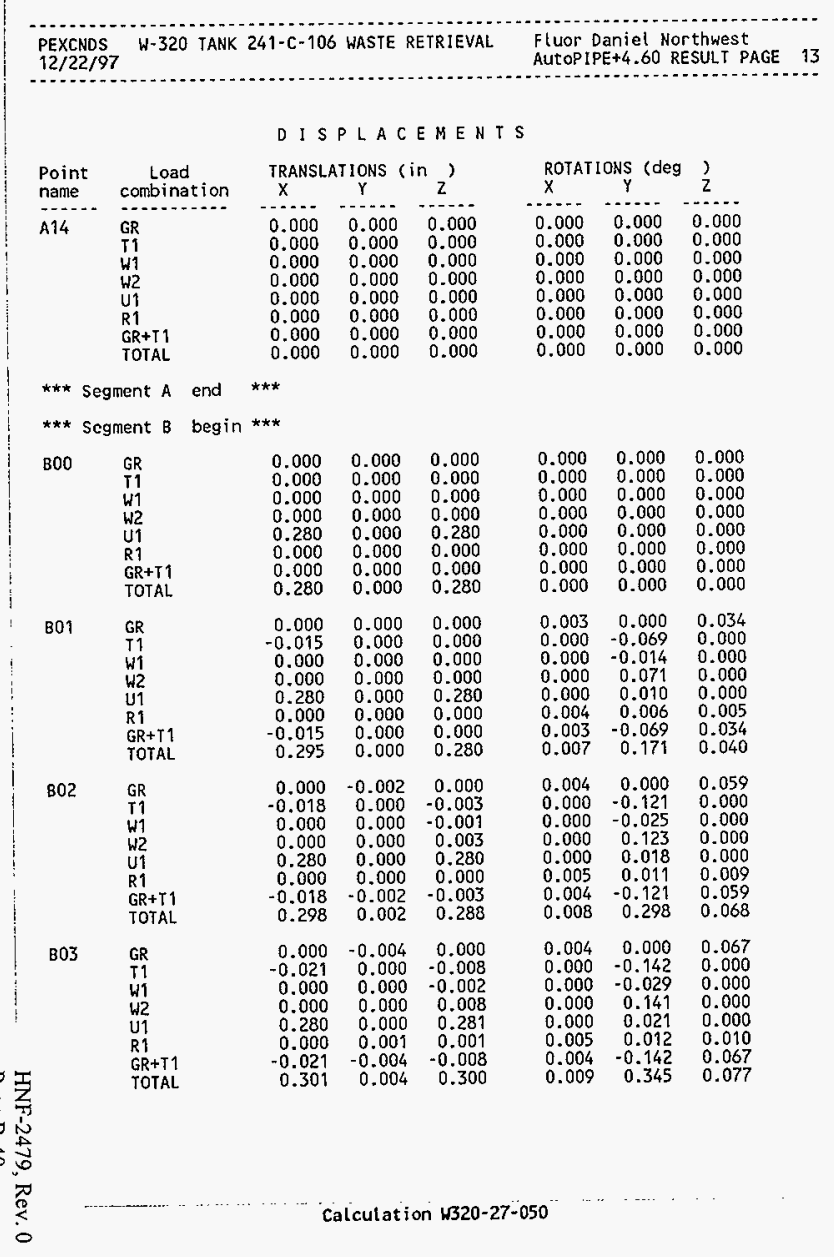

\begin{tabular}{|c|c|c|c|c|c|c|c|}
\hline \multirow{3}{*}{$\begin{array}{l}\text { PEXCNDS } \\
12 / 22 / 97 \\
\\
\text { Point } \\
\text { name }\end{array}$} & \multirow{2}{*}{ W-320 TANK } & $241-c-106$ & \multicolumn{2}{|c|}{ WASTE RETRIEVAL } & \multicolumn{3}{|c|}{$\begin{array}{l}\text { Fluor Daniel Northwest } \\
\text { Aut OPIPE+4.60 RESULT PAG }\end{array}$} \\
\hline & & \multicolumn{5}{|c|}{ DISPLACEMENTS } & \multirow[b]{2}{*}{92} \\
\hline & $\begin{array}{l}\text { Load } \\
\text { combination }\end{array}$ & $\begin{array}{l}\text { TRANSLA } \\
X \\
-\end{array}$ & Tlans (i & in $z^{\prime}$ & $\begin{array}{l}\text { ROTAT } \\
x \\
-\end{array}$ & IONS (deg & \\
\hline B04 & $\begin{array}{l}\text { GR } \\
\text { T1 } \\
\text { W1 } \\
\text { W2 } \\
\text { U1 } \\
\text { R1 } \\
\text { GR+TI } \\
\text { TOTAL }\end{array}$ & $\begin{array}{r}0.000 \\
-0.024 \\
0.000 \\
0.000 \\
0.280 \\
0.000 \\
-0.024 \\
0.304\end{array}$ & $\begin{array}{r}-0.007 \\
0.000 \\
0.000 \\
0.000 \\
0.000 \\
0.001 \\
-0.007 \\
0.008\end{array}$ & $\begin{array}{r}0.000 \\
-0.014 \\
-0.003 \\
0.014 \\
0.282 \\
0.001 \\
-0.014 \\
0.313\end{array}$ & $\begin{array}{l}0.004 \\
0.000 \\
0.000 \\
0.000 \\
0.000 \\
0.005 \\
0.004 \\
0.009\end{array}$ & $\begin{array}{r}0.000 \\
-0.152 \\
-0.031 \\
0.149 \\
0.022 \\
0.013 \\
-0.152 \\
0.366\end{array}$ & $\begin{array}{l}0.070 \\
0.000 \\
0.000 \\
0.000 \\
0.000 \\
0.011 \\
0.070 \\
0.080\end{array}$ \\
\hline B05 & $\begin{array}{l}\text { GR } \\
T 1 \\
W 1 \\
W 2 \\
\text { U1 } \\
R 1 \\
\text { GR+I1 } \\
\text { TOTAL }\end{array}$ & $\begin{array}{r}0.000 \\
-0.027 \\
0.000 \\
0.000 \\
0.280 \\
0.000 \\
-0.027 \\
0.307\end{array}$ & $\begin{array}{r}-0.009 \\
0.000 \\
0.000 \\
0.000 \\
0.000 \\
0.001 \\
-0.009 \\
0.011\end{array}$ & $\begin{array}{r}0.000 \\
-0.020 \\
-0.004 \\
0.019 \\
0.283 \\
0.002 \\
-0.020 \\
0.328\end{array}$ & $\begin{array}{l}0.004 \\
0.000 \\
0.000 \\
0.000 \\
0.000 \\
0.005 \\
0.004 \\
0.010\end{array}$ & $\begin{array}{r}0.000 \\
-0.161 \\
-0.032 \\
0.155 \\
0.023 \\
0.013 \\
-0.161 \\
0.385\end{array}$ & $\begin{array}{l}0.072 \\
0.000 \\
0.000 \\
0.000 \\
0.000 \\
0.011 \\
0.072 \\
0.083\end{array}$ \\
\hline B06 & $\begin{array}{l}\text { GR } \\
\text { T1 } \\
\text { W1 } \\
\text { W2 } \\
\text { U1 } \\
\text { R1 } \\
\text { GR+T1 } \\
\text { TOTAL }\end{array}$ & $\begin{array}{r}0.000 \\
-0.030 \\
0.000 \\
0.000 \\
0.280 \\
0.000 \\
-0.030 \\
0.310\end{array}$ & $\begin{array}{r}-0.012 \\
0.000 \\
0.000 \\
0.000 \\
0.000 \\
0.002 \\
-0.012 \\
0.014\end{array}$ & $\begin{array}{r}0.000 \\
-0.026 \\
-0.005 \\
0.025 \\
0.284 \\
0.002 \\
-0.026 \\
0.342\end{array}$ & $\begin{array}{l}0.005 \\
0.000 \\
0.000 \\
0.000 \\
0.000 \\
0.006 \\
0.005 \\
0.010\end{array}$ & $\begin{array}{r}0.000 \\
-0.178 \\
-0.035 \\
0.163 \\
0.025 \\
0.014 \\
-0.178 \\
0.416\end{array}$ & $\begin{array}{l}0.075 \\
0.000 \\
0.000 \\
0.000 \\
0.000 \\
0.012 \\
0.075 \\
0.087\end{array}$ \\
\hline $\mathrm{B} 06 \mathrm{~A}$ & $\begin{array}{l}\text { GR } \\
\text { T1 } \\
W 1 \\
W 2 \\
\text { U1 } \\
\text { U1 } \\
\text { GR+I1 } \\
\text { TOTAL }\end{array}$ & $\begin{array}{r}0.000 \\
-0.083 \\
0.000 \\
0.000 \\
0.280 \\
0.000 \\
-0.083 \\
0.364\end{array}$ & $\begin{array}{r}-0.044 \\
0.000 \\
0.000 \\
0.000 \\
0.000 \\
0.008 \\
-0.044 \\
0.052\end{array}$ & $\begin{array}{r}0.000 \\
-0.276 \\
-0.029 \\
0.090 \\
0.303 \\
0.009 \\
-0.276 \\
0.707\end{array}$ & $\begin{array}{l}0.016 \\
0.000 \\
0.000 \\
0.000 \\
0.000 \\
0.019 \\
0.016 \\
0.035\end{array}$ & $\begin{array}{r}0.000 \\
-0.478 \\
0.013 \\
-0.070 \\
0.001 \\
0.008 \\
-0.478 \\
0.570\end{array}$ & $\begin{array}{r}-0.023 \\
0.000 \\
0.000 \\
0.000 \\
0.000 \\
0.008 \\
-0.023 \\
0.031\end{array}$ \\
\hline $\mathrm{B} 07 \mathrm{~N}$ & $\begin{array}{l}\text { GR } \\
T 1 \\
W 1 \\
W 2 \\
\text { U1 } \\
R 1 \\
\text { GR+T1 } \\
\text { TOTAL }\end{array}$ & $\begin{array}{r}0.000 \\
-0.121 \\
0.000 \\
0.000 \\
0.280 \\
0.000 \\
-0.121 \\
0.402\end{array}$ & $\begin{array}{r}-0.010 \\
0.000 \\
0.000 \\
0.000 \\
0.000 \\
0.004 \\
-0.0100 \\
0.014\end{array}$ & $\begin{array}{r}0.000 \\
-0.439 \\
0.022 \\
0.041 \\
0.275 \\
0.005 \\
-0.439 \\
0.781\end{array}$ & $\begin{array}{l}0.024 \\
0.000 \\
0.000 \\
0.000 \\
0.000 \\
0.029 \\
0.024 \\
0.053\end{array}$ & $\begin{array}{r}0.000 \\
-0.174 \\
0.238 \\
-0.015 \\
-0.145 \\
0.024 \\
-0.174 \\
0.596\end{array}$ & $\begin{array}{r}-0.107 \\
0.000 \\
0.000 \\
0.000 \\
0.000 \\
0.020 \\
-0.107 \\
0.126\end{array}$ \\
\hline
\end{tabular}




\begin{tabular}{|c|c|c|c|c|c|c|c|}
\hline $\begin{array}{l}\text { PEXCND } \\
12 / 22\end{array}$ & $w-3 c$ & -7 & |AST & VAL & $\begin{array}{l}\text { Fluor } \\
\text { Autop }\end{array}$ & $\begin{array}{l}\text { niel Nor } \\
+4.60 \mathrm{RE}\end{array}$ & hwest \\
\hline \multirow[b]{2}{*}{$\begin{array}{l}\text { Point } \\
\text { name }\end{array}$} & \multicolumn{6}{|c|}{ DISPLACEMENTS } & \multirow[b]{2}{*}{ z } \\
\hline & $\begin{array}{l}\text { Load } \\
\text { combination }\end{array}$ & \multicolumn{3}{|c|}{$\underset{X}{\text { TRANSLATIONS (in }} \mathrm{z}^{\prime}$} & \multicolumn{2}{|c|}{$\begin{array}{l}\text { ROTATIONS (deg } \\
X \text { Y }\end{array}$} & \\
\hline $807 \mathrm{M}$ & $\begin{array}{l}\text { GR } \\
T 1 \\
W 1 \\
W 2 \\
\text { U1 } \\
\text { R1 } \\
\text { GR+T1 } 1 \\
\text { TOTAL }\end{array}$ & $\begin{array}{r}0.000 \\
-0.122 \\
0.000 \\
0.000 \\
0.280 \\
0.000 \\
-0.122 \\
0.402\end{array}$ & $\begin{array}{r}-0.009 \\
0.000 \\
0.000 \\
0.000 \\
0.000 \\
0.004 \\
-0.009 \\
0.013\end{array}$ & $\begin{array}{r}0.000 \\
-0.439 \\
0.023 \\
0.041 \\
0.274 \\
0.005 \\
-0.439 \\
0.782\end{array}$ & $\begin{array}{l}0.024 \\
0.000 \\
0.000 \\
0.000 \\
0.000 \\
0.030 \\
0.024 \\
0.053\end{array}$ & $\begin{array}{r}0.000 \\
-0.158 \\
0.247 \\
0.002 \\
-0.152 \\
0.024 \\
-0.158 \\
0.583\end{array}$ & $\begin{array}{r}-0.106 \\
0.000 \\
0.000 \\
0.000 \\
0.000 \\
0.019 \\
-0.106 \\
0.126\end{array}$ \\
\hline $\mathrm{B} 07 \mathrm{~F}$ & $\begin{array}{l}\text { GR } \\
T 1 \\
W 1 \\
\text { W2 } \\
\text { U1 } \\
\text { R1 } \\
\text { GR+T1 } \\
\text { TOTAL }\end{array}$ & $\begin{array}{r}0.000 \\
-0.122 \\
0.001 \\
0.000 \\
0.279 \\
0.000 \\
-0.122 \\
0.403\end{array}$ & $\begin{array}{r}-0.009 \\
0.000 \\
0.000 \\
0.000 \\
0.000 \\
0.004 \\
-0.009 \\
0.013\end{array}$ & $\begin{array}{r}0.000 \\
-0.440 \\
0.024 \\
0.041 \\
0.273 \\
0.005 \\
-0.440 \\
0.783\end{array}$ & $\begin{array}{l}0.024 \\
0.000 \\
0.000 \\
0.000 \\
0.000 \\
0.030 \\
0.024 \\
0.054\end{array}$ & $\begin{array}{r}0.000 \\
-0.142 \\
0.257 \\
0.018 \\
-0.158 \\
0.024 \\
-0.142 \\
0.598\end{array}$ & $\begin{array}{r}-0.106 \\
0.000 \\
0.000 \\
0.000 \\
0.000 \\
0.019 \\
-0.106 \\
0.125\end{array}$ \\
\hline B08 & $\begin{array}{l}\text { GR } \\
T 1 \\
\text { W1 } \\
\text { W2 } \\
\text { U1 } \\
\text { R1 } \\
\text { GR+T1 } \\
\text { TOTAL }\end{array}$ & $\begin{array}{r}0.000 \\
-0.139 \\
0.044 \\
0.016 \\
0.251 \\
0.004 \\
-0.139 \\
0.453\end{array}$ & $\begin{array}{l}0.000 \\
0.000 \\
0.000 \\
0.000 \\
0.000 \\
0.000 \\
0.000 \\
0.000\end{array}$ & $\begin{array}{r}0.000 \\
-0.432 \\
0.066 \\
0.056 \\
0.245 \\
0.007 \\
-0.432 \\
0.806\end{array}$ & $\begin{array}{l}0.051 \\
0.000 \\
0.000 \\
0.000 \\
0.000 \\
0.034 \\
0.051 \\
0.085\end{array}$ & $\begin{array}{r}0.000 \\
0.069 \\
0.302 \\
0.159 \\
-0.236 \\
0.025 \\
0.069 \\
0.791\end{array}$ & $\begin{array}{r}-0.073 \\
0.000 \\
0.000 \\
0.000 \\
0.000 \\
0.014 \\
-0.073 \\
0.087\end{array}$ \\
\hline B०9 & $\begin{array}{l}\text { GR } \\
T 1 \\
W 1 \\
W 2 \\
\text { U1 } \\
R 1 \\
\text { GR+T1 } \\
\text { TOTAL }\end{array}$ & $\begin{array}{r}0.000 \\
0.072 \\
-0.011 \\
-0.020 \\
0.003 \\
0.002 \\
0.072 \\
0.108\end{array}$ & $\begin{array}{l}0.000 \\
0.000 \\
0.000 \\
0.000 \\
0.000 \\
0.000 \\
0.000 \\
0.000\end{array}$ & $\begin{array}{r}0.000 \\
-0.072 \\
0.011 \\
0.020 \\
-0.003 \\
0.002 \\
-0.072 \\
0.108\end{array}$ & $\begin{array}{l}0.057 \\
0.000 \\
0.000 \\
0.000 \\
0.000 \\
0.014 \\
0.057 \\
0.071\end{array}$ & $\begin{array}{r}0.000 \\
0.254 \\
-0.079 \\
-0.001 \\
-0.162 \\
0.025 \\
0.254 \\
0.522\end{array}$ & $\begin{array}{r}-0.029 \\
0.000 \\
0.000 \\
0.000 \\
0.000 \\
0.018 \\
-0.029 \\
0.047\end{array}$ \\
\hline B10 N & $\begin{array}{l}\text { GR } \\
T 1 \\
W 1 \\
W 2 \\
\text { U1 } \\
\text { R1 } \\
\text { GR+T1 } \\
\text { TOTAL }\end{array}$ & $\begin{array}{r}0.000 \\
0.008 \\
-0.008 \\
-0.015 \\
0.002 \\
0.002 \\
0.008 \\
0.035\end{array}$ & $\begin{array}{r}-0.005 \\
0.000 \\
0.000 \\
0.000 \\
0.000 \\
0.001 \\
-0.005 \\
0.006\end{array}$ & $\begin{array}{r}0.000 \\
0.013 \\
0.014 \\
0.025 \\
-0.004 \\
0.003 \\
0.013 \\
0.059\end{array}$ & $\begin{array}{r}-0.015 \\
0.000 \\
0.000 \\
0.000 \\
0.000 \\
0.006 \\
-0.015 \\
0.020\end{array}$ & $\begin{array}{r}0.000 \\
-0.088 \\
-0.169 \\
-0.267 \\
0.068 \\
0.033 \\
-0.088 \\
0.605\end{array}$ & $\begin{array}{r}-0.064 \\
0.000 \\
0.000 \\
0.000 \\
0.000 \\
0.016 \\
-0.064 \\
0.080\end{array}$ \\
\hline
\end{tabular}

PEXCNDS W-320 TANK 241-C-106 WASTE RETRIEVAL

Fluor Daniel Northwest

$12 / 22197$

AUE 16
D IS PLACEMENTS

\begin{tabular}{|c|c|c|c|c|c|c|c|}
\hline \multirow{2}{*}{$\begin{array}{l}\text { Point } \\
\text { name }\end{array}$} & \multirow{2}{*}{$\begin{array}{l}\text { Load } \\
\text { combination }\end{array}$} & \multicolumn{3}{|c|}{$\underset{X}{\text { TRANSLAT J }} \underset{Y}{\text { ONS (in }} Z_{Z}^{\text {) }}$} & \multicolumn{2}{|c|}{ ROTATIONS (deg } & \multirow{2}{*}{ ? } \\
\hline & & & & & $x$ & & \\
\hline $\mathrm{B} 10 \mathrm{M}$ & $\begin{array}{l}\text { GR } \\
\text { Ti } \\
\text { W1 } \\
\text { W2 } \\
\text { UI } \\
\text { RI } \\
\text { GR+T1 } \\
\text { TOTAL }\end{array}$ & $\begin{array}{r}0.000 \\
0.007 \\
-0.009 \\
-0.016 \\
0.002 \\
0.002 \\
0.007 \\
0.036\end{array}$ & $\begin{array}{r}-0.004 \\
0.000 \\
0.000 \\
0.000 \\
0.000 \\
0.001 \\
-0.004 \\
0.005\end{array}$ & $\begin{array}{r}0.000 \\
0.013 \\
0.013 \\
0.023 \\
-0.003 \\
0.003 \\
0.013 \\
0.054\end{array}$ & $\begin{array}{r}-0.012 \\
0.000 \\
0.000 \\
0.000 \\
0.000 \\
0.005 \\
-0.012 \\
0.017\end{array}$ & $\begin{array}{r}0.000 \\
-0.086 \\
-0.161 \\
-0.265 \\
0.045 \\
0.032 \\
-0.086 \\
0.589\end{array}$ & $\begin{array}{r}-0.060 \\
0.000 \\
0.000 \\
0.000 \\
0.000 \\
0.014 \\
-0.060 \\
0.074\end{array}$ \\
\hline B10 F & $\begin{array}{l}\text { GR } \\
\text { T1 } \\
W 1 \\
\text { W2 } \\
\text { U1 } \\
\text { R1 } \\
\text { GR+T1 } \\
\text { TOTAL }\end{array}$ & $\begin{array}{r}0.000 \\
0.007 \\
-0.008 \\
-0.015 \\
0.002 \\
0.002 \\
0.007 \\
0.034\end{array}$ & $\begin{array}{r}-0.004 \\
0.000 \\
0.000 \\
0.000 \\
0.000 \\
0.001 \\
-0.004 \\
0.004\end{array}$ & $\begin{array}{r}0.000 \\
0.012 \\
0.011 \\
0.020 \\
-0.003 \\
0.002 \\
0.012 \\
0.049\end{array}$ & $\begin{array}{r}-0.011 \\
0.000 \\
0.000 \\
0.000 \\
0.000 \\
0.004 \\
-0.011 \\
0.015\end{array}$ & $\begin{array}{r}0.000 \\
-0.083 \\
-0.152 \\
-0.259 \\
0.042 \\
0.031 \\
-0.083 \\
0.566\end{array}$ & $\begin{array}{r}-0.056 \\
0.000 \\
0.000 \\
0.000 \\
0.000 \\
0.013 \\
-0.056 \\
0.069\end{array}$ \\
\hline $\mathrm{B} 11 \mathrm{~N}$ & $\begin{array}{l}\text { GR } \\
T 1 \\
\text { W1 } \\
\text { W2 } \\
\text { U1 } \\
\text { R1 } \\
\text { GR+T1 } \\
\text { TOTAL }\end{array}$ & $\begin{array}{r}0.000 \\
0.006 \\
0.000 \\
-0.001 \\
0.000 \\
0.000 \\
0.006 \\
0.007\end{array}$ & $\begin{array}{r}-0.001 \\
0.000 \\
0.000 \\
0.000 \\
0.000 \\
0.000 \\
-0.001 \\
0.001\end{array}$ & $\begin{array}{r}0.000 \\
0.002 \\
0.003 \\
0.006 \\
-0.001 \\
0.001 \\
0.002 \\
0.013\end{array}$ & $\begin{array}{l}0.000 \\
0.000 \\
0.000 \\
0.000 \\
0.000 \\
0.001 \\
0.000 \\
0.001\end{array}$ & $\begin{array}{r}0.000 \\
-0.056 \\
-0.098 \\
-0.181 \\
0.026 \\
0.021 \\
-0.056 \\
0.381\end{array}$ & $\begin{array}{r}-0.031 \\
0.000 \\
0.000 \\
0.000 \\
0.000 \\
0.007 \\
-0.031 \\
0.039\end{array}$ \\
\hline $\mathrm{B} 11 \mathrm{M}$ & $\begin{array}{l}\text { GR } \\
\text { Y1 } \\
W 1 \\
W 2 \\
\text { U1 } \\
\text { RI } \\
\text { GR+I I } \\
\text { TOTAL }\end{array}$ & $\begin{array}{l}0.000 \\
0.006 \\
0.000 \\
0.000 \\
0.000 \\
0.000 \\
0.006 \\
0.006\end{array}$ & $\begin{array}{r}-0.001 \\
0.000 \\
0.000 \\
0.000 \\
0.000 \\
0.000 \\
-0.001 \\
0.001\end{array}$ & $\begin{array}{r}0.000 \\
0.002 \\
0.003 \\
0.006 \\
-0.001 \\
0.001 \\
0.002 \\
0.012\end{array}$ & $\begin{array}{r}-0.001 \\
0.000 \\
0.000 \\
0.000 \\
0.000 \\
0.001 \\
-0.001 \\
0.002\end{array}$ & $\begin{array}{r}0.000 \\
-0.049 \\
-0.085 \\
-0.159 \\
0.023 \\
0.018 \\
-0.049 \\
0.334\end{array}$ & $\begin{array}{r}-0.028 \\
0.000 \\
0.000 \\
0.000 \\
0.000 \\
0.006 \\
-0.028 \\
0.035\end{array}$ \\
\hline$B 11 \mathrm{~F}$ & $\begin{array}{l}\text { GR } \\
T 1 \\
\text { W1 } \\
\text { W2 } \\
\text { U1 } \\
\text { R1 } \\
\text { GR+T1 } 1 \\
\text { TOTAL }\end{array}$ & $\begin{array}{l}0.000 \\
0.005 \\
0.000 \\
0.000 \\
0.000 \\
0.000 \\
0.005 \\
0.005\end{array}$ & $\begin{array}{r}-0.001 \\
0.000 \\
0.000 \\
0.000 \\
0.000 \\
0.000 \\
-0.001 \\
0.001\end{array}$ & $\begin{array}{r}0.000 \\
0.001 \\
0.003 \\
0.005 \\
-0.001 \\
0.001 \\
0.001 \\
0.010\end{array}$ & $\begin{array}{r}-0.001 \\
0.000 \\
0.000 \\
0.000 \\
0.000 \\
0.001 \\
-0.001 \\
0.003\end{array}$ & $\begin{array}{r}0.000 \\
-0.042 \\
-0.073 \\
-0.136 \\
0.019 \\
0.016 \\
-0.042 \\
0.285\end{array}$ & $\begin{array}{r}-0.024 \\
0.000 \\
0.000 \\
0.000 \\
0.000 \\
0.005 \\
-0.024 \\
0.029\end{array}$ \\
\hline
\end{tabular}




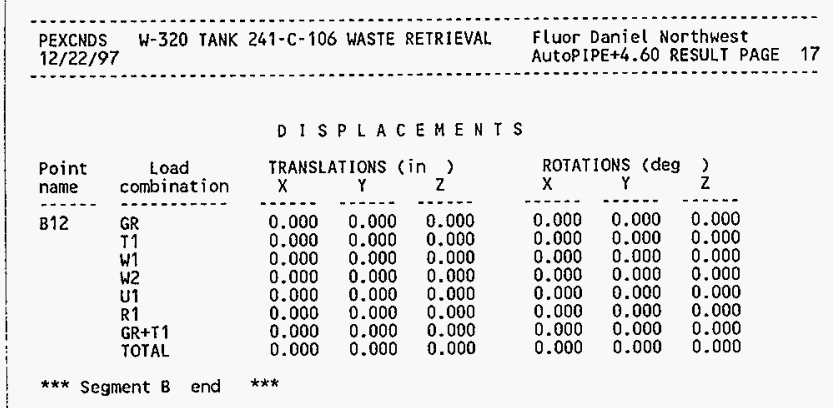

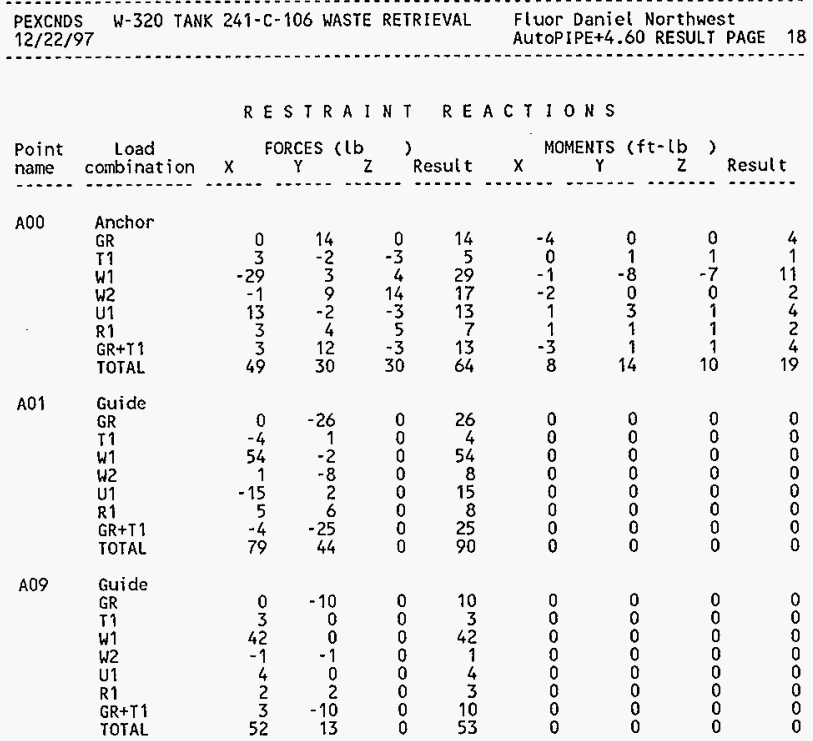

A10

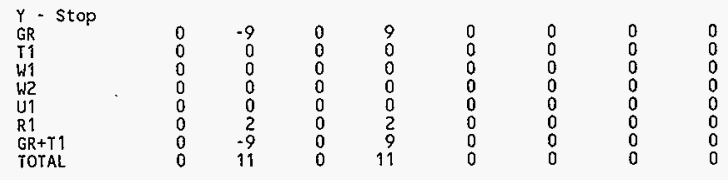




PEXCNDS W-320 TANK $241-\mathrm{C}-106$ WASTE RETRIEVAL Fluor Daniel Northwest
$12 / 22 / 97$

RESTRAINT REACTIONS

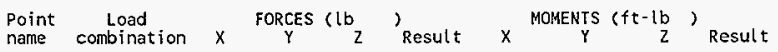

A13 Guide

$\begin{array}{ll}\text { Guide } & 0 \\ \text { GR } & 0 \\ \text { T1 } & 0 \\ \text { W1 } & 0 \\ \text { W2 } & 0 \\ \text { U1 } & 0 \\ \text { R1 } & 0 \\ \text { GR+II } & 0 \\ \text { TOTAL } & 0\end{array}$

$$
\begin{array}{rr}
-9 & 0 \\
0 & 5 \\
0 & -5 \\
0 & 32 \\
0 & 5 \\
2 & 2 \\
-9 & 5 \\
11 & 49
\end{array}
$$

9
5
5
32
5
2
10
50

$\begin{array}{ll}0 & 0 \\ 0 & 0 \\ 0 & 0 \\ 0 & 0 \\ 0 & 0 \\ 0 & 0 \\ 0 & 0 \\ 0 & 0\end{array}$

A14 Anchor

GR

I1

W2

U1

$G R+T 1$

$\begin{array}{rr}0 & -5 \\ -2 & \\ 19 & \\ 1 & \\ -2 & \\ 4 & \\ -2 & -1 \\ 27 & -5\end{array}$

$$
\begin{array}{rr}
-5 & 0 \\
0 & -2 \\
0 & 1 \\
0 & 17 \\
0 & -2 \\
1 & 1 \\
-5 & -2 \\
6 & 22
\end{array}
$$$$
\begin{array}{rr}
0 & 5 \\
-2 & 2 \\
1 & 19 \\
17 & 17 \\
-2 & 3 \\
1 & 4 \\
-2 & 5 \\
22 & 35
\end{array}
$$

5
2
19
17
3
4
5
35

0
0
0
0
0
0
0
0

$\begin{array}{rr}0 & -4 \\ 4 & 0 \\ -2 & 0 \\ -16 & 0 \\ 4 & 0 \\ 1 & 1 \\ 4 & -4 \\ 27 & 6\end{array}$

BOO Anchor

$\begin{array}{rr}0 & 29 \\ -39 & 39 \\ -9 & 9 \\ 55 & 55 \\ 6 & 6 \\ 5 & 6 \\ -39 & 49 \\ 114 & 119\end{array}$

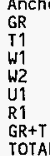

801

$$
\begin{aligned}
& \text { Guide } \\
& \text { GR } \\
& \text { T1 } \\
& \text { W1 } \\
& \text { W2 } \\
& \text { U1 } \\
& \text { R1 } \\
& \text { GR+T1 } \\
& \text { TOTAL }
\end{aligned}
$$

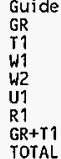

B08

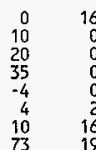

$$
\begin{array}{rr}
0 & 16 \\
34 & 35 \\
7 & 21 \\
-32 & 48 \\
-5 & 6 \\
3 & 6 \\
34 & 39 \\
81 & 111
\end{array}
$$$$
\begin{array}{r}
16 \\
35 \\
21 \\
48 \\
6 \\
6 \\
39 \\
111
\end{array}
$$$$
\begin{array}{rrr}
0 & -4 & 4 \\
9 & 0 & 9 \\
2 & 0 & 2 \\
-9 & 0 & 9 \\
-1 & 0 & 1 \\
1 & 1 & 1 \\
9 & -4 & 10 \\
22 & 5 & 23
\end{array}
$$

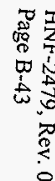

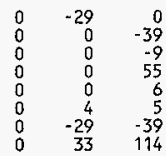

Y - stop

GR

W1

W1

GR+T1

$\begin{array}{rrrrllll}0 & -10 & 0 & 10 & 0 & 0 & 0 & 0 \\ 0 & 0 & 0 & 0 & 0 & 0 & 0 & 0 \\ 0 & 0 & 0 & 0 & 0 & 0 & 0 & 0 \\ 0 & 0 & 0 & 0 & 0 & 0 & 0 & 0 \\ 0 & 0 & 0 & 0 & 0 & 0 & 0 & 0 \\ 0 & 1 & 0 & 1 & 0 & 0 & 0 & 0 \\ 0 & -10 & 0 & 10 & 0 & 0 & 0 & 0 \\ 0 & 11 & 0 & 11 & 0 & 0 & 0 & 0\end{array}$

\section{PEXCNDS}

(1)

-320 TANK 241-C-106 WASTE RETRIEVAL

Fluor Daniel Northwest

$12 / 22 / 97$

PESUIT PAGE 20

RESTRAINT REACTIONS

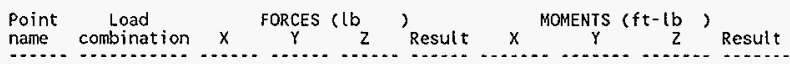

$\begin{array}{lrrrr}\text { Guide } & 0 & -10 & 0 & 10 \\ \text { GR } & -3 & 0 & -3 & 5 \\ \text { T1 } & 21 & 0 & 21 & 30 \\ \text { W1 } & 20 & 0 & 20 & 29 \\ \text { W2 } & 2 & 0 & 2 & 3 \\ \text { U1 } & 2 & 2 & 2 & 3 \\ \text { R1 } & -3 & -10 & -3 & 11 \\ \text { GR+T1 } & 12 & 48 & 69\end{array}$

$\begin{array}{ll}0 & 0 \\ 0 & 0 \\ 0 & 0 \\ 0 & 0 \\ 0 & 0 \\ 0 & 0 \\ 0 & 0 \\ 0 & 0\end{array}$

B12

$\begin{array}{lrrrrrrrr}\text { Anchor } & & & & & & & \\ \text { GR } & 0 & -5 & 0 & 5 & 0 & 0 & -5 & 5 \\ \text { T1 } & -7 & 0 & 9 & 11 & 0 & -9 & 0 & 9 \\ \text { W1 } & -3 & 0 & 16 & 16 & 0 & -16 & 0 & 16 \\ \text { W2 } & -21 & 0 & 36 & 41 & 0 & -31 & 0 & 31 \\ \text { U1 } & 2 & 0 & -3 & 4 & 0 & 4 & 0 & 4 \\ \text { R1 } & 3 & 1 & 4 & 5 & 0 & 4 & 1 & 4 \\ \text { GR+T1 } & -7 & -5 & 9 & 12 & 0 & -9 & -5 & 11 \\ \text { TOTAL } & 36 & 6 & 67 & 77 & 0 & 65 & 7 & 65\end{array}$


ASME $831.3 \mathrm{C}$ (1992) CODE COMPLIANCE

(Moments in $\mathrm{ft}-\mathrm{lb}$ )
Point Load In-Pl. Out-Pl. Torsion S.I.F Eq. Load code code name combination Moment Moment Moment In Out no. type stress Allow.

*** Segment $A$ begin $* * *$
A00 Max $P$

Cold to SUS+WIND

GR + Max P

Cold to $T 1$

SUS+WIND

SUS+WIND
SUS+SEIS

$\mathrm{A02}$

Max P

$\mathrm{GR}+\operatorname{Max} P$

Cold to

SUS+SEIS

$\mathrm{AO3}$

Max P

$G R+\operatorname{Max} P$

Cold to T1

SUS+WIND

$\mathrm{A} 04$

$\operatorname{Max} P$

$\mathrm{GR}+$ Max P

Cold to T1

SUS+SEIS

A05

Max P

$\mathrm{GR}+\operatorname{Max} \mathrm{P}$

Cold to T1

SUS+WIND

SUS+SEIS

A06

Max $P$

GR + Max P

SUS+WIND

SUS+SE IS
GR + Max P

A01 $\operatorname{Max} P$ (3a) HOOP

1.001 .00 (18) SUST 11.001 .00 (17) DISP 1.001 .00 (18) OCC

(3a) HOOP

1.001 .00 (18) SUST 11.001 .00 (17) DISP $1.001 .00(18)$ OCC (3a) 4008 11.001 .00 (17) DISP 1.001 .00 (18) OCC 1.001 .00 (18) OCC

(3a) HOOP 11.001 .00 (17) DISP 1.001 .00 (18) OCC

(3a) $\mathrm{HOOP}$ 1.001 .00 (18) SUST 11.001 .00 (17) DISP $1.001 .00(18)$ OCC

\section{(3a) $\mathrm{HOOP}$} 1.001 .00 (18) SUST 11.001 .00 (17) OISP $1.001 .00(18)$ OCC

(3a) $\mathrm{HOOP}$ 1.001 .00 (18) SUST 11.001 .00 (17) DISP $1.009 .00(18)$ OCC 1.001 .00 (18) SUST 1.001 .00 (18) SUST
PEXCNDS W-320 TANK $241-\mathrm{C}-106$ WASTE RETRIEVAL
$12 / 22 / 97$

Luor Daniel Northwest

AutoPIPE+4 60 PESUL PAGE

\begin{tabular}{|c|c|c|c|c|c|c|c|c|c|}
\hline $\begin{array}{l}\text { Point } \\
\text { name }\end{array}$ & $\begin{array}{l}\text { Load } \\
\text { combination }\end{array}$ & $\begin{array}{l}\text { ASME B } \\
\text { CMON } \\
\text { In-Pl. } \\
\text { Moment }\end{array}$ & $\begin{array}{l}331.3 \mathrm{c} 6 \\
\text { nents in } \\
\text { Out-Pl. } \\
\text { Moment }\end{array}$ & $\begin{array}{l}\text { 1992) } \\
\text { ft-lb } \\
\text { Torsion } \\
\text { Moment }\end{array}$ & $\begin{array}{l}\text { CODE COMPLIA } \\
\text { S.I.F } \\
t \text { In out }\end{array}$ & $\begin{array}{l}\text { ANCE } \\
\text { (S } \\
\text { Eq. } \\
\text { no. }\end{array}$ & $\begin{array}{l}\text { Stress } \\
\text { Load } \\
\text { type }\end{array}$ & $\begin{array}{l}\text { in psi } \\
\text { Code } \\
\text { stress }\end{array}$ & $\begin{array}{c}\text { Code } \\
\text { Allow. }\end{array}$ \\
\hline$A 07 \mathrm{~N}-$ & $\begin{array}{l}\text { Max } P \\
\text { GR }+ \text { Max } P \\
\text { Cold to TI } \\
\text { SUS+WIND } \\
\text { SUS+SE IS }\end{array}$ & $\begin{array}{l}1 \\
1 \\
8 \\
4\end{array}$ & $\begin{array}{l}0 \\
1 \\
2 \\
6\end{array}$ & $\frac{5}{5}$ & 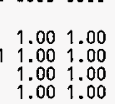 & $\begin{array}{l}(3 a) \\
(18) \\
(17) \\
(18) \\
(18)\end{array}$ & $\begin{array}{l}\text { HOOP } \\
\text { SUST } \\
\text { DISP } \\
\text { OCC } \\
\text { OCC }\end{array}$ & $\begin{array}{r}80 \\
208 \\
450 \\
2339 \\
2133\end{array}$ & $\begin{array}{l}16700 \\
16700 \\
25050 \\
22211 \\
22211\end{array}$ \\
\hline$A 07 \mathrm{~N}+$ & $\begin{array}{l}\text { Max P } \\
\text { GR + Max P } \\
\text { Cold to T1 } \\
\text { SUS+WIND } \\
\text { SUS+SEIS }\end{array}$ & $\begin{array}{l}1 \\
1 \\
8 \\
4\end{array}$ & $\begin{array}{l}0 \\
1 \\
2 \\
6\end{array}$ & 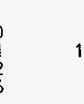 & $\begin{array}{lll}1.25 & 1.04 \\
1 & 1.25 & 1.04 \\
1.25 & 1.04 \\
1.25 & 1.04\end{array}$ & $\begin{array}{l}(3 a) \\
(18) \\
(17) \\
(18) \\
(18)\end{array}$ & $\begin{array}{l}\text { HOOP } \\
\text { SUST } \\
\text { DISP } \\
\text { OCC } \\
\text { OCC }\end{array}$ & $\begin{array}{r}80 \\
250 \\
517 \\
2881 \\
2344\end{array}$ & $\begin{array}{l}16700 \\
16700 \\
25050 \\
22211 \\
22211\end{array}$ \\
\hline$A 07 M$ & $\begin{array}{l}\text { Max P } \\
\text { GR + Max P } \\
\text { Cold to IT } \\
\text { SUS+WINO } \\
\text { SUS+SEIS }\end{array}$ & $\begin{array}{l}0 \\
1 \\
7 \\
3\end{array}$ & $\begin{array}{l}0 \\
1 \\
6 \\
5\end{array}$ & 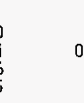 & 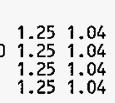 & $\begin{array}{l}(3 a) \\
(18) \\
(17) \\
(18) \\
(18)\end{array}$ & $\begin{array}{l}\text { HOOP } \\
\text { SUST } \\
\text { DISP } \\
\text { OCC } \\
\text { OCC }\end{array}$ & $\begin{array}{r}80 \\
187 \\
497 \\
3266 \\
2140\end{array}$ & $\begin{array}{l}16700 \\
16700 \\
25050 \\
22211 \\
22211\end{array}$ \\
\hline A07 F- & $\begin{array}{l}\text { Max P } \\
\text { GR + Max P } \\
\text { Cold to YI } \\
\text { SUS+WIND } \\
\text { SUS+SEIS }\end{array}$ & $\begin{array}{l}0 \\
1 \\
6 \\
3\end{array}$ & $\begin{array}{l}0 \\
0 \\
7 \\
2\end{array}$ & 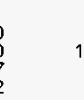 & 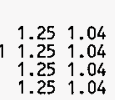 & $\begin{array}{l}(3 a) \\
(18) \\
(17) \\
(18) \\
(18)\end{array}$ & $\begin{array}{l}\text { HOOP } \\
\text { SUST } \\
\text { DISP } \\
\text { OCC } \\
\text { OCC }\end{array}$ & $\begin{array}{r}80 \\
168 \\
447 \\
3141 \\
1264\end{array}$ & $\begin{array}{l}16700 \\
16700 \\
25050 \\
22211 \\
22211\end{array}$ \\
\hline $\mathrm{A} 07 \mathrm{~F}+$ & $\begin{array}{l}\text { Max P } \\
\text { GR + Max ? } \\
\text { Cold to I1 } \\
\text { SUS+WIND } \\
\text { SUS+SEIS }\end{array}$ & $\begin{array}{l}0 \\
1 \\
6 \\
3\end{array}$ & $\begin{array}{l}0 \\
0 \\
7 \\
2\end{array}$ & 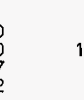 & 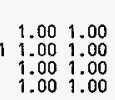 & $\begin{array}{l}(3 a) \\
(18) \\
(17) \\
(18) \\
(18)\end{array}$ & $\begin{array}{l}\text { HOOP } \\
\text { SUST } \\
\text { DISP } \\
\text { OCC } \\
\text { OCC }\end{array}$ & $\begin{array}{r}80 \\
147 \\
396 \\
2764 \\
1072\end{array}$ & $\begin{array}{l}16700 \\
16700 \\
25050 \\
22211 \\
22211\end{array}$ \\
\hline A08 N- & $\begin{array}{l}\text { Max P } \\
\text { GR }+ \text { Max P } \\
\text { Cold to T1 } \\
\text { SUS+WIND } \\
\text { SUS+SEIS }\end{array}$ & $\begin{array}{l}0 \\
1 \\
4 \\
2\end{array}$ & $\begin{array}{l}0 \\
0 \\
0 \\
0\end{array}$ & 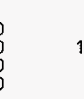 & 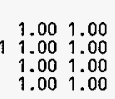 & $\begin{array}{l}(3 a) \\
(18) \\
(17) \\
(18) \\
(18)\end{array}$ & $\begin{array}{l}\text { HOOP } \\
\text { SUST } \\
\text { DISP } \\
\text { OCC } \\
\text { OCC }\end{array}$ & $\begin{array}{r}80 \\
158 \\
341 \\
1090 \\
586\end{array}$ & $\begin{array}{l}16700 \\
16700 \\
25050 \\
22211 \\
22211\end{array}$ \\
\hline $\mathrm{A} 08 \mathrm{~N}+$ & $\begin{array}{l}\text { Max P } \\
\text { GR + Max P } \\
\text { Cold to T1 } \\
\text { SUS+WIND } \\
\text { SUS+SE IS }\end{array}$ & $\begin{array}{l}0 \\
1 \\
4 \\
2\end{array}$ & $\begin{array}{l}0 \\
0 \\
0 \\
0\end{array}$ & 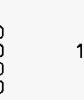 & 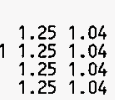 & $\begin{array}{l}(3 a) \\
(18) \\
(17) \\
(18) \\
(18)\end{array}$ & $\begin{array}{l}\text { HOOP } \\
\text { SUST } \\
\text { DISP } \\
\text { OCC } \\
\text { OCC }\end{array}$ & $\begin{array}{r}80 \\
183 \\
383 \\
1346 \\
717\end{array}$ & $\begin{array}{l}16700 \\
16700 \\
25050 \\
22211 \\
22211\end{array}$ \\
\hline
\end{tabular}

$80 \quad 16700$

37925050

$2557 \quad 22211$

8016700

$2438 \quad 16700$

$8156 \quad 22211$

$5321 \quad 2221$

8016700

188716700

$\begin{array}{lll}563 & 25050\end{array}$

6708
4572 22211

$105 \quad 16700$

$448 \quad 16700$

166922211

$1212 \quad 22211$

10516700

$276 \quad 16700$

15425050

98122211

$105 \quad 16700$

19516700

$\begin{array}{ll}146 & 25050 \\ 22211\end{array}$

84922211

$80 \quad 16700$

$287 \quad 16700$

$\begin{array}{rr}456 & 25050 \\ 2499 & 22211\end{array}$

$2266 \quad 22211$
$1161 \quad 16700$ 
ASME B31.3C (1992) CODE COMPLIANCE (Moments in ft-lb)
Point Load In-Pl. Out-Pl. Torsion S.l.F Eq. Load code Code
name combination Moment Moment Moment in Out no. type stress Allow. A08 M Max

$\begin{array}{llllll}\text { GR }+ \text { Max } P & 0 & 0 & 1.251 .04(18) & \text { SUST } \\ \text { Cold to T1 } & 1 & 1 & 11.251 .04(17) & \text { DISP } \\ \text { SUS+WIND } & 4 & 0 & 1.251 .04(18) & \text { OCC } \\ \text { SUS+SEIS } & 2 & 4 & 1.251 .04(18) & \text { OCC }\end{array}$

A08 F- $\operatorname{Max} P$

$\begin{array}{rlr}\text { (3a) HOOP } \\ 1.25 & 1.04 \text { (18) SUST } \\ 1.25 & 1.04 \text { (17) DISP }\end{array}$

GR + Max P SUS+WIND SUS+SEIS

A08 F+ Max P

$G R+\operatorname{Max} P$

Cold to $T 1$ SUS+WIND SUS+SEIS

A09

Max $P$

GR + Max P

Cold to $T 1$

SUS+WIND

SUS+SE IS

A10

$\operatorname{Max} P$

$\mathrm{GR}+\operatorname{Max} P$

Cold to $T 1$

SUS+WJND
SUS+SEIS

A11 $N-\operatorname{Max} P$

GR + Max $P$

Cold to $T 1$

SUS+WIND
SUS+SE IS

1.251 .04 (18) OCC

(3a)

1.001 .00 (18) SUST

01.001 .00 (17) DISP

$\begin{array}{llll}1.00 & 1.00(18) & \text { OCC } \\ 1.00 & 1.00(18) & \text { OCC }\end{array}$

(3a) 4009

$\begin{array}{rrrr}1.00 & 1.00 & \text { (3a) } & \text { HOOP } \\ 0 & 1.00 & 1.00 & \text { SUST } \\ 0 & 17) \text { DISP }\end{array}$

01.001 .00 (17) DISP

$\begin{array}{llll}1.00 & 1.00(18) & \text { OCC } \\ 1.00 & 1.00(18) & \text { OCC }\end{array}$

(3a) HOOP

$\begin{array}{llll}1.00 & 1.00 & \text { (3a) } & \text { HOOP } \\ 0 & 1.00 & \text { SUST } \\ 1.00 & (17) & \text { DISP }\end{array}$

01.001 .00 (17) DISP

$1.001 .00(18)$
1.001 .00 (18)
OCC

(3a) 4009

1.001 .00 (18) SUST

1.001 .00 (17) DISP

$1.001 .00(18)$ OCC
$1.001 .00(18)$ OCC

A11 $\mathrm{N}+\operatorname{Max} \mathrm{P}$

$\mathrm{GR}+\operatorname{Max} \mathrm{P}$

Cold to $T$

SUS+WIND
SUS+SE IS $\begin{array}{lll}1.25 & 1.04 \text { (3a) HOOP } \\ \text { (18) SUST }\end{array}$

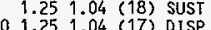

$1.251 .04(18)$ OCC
$1.251 .04(18)$ OCC

ASME 831.3C (1992) CODE COMPLIANCE

Point Load In-Pl. Out in ft-lb ' Stress in psi ? name combination Moment Moment Moment in Out no. type stress Allow.

$80 \begin{aligned} 16700 \\ 0\end{aligned}$

A11 M Max $P$ $\mathrm{GR}+\operatorname{Max} P$ Cold to $T 1$ SUS+WIND

25050

155922211

$80 \quad 16700$

$101 \quad 16700$

$432 \quad 25050$

188722211

$80 \quad 16700$

8916700

$369 \quad 25050$

$\begin{array}{ll}1284 & 22211 \\ 1768 & 22211\end{array}$

8016700

$1787 \quad 16700$

$1201 \quad 25050$

$\begin{array}{rr}10015 & 22211 \\ 4099 & 22211\end{array}$

$80 \quad 16700$

$1101 \quad 16700$

184925050

$\begin{array}{ll}2258 & 22211 \\ 2838 & 22211\end{array}$

8016700

$124 \quad 16700$

230125050

$\begin{array}{ll}5120 & 22211 \\ 2442 & 22211\end{array}$

$80 \quad 16700$

13516700

$2873 \quad 25050$

637422211 GR + Max P SUS+WI ND SUS+SE IS $\mathrm{GR}+\operatorname{Max} P$ Cold to T1 SUS+SE IS
A12 Max $P$ $\mathrm{GR}+\operatorname{Max} P$ Cold to $T$ SUS+SE IS

A13 Max $P$ GR + Max $P$ Cold to $T$ T SUS+WIND

A14 $\operatorname{Max} P$ GR + Max $P$ Cold to $T 1$ SUS+WIND

*** Segment $A$ end $* * *$

*** Segment $B$ begin ***

$800 \quad \operatorname{Max} P$

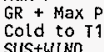
US+WIND SUS+SEIS
1.251 .04 (3a) HOOP $0 \quad 1.251 .04$ (17) DISP $1.251 .04(18)$ OCC

(3a) HOOP

1.251 .04 (18) SUST $0 \quad 1.251 .04$ (17) DISP $\begin{array}{llll}1.25 & 1.04 \text { (18) OCC } \\ 1.25 & 1.04 \text { (18) OCC }\end{array}$

(3a) HOOP

1.001 .00 (18) SUST $01.001 .00(17)$ DISP $\begin{array}{lll}1.001 .00(18) & \text { OCC } \\ 1.00 & 1.00(18) & \text { OCC }\end{array}$

(3a) HOOP

1.001 .00 (18) SUST 01.001 .00 (17) DISP $1.001 .00(18)$ OCC
$1.001 .00(18)$ OCC

(3a) HOOP 1.001 .00 (18) SUST 1.001 .00 (17) DISP $1.001 .00(18)$
$1.001 .00(18)$

(3а) HOOP 1.001 .00 (18) SUST $\begin{array}{ll}1.00 & 1.00(17) \\ 1.00 & 1.00(18) \text { DISP }\end{array}$ 1.001 .00 (18) OCC $80 \quad 16700$ $122 \quad 16700$ 25050 353522211

$80 \quad 16700$ $104 \quad 16700$ $2838 \quad 25050$ 45822211

22211 $227 \quad 16700$ $2393 \quad 22211$

$80 \quad 16700$ $738 \quad 16700$ $706 \quad 25050$ $663 \quad 22211$

$80 \quad 16700$ $1283 \quad 16700$ 208125050 69022221 2221

$80 \quad 16700$ 250 $2857 \quad 22211$ 1.001 .00 (3a) HOOP 1.001 .00 (17) DISP $1.001 .00(18)$ OCC
$1.001 .00(18)$ OCC

$80 \quad 16700$ 136116700 270525050 202022211 
ASME B31.3C (1992) CODE COMPLIANCE

(Moments in $\mathrm{ft}-\mathrm{lb}$ ) (Stress in psi)

Point load In-PL. Out-PI. Torsion S.I.F Eq. Load code code

name combination Moment Moment Moment in Out no. type stress Allow.

801 Max $P$

$\mathrm{GR}+\operatorname{Max} P$ Cold to $T 1$ SUS+WIND

$\begin{array}{rr}10 & \\ 0 & 19 \\ 10 & 2 \\ 11 & \\ & \\ 8 & \\ 0 & \\ 8 & \\ 9 & \end{array}$

0
19
24
4

0
18
20
4

1.001 .00 (3a) HOOP 1.001 .00 (18) SUST 1.001 .00 (18) OCC 1.001 .00 (18) OCC
1.001 .00 (18) OCC

$80 \quad 16700$ $2851 \quad 16700$ 558725050 984522211 $\begin{array}{ll}9845 & 22211 \\ 4231 & 22211\end{array}$

802 Max $P$

GR + Max P
Cold to T1 SUS+WIND SUS+SE IS

(3a) HOOP 1.001 .00 (18) SUS 1.001 .00 (18) OCC $1.001 .00(18)$
$1.001 .00(18)$ OCC

$80 \quad 16700$

$\begin{array}{rr}80 & 16700 \\ 2302 & 16700\end{array}$

$\begin{array}{ll}2302 & 16700 \\ 2316 & 25050\end{array}$

$8328 \quad 22211$

B03 Max

$G R+\operatorname{Max} P$ Cold to TI SUS+SEIS (3a) HOOP 1.001 .00 (18) SUS 1.001 .00 (18) OCC $1.001 .00(18)$ OCC

$105 \quad 16700$

$\begin{array}{ll}105 & 16700 \\ 576 & 16700\end{array}$

$1544 \quad 25050$

$2134 \quad 22211$

$B 04$ Max $P$

$G R+\operatorname{Max} P$ Cold to $T$ SUS+SEIS

$\begin{array}{rr}4 & 0 \\ 0 & 16 \\ 4 & 14 \\ 5 & 3\end{array}$

(3a) HOOP

$105 \quad 16700$ 1.001 .00 (18) SUST 1.001 .00 (17) DISP $1.001 .00(18)$ OCC $1.001 .00(18)$ OCC

(3a) HOOP $1.00 \quad 1.00$ (18) SUST 01.001 .00 (17) DISP 1.001 .00 (18) OCC

$R+\operatorname{Max} P$ Cold to $T 1$ SUS+WIND

B06

$\operatorname{Max} P$

$\mathrm{GR}+\operatorname{Max} P$

Cold to $T$ SUS+WIND
SUS+SE IS

$\begin{array}{rr}3 & 0 \\ 0 & 15 \\ 3 & 11 \\ 4 & 3\end{array}$

(3a) $\mathrm{HOOP}$

1.001 .00 (18) SUST 1.001 .00 (17) DISP $1.001 .00(18)$ OCC

(3a) $\mathrm{HOOP}$

B06A Max P

GR + Max P

Cold to $T$

SUS+SE IS
1.001 .00 (18) SUST $1.001 .00(18)$ OCC
$1453 \quad 2505$

1671
695
22211

$105 \quad 16700$

$324 \quad 16700$

$1363 \quad 25050$

1321
574 22211

$\begin{array}{rr}80 & 16700 \\ 707 & 16700\end{array}$

707
416700

$\begin{array}{ll}4172 & 25050 \\ 3190 & 22211\end{array}$

$1405 \quad 22211$

$\begin{array}{ll}80 & 16700\end{array}$

$1157 \quad 16700$

$710 \quad 25050$

$2215 \quad 22211$
ASME B31.3C (1992) CODE COMPLIANCE

(Moments in $\mathrm{ft}-\mathrm{lb}$ ) (Stress in psi ?

Point Load In-Pl. Out-Pl. Torsion S.I.F name combination Moment Moment Moment In Out no. type stress Allow. $B 07 N-$ Max $P$

$\mathrm{GR}+\operatorname{Max} \mathrm{P}$ cold to T1 SUS+WIND

0
0
0
1

0
14
23
6

1.001 .00 (3a) HOOP $1.001 .00(17)$ DISP 1.001 .00 (18) OCC 1.001 .00 (18) OCC

(3a) HOOP

$B 07 \mathrm{~N}+\operatorname{Max} \mathrm{P}$

$\mathrm{GR}+\operatorname{Max} P$ Cold to IT SUS+WIND

0
14
23
6 $\mathrm{GR}+\operatorname{Max} \mathrm{P}$ SUS+WIND

B07 F- Max P

$\mathrm{GR}+\operatorname{Max} \mathrm{P}$ Cold to T1 SUS+WIND SUS+SE IS
$B 07 F+\operatorname{Max} P$

$\mathrm{GR}+\operatorname{Max} \mathrm{P}$
Cold to T1 SUS+WIND

SUS+SEIS

$808 \operatorname{Max} P$ GR + Max $P$ Cold to $T 1$ SUS+WIND

$809 \operatorname{Max} P$ $\mathrm{GR}+\mathrm{Max} P$ Cold to $T$ SUS+WIND $\begin{array}{lll}1.25 & 1.04 & (3 a) \\ 18 \text { SUST }\end{array}$ 1.251 .04 (18) OCC

(3a) HOOP

1.251 .04 (18) SUST $0 \quad 1.251 .04$ (17) DISP

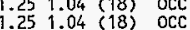

(3a) HOOP 1.251 .04 (18) SUST $0 \quad 1.251 .04$ (17) DISP $\begin{array}{llll}1.25 & 1.04 & (18) & \text { OCC } \\ 1.25 & 1.04(18) & \text { OCC }\end{array}$

(3a) HOOP $1.001 .00(18)$ SUST 01.001 .00 (17) DISP 1.001 .00 (18) OCC

(3a) $\mathrm{HOOP}$ 1.001 .00 (18) SUST 01.001 .00 (17) DISP

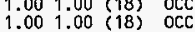

(3a) HOOP 01.001 .00 (17) DISP $1.001 .00(18)$
$1.001 .00(18)$ 1.001 .00 (18) SUST $\begin{array}{rr}80 & 16700 \\ 145 & 16700\end{array}$ $4200 \quad 25050$ $6860 \quad 22211$ 206122211

$80 \quad 16700$ $\begin{array}{rr}149 & 16700 \\ 5244 & 25050\end{array}$ 853422211 254122211

$\begin{array}{rr}80 & 16700 \\ 187 & 16700\end{array}$ 527525050 $8635 \quad 22211$ $2590 \quad 22211$

$80 \quad 16700$ 20316700 267050 851322211

$80 \quad 16700$ $196 \quad 16700$ $4218 \quad 25050$ $2113 \quad 22211$

$80 \quad 16700$ $1463 \quad 16700$ 331525050 $\begin{array}{ll}3031 & 22211 \\ 2817 & 22211\end{array}$

$80 \quad 16700$ $1534 \quad 16700$ $2244 \quad 25050$ $\begin{array}{rr}12059 & 22211 \\ 3649 & 22211\end{array}$ 


\section{ASME B31.3C (1992) CODE COMPLIANCE}

(Moments in $\mathrm{ft}-\mathrm{lb}$ ) (Stress in psi )
(Ml. Out-pl. Torsion S.l.F Eq. Load code code

Point Load In-Pl. Out-Pl. Torsion S.I.F Eq- Load Code Code name combination Moment Moment Moment In Out no. type Stress Allow. $810 \mathrm{~N}$ - Max P GR + Max $P$
Cold to T1 SUS+WIND
SUS+SEIS

$B 10 \mathrm{~N}+\operatorname{Max} \mathrm{P}$ $\mathrm{GR}+$ Max P Cold to $T 1$ SUS+WI ND
SUS+SE IS

B10 $M$ Max $P$

GR + Max P
Cold to T1 Cold to T1 SUS+WIND

B10 F- Max

$G R+M a x P$ Cold to Th SUS+SEIS

B10 F+ Max

$\mathrm{GR}+\operatorname{Max} P$ Cold to $T$ SUS+WIND
SUS+SE IS

B11 N- Max P

$\mathrm{GR}+\operatorname{Max} P$ Cold to $T$ SUS+WIND
SUS+SEIS

$B 11 \mathrm{~N}+\operatorname{Max} \mathrm{P}$

$\mathrm{GR}+\operatorname{Max} P$

Cold to $T$

SUS+WIIND
SUS+SEIS
1.001 .00 (3a) HOOP $1.001 .00(18)$
$1.001 .00(18)$

8016700

$764 \quad 16700$ $\begin{array}{rr}242 & 25050 \\ 1890 & 22211\end{array}$ $1473 \quad 22219$ 1.251 .04 (3a) HOOP 01.251 .04 (18) SUST 1.251 .04 (18) OCC 1.251 .04 (18) OCC

$80 \quad 16700$

$\begin{array}{rr}80 & 16700 \\ 793 & 16700\end{array}$ 30325050 219922211 21992221 (3a) HOOP 1.251 .04 (18) SUS $0 \begin{array}{lll}1.25 & 1.04 & (18) \\ 0 & 1.25 & \text { (17) DISP }\end{array}$ 1.251 .04 (18) OCC

$80 \quad 16700$

67216700

$400 \quad 25050$

$2726 \quad 22211$

(3a) HOOP

$80 \quad 16700$ 1.251 .04 (3a) 01.251 .04 (17) DISP 1.251 .04 (18) OCC

$\begin{array}{rr}80 & 16700\end{array}$

58725050

$3205 \quad 22211$

$1150 \quad 22211$

(3a) $\mathrm{HOOP}$

$\begin{array}{rr}80 & 76700 \\ 175 & 16700\end{array}$

1.001 .00 (18) SUST

1.001 .00 (17) DISP 1.001 .00 (18) OCC

$470 \quad 25050$

$2597 \quad 22211$

(3a) HOOP

8016700

1.001 .00 (18) SUST

01.001 .00 (17) DISP $\begin{array}{ll}1.001 .00(18) & \text { OCC } \\ 1.001 .00(18) & \text { OCC }\end{array}$

(3a) HOOP

1.251 .04 (18) SUST

$1.251 .04(18)$ OCC

1.251 .04 (18) OCC

$732 \quad 16700$ $\begin{array}{ll}1798 & 25050 \\ 9464 & 22211\end{array}$ $2282 \quad 22211$

8016700 $\begin{array}{ll}760 & 16700\end{array}$ 25050 $2693 \quad 22211$ 01.001 .00 (17) DISP
ASME B31 3c (1992) CODE COMPL IANCE

(Moments in $\mathrm{ft}-\mathrm{lb}$ ) (Stress in psi)

Point Load In-PL. Out-PL. Torsion S.I.F Eq. Load code Code name combination Moment Moment Moment In out no. type stress Allow.

B11 M Max P GR + Max $P$
Cold to T1 SUS+WIND

$\begin{array}{rl}0 & 3 \\ 6 & 0 \\ 31 & 3 \\ 5 & 4\end{array}$

(3a) HODP 0.1 .251 .04 (17) SUST $1.251 .04(18)$ OCC 8016700 $1061 \quad 16700$ $2345 \quad 25050$ SUS+SEIS 1.251 .04 (18) OCC

811 F- Max P

GR + Max P Cold to T1 SUS+WIND

0
7
32
6

$B 11 F+\operatorname{Max} P$ GR + Max P
Cold to T1 SUS+SEIS

B12 Max P

$G R+\operatorname{Max} P$ Cold to SUStSE IS 


$\begin{aligned} & \text { PEXCNDS W-320 TANK } 241-\mathrm{C}-106 \text { WASTE REIRIEVAL } \\ & 12 / 22 / 97\end{aligned}$
Fluor Daniel Northwest
SUTOPIPE +4.60 RESULT PAGE 29

Maximum displacements (in)

$\begin{array}{llll}\text { Maximum } X: & 0.453 & \text { Point : B08 } & \text { Load Comb.: TOTAL } \\ \text { Maximum } Y: & 0.052 & \text { Point }: B 06 A & \text { Load Comb.: TOTAL } \\ \text { Maximum Z: } & 0.806 & \text { Point }: B 08 & \text { Load Comb.: TOTAL } \\ \text { Max. total: } & 0.925 & \text { Point : B08 } & \text { Load Comb.: TOTAL }\end{array}$

Maximun rotations (deg)

$\begin{array}{lll}\text { Maximum } X: & 0.219 & \text { Point : A08 N } \\ \text { Maximum } Y: & 0.836 & \text { Point : A11 F } \\ \text { Maximum Z : } & 0.372 & \text { Point : A08 F } \\ \text { Max total: } & 0.847 & \text { Point : A11 F }\end{array}$

Max. total:

0.372
0.847

Point : A11 F

Maximum restraint forces(lb)

$\begin{array}{lrl}\text { Maximum } X: & 79 & \text { Point }: \text { A01 } \\ \text { Maximum } Y: & 44 & \text { Point }: A 01 \\ \text { Maximum } Z: & 114 & \text { Point }: \text { B01 } \\ \text { Max. total: } & 119 & \text { Point }: 801\end{array}$

Maximum restraint moments $(f t-l b)$

$\begin{array}{lll}\text { Maximum X : } & 8 & \text { Point : A00 } \\ \text { Maximum } Y & 65 & \text { Point }: B 12 \\ \text { Maximum } Z: & 10 & \text { Point }: A 00 \\ \text { Max. total: } & 65 & \text { Point : B12 }\end{array}$

Maximum $z$. total: load comb:- TOTAL Load Comb.: TOTAL

Lad Comb.: TOTAL

Load Comb.: TOTAL

Load Comb.: TOTAL

\section{PEXCNDS $W-320$ TANK $241-\mathrm{C}-106$ WASTE RETRIEVAL

\section{SYSTEM SUMMARY}

Maximum sustained stress

$$
\begin{array}{ll}
\text { Point } & \text { B01 } \\
\text { Stress psi } & 2851 \\
\text { Allowable psi } & 16700 \\
\text { Ratio } & 0.17 \\
\text { Load combination } & \text { GR }+ \text { Max P }
\end{array}
$$

Maximum displacement stress

$$
\begin{array}{ll}
\text { Point } & : 801 \\
\text { Stress psi } & : 5587 \\
\text { Allowable psi } & \vdots 25050 \\
\text { Ratio } & : 0.22 \\
\text { Load combination } & \text { Cold to } 11
\end{array}
$$

Maximum occasional stress

$$
\begin{array}{ll}
\text { Point } & \text { B12 } \\
\text { Stress psi } & : 15760 \\
\text { Allowable psi } & : 22211 \\
\text { Ratio } & : 0.71
\end{array}
$$

Load Comb.: TOTAL

Load combination: SUS+WIND

Maximum hoop stress

$$
\begin{array}{ll}
\text { Point } & \\
\text { Stress psi } & \text { A03 } \\
\text { Allowable psi } & : 16700 \\
\text { Ratio } & : 0.01
\end{array}
$$$$
\text { Load combination : Max } P
$$

$$
\begin{aligned}
& \text { Point } \\
& \text { Stress psi } \quad: 281 \\
& \text { Allowable psi } \\
& \text { Ratio } 16700 \\
& \text { Load combination } \\
& \text { : } G R+\text { Max P }
\end{aligned}
$$

Maximum displacement stress ratio

$$
\begin{array}{ll}
\text { Point } & \text { : } \\
\text { Stress psi } & 5587 \\
\text { Allowable psi } & \vdots 25050 \\
\text { Ratio } & 0.22 \\
\text { Load combination } & \text { Cold to T1 }
\end{array}
$$




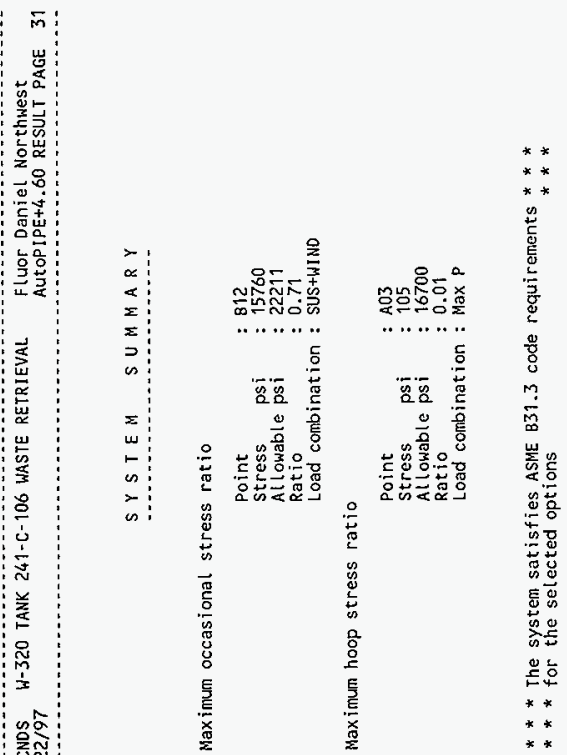


Table 4

Design Wind Pressures, $p$, and Forces, $F$

\begin{tabular}{|c|c|c|c|c|c|}
\hline \multirow{2}{*}{$\begin{array}{l}\text { Design wind } \\
\text { loading }\end{array}$} & \multirow{2}{*}{\multicolumn{2}{|c|}{ Buildings }} & \multirow[b]{2}{*}{ Other structures } & \multicolumn{2}{|c|}{$\begin{array}{l}\text { Flexible Buildings and Structures } \\
\text { (Height/Least Horizontal Dimension }>5 \text { or } \mathrm{f}<\mathrm{t} \mathrm{Hz} \text { ) }\end{array}$} \\
\hline & & & & Buildings & Other structures \\
\hline \multirow[t]{2}{*}{$\begin{array}{l}\text { Main } \\
\text { wind-force } \\
\text { resisting } \\
\text { systems }\end{array}$} & \multicolumn{2}{|c|}{$\begin{array}{l}p=q G_{h} C_{p}-q_{h}\left(G C_{p p}\right) * * \\
q * q_{z} \text { for windward wall cvaluated at height } 2 \\
\text { above ground } \\
q_{h} \text { for lceward wall, side walls, and roof evaluated } \\
\text { at mean roof height } \\
G_{h}: \text { given in Table } 8 \\
C_{p}: \text { given in Fig. } 2 \text { (Table } 10 \text { for arched roofs) } \\
G C_{p j:} \text { given in Table } 9\end{array}$} & $\begin{array}{l}F=q_{2} G_{h} C_{f} A_{f} \\
q_{2}: \text { evaluated as height } \\
z \text { above ground } \\
G_{\mathrm{h}}: \text { given in Table } 8 \\
C_{\mathrm{f}}: \text { given in Tables } 11-16 \\
A_{\mathrm{f}} \text { projected area normal } \\
\\
\text { to windt }\end{array}$ & 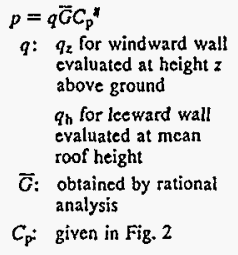 & $\begin{array}{l}F=q_{2} \bar{G} C_{\mathcal{A}} A_{t} \\
q_{z}: \text { evaluated at height } \\
z \text { above ground } \\
\bar{G}: \text { obtained by rational } \\
C_{f}: \text { givalysis } \\
A_{f}: \text { projected area normal } \\
\text { to windt }\end{array}$ \\
\hline & $h \leq 60 \mathrm{ft}$ & $h>60 \mathrm{ft}$ & & & \\
\hline $\begin{array}{l}\text { Components } \\
\text { and } \\
\text { cladding } \ddagger\end{array}$ & $\begin{aligned} p=q_{\mathrm{h}}\left[\left(G C_{\mathrm{p}}\right)-\left(G C_{\mathrm{pi}}\right)\right]^{* *} \\
q_{\mathrm{h}}: \begin{array}{l}\text { evaluated at mean } \\
\text { roof height using } \\
\text { Exposure } C \text { (sec } \\
\\
6.5 .3) \text { for all tertains }\end{array} \\
G C_{p:} \text { given in Figs. } 3 \mathrm{a} \\
\text { and } 3 \mathrm{~b}\end{aligned}$ & $\begin{aligned} & p=q\left[\left(G C_{\mathrm{p}}\right)-\left(G C_{\mathrm{pi}}\right)\right)^{* *} \\
& q: q_{2} \text { for positive } \\
& \text { pressure cvaluated } \\
& \text { at height } z \text { above } \\
& \text { ground } \\
& q_{\mathrm{h}} \text { for negative } \\
& \text { pressure cvaluated } \\
& \text { at mean roof height } \\
& G C_{\mathrm{p}}: \text { Given in Fig. } 45 \\
& G C_{\mathrm{pi}}: \text { Given in Table } 9\end{aligned}$ & 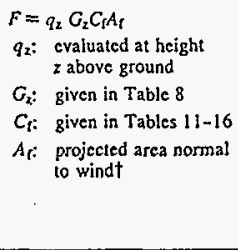 & $\begin{aligned} & p=q\left[\left(G C_{\mathrm{p}}\right)-\left(G C_{\mathrm{p}}\right)\right]^{* *} \\
& q: q_{z} \text { for positive } \\
& \text { pressure evaluated } \\
& \text { at height } z \text { above } \\
& \text { ground } \\
& q_{h} \text { for negative } \\
& \text { pressurc cvaluated } \\
& \text { at mean toof height } \\
& G C_{p}: \text { Given in Fig. } 4 \\
& G C_{\mathrm{pj}}: \text { Given in Table } 9\end{aligned}$ & $\begin{array}{l}F=q_{\mathrm{z}} G_{\mathrm{x}} C_{\mathrm{f}} A_{\mathrm{f}} \\
q_{\mathrm{z}}: \quad \text { evaluated at height } \\
z \text { above ground } \\
G_{\mathrm{z}}: \text { given in Table } 8 \\
C_{\mathrm{l}}: \text { given in Tables } 11-16 \\
A_{\mathrm{f}}: \begin{array}{l}\text { projected area normal } \\
\text { to windt }\end{array}\end{array}$ \\
\hline
\end{tabular}

* Positive pressure acts toward surface and negative pressure acts away from surface; values of external and internal pressures shall be combined algebraically to ascertain most critical load.

"Pressure shall be applied simultancously on windward and lecward walls and on roof surfaces as shown in Fig. 2.

$t A_{f}$ is the projected arca normal to the wind except where $C_{f}$ is given for the surface area.

† Major structural components supporing tributary areas greater than $700 \mathrm{~A}^{2}$ in extent may be designed using the provisions for main wind-force resisting systems.

$\S$ In the design of components and cladding for buildings having a mean roof height $h, 60 \mathrm{ft}<h<90 \mathrm{ft}, G C_{\mathrm{p}}$ values of Fig. 3 may be used provided $q$ is taken as $q_{\mathrm{h}}$ and Exposure $\mathrm{C}$ (see

6.5.3) is used for all terrains.

NOTE: Pressures are in pounds per square foot; forces are in pounds. . 
6.4.3 Wind-Tunnel Procedure. Properly conducted wind-tunnel tests or similar tests employing fluids other than ait may be used for the determination of design wind loads in lieu of the provisions of 6.4.2. This procedure is recommenced for those buildings or structures having unusual geometric shapes, response characteristics, or site locations for which channeling effects or buffeting in the wake of upwind obstructions warrant special consideration, and for which no reliable documentation pertaining to wind effects is available in the literature. The procedure is also recommended for those buildings or structures for which more accurate wind-loading information is desired.

Tests for the determination of mean and fluctuating forces and pressures shall be considered to be properly conducted only if: (1) the natural wind has been modeled to account for the variation of wind speed with height; (2) the natural wind has been modeled to account for the intensity of the longitudinal component of turbulence; (3) the geometric scale of the structural model is not more than three times the geometric scale of the longitudinal component of furbulence; (4) the response characteristics of the wind-tunnel instrumentation are consistent with the measurements to be made; and (5) due regard is given to the dependence of forces and pressures on the Reynolds number.

Tests for the purpose of determining the dynamic response of a structure shall be considered to be properly conducted only if requirements (I) through (5) are satisfied and the structural model is scaled with due regard to length, mass distribution, stiffness, and damping.

\subsection{Velocity Pressure}

6.5.1 Procedure for Calculating Velocity Pressure. The velocity pressure $q_{z}$ at height $z$ shall be calculated from the formula:

$q_{z}=0.00256 K_{z}(I V)^{2}$

where the basic wind speed $V$ is selected in accordance with the provisions of 6.5 .2 , the importance factor $I$ is set forth in Table 5 , and the velocity pressure exposure coefficient $K_{z}$ is given in Table 6 in accordance with the provisions of 6.5.3. The numerical coefficient 0.00256 shall be used except where sufficient climatic data are available to justify the selection of a different value of this factor for a specific design application.

6.5.2 Selection of Basic Wind Speed. The basic wind speed $V$ used in the determination of design wind loads on buildings and other structures shall be as given in Fig. 1 for the contiguous United States and Alaska and in Table 7 for Hawaii and Puerto Rico except as provided in 6.5.2.1 and 6.5.2.2. The basic wind speed used shall be at least $70 \mathrm{mph}$.

6.5.2.1 Special Wind Regions. Special consideration shall be given to those regions for which records or experience indicates that the wind speeds are higher than those reflected in Fig. 1 and Table 7. Some special regions are indicated in Fig. 1; however, all mountainous terrain, gorges, and ocean promontories shall be examined for unusual wind conditions and the authority having jurisdiction shall, if necessary, adjust the values given in Fig. 1 and Table 7 to account for higher local winds. Where necessary, such adjustment shall be based on meteorological advice and an estimate of the basic wind

Table 5

Importance Factor, $I$ (Wind Loads)

\begin{tabular}{ccc}
\hline & \multicolumn{2}{c}{1} \\
\cline { 2 - 3 } Category* & $\begin{array}{c}100 \text { miles from hurricane } \\
\text { oceanline and in other areas }\end{array}$ & $\begin{array}{c}\text { At huricane } \\
\text { oceanline }\end{array}$ \\
\hline I & 1.00 & 1.05 \\
II & 1.07 & 1.11 \\
III & 1.07 & 1.11 \\
IV & 0.95 & 1.00 \\
\hline
\end{tabular}

- See 1.4 and Table 1.

NOTES:

(1) The building and structure classification categories are listed in Table 1.

(2) For regions between the hurricane oceanline and 100 miles inland the importance factor $I$ shall be determined by linear interpolation.

(3) Hurricane oceanlines are the Atlantic and Gulf of Mexico coastal areas. 
Table 6

Velocity Pressure Exposure Coefficient, $K_{z}$

\begin{tabular}{ccccc}
\hline $\begin{array}{c}\text { Height above } \\
\text { ground level, } z \\
\text { (feet) }\end{array}$ & \multicolumn{5}{c}{$K_{z}$} \\
\cline { 2 - 5 } $0-15$ & Exposure A & Exposure B & Exposure C & Exposure D \\
\hline 20 & 0.12 & 0.37 & 0.80 & 1.20 \\
25 & 0.15 & 0.42 & 0.87 & 1.27 \\
30 & 0.17 & 0.46 & 0.93 & 1.32 \\
40 & 0.19 & 0.50 & 0.98 & 1.37 \\
50 & 0.23 & 0.57 & 1.06 & 1.46 \\
60 & 0.27 & 0.63 & 1.13 & 1.52 \\
70 & 0.30 & 0.68 & 1.19 & 1.58 \\
80 & 0.33 & 0.73 & 1.24 & 1.63 \\
90 & 0.37 & 0.77 & 1.29 & 1.67 \\
100 & 0.40 & 0.82 & 1.34 & 1.71 \\
120 & 0.42 & 0.86 & 1.38 & 1.75 \\
140 & 0.48 & 0.93 & 1.45 & 1.81 \\
160 & 0.53 & 0.99 & 1.52 & 1.87 \\
180 & 0.58 & 1.05 & 1.58 & 1.92 \\
200 & 0.63 & 1.11 & 1.63 & 1.97 \\
250 & 0.67 & 1.16 & 1.68 & 2.01 \\
300 & 0.78 & 1.28 & 1.79 & 2.10 \\
350 & 0.88 & 1.39 & 1.88 & 2.18 \\
400 & 0.98 & 1.49 & 1.97 & 2.25 \\
450 & 1.07 & 1.58 & 2.05 & 2.31 \\
500 & 1.16 & 1.67 & 2.12 & 2.36 \\
\hline \hline
\end{tabular}

NOTES:

(i) Linear interpolation for intermediate values of height $z$ is acceptable.

(2) For values of height $z$ greater than 500 feet, $K_{2}$ may be calculated from Eq. C3 in the Commentary.

(3) Exposure categories are defined in 6.5.3.

Table 7

Basic Wind Speed, $\boldsymbol{V}$

\begin{tabular}{lcc}
\hline & $\begin{array}{c}V \\
(\mathrm{mph})\end{array}$ \\
\hline & Location & 80 \\
& Hawaii & 95 \\
\hline
\end{tabular}

NOTE: The unique topographical features common to the islands of Hawait and Puerto Rico suggest that it may be advisable to adjust the values given in Table 7 to account for locally higher winds for structures sited near mountainous terrain, gorges, and ocean promontories.

speed obtained in accordance with the provisions of 6.5.2.2.

6.5.2.2 Estimation of Basic Wind Speeds from Climatic Data. Regional climatic data may be used in lieu of the basic wind speeds given in Fig. 1 and Table 7 provided: (1) acceptable extreme-value statistical-analysis procedures have been employed in reducing the data; (2) due regard is given to the length of record, averaging time, anemometer height, data quality, and terrain exposure; and (3) the basic wind speed used is not less than $70 \mathrm{mph}$.
6.5.2.3 Limitation. Tomadoes have not been considered in developing the basic wind-speed distributions. For those structures or buildings that must be designed to resist tomadic winds the designer is referred to the references in the Commentary (sec C6.5.2.3) on tomado-resistant design.

\subsubsection{Exposure Categories.}

6.5.3.I General.An exposure category that adequately reflects the characteristics of ground surface irregularities shall be determined for the site at which the building or structure is to be constructed. 
Calculation uj320-21-050 B-T oT B- Bb

BUILDINGS AND OTHER STRUCTURES

Table 8

Gust Response Factors, $G_{h}$ and $G_{z}$

\begin{tabular}{ccccc}
\hline $\begin{array}{c}\text { Height above } \\
\text { ground level,z } \\
\text { (feel) }\end{array}$ & Exposure A & Exposure B & Exposure C & Exposure D \\
\hline O- 15 & 2.36 & 1.65 & 1.32 & 1.15 \\
20 & 2.20 & 1.59 & 1.29 & 1.14 \\
25 & 2.09 & 1.54 & 1.27 & 1.13 \\
30 & 2.01 & 1.51 & 1.26 & 1.12 \\
40 & 1.88 & 1.46 & 1.23 & 1.11 \\
50 & 1.79 & 1.42 & 1.21 & 1.10 \\
60 & 1.73 & 1.39 & 1.20 & 1.09 \\
70 & 1.67 & 1.36 & 1.19 & 1.08 \\
80 & 1.63 & 1.34 & 1.18 & 1.08 \\
90 & 1.59 & 1.32 & 1.17 & 1.07 \\
100 & 1.56 & 1.31 & 1.16 & 1.07 \\
120 & 1.50 & 1.28 & 1.15 & 1.06 \\
140 & 1.46 & 1.26 & 1.14 & 1.05 \\
160 & 1.43 & 1.24 & 1.13 & 1.05 \\
180 & 1.40 & 1.23 & 1.12 & 1.04 \\
200 & 1.37 & 1.21 & 1.11 & 1.04 \\
250 & 1.32 & 1.19 & 1.10 & 1.03 \\
300 & 1.28 & 1.16 & 1.09 & 1.02 \\
350 & 1.25 & 1.15 & 1.08 & 1.02 \\
400 & 1.22 & 1.13 & 1.07 & 1.01 \\
450 & 1.20 & 1.12 & 1.06 & 1.01 \\
500 & 1.18 & 1.06 & 1.00 \\
\hline \hline
\end{tabular}

NOTES:

(1) For main wind-force resisting sysiems, use building or structure height $h=z$.

(2) Linear interpolation is acceptable for intermediate values of $z$.

(3) For height above ground of more than 500 feet, Eg. CS of the Commentary may be used.

(4) Value of gust response factor shall be not less than 1.0 . 


\section{BUILDINGS AND OTHER STRUCTURES}

Table 11

Force Coefficients for Monoslope Roofs over Unenclosed Buildings and $O$ ther Structures, $C_{\ell}$

\begin{tabular}{|c|c|c|c|c|c|c|c|}
\hline \multirow{2}{*}{$\begin{array}{c}\theta \\
\text { (degrees) }\end{array}$} & \multicolumn{7}{|c|}{$C_{\ell}$ for $L / B$ Values of: } \\
\hline & 5 & 3 & 2 & 1 & $1 / 2$ & $1 / 3$ & $1 / 5$ \\
\hline $\begin{array}{l}10 \\
15 \\
20 \\
25 \\
30\end{array}$ & $\begin{array}{l}0.2 \\
0.35 \\
0.5 \\
0.7 \\
0.9\end{array}$ & $\begin{array}{l}0.25 \\
0.45 \\
0.6 \\
0.8 \\
1.0\end{array}$ & $\begin{array}{l}0.3 \\
0.5 \\
0.75 \\
0.95 \\
1.2\end{array}$ & $\begin{array}{l}0.45 \\
0.7 \\
0.9 \\
1.15 \\
1.3\end{array}$ & $\begin{array}{l}0.55 \\
0.85 \\
1.0 \\
1.1 \\
1.2 \\
\end{array}$ & $\begin{array}{l}0.7 \\
0.9 \\
0.95 \\
1.05 \\
1.1\end{array}$ & $\begin{array}{l}0.75 \\
0.85 \\
0.9 \\
0.95 \\
1.0\end{array}$ \\
\hline \multirow{2}{*}{\multicolumn{2}{|c|}{$\begin{array}{c}\theta \\
\text { (degrees) }\end{array}$}} & \multicolumn{5}{|c|}{$\begin{array}{l}\text { Location of Center } \\
\text { of Pressure, } X / L \text {, } \\
\text { for } L / B \text { Values of: }\end{array}$} & \\
\hline & & \multicolumn{2}{|c|}{2 to 5} & 1 & \multicolumn{2}{|c|}{$1 / 5101 / 2$} & \\
\hline \multicolumn{2}{|c|}{$\begin{array}{c}10 \text { to } 20 \\
25 \\
30\end{array}$} & \multicolumn{2}{|c|}{$\begin{array}{l}0.35 \\
0.35 \\
0.35\end{array}$} & $\begin{array}{l}0.3 \\
0.35 \\
0.4\end{array}$ & \multicolumn{2}{|c|}{$\begin{array}{l}0.3 \\
0.4 \\
0.45\end{array}$} & \\
\hline
\end{tabular}

NOTES:

(1) Wind forces act normal to the surface and shall be direced inward or outwatd.

(2) Wind shall be assumed to deviate by \pm 10 degrees from horizontal.

(3) Notation:

$B$ : dimension of roof measured normal to wind direction, in feet; $L$ : dimension of roof measured paraltel to wind direction, in feet, $X$ : distance to center of pressure from windward edge of roof, in feet; $\theta$ : angle of plane of roof from horizontal, in degrees.

Table 12

Force Coefficients for Chimneys, Tanks, and Similar Structures, $C_{\mathrm{f}}$

\begin{tabular}{|c|c|c|c|c|}
\hline \multirow[b]{2}{*}{ Shape } & \multirow[b]{2}{*}{ Type of surface } & \multicolumn{3}{|c|}{$C_{f}$ for $h / D$ Values of: } \\
\hline & & 1 & 7 & 25 \\
\hline Square (wind normal to a face) & All & 1.3 & 1.4 & 2.0 \\
\hline Square (wind along diagonal) & All & 1.0 & 1.1 & 1.5 \\
\hline $\begin{array}{l}\text { Hexagonal or octagonal } \\
\left(D \sqrt{q_{z}}>2.5\right)\end{array}$ & Al! & 1.0 & 1.2 & 1.4 \\
\hline Round $\left(D \sqrt{q_{z}}>2.5\right)$ & $\begin{array}{l}\text { Moderately smooth } \\
\text { Rough }\left(D^{\prime} / D \approx 0.02\right) \\
\text { Very rough }\end{array}$ & $\begin{array}{l}0.5 \\
0.7\end{array}$ & $\begin{array}{l}0.6 \\
0.8\end{array}$ & $\begin{array}{l}0.7 \\
0.9\end{array}$ \\
\hline Round $\left(D{\sqrt{a_{z}}}_{2}<2.5\right)$ & A $1 !$ & 0.7 & 0.8 & 1.2 \\
\hline
\end{tabular}

NOTES:

(i) The design wind force shall be calculated based on the area of the structure project on a plane normal to the wind direction. The force shall be assumed to act parallel to the wind direction.

(2) Linear interpolation may be used for $h / D$ values other than shown.

(3) Notation:

$D$ : diameter or least horizontal dimension, in feet;

$D$ : depth of protruding elements such as ribs and spoilers, in feet; and $h$ : height of structure, in feet. 


\section{CHANNEL SELECTION CHART}

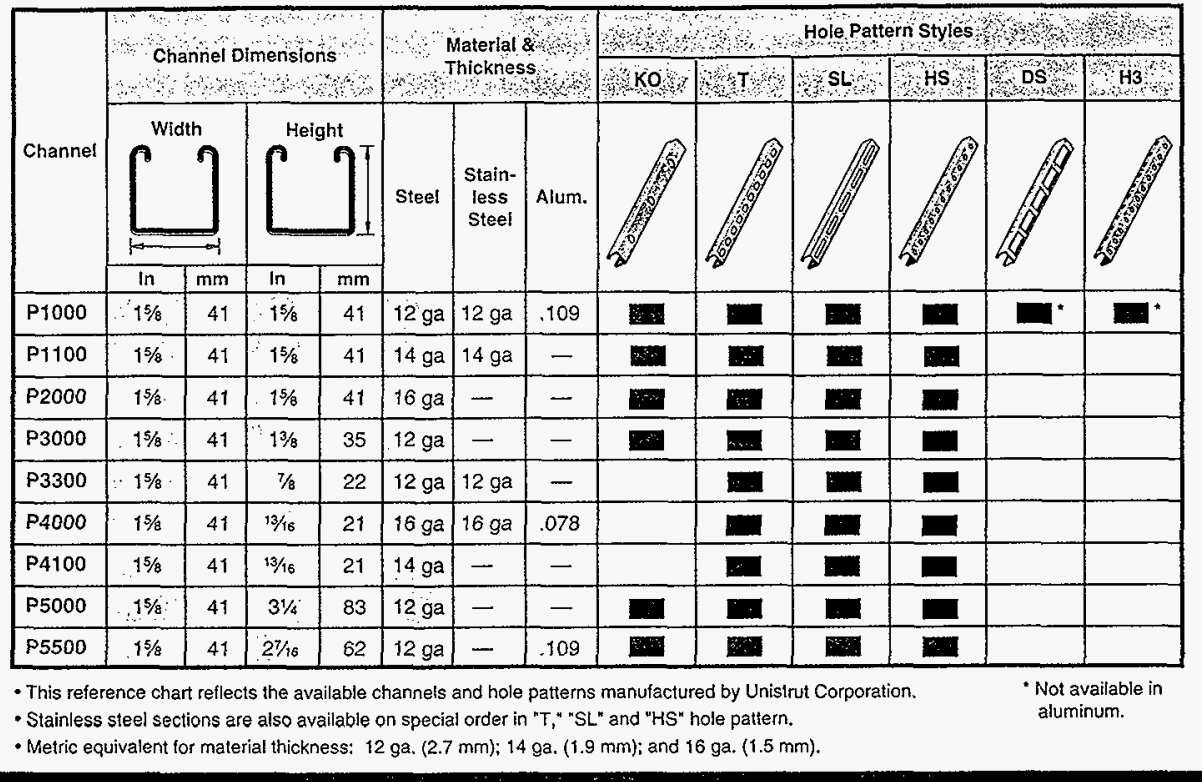

\section{CHANNELS \& COMBINATIONS IN DESCENDING ORDER OF STRENGTH}

\begin{tabular}{|l|r|r|r|r|}
\hline Channel & $\begin{array}{r}\text { S } \\
\ln ^{3}\end{array}$ & In & $\begin{array}{c}\text { Area } \\
\text { In }^{2}\end{array}$ & $\begin{array}{l}\text { Weight } \\
\text { Lbs/Ft }\end{array}$ \\
\hline P5001 & $1.716^{*}$ & $5.578^{*}$ & 1.794 & 6.10 \\
\hline P1004 A & 1.673 & 4.079 & 1.978 & 6.70 \\
\hline P5501 & 1.153 & 2.811 & 1.453 & 4.94 \\
\hline P1001 C41 & 1.145 & 1.860 & 2.223 & 7.60 \\
\hline P5000 & .628 & 1.099 & .897 & 3.05 \\
\hline P1001 & .572 & .930 & 1.112 & 3.80 \\
\hline P1101 & .456 & .741 & .834 & 2.84 \\
\hline P3001 & .431 & .593 & 1.007 & 3.40 \\
\hline P5500 &. .391 & .523 & .726 & 2.47 \\
\hline P2001 & .379 & .616 & .681 & 2.32 \\
\hline P9200 & .297 & .278 & .489 & 2.23 \\
\hline
\end{tabular}

\begin{tabular}{|c|c|c|c|c|}
\hline Channel & $\begin{array}{l}S \\
\text { in }\end{array}$ & $\begin{array}{l}1 \\
\text { in } \\
\text { n }\end{array}$ & $\begin{array}{l}\text { Area } \\
\text { in }^{2} \\
\text { nor }\end{array}$ & $\begin{array}{l}\text { Welght } \\
\text { Lbs/Ft }\end{array}$ \\
\hline P9000 & .203 & .164 & .384 & 2.05 \\
\hline P3301 & .202 & .177 & .797 & 2.70 \\
\hline P1000 & .202 & .185 & .556 & 1.90 \\
\hline P1100 & .166 & .149 & .417 & 1.42 \\
\hline P3000 & .154 & .121 & .503 & 1.70 \\
\hline$P 4101$ & .141 & .114 & .574 & 1.94 \\
\hline$P 2000$ & .140 & .124 & .340 & 1.16 \\
\hline P4001 & .125 & .101 & .478 & 1.64 \\
\hline P3300 & .072 & .037 & .398 & 1.35 \\
\hline$P 4100$ & .053 & .025 & .287 & .97 \\
\hline $\mathrm{P} 4000$ & .048 & .023 & .239 & .82 \\
\hline
\end{tabular}

- Effective section properties. 
P1000

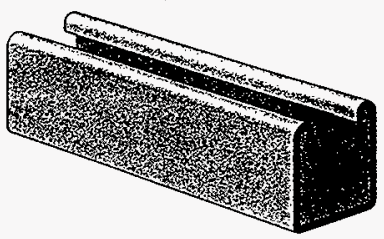

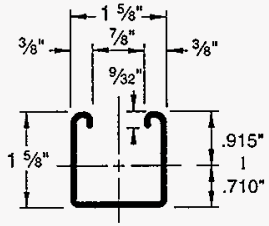

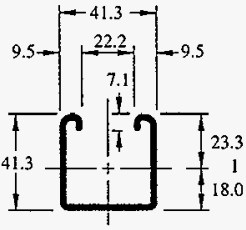

Pierced channels are found on pages 60 and 61

\section{P1001}

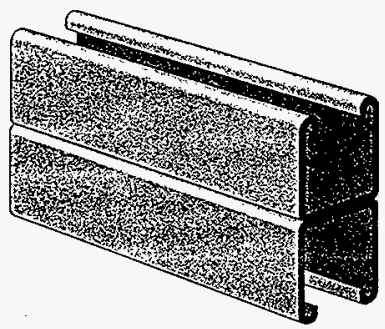

Weight: $190 \mathrm{Lbs} / \mathrm{C} \mathrm{Ft}(283 \mathrm{~kg} / 100 \mathrm{~m})$

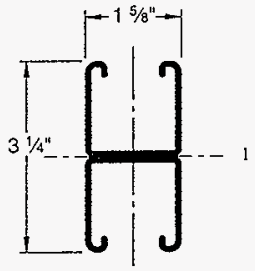

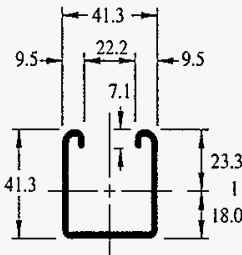

2

Weight: $380 \mathrm{Lbs} / \mathrm{C} \mathrm{Ft}(566 \mathrm{~kg} / 100 \mathrm{~m})$

BEAM LOAD

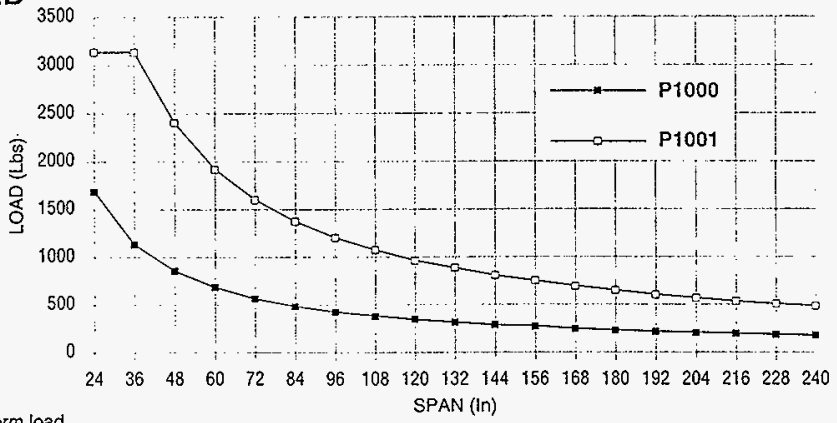

"Maximum allowable uniform load. SPAN (In)

\begin{tabular}{|c|c|c|c|c|c|c|c|c|c|c|c|c|c|c|}
\hline \multirow[t]{2}{*}{ Channel } & \multicolumn{2}{|c|}{ Weight } & \multicolumn{2}{|c|}{$\begin{array}{l}\text { Allowable } \\
\text { Moment }\end{array}$} & \multicolumn{2}{|c|}{$\begin{array}{l}\text { Material } \\
\text { Thickness }\end{array}$} & \multicolumn{2}{|c|}{$\begin{array}{l}\text { Standard } \\
\text { Lengths }\end{array}$} & \multicolumn{4}{|c|}{ Finishes } & \multicolumn{2}{|c|}{$\begin{array}{c}\text { Other } \\
\text { Materials }\end{array}$} \\
\hline & Lbs/Ft & $\mathrm{kg} / \mathrm{m}$ & $\ln +\mathrm{Lb}$ & $\mathrm{N} \cdot \mathrm{m}$ & In & $\mathrm{mm}$ & $10^{\prime}$ & $20^{\prime}$ & $\mathrm{PL}$ & GR & $\mathrm{HG}$ & $P G$ & SS & EA \\
\hline $\mathrm{P} 1000$ & 1.90 & 2.8 & 5,080 & 570 & $: 105$ & 2.7 & & & 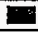 & 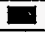 & 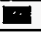 & & & \\
\hline P1001 & 3.80 & 5.7 & 14,390 & 1630 & 105 & 2.7 & & & & & & & & \\
\hline
\end{tabular}

Nominal thickness of 12 gage strip steel is .105 inches.

HNF-2479, Rev. 0

Page B-56 
P1000 \& P1001 CHANNELS

FOR 15/8" (41 MM) WIDTH SERIES CHANNEL

COLUMN LOADING DATA

\begin{tabular}{|c|c|c|c|c|c|c|c|c|c|c|c|c|}
\hline \multirow{2}{*}{\multicolumn{2}{|c|}{$\begin{array}{c}\text { Unbraced } \\
\text { Height }\end{array}$}} & \multirow{3}{*}{ Channel } & \multirow{2}{*}{\multicolumn{2}{|c|}{$\begin{array}{l}\text { Max. Allowable } \\
\text { Load at } \\
\text { Slot Face }\end{array}$}} & \multicolumn{8}{|c|}{ Maximum Column Load Applied at C.G. $\cdots$} \\
\hline & & & & & \multicolumn{2}{|c|}{$K=.65$} & \multicolumn{2}{|c|}{$K=.80$} & \multicolumn{2}{|c|}{$K=1.0$} & \multicolumn{2}{|c|}{$K=1.2$} \\
\hline $\ln$ & $\mathrm{mm}$ & & Lbs & $\mathrm{kN}$ & Lbs & $\mathrm{kN}$ & Lbs & kN & Lbs & $\mathrm{kN}$ & Lbs & kN \\
\hline \% & 610 & $\begin{array}{l}\text { P1000 } \\
\text { P1001 }\end{array}$ & $\begin{array}{l}3400 \\
6360\end{array}$ & $\begin{array}{l}15.1 \\
28.3\end{array}$ & $\begin{array}{r}9600 \\
23820\end{array}$ & $\begin{array}{r}42.7 \\
106.0\end{array}$ & $\begin{array}{r}9500 \\
23560 \\
\end{array}$ & $\begin{array}{r}42.3 \\
104.8\end{array}$ & $\begin{array}{l}9320 \\
23130\end{array}$ & $\begin{array}{r}41.5 \\
102.9\end{array}$ & $\begin{array}{r}9100 \\
22610 \\
2\end{array}$ & $\begin{array}{r}40.5 \\
100.6\end{array}$ \\
\hline $\begin{array}{r}\text { कर } \\
36 \\
3\end{array}$ & 914 & $\begin{array}{l}\text { P1000 } \\
\text { P1001 }\end{array}$ & $\begin{array}{l}3000 \\
6190\end{array}$ & $\begin{array}{l}13.3 \\
27.5\end{array}$ & $\begin{array}{r}7640 \\
23190 \\
\end{array}$ & $\begin{array}{r}34.0 \\
103.2\end{array}$ & $\begin{array}{r}7400 \\
22610\end{array}$ & $\begin{array}{r}32.9 \\
100.6\end{array}$ & $\begin{array}{r}7000 \\
21640\end{array}$ & $\begin{array}{l}31.1 \\
96.3\end{array}$ & 20490 & $\begin{array}{l}28.9 \\
91.0\end{array}$ \\
\hline & 1219 & $\begin{array}{l}\text { P1000 } \\
\text { P1001 }\end{array}$ & $\begin{array}{l}2570 \\
5970\end{array}$ & $\begin{array}{l}11.4 \\
26.6\end{array}$ & $\begin{array}{r}5910 \\
22310\end{array}$ & $\begin{array}{l}26.3 \\
99.2\end{array}$ & $\begin{array}{r}5530 \\
21270\end{array}$ & $\begin{array}{l}24.6 \\
94.6\end{array}$ & $\begin{array}{r}4980 \\
19560\end{array}$ & $\begin{array}{l}22.2 \\
87.0\end{array}$ & $\begin{array}{r}4430 \\
17460\end{array}$ & $\begin{array}{l}19.7 \\
77.7\end{array}$ \\
\hline & 1524 & $\begin{array}{l}\text { P1000 } \\
\text { P1001 }\end{array}$ & $\begin{array}{l}2230 \\
5690\end{array}$ & $\begin{array}{r}9.9 \\
25.3\end{array}$ & $\begin{array}{r}4780 \\
21180\end{array}$ & $\begin{array}{l}21.3 \\
94.2\end{array}$ & $\begin{array}{r}4390 \\
19560\end{array}$ & $\begin{array}{l}19.5 \\
87.0\end{array}$ & $\begin{array}{r}3850 \\
16870\end{array}$ & $\begin{array}{l}17.1 \\
75.0\end{array}$ & $\begin{array}{r}3330 \\
13590^{\circ}\end{array}$ & $\begin{array}{l}14.8 \\
60.5\end{array}$ \\
\hline $\begin{array}{r}72 \\
72 \\
\end{array}$ & 1829 & $\begin{array}{l}\text { P1000 } \\
\text { P1001 }\end{array}$ & $\begin{array}{l}1970 \\
5360\end{array}$ & $\begin{array}{r}8.8 \\
23.8\end{array}$ & $\begin{array}{r}4090 \\
19790\end{array}$ & $\begin{array}{l}18.2 \\
88.0\end{array}$ & $\begin{array}{r}3680 \\
17460\end{array}$ & $\begin{array}{l}16.4 \\
77.7\end{array}$ & $\begin{array}{r}3140 \\
13590\end{array}$ & $\begin{array}{l}14.0 \\
60.5\end{array}$ & $\begin{array}{l}2650 \\
9570\end{array}$ & $\begin{array}{l}11.8 \\
42.6\end{array}$ \\
\hline 84 & 2134 & $\begin{array}{l}\text { P1000 } \\
\text { P1001 }\end{array}$ & $\begin{array}{l}1760 \\
4970\end{array}$ & $\begin{array}{r}7.8 \\
22.1\end{array}$ & $\begin{array}{r}3600 \\
18150 \\
\end{array}$ & $\begin{array}{l}16.0 \\
80.7\end{array}$ & $\begin{array}{r}3170 \\
14980\end{array}$ & $\begin{array}{l}14.1 \\
66.6\end{array}$ & $\begin{array}{r}2630 \\
10130\end{array}$ & $\begin{array}{l}11.7 \\
45.1\end{array}$ & $\begin{array}{l}2160 \\
7030\end{array}$ & $\begin{array}{r}9.6 \\
31.3\end{array}$ \\
\hline 96 & 2438 & $\begin{array}{l}\text { P1000 } \\
\text { P1001 }\end{array}$ & $\begin{array}{l}1580 \\
4510\end{array}$ & $\begin{array}{r}7.0 \\
20.1\end{array}$ & $\begin{array}{r}3220 \\
16270\end{array}$ & $\begin{array}{l}14.3 \\
72.4\end{array}$ & $\begin{array}{r}2770 \\
12120\end{array}$ & $\begin{array}{l}12.3 \\
53.9\end{array}$ & $\begin{array}{l}2240 \\
7750\end{array}$ & $\begin{array}{l}10.0 \\
34.5\end{array}$ & $\begin{array}{l}1800 \\
5380\end{array}$ & $\begin{array}{r}8.0 \\
23.9\end{array}$ \\
\hline 108 & 2743 & $\begin{array}{l}\text { P1000 } \\
\text { P1001 }\end{array}$ & $\begin{array}{l}1430 \\
4030\end{array}$ & $\begin{array}{r}6.4 \\
17.9\end{array}$ & $\begin{array}{r}2910 \\
14120 \\
\end{array}$ & $\begin{array}{l}12.9 \\
62.8\end{array}$ & $\begin{array}{l}2450 \\
9570\end{array}$ & $\begin{array}{l}10.9 \\
42.6\end{array}$ & $\begin{array}{l}1930 \\
6130\end{array}$ & $\begin{array}{r}8.6 \\
27.3\end{array}$ & 4250 & 18.9 \\
\hline$\therefore 120$ & 3048 & $\begin{array}{l}\text { P1000 } \\
\text { P1001 }\end{array}$ & $\begin{array}{l}1290 \\
3610\end{array}$ & $\begin{array}{r}5.7 \\
16.1\end{array}$ & $\begin{array}{r}2640 \\
11750\end{array}$ & $\begin{array}{l}11.7 \\
52.3\end{array}$ & $\begin{array}{l}2180 \\
7750\end{array}$ & $\begin{array}{r}9.7 \\
34.5\end{array}$ & $\begin{array}{r}* 1 \\
4960\end{array}$ & 22.1 & 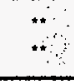 & $\begin{array}{l}* * \\
* *\end{array}$ \\
\hline
\end{tabular}

$\cdot \frac{\mathrm{KL}}{\mathrm{r}}>200$

\section{ELEMENTS OF SECTION}

\begin{tabular}{|c|c|c|c|c|c|c|c|c|c|c|c|c|c|c|}
\hline \multirow{3}{*}{ Channel } & \multirow{2}{*}{\multicolumn{2}{|c|}{$\begin{array}{l}\text { Areas of } \\
\text { Section }\end{array}$}} & \multicolumn{6}{|c|}{ Axis 1-1 } & \multicolumn{6}{|c|}{ Axis $2-2$} \\
\hline & & & \multicolumn{2}{|c|}{1} & \multicolumn{2}{|c|}{$s$} & \multicolumn{2}{|c|}{$\mathbf{r}$} & \multicolumn{2}{|c|}{1} & \multicolumn{2}{|c|}{$S$} & \multicolumn{2}{|c|}{$r$} \\
\hline & $\ln ^{2}$ & $\mathrm{~cm}^{2}$ & $\ln 4$ & $\mathrm{~cm}^{4}$ & $\ln ^{3}$ & $\mathrm{~cm}^{3}$ & In & $\mathrm{cm}$ & $\ln ^{4}$ & $\mathrm{~cm}^{4}$ & $\ln ^{3}$ & $\mathrm{~cm}^{3}$ & ln & $\mathrm{cm}$ \\
\hline P1000 & 556 & 3.6 & $\% 185$ & 7.7 & 202 & 3.3 & 577 & 1.5 & 236 & 9.8 & 290 & 4.7 & 651 & 1.7 \\
\hline P1001 & $1: 112$ & 7.2 & 930 & 38.7 & 672 & 9.4 & 915 & 2.3 & .472 & 19.6 & .580 & 9.5 & 651 & 1.7 \\
\hline
\end{tabular}




\section{P1887}

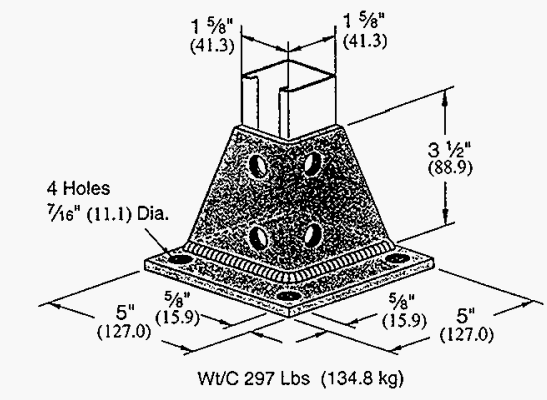

P2072
P2453

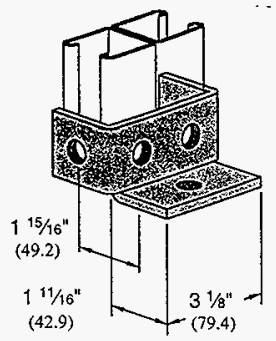

Wt/C 116 Lbs $(52.6 \mathrm{~kg})$

P2072 A

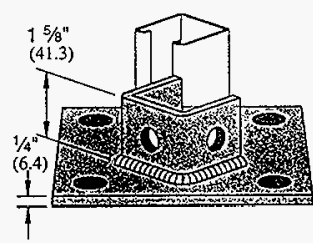

WV/C 307 Lbs $(139.3 \mathrm{~kg})$

\section{P2073}

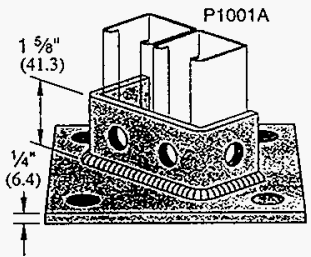

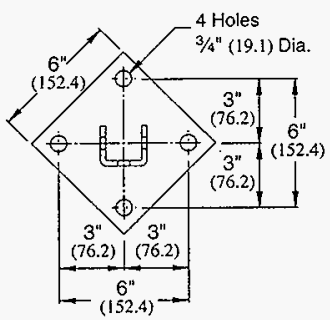

Wt/C 373 Lbs (169.2 kg)
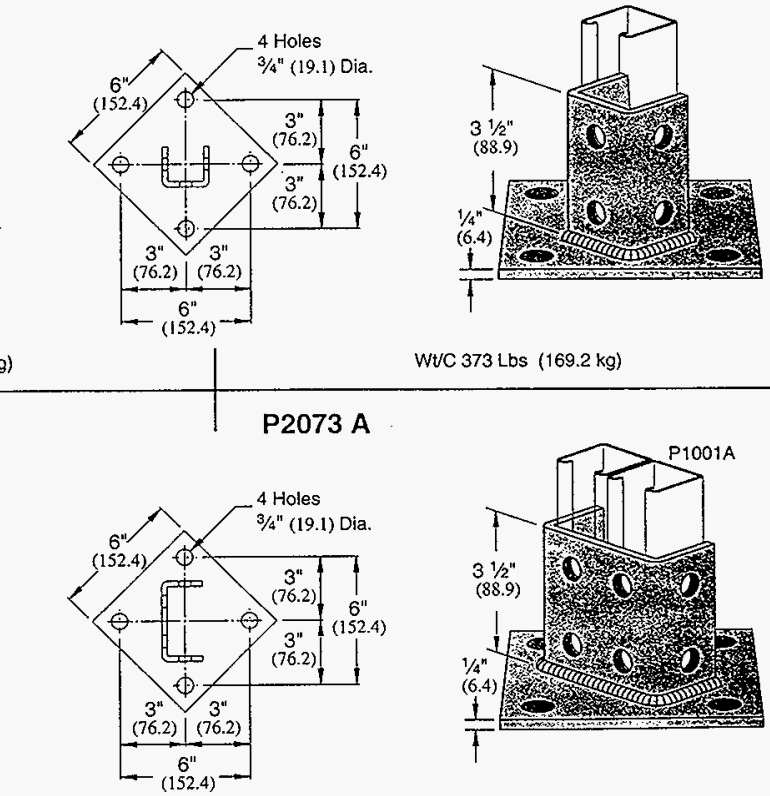

WtC 325 Lbs $(147.4 \mathrm{~kg})$

WUC 408 Lbs (185.1 kg)

\begin{tabular}{l} 
Hole Size \\
$\begin{array}{l}9 / 10^{\prime \prime} \text { Diameter } \\
14.3 \mathrm{~mm}\end{array}$ \\
\hline
\end{tabular}

Hole Spacing

$13 / 16^{n}(20.6 \mathrm{~mm})$ From End $178^{\prime \prime}(47.6 \mathrm{~mm})$ On Center

\begin{tabular}{|l|l|}
\hline Width & Thickness \\
\hline $15 / 3^{\prime \prime}$ & $1 / 4^{\prime \prime}$ \\
$41.3 \mathrm{~mm}$ & $6.4 \mathrm{~mm}$ \\
\hline
\end{tabular}




\section{Pipe Clamps -P1100 Series}

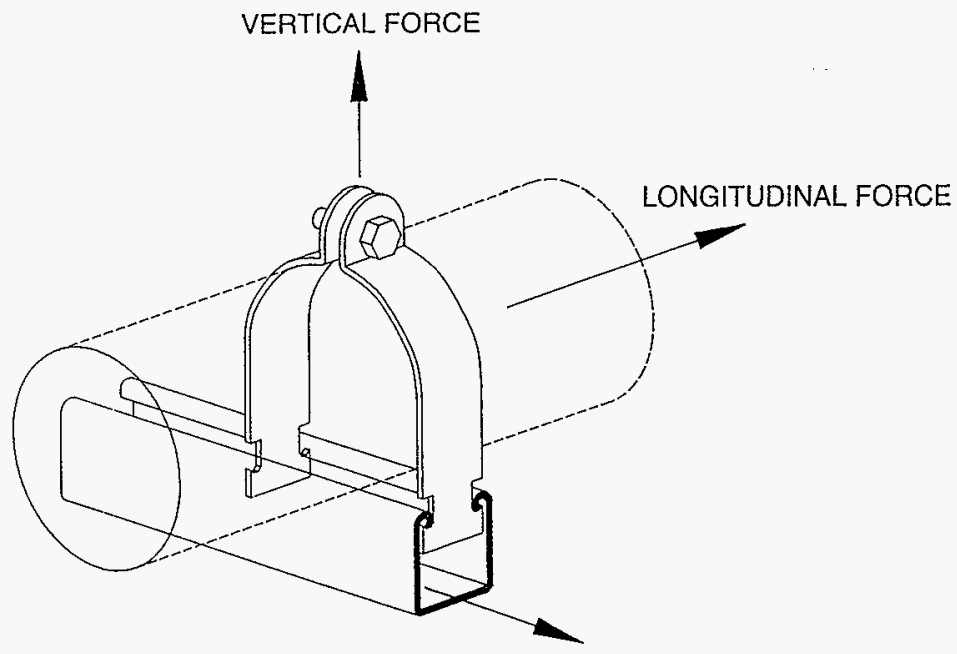

TRANSVERSE FORCE

\begin{tabular}{|c|c|c|c|c|c|c|c|c|c|c|c|c|}
\hline \multirow{4}{*}{$\begin{array}{c}\text { Unistrut } \\
\text { Part } \\
\text { Number }\end{array}$} & \multirow{3}{*}{\multicolumn{2}{|c|}{ Pipe Size }} & \multirow{3}{*}{\multicolumn{2}{|c|}{$\begin{array}{c}\text { Strap } \\
\text { Thickness }\end{array}$}} & \multirow{3}{*}{\multicolumn{2}{|c|}{$\begin{array}{c}\text { Screw } \\
\text { Size }\end{array}$}} & \multirow{2}{*}{\multicolumn{6}{|c|}{ Design Loads }} \\
\hline & & & & & & & \multirow{2}{*}{\multicolumn{2}{|c|}{$\begin{array}{l}\text { Vertical } \\
\text { Force }\end{array}$}} & & & & \\
\hline & & & & & & & & & \multicolumn{2}{|c|}{$\begin{array}{c}\text { Transverse } \\
\text { Force }\end{array}$} & \multicolumn{2}{|c|}{$\begin{array}{l}\text { Longitudinal } \\
\text { Force }\end{array}$} \\
\hline & In & $\mathrm{mm}$ & $\mathrm{Ga}$ & $\mathrm{mm}$ & In & $\mathrm{mm}$ & Lbs. & $N$ & Lbs. & $N$ & Lbs. & N \\
\hline P11t1 & $\Leftrightarrow 1 / 2 \approx$ & 15 & 2016 & 1.5 & $6 \times 1 / 4 \div 6$ & 6 & 84,400 & 1780 & $\therefore \because 70$ & 310 & 50 & 220 \\
\hline $\bar{P} 1112$ & $5 \div 3 / 4 ; 5$ & 20 & Pist4 & 1.9 & $\sin 1 / 4$ & 6 & 600 & 2670 & $\$ 2-100$ & 440 & 50 & 310 \\
\hline$P 1113$ & $301 \%$ & 25 & 146 & 1.9 & $1 / 4$ & 6 & 600 & 2670 & 150 & 670 & W 80 & 360 \\
\hline$P 1114$ & $1-1 / 4$ & 32 & $3414=$ & 1.9 & $1 / 4$ & 6 & $\sin 600$ & 2670 & 20.150 & 670 & 15150 & 670 \\
\hline P1115 & $31-1 / 2$ & 40 & \%12 & 2.7 & $1 / 4$. & 6 & $800^{\circ}$ & 3560 & 240 & 1070 & \% & 670 \\
\hline P1117 & $x$ 2in: & 50 & 12 \% & 2.7 & $51 / 4$ & 6 & $\$ 800$ & 3560 & $26: 240$ & 1070 & 200 & 890 \\
\hline P1118 & $2: 1 / 2$ & 65 & $1012 \div$ & 2.7 & $5 / 16 \%$ & 8 & 800 & 3560 & 240 & 1070 & $\because 200$ & 890 \\
\hline P1119 & $3 \mathrm{pr}$ & 80 & Yutan & 2.7 & $5 / 16 x$ & 8 & 5800 & 3560 & 24240 & 1070 & 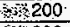 & 890 \\
\hline P1120 & $3: 1 / 2$ & 90 & sol11. & 3.0 & $3 / 8$ & 10 & $2=1000$ & 4450 & 320 & 1420 & 8200 & 890 \\
\hline P1121 & 4 & 100 & $b 111$ & 3.0 & $\% 3 / 8$ & 10 & $\sin 1000$ & 4450 & $\approx 320$ & 1420 & 200 & 890 \\
\hline $\bar{P} 1123$ & $\$ 50$ & 125 & CG11KY & 3.0 & $3 / 8$. 31 & 10 & Fis 1000 & 4450 & 12320 & 1420 & 6200 & 890 \\
\hline P1124 & 636 & 150 & 109 & 3.4 & $53 / 8 \times$ & 10 & $\$ 1000^{\circ}$ & 4450 & $450^{\circ}$ & 2000 & 375 & 1670 \\
\hline P1126 & $8 \times 8 \times 8$ & 200 & $x+10 \%$ & 3.4 & $3 / 8,3$ & 10 & 2.1000 & 4450 & 550 & 2450 & 58500 & 2220 \\
\hline
\end{tabular}

\section{Renewed}

35660 Clinton Street

Wayne. Michigan 48184

(800) $521-7730$

R:0120 Jill22:3

Office of Statewito Health Flanning

art Devr!:3: :ent

Fixed Ecyin: x: A: Anchorage

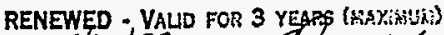
DATE $1 / 22 / 93$

\section{Wen}

FAX: (313) $721-4106$
William Merke!

Structural Engineer

\section{Date}

$7-2293$ 


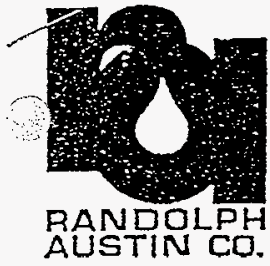

Fandolph Pumps are available in sizes ranging from sma volume laboratory yces to large volume in-plant models. They are ideal for transferring coriosives, abrasives, sterile solutions and other problem thuics. In additon, viscous liquids (at requead flow rates) dry fowders. and gases can be handled. A vacuum of about 26 inches of mepcury and a pressure of 20 pounds per square inch can be achieved with this pump. Capacity ratings were determined in lests with water at ambient temperature and atrnospheric pressure.

\section{SERIES 250 PUMPHEAD}

\begin{tabular}{|c|c|}
\hline \multirow{3}{*}{$\begin{array}{l}\text { Capacity: } \\
\text { Tube sizes: }\end{array}$} & to $447 \mathrm{~m}$ Umin. \\
\hline & $5 / x^{*} O 0 \times 1 / a^{2} 10$ \\
\hline & $\%$ \\
\hline $\begin{array}{l}\text { Dimonsions: } \\
\text { Shatt Dlameter: }\end{array}$ & $\begin{array}{l}\mathrm{L} 2 \%^{*} \times W 2 \%^{\circ} \times \mathrm{H} 2 \%^{\circ} \\
2 / 16^{\circ}\end{array}$ \\
\hline
\end{tabular}

\section{SERIES 500 PUMPHEAD}

\begin{tabular}{|c|c|}
\hline $\begin{array}{l}\text { Capacity: } \\
\text { Tube sizes: }\end{array}$ & $\begin{array}{l}1057 \mathrm{gph} \\
x / \%^{\circ} 00 \times \% \mathrm{x}^{\circ} 10 \\
1 / 10^{\circ} 00 \times \% \mathrm{~K}^{\circ} 10\end{array}$ \\
\hline $\begin{array}{l}\text { Dimensions: } \\
\text { Shatt Dlameter: }\end{array}$ & $\begin{array}{l}14^{\prime} / 2^{*} \times W 4^{1} / 2^{*} \times H^{\prime} /^{\prime} 2^{*} \\
1 / 2^{*}\end{array}$ \\
\hline
\end{tabular}
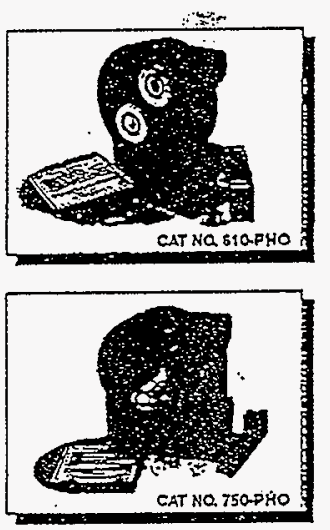

SERIES Gi10 PUMPHEAD

Capacity:

Tube sizes:
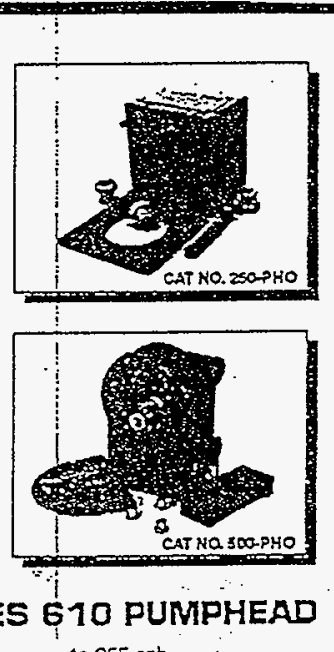

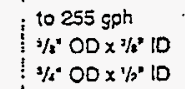

Dimension: : $L 6^{*} \times W 5^{1 / 2^{*}} \times H \in H / 4^{*}$

Shatt Dlameteri \%"

\section{SERIES 7 SO PUMPHEAD}

Capacity:

Tube sizas:

$$
\begin{aligned}
& 10662 \text { gph } \\
& 18 / 14^{x} 00 \times \% 2^{2} 10 \\
& 1 \% 1 x^{4} 00 \times \%=10
\end{aligned}
$$

Dimenslons: i $29^{\circ} \times \mathrm{W}^{\circ} 1^{\circ} \times \mathrm{H}^{\circ} \times 10^{\circ} \mathrm{s}^{\circ}$

Shaft Diamoter: $\%$

HNF-2479, Rev. 0

Page B-60

\section{SERIES 880 PUMPHEAD}
Capacity to:
$1410 \mathrm{ggh}$
Tube sizes:
$1 \%=00 \times \%=10$
$11 / 2^{\prime} 00 \times 1 \% 10$
Dimensions:
L $16^{\circ} \times$ W 10\%" H17 $^{*}$
Shat Dlameter: $1 \%$

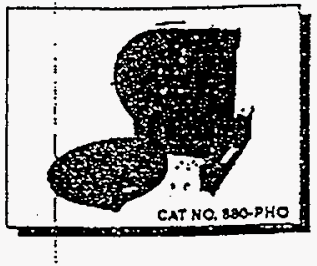


Calculation us $320-27-050$

$B-1<$ of $b-30$ HNF-SD-WM-DA-230

KAISER ENGINEERS

HANFORD

DESIGN ANALYSIS

client

WHC - TWRS Mitigation Systems Integration.

subject Structural Analysis of 500-CFM Saltwell Exhauster Skid

Location TWRS Single Shell Tank Farms cote. No. $n / a$

Revision 0

Page No. 60 of

$10 / J \infty b$ No.

Date 12 Apr 95 checked $5 / 21 / 96$ Revised

KN.

N. SEISMIC DISPLACEMENT OF SYSTEH, CONT'D:

$\therefore$ NAT FREQUENCY OF SILID IN LARECAL DIRETON IS:

$$
f=3.13 \sqrt{\frac{1}{0.02}}=22 \mathrm{~Hz} .
$$

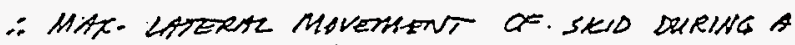
SC-2 SESHIC ENATT DZuTL:

$$
x=\frac{5(386.4)(0.55)^{2}}{4 \pi^{2}(22)^{2}(0.5)(0.74)}=0.083 \mathrm{~N} .
$$

FOK SC-1 DESIGN BASIS ERKTHQUAKE, CATERAT COAS

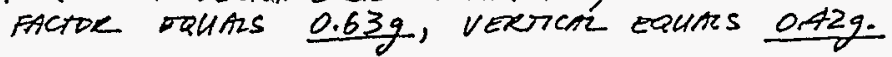

$$
\therefore g_{H}=\sqrt{2(0.63)^{2}}=0.89 g \text {. }
$$

$\therefore$ MAT. OISPRE ENT ERTS

$$
x=\frac{5(386.4)(0.89)^{2}}{4 \pi^{2}(22)^{2}(0.5)(1-0.42)}=0.28 \mathrm{mr}
$$

MHX. VERTICH SETSMIC CONO EQUHS:

$$
g_{v}=(0.42)(7300)=3066 \mathrm{LB} .
$$

$\therefore$ MAX. DOME LOAS EQKACS

$$
V_{\text {MAT }}=7300+3066=10.4 \mathrm{k1PS}
$$

KEH $0037.00(06 / 92)$ KEF055

A-63

HNF-2479, Rev. 0

Page B-61 


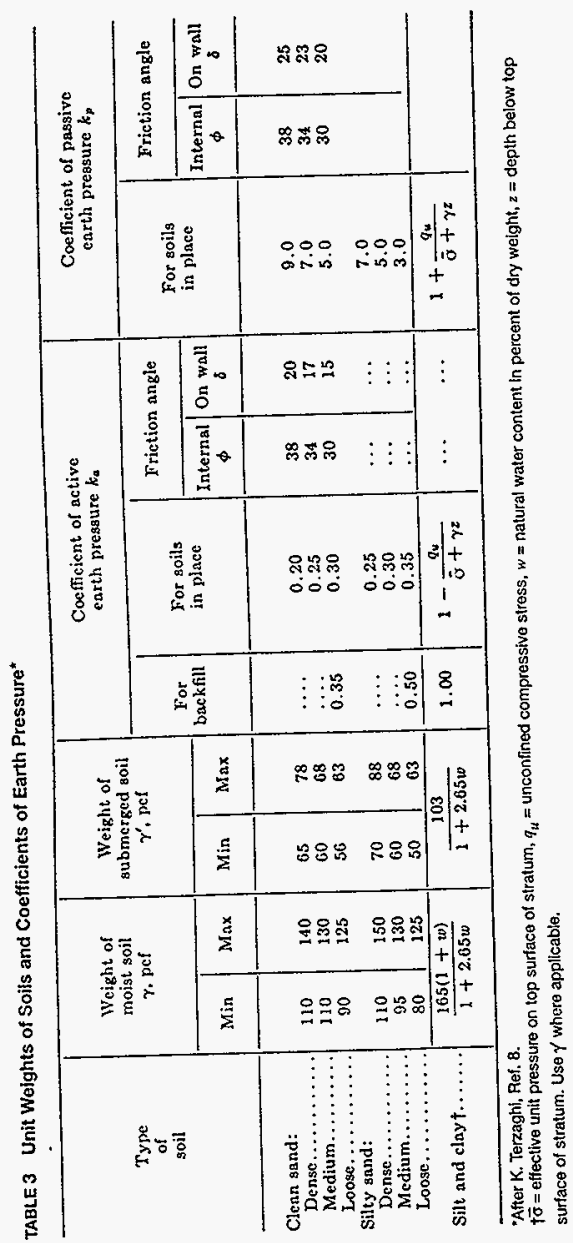


edrivig may rgy. emove is pri-

ing rexcludes at pilese used ing for-

ile dur$n$ of all n. Thus re solu. nce and :eeze or

;ing dy:an vary that ner $\therefore$ monitor of axial nounted 8 or can equation

piles are og resis\& near a penetradriving cushion

s seldom $-t$ the test e be corie elastic loaded to -, may be as the inunit load $=11$ not exElure load

c assimnis a 3 sis on the

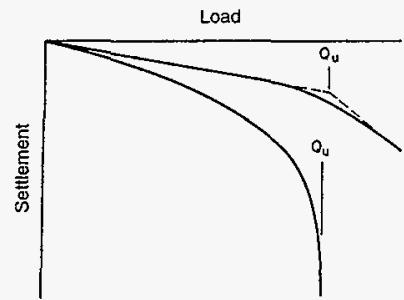

Fig. 26 Failure loads-pile-load tests.

If piles are to be driven through a soft layer and into a firm stratum, the support provided by the sof layer may disappear as the layer consolidates so that all the load is transmitted to the firm stratum. The capacity of the latter may be determined by conducting a pair of load tests, one on a pile driven into the firm stratum and the second, which must be carried to failure, on a pile stopping 2 to $3 \mathrm{ft}$ above the firm stratum. By subtracting the load carried in the soft layer from the load for the pile penetrating the firm stratum the support of the latter is obtained. A careful analysis of these conditions is required. If the soft layer is likely to settle as a consequence of the new construction, it may ultimately tend to drag down the piles with a load equivalent to the temporary support it originally provided. This is known as negative skin friction and further reduces the usable capacity of the pile support provided by the firm stratum.

36. Piles in Sand Piles driven into sand generally act in friction, point bearing, or in combination. Their ultimate capacity can be estimated from a formula such as Janbu's (Table 6) or, in the case of friction piles, by

$$
Q_{u t t}=\left(\frac{1}{2} \gamma l^{2}-\frac{1}{2} \gamma_{w} l_{w}^{2}\right) k \pi d \tan \phi_{f}
$$

$$
\text { where } \begin{aligned}
Q_{u} & =\text { ultimate load capacity neglecting point resistance } \\
\gamma & =\text { saturated unit weight of soil } \\
l & =\text { length of pile } \\
\gamma_{w} & =\text { unit weight of water } \\
l_{w} & =\text { length of pile below water table } \\
d & =\text { pile diameter } \\
k & =\text { coefficient of lateral earth pressure } \\
\tan \phi_{f} & =\text { coefficient of friction between sand and pile }
\end{aligned}
$$

Values of $k$ and tan $\phi_{f}$ are difficult to evaluate. For driven or vibrated piles, $k$ may be taken as 1.0 , but it should not exceed 0.4 if the piles are jetted into the sand. The coefficient of friction may be selected from Table 7.

It should be recognized that these procedures are not precise and, where possible, pile load tests should be conducted as a more reliable indication of pile behavior.

37. Piles In Clay The capacity of a pile driven into clay cannot be reliably predicted from a pile-driving formula. It is best to use the results of a pile load test. However, tests are rather expensive, and the following somewhat less satisfactory procedure may be employed. The ultimate bearing capacity of a single cylindrical friction pile is approximately equal to the adhesion that can be developed between the pile and the surrounding soil times the embedded surface area of the pile. The adhesion is difficult to estimate as it may range from about one-half to one-tenth of the unconfined compressive strength. In general, the stiffer the clay, the smaller the relative adhesion factor (Fig. 27). If Fig. 27 is used, a safery factor of 3 should be used for the maximum probable loading. However, a 


\section{- Calculation w320-27-050 B-15 of B-36}

7-42 Retaining Structures and Foundations

\begin{tabular}{|c|c|c|}
\hline \multirow{2}{*}{ Pile material } & \multicolumn{2}{|c|}{$\tan \phi_{f}$} \\
\hline & Driven piles & $\begin{array}{l}\text { Jetted or } \\
\text { drilled piles }\end{array}$ \\
\hline $\begin{array}{l}\text { Timber.............. } \\
\text { Steel: pipe, ВР. fluted. } \\
\text { Concrete............. } \\
\text { Corrugated steel shells. }\end{array}$ & $\begin{array}{l}0.65 \\
0.45 \\
0.65 \\
0.70\end{array}$ & $\begin{array}{l}0.53 \\
0.36 \\
0.53 \\
0.58\end{array}$ \\
\hline
\end{tabular}

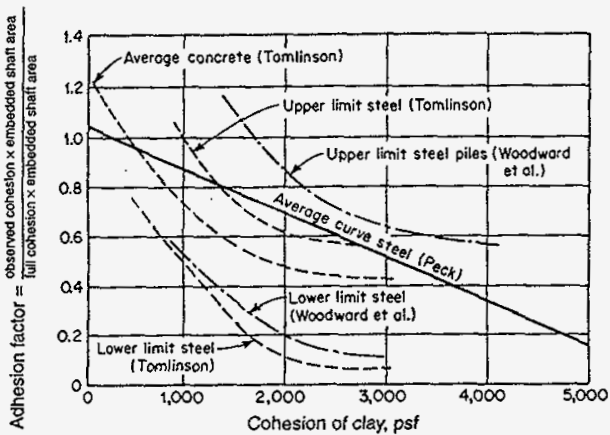

Fig. 27 The adhesion on piles compared with the cohesive strength of clay. (After Tomlinson.'t)

safety factor of at least 2 should be used for the extreme maximum loading of the pertinent buildingcode load requirement. The relatively small contribution from end bearing in the case of friction piles is generally neglected in the analysis of a single pile. If the subsoil contains well-defued layers of varying strength, the adhesion in each layer should be independently determined. Because of the uncertainty in determining the adhesion in stiff to hard clays, pile load tests should always be used to check the desigh load whenever friction piles are driven into such deposits.

For most foundations, friction piles are driven in groups. Therefore, it is necessary to investigate the ultimate load capacity of the group to be certain that it is not less than the product of the load on a single pile and the number of piles, irrespective of how the single-pile load may have been determined. The design capacity is the minimum of these two procedures.

The load capacity of a group of friction piles consists of the shearing resistance on the surface perimeter of the pile group plus the bearing capacity on the plan area of the group at the level of the pile tips. Thus

$$
Q_{d}=(B+L) l q_{u 1}+2.5 q_{u 2}\left(1+\frac{0.3 B}{L}\right) B L
$$

where $Q_{d}=$ ultimate load on group, tons

$B=$ width of pile group, out to out, ft 


\section{Calcuation w320-27.050

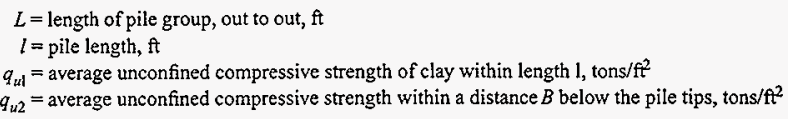

The maximum probable loading on the group should not exceed $Q_{d} / 3$. Although the base bearing capacity may contribute considerably to the capacity of the pile group, it should be noted that the greatest benefit of a friction pile foundation is obtained with the longest piles possible within the limits of economy. The longer the pile, the smaller the settlement in most instances.

Piles driven into clays that increase materially in strength with depth may be analyzed as for friction piles. However, the point resistance, which may represent a sizable proportion of the pile capacity, can be determined only by means of loading tests. The safe load on a group may be taken as the safe load per pile as determined from load tests times the number of piles in the group. In some localities pile-driving formulas have been adjusted to indicate safe loads corresponding to the piledriving resistance. Such formulas should never be used outside the geological region in which they were developed.

Piles driven through relatively soft materials to a stiff or hard clay act in point bearing. The load capacity of a group of such piles is equal to the product of the number of piles in the group and the safe load per pile without regard to their spacing. However, these conditions are ideal for the development of negative skin friction (Art. 35), which may be a sizable proportion of the pile load capacity. The magninude of the negative skin friction can be determined from pile load tests (Sec. 6, Axt. 17). It may also be estimated as the average shearing resistance of the soft material multiplied by the surface area of the embedded piles.

38. Settlement of Pile Foundations Any pile foundation which has a compressible stratum located below the pile tips is likely to settle, and the magnitude of the settlement should be predicted. It is computed in the same manner as for footings on clay except that the change in pressure $\Delta p$ is determined somewhat differently depending upon whether the piles act in point bearing or as friction piles.

For a point-bearing pile foundation, the load on the pile group is assumed to be applied to the subsoil at the level of the pile tips on an area equal to the plan area of the pile group. Below the tips, it is considered to be spread uniformly at an angle of $30^{\circ}$ from the vertical.

The settlement of a group of friction piles is computed in a similar manner. However, the level of the application of the load to the subsoil is less certain, as load is transferred through much of the length of the piles. A commonly used approximate procedure is based on the assumption that the load is applied at the lower third point of the piles. The load is assumed to spread at an angle of $30^{\circ}$ from the vertical, and any compressible material below the lower third point is assumed to contribute to the settlement of the group.

39. Laterally Loaded Piles Where a pile-supported structure is subjected to lateral loads, the vertical piles may provide more lateral resistance than is commonly realized. Prevailing rules of thumb commonly permit an arbitrary lateral load per pile-often $1000 \mathrm{lb}$-without any consideration as to the type of pile or the soil in which it is driven. Since a pile-supported structure does not transmit load directly to the soil beneath the pile cap, frictional resistance should not be assumed between the base of the structure and the underlying soil. Therefore, the piles must be adequate to resist all lateral loads.

The ultimate lateral bearing pressure per unit length of pile at a given depth in clay is

$$
Q_{d}=9 c B=4.5 q_{u} B
$$

and in sands

$$
Q_{d}=3 B \gamma z \frac{1+\sin \phi}{1-\sin \phi}
$$




\section{7-44 Retaining Structures and Foundations}

where $Q_{d}=$ ultimate load per unit length of pile, lb/ft

$c=$ cohesion, psf

$q_{u}=$ unconfined compressive strength, $\mathrm{psf}$

$B=$ width of pile, $\mathrm{ft}$

$\gamma=$ effective unit weight of soil, pcf

$z=$ depth, ft

$\phi=$ angle of shearing resistance

The working load should not exceed $Q_{d} / 2$ beyond a depth of $4 B$ under any circumstance.

For lateral loads smaller than $Q_{d} / 2$, the soil reaction at any depth is given by

$$
w=\frac{C_{w} Q_{h g}}{T}
$$

where $w=$ soil reaction, $1 \mathrm{~b} /$ in

$C_{w}=$ soil reaction coefficient from Fig. 28

$Q_{h g}=$ shear at ground surface, lb

$\stackrel{T}{T}=$ relative stiffiness of pile $=\sqrt[5]{E I / n_{h}}$, in

$E I=$ flexural stiffness of pile, $\mathrm{lb}-\mathrm{in}^{2}$

$n_{h}=$ constant of horizontal subgrade reaction, $1 \mathrm{~b} / \mathrm{in}^{3}$

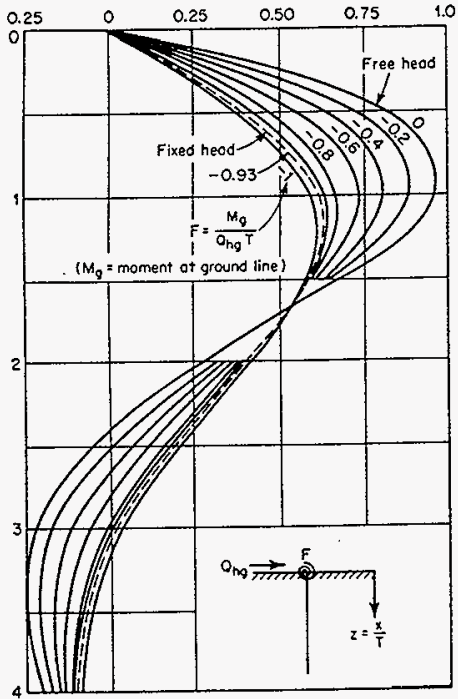

Fig. 28 Coefficients for soil reaction, laterally loaded piles.

(From Prakash, 1962.2') 


$$
\text { Ealculation w320-27-050 B-18 of B-36 }
$$

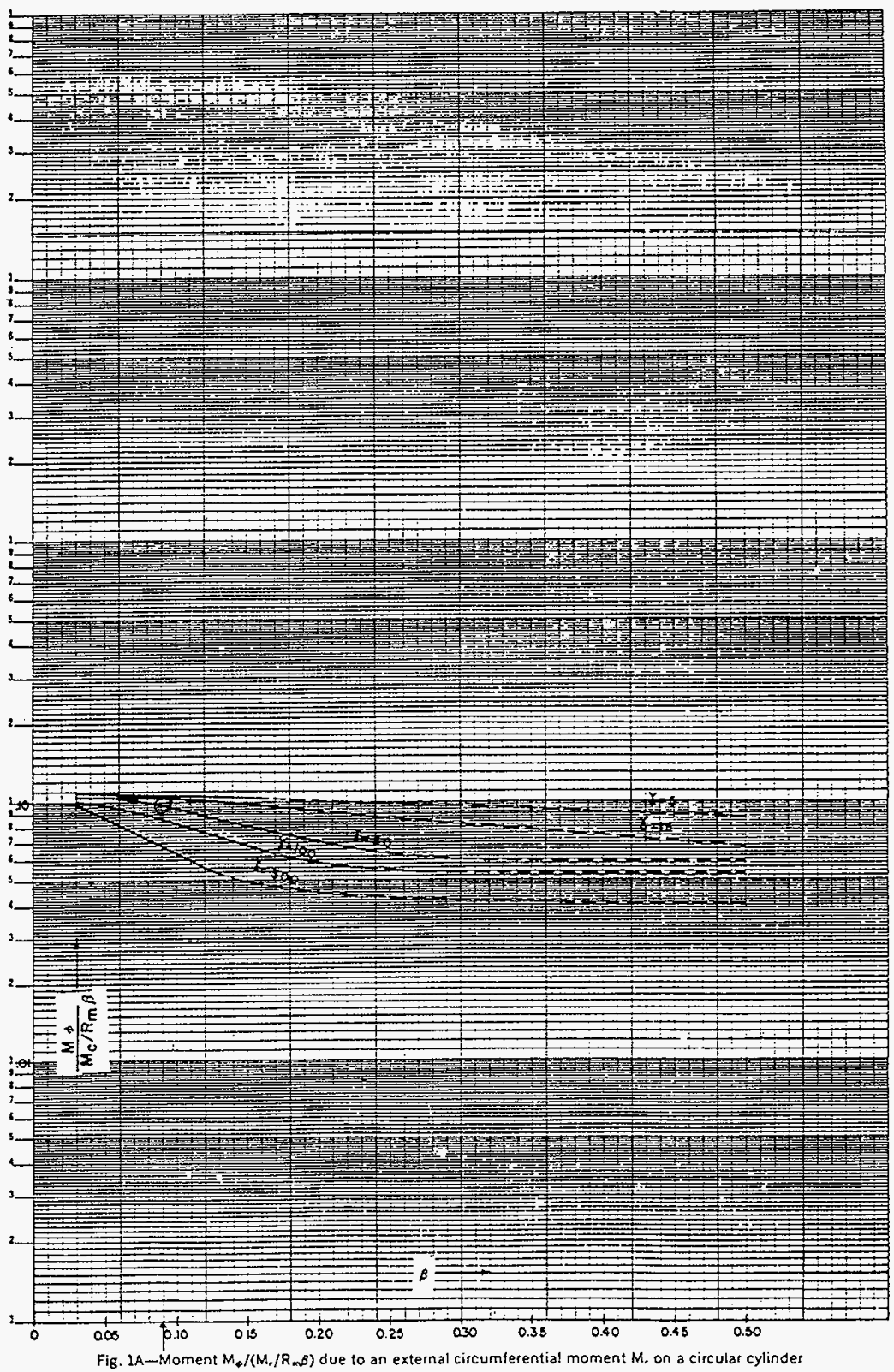




\section{Calculation w320-27-050 B-19 of $3-36$}

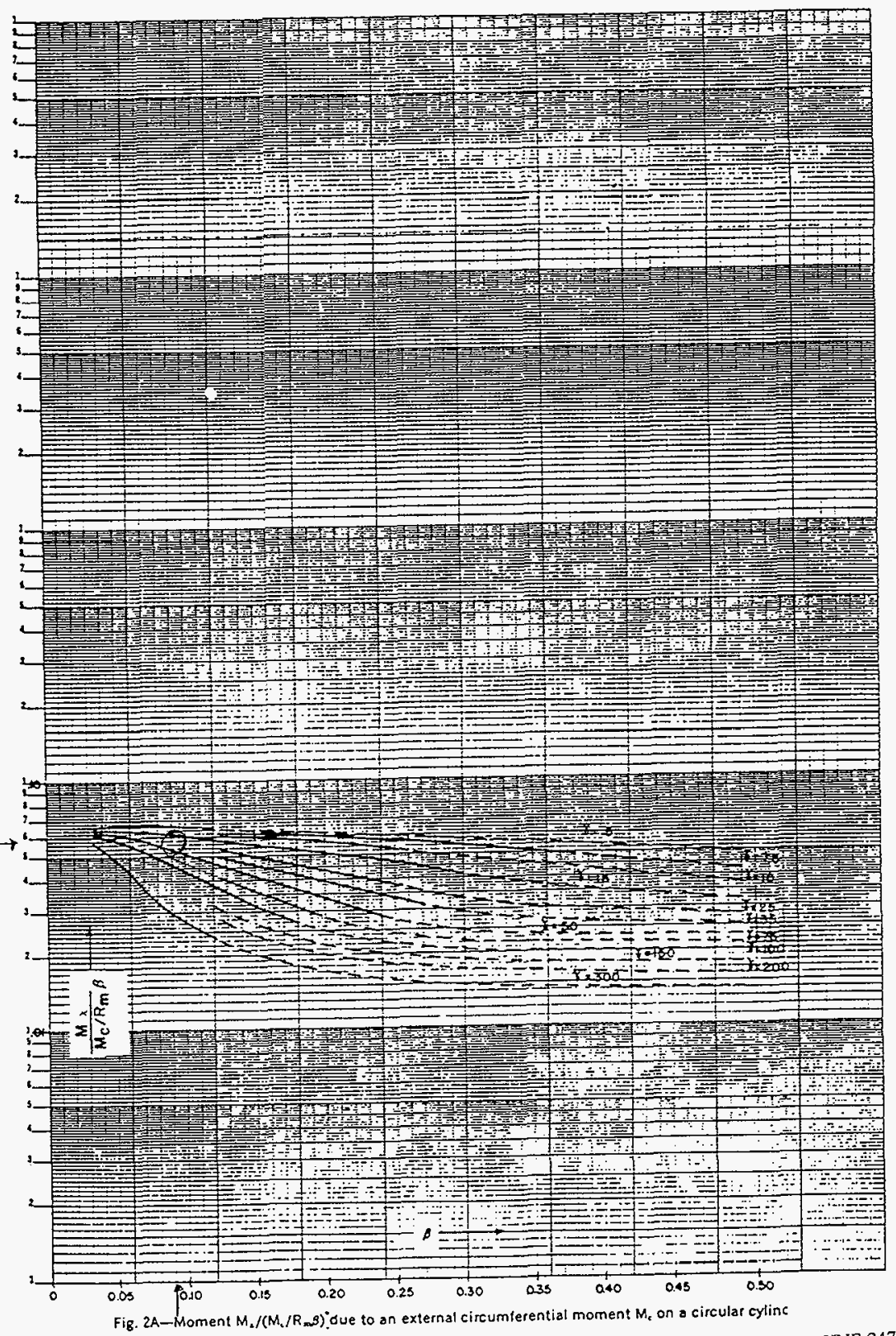

Fig. $2 A-$ Moment $M_{2} /\left(M_{L} / R_{m} 3\right)^{\circ}$ oue to an external circumferential moment $M_{c}$ on a circular cylinc 


$$
\text { Cocintos is } 320-27-050 \quad 6-20 \text { of } B-3 \hat{6}
$$

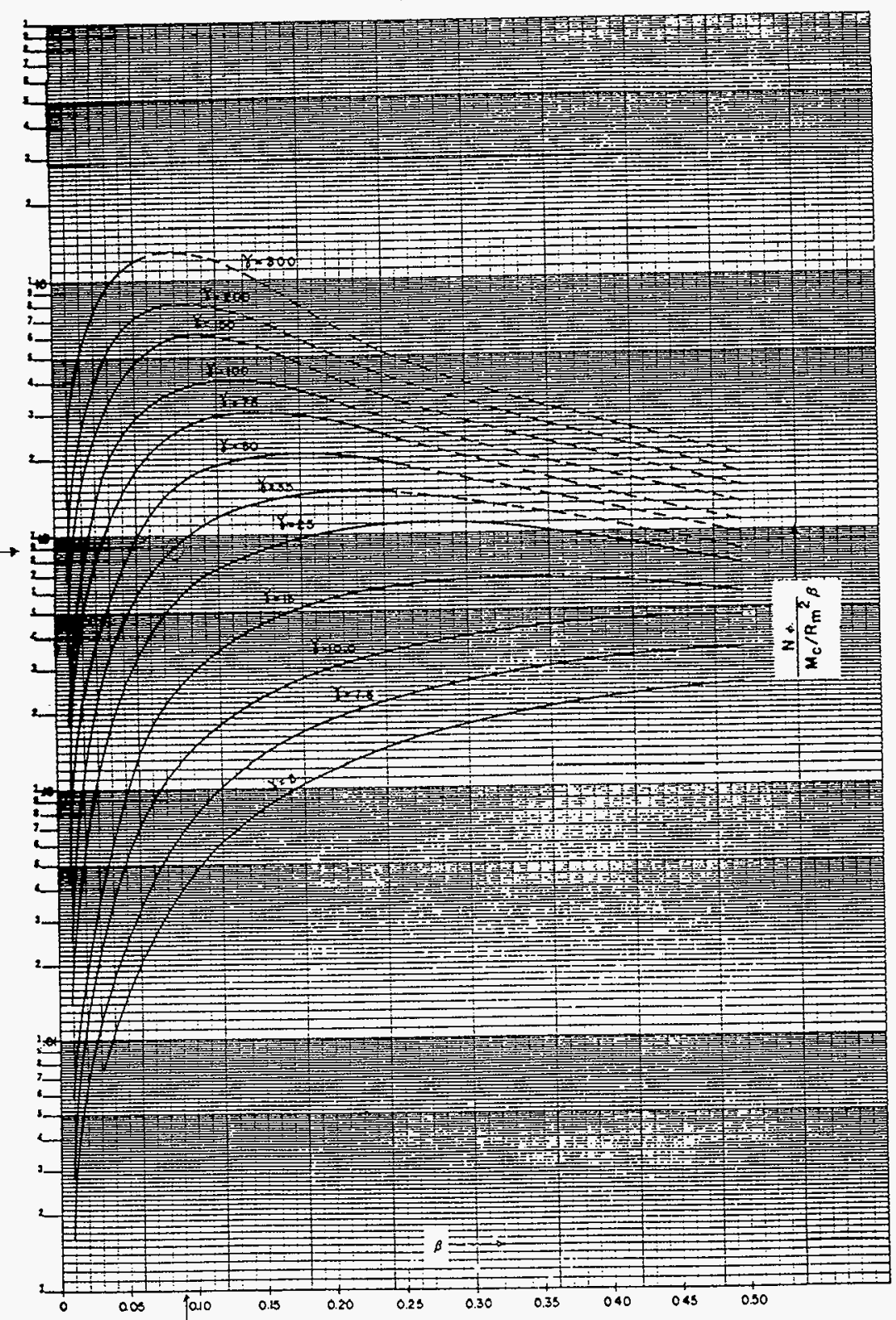

Fig. $3 A-$ Membrane force $N_{\infty} /\left(M_{1} / R_{m}^{2} B\right)$ due to an external circumferential moment $M_{c}$ on a circular cylinder 

Calculation
w320-27-050
$B-21$ of $B-36$

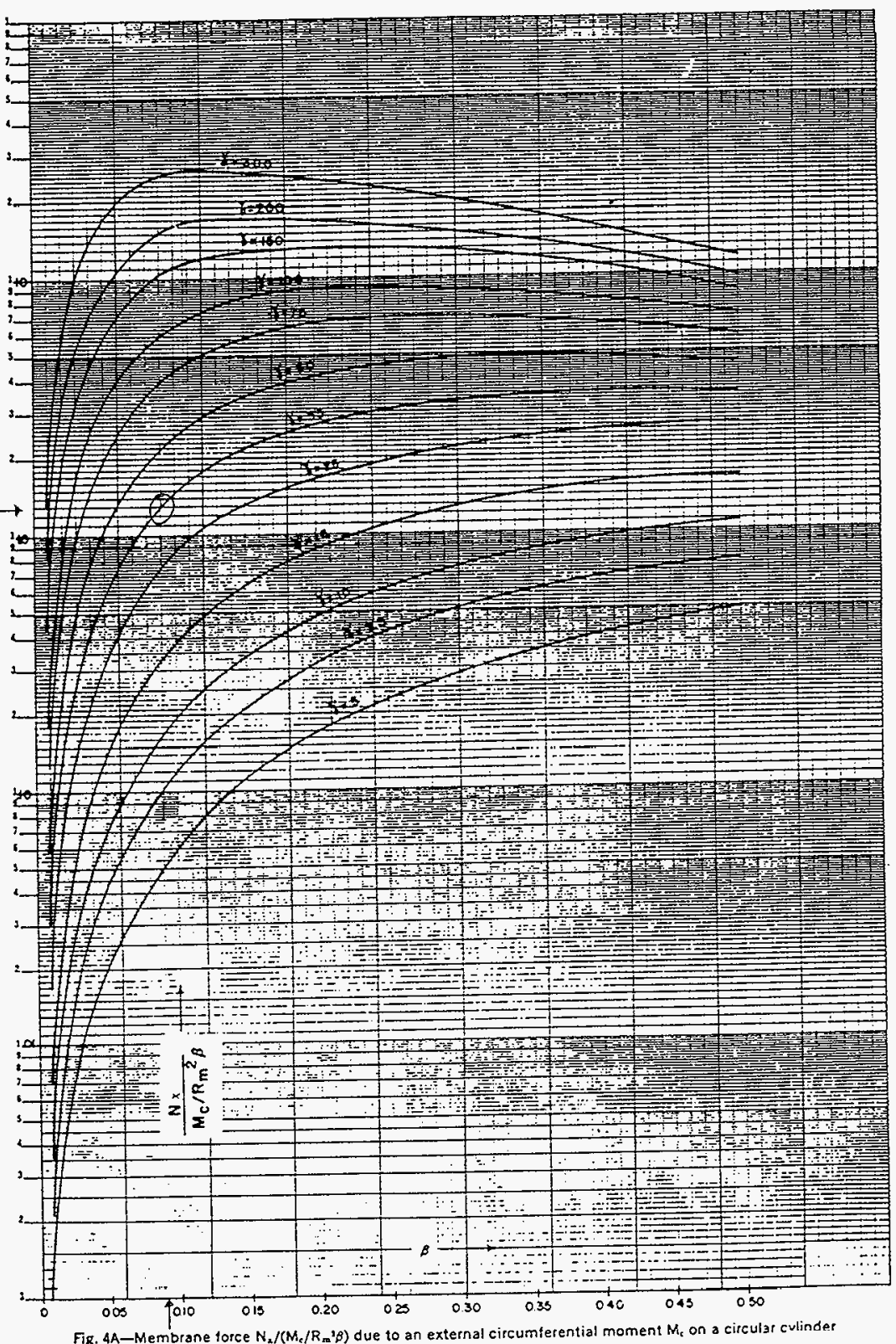

Fig. 4A-Membrane force $N_{\alpha} /\left(M_{f} / R_{m}{ }^{1} \beta\right)$ due to an external circumferential moment $M_{c}$ on a circular culinder 


\section{Calculation $0320-27-050 \quad B-22$ of $B-36$}

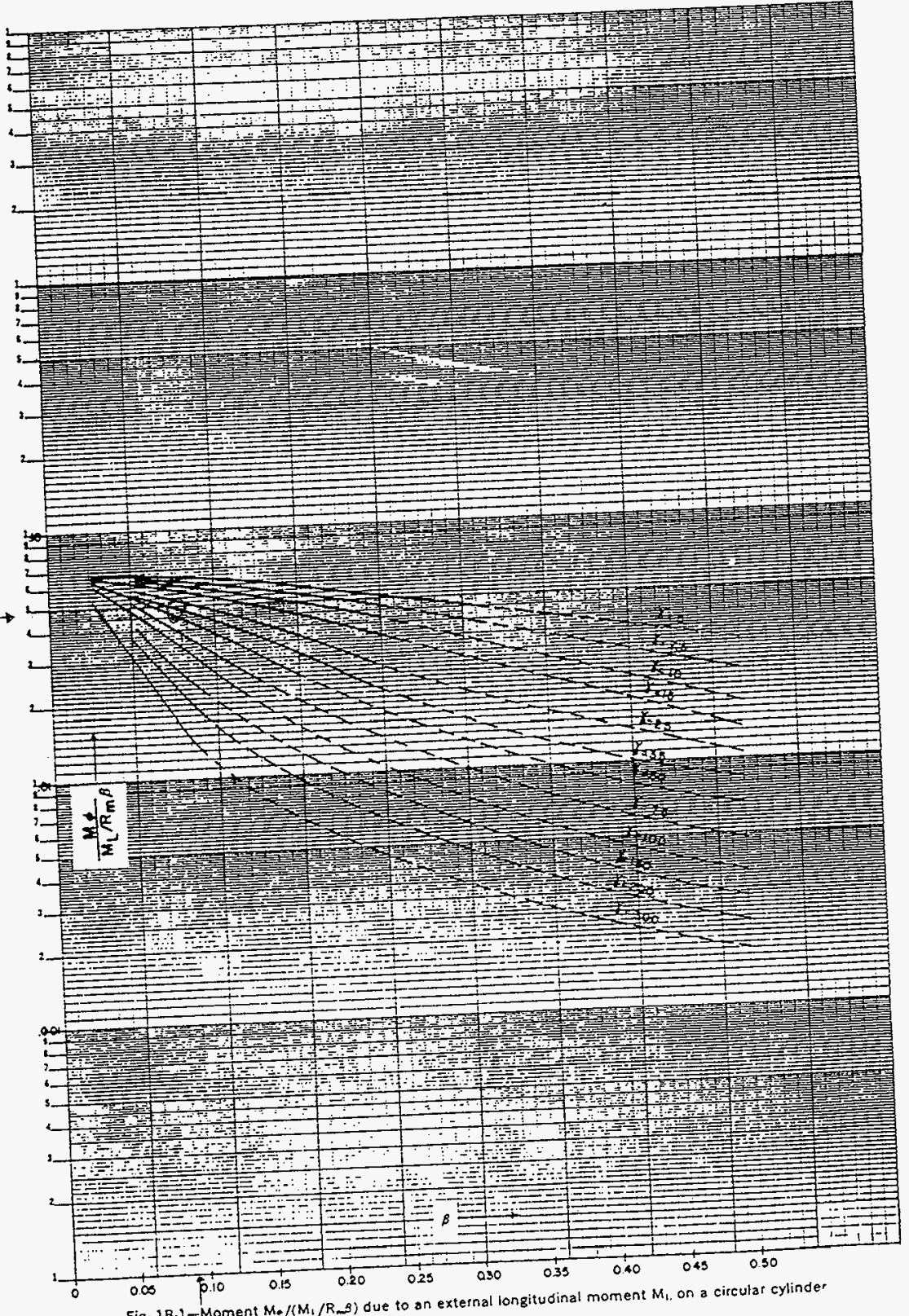

Fig. 1B.1-Moment $M_{-} /\left(M_{1} / R-3\right)$ oue to on external longitudinal moment $M_{1}$, on a circular cylinder 


\section{Calculation w320.27-050 \\ $B-23$ of $B-36$}

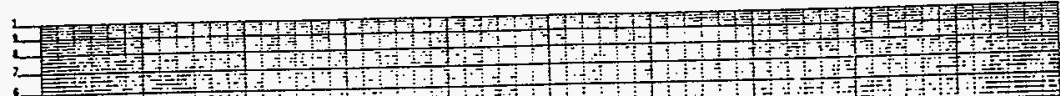

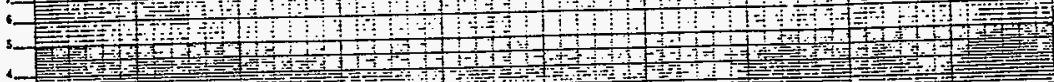

4 34

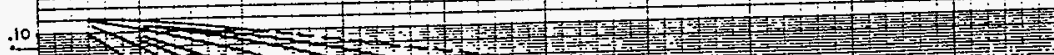

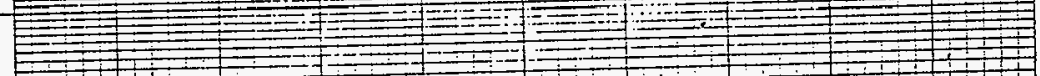

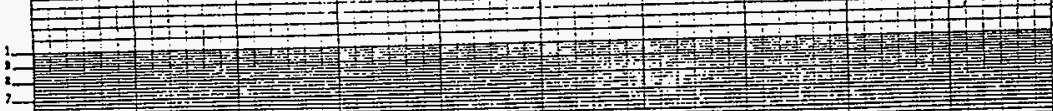
30 3.4

$+$

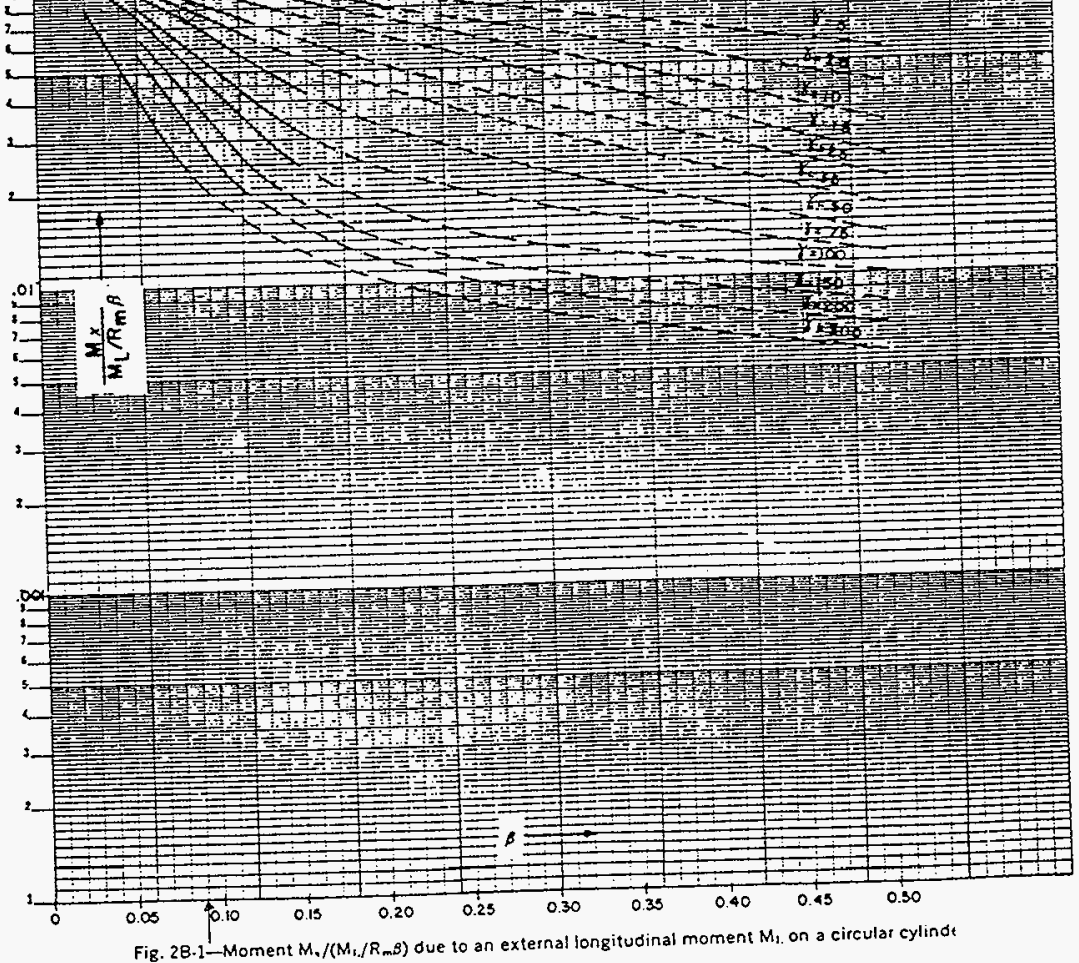

Fig. 28.1-Moment $M_{.} /\left(M_{i} / R_{m} s\right)$ due to an external longitudinal moment $M_{1}$ an a circular cylindt 


\section{Caiciation 0u320-27-050 \\ $B-24$ of $B-36$}

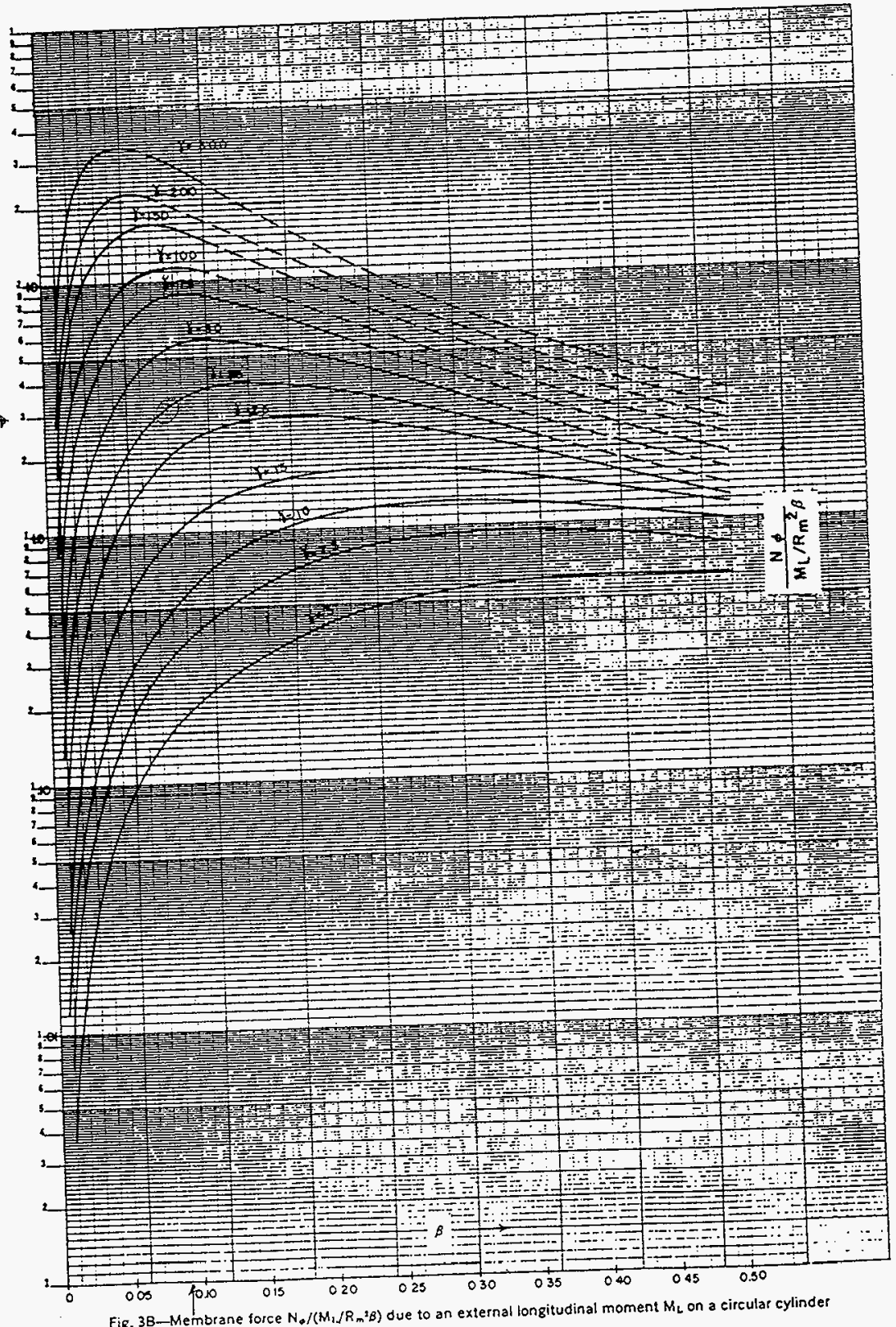

Fig- 3B-Membrane force $N_{*} /\left(M_{1} / R_{m}^{2} B\right)$ due to an external longitudinal moment $M_{L}$ on a circular cylinder 


\section{Calculation w320.27.050 \\ $B-25$ of $B-36$}

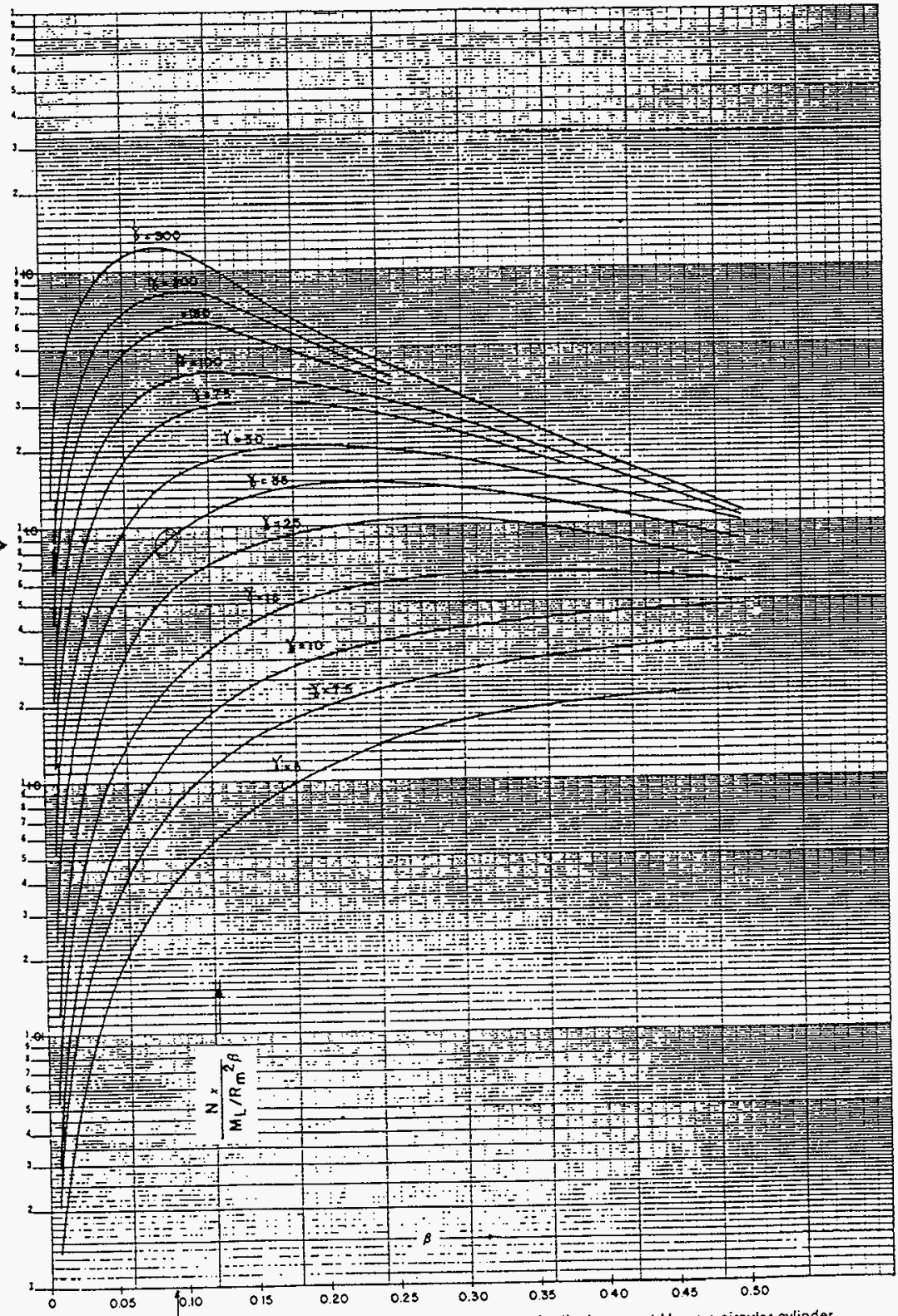

Fig. 4B-Memorane force $N_{\alpha} /\left(M_{L} / R_{\infty}{ }^{\prime} \beta\right)$ due to an external longitudinal moment $M_{L}$ on a circular cylinder 


\section{Calculation $\omega=20-27-050 \quad B-26$ of $B=36$}

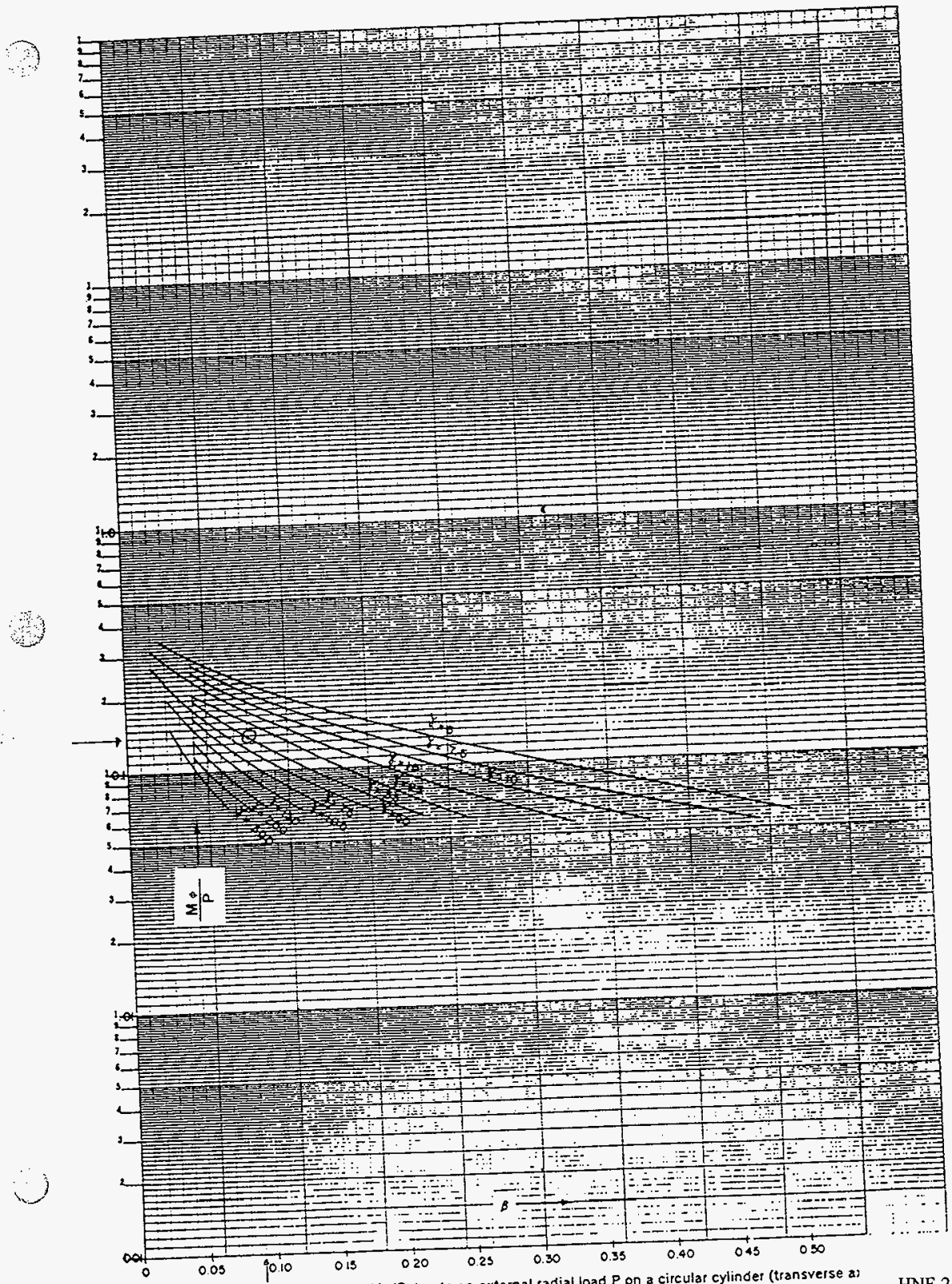

Fig. 1C-Bending moment $M_{0} / P$ due to an external radial load $P$ on a circular cylinder (transverse a)

HNF-2479, Rev. 0 


\section{Colojot os s520-27-050 B-27 of B-36}

(1)

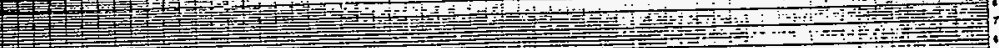
102010

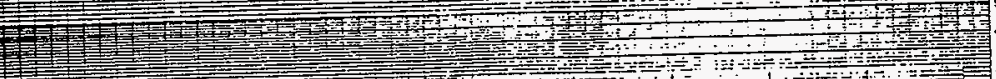

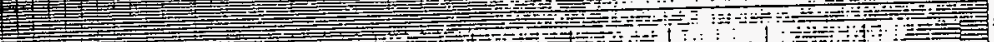

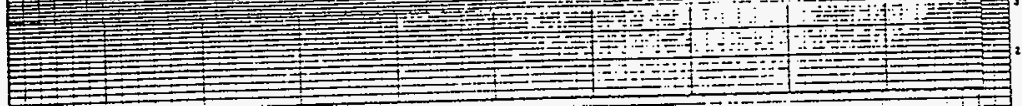

$0+10+19+1$

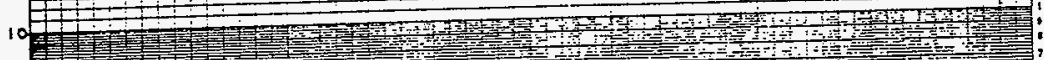
1 (1)

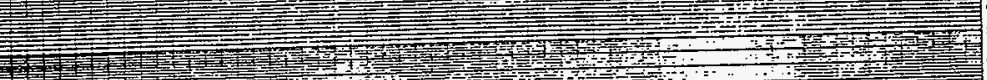

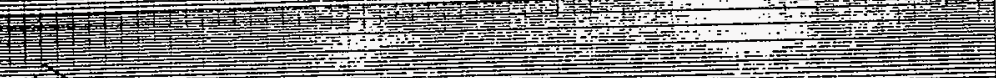
3 $\mathrm{SST}$

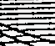

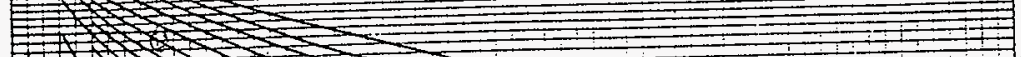

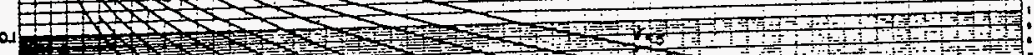

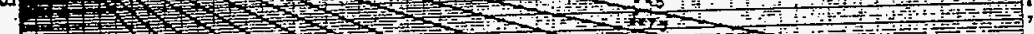
(1)

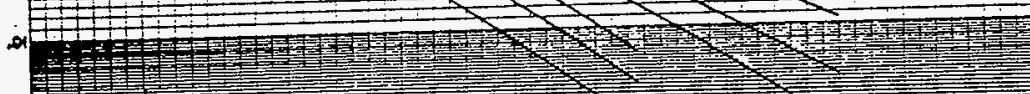
作, $x_{0}$

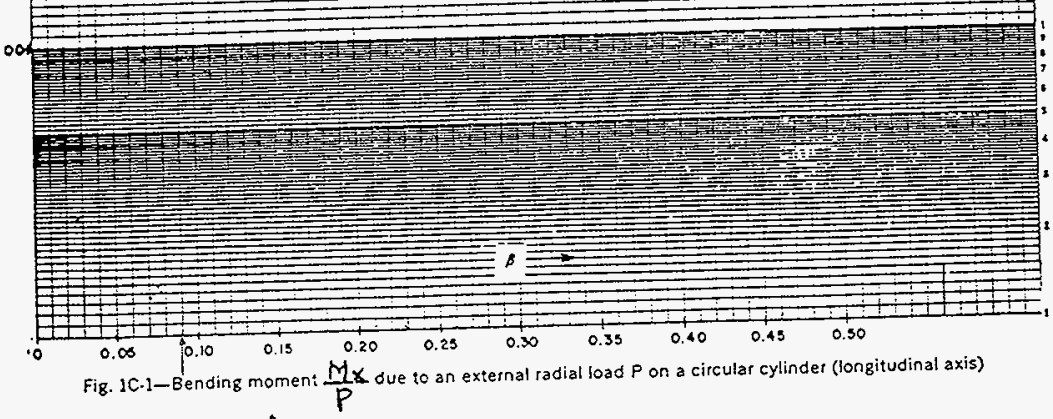




\section{Calculation w320-27-0.50 \\ $B-28$ of $B-36$}

2

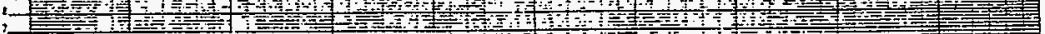

3 1

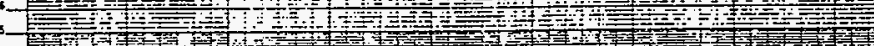

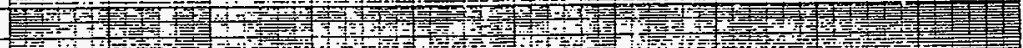

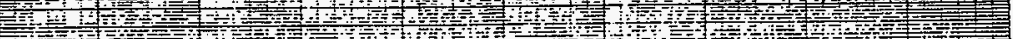
S=

, $\Rightarrow z$ - 0 -

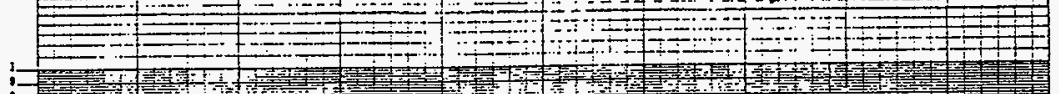
if 1

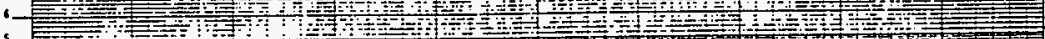

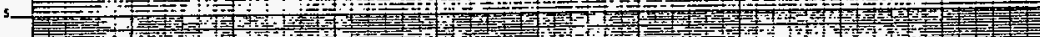

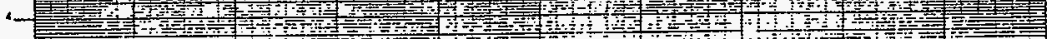
,

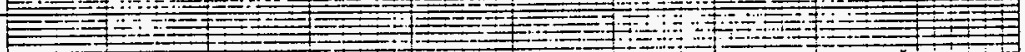

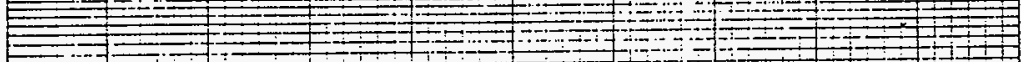

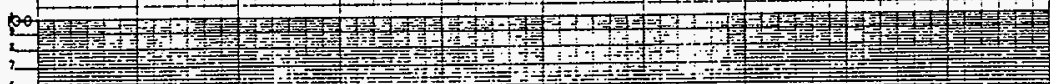
(1)

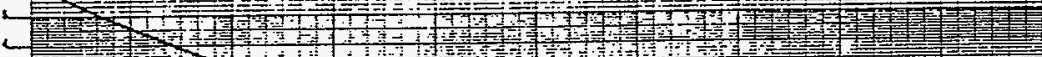

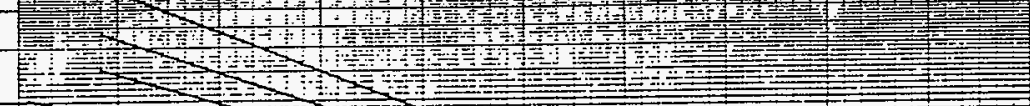

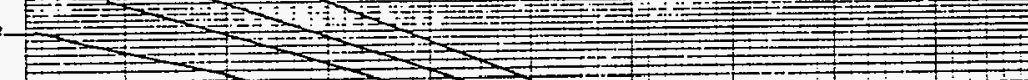

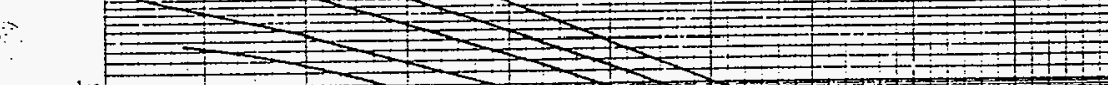

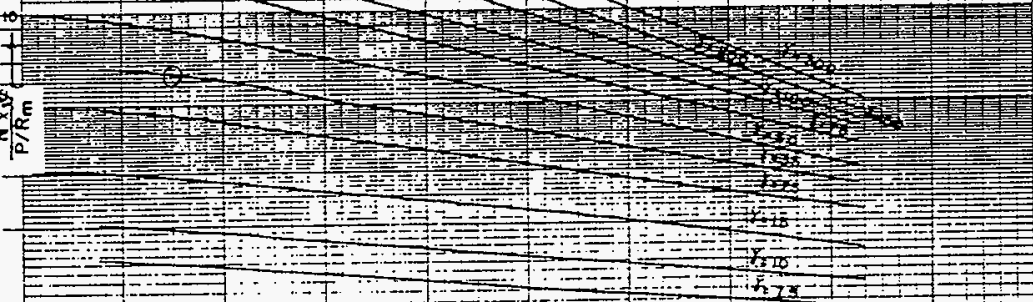

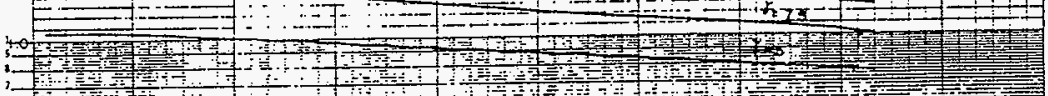

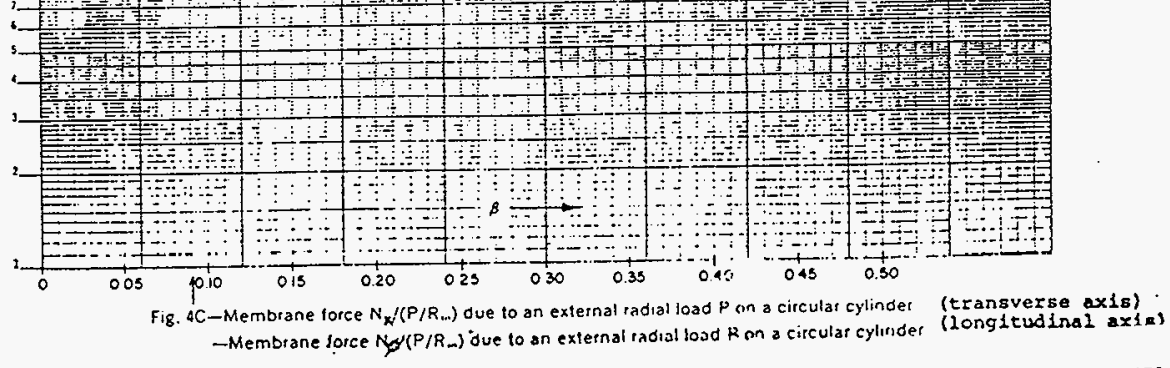




\section{A DUCT FRICTION

Page B-78

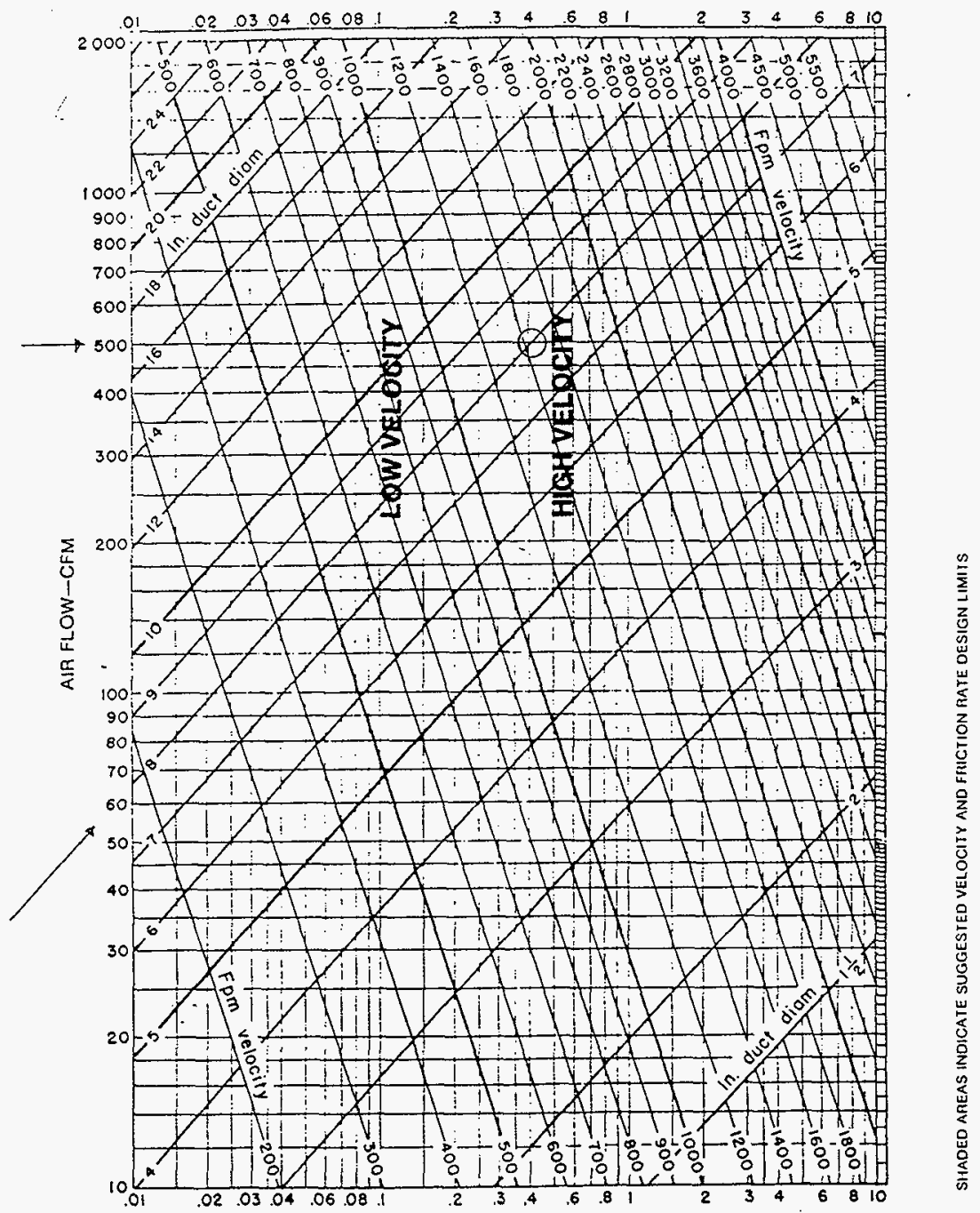

FRICTION LOSS-INCHES OF WATER PER $100 \mathrm{FT}$ 


\section{Calculation W320-27-050 \\ PRESSURE INFORMATION FOR 政IUP Atlax AND ftlax-FLYTE FLEXIBLE DUCT/HOSE}

配Le flax and flax-FLYTE hoses are engineered to operate safely and efficiently in the pres. sure ranges required in most industrial fume and dust control systems. DURA-VENT Corporation suggests that the following polnts be considered when service at higher pressures is intended.

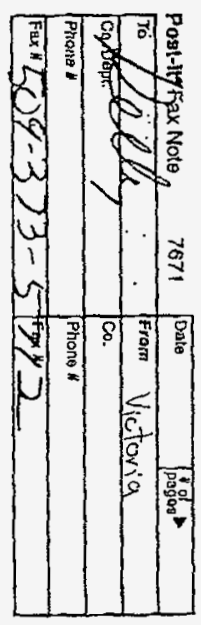

1. If more volume is needed, it is better to go to a larger 1.0. rather than io increased pressure in a smaller hose. This is especially true where bends are pressnt or the hose is being flexed while under pressure. Bends and flexing decrease working and burst pressures.

2. In high-velocity applications, installing the duct/hose so that the direction of flow is with the hose lap will help extend the life of the hose.

3. When pressures in excess of 3 p.s.l. are anticipated and cuffed ends are re. quired, it is recommended that fabric cuffs be used rather than molded cuffs.

4. At least two (2) extra coats of neoprene should be added to the hose for high pressure applications.

5. Under vacuum, flexible ductihose tends to contract and lose flexibility. Use short, straight lengths for high vacuum service and keep bends to a minimum. Be sure both ends are secureiy fastened.

6. For high pressure and volume service, such as Car Wash driers, a nylon hose offers the best value for the money spent.

7. For safe operations and to maximize duct/hose life, stay within the Manu. facturer's recornmended working pressure limits. "Remember, Engineering Data in this publication is gathered on new hose inder.optimum conditions. Time and use tend to lessen performance values. Combinations of adverse conditions can shorten hose life significantly, especlaily excessive pressure combined with bending or flexing.

POSITIVE AND NEGATIVE PRESSURE LIMITS

(POSTIVE PRESSURE IN P.\$.1. - NEGATIYE PFESSUAE IN in HO)

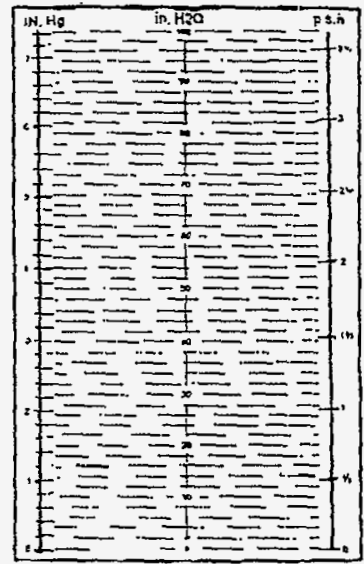

\begin{tabular}{|c|c|c|c|c|c|c|c|c|c|c|}
\hline \multirow{2}{*}{ mese } & \multicolumn{3}{|c|}{$2 \mathrm{CN}-2(2 \mathrm{PN})$} & \multicolumn{3}{|c|}{$2 N N-2$} & \multicolumn{2}{|c|}{ 1CN-2EP } & \multicolumn{2}{|c|}{ INK-EEP } \\
\hline & $\operatorname{sen} x$ & masters & 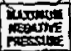 & monstic & minis & nowes & oxsts & $\operatorname{son} 6$ & nises & moneste \\
\hline-1 & 130 & 43 & 30 & 125 & 41 & 30 & & & & \\
\hline $11 \%$ & 128 & 42: & 30 & $125:$ & $41^{\circ}$ & 30. & & & & \\
\hline $11 / 2$ & 128 & 42 & 30 & 125 & 41 & 30 & & & & \\
\hline 2 & 105 & 35 & 28 & $100^{\circ}$ & 33 & 28 & & & & \\
\hline $21 / 2$ & $B 4$ & 28 & 28 & 80 & 27 & 29 & & & & \\
\hline 3 & 73 & 24 & 27 & $70^{\prime}$ & 23 & $27^{\prime \prime}$ & & & & \\
\hline 4 & 57 & 19 & 25 & 55 & 18 & 25 & 39 & 13 & 40 & 13 \\
\hline 5 & 48 & 16 & 18 & $43^{\circ}$ & 14 & 18 & & & & \\
\hline 6 & 48 & 16 & 14 & 43 & 14 & 14 & 34 & 11 & 35 & 11 \\
\hline 7 & 35 & 19 & 12 & 35 & 12 & 12. & & & & \\
\hline 1.8 & 35 & 11 & 10 & 33 & 11 & 10 & 30 & 10 & 30 & 10 \\
\hline$\because 10$ & 30 & 10 & 5 & 30 & 10 & 5 & 25 & 8 & 25 & 8 \\
\hline $1 . \overline{12}$ & 25 & 9 & 3 & 24 & 8 & 3 & 22 & 7 & 20 & 7 \\
\hline$\because 14$ & 20 & 7 & 2 & $20^{\circ}$ & 6 & 25 & & & & \\
\hline 16 & 17 & 6 & 2 & 15 & 5 & 2 & & & & \\
\hline 18 & 13 & 4 & 1 & 10 & 3 & 1. & & & & \\
\hline
\end{tabular}

Data shown above are tor stralght lengths $Q 70^{\circ} \mathrm{F}$ 


\section{DURA-VENT}

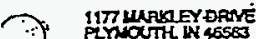

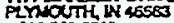 \\ $1+800048.8500$ \\ (19) \\ Fin:(21) 25:2505}

\section{?}

SPECIEICATION SHEET

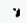

$\because 8^{\prime} \quad I \dot{D}=P H$

\section{CONSTRUCTION:}

TEMPERATURE:
2PLY NEOPRENE IAPREGINATED POLYESTER DUCT WITH A . CONTINUUOUS SPRINE STEEL WIRE HELIX SUPPORT.

$-40 F T 0+250 F$

\section{MATERIAL SPECIFICATIONS:}

WEIGHT:

TENSIL:

TENSIL:

ABRASION:

CLOTH:

FLAME RESIS:
9 OZ. (+ OR - .5OZ SQ/YO)

WARP - 133 FILL- 95 LBS - UNCOATEP

WARP - 170 FILL- IAO LBS - COATED

CYCLES TO FABRIC- $180 /$ CYCLES THSU FAB-SQ0, 100 \& POLYESTER SHEETING

1) UL9A-VO

2) MINS 540-106-1 (MARE ISLAND NSY)

3) CALIFORNIA $T-19$

9) NFPA 701 - LARGE SCALE

PRESSURE RATE:

BENO RAOIUS:

WIEGHT:

COATINGS:
POSITIVE- $\|$ PSI NEGATIVE- /O"MERCURY

65 CENTERLIHE BENO RAOIUS

1.75 LBS PER FOOT

THIS PRODUCT IS ALSO AVAILABLE WITH TWO DIFFERENT TYPES OF ADOITIONAL COATINGS. 1) NEOPRENE COATING TO EXTEND DUCT LIFE AGAINST ABRASION AND. SEALS DUCT, 2) URETHANE TO TO EXTEND DUCT LIFE AGAINST ABRASION ANO GIVES DUCT A SLICK FINISH TO PREVENT INTERNAL BUILO-UP OF PRODUCT.
HNF-2479, Rev. 0

Page B-80

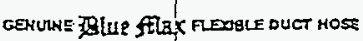




\section{DESIGN LOADS FOR FACILITIES}

\section{Safety Class Upgrades}

NON-REACTOR FACILITIES

Safety Class 1 Structures, Systems, and Components

Wind Loads

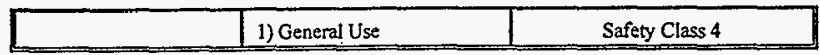

(a) PNNL currently uses the DOE Order 6430.1A safety class designations. The design of PNNL Nonsafety Class facilities shall use the General Use Safety Class 4 design load criteria as a mininum. The design of emergency facilities, mission dependent facilities, or other facilities may use Moderate Hazard Safety Class 2 or Important/Low Hazard Safety Class 3 criteria. The use of these higher criteria shall be determined by PNNL prior to design and transmitted to others as needed through normal project documentation.

Safety Class designation or Facility Use Category may be upgraded by DOE direction to provide additional conservatism.:

Safety Class 1 structures, systems, components, and equipment (DOE Order 6430.1 A, Safety Class) are those that perform a function required for nuclear criticality safety or whose failure might result in a significant release of radioactive, hazardous, or toxic materiais as defined by DOE Order 6430.1A, Division 13, as it relates to non-reactor nuclear facilities. Included in this category are those systems, components, and equipment vital for safe shutdown.

Safety Class 1 structures, systems, components, and equipment are designed for nominal dead, live, snow, and soil loads (as defined in ASCE 7-88), for normal operating loads as defined in the facility functional design criteria, and for the natural phenomena loading of extreme wind, earthquake, ashfall, and flood. Structures, systems, components, and equipment of any safety class need not be subjected simultaneously to any combination of extreme wind, earthquake ground motions, ashfall, and flood. Load combinations and allowable stresses for these loads are noted in Section, "Load Combination and Allowable Stresses." Application of these load combinations and allowable stresses for supports of systems, components, and equipment is appropriate.

Non-reactor Safety Class 1 (UCRL-15910 High Hazard) structures, systems, components, and equipment are designed for wind loads in accordance with ASCE 7-88 using the following criteria:

"Fastest Mile" Wind Speed
@eight $(\mathrm{H})=10$ meters (33 feet)
Importance Factor
Exposure Class
Missile (horizontal)

$40 \mathrm{~m} / \mathrm{s}$ (90 miles per hour)

$$
\begin{aligned}
& 1.0 \\
& \text { C } \\
& 50 \times 100 \mathrm{~mm}(2 \times 4) \text { Timber Plank } 7 \mathrm{~kg} \\
& \text { ( } 15 \text { pounds) @ } 22 \mathrm{~m} / \mathrm{s} \\
& \text { ( } 50 \text { miles per hour) maximum trajectory } \\
& \text { height=15 m ( } 50 \text { feet). }
\end{aligned}
$$

These requirements apply except where adjacent structures or high ground create a potential for missile impacts at higher elevations. 


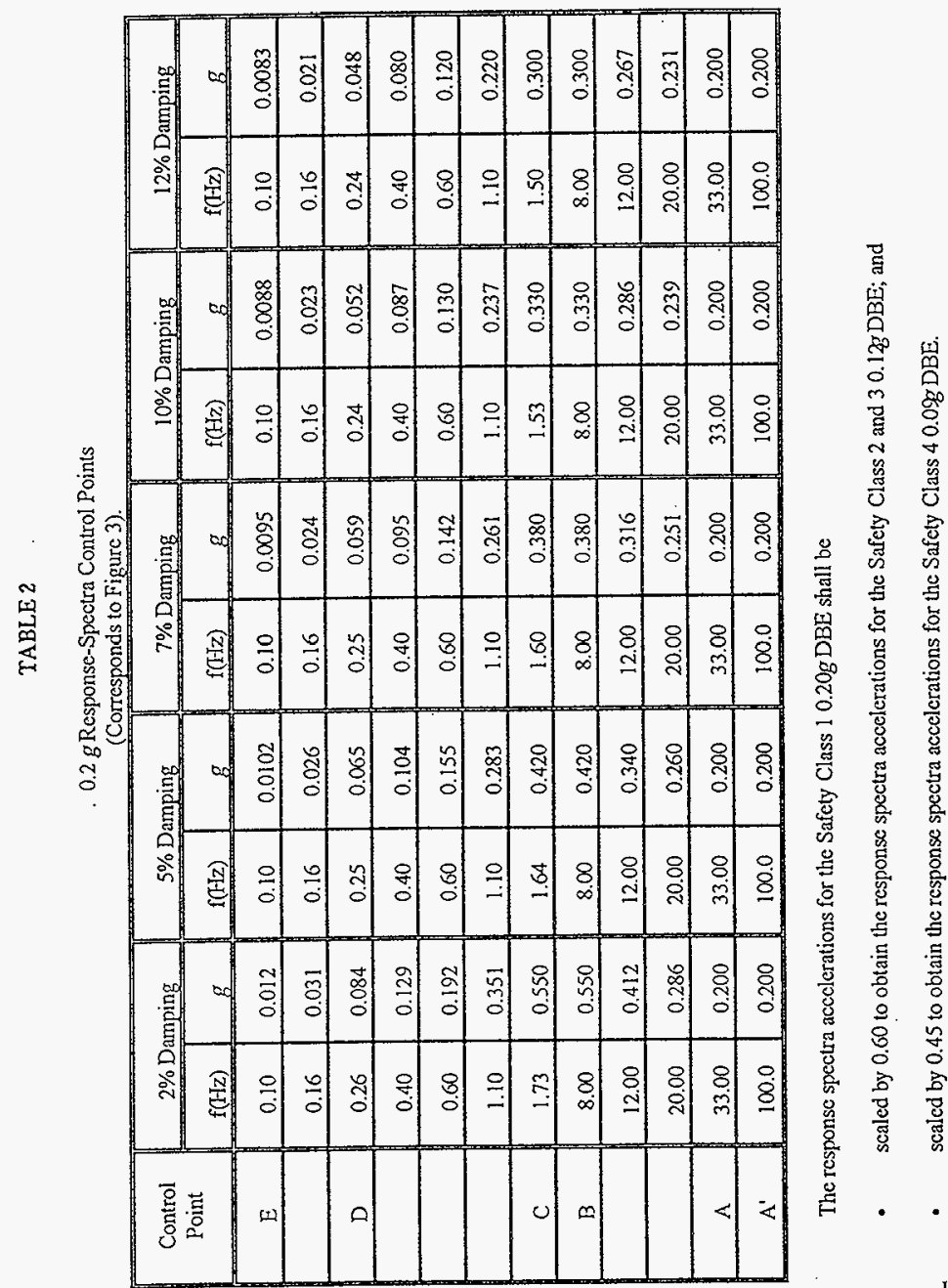

HNF-2479, Rev. 0 Page B-82 
(a) (d) The total number of pressure-temperature variations above the design conditions shall not exceed 1000 during the life of the piping system.

(e) In no case shall the increased pressure exceed the test pressure used under para. 345 for the piping system.

(f) Occasional variations above design conditions shall remain within one of the following limits for pressure design.

(I) Subject to the owner's approval, it is permissible to exceed the pressure rating or the allowable stress for pressure design at the temperature of the increased condition by not more than:

(a) $33 \%$ for no more than $10 \mathrm{hr}$ at any one time and no more than $100 \mathrm{hr} / \mathrm{yr}$; or

(b) $20 \%$ for no more than $50 \mathrm{hr}$ at any one time and no more than $500 \mathrm{hr} / \mathrm{yr}$.

The effects of such variations shall be determined by the designer to be safe over the service life of the piping system by methods acceptable to the owner. (See Appendix V.)

(2) When the variation is self-limiting (e.g., due to a pressure relieving event), and lasts no more than $50 \mathrm{hr}$ at any one time and not more than $500 \mathrm{hr} /$ year, it is permissible to exceed the pressure rating or the allowable stress for pressure design at the temperature of the increased condition by not more than $20 \%$.

(g) The combined effects of the sustained and cyclic variations on the serviceability of all components in the system shall have been evaluated.

(h) Temperature variations below the minimum temperature shown in Appendix A are not permitted unless the requirements of para. 323.2.2 are met for the lowest temperature during the variation.

(i) The application of pressures exceeding pressuretemperature ratings of valves may under certain conditions cause loss of seat tightness or difficulty of operation. The differential pressure on the valve closure element should not exceed the maximum differential pressure rating established by the valve manufacturer. Such applications are the owner's responsibility.

302.2.5 Ratings at Junction of Different Services. When two services that operate at different pressuretemperature conditions are connected, the valve segregating the two services shall be rated for the more severe service condition. If the valve will operate at a different temperature due to its remoteness from a header or piece of equipment, this valve (and any mating flanges) may be selected on the basis of the different temperature, provided it can withstand the required pressure tests on each side of the valve. For piping on either side of the valve, however, each system shall be designed for the conditions of the service to which it is connected.

\subsection{Allowable Stresses and Other Stress Limits}

302.3.1 General. The allowable stresses defined in (a), (b), and (c) below shall be used in design calculations unless modified by other provisions of this Code.

(a) Tension. Basic allowable stresses $S$ in tension for metals and design stresses $S$ for bolting materials, listed in Tables A-1 and A-2, respectively, are determined in accordance with para. 302.3.2.

In equations elsewhere in the Code where the product $S E$ appears, the value $S$ is multiplied by one of the following quality factors ${ }^{1}$ :

(I) casting quality factor $E_{c}$ as defined in para. 302.3.3 and tabulated for various material specifications in Table A-1A, and for various levels of supplementary examination in Table $302.3 .3 \mathrm{C}$; or

(2) longitudinal weld joint factor $E_{j}$ as defined in 302.3.4 and tabulated for various material specifications and classes in Table A-1B, and for various types of joints and supplementary examinations in Table 302.3.4.

The stress values in Tables A-1 and A-2 are grouped by materials and product forms, and are for stated temperatures up to the limit provided in para. 323.2.1(a). Straight line interpolation between temperatures is permissible. The temperature intended is the design temperature (see para. 301.3).

(b) Shear and Bearing. Allowable stresses in shear shall be 0.80 times the basic allowable stress in tension tabulated in Table A-1 or A-2. Allowable stress in bearing shall be 1.60 times that value.

(c) Compression. Allowable stresses in compression shall be no greater than the basic allowable stresses in tension as tabulated in Appendix A. Consideration shall be given to structural stability.

302.3.2 Bases for Design Stresses. ${ }^{2}$ The bases for establishing design stress values for bolting materials and allowable stress values for other metallic materials in this Code are as follows.

\footnotetext{
${ }^{1}$ If a component is made of castings joined by longitudinal welds, both a casting and a weld joint quality factor shall be applied. The equivalent quality factor $E$ is the product of $E_{c}$, Table A.1A, and $E_{j}$, Table A-1B.

${ }^{2}$ These bases are the same as those for BPV Code, Section VIII, Division 2, given in Section II, Part D. Stress values in B31.3, Appen$\operatorname{dix} A$, at temperatures below the creep range generally are the same as those listed in Section II, Part D, Tables 2A and 2B, and in Table 3 for bolting, corresponding to those bases. They have been adjusted as necessary to exclude casting quality factors and longitudinal weld
} 
302.3.6 Limits of Calculated Stresses due to Occasional Loads

(a) Operation. The sum of the longitudinal stresses due to pressure, weight, and other sustained loadings $S_{L}$ and of the stresses produced by occasional loads, such as wind or earthquake, may be as much as 1.33 times the basic allowable stress given in Appendix A. For castings, the basic allowable stress shall be multiplied by the casting quality factor $E_{c}$. Where the allowable stress value exceeds two-thirds of yield strength at temperature, the allowable stress value must be reduced as specified in para. 302.3.2(e). Wind and earthquake forces need not be considered as acting concurrently.

(b) Test. Stresses due to test conditions are not subject to the limitations in para. 302.3. It is not necessary to consider other occasional loads, such as wind and earthquake, as occurring concurrently with test loads.

\subsection{Allowances}

In determining the minimum required thickness of a piping component, allowances shall be included for corrosion, erosion, and thread depth or groove depth. See definition for $c$ in para. 304.1.1(b).

302.4.1 Mechanical Strength. When necessary, the wall thickness shall be increased to prevent overstress, damage, collapse, or buckling due to superimposed loads from supports, ice formation, backfill, or other causes. Where increasing the thickness would excessively increase local stresses or the risk of brittle fracture, or is otherwise impracticable, the required strength may be obtained through additional supports, braces, or other means without an increased wall thickness. Particular consideration should be given to the mechanical strength of small pipe connections to piping or equipment.

\section{PART 2 \\ PRESSURE DESIGN OF PIPING COMPONENTS}

\section{GENERAL}

Components manufactured in accordance with standards listed in Table 326.1 shall be considered suitable for use at pressure-temperature ratings in accordance with para. 302.2.1. The rules in para. 304 are intended for pressure design of components not covered in Table 326.1, but may be used for a special or more rigorous design of such components. Designs shall be checked for adequacy of mechanical strength under applicable loadings enumerated in para. 301.

\section{PRESSURE DESIGN OF COMPONENTS}

\subsection{Straight Pipe}

\subsubsection{General}

(a) The required thickness of straight sections of pipe shall be determined in accordance with Eq. (2):

$$
t_{m}=t+c
$$

The minimum thickness $T$ for the pipe selected, considering manufacturer's minus tolerance, shall be not less than $t_{m}$.

(b) The following nomenclature is used in the equations for pressure design of straight pipe.

$t_{m}=$ minimum required thickness, including mechanical, corrosion, and erosion allowances

$t=$ pressure design thickness, as calculated in accordance with para. 304.1.2 for internal pressure or as determined in accordance with para. 304.1.3 for external pressure

$c=$ the sum of the mechanical allowances (thread or groove depth) plus corrosion and erosion allowances. For threaded components, the nominal thread depth (dimension $h$ of ASME B1.20.1, or equivalent) shall apply. For machined surfaces or grooves where the tolerance is not specified, the tolerance shall be assumed to be $0.5 \mathrm{~mm}(0.02 \mathrm{in}$.) in addition to the specified depth of the cut.

$T=$ pipe wall thickness (measured or minimum per purchase specification)

$d=$ inside diameter of pipe. For pressure design calculation, the inside diameter of the pipe is the maximum value allowable under the purchase specification.

$P=$ internal design gage pressure

$D=$ outside diameter of pipe as listed in tables of standards or specifications or as measured

$E=$ quality factor from Table A-1A or A-1B

$S=$ stress value for material from Table A-1

$Y=$ coefficient from Table 304.1.1, valid for $t<D / 6$ and for materials shown. The value of $Y$ may be interpolated for intermediate temperatures.

For $t \geq D / 6$,

$$
Y=\frac{d+2 c}{D+d+2 c}
$$


5.10.3.2 Loadings. Stresses and deflections, or charts used to determine them, shall be based on calculations that consider the following loads where applicable.

(a) Differential pressure across the duct wall as affected by:

(l) maximum positive or negative pressure during all conditions of operation accounting for possible damper positions;

(2) pressure transjents due io:

(a) pipe breaks, including both postulated Loss-of-Coolant Accident (LOCA) and lesser pipe break incidents which may cause external pressure rises and/or internal pressure pulses originating in sections of duct with openings in possible pipe break areas;

(b) extreme wind conditions, including tornado, hurricane; closure;

(c) rapid damper, plenum door, or valve

(b) duct weight, including insulation;

(c) duct sections with exposed top surfaces, which could be used as a walkway or crawl space, shall be capable of supporting a $250 \mathrm{lb}$ weight concentrated midway between hangers;

(d) seismic forces;

(e) thermal expansion.

5.10.3.3 Stress. Allowable stress shall be 0.6 of the yield stress for loads encountered during normal plant operation and shutdown, and shall be 0.9 of the yield stress for combined loads which include the Safe Shutdown Earthquake and Design Basis Tornado.

5.10.3.4 Static Deflection. Allowable static deflections shall not exceed the following values:

(a) plate or sheet: $1 / 8 \mathrm{in}$. per $\mathrm{ft}$ of the maximum unsupported panel span in direction of airflow but not more than $\%$ in. relative to stiffeners;

(b) stiffeners and flange connections: $1 / 8$ in. per $\mathrm{ft}$ of span but not more than $3 / 4$ in;

(c) flange connection to dampers and fans: $1 / 360$ of the span or $1 / 8$ in. maximum.

5.10.4 Duct Construction. Transverse joints shall be gasketed flange, seal-welded flange, or buttwelded. Longitudinal seams shall be either all-welded, seal-welded mechanical, or in accordance with SMACNA - High Pressure Duct Construction Standards (Pittsburgh Lock or ASME Lock Seam) as required to meet structural and leaktightness requirements of paras. 5.10 .3 and 4.14 , respectively.

Mechanical lock seams, if used, must meet seismic structural design requirements. For all-welded joints, the minimum duct thickness shall be 18 gauge $(0.047$ in.) to ensure reliability of the weld. Turning vanes, where used, shall be reinforced and fastened to the duct elbow by welding to withstand the loading specified. Radius elbows, where used, should have a minimum centering radius of 1.0 times the width or diameter of the duct in the plane of the bend.

Placement and design of hangers and supports shall meet the stress criteria given in para. 5.10.3.3 whenconsidering the sources of load given in para. 5.10.3.2.

Stiffeners shall be of sufficient size and quantity and welded to the duct to meet the structural requirements of para. 5.10.3. Stiffener materials shall be compatible with the material of the duct.

Supports shall be formed of fabricated structural members of a material compatible with the duct and stiffeners. Supports shall be securely fastened to building members by welding or by the use of bolts. Supports shall be fastened to the duct or stiffeners in accordance with the structural requirements.

Accessories shall be provided, as required, for the termination of the duct at outlets and inlets. Access doors shall be provided for inspection and maintenance of devices mounted inside the duct. Access doors shall be designed and installed to minimize leakage in accordance with the allowable leakage of para. 4.14.

Duct ends of flexible connectors shall be supported and positioned such that they do not tension the fabric.

5.10.5 Welding. Welding shall be in accordance with para. 7.3 .

5.10.6 Materials. Ducts may be fabricated from stainless steel, carbon steel, galvanized steel sheet, plate, pipe, or rolled structural sections. Structural members may be fabricated from plain or galvanized carbon steel.

Stainless steel shall conform to ASTM A 666 or ASTM A 240. Carbon steel shall conform to ASTM A 36 for structural shapes or ASTM A 283 Grade C or D, or ASTM A 284 Grade C or D for plate. Carbon steel shall be hot-rolled pickled and oiled per ASTM A 570, or hot-rolled pickled and oiled, or cold-rolled per ASTM A 606 or A 607 . Galvanized steel shall be in accordance with ASTM A 526 or A 527 , coated to ASTM A 525, Coating Designation 690.

Use of nonmetallic materials in fabrication or installation of ducts and duct components shall, in addition to considerations of allowable stress, be based on resistance to deterioration from contaminants, heat, 
HNF-2479, Rev. 0

W320-27-051

Jumper Flushing Supply Head Analysis

$c-i$ 


\begin{tabular}{|l|c|c|}
\hline \multirow{3}{*}{$\begin{array}{l}\text { FLUOR DANIEL } \\
\text { NORTHWEST INC. }\end{array}$} & $\begin{array}{c}\text { CALCULATION IDENTIFICATION } \\
\text { AND INDEX }\end{array}$ & \begin{tabular}{c} 
Page i of ii \\
\cline { 2 - 3 }
\end{tabular} \\
\hline
\end{tabular}

This sheet shows the status and description of the attached Design Analysis sheets.

Discipline: (27) Piping WO/Job No.: ER4319N-320

Calculation No.: W320-27-051

Project No. \& Name: W-320 Tank 241-C-106 Waste Retrieval

Calculation Item: Jumper Flushing Supply Head Analysis

These calculations apply to:

Dwg. No.: See References

Rev. No.

Dwg. No.:

Rev. No.

Other (Study, CDR):

Rev. No.

The status of these calculations is:

[] Preliminary Calculations

[X] Final Calculations

[] Check Calculations (On Calculation Dated)

[1 Void Calculation (Reason Voided)

Incorporated in Final Drawings?

This calculation verified by independent "check" calculations?

[X] Yes [I No

[] Yes $[X]$ No

Original and Revised Calculation Approvals:

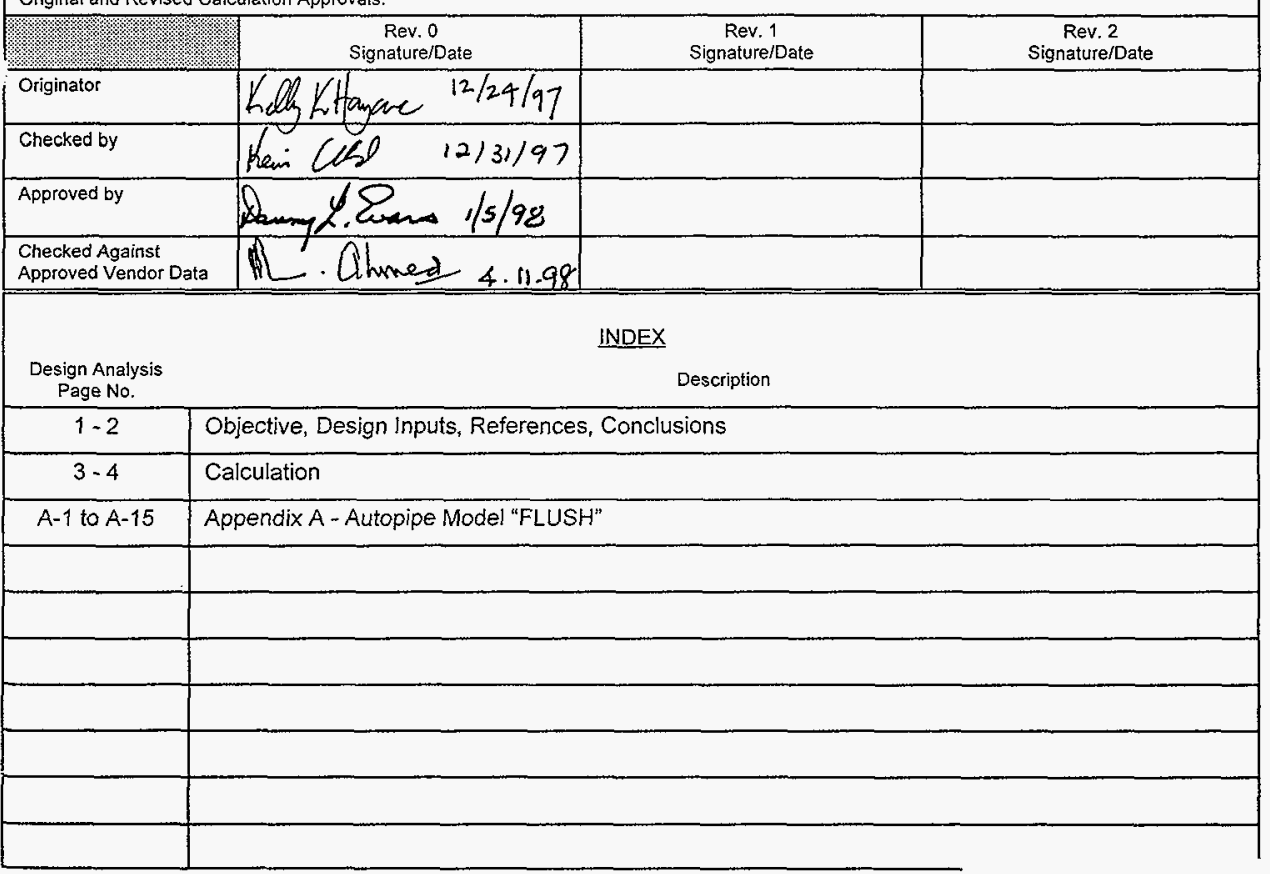




\begin{tabular}{|c|c|c|c|c|c|c|c|c|c|c|}
\hline \multicolumn{10}{|c|}{$\begin{array}{l}\text { CALCULATION CROSS INDEX (Typical) } \\
\text { Subject Calculation No.: W320-27-051 }\end{array}$} & \multirow{3}{*}{$\frac{\text { Page ii of } i i}{\begin{array}{c}\text { Discipline managers signature and } \\
\text { date indicating evaluation } \\
\text { complete. }\end{array}}$} \\
\hline \multirow[t]{2}{*}{$\begin{array}{l}\text { Subject } \\
\text { Calculation } \\
\text { Revision } \\
\text { No. }\end{array}$} & \multirow[t]{2}{*}{$\begin{array}{l}\text { Superceded } \\
\text { by } \\
\text { Calculation } \\
\text { No. }\end{array}$} & \multicolumn{2}{|c|}{ 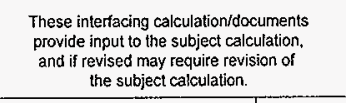 } & \multicolumn{2}{|c|}{$\begin{array}{l}\text { Results and conclusions of the subiject } \\
\text { calcultation are used in these interfacing } \\
\text { calculations and/or documents }\end{array}$} & \multicolumn{2}{|c|}{$\begin{array}{l}\text { Does the output } \\
\text { interface calculationt } \\
\text { documents require } \\
\text { revision? }\end{array}$} & \multicolumn{2}{|c|}{$\begin{array}{l}\text { Has the output } \\
\text { interfacecalculation' } \\
\text { documents been } \\
\text { revised? }\end{array}$} & \\
\hline & & Calculation/Document No. & $\begin{array}{c}\text { Revision } \\
\text { No. }\end{array}$ & CalculationiDocument No. & $\begin{array}{c}\text { Revision } \\
\text { No. } \\
\end{array}$ & Yes & No & Yes & No & \\
\hline 0 & NA & $\mathrm{H}-2-818501$, Sheet 1 & 23 & NA & & & $r$ & & - & 1 \\
\hline & & $\mathrm{H}-2-818503$, Sheet 1 & $x^{3}$ & & & & - & & $r$ & ¿L Evans $7 / 21 / 98$ \\
\hline & & $\mathrm{H}-2-818510$, Sheet 1 & 81 & & & & - & & $r$ & 1 \\
\hline & & ECN W-320-696 & -- & & & & $r$ & & $r$ & $y$ \\
\hline & & & & & & & & & & \\
\hline & & & & & & & & & & \\
\hline & & & & & & & & & & \\
\hline & & & & & & & & & & \\
\hline & & & & & & & & & & \\
\hline & & & & & & & & & & \\
\hline & & & & & & & & & & \\
\hline & & & & & & & & & & \\
\hline & & & & & & & & & & \\
\hline & & & & & & & & & & \\
\hline & & & & & & & & & & \\
\hline & & & & & & & & & & \\
\hline & & & & & & & & & & \\
\hline & & & & & & & & & & \\
\hline
\end{tabular}


Client: Numatec

Subject: Jumper Flushing Supply Head Analysis
Wo/Job No:: ER4319N-320

Date: $12 / 24 / 97$ By: Kelly Hayase Checked: 12/31/97 By: Kevin By:

\section{QBJECTIVE:}

The objective of this calculation is to analyze the addition of the jumper flushing supply heads to Jumpers AY-02A-U11-A-(C) and AY-02E-U2-A-(B).

\section{DESIGN INPUTS:}

\section{CRITERIA AND SOURCE:}

1. HNF-SD-W320-FDC-001, Rev. 4

\section{GIVEN OR KNOWN DATA:}

1. ECN W-320-696

\section{ASSUMPTIONS:}

1. For conservatism, the jumper flushing supply heads shall be assumed to be Safety Class (for analysis purposes). Therefore, the jumper flushing supply heads shall be analyzed to Safety Class 1 loads as defined in Reference \#2.

\section{METHODS TO BE USED:}

Autopipe (Ref. \#1) shall be used for the pipe stress analysis of the flush jumpers.

The flush jumpers will be added to Jumpers AY-02A-U11-A-(C) and AY-02E-U2-A-(B). These jumpers have been analyzed in Reference $\# 3$, without the flush jumpers attached.

a) The addition of the flush jumpers will not affect the thermal analysis of Jumpers AY-02A-U11$A-(C)$ and $A Y-02 E-U 2-A-(B)$ in Ref. \#3 because one end of the flush jumpers is free to expand thermally (connected to hose).

b) The addition of the flush jumpers will have a negligible affect on the sustained load analysis of Jumpers AY-02A-U11-A-(C) and AY-02E-U2-A-(B) in Ref. \#3 because of the light weight (approximately $77 \mathrm{lbs}$ ) of the flush jumpers.

C) The addition of the flush jumpers will affect the seismic analysis of Jumpers AY-02A-U11-A(C) and AY-02E-U2-A-(B) in Ref. \#3. The maximum stress due to the cantilevered affect of the flush jumper will occur near the connection point between the flush jumper and the rest of the jumper. The rest of the stresses in Jumpers AY-02A-U11-A-(C) and AY-02E-U2-A-(B) will be affected only slightly because of the small mass of the flush jumper.

d) The flush jumpers will be analyzed independently from Jumpers AY-02A-U11-A-(C) and AYO2E-U2-A-(B) in Ref. \#3. The model of the flush jumpers will include the connector head and the pipe after the connector head to the first branch point on the main pipe of Jumpers AY02A-U11-A-(C) and AY-02E-U2-A-(B). The sustained and the thermal analyses of the flush 


\section{DESIGN ANALYSIS}

Page No: 2 of 4

Client: Numatec

Subject: Jumper Flushing Supply Head Analysis

Location: 241-AY
WO/Job No.: ER4319/N-320

Date: $12 / 24 / 97$ By: Kelly Hayase

Checked: $12 / 31 / 97$

Revised: Cleveland

By:

jumper are not critical but shall be included in the Autopipe analysis for completeness. The seismic analysis will include the portion of Jumpers AY-02A-U11-A-(C) and AY-02E-U2-A-(B) which will experience the maximum stresses.

e) If the analysis of the flush jumpers show that the maximum stresses are acceptable, then Jumpers AY-02A-U11-A-(C) and AY-02E-U2-A-(B) in Ref. \#3 will not need to be re-analyzed.

The seismic input for the flush jumper should be the structural response spectra of Jumpers $A Y-02 A-$ U11-A-(C) and AY-02E-U2-A-(B) because the flush jumpers are connected to the jumpers instead of directly to ground. However, for simplification, the ground response spectra from Ref. \#2 is used. To account for possible differences between the ground response spectra and the structural response spectra of the jumpers, a factor of 2 is multiplied to the ground response spectra from Ref. \#2.

\section{REFERENCES/SOURCES:}

1. Autopipe Pipe Stress Analysis Program, Version 4.6, by Rebis Inc.

2. FDNW Practice \# 134.215.1217, "Design Loads for Facilities"

3. Calculation W320-27-029, Rev. 3, "AY Farm Jumper Stress Analysis"

4. ASME B31.3-1996, "Process Pipe"

5. ECN W-320-696

6. Drawings: H-2-818501, Sheet 1, Rev. 2 H-2-818503, Sheet 1, Rev. 2 H-2-818510, Sheet 1, Rev. 0

\section{CONCLUSIONS:}

Based on the results of this calculation, the jumper flushing supply heads stresses satisfies the requirements of ASME B31.3 for the design loads for Safety Class systems. The addition of the flush jumpers to Jumpers $A Y-02 A-U 11-A-(C)$ and $A Y-02 E-U 2-A-(B)$ is acceptable, and Ref. \#3 will not need to be revised. 
Client: Numatec

Subject: Jumper Flushing Supply Head Analysis

Location: 241-AY
WO/Job No:: ER4319N-320

Date: $12 / 24 / 97$

Checked: 12/31/97

By: Kelly Hayase

Revised:
By: Kewin Clereland

$B y$ :

\section{CALCULATIONS:}

Autopipe Analysis Input

Pipe: $\quad 2$ " and $3 "$ Sch 40 S pipe, ASTM A312-TP304L

Fluid: Water

Pressure: $\quad 400 \mathrm{psig}$ (assumed conservative, the design pressure of the SN and SL pipe is $320 \mathrm{psig}$ )

Temperature: A thermal analysis of the flush jumper is not critical because the jumper is fixed at one end and free (connected to hose) at the other end. However, for completeness of the Autopipe analysis, an ambient temperature of $70^{\circ} \mathrm{F}$ and an operating temperature of $150^{\circ} \mathrm{F}$ is used.

Seismic Input: Safety Class 1 Spectra, $0.2 \mathrm{~g}$ (Ref. \#2), with a factor of 2 applied 


\section{s}

Client: Numatec

Subject: Jumper Flushing Supply Head Analysis

Location: 241-AY

\section{DESIGN ANALYSIS}

Revision: 0

Page No: 4 of 4
WO/Job No:: ER4319N-320

Date: $12 / 24 / 97$ By: Kelly Hayase Checked: 1 2/31/97

By: Kevin Clerelond

Revised:

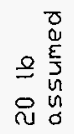

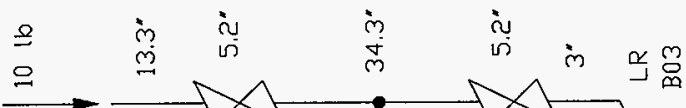

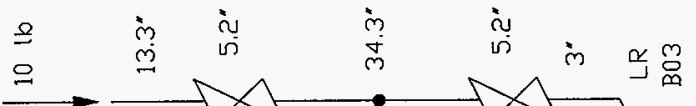

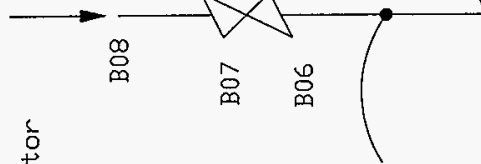

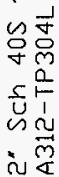

虽 鬲

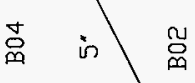

官

品

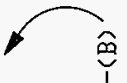

$1 / 1$

$\frac{1}{4}$

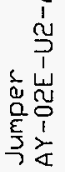

$+$

产

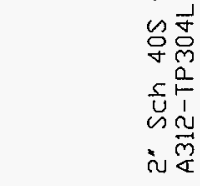

응

4

రำ

$\frac{d}{5}$

in

⿶)

을

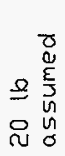
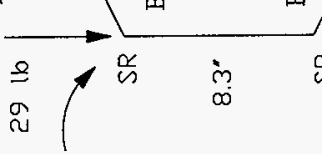

थก

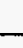

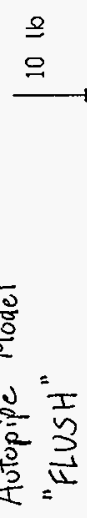

in ì
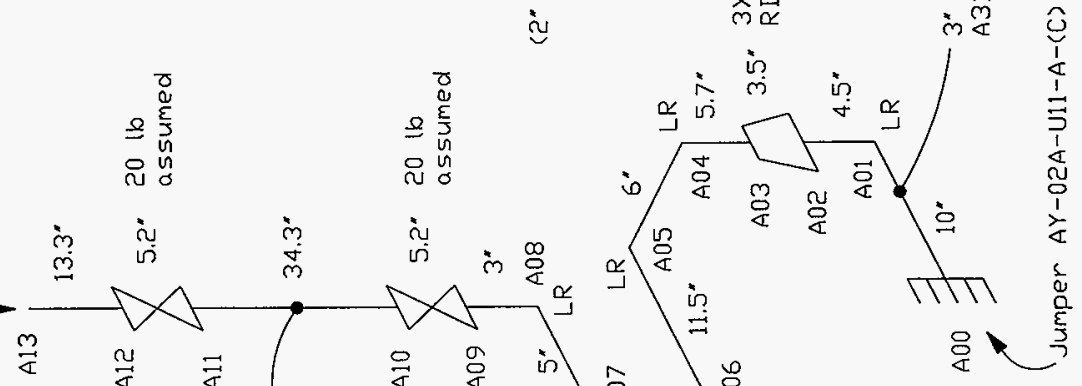

$\stackrel{m}{q}$
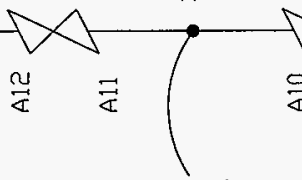

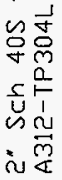

ç

iบ

品

$\times$

$\frac{\alpha}{s}$

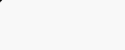<smiles>C1CCCCC1</smiles><smiles>c1cnc2[se]oc2c1</smiles>

命吉 ธิ जू m 


\section{FLUSH \\ Fluor Daniel Northwest \\ $\star * *$ \\ $* *$

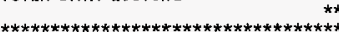

SYSTEM NAME : FLUSH

PROJECT ID : W-320 TANK 241-C-106 WASTE RETRIEVAL

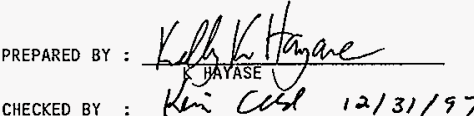

PIPING CODE : 831.3

AMBIENT YEMP. $(\operatorname{deg} F): 70.0$

COMPONENT LIBRARY

: AUTOPIPE

MATERIAL LIBRARY

: AUTOB313

MODEL REVISION NUMBER 


FLUSH
$12 / 22 / 97$

POINI DATA LISTING

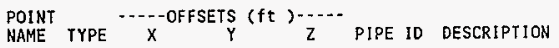

*** SEGMENT A

$\begin{array}{lllll}\text { AOO } & \text { Run } & 0 & 0 & 0 \\ \text { A01 Bend } & 0 & 0 & -0.83\end{array}$

Long Elbow, Radius $=4.50$ inch Bend angle change $=90.00 \mathrm{deg}$ Mid point at 50.00 percent SIF - In 1.78, out $=1.48$ $\mathrm{F}$ lex $=4.577$

$\begin{array}{lllll}\text { A02 } & \text { Redu } & 0 & 0.38 & 0 \\ \text { A03 } & \text { Run } & 0 & 0.29 & 0 \\ \text { A04 } & \text { Bend } & 0 & 0.47 & 0\end{array}$

A05 Bend $-0.50 \quad 0 \quad 0$

A06 Bend $0 \quad 0 \quad 0.96$

A07 Bend $0 \quad 0.78 \quad 0$

$\begin{array}{llll}\text { A08 Bend } & 0 & 0 & -0.42\end{array}$

A09 Valv $\quad 0 \quad 0.25 \quad 0$

$\begin{array}{lllll}\text { A10 } & \text { Run } & 0 & 0.43 & 0 \\ \text { A11 } & \text { Valv } & 0 & 2.86 & 0\end{array}$

$\begin{array}{lllll}\text { A12 } & \text { Run } & 0 & 0.43 & 0 \\ \text { A13 } & \text { Run } & 0 & 1.11 & 0\end{array}$

Long Elbow, Radius $=3.00$ inch Bend angle change $=90.00 \mathrm{deg}$ Mid point at 50.00 percent SIF - In 1.73 , Out $=1.44$ Flex $=4.404$

Long Elbow, Radius $=3.00$ inch Bend angle change $=90.00 \mathrm{deg}$ Nid point at 50.00 percent SIF - In 1.73, out $=1.44$ flex $=4.404$

Long Elbow, Radius $=3.00$ inch Bend angle change $=90.00 \mathrm{deg}$ Mid point at 50.00 percent SiF - In 1.73 , Out $=1.44$ $\mathrm{Flex}=4.404$

Short Elbow, Radius $=2,00$ inch Bend angle change $=90.00 \mathrm{deg}$ Mid point at 50.00 percent SIF - In 2.27
Flex $=6.606$

Long Elbow, Radius $=3.00$ inch Bend angle change $=90.00 \mathrm{deg}$ Mid point at 50.00 percent Sif - in 1.73 , Out $=1.44$ Flex $=4.404$

Rating $=150$, Weight $=20 \mathrm{lb}$ Surface factor $=4.00$, SIF $=1.00$ Surface factor $=4.00$, sif $=1.00$

$\begin{array}{llll}\text { A13 Run } & 0 & 1.11 & 0\end{array}$

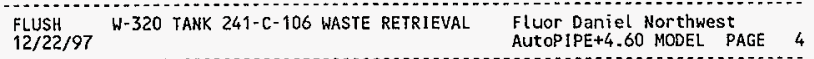

POINTT DATA LISTING

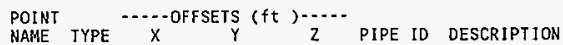

NAME TYPE

$\begin{array}{lcrrr}* * * & \text { SEGMENT B } & & & \\ \text { B00 RUn } & 3.00 & 0 & -3.00 & \text { 2"IPIPE } \\ 801 & \text { Bend } & -0.46 & 0 & 0\end{array}$

Short Elbow, Radius $=2.00$ inch Bend angle change $=90.00 \mathrm{deg}$ Mid point at 50.00 percent
SIF - In 2.27 , Out $=1.89$ Flex $=6.606$

BO

Rating $=150$, weight $=20 \mathrm{lb}$
Short $\varepsilon l$ bow, Radius $=2.00$ inch Bend angle change $=90.00 \mathrm{deg}$ Mid point at 50.00 percent SIF - In 2.27, Out $=1.89$ Flex $=6.606$

803

Bend

$$
0
$$$$
0
$$

0.42

B04 Valv

B05 Run
B06 Valv

0

0.

250

\section{B07 Run \\ B08 Run}

0

0.43
2.86

0

Total weight of empty pipes : $62 \mathrm{lb}$
Long Elbow, Radius $=3.00$ inch Bend angle change $=90.00$ deg Mid point at 50.00 percent SIF - In 1.73 , Out $=1.44$ $F$ lex $=4.404$

Rating $=150$, weight $=20 \mathrm{lb}$ Surface factor $=4.00$, SIF $=1.00$

Rating $=150$, weight $=20 \mathrm{lb}$ surface factor $=4.00$, SIF $=1.00$ 


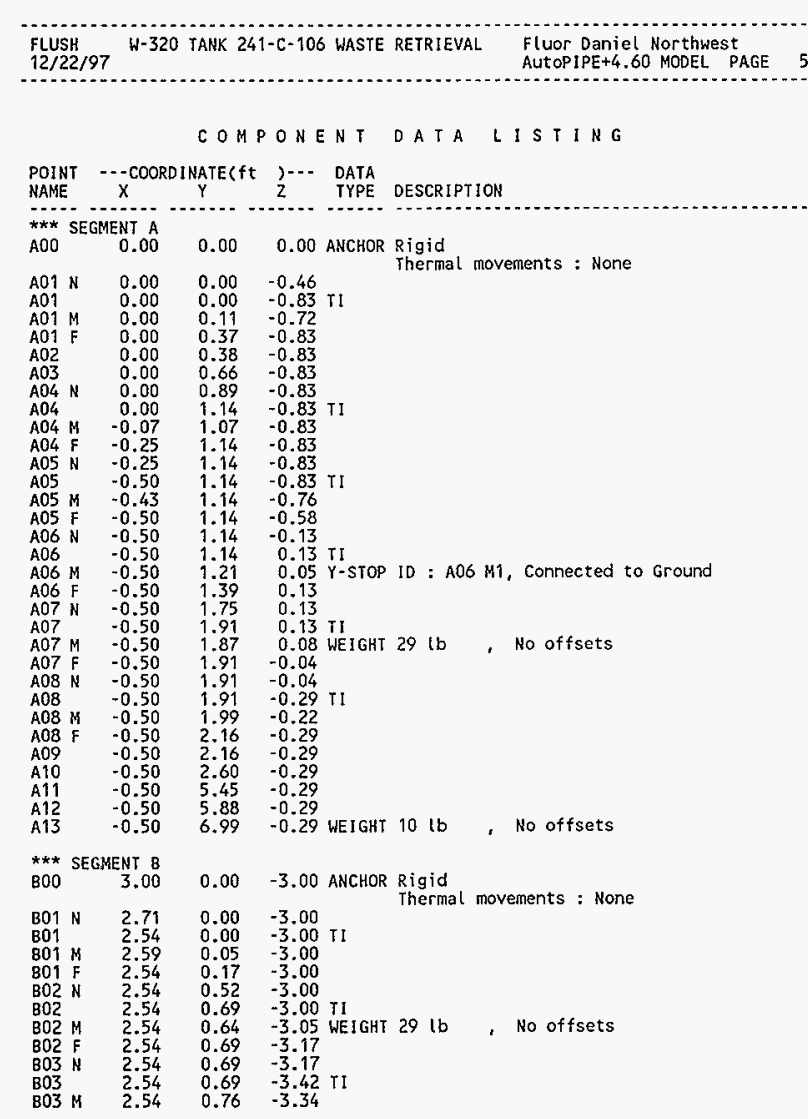

\begin{tabular}{|c|c|c|c|c|c|}
\hline $\begin{array}{l}\text { FLUSH } \\
12 / 22 / 97\end{array}$ & $w-320$ & TANK 24 & १-C-106 WASTE & RETRIEVAL & $\begin{array}{l}\text { Fluor Daniel Northwest } \\
\text { AutoPIPE }+4.60 \mathrm{MODEL} \text { PAGE } 6\end{array}$ \\
\hline & & $\mathrm{COM}$ & PONENT & $D A T A$ & I S T I N G \\
\hline $\begin{array}{l}\text { POINT } \\
\text { NAME }\end{array}$ & $-x^{-C O O R D}$ & ${ }_{Y}$ INATE $\mathrm{ft}$ & $\begin{array}{ll}\gamma-\cdots & \text { DATA } \\
Z & \text { TYPE }\end{array}$ & DESCRIPTION & \\
\hline $\begin{array}{l}\text { B03 F } \\
\text { B04 } \\
\text { B05 } \\
\text { B06 } \\
\text { B07 } \\
\text { B08 }\end{array}$ & $\begin{array}{l}2.54 \\
2.54 \\
2.54 \\
2.54 \\
2.54 \\
2.54\end{array}$ & $\begin{array}{l}0.94 \\
0.94 \\
1.37 \\
4.23 \\
4.66 \\
5.77\end{array}$ & $\begin{array}{l}-3.42 \\
-3.42 \\
-3.42 \\
-3.42 \\
-3.42 \\
-3.42 \text { WEIGHT }\end{array}$ & $10 \mathrm{lb}$ & No offsets \\
\hline
\end{tabular}


FLUSH W-320 TANK $241-\mathrm{C}-106$ WASTE RETRIEVAL Fluor Daniel Northwest
AutoPIPE+4.60 MODEL PAGE

PI PE DATA LI ST I NG

Pipe ID/ Non/ 0.D. -...-Thickness(inch)-.... Spec Weight(lb/ft) Material Sch inch W.Th. Corr Mill Insu Ling Grav Pipe other Total

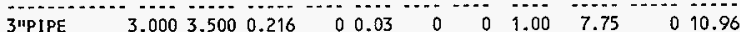
A312-TP304L $40 \mathrm{~S}$

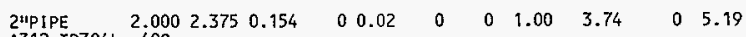
A312-TP304L $40 \mathrm{~S}$

\begin{tabular}{|c|c|c|c|c|c|c|c|}
\hline $\begin{array}{l}\text { FLUSH } \\
12 / 22 / 97\end{array}$ & -320 TANK & $241-c-10$ & 5 WASTE & RETRIE & $\begin{array}{l}\mathrm{Fl} \\
\mathrm{Au}\end{array}$ & $\begin{array}{l}\text { uor Dani } \\
\text { toPIPE+4. }\end{array}$ & $\begin{array}{l}\text { Northwe } \\
0 \text { MODEL }\end{array}$ \\
\hline & $\mathrm{MA}$ & $=R ! A L$ & D A & $T A$ & IS T I & $N G$ & \\
\hline $\begin{array}{l}\text { Material } \\
\text { Name }\end{array}$ & Pipe ID & $\begin{array}{l}\text { Density } \\
\text { lb/cu.ft }\end{array}$ & $\begin{array}{l}\text { Pois. } \\
\text { Ratio }\end{array}$ & $\begin{array}{l}\text { Temper. } \\
\text { deg F }\end{array}$ & $\begin{array}{l}\text { Modulus } \\
\text { E6 psi }\end{array}$ & $\begin{array}{l}\text { Expans. } \\
\text { in/10oft }\end{array}$ & $\begin{array}{l}\text { Allow. } \\
\text { psi }\end{array}$ \\
\hline A312-TP304L & 3"PIPE & 501.0 & 0.30 & $\begin{array}{r}70.0 \\
150.0\end{array}$ & 28.30 & 0.8985 & $\begin{array}{l}16700.0 \\
16700.0\end{array}$ \\
\hline A312-TP304L & 2 2"PIPE & 501.0 & 0.30 & $\begin{array}{r}70.0 \\
150.0\end{array}$ & 28.30 & 0.8985 & $\begin{array}{l}16700.0 \\
16700.0\end{array}$ \\
\hline
\end{tabular}




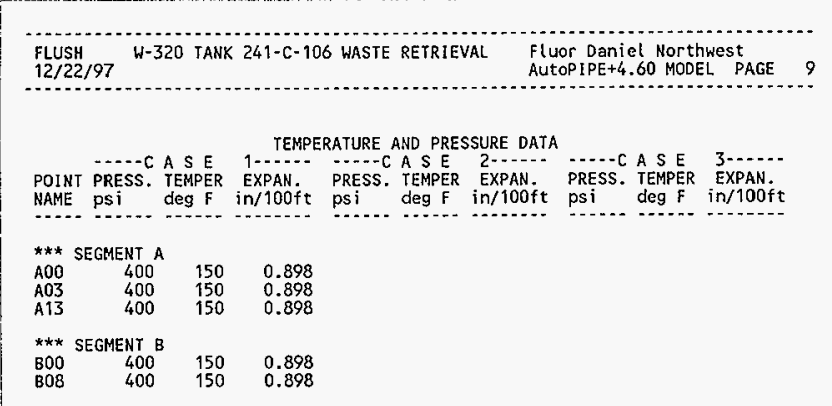

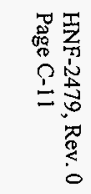

FLUSH W-320 TANK $241-\mathrm{C}-106$ WASTE RETRIEVAL

Fluor Daniel Nor thwest

RutOPIPE+4.60 RESULT PAGE

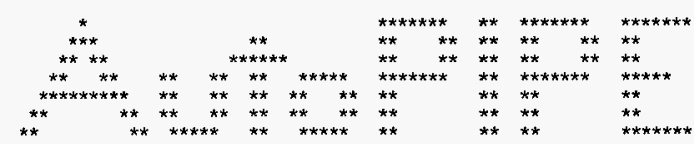

Pipe Stress Analysis and Design Program

Version: 4.60 .03

Edition: Plus-Dos

Developed and Maintained by

Engineering Design Automation, Ine. 1600 Riviera Ave. Suite 300 


\section{ANALYSIS SUMMARY}

Current model revision number : 5

Static - Date and Time of analysis

Model Revision Number

Dec 22, $1997 \quad 2: 48 \mathrm{PM}$

5

Load cases analyzed ................. 2

Gaps/Friction/Yielding considered ...... NO

Hanger design run...$\ldots \ldots \ldots \ldots \ldots \ldots$. No

Cut short included $\ldots \ldots \ldots \ldots \ldots \ldots \ldots \ldots \ldots$ No

Weight of contents included ............. Yes

Pressure stiffening case ............. 0

Water elevation for buoyancy loads .... Not considered

Modal - Date and Time of analysis ......... Dec 22, 1997 2:48 PM

Model Revision Number ................. 5

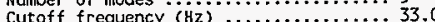

Weight of contents included $\ldots . . . . . . . .$. Yes

pressure stiffening case ............. 0

Water elevation for buoyancy loads .... Not considered

Response - Date and Time of analysis .......... Dec 22, 1997 2:48 PM Model Revision Mumber

5

Number of load cases $\ldots \ldots \ldots \ldots \ldots \ldots \ldots 1$

Date and time of modai analysis ......... Dec 22, $1997 \quad 2: 48 \mathrm{PM}$

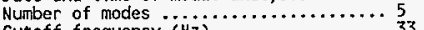

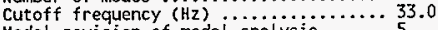

Model revision of modal analysis ...... 5

Weight of contents included ............ Yes

Pressure stiffening case ................

Water elevation for buoyancy loads.... Not considered

FLUSH
$12 / 22 / 97$

CODE COMPLIANCE COMBINATIONS

\begin{tabular}{|c|c|c|c|c|c|c|}
\hline Combination & Category & Method & Load & Factor & Allowable & Remarks \\
\hline$G R+\operatorname{Max} P$ & Sustain & Sum & $\begin{array}{l}\text { Gravity } \\
\text { Max Long }\end{array}$ & $\begin{array}{l}1.00 \\
1.00\end{array}$ & Automatic & Default \\
\hline Cold to TI & Expansion & Sum & Thermal 1 & 1.00 & Automatic & Default \\
\hline Sus. + R1 & occasion & Abs sum & $\begin{array}{l}\text { Response } 1 \\
\text { Max Sus }\end{array}$ & $\begin{array}{l}1.00 \\
1.00\end{array}$ & Automatic & Default \\
\hline $\operatorname{Max} P$ & Hoop & & Max Hoop & 1.00 & Automatic & Default \\
\hline
\end{tabular}

OTHER USER COMBINATIONS

$\begin{array}{lllll}\text { Combination Method } & \text { Load } & \text { Factor } & \text { Remarks } \\ \text { GR } & \text { Sum } & \text { Gravity } & 1.00 & \text { Default } \\ \text { T1 } & \text { Sum } & \text { Thermal } 1 & 1.00 & \text { Default } \\ \text { R1 } & \text { Sum } & \text { Response } 1 & 1.00 & \text { Default }\end{array}$

CODE COMPLIANCE

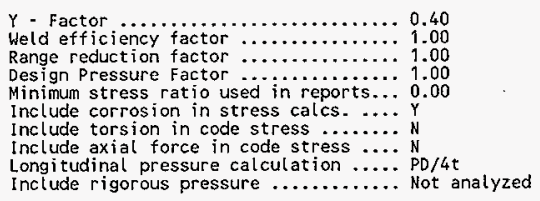

Weld efficiency factor ................... 1.00

Range reduction factor $\cdots \cdots \cdots \cdots \cdots \cdots \cdots$

Minimum stress ratio used in reports... 0.00

Include corrosion in stress calcs. .....

Include axial force in code stress......

include rigorous pressure .... 


\section{FLUSH W-320 TANK 241-C-106 WASTE RETRIEVAL Fluor Daniel Nor thwest AutoPIPE+4.60 RESUIT PAGE}

RESPONSE SPECTRUM LOAD CASES

Number of load cases analysed : 1

Load case 1 - R1

Missing mass : Yes

Combination method : Grouping

$\begin{array}{ll}X \text { - Spectrun : } & S C 1 \\ \text { Multiplier : } 2.00\end{array}$

SC1

$\begin{array}{cccccc}\text { Freq(Hz) } & \text { Grav } & \text { Freq(Hz) } & \text { Grave } & \text { Freq(Hz) } & \text { Grave } \\ 0.100 & 0.01 & 0.160 & 0.03 & 0.250 & 0.06 \\ 0.400 & 0.10 & 0.600 & 0.16 & 1.100 & 0.28 \\ 1.640 & 0.42 & 8.000 & 0.42 & 12.000 & 0.34 \\ 20.000 & 0.26 & 33.000 & 0.20 & 100.000 & 0.20\end{array}$

20.000

0.26

Y- Spectrum : $\mathbf{S C 1}$

SC1

Freq( $\mathrm{Hz})$ Grave )

$\begin{array}{ll}0.100 & 0.01 \\ 0.400 & 0.10 \\ 1.640 & 0.42\end{array}$

Freq(Hz) Grav(

0.160

0.600

0.600
8.000

33.000

20.000

0.26

Z- spectrum : SCl

Multiplier : 2.00

SC1

Freq(Hz) Grave $\ldots$ )

$\begin{array}{ll}0.100 & 0.01 \\ 0.400 & 0.10\end{array}$

1.640
20.000

0.10
0.42

0.10
0.42
0.26
Freq( $\mathrm{Hz})$ Grave $\begin{array}{ll}0.160 & 0.03 \\ 0.600 & 0.16\end{array}$ $\begin{array}{rr}0.600 & 0.16 \\ 8.000 & 0.42\end{array}$
Freq(Hz) Grave $0.250 \quad 0.06$ $\begin{array}{rl}0.250 & 0.06 \\ 1.100 & 0.28\end{array}$ $100.000 \quad 0.20$

\section{FLUSH}

W-320 TANK 241-C-106 WASTE RETRIEVAL

Fluor Daniel Northwest
AutoPIPE+4.60 RESULT PAGE

FREQUENCIES

\begin{tabular}{crrrrrr}
$\begin{array}{l}\text { Mode } \\
\text { Number }\end{array}$ & $\begin{array}{c}\text { Frequency } \\
\text { (Rads/sec) }\end{array}$ & $\begin{array}{c}\text { Frequency } \\
\text { (Hertz) }\end{array}$ & $\begin{array}{c}\text { Perjod } \\
\text { (Sec) }\end{array}$ & \multicolumn{2}{c}{ Participation factors } \\
\hline 1 & 21.4344 & 3.4114 & 0.293 & 0.350 & 0.018 & 0.216 \\
2 & 27.5783 & 4.3892 & 0.228 & 0.208 & -0.028 & -0.320 \\
3 & 28.6932 & 4.5667 & 0.219 & 0.056 & -0.033 & -0.368 \\
4 & 29.5853 & 4.7086 & 0.212 & -0.377 & -0.012 & -0.052 \\
5 & 142.3572 & 22.6568 & 0.044 & 0.303 & 0.009 & 0.162
\end{tabular}




\begin{tabular}{|c|c|c|c|c|c|c|c|}
\hline $\begin{array}{l}\text { FLUSH } \\
12 / 22 / 97\end{array}$ & \multicolumn{4}{|c|}{ W-320 TANK $241-\mathrm{C}-106$ WASTE RETRIEVAL } & \multicolumn{3}{|c|}{$\begin{array}{l}\text { Fluor Daniel Northwest } \\
\text { AutoPI PE+4.60 RESULT PAC }\end{array}$} \\
\hline \multicolumn{8}{|c|}{ DISPLACEMENTS } \\
\hline $\begin{array}{l}\text { Point } \\
\text { name }\end{array}$ & $\begin{array}{l}\text { Load } \\
\text { combination }\end{array}$ & $\underset{X}{\text { TRANSL }}$ & ATIONS & in $z^{\prime}$ & $\begin{array}{l}\text { ROTAT } \\
x\end{array}$ & $\underset{Y}{\text { ONS }}$ (deg & z \\
\hline \multicolumn{8}{|c|}{$* * *$ Segnent A begin $* * *$} \\
\hline$A 00$ & $\begin{array}{l}\text { GR } \\
\text { Ti } \\
\text { RI }\end{array}$ & $\begin{array}{l}0.000 \\
0.000 \\
0.000\end{array}$ & $\begin{array}{l}0.000 \\
0.000 \\
0.000\end{array}$ & $\begin{array}{l}0.000 \\
0.000 \\
0.000\end{array}$ & $\begin{array}{l}0.000 \\
0.000 \\
0.000\end{array}$ & $\begin{array}{l}0.000 \\
0.000 \\
0.000\end{array}$ & $\begin{array}{l}0.000 \\
0.000 \\
0.000\end{array}$ \\
\hline$A 01 \mathrm{~N}$ & $\begin{array}{l}\mathrm{GR} \\
\mathrm{T} 1 \\
\mathrm{R} 1\end{array}$ & $\begin{array}{l}0.000 \\
0.000 \\
0.000\end{array}$ & $\begin{array}{l}0.000 \\
0.000 \\
0.001\end{array}$ & $\begin{array}{r}0.000 \\
-0.004 \\
0.000\end{array}$ & $\begin{array}{r}-0.001 \\
0.001 \\
0.010\end{array}$ & $\begin{array}{l}0.000 \\
0.000 \\
0.001\end{array}$ & $\begin{array}{l}0.001 \\
0.001 \\
0.015\end{array}$ \\
\hline A01 M & $\begin{array}{l}\mathrm{GR} \\
\mathrm{YI} \\
\mathrm{R} 1\end{array}$ & $\begin{array}{l}0.000 \\
0.000 \\
0.001\end{array}$ & $\begin{array}{l}0.000 \\
0.001 \\
0.002\end{array}$ & $\begin{array}{r}0.000 \\
-0.006 \\
0.001\end{array}$ & $\begin{array}{r}-0.003 \\
0.004 \\
0.029\end{array}$ & $\begin{array}{l}0.000 \\
0.001 \\
0.005\end{array}$ & $\begin{array}{l}0.002 \\
0.002 \\
0.028\end{array}$ \\
\hline $\mathrm{A} 01 \mathrm{~F}$ & $\begin{array}{l}\text { GR } \\
\text { I1 } \\
\text { R1 }\end{array}$ & $\begin{array}{l}0.000 \\
0.000 \\
0.003\end{array}$ & $\begin{array}{l}0.000 \\
0.004 \\
0.002\end{array}$ & $\begin{array}{r}0.000 \\
-0.007 \\
0.003\end{array}$ & $\begin{array}{r}-0.003 \\
0.009 \\
0.044\end{array}$ & $\begin{array}{l}0.001 \\
0.001 \\
0.010\end{array}$ & $\begin{array}{l}0.003 \\
0.005 \\
0.055\end{array}$ \\
\hline $\mathrm{A} 02$ & $\begin{array}{l}\text { GR } \\
\text { T1 } \\
\text { R1 }\end{array}$ & $\begin{array}{l}0.000 \\
0.000 \\
0.003\end{array}$ & $\begin{array}{l}0.000 \\
0.004 \\
0.002\end{array}$ & $\begin{array}{r}0.000 \\
-0.007 \\
0.003\end{array}$ & $\begin{array}{r}-0.003 \\
0.009 \\
0.044\end{array}$ & $\begin{array}{l}0.001 \\
0.001 \\
0.010\end{array}$ & $\begin{array}{l}0.003 \\
0.005 \\
0.055\end{array}$ \\
\hline $\mathrm{A} 03$ & $\begin{array}{l}\text { GR } \\
\text { T1 } \\
\text { R1 }\end{array}$ & $\begin{array}{r}0.000 \\
-0.001 \\
0.007\end{array}$ & $\begin{array}{l}0.000 \\
0.006 \\
0.002\end{array}$ & $\begin{array}{r}0.000 \\
-0.006 \\
0.005\end{array}$ & $\begin{array}{r}-0.003 \\
0.011 \\
0.050\end{array}$ & $\begin{array}{l}0.001 \\
0.001 \\
0.008\end{array}$ & $\begin{array}{l}0.004 \\
0.006 \\
0.068\end{array}$ \\
\hline A04 N & $\begin{array}{l}\text { GR } \\
\text { T1 } \\
\text { R1 }\end{array}$ & $\begin{array}{r}-0.001 \\
-0.001 \\
0.011\end{array}$ & $\begin{array}{l}0.000 \\
0.008 \\
0.002\end{array}$ & $\begin{array}{r}-0.001 \\
-0.006 \\
0.008\end{array}$ & $\begin{array}{r}-0.004 \\
0.014 \\
0.060\end{array}$ & $\begin{array}{l}0.001 \\
0.001 \\
0.008\end{array}$ & $\begin{array}{l}0.005 \\
0.008 \\
0.090\end{array}$ \\
\hline A04 M & $\begin{array}{l}\text { GR } \\
\text { T1 } \\
\text { R1 }\end{array}$ & $\begin{array}{r}-0.001 \\
-0.002 \\
0.015\end{array}$ & $\begin{array}{l}0.000 \\
0.010 \\
0.004\end{array}$ & $\begin{array}{r}-0.001 \\
-0.005 \\
0.011\end{array}$ & $\begin{array}{r}-0.005 \\
0.026 \\
0.098\end{array}$ & $\begin{array}{l}0.001 \\
0.004 \\
0.017\end{array}$ & $\begin{array}{l}0.010 \\
0.015 \\
0.170\end{array}$ \\
\hline $\mathrm{A} 04 \mathrm{~F}$ & $\begin{array}{l}\text { GR } \\
\text { T1 } \\
\text { R1 }\end{array}$ & $\begin{array}{r}-0.001 \\
-0.004 \\
0.018\end{array}$ & $\begin{array}{r}-0.001 \\
0.010 \\
0.012\end{array}$ & $\begin{array}{r}-0.001 \\
-0.004 \\
0.014\end{array}$ & $\begin{array}{r}-0.005 \\
0.032 \\
0.118\end{array}$ & $\begin{array}{l}0.000 \\
0.007 \\
0.039\end{array}$ & $\begin{array}{l}0.014 \\
0.021 \\
0.247\end{array}$ \\
\hline$A 05 \mathrm{~N}$ & $\begin{array}{l}\text { GR } \\
\text { T1 } \\
\text { R1 }\end{array}$ & $\begin{array}{r}-0.001 \\
-0.004 \\
0.018\end{array}$ & $\begin{array}{r}-0.001 \\
0.010 \\
0.012\end{array}$ & $\begin{array}{r}-0.001 \\
-0.004 \\
0.014\end{array}$ & $\begin{array}{r}-0.005 \\
0.032 \\
0.118\end{array}$ & $\begin{array}{l}0.000 \\
0.007 \\
0.039\end{array}$ & $\begin{array}{l}0.014 \\
0.021 \\
0.247\end{array}$ \\
\hline A05 M & $\begin{array}{l}\text { GR } \\
\text { I1 } \\
\text { R1 }\end{array}$ & $\begin{array}{r}-0.001 \\
-0.005 \\
0.019\end{array}$ & $\begin{array}{r}-0.001 \\
0.008 \\
0.020\end{array}$ & $\begin{array}{r}-0.001 \\
-0.004 \\
0.015\end{array}$ & $\begin{array}{r}-0.005 \\
0.038 \\
0.118\end{array}$ & $\begin{array}{l}0.000 \\
0.007 \\
0.052\end{array}$ & $\begin{array}{l}0.015 \\
0.026 \\
0.304\end{array}$ \\
\hline
\end{tabular}

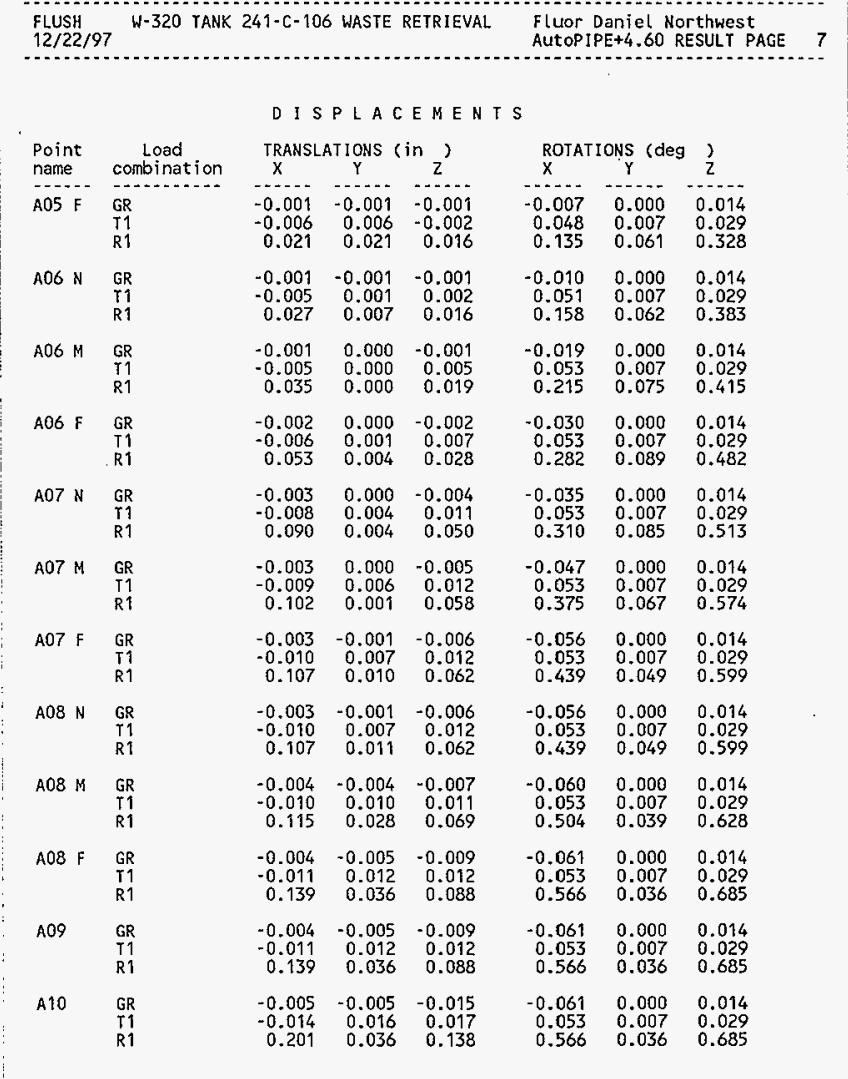




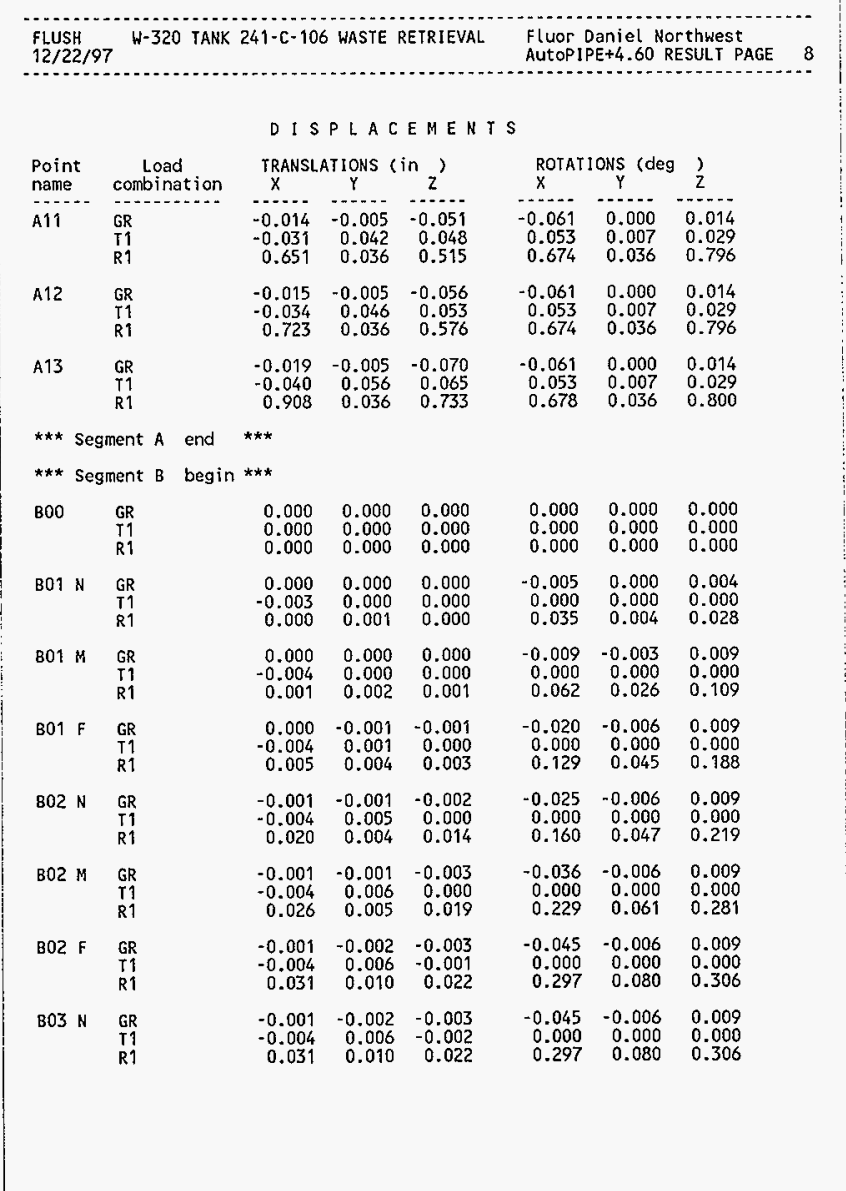

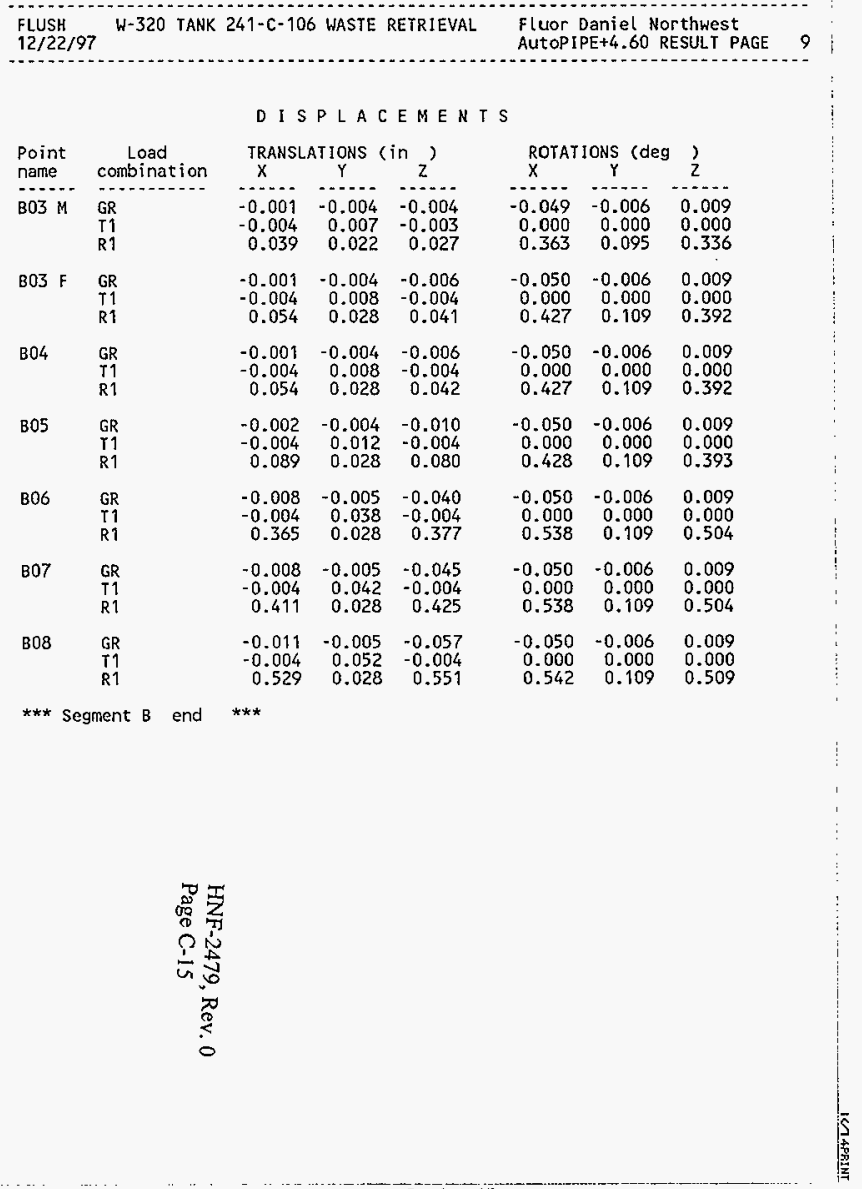




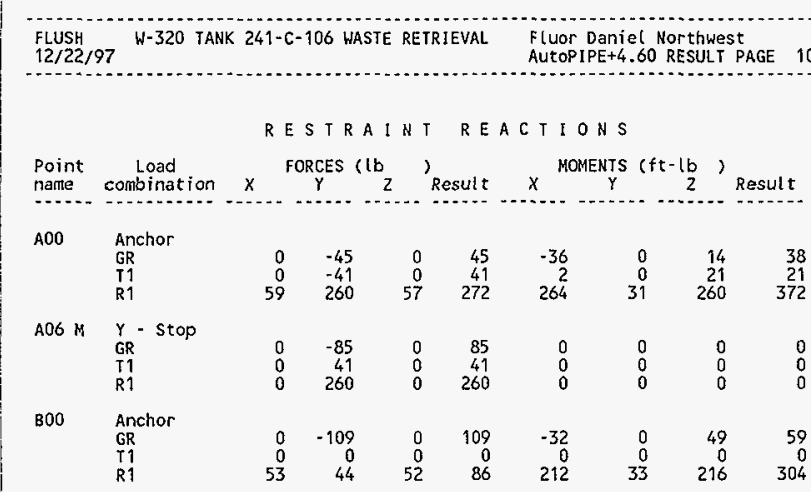

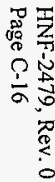

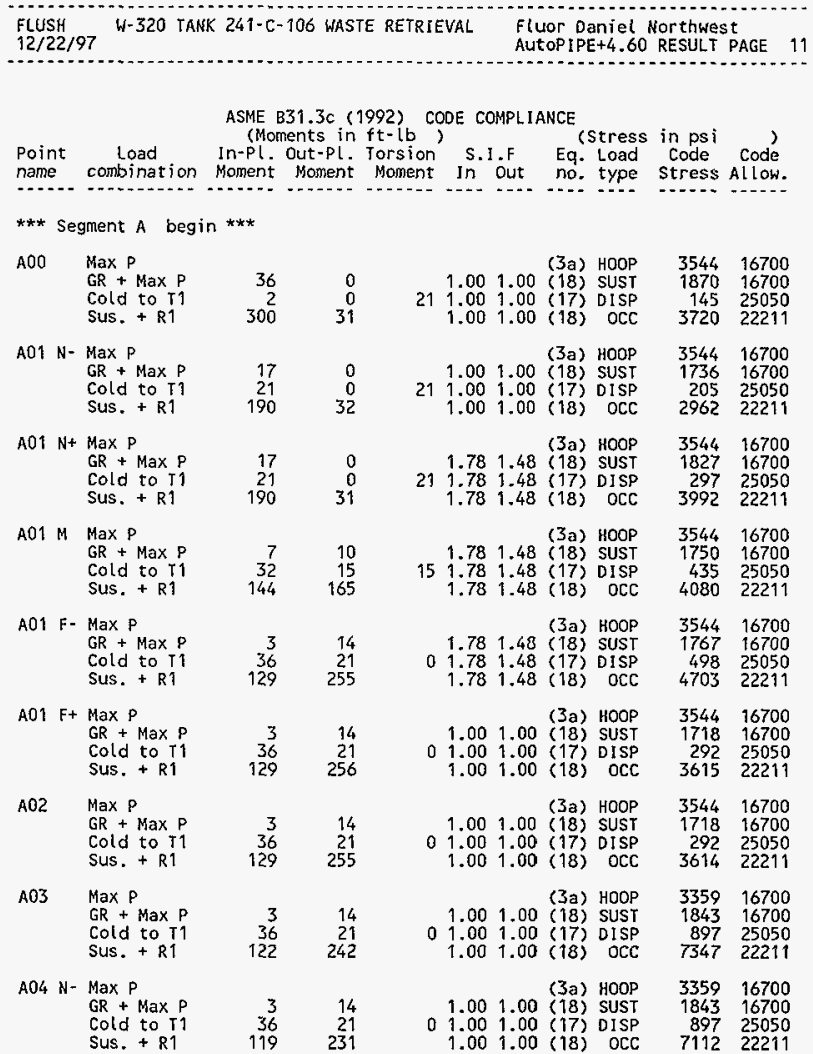

Page A-10 of A-15 


\section{FLUSH}

-320 TANK $241-\mathrm{C}-106$ WASTE RETRIEVAL

Fluor Daniel Northwest

AutoPIPE+4 60 RESUIT PAGE

ASME B31.3C (1992) CODE COMPLIANCE

Point Load In-Pl. Out-Pl. Torsion S.I.F Eq. Load code code name combination Moment Moment Moment in out no. type stress Allow. $\mathrm{AO} 4 \mathrm{~N}+\mathrm{Max}$ GR + Max $P$ Gold to $T$

$\begin{array}{rr}14 & 3 \\ 21 & 36 \\ 231 & 119\end{array}$
(3a) HOOP

1.731 .44 (18) SUST 335916700 206016700 136225050 $10871 \quad 22211$

A04 M Max $P$ Cold to $T 1$

(3a) HOOP 1.731 .44 (18) SUST

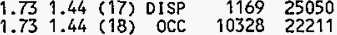

A04 F= Max $P$ $\mathrm{GR}+\operatorname{Max} \mathrm{P}$ Cold to $T 1$ $\begin{array}{rr}18 & 26 \\ 219 & 108\end{array}$

(3a) HOOP $\begin{array}{lll}1.73 & 1.44 & (17) \\ 1.73 & 1.44 \text { (18) OCC }\end{array}$

$3359 \quad 16700$ $1791 \quad 16700$ $\begin{array}{rr}7 & 0 \\ 10 & 0 \\ 212 & 39\end{array}$

(3a) HOOP $1.001 .00(18)$ OCC
OCO $G R+\operatorname{Max} P$ Cold to $T 1$ $\begin{array}{rr}7 & 0 \\ 10 & 0 \\ 212 & 39\end{array}$

(3a) HOOP 1.001 .00 (18) SUST $G R+\operatorname{Max} P$ Cold to $T 1$ 7
212

A05 $\mathrm{N}+\mathrm{Max}$ $G R+\operatorname{Max} P$ Cold to $T 1$ $36 \begin{array}{llll}1.73 & 1.44 & (3 a) & \text { HOOP } \\ 1.73 & 1.44 & \text { (17) } & \text { SUST } \\ & \text { DISP }\end{array}$ $\operatorname{Max} P$

$\mathrm{GR}+\operatorname{Max} P$ Cold to T1 Sus. + R1

A05 F- Max P $G R+\operatorname{Max} P$ Cold to T1 Sus. + R1

A05 F+ Max P $G R+\operatorname{Max} P$ Cold to T1
Sus. + R1

A06 N- Max P

$G R+\operatorname{Max} P$ Cold to $T 1$
sus. $+R 1$ 1.731 .44 (18) OCC

$\begin{array}{rr}0 & 7 \\ 0 & 10 \\ 39 & 211\end{array}$
$\begin{array}{llll}1.73 & 1.44 \text { (3a) HOOP } \\ 18) & \text { SUST } \\ 1.73 & 1.44 \text { (17) } & \text { DISP }\end{array}$ $\begin{array}{lll}22 & 1.73 & 1.44(17) \text { DISP } \\ 1.73 & 1.44(18) \text { OCC }\end{array}$ $\begin{array}{rrrr}\text { (3a) } & \text { HOOP } \\ 0 & 1.73 & 1.44 \text { (18) SUST } \\ 0 & 1.73 & 1.44 & \text { (17) } \\ & \text { DISP }\end{array}$ 1.731 .44 (18) OCC

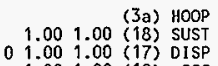
1.001 .00 (18) OCC

\section{(3a) HOOP} 1.001 .00 (18) SUST $01.001 .00(17)$ DISP
$1.001 .00(18)$ OCC 1.731 .44 (18) OCC

$361.73 \quad 1.44$ (18) SUST 361.001 .00 (18) SUST $361.001 .00(17)$ DISP
948922211

335916700

168616700

811
$6154 \quad 22211$

335916700

168516700

$\begin{array}{rr}810 & 25050 \\ 6154 & 22211\end{array}$

$3359 \quad 16700$

$\begin{array}{rr}1748 & 16700 \\ 843 & 25050\end{array}$

$\begin{array}{rr}843 & 25050 \\ 8233 & 22211\end{array}$

335916700 160316700 $\begin{array}{rr}919 & 25050 \\ 4337 & 22211\end{array}$

335916700 183016700 $\begin{array}{rr}809 & 25050 \\ 5247 & 22211\end{array}$ 335916700 174216700 $4113 \quad 22211$ 335916700 198016700 580922211
ASME 831.3C (1992) CODE COMPLIANCE

point Load In-PL (stress in psi c.l.F name combination Moment Moment Moment In out no. type stress Allow. A06 $\mathrm{N}+\mathrm{Max}$

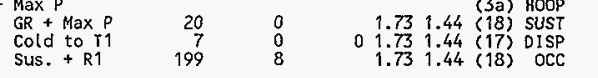

335916700

1.731 .44 (18) OCC

A06 M Max P

(3a) HOOP $G R+\operatorname{Max} P$ Cold to $T$ 1.731 .44 (18) SUST $\begin{array}{lll}0 & 1.73 & 1.44(17) \text { DISP } \\ 1.73 & 1.44(18) \text { OCC }\end{array}$

A06 F- $\operatorname{Max} P$ GR + Max P Cold to $T$

24
0
238

32
0
238

144

$\operatorname{Max} P$

GR + Max P Cold to T1
Sus. $+R 1$

32
0
238

A07 N- Max P $\mathrm{GR}+\operatorname{Max} \mathrm{P}$ Cold to $T 1$
sus. + R1

A07 $\mathrm{N}+\operatorname{Max} \mathrm{P}$ GR + Max P Cold to T1
Sus. + R1

A07 $M$ Max $P$ GR + Max $P$ Cold to T
sus. +81 220

220

$$
\begin{array}{r}
0 \\
0 \\
211
\end{array}
$$

(3a) HOOP

1.73
0 1.44 (18) SUST $\begin{array}{lll}0 & 1.73 & 1.44 \\ 1.73 & 1.44(17) & \text { DISP }\end{array}$

(3a) HOOP 1.001 .00 (18) SUST $01.001 .00(17)$ DISP
$1.001 .00(18)$ OCC 1.001 .00 (3a) HOOP $01.001 .00(17)$
$1.001 .00(18)$ OCC 2.271 .89 (13a) HOOP $2.271 .89(17)$ DISP
2.271 .89 (18) OCC $\begin{array}{rr}32 & 0 \\ 0 & 0 \\ 220 & 192\end{array}$ (3a) HOOP $2.27 \quad 1.89$ (18) SUST 2.271 .89 (17) $01 \mathrm{SP}$
2.271 .89 (18) OCC $\begin{array}{rr}27 & 0 \\ 0 & 0 \\ 209 & 144\end{array}$

A07 F- Max P $G R+\operatorname{Max} P$ Cold to T Sus. + R

18 2.271 .89 (18) SUST $\begin{array}{lll}2.27 & 1.89 & (17) \\ 2.27 & 1.89 \text { (18) OISP }\end{array}$

A07 F+ Max P $\mathrm{GR}+\operatorname{Max} \mathrm{P}$ Cold to $T$ Sus, + R

19 (3a) HOOP
1.001 .00 (18) SUST $01.001 .00(17)$ DISP
$1.001 .00(18)$ OCC

A08 N- Max P $G R+\operatorname{Max} P$ Sus. $+R 1$ (3a) HOOP
$1.00,13$ (3) HOOP 1.001 .00 (18) SUST $01.001 .00(17)$ DISP
$1.001 .00(18)$ OCC
35916700

$\begin{array}{ll}270 & 25050 \\ 8930 & 22211\end{array}$

$3359 \quad 16700$ 244816700 1153322211

335916700 273816700 $12758 \quad 22211$ $3359 \quad 16700$ 223316700 853322211 $3359 \quad 16700$ 223316700 798422211 335916700 310916700 $15100 \quad 22211$

335916700 286316700 1345822211

335916700 243816700 $11159 \quad 22211$

335916700 193716700 578322211 $\begin{array}{ll}3359 & 16700 \\ 1932 & 16700\end{array}$ $\begin{array}{rr}0 & 25050 \\ 5777 & 22211\end{array}$ 


\section{FLUSH}

W-320 TANK 241-C-106 WASTE RETRIEVAL

Fluor Daniel Northwest

AutoPIPE +4.60 RESULT PAGE 14

ASME B31.3C (1992) CODE COMPLIANCE

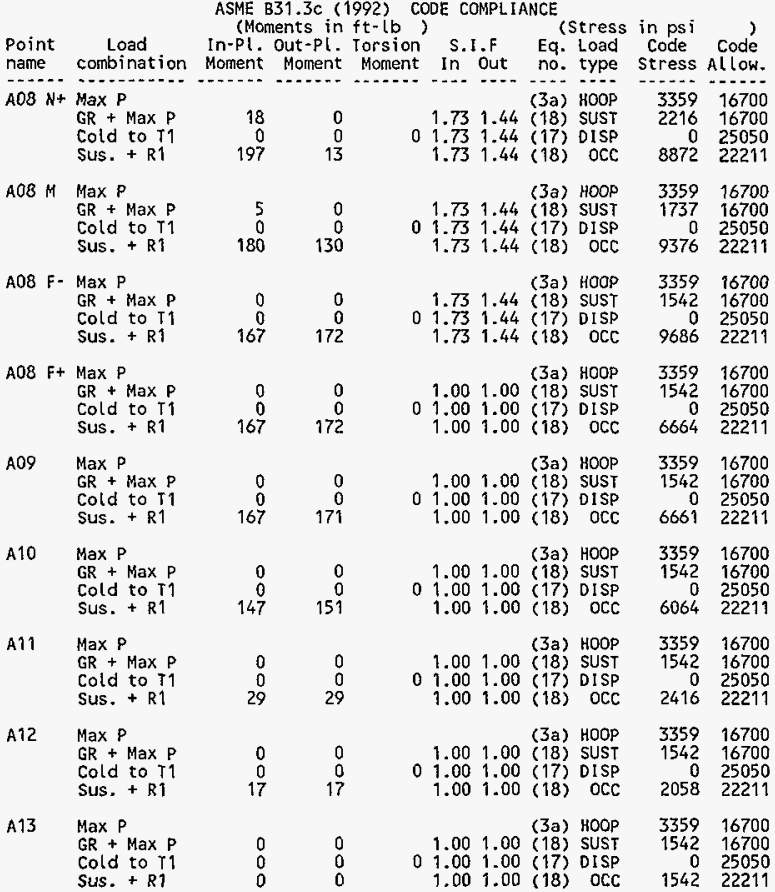

$* * *$ Segment $A$ end $* * *$

$* * *$ Segment $B$ begin ***
AME 831.3C (1992) CODE COMPLIANCE

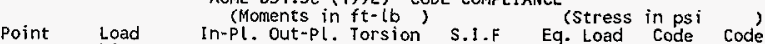
name combination Moment Moment Moment In Qut no. type stress Allow.
BOO Max GR + Max P Cold to $T$ Cold to T
Sus. $t$ R1

49
0
265

$\begin{array}{rr}49 & 0 \\ 0 & 0 \\ 265 & 33\end{array}$

B01 N-Max $P$

$G R+\operatorname{Max} P$ Cold to T1

$\begin{array}{r}18 \\ 0 \\ \hline\end{array}$

Max $P$

$G R+\operatorname{Max} P$ Cold to T1 Sus. + R1

801 if Max $P$

$G R+\operatorname{Max} P$

Cold to

B01 F- Max P

$G R+\operatorname{Max} P$ Cold to $I 1$

Sus. + R1

B01 $F+\operatorname{Max} P$ $G R+\operatorname{Max} P$ Sus. + R

$B 02$ N- MaX GR + Max P Cold to $\mathrm{T} 1$ Sus. $+R$

B02 N+ Max GR + Max P Cold to $T 1$ Max P $\mathrm{GR}+\operatorname{Max}$ Cold to $T 1$
Sus. $+\mathrm{R} 1$ Max P GR + Max P Cold to T1
Sus. + RI $\begin{array}{rr}18 & 0 \\ 0 & 0 \\ 233 & 23\end{array}$

$\begin{array}{rr}5 & 23 \\ 0 & 0 \\ 218 & 169\end{array}$
$208 \quad 142$
1.001 .00 (3a) HOOP 1.001 .00 (18) SUST 1.001 .00 (18) OCC

(3a) HOOP 1.001 .00 (18) SUST 1.001 .00 (18) OCC

(3a) HOOP 2.271 .89 (18) SUST 2.271 .89 (18) OCC (3a) HOOP

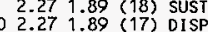
2.271 .89 (17) DISP

(3a) 4009

(3a) HOOP $\begin{array}{lll}2.27 & 1.89 \\ 2.27 & 1.89 & \text { (18) SUST }\end{array}$ 2.271 .89 (18) OCC 1.001 .00 (3a) HOOP $01.001 .00(17)$ DISP 1.001 .00 (18) OCC

\section{(3a) $\mathrm{HOOP}$}

1.001 .00 (18) SUST 01.001 .00 (17) DISP

(3a) HOOP 2.271 .89 (18) SUSI 02.271 .89 (17) DISP 335916700 259916700 $\begin{array}{rr}0 & 25050 \\ 7271 & 22211\end{array}$

$3359 \quad 16700$ 192416700 655522211

$3359 \quad 16700$ $2408 \quad 16700$ $0 \quad 25050$

335916700 249516700 $14409 \quad 22211$ $3359 \quad 16700$ 84216700 1584122271 $3359 \quad 16700$ 0 $8444 \quad 22211$ $3359 \quad 16700$ 222916700 $7923 \quad 22211$ 335916700 $3101 \quad 16700$ $\begin{array}{rr}0 & 25050 \\ 14981 & 22211\end{array}$ (3) HOOP 2.271 .89 (18) SUSI

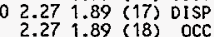
$3359 \quad 16700$ 285516700 $\begin{array}{rr}0 & 25050 \\ 13368 & 22211\end{array}$ 2.271 .89 (1) 18 ) $\begin{array}{ll}\text { HOOP } \\ \text { SUST }\end{array}$

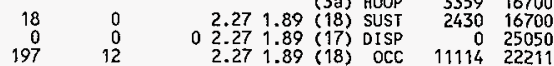

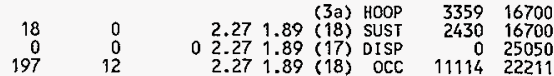

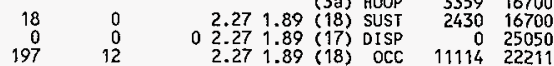


ASME B31.3C (1992) CODE COMPLIANCE

(Monsents in $\mathrm{ft}-\mathrm{lb}$ )' (stress in psi ) name combination Moment Moment Moment in Qut no. Load Code Code $\mathrm{BO} \mathrm{F}+\mathrm{Max}$ Cold to $T 1$

$\begin{array}{rr}18 & 0 \\ 0 & 0 \\ 197 & 12\end{array}$

1.001 .00 (18) SUST (18) SUST Sus. + R 01.001 .00 (17) DISP 335916700 $1934 \quad 16700$ 0
$5763 \quad 22051$

B03 N- Max P $\mathrm{GR}+\operatorname{Max} \mathrm{P}$ Cold to T1

3a) $\mathrm{HOOP}$

$\begin{array}{rr}18 & 0 \\ 0 & 0 \\ 197 & 12\end{array}$

1.001 .00 (18) SUST $01.001 .00(17)$ DISP $1.001 .00(18)$ OCC

16700

$1930 \quad 16700$

025050

$\mathrm{B} 03 \mathrm{~N}+\operatorname{Max} \mathrm{P}$ $G R+\operatorname{Max} P$ Cold to T1

1.731 .44 (18) SUS 01.731 .44 (17) DISP 1.731 .44 (18) OCC

3a) $\mathrm{HOOP}$ $\begin{array}{lll}1.73 & 1.44 & \text { (18) SUST } \\ 0 & 1.73 & 1.44 \\ 1.73 & 1.44 & (17) \text { DISP }\end{array}$ $G R+\operatorname{Max} P$ Cold to T?

5
180

\section{0
80} $\mathbf{0}$
128

B03 F- Max P $\mathrm{GR}+\operatorname{Max} P$ Cold to I1

\section{(3a) $\mathrm{HOO}$}

1.731 .44 (18) SUST

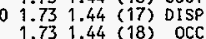
$3359 \quad 16700$ $2214 \quad 16700$ 884322211

335916700 173916700 $\begin{array}{rr}0 & 25050 \\ 9321 & 22211\end{array}$ $\operatorname{Max} P$ $\mathrm{GR}+\operatorname{Max} P$ Cold to T1 $\begin{array}{rr}0 & 0 \\ 0 & 0 \\ 166 & 170\end{array}$

(3a) HOOP 1.001 .00 (18) SUST 1.001 .00 (17) DISP 1.001 .00 (18) OCC

(3a) HOOP $1.001 .00(18)$ SUS 01.001 .00 (17) DISP

335916700

$1542 \quad 16700$ $\begin{array}{rr}0 & 25050 \\ 9631 & 22211\end{array}$

$3359 \quad 16700$

$1542 \quad 16700$ 0
625
22211

BO4 Max

$G R+\operatorname{Max} P$ Cold to T1

$\begin{array}{rr}0 & 0 \\ 0 & 0 \\ 166 & 169\end{array}$

805

Max

$\mathrm{GR}+\operatorname{Max} \mathrm{P}$ Cold to T1

$\begin{array}{rr}0 & 0 \\ 0 & 0 \\ 147 & 150\end{array}$

(3a) HOOP

1.001 .00 (18) SUST 1.001 .00
$1.001 .00(18)$ DISP

$3359 \quad 16700$

$1542 \quad 76700$ $6623 \quad 22219$

335916700

$1542 \quad 16700$

603722211

(3a) HOOP

1.001 .00 (18) SUST

335916700

154216700

$\begin{array}{rr}0 & 25050 \\ 2415 & 22211\end{array}$

Cold to T
Sus + R1

$\begin{array}{rr}0 & 0 \\ 0 & 0 \\ 29 & 29\end{array}$

01.001 .00 (17) DISP
1.001 .00 (18) OCC

1.001 .00 (3a) HOOP

01.001 .00 (17) DISP

335916700

154216700

$\begin{array}{rr}0 & 25050 \\ 2058 & 22211\end{array}$

\begin{tabular}{|c|}
\hline $\begin{array}{l}\text { GR + Max P } \\
\text { Cold to T1 } \\
\text { Sus. + R1 }\end{array}$ \\
\hline
\end{tabular}

ASME B31.3C (1992) CODE COMPLIANCE

(Moments in $\mathrm{ft}-\mathrm{lb}$ ) (stress in psi cod Point Load In-Pl. Out-Pl. Torsion S.l.F Eq. Load Code Code

name combination Moment Moment Moment In Out no. type Stress Allow.
B08 Max P B08 Max $\mathrm{P}$ GR + Max Cold to T1 335916700

$* * *$ Segment $B$ end $* * *$ 


FLUSH $12 / 22 / 97$ W-320 IANK $241-\mathrm{C}-106$ WASTE RETRIEVAL Fluor
SY S T E M S U M M A R Y Y

Maximum displacenents (in)

$\begin{array}{llll}\text { Maximum X : } & 0.908 & \text { Point : A13 } & \text { Load Comb.: R1 } \\ \text { Maximum Y : } & 0.056 & \text { Point }: A 13 & \text { Load Comb.: T1 } \\ \text { Maximum Z : } & 0.733 & \text { Point :A13 } & \text { Load Comb.: R1 } \\ \text { Max. total: } & 1.167 & \text { Point : A13 } & \text { Load Comb.: R1 }\end{array}$

Maximum rotations (deg)

$\begin{array}{llll}\text { Maximum X: } & 0.678 & \text { Point : A13 } & \text { Load Comb.: R1 } \\ \text { Maximum Y } & 0.109 & \text { Point }: \text { B03 F } & \text { Load Comb.: R1 } \\ \text { Maximum Z }: & 0.800 & \text { Point : A13 } & \text { Load Comb.: R1 } \\ \text { Max. total: } & 1.049 & \text { Point : A13 } & \text { Load Comb.: R1 }\end{array}$

Maximum restraint forces(lb)

$\begin{array}{lrll}\text { Maximum } X: & 59 & \text { Point }: A 00 & \text { Load Comb.: R1 } \\ \text { Maximum } Y: & 260 & \text { Point }: A 00 & \text { Load Comb.: R1 } \\ \text { Maximum Z } & 57 & \text { Point }: A 00 & \text { Load Comb.: R1 } \\ \text { Max. total: } & 272 & \text { Point }: \text { A00 } & \text { Load Comb.: R1 }\end{array}$

Maximun restraint moments( $f t-l b$ )

$\begin{array}{lrll}\text { Maximum } X: & 264 & \text { Point }: A 00 & \text { Load Comb.: R1 } \\ \text { Maximum } Y: & 33 & \text { Point }: \text { BOD } & \text { Load Comb.: R1 } \\ \text { Maximum } Z: & 260 & \text { Point }: A 00 & \text { Load Comb.: R1 } \\ \text { Max. total: } & 372 & \text { Point }: A 00 & \text { Load Comb.: R1 }\end{array}$

焉富

\section{FLUSH}

W-320 TANK 241-C-106 WASTE RETRIEVAL

Fluor Daniel Northwes

$12 / 22 / 97$

AutoPIPE+4.60 RESULT PACE

SYSTEM SUMMARY

Maximum sustained stress

$\begin{array}{ll}\text { Point } & \text { A07 N } \\ \text { Stress psi } & 3109 \\ \text { Allowable psi } & \vdots 16700 \\ \text { Ratio } & 0.19 \\ \text { Load combination } & \mathrm{GR}+\text { Max P }\end{array}$

Maximum displacement stress

$\begin{array}{ll}\text { Point } & \text { A04 N } \\ \text { Stress psi } & 1362 \\ \text { Allowable psi } & \vdots 25050 \\ \text { Ratio } & 0.05 \\ \text { Load combination } & \text { Cold to T1 }\end{array}$

Maximum occasional stress

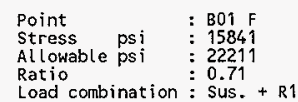

Maximum hoop stress

Point
Stress psi $\quad$ A00
Allowable psi $\quad \vdots 6400$
Ratio 1670.21
Load combination : Max P

Maximum sustained stress ratio

$$
\begin{array}{ll}
\text { Point } & \text { A07 N } \\
\text { Stress psi } & 3109 \\
\text { Allowable psi } & 16700 \\
\text { Rat jo } & 0.19 \\
\text { Load combination : } G R+\text { Max P }
\end{array}
$$

Maximum displacement stress ratio

$$
\begin{array}{ll}
\text { Point } & \text { A04 N } \\
\text { Stress psi } & : 1362 \\
\text { Al lowable psi } & : 25050 \\
\text { Ratio } & 0.05 \\
\text { Load combination : Cold to T1 }
\end{array}
$$



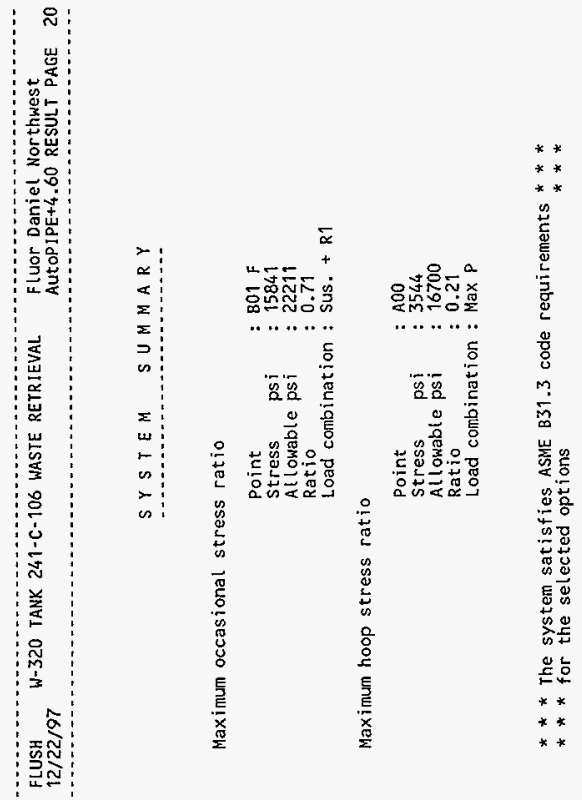
HNF-2479, Rev. 0

W320-27-053

New Supernate Jumper Analysis

D-i 
CALCULATION IDENTIFICATION AND INDEX
Page $i$ of $i i$

Date

$1 / 12 / 98$

This sheet shows the status and description of the attached Design Analysis sheets.

Discipline: (27) Piping

WolJob No: ER4319N-320

Calculation No.: W320-27-053

Project No. \& Name: W-320 Tank 241-C-106 Waste Retrieval

Calculation Item: New Supernate Jumper Analysis

These calculations apply to:

Dwg. No.: See References

Rev. No.

Dwg. No:

Rev. No.

Other (Study, CDR):

Rev. No.

The status of these calculations is:

1] Preliminary Câlculations

[X] Final Calculations

[1 Check Calculations (On Calculation Dated)

[] Void Calculation (Reason Voided)

incorporated in Final Drawings?

This calculation verified by independent "check" calculations?

Original and Revised Calculation Approvals:

\begin{tabular}{|c|c|c|}
\hline & $\begin{array}{c}\text { Rev. } 0 \\
\text { Signature/Date }\end{array}$ & $\begin{array}{c}\text { Rev. } 1 \\
\text { Signature/Date }\end{array}$ \\
\hline Originator & hell \& Hanare $1 / 12 / 98$ & \\
\hline Checked by & & \\
\hline Approved by & & \\
\hline $\begin{array}{l}\text { Checked Against } \\
\text { Approved Vendor Data }\end{array}$ & & \\
\hline
\end{tabular}

\section{INDEX}

Design Analysis

Page No.

Description

\begin{tabular}{|c|l|}
\hline $1-2$ & Objective, Design Inputs, References, Conciusions \\
\hline $3-15$ & Calculation \\
\hline A-1 to A-19 & Appendix A - Autopipe Model "U3U11B" \\
\hline B-1 to B-19 & Appendix B - Reference Information \\
\hline
\end{tabular}




\begin{tabular}{|c|c|c|c|c|c|c|c|c|c|c|}
\hline \multicolumn{10}{|c|}{$\begin{array}{l}\text { CALCULATION CROSS INDEXX (Typical) } \\
\text { Subject Calculation No.:W320-27-053 }\end{array}$} & \multirow{3}{*}{ 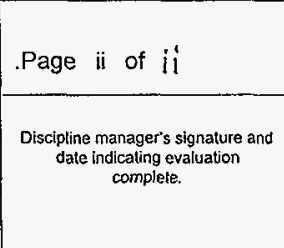 } \\
\hline \multirow[t]{2}{*}{ 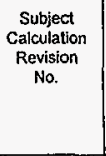 } & \multirow[t]{2}{*}{ 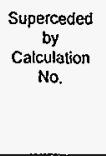 } & \multicolumn{2}{|c|}{ 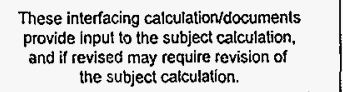 } & \multicolumn{2}{|c|}{ 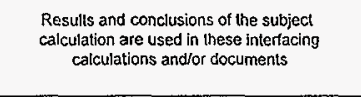 } & \multicolumn{2}{|c|}{ 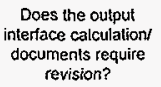 } & \multicolumn{2}{|c|}{ 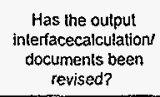 } & \\
\hline & & Caculatilion Document No. & 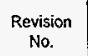 & Calculationflocoument No. & 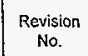 & res & № & Yes & No & \\
\hline 0 & NA & H-2-818504, Sheet 1 & $s^{t}$ & $\mathrm{NA}$ & & & 2 & & r & z/algs dP \& \\
\hline & & $\mathrm{H}-2-818504$, Sheet 2 & $\$ 1$ & & & & 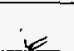 & & $=$ & $7 / 2179,928 \mathrm{Ban}$ \\
\hline & & & & & & & & & & \\
\hline & & & & & & & & & & \\
\hline & & & & & & & & & & \\
\hline & & & & & & & & & & \\
\hline & & & & & & & & & & \\
\hline & & & & & & & & & & \\
\hline & & & & & & & & & & \\
\hline & & & & & & & & & & \\
\hline & & & & & & & & & & \\
\hline & & & & & & & & & & \\
\hline & & & & & & & & & & \\
\hline & & & & & & & & & & \\
\hline & & & & & & & & & & \\
\hline & & & & & & & & & & \\
\hline & & & & & & & & & & \\
\hline
\end{tabular}


Client: Numatec

Subject: New Supernate Jumper Analysis
WO/Job No.: ER4319/N-320

Date: $1 / 12 / 98 \quad$ By: Kelly Hayase

Checked: $1 / 20 / 98$

By: K. Clevelond

Revised:

By:

\section{OBJECTIVE:}

The objective of this calculation is to analyze the new supernate jumper, Jumper Assembly AY-02A-U3-U11-B.

\section{DESIGN INPUTS:}

CRITERIA AND SOURCE:

1. HNF-SD-W320-FDC-001, Rev. 4

\section{GIVEN OR KNOWN DATA:}

1. Jumper Assembly AY-02A-U3-U11-B shall be used only for supernate transfers.

\section{ASSUMPTIONS:}

1. For conservatism, the jumper shall be analyzed to Safety Class seismic loads. (ie; Safety Class 1 seismic loads as defined in Reference \#3 shall be used)

2. Purex connectors are used on Project $W-320$ for jumper connectors. However, this calculation shall use Integral Seal Block (ISB) connectors for the analysis. It is assumed that the ISB connector stiffnesses and allowable piping loads are comparable to those of the Purex connector.

\section{METHODS TO BE USED:}

1. Autopipe Pipe Stress Analysis Program shall be used for the analysis of the new supernate jumper.

2. Autopipe does not have a standard component which to model 3-way valves. Autopipe models a standard two way valve as being 100 times stiffer than the connecting pipe material at the start of the valve. (Ref. \#2, M1,6) Therefore this analysis shall use a modified pipe to model a 3-way valve. (The pipe identifier shall be 2"-3way) The modified pipe shall have a Modulus of Elasticity 100 times greater than steel with all of the other properties the same as a 2 " pipe. The weight of the 3-way valve will be located at the junction point/center of the valve. The lengths of these modified pipe segments shall be the length of the valve.

3. The ISB connectors shall be modeled as short radius elbows and flexible joints with stiffnesses provided in Table 3.5 of Reference \#4. The translational stiffnesses are rigid per the recommendations of Reference \#4. The piping loads at the connectors shall be compared to the ISB connector allowable piping loads.

4. During installation of the jumper assembly, the jumper will be lifted by the bail. This produces a different state of stress in the pipe and the dunnage than the installed condition. Therefore a separate analysis is required for the jumper in the lifting condition. 
Client: Numatec

Subject: New Supernate Jumper Analysis

Location; 241-AY
WO/Job No:: ER4319M-320

Date: $1 / 12 / 98$ By: Kelly Hayase

Checked: 1120198 By: $K$. Clevelond

Revised: By:

\section{REFERENCES/SOURCES:}

1. ASME B31.3-1996, "Process Pipe"

2. Autopipe Pipe Stress Analysis Program, Version 4.6, by Rebis Inc.

3. FDNW Practice \# 134.215.1217, "Design Loads for Facilities"

4. WHC-SD-W236A-DA-002, Rev. 0, "Stress Analysis of Single Port Integral Seal Block (ISB) Jumper Connector for 2-, 3-, and 4-in. Sizes." (Appx B-1 to B-4)

5. SD-RE-DGS-002, Rev. 3 (Appx B-6)

6. PBM Multi-Port Ball Valves, Reference Book Sec. IV (Appx B-5)

7. Calculation W320-27-029, Rev. 3, "AY Farm - Jumper Stress Analysis"

8. WRC Bulletin 107, "Local Stresses in Spherical and Cylindrical Shelis due to External Loadings", Wichman, Hopper, and Mershon, 1979. (Appx B-11 to B-19)

9. WHC-SD-WM-DA-063, Rev, 0, "Capacities of Standard Lifting Bails, Dwg H-2-90161, Rev. 1" (Appx B-7 to B-10)

10. HNF-SD-W320-FDC-001, Rev. 4, "Functional Design Criteria for Tank 241-C-106 Waste Retrieval, Project W-320"

11. Construction Spec. W-320-C7, Section 15493.

12. Drawing Numbers $\mathrm{H}-2-818504$, Sheet 1, Rev. 0

H-2-818504, Sheet 2, Rev. 0

H-2-90161, Sheet 1, Rev. 4

\section{CONCLUSIONS:}

1. Based on the results of this calculation, the new supernate jumper, Jumper Assembly AY-02A-U3-U11-B, satisfies the requirements of ASME B31.3 for the design loads for Safety Class systems.

2. The piping loads on the connectors satisfy the allowable piping loads for the ISB connector, therefore the Purex connector is judged to be acceptable.

3. The nozzle/wall anchor loads are summarized in Table 3. These loads are the same magnitude as the loads determined in Reference \#7, therefore, they are acceptable.

4. The jumper assembly is acceptable during the lifting condition. 


\section{DESIGN ANALYSIS}

Revision: 0

Page No.: 3 of 15

Client: Numatec

Subject: New Supernate Jumper Analysis

Location: 241-AY
WO/Job No.: ER4319N-320

Date: $1 / 12 / 98$ By: Kelly Hayase

Checked: $1 / 20 / 98$

By: K. Cleveland

Revised:

By:

\section{CALCULATIONS:}

Autopipe Analysis Input:

Pipe: $2 "$ and $4 "$ sch 40, A106 Gr B

Fluid: Supernate, $S G=1.12$ (Ref. \#10)

Pressure: $\quad 320$ psig (Ref. \#11)

Temperature range: $\quad 40$ to $180^{\circ} \mathrm{F}$ (Ref. \#10)

Seismic Input: Safety Class 1 spectra, $0.2 \mathrm{~g}, 5 \%$ damping (Ref. \#3)

Table 1: Connector Stiffnesses used in Autopipe

\begin{tabular}{|c|c|c|c|c|}
\hline & $\begin{array}{c}\text { Axial } \\
\mathrm{lb} / \mathrm{in}\end{array}$ & $\begin{array}{c}\text { Shear } \\
\mathrm{lb} / \mathrm{in}\end{array}$ & $\begin{array}{c}\text { Torsion } \\
\mathrm{ft} \cdot \mathrm{lb} / \mathrm{deg}\end{array}$ & $\begin{array}{c}\text { Bending } \\
\mathrm{ft} \cdot \mathrm{lb} / \mathrm{deg}\end{array}$ \\
\hline $2^{\prime \prime}$ Connector & $1.35 \times 10^{7}$ & Rigid & 107 & 659 \\
\hline $4^{\prime \prime}$ Connector & $2.33 \times 10^{7}$ & Rigid & 304 & 2080 \\
\hline
\end{tabular}


Client: Numatec

Subject: New Supernate Jumper Analysis

Location: 241-AY
WO/Job No:: ER4319N-320

Date: $1 / 12 / 98$

Checked: $1 / 24198$

By: Kelly Hayase

By: K. Clerelond

Revised:

By:

\section{Check Piping Loads on Connector}

All the axial piping loads from the jumper analyses (Table 2) satisfy the seating and unseating limits on the connectors. (See Table 3.3 and 3.4 of Reference \#4)

All the shear, forsion, and bending piping loads (Table 2) satisfy the interaction check for the connectors.

$$
I=f y z / F y z+m x / M x+m y z / M y z<1.0
$$

Where: fyz $=$ Resultant shear force (wrt connector axis) on connector determined from the analysis $\mathrm{mx}=$ Torsion on connector determined from the analysis

myz $=$ Resultant bending force (wrt connector axis) on connector determined from the analysis

Fyz $=$ Acceptable shear load from Table 3.4, Reference $\# 4$

$\mathrm{Mx}=$ Acceptable torsional load from Table 3.4, Reference \#4

Myz = Acceptable bending load from Table 3.4, Reference \#4

For 2 " Connector $\quad F y z=1330 \mathrm{lb}$

$\mathrm{Mx}=260 \mathrm{ft} \cdot \mathrm{lb}$

$M y z=365 \mathrm{ft} \cdot \mathrm{b}$

For 4" Connector

$F y z=2220 \mathrm{lb}$

$M x=780 \mathrm{ft} \cdot 1 \mathrm{~b}$

$M y z=1170 \mathrm{ft} \cdot \mathrm{lb}$

Table 2: Connector Loads

\begin{tabular}{|c|c|c|c|c|c|c|c|c|c|}
\hline Node & $\begin{array}{c}\text { Axial } \\
\mathrm{lb}\end{array}$ & $\begin{array}{c}\text { Shear } \\
\mathrm{lb}\end{array}$ & $\begin{array}{c}\text { Shear } \\
\mathrm{lb}\end{array}$ & $\begin{array}{c}\text { Resultant } \\
\text { Shear }\end{array}$ & $\begin{array}{c}\text { Torsion } \\
\mathrm{ft} \cdot \mathrm{lb}\end{array}$ & $\begin{array}{c}\text { Moment } \\
\mathrm{ft} \cdot \mathrm{lb}\end{array}$ & $\begin{array}{c}\text { Moment } \\
\mathrm{ft} \cdot \mathrm{lb}\end{array}$ & $\begin{array}{c}\text { Resultant } \\
\text { Moment }\end{array}$ & Interaction \\
\hline $\begin{array}{c}\mathrm{A} 01 \\
4^{\prime \prime}\end{array}$ & 60 & 145 & 37 & 150 & 8 & 14 & 189 & 190 & 0.24 \\
\hline $\begin{array}{c}\mathrm{A} 15 \\
2^{\prime \prime}\end{array}$ & 163 & 83 & 456 & 463 & 9 & 51 & 19 & 54 & 0.53 \\
\hline $\begin{array}{c}\mathrm{B} 08 \\
4^{\prime \prime}\end{array}$ & 484 & 89 & 187 & 207 & 37 & 334 & 23 & 335 & 0.43 \\
\hline
\end{tabular}


FLUOR DANIEL NORTHWEST INC.

\section{DESIGN ANALYSIS}

Calc. No.: W320-27-053

Revision: 0

Page No.: 5 of 15
Client: Numatec

Subject: New Supernate Jumper Analysis

Location: 241-AY
WO/Job No:: ER4319M-320

Date: $1 / 12 / 98$

Checked: 1/20/98

By: Kelly Hayase

Revised:

By:

Table 3: Total Nozzle/Wall Anchor Loads

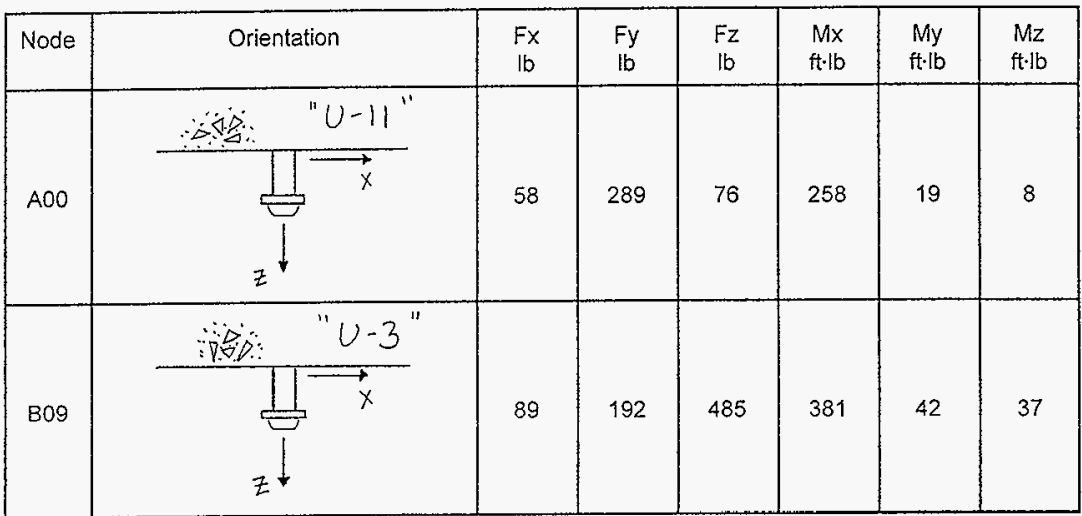




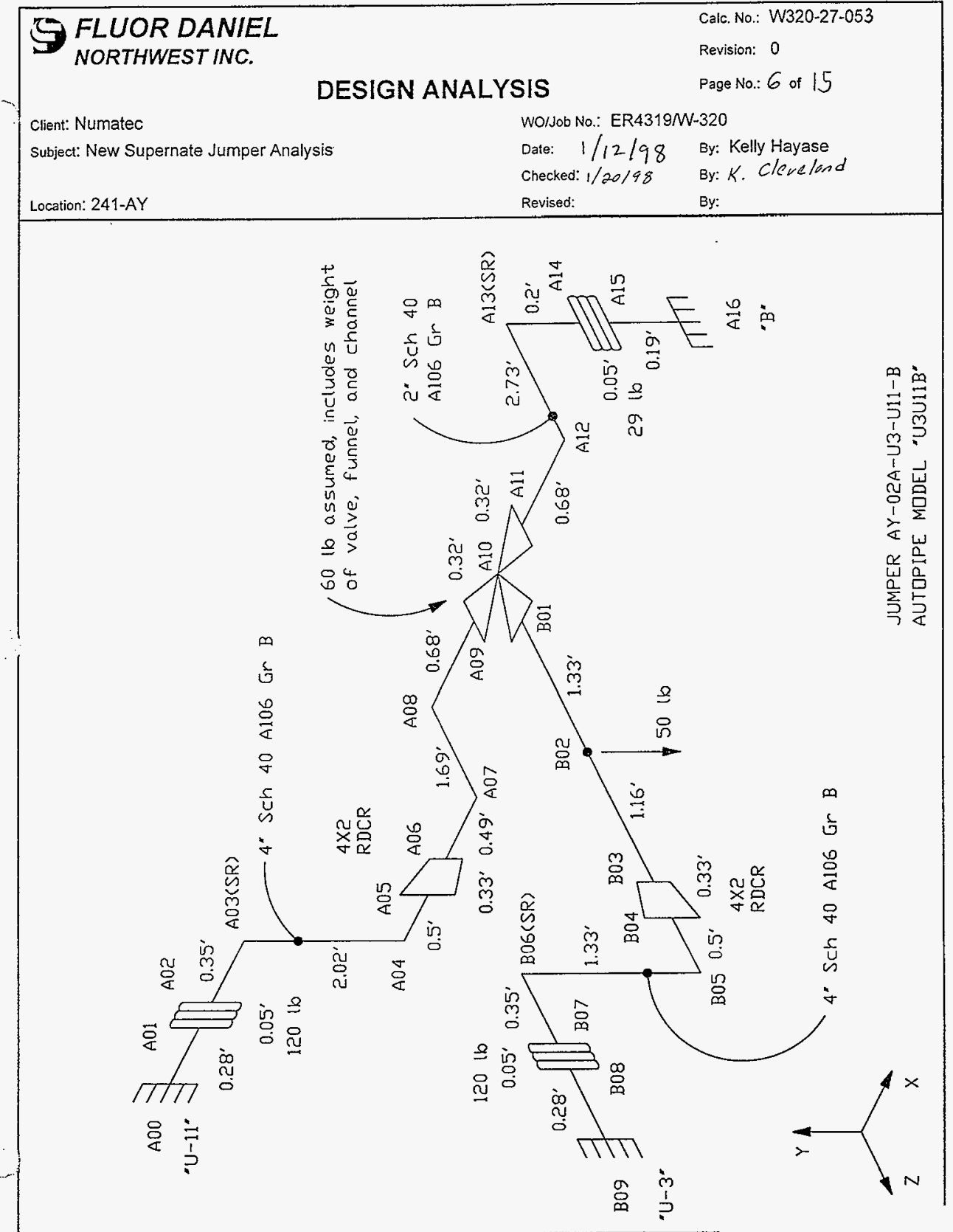


FLUOR DANIEL NORTHWEST, INC.

DESIGN ANALYSIS
Talc. No. W320-27-053

Revision $\frac{0}{7}$ of 15

Client Numatec WO/Job No. ER 4319/w-320

Subject New Supernate Junker Analysis

Date 1/12/98 By Kelly Hayase

Location $241-A Y$

Revised

By

Check Irfting bail capacity (Ref, $\neq 9$ )

The $\frac{3}{4} "$ diameter bar and $\frac{5}{16}$ "weld on the lifting bail (Detail F) is similar to the Standard Rigid Lifting Bail Assembly 5. Assembly 5 is rated for 47516 , which is dictated by the stress in the bar. (Rd. $\neq 9$ ) Therefore, the $\frac{3 "}{4}$ "diameter bar and $\frac{5}{16}$ "weld on the lifting bail is adequate for the $4201 \mathrm{~b}$ jumper weight.

$\frac{3}{16}$ "weld between the $\frac{3}{4}$ "pipe and $\frac{1}{2} " 2 \frac{1}{2} \times 7^{\prime \prime}$ plate

$$
\begin{aligned}
& \longrightarrow \times \quad A_{\omega}=2 \times 3.25 \mathrm{in}=6.5 \mathrm{in} \\
& f_{w}=\frac{420 \mathrm{bb}}{6.5 \mathrm{in}}=65 \mathrm{~b} / \mathrm{in}<1.450 \mathrm{~b} / \mathrm{in}=f_{\text {wallow }} \quad 0 . \mathrm{k} . \\
& f_{\text {wallow }}=7733(\omega) \text { bin }=7733\left(\frac{3}{16}\right)=1450 \mathrm{~b} / \mathrm{in} \quad\left(R_{c} f * 9\right)
\end{aligned}
$$

HNF-2479, Rev. 0

Page D-9 
FLUOR DANIEL NORTHWEST, INC.

DESIGN ANALYSIS
Calc. No. W/320-27-053

Revision

Page No. 8 of 15

Client Numatec

WO/Job No. ER $4319 / \omega-320$

Subject New) Supernate Jumper A
Location 241-AY
Lifting bail (continued)

$\frac{3}{4}$ bar sticking out of $\frac{3}{4} " p i p e$

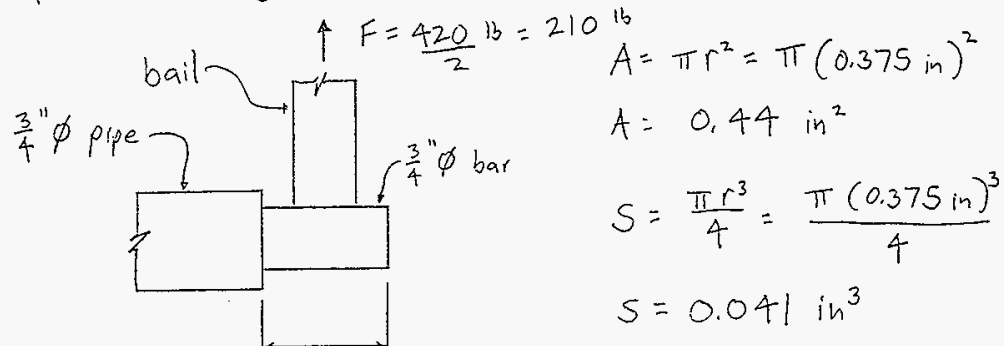

$M=(1.5 \mathrm{in})(210 \mathrm{~B})=315 \mathrm{in} \cdot 16$

$$
\sigma=\frac{315 \mathrm{inib}}{0.041 \mathrm{in}^{3}}=7683 \text { psi }<11600 \text { psi }=\sigma_{\text {allow }} \quad\left(R_{c} f \pm q\right)
$$

OK.

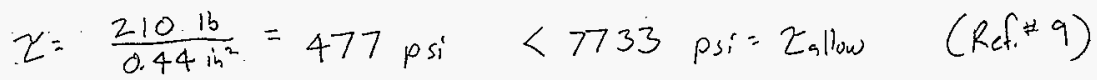

$0, k$

All other components of the lifting bail are not critical, therefore the lifting bail is acceptable.

HNF-2479, Rev. 0

Page D-10 
FLUOR DANIEL NORTHWEST, INC.

DESIGN ANALYSIS
Calc. No. W320.27-053

Revision 0

Page No. 9 of 15

Client Numatec

WO/Job No. ER 4319/w-320

Subject New Supemate Jumper Analysis Date $1 / 12 / 98$ By Kelly Hays

Location $241-A Y$

Revised

By

Check final weld between lifting bail base and $6^{\prime \prime} \times 6^{\prime \prime}$ plate.

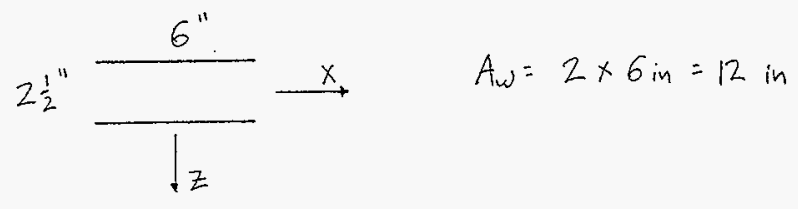

Force on weld $F_{Y}=2 \times 42016=840 \mathrm{~b}$

impact load

$$
\begin{aligned}
& f_{\omega}=\frac{840 \mathrm{lb}}{12 \mathrm{in}}=70 \mathrm{l} / \mathrm{in} \\
& t_{w}=\frac{f_{w}}{(0.707) \sigma_{a l l} l_{w}}=\frac{70 \mathrm{k} / \mathrm{in}}{(0.707)(16900 \mathrm{psi})(0.8)}=0.01 \text { in }\left\langle\frac{3}{16}\right. \text { " fillet weld } \\
& \$ 331.3 \text { allow }{ }_{\text {factor for }}
\end{aligned}
$$

Check weld between 6" 6 " plate (under) and C3 34.1

$$
\begin{aligned}
& 1.41 " \square \longrightarrow \quad A_{\omega}=2(3 \mathrm{in}+2 \times 1.41 \mathrm{in})=11.64 \mathrm{in} \\
& f_{\omega}=\frac{840 \mathrm{ib}}{11.64 \mathrm{in}}=72 \\
& t_{\omega}=\frac{72 \mathrm{ib}}{(0.707)(16900 \mathrm{psi})(0.8)}=0.01 \mathrm{in}<\frac{1}{8} \text { " fillet weld }
\end{aligned}
$$

HNF-2479, Rev. 0

Page D-11 
FLUOR DANIEL NORTHWEST, INC.

DESIGN ANALYSIS
Cali. No. W320.27-053

Revision $O$

Page No. $\frac{0}{10}$ of 15

Client Numatec WO/Job No. ER $4319 / \omega-320$

Subject New Supenate Jumper Analysis Date 1/12/98 By Kelly Harare

Location $241-A Y$

Checked $1 / 20198$. By $K$. Cleveland

check bending stress in $C_{3} \times 4,1$ (diving installation/ lifting)

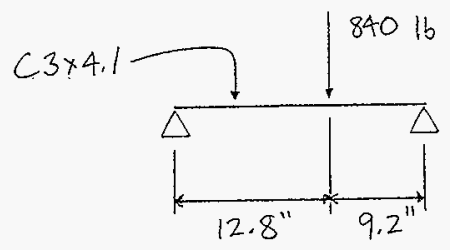

$$
S=0.202 \mathrm{in}^{3}
$$

neglect gusset plate

$$
M=\frac{(840 \mathrm{ib})(12.8 \mathrm{in})(9.2 \mathrm{in})}{(22 \mathrm{in})}=4496 \mathrm{in} . \mathrm{b}
$$

$$
\sigma=\frac{M}{S}=\frac{4496 \mathrm{in.16}}{0.202 \mathrm{in}^{3}}=22257 \mathrm{psi}<22477 \mathrm{psi}=\sigma_{\text {allow }}
$$

$$
\begin{aligned}
& \sigma_{\text {allow }}=(16900 \text { psi })(1.33)=22477 \text { psi } \\
& \begin{array}{l}
\text { B31.3allow } \\
\text { for A36 }
\end{array} \quad \begin{array}{l}
\text { factor for } \\
\text { occasional loads }
\end{array}
\end{aligned}
$$

HNF-2479, Rev. 0

Page D-12 
FLUOR DANIEL NORTHWEST, INC.

DESIGN ANALYSIS
Calc. No. w320-27-053

Revision No. $\frac{0}{11 \text { of } 15}$

Client Numatec

WO/Job No. ER 43/9/w-320

\begin{tabular}{ll}
\hline Subject New Supernate Jumped Analysis & Date $1 / 12 / 98$ \\
\hline Location 241-AY & Checked $1 / 20 / 98$ \\
\hline. & Revised \\
Check weld between bar and pipe (installed)
\end{tabular}

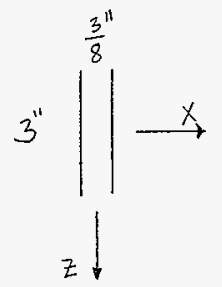

$$
\begin{aligned}
& A_{\omega}=2 \times 3 \mathrm{in}=6 \mathrm{in} \\
& S_{\omega}=0.375 \mathrm{in} \times 3 \mathrm{in}=1.125 \mathrm{in}^{2}
\end{aligned}
$$

Force on weld $F_{Y} \approx 50$ 16 (assumed, conservative)

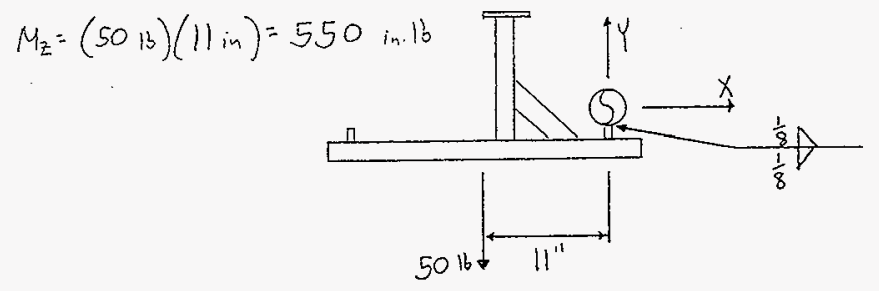

$$
\begin{aligned}
& f_{\omega}=\frac{50 \mathrm{ib}}{6 \mathrm{in}}+\frac{550 \mathrm{in.16}}{1.125 \mathrm{in}^{2}}=497 \mathrm{ib} / \mathrm{in} \\
& t_{\omega}=\frac{497 \mathrm{~kb} / \mathrm{in}}{(0.707)(16900 \mathrm{psi})(0.8)}=0.05 \mathrm{in}<\frac{1}{8}^{\prime \prime} \text { fillet weld }
\end{aligned}
$$

$0 . K$

HNF-2479, Rev. 0

Page D-13 
FLUOR DANIEL NORTHWEST, INC.

DESIGN ANALYSIS
Talc. No. w320.27-053

Revision $\mathrm{O}$

Page No. 12 of 15

Client Numatec

WO/Job No. ER 4319/w-320

Subject New Supernate Jumper Analysis

Date $1 / 12 / 98$ By Kelly Hayase

Location $241-A Y$

Checked $1 / 20 / 98$ By K. Cleveland

Revised

By

Local stresses in pipe due to welded bar (installed)

Determine exact weight of dunnage

$$
\begin{aligned}
& \text { C } 3 \times 4.1 \\
& 6^{\prime \prime} \times 6^{\prime \prime} \times \frac{1}{2} \text { "plate } \\
& 10^{\prime} \times 3^{\prime \prime} \times \frac{1}{4} \text { "plate } \\
& 1 \frac{1}{2} \times \frac{1}{4} " \times 3^{\prime \prime} \text { bar } \\
& 1 \frac{1}{2} \times \frac{3^{\prime \prime}}{8} \times 3^{\prime \prime} \text { bar } \\
& \text { lifting bail }
\end{aligned}
$$$$
(3 \mathrm{ft})\left(4.1^{16 / 6 t}\right)=12.3 \mathrm{lb}
$$$$
(6 \text { in })(6 \text { in })(0.5 \mathrm{in})\left(0.283^{13 / \mathrm{in}^{3}}\right)=5.113
$$$$
(10 \mathrm{in})(3 \mathrm{in})(0.25 \mathrm{in})\left(0.283 \mathrm{~b} / \mathrm{in}^{3}\right)=2.1 \mathrm{lb}
$$$$
(1.5 \mathrm{in})(0.2 \mathrm{sin})(3 \mathrm{in})\left(0.283 \mathrm{~b} / \mathrm{in}^{3}\right)=0.3 \mathrm{lb}
$$$$
(1.5 \mathrm{in})(0.375 \mathrm{in})(3 \mathrm{in})(0.283 \mathrm{k} / \mathrm{ins})=0.5 \mathrm{lb}
$$

Use $p=31 \mathrm{lb}$

$$
\frac{21016}{30.316}
$$

$$
M_{c}=(31 \mathrm{ib})(11 \mathrm{in})=341 \mathrm{in} .16
$$

Geometric properties

$$
\begin{aligned}
& C_{1}=0.1875^{\prime \prime} \\
& C_{2}=1.5^{\prime \prime} \\
& T=0.154^{\prime \prime} \\
& R_{m}=1.1105^{\prime \prime} \\
& \beta_{1}=\frac{0.1875}{1.1105}=0.17 \\
& \beta_{2}=\frac{1.5}{1.1105}=1.35 \\
& \gamma=\frac{1.1105}{0.154}=7.2
\end{aligned}
$$

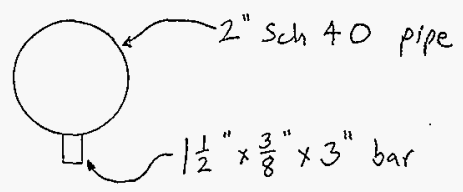

$$
\frac{\beta_{1}}{\beta_{2}}=0.125
$$

HNF-2479, Rev. 0

Page D-14 


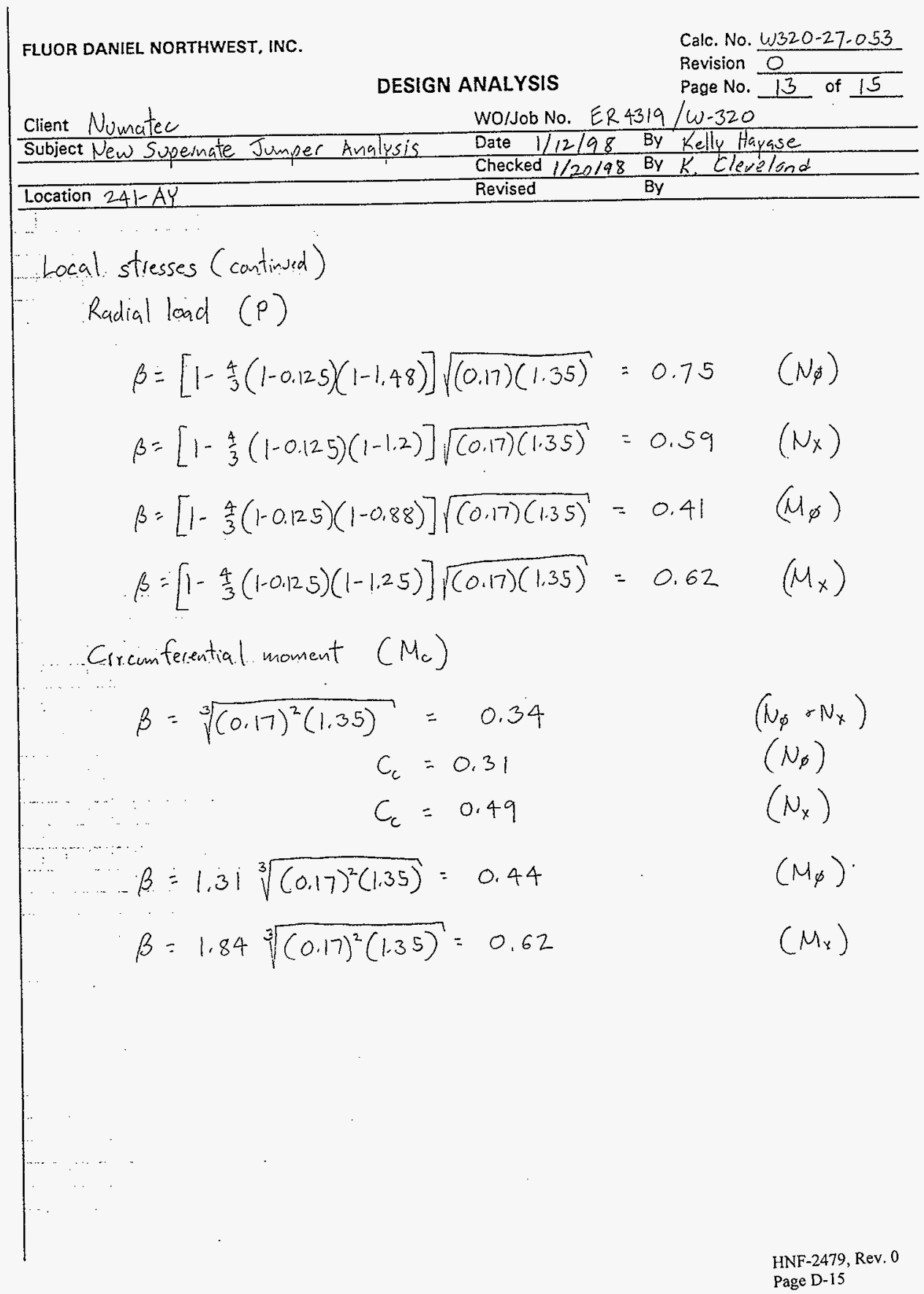




\section{DESIGN ANALYSIS Page No: 14 of 15}

Client: Numatec

Subject: New Supernate Jumper Analysis

Location: 241-AY
WO/Job No: ER4319M N-320

Date: $1 / 12 / 98$ By: Kelly Hayase

Checked: $1 / 20198$ By: K. Clevelond

Revised:
By:

Local stresses (continued)

Tabie 5-Computation Sheet for Local Stresses in Cylindrical Shells

1: Applied Leac's

Redial lood.

Circ. Kament,

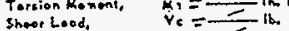

Shror Lood. $\quad Y_{L}=-$ Lt.

2. Comatr

Yeatel thicknast, $\quad T-0.154$ ia

Areceturent redius, io 5 Tios ito

Vensel rodius, $R_{m}=1105$ in.
1. Enomotric Porameters

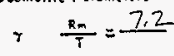

B. $\quad(0.875) \frac{10}{R_{m}}=-$

Siress Concentrolion due to:

1) membrone lood. $\mathrm{kn} \frac{1.0}{1.0}$

b) Bonding lood, $\mathrm{Kb}$

- NOTE: Emer all force values in

eceordonse with sign convention
Revision: 0

\begin{tabular}{|c|c|c|c|c|c|c|c|c|c|c|c|}
\hline \multirow{2}{*}{$\beta$} & \multirow{2}{*}{ Fis } & \multirow{2}{*}{$\begin{array}{c}\text { Read eurres } \\
\text { for }\end{array}$} & \multirow{2}{*}{$\begin{array}{l}\text { Compuse abes lut velues of } \\
\text { stross ond antet result }\end{array}$} & \multicolumn{8}{|c|}{ 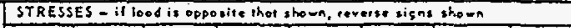 } \\
\hline & & & & Au & $4 L$ & Bu & $B L$ & $C_{\psi}$ & $\mathrm{Cl}$ & $O_{10}$ & $D L$ \\
\hline 0.75 & $\begin{array}{c}36-0=: \\
4 C\end{array}$ & $\frac{k_{\omega}}{p / k_{m}}=1.0$ & $k_{n}\left(\frac{N G}{n_{i} k_{m}}\right) \cdot \frac{p}{k_{m} T}=$ & - & - & $\dot{-}$ & 一 & 18 & - & - & - \\
\hline .4 & $\begin{array}{l}2 c \text { or } \\
26-1-\end{array}$ & $\frac{m i}{p} 0.064$ & K. $\left(\frac{k \phi}{P}\right) \cdot \frac{\sigma P}{7^{2}}=$ & - & $t$ & - & + & -5 & 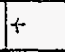 & - & H \\
\hline 0.34 & IA & $\frac{K d}{K c / R-2 \beta}=$ & $x_{n}\left(\frac{k_{0}}{\mu_{c} / R_{m}^{2} \beta}\right)+\frac{k_{c}}{k_{m}^{2} \beta \tau} \times Q_{0} 31$ & YYS & 30 & (1) & YOP & 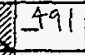 & - & $f$ & \\
\hline 0.44 & is & 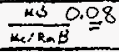 & 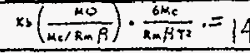 & 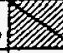 & & & & $\sqrt{14}$ & It & 7 & \\
\hline & 34 & $\frac{k s}{k L / \operatorname{Rm}^{2} B}=$ & $\operatorname{sn}\left(\frac{N \phi}{\mu 1, R_{m}{ }^{2} \beta}\right) \cdot \frac{4}{\sin ^{2} \beta T}=$ & - & - & + & $1+$ & & 28 & Y & 30 \\
\hline & 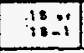 & $\frac{\omega}{\alpha t / x_{-\beta} \beta}=$ & 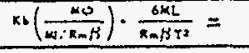 & $1-$ & + & + & - & & OII & & ones \\
\hline & \multicolumn{3}{|c|}{ 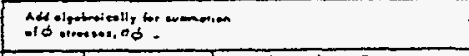 } & & & & & & & & \\
\hline 0.59 & $\underset{40}{30}$ & $\frac{k}{1 R_{m}}=1.0$ & $K \cdot\left(\frac{K_{x}}{H K=}\right) \cdot \frac{P}{R_{m} T}=$ & - & $\rightarrow$ & - & - & 18 & - & $\longrightarrow$ & \\
\hline 0.62 & $\begin{array}{c}2 c-1 \\
-0 x-2 c-\end{array}$ & $\frac{\mu}{p}=0.0$ & $K_{b}\left(\frac{k_{x}}{p}\right) \cdot \frac{6 p}{T^{2}}=3$ & - & $f$ & - & 4 & & + & $\rightarrow$ & $r$ \\
\hline 0.34 & 4 & 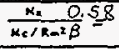 & $x_{n}\left(\frac{k_{2}}{k_{c} / k_{n}^{2} \beta}\right) \cdot \frac{k_{c} \times 0.49}{k_{m}^{2} \beta \tau} \neq$ & Ple & 30 & Pe & 10 & 1501 & $\rightarrow$ & + & + \\
\hline 0.62 & 24 & $\frac{\mu_{k}}{\alpha_{c} / \alpha_{m} \beta} 0.0 \pm \overline{3}$ & $\therefore\left(\frac{u_{k}}{k_{c} / x-\beta}\right) \cdot \frac{6 \mu_{e}}{k m \beta T^{2}}=5$ & Yoes & & Q110 & WOes & 5388 & $\div$ & to & - \\
\hline & 44 & $\frac{N_{k}}{\lambda t / k=1 \beta}=$ & $x_{n}\left(\frac{K_{K}}{M U R_{m}^{2} \beta}\right)+\frac{k t}{R_{n}=2 \beta T}=$ & - & - & $t$ & $1+$ & OPOS & OP & OP & OPO \\
\hline & \begin{tabular}{cc|c|}
28 & $\cdots$ \\
28 & -1
\end{tabular} & $\frac{M_{n}}{M L_{I} \operatorname{Rn} B}=$ & $K_{1}\left(\frac{k_{*}}{k_{L} \cdot k_{m} / R}\right) \cdot \frac{6 k_{t} t}{k_{m} k^{2} T^{2}}=$ & - & + & $1+$ & - & ODS & PIS & OP & YOP. \\
\hline & \multicolumn{3}{|c|}{ 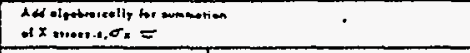 } & & & & : & 1462 & & & \\
\hline & \multicolumn{2}{|c|}{ 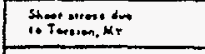 } & $r s x=r \times 0=\frac{-M_{t}}{2 \pi t}$ & $t$ & $t$ & $t$ & $t$ & + & $t$ & 4 & $f$ \\
\hline & \multicolumn{2}{|c|}{$\begin{array}{l}\text { Shoer nowets to } \\
\text { nolow, Ve }\end{array}$} & $T \times O=-\frac{Y c}{Y_{0} T}$ & + & $t$ & - & - & PINES & 0 & OPS & YOY \\
\hline \multirow[t]{2}{*}{ 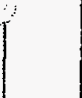 } & \multicolumn{2}{|c|}{ Show strest ate. } & T.S $-\frac{\mathrm{YL}}{\pi}$ & OE & Y & OI & OPose & & - & 4 & $t$ \\
\hline & \multicolumn{3}{|c|}{ 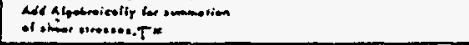 } & & & & & & & & \\
\hline
\end{tabular}


FLUOR DANIEL NORTHWEST, INC.

DESIGN ANALYSIS
Talc. No. W) $320-2.7-0,53$

Revision $\frac{0}{15}$

Page No. 15 of 15

Client Numater

WO/Job No. ER $4319 / \omega-320$

Subject New Supervate Jumper Analysis

Date $1 / 12 / 98$ By Kelly hlaynse

Location 24I-AY

Checked 1/20/98 By K. Cleveland

Revised

Combine local stresses o global stresses

Hoop sties s

$$
\begin{aligned}
15299 \text { psi } & +3350 \text { psi }=18649 \text { psi }<20,000 p_{s i}=\sigma_{\text {allow }} \\
& \text { (max from Avtapipe) }
\end{aligned}
$$

Sustained stress

$$
7462 \text { psi }+4269 p^{s i}=11731 \text { psi }<20,000 \text { psi }=\sigma_{a l l} \text { oud }
$$

(max from Autuppe)

$0, K$

Displacement sties

$$
7462 p_{s i}+7662 \text { psi }=15124 \text { psi }<30,000 \text { psi }=T_{a} l_{\text {los }}
$$

(max from Autunite)

$0, k$

Occasional stress

$$
7462 p_{s i}+5696 p_{s i}=13158 p_{\text {si }}<26600 p_{s i}=\sigma_{a l} l_{w}
$$

(max from Autupipe)

$O, K$.

HNF-2479, Rev. 0

Page D-17 


U3U118
$01 / 06 / 98$

POINT DATA LISTING

POINT TYPE

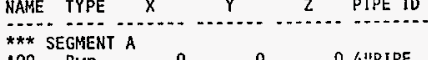

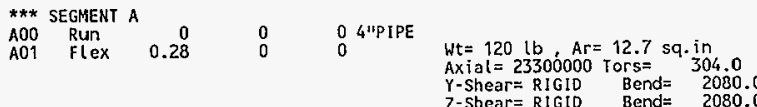

$\begin{array}{lllll}\text { A02 Run } & 0.05 & 0 & 0 & \\ \text { A03 Bend } & 0.35 & 0 & 0 & \text { Short Elbow, Radius }=4.00 \text { inch }\end{array}$

Mid point at 50.00 percent

A04 Bend $0 \quad-2.02 \quad 0$

$\begin{array}{lllll}\text { A05 } & \text { Redu } & 0.50 & 0 & 0 \\ \text { A06 } & \text { Run } & 0.33 & 0 & 0 \\ \text { A07 } & \text { Bend } & 0.49 & 0 & 0\end{array}$

$\begin{array}{lllll}A 08 & B & 0 & 0 & -1.69\end{array}$

$\begin{array}{lllll}\text { A09 } & \text { Run } & 0.68 & 0 & 0 \\ \text { A10 } & \text { Tee } & 0.32 & 0 & 0 \\ \text { A19 } & \text { Run } & 0.32 & 0 & 0 \\ \text { A12 } & \text { Bend } & 0.68 & 0 & 0\end{array}$

A13 Bend $0 \quad 0 \quad-2.73$

Long Elbow, Radius $=3.00$ inch
Long Elbow, Radius $=3.00$ inch Bend angle change $=90.00 \mathrm{deg}$ Mid point at 50.00 percent Sif - In 1.73, out $=1.44$ $\mathrm{Flex}=4.404$

Short Elbow, Radius $=2.00$ inch Bend angle change $=90.00 \mathrm{dcs}$ Mid point at 50.00 percent SIf - in 2.27 , Out $=1.89$ Flex $=6.606$ 8end angle change $=90.00$ deg

SIF - In 2.56, Dut $=2.13$

Flex $=7.908$

Long Elbow, Radius $=6.00$ inch Bend angle change $=90.00 \mathrm{deg}$ Mid point at 50.00 percent SiF - In 1.95, out $=1.63$

flex $=5.272$

U3U19B W-302 TANK 241-C-106 WASTE RETRIEVAL

Auor Danie Northwest

$01 / 06 / 98$

Aut OPIPE+4.60 MODEL PACE

POINT DATA LISTING

POINT

A14 Flex 0 o 0.20 o

$W t=29 \mathrm{lb}, \mathrm{Ar}=3.4$ sq. in Axial $=13500000$ Tors $=107.0$

$\begin{array}{lll}\gamma \text {-Shear }=\text { RIGID } & \text { Bend }= & 659.0 \\ \text { Z-Shear= RIGID } & \text { Bend }= & 659.0\end{array}$

\begin{tabular}{|c|c|c|c|c|}
\hline $\begin{array}{l}\text { A } 15 \\
\text { A } 16\end{array}$ & $\begin{array}{l}\text { Run } \\
\text { Run }\end{array}$ & $\begin{array}{l}\mathbf{0} \\
0\end{array}$ & $\begin{array}{l}-0.05 \\
-0.19\end{array}$ & $\begin{array}{l}0 \\
0\end{array}$ \\
\hline$\star * *$ & SEGMENT & 300 & & \\
\hline $\begin{array}{l}\mathrm{A} 10 \\
\mathrm{~B} 01 \\
\mathrm{~B} 02 \\
\mathrm{~B} 03 \\
\mathrm{~B} 04\end{array}$ & $\begin{array}{l}\text { Tee } \\
\text { Run } \\
\text { Run } \\
\text { Redu } \\
\text { Run } \\
\text { Bend }\end{array}$ & $\begin{array}{r}3.00 \\
0 \\
0 \\
0 \\
0 \\
0\end{array}$ & $\begin{array}{r}-2.02 \\
0 \\
0 \\
0 \\
0 \\
0\end{array}$ & 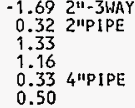 \\
\hline
\end{tabular}

BO5 Bend

806 Bend $0 \quad 1.33 \quad 0$

Long Elbow, Radius $=6.00 \mathrm{inch}$ Bend angle change $=90.00$ deg Mid point at 50.00 percen SIF - In 1.95 , out $=1.63$ Flex $=5.272$

Short Elbow, Radius $=4.00$ inch Bend angle change $=90.00 \mathrm{deg}$ Mid point at 50.00 percent SiF - in 2.56 , Out $=2.13$

Long Elbow, Radius $=3.00$ inch Bend angle change $=90.00$ deg Mid point at 50.00 percent flex $=4.404$ Bend angle change $=90.00 \mathrm{deg}$ Mid point at 50.00 percent Sif $=$ [n 1.73 , out $=1.44$ $\mathrm{Flcx}=4.404$

B07

Flex

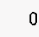

0

0.35

$\begin{array}{lllll}808 & \text { Run } & 0 & 0 & 0.05 \\ 809 & \text { Run } & 0 & 0 & 0.28\end{array}$

Total weight of empty pipes : $105 \mathrm{lb}$
Wt $=120 \mathrm{lb}, \mathrm{Ar}=12.7 \mathrm{sq} \cdot \mathrm{in}$ Axial $=23300000$ Tors $=304.0$ $\begin{array}{lll}\gamma \text {-Shear }=\text { RIGID } & \text { Bend }= & 2080.0 \\ \text { Z-Shear= RIGID } & \text { Bend }= & 2080.0\end{array}$ 


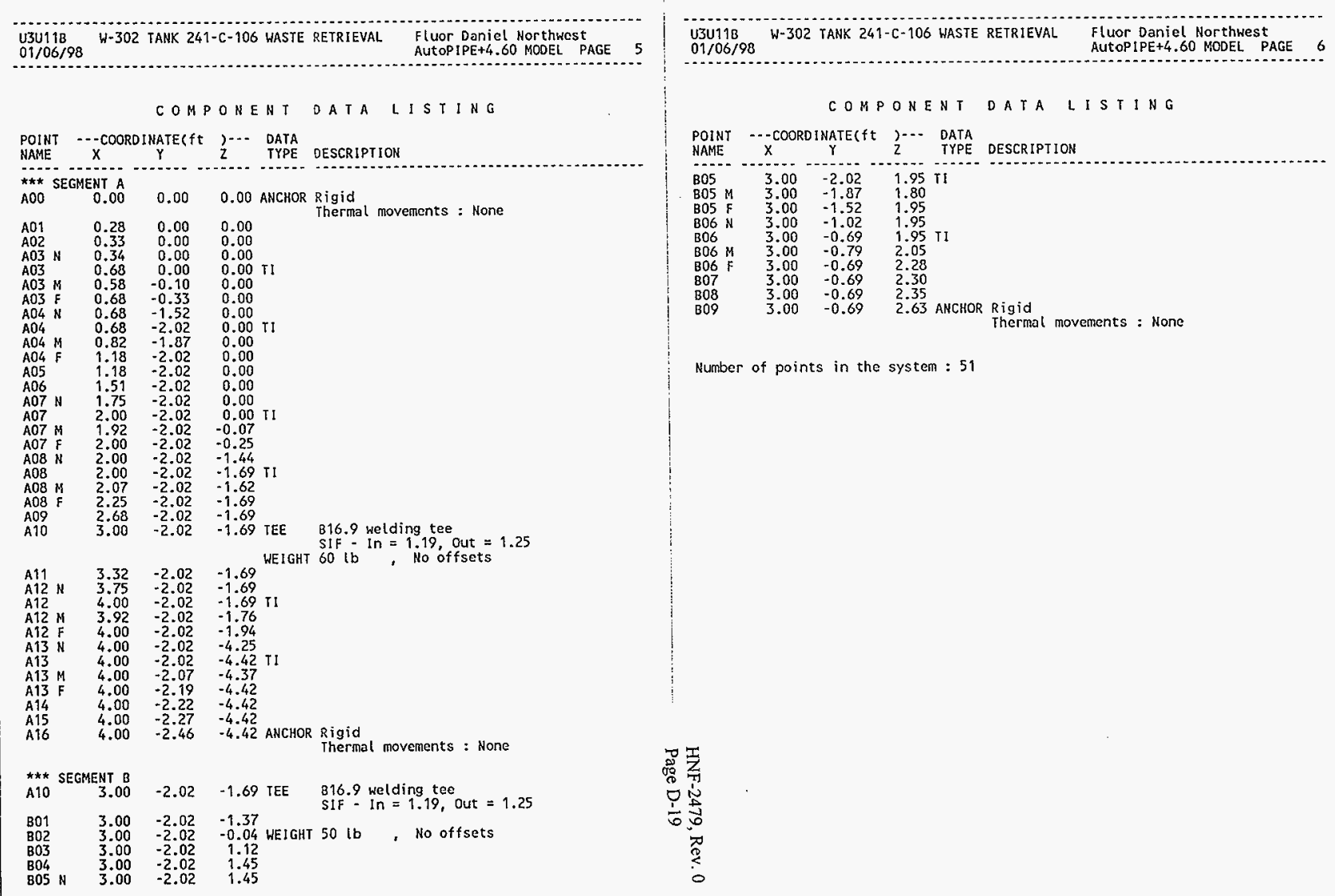




\begin{tabular}{|c|c|c|c|c|c|c|c|c|c|c|}
\hline \multirow[t]{2}{*}{$\begin{array}{l}\text { U3U11B } \\
01 / 06 / 98\end{array}$} & \multicolumn{3}{|c|}{ H-302 TANK 241-C-106 } & HASTE RET & TRIEVA & & \multicolumn{4}{|c|}{$\begin{array}{l}\text { Fluor Daniel Hor thwest } \\
\text { ALtoPIPE }+4.60 \text { MODEL PAGE }\end{array}$} \\
\hline & & & ] $P E$ & DATA & 11 & S T I & ING & & & \\
\hline $\begin{array}{l}\text { Pipe } \mathrm{iDf} \\
\text { Material }\end{array}$ & $\begin{array}{l}\text { Nom/ } \\
\text { Sch }\end{array}$ & $\begin{array}{l}\text { O.D. } \\
\text { inch }\end{array}$ & W.Th. & $\begin{array}{l}\text { hickness(i } \\
\text { Corr Mill }\end{array}$ & $\begin{array}{l}\text { inch )- } \\
\text { Insu }\end{array}$ & Ling & $\begin{array}{l}\text { Spec } \\
\text { Grav }\end{array}$ & $\begin{array}{l}\text { Weigh } \\
\text { Pipe }\end{array}$ & $\begin{array}{l}\text { Itclb/f } \\
\text { Other }\end{array}$ & $\begin{array}{l}\text { t }) \\
\text { Total }\end{array}$ \\
\hline $\begin{array}{l}\text { 4"PIPE } \\
\text { A106-B }\end{array}$ & $40^{4}$ & 4.500 & 0.237 & 00.03 & 0 & 0 & 1.12 & 10.78 & 0 & 16.96 \\
\hline $\begin{array}{l}\text { 2"PIPE } \\
\text { A106-B }\end{array}$ & $\begin{array}{l}2.000 \\
40\end{array}$ & 2.375 & 0.154 & 00.02 & 0 & 0 & 1.12 & 3.65 & 0 & 5.28 \\
\hline $2_{N S}^{\prime \prime-3 W A Y}$ & $\begin{array}{c}2.000 \\
40\end{array}$ & 2.375 & 0.154 & 00.02 & 0 & 0 & 1.12 & 3.65 & 0 & 5.28 \\
\hline
\end{tabular}

U3U13B
$01 / 06 / 98$ W02 TANK $241-\mathrm{C}-106$ WASTE RETRIEVAL $\begin{aligned} & \text { Fluor Daniel Nor thwest } \\ & \text { AUtOPIPE }+4.60 \mathrm{MODEL} \text { PAGE }\end{aligned}$

\section{MATERIAL DATA LISTING}

Material Density Pois. Temper. Modulus Expans. Allow.

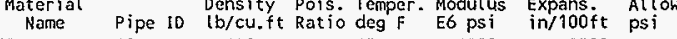

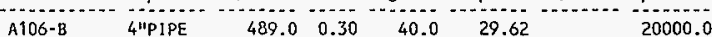
$\begin{array}{lll}180.0 & 1.0406 \quad 20000.0\end{array}$

A106-8 2"1PE $\quad 489.0 \quad 0.30 \quad 40.0 \quad 29.62 \quad 1.0406 \quad 20000.0$

NS $\quad 2$ 2"-3WAY $\quad 489.0 \quad 0.30 \quad \begin{array}{rrrrr}40.0 & 2900.00 & 1.0920 & 20000.0\end{array}$




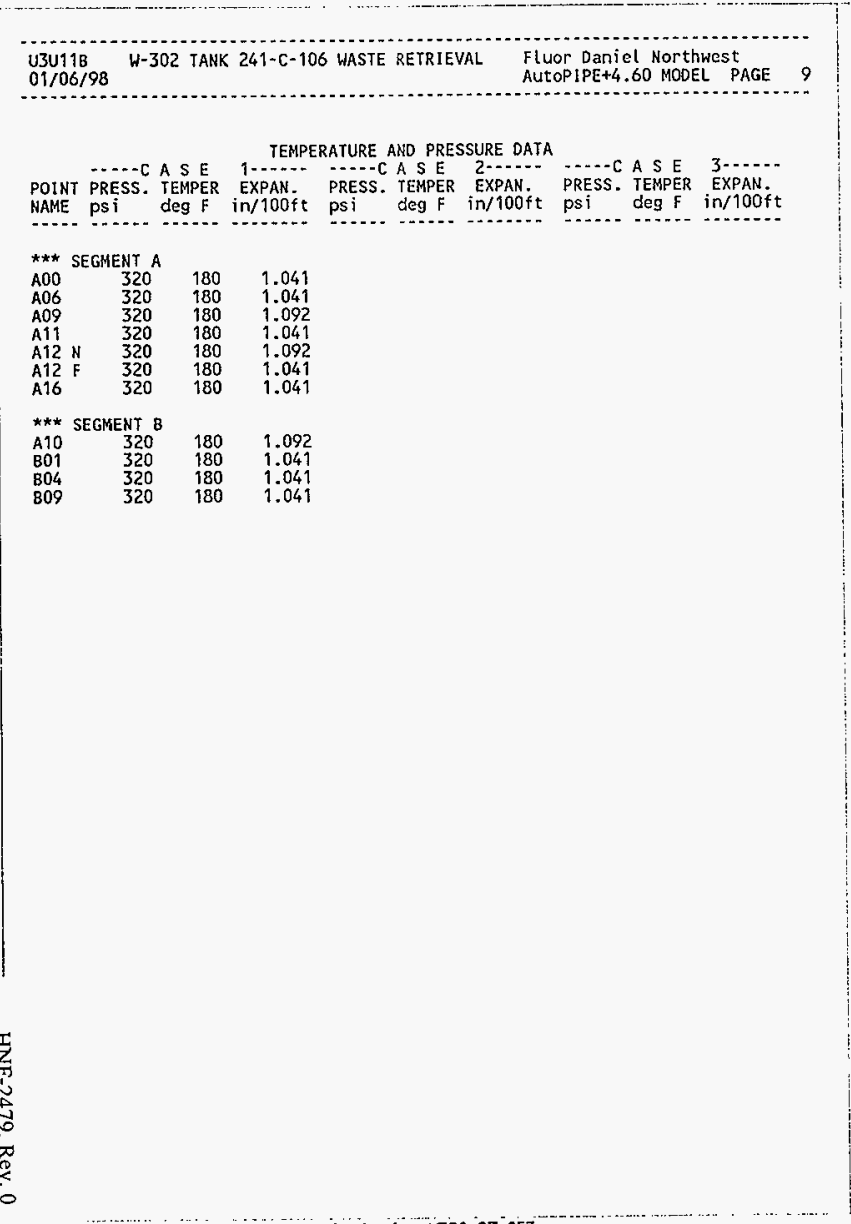

luor Daniel Northwest AutOPIPE+4.60 RESULT PAGE

1

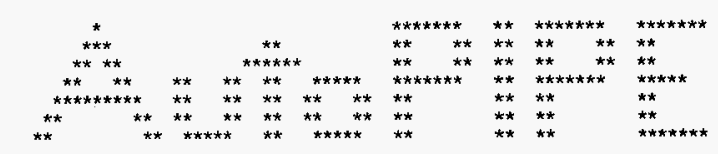

Pipe Stress Analysis and Design Program

Version: 4.60 .03

Edition: Plus-Dos

Developed and Maintained by

Engincering Design Automation, Inc.

1600 Riviera Ave.., Suite 300

Walnut Creek. CA 94596 


\section{ANALYSIS SUMMARY}

Current model revision number : 3

Static - Date and time of analysis Model Revision Number

.....................

Load cases analyzed .................... GR T1

Gaps/Friction/Yielding considered ...... No Hanger design run $\ldots \ldots \ldots \ldots \ldots \ldots \ldots$ No

Cut short included $\ldots \ldots \ldots \ldots \ldots \ldots \ldots$ No

Weight of contents included $\ldots \ldots \ldots \ldots$. Yes

Pressure stiffening case ............. 0

Water elevation for buoyancy ioads ..... Not considered

Modal - Date and Time of analys is .......... Jan 6, 1998 12:50 PM Hodel Revision Number . ............... 3

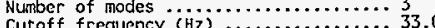

Cutoff frequency (Hz)

Weight of contents included $\ldots . . . \ldots \ldots$. Yes

Pressure stiffening case ...............

Water elevation for buoyancy loads ..... Not considercd

Response - Date and $T$ ime of analys is .......... Jan 6, 1998 12:50 PM Model Revision Number ................... 3

Number of load cases $\ldots \ldots \ldots \ldots \ldots \ldots \ldots \ldots$ i

Load cases analyzed $\ldots \ldots \ldots \ldots$................ Ran $6,1998 \quad 12: 50 \mathrm{PM}$

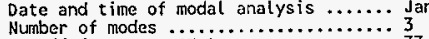

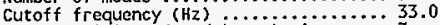

Model revision of modal analysis ...... 3

Weight of contents included ............ Yes

Number of mass points per span .......... Automatic

Pressure stiffening case ................

Water elevation for buoyancy loads .... Not considered

\section{CODE COMPLIANCE COMBINATIONS}

\begin{tabular}{|c|c|c|c|c|c|c|}
\hline Combination & Category & Method & Load & Factor & Allowable & Remarks \\
\hline$G R+\operatorname{Max} P$ & Sustain & Sum & $\begin{array}{l}\text { Gravity } \\
\text { Max Long }\end{array}$ & $\begin{array}{l}1.00 \\
1.00\end{array}$ & Automatic & Default \\
\hline old to T1 & Expansion & sum & Thermal 1 & 1.00 & Automatic & Default \\
\hline Sus. $+R 1$ & Dccasion & Abs sum & $\begin{array}{l}\text { Response } 1 \\
\text { Max Sus }\end{array}$ & $\begin{array}{l}1.00 \\
1.00\end{array}$ & Automatic & Defau \\
\hline $\operatorname{tax} P$ & Hoop & & Max Hoop & 1.00 & Automat ic & Def \\
\hline
\end{tabular}

\section{OTHER USER CONBINATIONS}

\begin{tabular}{lllll} 
Combination Method & \multicolumn{1}{c}{ Load } & Factor & Remarks \\
GR & Sum & Gravity & 1.00 & Default \\
T1 & Sum & Thermal 1 & 1.00 & Default \\
R1 & Sum & Response 1 & 1.00 & Default \\
GR+T1 & Sum & $\begin{array}{l}\text { Gravity } \\
\text { Thermal } 1\end{array}$ & 1.00 & User \\
TOTAL & Abs sum & $\begin{array}{l}\text { GR+T1 } \\
\text { Response } 1\end{array}$ & 1.00 & User \\
& & & 1.00 &
\end{tabular}

\section{CODE COMPLIANCE}

\begin{tabular}{|c|c|}
\hline 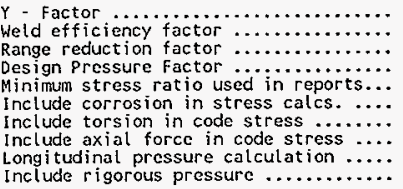 & $\begin{array}{l}0.40 \\
1.00 \\
1.00 \\
1.00 \\
0.00 \\
Y\end{array}$ \\
\hline
\end{tabular}




\begin{tabular}{|c|c|c|c|c|c|c|}
\hline $\begin{array}{l}\text { U3U118 } \\
01 / 06 / 98\end{array}$ & W-302 TANK & $241-C-106 W$ & ASTE RET & EVAL & $\begin{array}{l}\text { Ior Danic } \\
\text { oP IPE+4. }\end{array}$ & $\begin{array}{l}\text { Northwes } \\
\text { RESULT }\end{array}$ \\
\hline & $F R$ & QUENC & $1 \mathrm{ES}$ & & & \\
\hline $\begin{array}{l}\text { Mode } \\
\text { Number }\end{array}$ & $\begin{array}{l}\text { Frequency } \\
\text { (Rads/sec) }\end{array}$ & $\begin{array}{l}\text { Frequency } \\
\text { (Hertz) }\end{array}$ & $\begin{array}{c}\text { Period } \\
\text { (Sec) }\end{array}$ & $\begin{array}{l}\text { Partic } \\
x\end{array}$ & ation $\mathrm{fo}$ & $\begin{array}{r}r s \\
2\end{array}$ \\
\hline 1 & 90.9203 & 14.4704 & 0.069 & -0.589 & -0.338 & 0.144 \\
\hline 2 & 123.7139 & 19.6897 & 0.051 & 0.393 & -0.453 & 0.276 \\
\hline 3 & 200.7691 & 31.9534 & 0.031 & -0.052 & -0.231 & -0.3 \\
\hline
\end{tabular}


SOL.0 220.0 $520^{\circ} 0 \quad 510^{\circ} 0 \quad 520^{\circ} 0 \quad 520^{\circ} 0$ $600.0-010.0-410.0$ $590^{\circ} 0-2500^{\circ}-250.0 \quad 120^{\circ} 0-850^{\circ} 0-200^{\circ}$

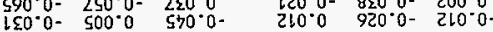

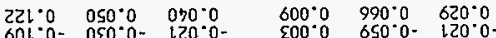
$601^{\circ} 0-080^{\circ} 0-120^{\circ} 0-$ $5,0.0 .050^{\circ} 0.820 .0$ $\angle 20^{\circ} 0-100^{\circ} 08 \% 0^{\circ} 0$.

$72 l^{\circ} 0 \quad 750^{\circ} 0 \quad 950^{\circ} 0$ +10.0 510.0 $8100^{\circ}$ $720^{\circ} 0-120^{\circ} 0-$ ร20.0 $980^{\circ} 0-200^{\circ} 0 \quad 270^{\circ} 0$

$821^{\circ} 0 \quad 610^{\circ} 0 \quad \$ \& 0^{\circ} 0$ टl1.0- 010.0- $510^{\circ} 0-$ 9l0. $6000^{\circ}$ SEO. $200^{\circ} 0$ 6E0.0-

621.0 $510^{\circ} 0$ 050.0 $\angle 10^{\circ} 0 \quad \angle 00^{\circ} 0$ $810^{\circ} 0$ $\angle 10^{\circ} 0-110^{\circ} 0-720^{\circ} 0$ $580^{\circ} 0-500^{\circ} 0$ 920\%-

$821.0 \quad 210 \circ 0 \quad 620^{\circ} 0$ 810.0 200.0 810.0 $\angle \angle 0^{\circ} 0^{-} 110^{\circ} 0^{-}+220^{\circ} 0$ $7 \mathrm{EO}^{\circ} 0^{-} 500^{\circ} 0 \quad 5 \mathrm{KO}^{\circ} 0^{-}$

$8210^{\circ} \%$ \$10.0 $620^{\circ} 0$ $111^{\circ} 0^{-} \angle 00^{\circ} 0^{-} \quad 110^{\circ} 0^{-}$ $810^{\circ} 0 \quad \angle 00^{\circ} 0 \quad 810^{\circ} 0$

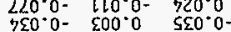

$221.0 \quad 110^{\circ} 0 \quad 820^{\circ} 0$ $201^{\circ} 0^{-} 900^{\circ} 0-010^{\circ} 0-$ $810^{\circ} 0 \quad 900^{\circ} 0 \quad 810^{\circ} 0$ $5 \angle 0^{\circ} 0^{-} \quad 600^{\circ} 0^{\circ} \quad 720^{\circ} 0$ $220^{\circ} 0-700^{\circ} 0 \quad \$ 20^{\circ} 0-$ ( 6әр) $\stackrel{\lambda}{\text { SNOILVLOY }}$ $900^{\circ} 0$ 900.0 $600^{\circ} 0$

$600^{\circ} 0-570^{\circ} 0-600^{\circ} 0-$

L20.0 $590^{\circ} 0$ OSO

$500^{\circ} 0 \quad \angle \mathrm{SO}^{\circ} 0^{\circ}-220^{\circ} 0$

$900^{\circ} 0 \quad 900^{\circ} 0 \quad 800^{\circ} 0$

$800^{\circ} 0-\quad 570^{\circ} 0=020^{\circ}$

2LO० $00^{-} 210^{\circ} 0^{-}$

$110^{\circ} 0 \quad 850^{\circ} 0 \quad 250^{\circ} 0$

$500 \circ 250^{\circ} 0.7200^{\circ}$

$900^{\circ} 0 \quad 500^{\circ} 0 \quad 800^{\circ} 0$

$210^{\circ} 0$ $010^{\circ} 0^{\circ}$ 210.0-

$110^{\circ} 0 \quad 150^{\circ} 0 \quad 550^{\circ} 0$

$500^{\circ} 0 \quad \angle 70^{\circ} 0^{\circ} \angle 20^{\circ} 0-$

$200^{\circ} 0$ 700 00 800

$\begin{array}{lll}800^{\circ} 0^{-} & 650^{\circ} 0^{-} & 510^{\circ} 0^{-} \\ 510^{\circ} 0 & 800^{\circ} 0^{-} & 210^{\circ} 0^{-}\end{array}$

$\begin{array}{lll}160^{\circ} 0 & 270^{\circ} 0 & 850^{\circ} 0 \\ 700^{\circ} 0 & 650^{\circ} 0^{-} & 050^{\circ} 0-\end{array}$

$200^{\circ} 0$ \&00 0 \% $800^{\circ} 0$

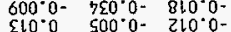

$110^{\circ} 0$ ट70 0 Bह0

$700^{\circ} 0$ 650.0- $050^{\circ} 0-$

$200^{\circ} 0 \quad 500^{\circ} 0 \quad 800^{\circ} 0$

$\begin{array}{lll}600^{\circ} 0^{-} & 550^{\circ} 0^{\circ} & 810^{\circ} 0^{-} \\ 210^{\circ} 0^{\circ} & 500^{\circ} & 210^{\circ} 0^{-}\end{array}$

$010^{\circ} 0 \quad 150^{\circ} 0 \quad 850^{\circ} 0$

$500^{\circ} 0 \quad 620^{\circ} 0-1.50^{\circ} 0$

$\begin{array}{lll}200^{\circ} 0 & 200^{\circ} 0 & 200^{\circ} 0 \\ 600^{\circ} 0- & 920^{\circ} 0- & 020^{\circ} 0-\end{array}$

$210^{\circ} \mathrm{500} 0^{\circ}$ LLO०

$e^{z}$ u! ) SNOILYTSYYI

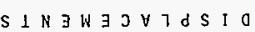

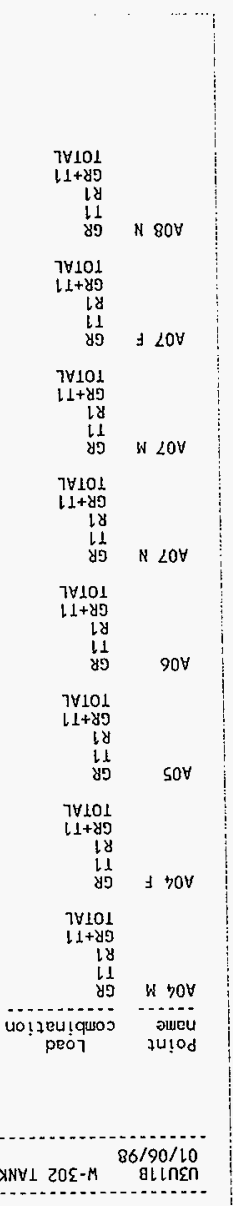

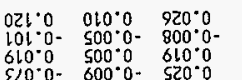

$820^{\circ} 0^{-}$700.0 $2500^{\circ} 0$ -

$911^{\circ} 0 \quad 600^{\circ} 0 \quad 920^{\circ} 0$

$260^{\circ} 0-700^{\circ} 0-200^{\circ} 0$

$610^{\circ} 0 \quad 500^{\circ} 0 \quad 610^{\circ} 0$

$0 \angle 0^{\circ} 0-800^{\circ} 0-320^{\circ}$

$\angle 20^{\circ} 0^{-} \$ 200^{\circ} 0$ टृ0.0-

$\begin{array}{lll}506^{\circ} 0 & 800^{\circ} 0 & 520^{\circ} 0 \\ 880^{\circ} 0- & 700^{\circ} 0- & 200^{\circ}\end{array}$

$880^{\circ} 0-700^{\circ} 0-\quad \angle 00^{\circ} 0-$

$\angle 10.0200 \%$ $810^{\circ} 0$

$\begin{array}{lll}290^{\circ} 0- & 800^{\circ} 0- & 7200^{\circ} \\ 920^{\circ} & 700^{\circ} 0 & 120^{\circ}\end{array}$

$160^{\circ} \mathrm{O} \quad \angle 00^{\circ} \mathrm{O} \quad 520^{\circ} 0$

$\angle 20^{\circ} 0-800^{\circ} 0^{-} 900^{\circ} 0$

$710-5000$ 8LO

$\$ 20^{\circ} 0^{-} \rightarrow 00^{\circ} 0$ L $280^{\circ} 0^{-}$

$160^{\circ} 0 \quad 200^{\circ} 0 \quad \$ 20^{\circ} 0$

$\angle 20^{\circ} 0-800^{\circ} 0-900^{\circ} 0$

7100 \%

$7500-2000-720.0$

$200^{\circ} 0 \quad 000^{\circ} 0 \quad 000^{\circ} 0$

$\begin{array}{ccc}200^{\circ} 0 & 000^{\circ} 0 & 000^{\circ} 0 \\ 0 & 000^{\circ} 0 & 000^{\circ} 0\end{array}$

$\begin{array}{lll}000^{\circ} 0- & 000^{\circ} 0 & 000^{\circ} 0 \\ 200 & 000^{\circ} 0 & 000^{\circ} 0\end{array}$

$100.0-000.0000$

100.000 .000 .0

$000.0 \quad 000.0 \quad 000.0$

$000.0 \quad 000.0 \quad 000.0$

$000^{\circ} 000^{\circ} 0 \quad 000^{\circ} 0$

$000^{\circ} 000^{\circ} 0 \quad 000^{\circ} 0$

$000^{\circ} 000^{\circ} 0000^{\circ}$

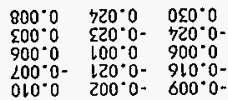

$200^{\circ} 0 \quad 110^{\circ} 0 \quad 100^{\circ} 0$

$100^{\circ} 0$ 010.0 $000^{\circ} 0$

$100.0100^{\circ} 0 \quad 100$

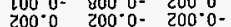

$100.0 \quad 1000^{\circ} 0 \quad 700^{\circ} 0$

$000^{\circ} 200^{\circ} 0-700.0$

$000^{\circ} 100^{\circ} 000^{\circ}$

$000^{\circ}+400^{\circ} 0-700^{\circ}$

$000^{\circ} 0$ 100. 0 - $100^{\circ} 0$ -

$000^{\circ} 0 \quad 100^{\circ} 0 \quad \$ 00^{\circ} 0$

$200^{\circ} 0$ 100.0- $500^{\circ} 0$

$000^{\circ} \quad 000^{\circ} 0 \quad 000^{\circ} 0$

$800^{\circ} 0 \quad 800^{\circ} 0$

$000^{\circ} 000^{\circ} 0 \quad 000^{\circ} 0$

$000^{\circ} 0 \quad 100^{\circ} 0 \quad \varepsilon 00^{\circ} 0$

$000^{\circ} 0$ 100.0- $1000^{\circ} 0$

$000^{\circ} 0$

$000^{\circ} 0 \quad \varepsilon 00^{\circ} 0$

$000^{\circ} 0 \quad 000^{\circ} 0 \quad 000^{\circ} 0$

$000^{\circ} 0 \quad 000^{\circ} 0 \quad \varepsilon 00^{\circ} 0$

$000^{\circ} 0 \quad 000^{\circ} 0 \quad 500^{\circ} 0$

$000^{\circ} 0 \quad 000^{\circ} 0 \quad 000^{\circ}$

$000^{\circ} 0 \quad 000^{\circ} 0 \quad \Sigma 00^{\circ} 0$

$000^{\circ} 0000^{\circ} 0 \quad 000^{\circ} 0$

$000^{\circ} 0 \quad 000^{\circ} 0 \quad 000^{\circ} 0$

$000^{\circ} 0000^{\circ} 0 \quad 000^{\circ} 0$

$000^{\circ} 0 \quad 000^{\circ} 0 \quad 000^{\circ} 0$

$000^{\circ} 0000^{\circ} 0 \quad 000^{\circ} 0$

$000^{\circ} 0 \quad 000^{\circ} 0 \quad 000^{\circ} 0$

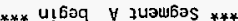

$7 \forall 101$

เy

II N NOV

$7 \forall 101$

$1+89$
Ld

पग $\rightarrow$ EOH

7101

(1)

עפ $4 \mathrm{cOH}$

$7 \forall 101$

ly

li 29504

$7 \forall 101$

$+4$

d9

208

11

IOH

$1 \forall 101$

11
( 2 แ! ) ล $x$

uolzeutquos

peó 7

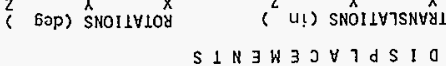




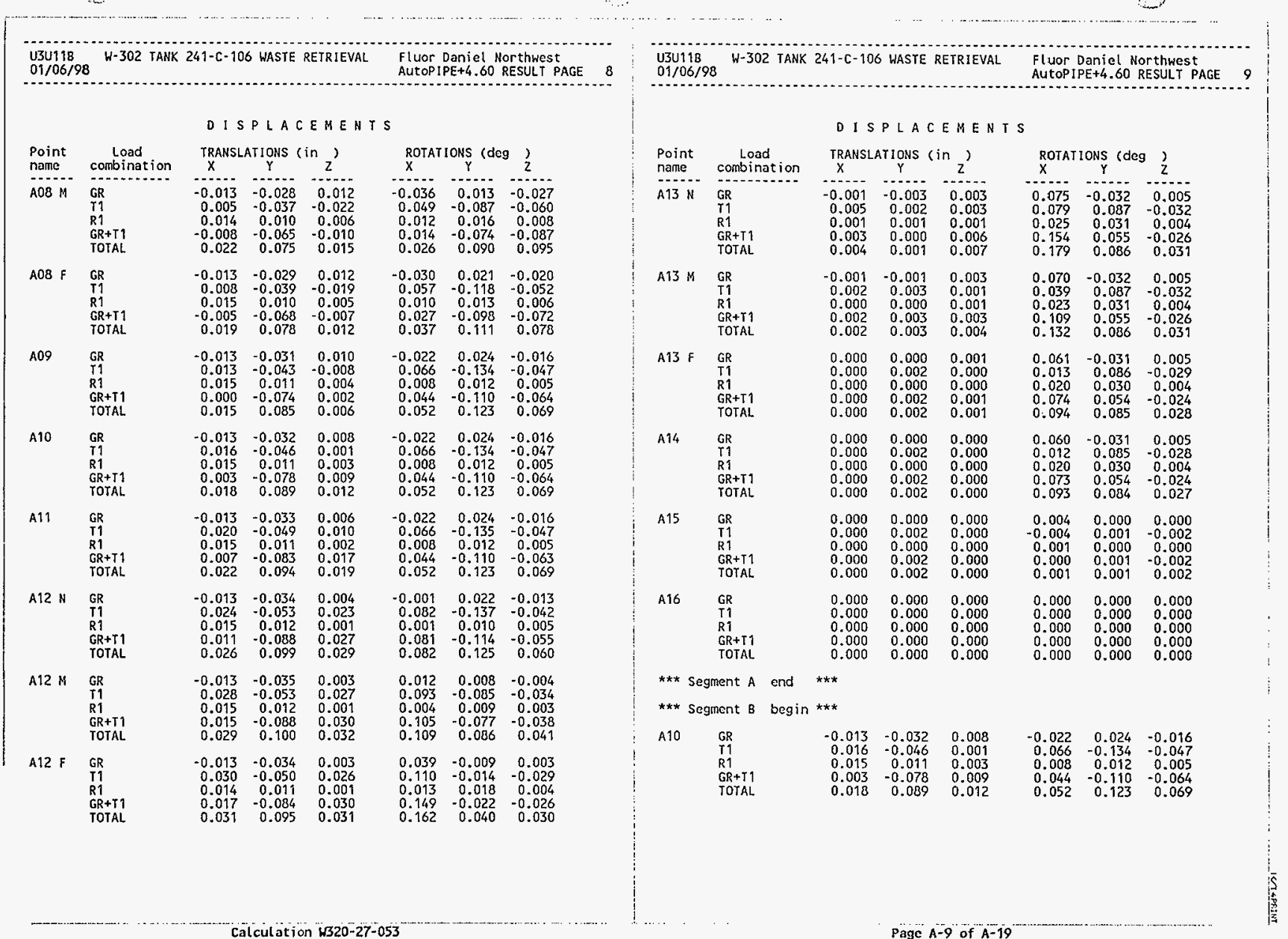




\begin{tabular}{|c|c|c|}
\hline $\begin{array}{l}921^{\circ} 0 \\
801^{\circ} 0- \\
720^{\circ} 0 \\
960^{\circ} 0^{\circ-} \\
200^{\circ} 0^{-0}\end{array}$ & $\begin{array}{l}\varepsilon 10^{\circ} 0 \\
200^{\circ} 0 \\
110^{\circ} 0 \\
\$ 00^{\circ} 0^{-} \\
500^{\circ} 0\end{array}$ & $\begin{array}{l}\angle 00^{\circ} 0 \\
961^{\circ} 0- \\
110^{\circ} 0 \\
691^{\circ} 0- \\
\angle 20^{\circ} 0^{\circ}-\end{array}$ \\
\hline $\begin{array}{l}921^{\circ} 0 \\
500^{\circ} 0^{-} \\
720^{\circ} 0 \\
960^{\circ} 0^{-} \\
200^{\circ} 0^{-}\end{array}$ & $\begin{array}{l}\varepsilon 10^{\circ} 0 \\
100^{\circ} 0 \\
210^{\circ} 0 \\
700^{\circ} 0^{-} \\
900^{\circ} 0\end{array}$ & $\begin{array}{l}802^{\circ} 0 \\
261^{\circ} 0- \\
110^{\circ} 0 \\
691^{\circ} 0- \\
820^{\circ} 0-\end{array}$ \\
\hline $\begin{array}{l}521^{\circ} 0 \\
200^{\circ} 0^{-} \\
\Sigma 20^{\circ} 0 \\
760^{\circ} 0^{-} \\
200^{\circ} 0^{-}\end{array}$ & $\begin{array}{l}210^{\circ} 0 \\
100^{\circ} 0 \\
210^{\circ} 0 \\
500^{\circ} 0- \\
900^{\circ} 0\end{array}$ & $\begin{array}{l}002^{\circ} 0 \\
\angle 81^{\circ} 0^{-} \\
\varepsilon 10^{\circ} 0 \\
250^{\circ} 0- \\
5 \varepsilon 0^{\circ} 0^{-}\end{array}$ \\
\hline $\begin{array}{l}\sum 2 l^{\circ} 0 \\
001^{\circ} 0^{-} \\
\angle 20^{\circ} 0 \\
\$ 60^{\circ} 0^{-} \\
800^{\circ} 0^{-}\end{array}$ & $\begin{array}{l}210^{\circ} 0 \\
200^{\circ} 0^{-} \\
210^{\circ} 0 \\
600^{\circ} 0^{-} \\
200^{\circ} 0^{-}\end{array}$ & $\begin{array}{l}\angle 81^{\circ} 0 \\
891^{\circ} 0^{-} \\
510^{\circ} 0 \\
221^{\circ} 0^{-} \\
170^{\circ} 0^{-}\end{array}$ \\
\hline $\begin{array}{l}\sum Z !^{\circ} 0 \\
001^{\circ} 0- \\
\Sigma 20^{\circ} 0 \\
\sum 60^{\circ} 0^{-} \\
800^{\circ} 0^{-}\end{array}$ & $\begin{array}{l}+10^{\circ} 0 \\
200^{\circ} 0^{-} \\
210^{\circ} 0 \\
600^{\circ} 0^{-} \\
200^{\circ} 0\end{array}$ & $\begin{array}{l}\text { s8t:0 } \\
891 \cdot 0- \\
\text { s10 } \\
221 \cdot 0 \\
170^{\circ} 0-\end{array}$ \\
\hline $\begin{array}{l}121^{\circ} 0 \\
660^{\circ} 0- \\
220^{\circ} 0 \\
160^{\circ} 0- \\
800^{\circ} 0^{-}\end{array}$ & $\begin{array}{l}910^{\circ} 0 \\
800^{\circ} 0^{-} \\
210^{\circ} 0 \\
110^{\circ} 0^{-} \\
200^{\circ} 0\end{array}$ & $\begin{array}{l}\text { sLl:0 } \\
091 \cdot 0- \\
\text { s10.0 } \\
910^{\circ} 0^{-} \\
\Sigma \neq 0^{\circ} 0^{-}\end{array}$ \\
\hline $\begin{array}{l}960^{\circ} 0 \\
880^{\circ} 0- \\
210^{\circ} 0 \\
120^{\circ} 0- \\
210^{\circ} 0^{-}\end{array}$ & $\begin{array}{l}150^{\circ} 0 \\
650^{\circ} 0- \\
210^{\circ} 0 \\
850^{\circ} 0^{-}- \\
+10^{\circ} 0\end{array}$ & $\begin{array}{l}\varepsilon 90^{\circ} 0 \\
\angle 70^{\circ} 0^{-} \\
910^{\circ} 0 \\
000^{\circ} 0 \\
\angle 70^{\circ} 0^{-}\end{array}$ \\
\hline $\begin{array}{l}690^{\circ} 0 \\
590^{\circ} \\
500^{\circ}- \\
270^{\circ} 0^{-} \\
910^{\circ} 0^{-0}\end{array}$ & $\begin{array}{l}\text { 2टl. } 0 \\
011^{\circ} 0- \\
210^{\circ} 0 \\
7 \varepsilon 1 \cdot 0- \\
720^{\circ} 0\end{array}$ & $\begin{array}{l}250^{\circ} 0 \\
770^{\circ} 0 \\
800^{\circ} 0 \\
990^{\circ} 0 \\
220^{\circ} 0-\end{array}$ \\
\hline & $\lambda$ & $k$ \\
\hline
\end{tabular}

\begin{tabular}{|c|c|c|}
\hline $\begin{array}{l}\angle 00^{\circ} 0 \\
900^{\circ} 0 \\
100^{\circ} 0 \\
500^{\circ} 0 \\
200^{\circ} 0\end{array}$ & $\begin{array}{l}810^{\circ} 0 \\
260^{\circ} 0- \\
100^{\circ} 0 \\
510^{\circ} 0^{-} \\
200^{\circ} 0-\end{array}$ & $\begin{array}{l}010^{\circ} 0 \\
200^{\circ} 0- \\
200^{\circ} 0 \\
900^{\circ} 0- \\
100^{\circ} 0-\end{array}$ \\
\hline $\begin{array}{l}620^{\circ} 0 \\
\angle 20^{\circ} 0 \\
200^{\circ} 0 \\
220^{\circ} 0 \\
500^{\circ} 0\end{array}$ & $\begin{array}{l}£ 20^{\circ} 0 \\
220^{\circ} 0- \\
100^{\circ} 0 \\
020^{\circ} 0- \\
200^{\circ} 0-\end{array}$ & $\begin{array}{l}\varepsilon 20^{\circ} 0 \\
810^{\circ} 0^{-0} \\
500^{\circ} 0 \\
910^{\circ} 0- \\
200^{\circ} 0^{-0}\end{array}$ \\
\hline 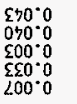 & $\begin{array}{l}\varepsilon 50^{\circ} 0 \\
250^{\circ} 0^{-} \\
100^{\circ} 0 \\
620^{\circ} 0- \\
\varepsilon 00^{\circ} 0^{-}\end{array}$ & $\begin{array}{l}250^{\circ} 0 \\
920^{\circ} 0^{-} \\
200^{\circ} 0 \\
\$ 20^{\circ} 0^{-} \\
200^{\circ} 0^{-0}\end{array}$ \\
\hline $\begin{array}{l}5 \$ 0^{\circ} 0 \\
270^{\circ} 0 \\
500^{\circ} 0 \\
750^{\circ} 0 \\
800^{\circ} 0\end{array}$ & $\begin{array}{l}870^{\circ} 0 \\
970^{\circ} 0- \\
200^{\circ} 0 \\
070^{\circ} 0- \\
900^{\circ} 0-\end{array}$ & $\begin{array}{l}\angle 80^{\circ} 0 \\
620^{\circ} 0^{-0} \\
800^{\circ} 0 \\
920^{\circ} 0^{-0} \\
800^{\circ} 0^{-1}\end{array}$ \\
\hline $\begin{array}{l}\$ \neq 0^{\circ} 0 \\
270^{\circ} 0 \\
800^{\circ} 0 \\
780^{\circ} 0 \\
300^{\circ} 0\end{array}$ & $\begin{array}{l}640^{\circ} 0 \\
970^{\circ} 0- \\
200^{\circ} 0 \\
170^{\circ} 0- \\
900^{\circ} 0-\end{array}$ & $\begin{array}{l}\angle \varepsilon 0^{\circ} 0 \\
620^{\circ} 0- \\
800^{\circ} 0 \\
920^{\circ} 0^{\circ} \\
\varepsilon 00^{\circ} 0^{-}\end{array}$ \\
\hline $\begin{array}{l}\qquad \vdash 0^{\circ} 0 \\
8 \varepsilon 0^{\circ} 0 \\
\varepsilon 00^{\circ} 0 \\
0 \varepsilon 0^{\circ} 0 \\
800^{\circ} 0\end{array}$ & $\begin{array}{l}190^{\circ} 0 \\
850^{\circ} 0- \\
500^{\circ} 0 \\
670^{\circ} 0^{-} \\
600^{\circ} 0^{-}\end{array}$ & $\begin{array}{l}880^{\circ} 0 \\
820^{\circ} 0- \\
600^{\circ} 0 \\
520^{\circ} 0- \\
\varepsilon 00^{\circ} 0-\end{array}$ \\
\hline $\begin{array}{l}080^{\circ} 0 \\
920^{\circ} 0 \\
800^{\circ} 0 \\
810^{\circ} 0 \\
800^{\circ} 0\end{array}$ & $\begin{array}{l}060^{\circ} 0 \\
280^{\circ} 0^{-} \\
200^{\circ} 0 \\
290^{\circ} 0^{-} \\
120^{\circ} 0^{-}\end{array}$ & $\begin{array}{l}980^{\circ} 0 \\
720^{\circ} 0- \\
210^{\circ} 0 \\
810^{\circ} 0- \\
900^{\circ} 0^{-0}\end{array}$ \\
\hline $\begin{array}{l}910^{\circ} 0 \\
510^{\circ} 0 \\
500^{\circ} 0 \\
500^{\circ} 0 \\
800^{\circ} 0\end{array}$ & $\begin{array}{l}260^{\circ} 0 \\
180^{\circ} 0- \\
110^{\circ} 0 \\
150^{\circ} 0- \\
150^{\circ} 0^{-}\end{array}$ & $\begin{array}{l}810^{\circ} 0 \\
+00^{\circ} 0- \\
+10^{\circ} 0 \\
200^{\circ} 0 \\
110^{\circ} 0-\end{array}$ \\
\hline$c^{z}$ ut & () ) รNOILV & $\begin{array}{c}x \\
\text { רSw1 }\end{array}$ \\
\hline
\end{tabular}

$7 V 101$
$11+49$

II

४1

N 908

$7 \times 101$

$11+89$

II

$+508$

7 vial

$11+49$

I.

บ9

W 508

$7 \$ 101$
$11+89$

11

N 508

$7 \times 101$
$11+49$

$11+89$
14

18
11
89

708

$7 V 101$

$11+\mathrm{dg}$
ly

เป

$\operatorname{cog}$

$7 \forall 101$

$11+d 9$

it

208

SEl०0 $210 \% 0$ 88L.0

$101^{\circ} 0-200^{\circ} 0$ 8L $81.0-$

$560^{\circ} 0$ - $700^{\circ} 0$ - $590^{\circ} 0$

$900^{\circ} 0 . \quad 500^{\circ} 0 \quad \varsigma 20^{\circ} 0$ -

( $)$ (ธap) SHOLIVIOY

S 1 N $\exists$ * $3 \forall 7 d S 10$

$S \perp N \exists W \exists J \vee T d S \perp 0$ 


\section{U3บ118}

W-302 TANK 241-C-106 WASTE RETRIEVAL

Daniel Nor thwest

RESTRAINT REACTIONS FORCES ( $1 \mathrm{~b}$ )

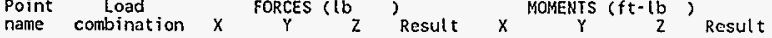
AOO Anchor $\begin{array}{lrrrrrrrr}\text { Anchor } & 18 & -212 & -8 & 212 & -9 & 10 & -109 & 109 \\ \text { GR } & -40 & -25 & -4 & 47 & 7 & -13 & -117 & 118 \\ \text { R1 } & 54 & 53 & 46 & 88 & 6 & 16 & 32 & 36 \\ \text { GR+T1 } & -22 & -236 & -12 & 238 & -2 & -3 & -226 & 226 \\ \text { TOTAL } & 76 & 289 & 58 & 305 & 8 & 19 & 258 & 259 \\ \text { Anchor } & & & & & & & & \\ \text { GR } & -21 & -76 & 90 & 120 & 56 & -3 & 7 & 57 \\ \text { I1 } & 85 & -71 & -506 & 518 & -97 & 9 & -35 & 104 \\ \text { R1 } & 18 & 17 & 40 & 47 & 20 & 3 & 6 & 21 \\ \text { GR+T1 } & 65 & -147 & -416 & 446 & -40 & 6 & -28 & 50 \\ \text { IOTAL } & 83 & 164 & 456 & 492 & 61 & 9 & 34 & 70\end{array}$

809 Anchor

GR RR+T1 TOTAL

$\begin{array}{rrr}8 & -2 & 115 \\ 7 & -29 & 241 \\ 27 & 7 & 39 \\ 15 & -31 & 355 \\ 42 & 37 & 386\end{array}$

U3U11B

$01 / 06 / 98$

W-302 TANK 241-C-106 WASTE RETRIEVAL

Fluor Daniel Northwest

GLOBAL FORCES \& MONENTS

Point Load name combination $X$ F $Y$ Result $X$ Result

$\star \star \star *$ Segment A begin $* \star *$

A00

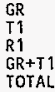

$\mathrm{A} 01$

GR

R 1

GR+T I

$\mathrm{A} 02$

$G R$
Ri
Gi

GR+T

\begin{abstract}
GR
\end{abstract}
$\mathrm{A} 03 \mathrm{~N} \quad \mathrm{GR}$

$T 1$
$R 1$
$G R+Y 1$
TOTAL

GR

$A 03 \mathrm{M} G \mathrm{GR}$

I1

$G R+T\}$

TOTAL

A03 F

GR
T1
81

$\mathrm{R} 1$
$\mathrm{G} R+\mathrm{T} 1$

TOIAL

A04 N

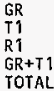

$\begin{array}{rr}-18 & 2 \\ 40 & \\ 54 & \\ 22 & 25 \\ 76 & 2\end{array}$

212
25
52
236
289

$\begin{array}{rr}8 & 212 \\ 4 & 47 \\ 45 & 88 \\ 12 & 238 \\ 57 & 304\end{array}$

87
25

25
34
12
145

$\begin{array}{rr}8 & 89 \\ 4 & 47 \\ 26 & 57 \\ 12 & 114 \\ 37 & 161\end{array}$

87

$8 \quad 89$

$\begin{array}{rr}4 & 47 \\ 10 & 36 \\ 12 & 114\end{array}$

$\begin{array}{rrr}112 & 10 & 36 \\ 131 & 22 & 114\end{array}$

-7
-7
-7
-7
-7

87
25
19
111

$\begin{array}{ll}8 & 89 \\ 4 & 47\end{array}$

4
10
12
22

47
35
114
141

9
-7
6
2
8

82
25
19
107

$\begin{array}{rr}8 & 84 \\ 4 & 47 \\ 9 & 35 \\ 12 & 110 \\ 21 & 137\end{array}$

10
-7
5
3
8

78

$\begin{array}{rr}8 & 80 \\ 4 & 47 \\ 9 & 34 \\ 12 & 105 \\ 21 & 132\end{array}$

12
-6
4
6
10

120

58
25
17
82
100
MOMENTS ( $t \mathrm{t}-\mathrm{lb}$

9
-7
6
2
8
9
-7
6
2
8
9
-7
6
2
8
9
-7
6
2
8

$\begin{array}{rrr}-10 & 109 & 109 \\ 13 & 117 & 118 \\ 16 & 32 & 36 \\ 3 & 226 & 226 \\ 19 & 258 & 259 \\ -8 & 50 & 51 \\ 14 & 111 & 112 \\ 8 & 29 & 31 \\ 6 & 160 & 160 \\ 14 & 189 & 190 \\ -7 & 42 & 44 \\ 14 & 109 & 110 \\ 8 & 29 & 31 \\ 7 & 152 & 152 \\ 15 & 181 & 182 \\ & & \\ -7 & 41 & 43 \\ 14 & 109 & 110 \\ 8 & 29 & 31 \\ 7 & 150 & 150 \\ 15 & 179 & 180\end{array}$

$\begin{array}{rr}23 & 26 \\ 99 & 101\end{array}$

99
28
122

$151 \quad 152$

19
88
23
107
130

23
89
26
108
132

40
41

41
16
81
96 


\begin{tabular}{|c|c|c|c|c|c|c|c|c|c|c|}
\hline $\begin{array}{l}\text { U3U118 } \\
01 / 06 / 98\end{array}$ & \multicolumn{3}{|c|}{ W-302 TANK 241-C-106 WASTE } & E RET & EVAL & \multicolumn{5}{|c|}{$\begin{array}{l}\text { Fluor Daniel Nor thwest } \\
\text { AutoPIPE+4.60 RESULT PAGE }\end{array}$} \\
\hline \multirow[b]{2}{*}{$\begin{array}{l}\text { Point } \\
\text { name }\end{array}$} & \multicolumn{2}{|c|}{$G L O B A L$} & \multicolumn{8}{|c|}{ FORCES \& MOMENTS } \\
\hline & $\begin{array}{l}\text { Load } \\
\text { combination }\end{array}$ & $x^{F}$ & CCES $\left(I_{Y}\right.$ & $z$ & esult & $x^{\text {MON }}$ & ${ }_{Y}^{1 T S}(f t-l b$ & $\begin{array}{l}b \\
z\end{array}$ & Result & \\
\hline A04 M & $\begin{array}{l}\text { GR } \\
\text { TI } \\
\text { R1 } \\
\text { GR+TH } \\
\text { TOTAL }\end{array}$ & $\begin{array}{r}-18 \\
40 \\
25 \\
22 \\
47\end{array}$ & $\begin{array}{l}51 \\
25 \\
17 \\
76 \\
93\end{array}$ & $\begin{array}{r}8 \\
4 \\
8 \\
12 \\
20\end{array}$ & $\begin{array}{r}54 \\
47 \\
31 \\
80 \\
106\end{array}$ & $\begin{array}{r}24 \\
0 \\
14 \\
24 \\
38\end{array}$ & $\begin{array}{l}-3 \\
16 \\
12 \\
13 \\
24\end{array}$ & $\begin{array}{l}38 \\
23 \\
21 \\
62 \\
82\end{array}$ & & $\begin{array}{l}46 \\
28 \\
28 \\
67 \\
94\end{array}$ \\
\hline $\mathrm{A} 04 \mathrm{~F}$ & $\begin{array}{l}\text { GR } \\
\text { II } \\
\text { RI } \\
\text { GR+II } \\
\text { TOTAL }\end{array}$ & $\begin{array}{r}-18 \\
40 \\
24 \\
22 \\
46\end{array}$ & $\begin{array}{l}44 \\
25 \\
17 \\
69 \\
86\end{array}$ & $\begin{array}{r}8 \\
4 \\
8 \\
12 \\
20\end{array}$ & $\begin{array}{r}48 \\
47 \\
31 \\
73 \\
100\end{array}$ & $\begin{array}{l}25 \\
1 \\
15 \\
26 \\
41\end{array}$ & $\begin{array}{l}-1 \\
17 \\
14 \\
17 \\
30\end{array}$ & $\begin{array}{r}24 \\
9 \\
18 \\
33 \\
51\end{array}$ & & $\begin{array}{l}35 \\
20 \\
27 \\
45 \\
72\end{array}$ \\
\hline A05 & $\begin{array}{l}\text { GR } \\
\text { II } \\
R 1 \\
\text { GR+TI } \\
\text { IOTAL }\end{array}$ & $\begin{array}{r}-18 \\
40 \\
24 \\
22 \\
46\end{array}$ & $\begin{array}{l}44 \\
25 \\
17 \\
69 \\
86\end{array}$ & $\begin{array}{r}8 \\
4 \\
8 \\
12 \\
20\end{array}$ & $\begin{array}{r}48 \\
47 \\
31 \\
73 \\
100\end{array}$ & $\begin{array}{r}25 \\
1 \\
15 \\
26 \\
41\end{array}$ & $\begin{array}{l}-1 \\
17 \\
14 \\
17 \\
30\end{array}$ & $\begin{array}{r}24 \\
9 \\
18 \\
33 \\
51\end{array}$ & & $\begin{array}{l}35 \\
19 \\
27 \\
45 \\
72\end{array}$ \\
\hline A06 & $\begin{array}{l}G R \\
T 1 \\
R 1 \\
\text { GR+II } \\
\text { TOTAL }\end{array}$ & $\begin{array}{r}-18 \\
40 \\
24 \\
22 \\
46\end{array}$ & $\begin{array}{l}41 \\
25 \\
17 \\
65 \\
83\end{array}$ & $\begin{array}{r}8 \\
4 \\
9 \\
12 \\
20\end{array}$ & $\begin{array}{l}45 \\
47 \\
31 \\
70 \\
97\end{array}$ & $\begin{array}{r}25 \\
1 \\
15 \\
26 \\
41\end{array}$ & $\begin{array}{r}2 \\
19 \\
16 \\
21 \\
36\end{array}$ & $\begin{array}{r}10 \\
0 \\
13 \\
11 \\
24\end{array}$ & & $\begin{array}{l}27 \\
19 \\
25 \\
35 \\
60\end{array}$ \\
\hline $\mathrm{A} 07 \mathrm{~N}$ & $\begin{array}{l}\text { GR } \\
\text { T1 } \\
\text { R1 } \\
\text { GR+T1 } \\
\text { TOTAL }\end{array}$ & $\begin{array}{r}-18 \\
40 \\
23 \\
22 \\
45\end{array}$ & $\begin{array}{l}39 \\
25 \\
17 \\
64 \\
82\end{array}$ & $\begin{array}{r}8 \\
4 \\
9 \\
12 \\
21\end{array}$ & $\begin{array}{l}44 \\
47 \\
30 \\
69 \\
96\end{array}$ & $\begin{array}{r}25 \\
1 \\
15 \\
26 \\
41\end{array}$ & $\begin{array}{l}4 \\
20 \\
17 \\
24 \\
41\end{array}$ & $\begin{array}{r}1 \\
-5 \\
10 \\
-5 \\
15\end{array}$ & & $\begin{array}{l}26 \\
20 \\
25 \\
35 \\
60\end{array}$ \\
\hline $\mathrm{A} 07 \mathrm{M}$ & $\begin{array}{l}\text { GR } \\
\text { I1 } \\
\text { R1 } \\
\text { GR+TI } \\
\text { TOTAL }\end{array}$ & $\begin{array}{r}-18 \\
40 \\
23 \\
22 \\
45\end{array}$ & $\begin{array}{l}38 \\
25 \\
18 \\
63 \\
81\end{array}$ & $\begin{array}{r}8 \\
4 \\
9 \\
12 \\
21\end{array}$ & $\begin{array}{l}43 \\
47 \\
30 \\
68 \\
95\end{array}$ & $\begin{array}{l}22 \\
-1 \\
14 \\
21 \\
35\end{array}$ & $\begin{array}{l}4 \\
23 \\
17 \\
27 \\
44\end{array}$ & $\begin{array}{r}-6 \\
-10 \\
8 \\
-16 \\
24\end{array}$ & & $\begin{array}{l}24 \\
25 \\
23 \\
38 \\
61\end{array}$ \\
\hline A07 F & $\begin{array}{l}\text { GR } \\
\text { I1 } \\
R 1 \\
\text { GR+T1 } \\
\text { TOTAL }\end{array}$ & $\begin{array}{r}-18 \\
40 \\
23 \\
22 \\
45\end{array}$ & $\begin{array}{l}37 \\
25 \\
18 \\
62 \\
80\end{array}$ & $\begin{array}{r}8 \\
4 \\
9 \\
12 \\
21\end{array}$ & $\begin{array}{l}42 \\
47 \\
30 \\
67 \\
94\end{array}$ & $\begin{array}{l}16 \\
-6 \\
11 \\
10 \\
21\end{array}$ & $\begin{array}{l}31 \\
13 \\
32 \\
45\end{array}$ & $\begin{array}{r}-9 \\
-12 \\
7 \\
-21 \\
28\end{array}$ & & $\begin{array}{l}18 \\
33 \\
19 \\
39 \\
57\end{array}$ \\
\hline $\mathrm{AOBN}$ & $\begin{array}{l}\text { GR } \\
\text { T1 } \\
\text { RI } \\
\text { GR+T1 } \\
\text { TOTAL }\end{array}$ & $\begin{array}{r}-18 \\
40 \\
22 \\
22 \\
44\end{array}$ & $\begin{array}{l}31 \\
25 \\
17 \\
56 \\
73\end{array}$ & $\begin{array}{r}8 \\
4 \\
10 \\
12 \\
22\end{array}$ & $\begin{array}{l}37 \\
47 \\
29 \\
61 \\
88\end{array}$ & $\begin{array}{r}-25 \\
-35 \\
12 \\
-60 \\
72\end{array}$ & $\begin{array}{r}-19 \\
78 \\
15 \\
58 \\
73\end{array}$ & $\begin{array}{r}-9 \\
-12 \\
7 \\
-21 \\
28\end{array}$ & & $\begin{array}{r}33 \\
86 \\
20 \\
86 \\
106\end{array}$ \\
\hline
\end{tabular}

GLOBAL FORCES \& MOMENTS

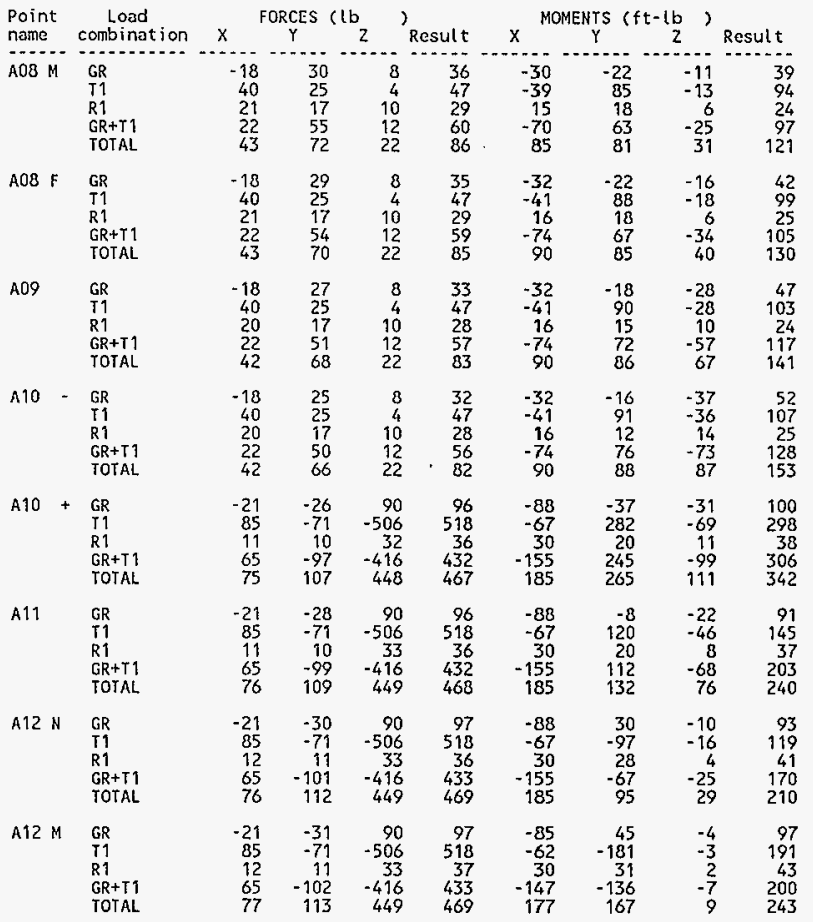




\begin{tabular}{|c|c|c|c|c|c|c|c|c|c|c|}
\hline $\begin{array}{l}\text { U3U118 } \\
01 / 06 / 98\end{array}$ & \multicolumn{5}{|c|}{ W-302 TANK 241-C-106 WASTE RETRIEVAL } & \multicolumn{5}{|c|}{$\begin{array}{l}\text { Fluor Daniel Northwest } \\
\text { AutoPIPE+4.60 RESULT PAGE } 16\end{array}$} \\
\hline \multicolumn{11}{|c|}{$G L O B A L$} \\
\hline $\begin{array}{l}\text { Point } \\
\text { name }\end{array}$ & $\begin{array}{l}\text { Load } \\
\text { combination }\end{array}$ & $x$ & $\underset{Y}{\text { ORCES }}(1$ & 16 & Result & $x^{\text {MOI }}$ & ENTS $y^{-1}$ & $\begin{array}{ll}(b) \\
z\end{array}$ & Resut & \\
\hline $\mathrm{A} 12 \mathrm{~F}$ & $\begin{array}{l}\text { GR } \\
\text { Y1 } \\
\text { R1 } \\
\text { GR+I1 } \\
\text { TOTAL }\end{array}$ & $\begin{array}{r}-21 \\
85 \\
14 \\
65 \\
78\end{array}$ & $\begin{array}{r}-32 \\
-71 \\
13 \\
-103 \\
116\end{array}$ & $\begin{array}{r}90 \\
-506 \\
34 \\
-416 \\
450\end{array}$ & $\begin{array}{r}98 \\
518 \\
39 \\
433 \\
471\end{array}$ & $\begin{array}{r}-80 \\
-49 \\
28 \\
-129 \\
157\end{array}$ & $\begin{array}{r}48 \\
-203 \\
31 \\
-155 \\
186\end{array}$ & $\begin{array}{r}-2 \\
2 \\
1 \\
0 \\
2\end{array}$ & & $\begin{array}{r}93 \\
209 \\
41 \\
202 \\
243\end{array}$ \\
\hline $\mathrm{A} 13 \mathrm{~N}$ & $\begin{array}{l}\text { GR } \\
T 1 \\
R 1 \\
\text { GR+T1 } \\
\text { TOTAL }\end{array}$ & $\begin{array}{r}-21 \\
85 \\
14 \\
65 \\
79\end{array}$ & $\begin{array}{r}-45 \\
-71 \\
14 \\
-115 \\
129\end{array}$ & $\begin{array}{r}90 \\
-506 \\
34 \\
-416 \\
450\end{array}$ & $\begin{array}{l}102 \\
518 \\
39 \\
436 \\
475\end{array}$ & $\begin{array}{r}9 \\
114 \\
4 \\
124 \\
128\end{array}$ & $\begin{array}{r}0 \\
-5 \\
1 \\
-5 \\
6\end{array}$ & $\begin{array}{r}-2 \\
2 \\
1 \\
0 \\
2\end{array}$ & & $\begin{array}{r}99 \\
114 \\
4 \\
124 \\
128\end{array}$ \\
\hline$A 13 \mathrm{M}$ & $\begin{array}{l}\text { GR } \\
\text { T1 } \\
\text { R1 } \\
\text { GR+T1 } \\
\text { TOTAL }\end{array}$ & $\begin{array}{r}-21 \\
85 \\
14 \\
65 \\
79\end{array}$ & $\begin{array}{r}-45 \\
-71 \\
14 \\
-116 \\
130\end{array}$ & $\begin{array}{r}90 \\
-506 \\
34 \\
-416 \\
450\end{array}$ & $\begin{array}{l}103 \\
518 \\
40 \\
437 \\
475\end{array}$ & $\begin{array}{r}19 \\
98 \\
7 \\
117 \\
123\end{array}$ & $\begin{array}{r}-2 \\
5 \\
3 \\
3 \\
5\end{array}$ & $\begin{array}{r}-1 \\
-2 \\
1 \\
-3 \\
4\end{array}$ & & $\begin{array}{r}19 \\
98 \\
7 \\
117 \\
124\end{array}$ \\
\hline $\mathrm{A} 13 \mathrm{~F}$ & $\begin{array}{l}\text { GR } \\
\text { T1 } \\
\text { RI } \\
\text { GR+T1 } \\
\text { TOTAL }\end{array}$ & $\begin{array}{r}-21 \\
85 \\
14 \\
65 \\
79\end{array}$ & $\begin{array}{r}-46 \\
-71 \\
14 \\
-117 \\
130\end{array}$ & $\begin{array}{r}90 \\
-506 \\
34 \\
-416 \\
450\end{array}$ & $\begin{array}{l}103 \\
518 \\
40 \\
437 \\
475\end{array}$ & $\begin{array}{l}32 \\
42 \\
11 \\
74 \\
84\end{array}$ & $\begin{array}{r}-3 \\
9 \\
3 \\
6 \\
9\end{array}$ & $\begin{array}{r}2 \\
-12 \\
2 \\
-10 \\
12\end{array}$ & & $\begin{array}{l}32 \\
44 \\
11 \\
74 \\
85\end{array}$ \\
\hline A 14 & $\begin{array}{l}\text { GR } \\
\text { I1 } \\
\text { R1 } \\
\text { GR+T1 } \\
\text { TOTAL }\end{array}$ & $\begin{array}{r}-21 \\
85 \\
15 \\
65 \\
80\end{array}$ & $\begin{array}{r}-75 \\
-71 \\
15 \\
-146 \\
161\end{array}$ & $\begin{array}{r}90 \\
-506 \\
37 \\
-416 \\
453\end{array}$ & $\begin{array}{l}119 \\
518 \\
43 \\
446 \\
487\end{array}$ & $\begin{array}{l}35 \\
23 \\
12 \\
58 \\
70\end{array}$ & $\begin{array}{r}-3 \\
9 \\
3 \\
6 \\
9\end{array}$ & $\begin{array}{r}2 \\
-15 \\
2 \\
-13 \\
15\end{array}$ & & $\begin{array}{l}35 \\
29 \\
12 \\
60 \\
72\end{array}$ \\
\hline A15 & $\begin{array}{l}\text { GR } \\
T 1 \\
R 1 \\
\text { GR+T1 } \\
\text { TOTAL. }\end{array}$ & $\begin{array}{r}-21 \\
85 \\
18 \\
65 \\
83\end{array}$ & $\begin{array}{r}-75 \\
-71 \\
17 \\
-146 \\
163\end{array}$ & $\begin{array}{r}90 \\
-506 \\
40 \\
-416 \\
456\end{array}$ & $\begin{array}{l}119 \\
518 \\
47 \\
446 \\
491\end{array}$ & $\begin{array}{l}40 \\
-2 \\
13 \\
38 \\
51\end{array}$ & $\begin{array}{r}-3 \\
9 \\
3 \\
6 \\
9\end{array}$ & $\begin{array}{r}3 \\
-19 \\
3 \\
-16 \\
19\end{array}$ & & $\begin{array}{l}40 \\
22 \\
14 \\
41 \\
55\end{array}$ \\
\hline A16 & $\begin{array}{l}\text { GR } \\
T 1 \\
R 1 \\
\text { GR+T1 } \\
\text { TOTAL }\end{array}$ & $\begin{array}{r}-21 \\
85 \\
18 \\
65 \\
83\end{array}$ & $\begin{array}{r}-76 \\
-71 \\
17 \\
-147 \\
164\end{array}$ & $\begin{array}{r}90 \\
-506 \\
40 \\
-416 \\
456\end{array}$ & $\begin{array}{r}120 \\
518 \\
47 \\
446 \\
491\end{array}$ & $\begin{array}{r}56 \\
-97 \\
20 \\
-40 \\
61\end{array}$ & $\begin{array}{r}-3 \\
9 \\
3 \\
6 \\
9\end{array}$ & $\begin{array}{r}7 \\
-35 \\
6 \\
-28 \\
34\end{array}$ & & $\begin{array}{r}57 \\
104 \\
21 \\
50 \\
70\end{array}$ \\
\hline & gment & k** & & & & & & & & \\
\hline & nt 8 & & & & & & & & & \\
\hline
\end{tabular}

UZU11B W-302 TANK 241-C-106 WASTE RETRIEVAL

Fluor Daniel Northwest

U3) 1106

W-302 TANK 241-C-106 WASTE RETRIEVAL

60 RESULT PAGE

GLOBAL FORCES \& MOMENTS

Point Load FORCES ( $\mathrm{lb}$ ) MOMENTS ( $\mathrm{ft}-\mathrm{lb}$ name combination $x \quad Y \quad z$ Result $X$ M $Y$ Result

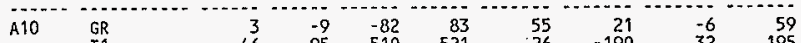
11
$R 1$ GR+I 1 TOTAL -46
10
-43
5 $\begin{array}{lll}95 & 510 & 521 \\ 13 & 27 & 31\end{array}$ $\begin{array}{rrr}55 & 21 & -6 \\ 26 & -190 & 32 \\ 27 & 12 & 14\end{array}$

801 GR R1 $\mathrm{GR}+\mathrm{T} 1$
TOTAL $\begin{array}{rrrr}3 & -10 & -82 & 83 \\ -46 & 95 & 510 & 521\end{array}$ $81-169$ 69 $\begin{array}{rr}32 & 195 \\ 14 & 33\end{array}$

$\mathrm{BO2}$ GR R1 GR+T1 TOTAL

$802+G R$ I 1
$R 1$
$G R+T$

803 TOTAL

GR R1 TOTAL

804

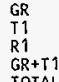

B05 GR TI $R 1$
$G R+T$ TOTAL

B05 M

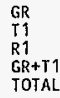




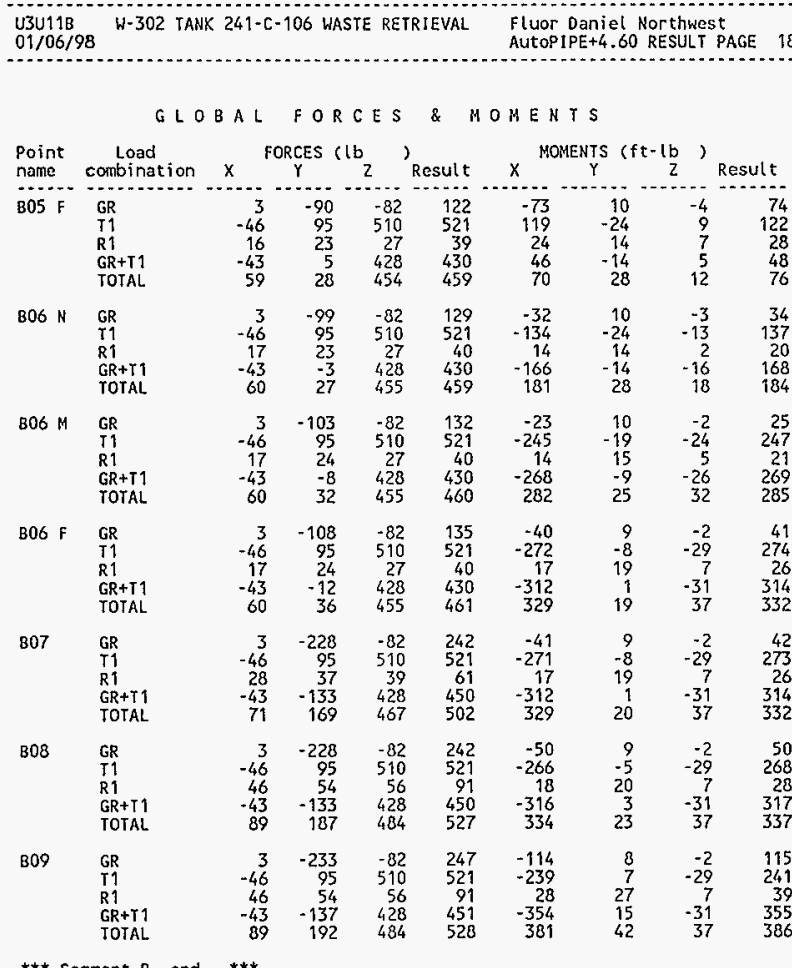

U3U118 W-302 TANK 241-C-106 WASTE RETRIEVAL Fluor Daniel Northwest

$01 / 06 / 98$

ASME B31.3C (1992) CODE COMPLIANCE

(Moments in $\mathrm{ft}-\mathrm{lb}$ ) (stress in psi)

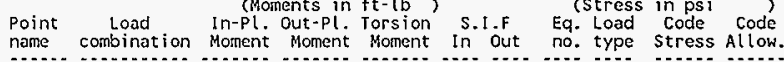

\section{*** Segment A begin $* * *$}

A00 Max $P$

(3а) HOOP 335020000

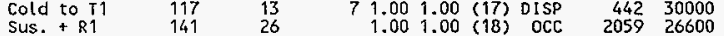

A01 Max

50 (3a) HOOP GR+Max $P \quad 50 \quad 8 \quad 21.001 .00$ (18) SUST $\begin{array}{llll}\text { Sus. }+R 1 & 79 & 16 & 1000\end{array}$

335020000 170720000 $417 \quad 30000$ 181926600

$\mathrm{A} 02$ Max $P$

$G R+\operatorname{Max} P$ Cold to 11

$\begin{array}{rr}42 & 7 \\ 109 & 14 \\ 72 & 15\end{array}$

7
14
15

(3a) HOOP 1.001 .00 (18) SUS Sus. + RI

1.001 .00 (18) OCC

A03 N- Max P Cold to $T$

41
109

7

Sus. + R1

70

7
14
15

A03 $\mathrm{N}+\operatorname{Max} P$

GR + Max $P$

41
109
70

14

A03 $M$ Max $P$

$\mathrm{GR}+\operatorname{Max}$

Cold to T

23

23
99
51

A03 F- Max $P$

$\mathrm{GR}+\mathrm{Max}$
Cold to $\mathrm{T}$

Sus. + R1

$A 03 \&+\operatorname{Max} P$

$\begin{array}{lrr}\text { GR }+ \text { Max P } & 12 & 19 \\ \text { Cold to T1 } & 6 & 88 \\ \text { Sus. }+R 1 & 16 & 42\end{array}$

1.001 .00 (3a) HOOP

71.001 .00 (17) DISP

1.001 .00 (18) OCC

(3a) HOOP

$\begin{array}{llll}2.56 & 2.13 & (3 a) & \text { HOOP } \\ 2.56 & 2.13 & \text { SUST } \\ 2.56) & \text { DISP }\end{array}$

2.562 .13 (18) OCC

2.562 .13 (18) 13 SUST

162.562 .13 (17) DISP 2.562 .13 (18) OCC

(3a) HOOP

2.562 .13 (18) SUST

152.562 .13 (17) DISP

1.001 .00 (3a) HOOP

151.001 .00 (17) DISP

Sus. $+R$

A04 N- Max P

GR + Max

21

Sus. $t$ ?
1.001 .00 (3a) HOOP

151.001 .00 (i7) DISP 1.001 .00 (18)
$3350 \quad 20000$

41230000

179326600

$3350 \quad 20000$

167520000

41130000

$3350 \quad 20000$

191720000

30000

$2204 \quad 26600$

$3350 \quad 20000$

$1741 \quad 20000$

95130000

$3350 \quad 20000$

172620000

$840 \quad 30000$

$3350 \quad 20000$

160420000

$333 \quad 30000$

$3350 \quad 20000$

168920000

16330000 


\section{U3U11B}

W-302 TANK $241-\mathrm{C}-106$ WASTE RETRIEVAL

Fluor Daniel Northwest

AutOPIPE +4.60 RESULT PAGE 20

$01 / 06 / 98$

ASME B31.3C (1992) CODE COMPLIANCE

(Moments in $\mathrm{ft}-(\mathrm{b})$ (stress in psi)

point Load In-pl. Out-pl. Torsion S.I.F Eq. Load code code

name combination Moment Moment Moment in Out no. type stress Allow.

$\mathrm{A} 04 \mathrm{~N}+\mathrm{Max} \mathrm{P}$

$\mathrm{GR}+\operatorname{Max}$

Cold to $T$

$\begin{array}{ll}40 & 21 \\ 41 & 1\end{array}$

1.951 .63 (3a) HOOP

$\operatorname{Max} P$

$\mathrm{GR}+\operatorname{Max} P$

Cold to $T$

1.951 .63 (17) DISP

335020000

183920000

197126600

Sus. $+R$

$\begin{array}{ll}38 & 15 \\ 23 & 11\end{array}$

(3a) HOOP

$3350 \quad 20000$

181320000

19753000

$11.95 \quad 1.63$ (17) DISP

1.951 .63 (18) OCC

(3a) HOOP

$\operatorname{Max} P$

GR + Max P

Sus. $+R 1$

$\begin{array}{rr}24 & 1 \\ 9 & 17\end{array}$

1.951 .63 (18) SUST

$3350 \quad 20000$

$\begin{array}{ll}3350 & 20000 \\ 1696 & 20000\end{array}$

12430000

185426600

1.951 .63 (18) OCC

(3a) HOOP

$\begin{array}{rrrrrr}24 & 1 & 1.00 & 1.00(18) & \text { SUST } \\ 9 & 17 & 11.00 & 1.00(17) & \text { DISP } \\ 43 & 14 & 1.00 & 1.00(18) & \text { OCC }\end{array}$

$\mathrm{GR}+\operatorname{Max} \mathrm{P}$

Cold to T
Sus. $+R 1$

335020000

161020000

169526600

(3a) HOOP

A05 Max $P$

GR + MaxP $\quad 24 \quad 1 \quad 11.001 .00(18)$ SUST

$\begin{array}{lrlr}\text { Cold to T1 } & 9 & 17 & 11.001 .00(17) \text { DIS? } \\ \text { Sus. + R1 } & 43 & 14 & 1.001 .00(18) \text { OCC }\end{array}$

(3a) HOOP

A06 Max

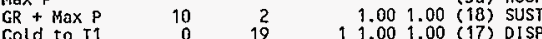

$\begin{array}{llll}\text { Sus. }+\mathrm{R} 1 & 23 & 17 & 11.001 .00(18) \text { OCC }\end{array}$

A07 N- Max P

$G R+\operatorname{Max} P$

Cold to T1
Sus. $t$ R1

$\begin{array}{rr}1 & 4 \\ 5 & 20 \\ 10 & 21\end{array}$

(3a) $\mathrm{HOOP}$

$1.001 .00(18)$ SUST

1.001 .00 (17) DI SP

Max $P$

$G R+M a x P$

Cold to T1
Sus. + R1

$\begin{array}{rr}4 & 1 \\ 20 & 5 \\ 21 & 10\end{array}$

(3a) HOOP

$\begin{array}{lll}1.73 & 1.44 & (18) \\ 1.73 & 1.44(17) & \text { SISP }\end{array}$

1.731 .44 (18) OCC

$\begin{array}{lll}1.73 & 1.44 \text { (3a) HOOP } \\ \text { SUST }\end{array}$

GR + Max $P$

Sus. + R1

$\begin{array}{rr}4 & 11 \\ 23 & 8 \\ 21 & 26\end{array}$

1.73
1.731 .44 (18) OCC

A07 F- Max P

GR + Max $P$

Cold to T1
Sus. + R1 $\begin{array}{rr}1 & 16 \\ 31 & 6 \\ 14 & 27\end{array}$
1.731 .44 (3a) HOOP

$12 \begin{aligned} & 1.73 \\ & 1.731 .44 \text { (17) DISP }\end{aligned}$
$3350 \quad 20000$

160920000

$73 \quad 30000$

268720000

145620000

40230000

268720000

131720000

438
1737

268720000

137820000

$2077 \quad 26600$

268720000

161720000

$906 \quad 30000$

268720000

$1724 \quad 20000$

$\begin{array}{ll}1173 & 30000 \\ 2318 & 26600\end{array}$
U3U11B W-302 TANK 241-C-106 WASTE RETRIEVAL Fluor Daniel Nor thwest

$01 / 06 / 98$

AUTOPIPE+4.60 RESULT PAGE 21

\begin{tabular}{|c|c|c|c|c|c|c|c|c|}
\hline $\begin{array}{l}\text { Point } \\
\text { name }\end{array}$ & $\begin{array}{l}\text { Load } \\
\text { combination }\end{array}$ & $\begin{array}{l}\text { ASME B } \\
\text { (Mom } \\
\text { In-PL. } \\
\text { Moment }\end{array}$ & $\begin{array}{l}331.3 \mathrm{c} \text { ( } 1 \\
\text { nents in } \\
\text { Out-pl. } \\
\text { Moment }\end{array}$ & $\begin{array}{l}1992) \\
f t-\text { lb } \\
\text { Jorsion } \\
\text { Moment }\end{array}$ & $\begin{array}{l}\text { CODE COMPLI } \\
\text { S.I.F } \\
\text { In out }\end{array}$ & $\begin{array}{l}\text { ANCE } \\
\text { (Stress } \\
\text { Eq. Load } \\
\text { no. type }\end{array}$ & $\begin{array}{l}\text { in psi } \\
\text { Code } \\
\text { stress }\end{array}$ & $\begin{array}{c}\text { J } \\
\text { Code } \\
\text { Al low. }\end{array}$ \\
\hline $\mathrm{A} 07 \mathrm{~F}+$ & $\begin{array}{l}\text { Max } P \\
\text { GR + Max P } \\
\text { Cold to T1 } \\
\text { Sus. + R1 }\end{array}$ & $\begin{array}{r}16 \\
6 \\
27\end{array}$ & $\begin{array}{l}1 \\
31 \\
14\end{array}$ & 12 & $2 \begin{array}{ll}1.00 & 1.00 \\
1.00 & 1.00 \\
1.00 & 1.00\end{array}$ & $\begin{array}{l}\text { (3a) HOOP } \\
\text { (18) SUST } \\
\text { (17) DISP } \\
\text { (18) DCC }\end{array}$ & $\begin{array}{r}2687 \\
1573 \\
710 \\
1941\end{array}$ & $\begin{array}{l}20000 \\
20000 \\
30000 \\
26600\end{array}$ \\
\hline $\mathrm{A} 08 \mathrm{~N}$ & $\begin{array}{l}-\operatorname{Max} P \\
\text { GR }+\operatorname{Max} P \\
\text { Cold to T1 } \\
\text { Sus. + R1 }\end{array}$ & $\begin{array}{l}25 \\
35 \\
37\end{array}$ & $\begin{array}{l}19 \\
78 \\
34\end{array}$ & 12 & 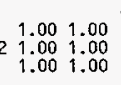 & $\begin{array}{l}\text { (3a) HOOP } \\
\text { (18) SUST } \\
\text { (17) DISP } \\
\text { (18) OCC }\end{array}$ & $\begin{array}{l}2687 \\
1910 \\
1838 \\
2322\end{array}$ & $\begin{array}{l}20000 \\
20000 \\
30000 \\
26600\end{array}$ \\
\hline $\mathrm{A} 08 \mathrm{~N}$ & $\begin{array}{l}+ \text { Max } P \\
\text { GR + Max P } \\
\text { Cold to T1 } \\
\text { Sus. + RI }\end{array}$ & $\begin{array}{l}19 \\
78 \\
34\end{array}$ & $\begin{array}{l}25 \\
35 \\
37\end{array}$ & & $\begin{array}{lll}1.73 & 1.44 \\
1.73 & 1.44 \\
1.73 & 1.44\end{array}$ & $\begin{array}{l}\text { (3a) } \text { IOOP } \\
(18) \text { SUST } \\
(17) \text { DISP } \\
(18) \text { OCC }\end{array}$ & $\begin{array}{l}2687 \\
2283 \\
3082 \\
2956\end{array}$ & $\begin{array}{l}20000 \\
20000 \\
30000 \\
26600\end{array}$ \\
\hline $\mathrm{A} 08 \mathrm{M}$ & $\begin{array}{l}\text { Max P } \\
\text { GR + Max P } \\
\text { Cold to T1 } \\
\text { Sus. + R1 }\end{array}$ & $\begin{array}{l}22 \\
85 \\
40\end{array}$ & $\begin{array}{l}29 \\
37 \\
41\end{array}$ & 18 & $\begin{array}{lll}8 & 1.73 & 1.44 \\
1.73 & 1.44 \\
1.73 & 1.44\end{array}$ & $\begin{array}{l}\text { (3a) HOOP } \\
\text { (18) SUST } \\
(17) \text { DISP } \\
\text { (18) OCC }\end{array}$ & $\begin{array}{l}2687 \\
2453 \\
3373 \\
3206\end{array}$ & $\begin{array}{l}20000 \\
20000 \\
30000 \\
26600\end{array}$ \\
\hline A08 F & $\begin{array}{l}- \text { Max } P \\
\text { GR + Max P } \\
\text { Cold to T1 } \\
\text { Sus. + R1 }\end{array}$ & $\begin{array}{l}22 \\
38 \\
40\end{array}$ & $\begin{array}{l}16 \\
18 \\
22\end{array}$ & 41 & $\begin{array}{ll}1.73 & 1.44 \\
1.73 & 1.44 \\
1.73 & 1.44\end{array}$ & $\begin{array}{l}\text { (3a) HOOP } \\
\text { (18) SUST } \\
\text { (17) DISP } \\
\text { (18) OCC }\end{array}$ & $\begin{array}{l}2687 \\
2190 \\
3439 \\
2882\end{array}$ & $\begin{array}{l}20000 \\
20000 \\
30000 \\
26600\end{array}$ \\
\hline $108 \mathrm{~F}$ & $\begin{array}{l}+ \text { Max } P \\
\text { GR }+ \text { Max } P \\
\text { Cold to T1 } \\
\text { Sus. + RT }\end{array}$ & $\begin{array}{l}16 \\
18 \\
22\end{array}$ & $\begin{array}{l}22 \\
88 \\
40\end{array}$ & 41 & $\begin{array}{lll}1.001 .00 \\
1 & 1.00 & 1.00 \\
1.00 & 1.00\end{array}$ & $\begin{array}{l}\text { (3a) HOOP } \\
\text { (18) SUST } \\
(17) \text { DISP } \\
(18) \text { OCC }\end{array}$ & $\begin{array}{l}2687 \\
1820 \\
2122 \\
2225\end{array}$ & $\begin{array}{l}20000 \\
20000 \\
30000 \\
26600\end{array}$ \\
\hline$A 09$ & $\begin{array}{l}- \text { Max } P \\
\text { GR + Max P } \\
\text { Cold to T1 } \\
\text { Sus. + RT }\end{array}$ & $\begin{array}{l}28 \\
28 \\
38\end{array}$ & $\begin{array}{l}18 \\
90 \\
33\end{array}$ & 41 & $\begin{array}{l}1.001 .00 \\
11.00 \\
1.00 \\
1.001 .00\end{array}$ & $\begin{array}{ll}(3 a) & \text { HOOP } \\
(18) & \text { SUST } \\
(17) & \text { DISP } \\
(18) & \text { OCC }\end{array}$ & $\begin{array}{l}2687 \\
1959 \\
2207 \\
2333\end{array}$ & $\begin{array}{l}20000 \\
20000 \\
30000 \\
26600\end{array}$ \\
\hline$A 09$ & $\begin{array}{l}+\operatorname{Max} P \\
\text { GR }+\operatorname{Max} P \\
\text { Cold to T1 } \\
\text { Sus. + R1 }\end{array}$ & $\begin{array}{l}28 \\
28 \\
38\end{array}$ & $\begin{array}{l}18 \\
90 \\
33\end{array}$ & 41 & 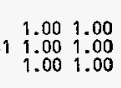 & $\begin{array}{ll}\text { (3a) HOOP } \\
(18) & \text { SUST } \\
(17) & \text { DISP } \\
(18) & \text { OCC }\end{array}$ & $\begin{array}{l}2687 \\
1959 \\
2207 \\
2333\end{array}$ & $\begin{array}{l}20000 \\
20000 \\
30000 \\
26600\end{array}$ \\
\hline A10 & $\begin{array}{l}-\operatorname{Max} P \\
\text { GR }+ \text { Max } P \\
\text { Cold to T1 } \\
\text { Sus. + R1 }\end{array}$ & $\begin{array}{l}16 \\
91 \\
28\end{array}$ & $\begin{array}{l}37 \\
36 \\
51\end{array}$ & 41 & $\begin{array}{lll}1.19 & 1.25 \\
1.19 & 1.25 \\
1.19 & 1.25\end{array}$ & $\begin{array}{ll}\text { (3a) HOOP } \\
(18) & \text { SUST } \\
(17) & \text { DISP } \\
(18) & \text { OCC }\end{array}$ & $\begin{array}{l}2687 \\
2297 \\
2670 \\
2789\end{array}$ & $\begin{array}{l}20000 \\
20000 \\
30000 \\
26600\end{array}$ \\
\hline$A 10$ & $\begin{array}{l}+\operatorname{Max} P \\
\text { GR }+\operatorname{Max} P \\
\text { Cold to TI } \\
\text { Sus. }+R\}\end{array}$ & $\begin{array}{r}37 \\
282 \\
57\end{array}$ & 31 & 67 & 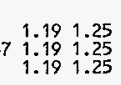 & $\begin{array}{ll}(3 a) & \text { HOOP } \\
(18) & \text { SUST } \\
(17) & \text { DISP } \\
(18) & \text { OCC }\end{array}$ & $\begin{array}{l}2687 \\
2485 \\
7540 \\
3082\end{array}$ & $\begin{array}{l}20000 \\
20000 \\
30000 \\
26600\end{array}$ \\
\hline
\end{tabular}




\begin{tabular}{|c|c|c|c|c|c|c|c|c|}
\hline $\begin{array}{l}\text { U3U11B } \\
01 / 06 / 9\end{array}$ & $W-302$ TAN & $K 241-0$ & 106 WAST & TE RETR I & EVAL & $\begin{array}{l}\text { Daniel } \\
\text { IPE+4.60 }\end{array}$ & $\begin{array}{l}\text { prthwes } \\
\text { RESULT }\end{array}$ & $\begin{array}{l}\text { St } \\
\text { PAGE }\end{array}$ \\
\hline $\begin{array}{l}\text { Point } \\
\text { name } \\
\text { A11 }\end{array}$ & $\begin{array}{l}\text { Load } \\
\text { combination } \\
\text { Max P } \\
\text { GR + Max P } \\
\text { Cold to T1 } \\
\text { Sus. + R1 }\end{array}$ & $\begin{array}{l}\text { ASME B } \\
\text { (Mon } \\
\text { In-Pl. } \\
\text { Moment }\end{array}$ & $\begin{array}{l}\text { ASME B31.3c (1992) } \\
\text { (Moments in } \mathrm{ft}-\mathrm{lb} \\
\text { In-pl. Out-Pl. Torsion } \\
\text { Moment Moment Moment }\end{array}$ & $\begin{array}{l}\text { 1992) c } \\
\text { ft-lb } \\
\text { Torsion } \\
\text { Moment }\end{array}$ & 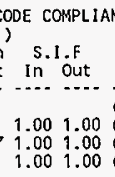 & $\begin{array}{l}\text { ANCE } \\
\text { (stress } \\
\text { Eq. Load } \\
\text { no. type } \\
\text { (3a) HOOP } \\
\text { (3) } \\
\text { (18) SUST } \\
\text { (17) DISP } \\
\text { (18) OCC }\end{array}$ & \begin{tabular}{l} 
in psi \\
Code \\
stress \\
\hdashline 2687 \\
1738 \\
3103 \\
2207
\end{tabular} & $\begin{array}{c}\text { Code } \\
\text { Allow. } \\
20000 \\
20000 \\
30000 \\
26600\end{array}$ \\
\hline Al1 + & $\begin{array}{l}\text { Max P } \\
\text { GR + Max P } \\
\text { Cold to T1 } \\
\text { Sus. + RI }\end{array}$ & $\begin{array}{l}22 \\
46 \\
30\end{array}$ & $\begin{array}{r}8 \\
120 \\
29\end{array}$ & & 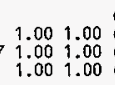 & $\begin{array}{l}(33) \text { HOOP } \\
(18) \text { SUST } \\
(17) \text { OISP } \\
(18) \text { OCC }\end{array}$ & $\begin{array}{l}2687 \\
1738 \\
3103 \\
2207\end{array}$ & $\begin{array}{l}20000 \\
20000 \\
30000 \\
26600\end{array}$ \\
\hline A12 N- & $\begin{array}{l}\text { Max } P \\
G R+\operatorname{Max} P \\
\text { Cold to T1 } \\
\text { Sus. + R1 }\end{array}$ & $\begin{array}{l}10 \\
16 \\
13\end{array}$ & $\begin{array}{l}30 \\
97 \\
58\end{array}$ & & 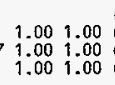 & $\begin{array}{l}\text { (3a) HOOP } \\
\text { (18) SUST } \\
\text { (17) DISP } \\
\text { (18) OCC }\end{array}$ & $\begin{array}{l}2687 \\
1916 \\
2553 \\
2512\end{array}$ & $\begin{array}{l}20000 \\
20000 \\
30000 \\
26600\end{array}$ \\
\hline A12 $\mathrm{NH}$ & $\begin{array}{l}\text { Max } P \\
\text { GR }+ \text { Max } P \\
\text { Cold to TI } \\
\text { Sus. + Ri }\end{array}$ & $\begin{array}{l}30 \\
97 \\
58\end{array}$ & $\begin{array}{l}10 \\
16 \\
13\end{array}$ & & $\begin{array}{ll}1.73 & 1.44 \\
1.73 & 1.44 \\
1.73 & 1.44\end{array}$ & $\begin{array}{l}\text { (3a) HOOP } \\
\text { (18) SUST } \\
\text { (17) DISP } \\
\text { (18) OCC }\end{array}$ & $\begin{array}{l}2687 \\
2399 \\
3916 \\
3429\end{array}$ & $\begin{array}{l}20000 \\
20000 \\
30000 \\
26600\end{array}$ \\
\hline A12 M- & $\begin{array}{l}\text { Max P } \\
\text { GR }+ \text { Max P } \\
\text { Cold to T1 } \\
\text { Sus. + Ri }\end{array}$ & $\begin{array}{r}45 \\
181 \\
76\end{array}$ & $\begin{array}{l}63 \\
46 \\
85\end{array}$ & & $\begin{array}{ll}1.73 & 1.44 \\
1.73 & 1.44 \\
1.73 & 1.44\end{array}$ & $\begin{array}{l}\text { (3a) HOOP } \\
\text { (18) SUST } \\
\text { (17) OISP } \\
\text { (18) OCC }\end{array}$ & $\begin{array}{l}2687 \\
3799 \\
6901 \\
5137\end{array}$ & $\begin{array}{l}20000 \\
20000 \\
30000 \\
26600\end{array}$ \\
\hline A12 $\mathrm{M}+$ & $\begin{array}{l}\text { Max P } \\
G R+\text { Max } P \\
\text { Cold to T1 } \\
\text { Sus. }+R 1\end{array}$ & $\begin{array}{r}45 \\
181 \\
76\end{array}$ & $\begin{array}{l}63 \\
46 \\
85\end{array}$ & & 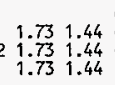 & $\begin{array}{l}\text { (3a) HOOP } \\
\text { (18) SUST } \\
\text { (17) DISP } \\
\text { (18) OCC }\end{array}$ & $\begin{array}{l}2687 \\
3799 \\
6901 \\
5137\end{array}$ & $\begin{array}{l}20000 \\
20000 \\
30000 \\
26600\end{array}$ \\
\hline A12 F- & $\begin{array}{l}\text { Max P } \\
\text { GR + Max P } \\
\text { Cold to T1 } \\
\text { Sus. + R1 }\end{array}$ & $\begin{array}{r}48 \\
203 \\
79\end{array}$ & $\begin{array}{r}80 \\
49 \\
107\end{array}$ & & $\begin{array}{ll}1.73 & 1.44 \\
1.73 & 1.44 \\
1.73 & 1.44\end{array}$ & $\begin{array}{ll}\text { (3a) } & \text { HOOP } \\
(18) & \text { SUST } \\
(17) & \text { OISP } \\
\text { (18) } & \text { OCC }\end{array}$ & $\begin{array}{l}2687 \\
4269 \\
7662 \\
5696\end{array}$ & $\begin{array}{l}20000 \\
20000 \\
30000 \\
26600\end{array}$ \\
\hline A12 F+ & $\begin{array}{l}\text { Max } P \\
\text { GR + Max P } \\
\text { Cold to } 11 \\
\text { Sus. + Ri }\end{array}$ & $\begin{array}{r}80 \\
49 \\
107\end{array}$ & $\begin{array}{r}48 \\
203 \\
79\end{array}$ & & $\begin{array}{lll}1.00 & 1.00 \\
1.00 & 1.00 \\
1.00 & 1.00\end{array}$ & $\begin{array}{l}\text { (3a) } \text { HOOP } \\
\text { (18) SUST } \\
\text { (17) DISP } \\
\text { (18) OCC }\end{array}$ & $\begin{array}{l}2687 \\
3224 \\
4463 \\
4111\end{array}$ & $\begin{array}{l}20000 \\
20000 \\
30000 \\
26600\end{array}$ \\
\hline A13 N- & $\begin{array}{l}\text { Max P } \\
\text { GR + Max P } \\
\text { Cold to T1 } \\
\text { Sus. + } 81\end{array}$ & $\begin{array}{r}9 \\
114 \\
13\end{array}$ & $\begin{array}{l}0 \\
5 \\
1\end{array}$ & & $\begin{array}{ll}1.00 & 1.00 \\
1.00 & 1.00 \\
1.00 & 1.00\end{array}$ & $\begin{array}{l}\text { (3a) } \text { HOOP } \\
\text { (18) SUST } \\
\text { (17) DISP } \\
\text { (18) OCC }\end{array}$ & $\begin{array}{l}2687 \\
1432 \\
2449 \\
1520\end{array}$ & $\begin{array}{l}20000 \\
20000 \\
30000 \\
26600\end{array}$ \\
\hline $\mathrm{A} 13 \mathrm{~N}+$ & $\begin{array}{l}\text { Max } P \\
G R+\operatorname{Max} P \\
\text { Cold to I1 } \\
\text { Sus. + R1 }\end{array}$ & $\begin{array}{r}99 \\
114 \\
13\end{array}$ & $\begin{array}{l}0 \\
5 \\
1\end{array}$ & & $\begin{array}{ll}2.27 & 1.89 \\
2.27 & 1.89 \\
2.27 & 1.89\end{array}$ & $\begin{array}{l}\text { (3a) HOOP } \\
\text { (18) SUSI } \\
\text { (17) DISP } \\
\text { (18) OCC }\end{array}$ & $\begin{array}{l}2687 \\
1684 \\
5556 \\
1881\end{array}$ & $\begin{array}{l}20000 \\
20000 \\
30000 \\
26600\end{array}$ \\
\hline
\end{tabular}

ASME B31.3C (1992) CODE COMPLIANCE

Point Load In-plonents in $\mathrm{ft}-\mathrm{lb}$ ) ${ }^{2}$ (Stress in $\mathrm{psi}$ ) name combination Moment Moment A13 $M$ Max $\mathrm{GR}+\operatorname{Max} P$ Sus. + Ri

-.. Max $?$ GR + Max $P$ Cold to T1
Sus. $+R 1$

$$
\begin{aligned}
& 19 \\
& 98 \\
& 25
\end{aligned}
$$
-..- -..Cos Allow. 268720000 215520000 476230000

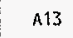

(3a) $\mathrm{HOOP}$ 2.271 .89 (18) SUST $\begin{array}{lll}2.27 & 1.89 \text { (17) DISP } \\ 2.27 & 1.89 \text { (18) OCC }\end{array}$

\section{0} 277820000 209630000 329626600

268720000 191520000 $\begin{array}{rr}951 & 30000 \\ 2144 & 26600\end{array}$

A14 Max P $\mathrm{GR}+\operatorname{Max}$ Cold to T1 Sus. + RI

$$
\begin{aligned}
& 32 \\
& 42 \\
& 42
\end{aligned}
$$

(3a) $\mathrm{HOOP}$ 1.001 .00 (18) SUST 91.001 .00 (17) DISP $1.001 .00(3 a)$ HOOP $\begin{array}{lr}35 & 2 \\ 23 & 15\end{array}$

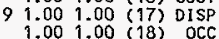

A15 Max $P$ $\mathrm{GR}+\operatorname{Max} \mathrm{P}$ Cold to TI Sus. + R1

(3a) HOOP

A16 Max $P$ GR + Max $P$ Cold to T1 Sus. $+R$ ? $1.001 .00(18)$ SUST $\begin{array}{rr}40 & 3 \\ 2 & 19\end{array}$ 1.001 .00 (18) OCC

268720000 198620000 224126600

268720000 208420000 237526600

268720000 245220000 $\begin{array}{ll}2217 & 30000 \\ 2898 & 26600\end{array}$

*** Segment $A$ end ***

*** Segment 8 begin $* * \star$

A 10

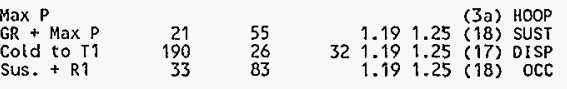
$\begin{array}{llllll}56 & 7 & 1.00 & 1.00(3 a) & \text { HOOP } \\ 97 & 35 & 91.00 & \text { SUST } \\ 76 & 13 & 9 & 1.00 & (17) & \text { OISP }\end{array}$ 1.001 .00 (18) OCC
BO1 - $\operatorname{Max} P$ Cold to $T$ Sus. $+R$ 52
56
76 $\begin{array}{llll}1.00 & 1.00(3 a) & \text { HOOP } \\ 18) & \text { SUST } \\ 1.00 & 1.00(17) & \text { DISP }\end{array}$ $B 01+\operatorname{Max} P$ $G R+\operatorname{Max} P$ Cold to T1
sus. $+\mathrm{R} 1$ (3a) HOOP

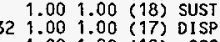

268720000 271320000 345926600

268720000 243220000 401230000

268720000 243220000 401230000 


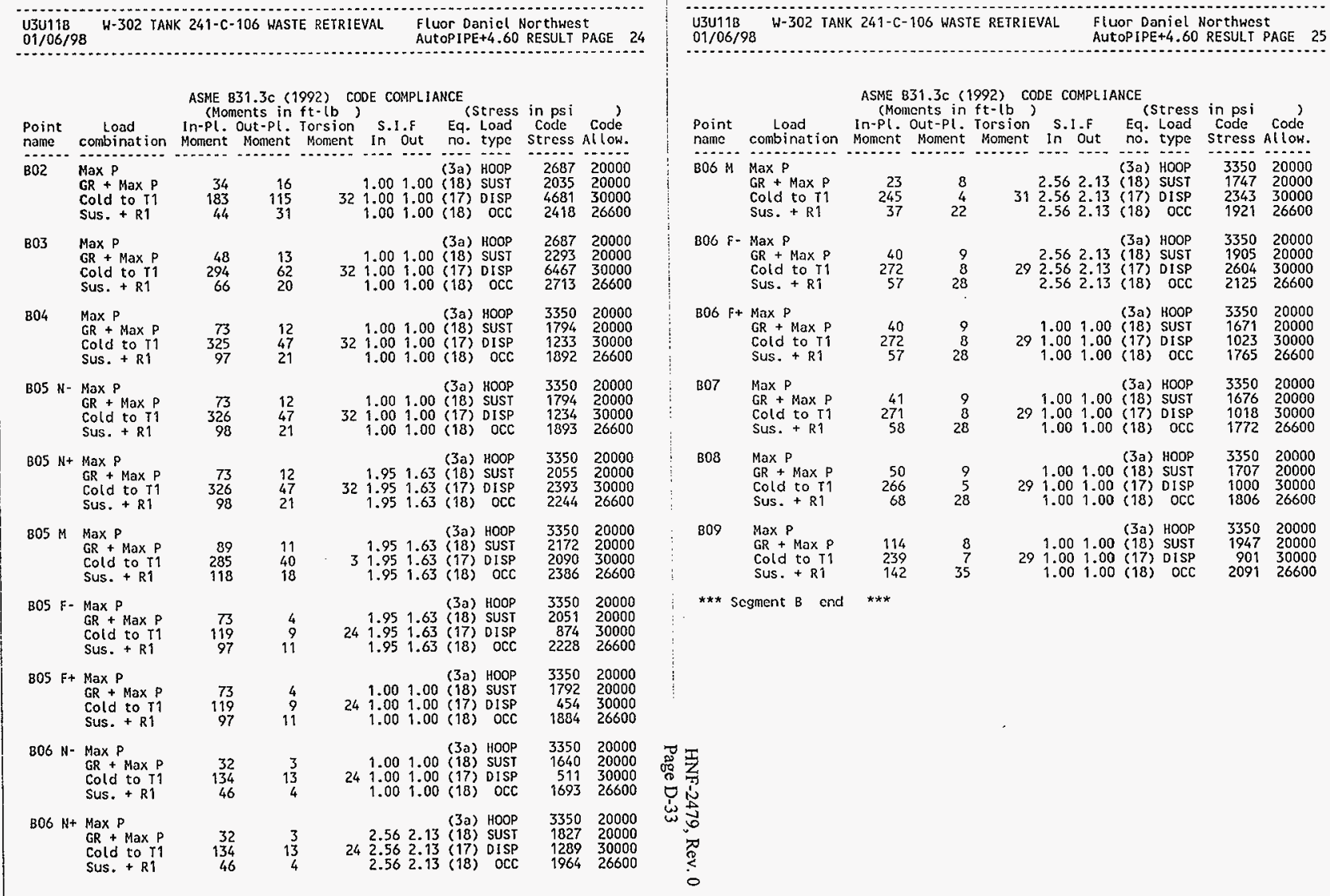




\section{U3U11B} $01 / 06 / 98$

W-302 TANK $241-\mathrm{C}-106$ WASTE RETRIEVAL

Fluor Daniel Morthwest AutoPIPE +4.60 RESULT PAGE 26

\section{SYSTEM SUMMARY}

Maximun displacenents (in)

$\begin{array}{llll}\text { Maximum X: } & 0.038 & \text { Point : A04 F } & \text { Load Comb.: TOTAL } \\ \text { Maximum Y : } & 0.100 & \text { Point : A12 M } & \text { Load Comb.: YOTAL } \\ \text { Maximum Z : } & 0.045 & \text { Point : B05 N } & \text { Load Comb.: TOTAL } \\ \text { Max. total: } & 0.109 & \text { Point : A12 M } & \text { Load Comb.: TOTAL }\end{array}$

Maximun rotations (deg)

$\begin{array}{lrll}\text { Maximum X: } & 0.208 & \text { Point : B05 F } & \text { Load Comb.: TOTAL } \\ \text { Maximum Y : } & -0.137 & \text { Point : A12 N } & \text { Load Comb.: T1 } \\ \text { Maximum Z : } & 0.129 & \text { Point : A06 } & \text { Load Comb.: TOTAL } \\ \text { Max. total: } & 0.244 & \text { Point : B05 F } & \text { Load Comb.: TOTAL }\end{array}$

\section{Maximum restraint forces(lb)}

$\begin{array}{lrll}\text { Maximum X: } & 89 & \text { Point : B09 } & \text { Load Comb.: TOTAL } \\ \text { Maximum Y } & 289 & \text { Point }: A 00 & \text { Load Comb.: TOTAL } \\ \text { Maximum Z : } & 510 & \text { Point : B09 } & \text { Load Comb.: T1 } \\ \text { Max. total: } & 529 & \text { Point : B09 } & \text { Load Comb.: TOTAL }\end{array}$

Maximum restraint moments $(f t-l b)$

$\begin{array}{lll}\text { Maximum X: } & 381 & \text { Point : } 809 \\ \text { Maximum } Y: & 42 & \text { Point }: B 09 \\ \text { Maximum Z : } & 258 & \text { Point }: A 00 \\ \text { Max. total: } & 386 & \text { Point }: B 09\end{array}$

Load Comb.: TOTAL Load Comb.: TOTAL Load Comb.: TOTAL

\section{U3U118 $01 / 06 / 98$ \\ W-302 TANK 241-C-106 WASTE RETRIEVAL \\ Fluor Daniel Northwest \\ AutoPIPE+4,60 RESULT PAGE}

\section{SYSTEM SUMMARY}

Maximum pipe forces $(t b)$

$\begin{array}{lrll}\text { Maximum } X: & 89 & \text { Point }: \text { B08 } & \text { Load Comb.: TOTAL } \\ \text { Maximum } Y: & 289 & \text { Point }: \text { A00 } & \text { Load Comb.: TOTAL } \\ \text { Maximum Z }: & 510 & \text { Point : A10 } & \text { Load Comb.: T1 } \\ \text { Max. total: } & 528 & \text { Point }: \text { B09 } & \text { Load Comb.: TOTAL }\end{array}$

Maximum pipe moments $(\mathrm{ft}-\mathrm{lb})$

$\begin{array}{llll}\text { Maximum } x: & 381 & \text { Point }: \text { B09 } & \text { Load Comb.: TOTAL } \\ \text { Maximum } Y: & 282 & \text { Point }: A 10 & \text { Load Comb.: T1 } \\ \text { Maximum } Z: & 258 & \text { Point }: \text { A00 } & \text { Load Comb.: TOTAL } \\ \text { Max. total: } & 386 & \text { Point }: \text { B09 } & \text { Load Comb.: TOTAL }\end{array}$




\section{SYSTEM SUMHARY}

Maximum sustained stress

$$
\begin{array}{ll}
\text { Point } & \text { A12 F } \\
\text { Stress psi } & 4269 \\
\text { Allowable psi } & \vdots 20000 \\
\text { Ratio conbination } & 0.21 \\
\text { Load con }+ \text { Mox P }
\end{array}
$$

Maximum displacement stress

$$
\begin{array}{ll}
\text { Point } & \text { A12 F } \\
\text { Stress psi } & \vdots 662 \\
\text { Allowable psi } & \vdots 30000 \\
\text { Ratio } & : 0.26
\end{array}
$$$$
\text { Load combination : Cold to T1 }
$$

Maximum occasional stress

$$
\begin{array}{ll}
\text { Point } & \text { A12 F } \\
\text { Stress psi } & 5696 \\
\text { Al Lowable psi } & : 26600 \\
\text { Ratio } & 0.21 \\
\text { Load combination } & \text { Sus. + } 81
\end{array}
$$

Maximum hoop stress

$$
\begin{array}{ll}
\text { Point } & \text { A00 } \\
\text { Stress psi } & 3350 \\
\text { Allowable psi } & : 20000 \\
\text { Ratio } & 0.17 \\
\text { Load combination } & \text { Max P }
\end{array}
$$

Maximum sustained stress ratio

$$
\begin{array}{ll}
\text { Point } & \text { A12 F } \\
\text { Stress psi } & 4269 \\
\text { Allowable psi } & : 20000 \\
\text { Ratio } & 0.21 \\
\text { Load combination : } G R+\text { Max P }
\end{array}
$$

Maximum displacement stress ratio

$$
\begin{aligned}
& \text { Point } \quad: \$ 12 \mathrm{~F} \\
& \text { Stress psi } \quad 7^{7662} \\
& \begin{array}{ll}
\text { Allowable psi } & 30000 \\
\text { Ratio } & 0.26
\end{array} \\
& \text { Load combination : cold to T }
\end{aligned}
$$

\section{U3U118 W-302 TANK 249-C-106 WASTE RETRIEVAL Fluor Daniel Nor thwes}

\section{SYSTEM SUMMARY}

Maximum occasional stress ratio

$\begin{array}{ll}\text { Point } & : \text { A12 F } \\ \text { Stress psi } & 5696 \\ \text { Allowable psi } & : 26600 \\ \text { Ratio } & : 0.21 \\ \text { Load combination } & \text { Sus. + R1 }\end{array}$

Haximum hoop stress ratio

$$
\begin{array}{ll}
\text { Point } & : A 00 \\
\text { Stross psi } & : 3350 \\
\text { Allowable psi } & : 20000 \\
\text { Ratio } & : 0.17 \\
\text { Load combination : Max P }
\end{array}
$$

* * * The system satisfics ASME B31.3 code requirements * * * 


$$
\text { Calculation w320-27-053 } \quad B-1 \text { of } 3-19
$$

WHC-SD-W236A-DA-ODL

Rev. 0

System_Model_Results

A system model was developed to determine stresses in all structural components except the block from the non-axial external piping loads. These structural components include the block top region tinder the screw bearing point. Only the $50 \mathrm{lbf}$-ft pre-load torque was considered. Acceptable load components of the piping external forces and moments are factored into Table 3.4. In all cases, except for the axial force, the acceptable levels are limited by the strength of the hook eyes under the condition of tight clearances between the pin and hook which transmits lateral book moments to the pin. Further discussion is provided in Section 5.5.5, and suggestions for further work that could increase the allowable loads is given in Section 6.1 .

The system model also provides stiffnesses, given in Table 3.5, for the connector assemblies under the external piping load components. They could be used by the piping analyst to calculate spring stiffnesses for the piping model to provide relief in the calculation of actual reactions. It is recommended that the piping model have a rigid link from the piping attachment point to the center of the spherical bjock-nozzle interface, and that the stiffnesses be used at this point. In this case, the lateral stiffnesses Kuy and Kuz may be taken as rigid.

\section{Acceptable External Piping Iosis}

Actual axial piping forces (with respect to the connector) should be checked against limits in Tables 3.3 and 3.4 for unseating and seating limits, respectively. Any combination of the remaining five components of joading is acceptable if the absolute sum of ratios of the applied force/moment components of shear, torsion and bending to the limit values of Table 3.4. is less than unity. The two components of shear force or bending moment should be combined with a circular interaction rule by forming the square root of the sum of the squares.

Acceptable loads of Table 3.4 do not reflect the $1 / 3^{\circ}$ increase in allowable stresses permitted in Section 1.5.6 of (AISC, 1989) for wind and seismic loads. Thus, jumper piping analysis reactions based on seismic loading could be compared with values of Table 3.4 increased by $1 / 3$ provided that analysis reactions based on the non-seismic loadings compare favorably with the table as shown.

An example is provided by the worst case in a preliminary study of MWTF jumper piping provided in Appendix F. At pressure and temperature and with forces referenced to the intersection of the pipe and block centerlines, the piping analysis force and moment components are:

$$
\begin{aligned}
& f x=-114 \mathrm{lbf} \quad f y=419 \mathrm{lbf} \quad \mathrm{fz}=237 \mathrm{lbf} \\
& \mathrm{mx}=-7 \mathrm{ft}-1 \mathrm{bf} \quad \mathrm{my}=\cdot-58 \mathrm{ft}-1 \mathrm{bf} \quad \mathrm{mz}=173 \mathrm{ft}-\mathrm{lbf} \\
& \text { Connector size }=2 \text { in. } \\
& \text { Pre-load torque }=50 \mathrm{ft}-16 f \text {. } \\
& \text { Temperature }=250^{\circ} \mathrm{F}
\end{aligned}
$$

Figure I provioes the coordinate system for interpretation of the components. Then the axial force is checked as follows:

Seating: $\quad \mathrm{fx}_{\mathrm{x}}=-114 \mathrm{lbf}, \mathrm{Fx}=7,370 \mathrm{lbf}$ (Table 3.4), $-\mathrm{fx}<\mathrm{Fx}, \mathrm{OK}$

Unseat: $\quad f x<0$, no check necessary. 
The interaction of shear, torsion and bending is formed by comparing the applied values with the limits of Table 3.4 and summing:

Shear: $\quad f y z=\operatorname{sqr}\left(f y^{2}+f z^{2}\right)=\operatorname{sgrt}\left(419^{2}+237^{2}\right)=482 \mathrm{ft}-\mathrm{lbf}$

Torsion: $\quad|\mathrm{mx}|=7 \mathrm{ft}-\mathrm{lbf}$

Bending: $\quad$ myz $=\operatorname{sqr}\left(m y^{2}+m z^{2}\right)=\operatorname{sqrt}\left(58^{2}+173^{2}\right)=182 \mathrm{ft}-1 b f$

$I=f y z / F y z+.|m x| / M x+m y z / M y z=482 / 1330+7 / 260+182 / 365=0.900 \mathrm{OK}$

Note that the unseating axial force limit is dependent on pre-load, pressure and temperature. For example, if the axial load is positive, it tends to unseat the block. At 4,000 lbf in a cold condition with a 2-in. connector, Table 3.3 shows a 3,390 lbf limit indicating that the condition is unaceeptable. Such axial forces are unlikely under piping thermal expansion environments at temperature. Axial piping forces which tend to increase the seating force need not be checked against Table 3.3. All axial forces are to be checked against the limits of Table 3.4 .

Table 3.1. Nominal System Model Piping Reaction Loads.

\begin{tabular}{|l|l|l|l|l|l|l|}
\hline $\begin{array}{l}\text { Connector } \\
\text { Size }\end{array}$ & $\begin{array}{l}\text { Fx } \\
\text { (lbf) }\end{array}$ & $\begin{array}{l}\text { Fy } \\
\text { (lbf) }\end{array}$ & $\begin{array}{l}\text { Fz } \\
(\mathrm{bf})\end{array}$ & $\begin{array}{l}\mathrm{Mx} \cdot \\
(\mathrm{ft}-\mathrm{lbf})\end{array}$ & $\begin{array}{l}\mathrm{My} \\
(\mathrm{ft}-1 \mathrm{bf})\end{array}$ & $\begin{array}{l}\mathrm{Mz} \\
(\mathrm{ft}-\mathrm{lb})\end{array}$ \\
\hline 2 -in. & 2,300 & 1,000 & 400 & 1,600 & 1,600 & 2,000 \\
\hline 3 -in. & 15,000 & 2,000 & 2,000 & 7,000 & 7,000 & 4,000 \\
\hline 4 -in. & 27,000 & 3,000 & 3,000 & 13,000 & 13,000 & 7,000 \\
\hline
\end{tabular}

Table 3.2. Axial Load Capacities of the Supporting Components (One Hook).

\begin{tabular}{|l|l|l|l|l|l|}
\hline Component & Material & $\begin{array}{l}2 \text { in. } \\
\text { (lbf) }\end{array}$ & $\begin{array}{l}3 \text { in. } \\
\text { (lbo) }\end{array}$ & $\begin{array}{c}4 \text { in. } \\
\text { (lbf) }\end{array}$ & Remarks \\
\hline Hook & $\begin{array}{l}\text { ASTM A 747 Grade CB7Cu-1 } \\
\text { or CB7Cu-2, H1075 Ht. Tr. }\end{array}$ & 5,943 & 8,750 & 12,717 & See App. A \\
\hline Hook Pin & As required by Table 4.1 & 14,420 & 24,930 & 35,400 & See App. C \\
\hline $\begin{array}{l}\text { Operating } \\
\text { Nut }\end{array}$ & ASTM A 148 & 9,705 & 14,669 & 27,580 & See App. A \\
\hline $\begin{array}{l}\text { Operating } \\
\text { Screw }\end{array}$ & ASTM A 193 Grade B7 C.S. & 19,442 & 37,895 & 53,149 & See App. A \\
\hline
\end{tabular}


WHC-SD-W236A-DA-002

Rev. 0

Table 3.3. Seating Forces for Various Pre-loads!

\begin{tabular}{|l|r|r|r|}
\hline Connector Size & Torque (ft-lbf) & Cold (bf) & \multicolumn{1}{c|}{ Hot (lbo } \\
\hline 2 -in. & 50 & 3,390 & 9,160 \\
\cline { 2 - 4 } & 180 & 15,200 & 21,000 \\
\hline 3 -in. & 50 & $-1,920$ & 6,210 \\
\cline { 2 - 4 } & 490 & 20,600 & 28,700 \\
\hline 4 -in. & 50 & $-4,310$ & 6,310 \\
\hline & 230 & 2,560 & 13,700 \\
\hline
\end{tabular}

1. Intemal pressure $=400$ psi. Cold springing cifects are not included.

2. Hot condition temperate $=250^{\circ} \mathrm{F}$

Table 3.4. Standard Connector Acceptable Piping Loads'

\begin{tabular}{|c|c|c|c|c|c|}
\hline $\begin{array}{c}\text { Connector Size } \\
.\end{array}$ & $\begin{array}{r}\text { Axial Force } \\
\text { Fx } \\
(1 b f)\end{array}$ & $\begin{array}{r}\text { Shear } \\
\text { Fyz } \\
\text { (Ibf) }\end{array}$ & $\begin{array}{r}\text { Torsion } \\
M x \\
\text { (ft-lbf) }\end{array}$ & $:$ & $\begin{array}{r}\text { Bending } \\
\text { Myz } \\
\text { (At-lbf) } \\
\end{array}$ \\
\hline 2-in. & $7,370^{3.6}$ & $1.330^{\mathrm{s}}$ & 260 & & $365^{5}$ \\
\hline 3-in. & $38,100^{3,7}$ & 1,540 & 410 & . & 630 \\
\hline 4-in. & $42,100^{3.7}$ & 2,220 & $780^{\circ}$ & - & 1,170 \\
\hline
\end{tabular}

1. Design pressure $=400 \mathrm{psi}$, temperature $=250 \cdot \mathrm{F}$, pre-load torque $=50 \mathrm{n}$-ibf. Acceptable losds do not rellect the $1 / 3$ increase in allowable stresses permitted in Seetion 1.5.6 of (AISC, 1989) for wind and seismic losds.

2. To $b$ limited by fores that would unseat the block nozzle interface per Tsble 3.3 .

3. Limited by block andlysis at the same design parameters.

4. Refereneed to intersection of piping and connector centerlines.

5. Reduce by $25 \%$ for $304 \mathrm{~L} / 316 \mathrm{~L}$ nozle marerist.

6. Raduce by $35 \%$ for $304 \mathrm{~L} / 316 \mathrm{~L}$ block material.

7. Reduce by $25 \%$ for $304 \mathrm{~L} / 316 \mathrm{~L}$ block material. 
Table 3.5. Connector Stiffnesses to Piping Reaction Loads (Standard Configuration).

\begin{tabular}{|c|c|c|c|c|c|c|}
\hline $\begin{array}{l}\text { Connector } \\
\text { size }\end{array}$ & $\begin{array}{l}\text { Kuxi2, } \\
\mathrm{lbf} / \mathrm{in}\end{array}$ & $\mathrm{Kuy}^{3}, \mathrm{lbf} / \mathrm{in}$ & $\mathrm{Kuz} \mathrm{z}^{3}, \mathrm{lb} f / \mathrm{in}$ & $\begin{array}{c}\text { Krotx, } \\
\text { lbf-in/rad }\end{array}$ & $\begin{array}{c}\text { Kroty, } \\
\text { lbf-in/rad }\end{array}$ & $\begin{array}{c}\text { Krotz, } \\
\text { lbf-in/rad }\end{array}$ \\
\hline 2-in. & $1.35 \mathrm{e}+7$ & $2.78 \mathrm{e}+4$ & $2.78 e+4$ & $7.38 e+4$ & $4.53 e+5$ & $4.53 e+5$ \\
\hline 3-in. & $1.90 e+7$ & $2.47 e+4$ & $2.47 \mathrm{i}+4$ & $1.02 e+5$ & $9.16 e+5$ & $9.16 e+5$ \\
\hline 4-in. & $2.33 e+7$ & $2.52 e+4$ & $2.52 e+4$ & $2.09 e+5$ & $1.43 e+6$ & $1.43 e+6$ \\
\hline
\end{tabular}

1. See ANSYS (1992) for notetion. See Figure 1 for the coordinate system.

2. Applicable only for a positivo seating force.

3. Kuy and Kuz should be taken as rigid provided thet the piping model runs a rigid link from the pipc-block . interface to the center of the spherical seating surfece. This is the preferted modeling method.

4. Connector stiffnesses shown relate to flexibility between the pipe suschment and nozzle flange area. They do not account for the straight pipe flexibility from the nozzle flange ares to the conerete or other amehor point. A pplicable pre-load torque is $50 \mathrm{ft}-\mathrm{lbf}$.

\section{Conditions of Design}

Since the hook-nozzle load application point was taken at the center of the flange overhang, validity of the analysis requires that a substantial majority, say $80 \%$, of the maximum possible hook-flange contact area be achieved.

\section{Connector Boundaries}

Validity of the analysis herein extends from the pipe opening of the block to the flange of the nozzle. The applicable region of the analysis does not include the pipe and the weld attachment at the opening or the non-standard pipe between the nozzle flange and kick-plate or concrete embedment.

\subsection{THREE-WAY CONEIGURATION}

\section{Acceptable Piping Reactions}

As in the standard connector, acceptable piping reactions have been determined only for a pre-load torque of $50 \mathrm{lbf}-\mathrm{ft}$.

Limits are placed on net piping loads to the block in order to guard against lift-off of the block from an insert. Such lift-off is characterized by pivoting of the block about the other two inserts or by sliding up an inclined plane. Net incoming piping moments and forces are limited by the equation

$$
\frac{F_{x} \cdot M_{T} / R}{F_{a l b m}-F_{x}}+\frac{M_{o}}{M_{\alpha l m}-F_{x} R / 2}<1
$$




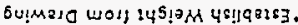

\begin{tabular}{|c|c|c|c|c|c|c|c|c|c|c|}
\hline & $24 ! 0 \mathrm{~g} \cdot \mathrm{L}$ & $|1-\varepsilon \operatorname{cr}-\tau-H|$ & & & & & $\tau / L Z-\zeta \mid$ & $i$ & JOMOT UUOJ IISM I & \\
\hline & $\longdiv { 1 0 1 0 0 \mathrm { d } - \mathrm { C } }$ & $\mid z \cdot 607 z-z \cdot H$ & $\varepsilon$ & & & & $\Sigma / \xi !-\xi 1$ & i & 1 10MOT.U405. 1003 & \\
\hline & 12u!Od.L & $|\tau-\infty \cos \cdot \tau \cdot h|$ & SS & & & & $196 / 66-6$ & & $\operatorname{soden} \cdot 2013$ & \\
\hline & T & I & & & & & $\mathrm{T}$ & & & \\
\hline$\angle \cdot \cos 2 \cdot 2 \cdot H$ & ESt & $|s-\cos 2 \cdot z \cdot H|$ & Cs! & $9 ! / 1 !-61$ & $2.1-9$ & Q/E.3 & 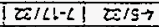 & $8 i \hat{\mathrm{C}}+\hat{E}$ & $x \cup \times 18$ & 7 \\
\hline $\operatorname{sen} 2 \cdot 2 \cdot 4$ & $5 !$ & & & & $2 / 1-9$ & $8 / 2 \rightarrow$ & $\mid \bar{\epsilon} /<! \cdot\langle! \delta / 5 \rightarrow$ & $8 \longdiv { 6 - 5 }$ & -GnI दावE $\times 2 \mid$ & $r$ \\
\hline $7 \cos 2 \cdot z+41$ & $15 !$ & & & & $z / 5-3$ & $8 / \varepsilon-9$ & $\mid \tau / \angle b-l i \quad \sigma_{i} / 57$ & $8 / \varepsilon-\varepsilon$ & ०दn! did $\varepsilon \times \varepsilon$ & 5 \\
\hline$\varepsilon \cdot \cos 2 \cdot 2 \cdot h$ & $\$ 21$ & & & & $2 / 5-9$ & $|8 / \varepsilon-9|$ & 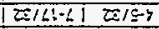 & $\delta / \varepsilon-\varepsilon$ & $29 n ! d ! 0 \varepsilon \times 1$ & $r$ \\
\hline$\tau \cdot \cos z \cdot \tau \cdot H$ & iz! & 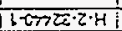 &.$c z !$ & $9: 161-11$ & $2 / 1-\hat{3}$ & $8 / \varepsilon-7$ & $|\varepsilon / \leq b-\angle| \quad \varepsilon / \hat{s}+7$ & $8,6-6$ & $\because x+1$ & $y$ \\
\hline & & 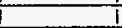 & & & & & & & & \\
\hline $8-\widehat{s} \cdot 2 \cdot 2 \cdot H 1$ & Es & $|\angle \cos \theta \cdot 2 \cdot 4|$ & $S^{\circ}<3$ & $9 !|<-1|$ & $3 ! 1 \div 5$ & SI & $\mid s: 1 \div-91$ ह15- & $\varepsilon$ & $x+0|5|$ & $\varepsilon$ \\
\hline $95 ! 06 \cdot 2 \cdot 4 !$ & -1 & 1 & -6 & & $196 / 5-9$ & $\$$ & $|g ! / 5-9| \varepsilon ! / 8-5$ & $\varepsilon$ & 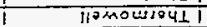 & $\varepsilon$ \\
\hline$|\cdot \cos \sigma \cdot 2 \cdot H|$ & 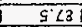 & & & $\because$ & $\mid 8: 1 E-I$ & 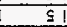 & $9: / 5-31$ ह1/5- & c & C/IEरQME। & $\varepsilon$ \\
\hline $\mathrm{Z \cdot H}$ & 8 & & & & $96 / \bar{a}-\mathrm{E}$ & $\mathbf{s}$ & $9: 15-3186 / 5 \cdot \varepsilon$ & $\varepsilon$ & - qni cior $\times \tau i$ & $\varepsilon$ \\
\hline$z \cdot 4$ & $u$ & $\varepsilon \cdot \cos \Sigma+Z \cdot H \mid$ & 91 & S: $/ L-1 \mid$ & $9 ! / 5-5$ & 5 & 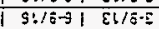 & $\varepsilon$ & $\varepsilon \times z 1$ & $\bar{\varepsilon}$ \\
\hline$-2 \cdot 4$ & 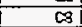 & & & & \$6 & इ। & $|9 ! / 53|$ & E & $0 q \pi 1010 \mathrm{C} \times \varepsilon \mid$ & $\varepsilon$ \\
\hline $\mathrm{Z} \cdot \mathrm{HI}$ & $\angle i$ & $\overline{26} \cdot 2 \cdot 4$ & $\overline{9 L}$ & $9 ! /<-1 !$ & $96 / 5.5$ & s! & 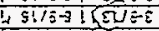 & $\varepsilon$ & $\varepsilon \times \varepsilon !$ & $\varepsilon$ \\
\hline & & & & & & $8 \leqslant-1$ & i) & 1 & i & \\
\hline$\cdot z \cdot 4 !$ & stes & $|\varepsilon \cdot 0 Z>Z \cdot z \cdot 4|$ & $\bar{E}$ & $8 ;(-1)$ & g/दह & $8 / \varepsilon+\varepsilon$ & $19 ! \pi ! 1->1]^{1} \quad 8 / L-2$ & $3 / 1-2$ & xu? & $\bar{z}$ \\
\hline$-\mathrm{Z} \cdot \mathrm{Hi}$ & .1 & & & $i$ & & $8 / \tau-\hat{c}$ & $8: t-51 \quad 816 \cdot 2$ & $r / 1-z$ & Пtलmowsou & $z$ \\
\hline$L \cdot 12$ & $5 \cdot \mid \varepsilon$ & & 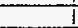 & 1 & & & -1 & & $00 ! 12$ ก $01 ! 20 y$ & 2 \\
\hline $2 \cdot 4$ & $\overline{\bar{\varepsilon}}$ & $|1 \cdot\langle l\rangle \tau=Z \cdot H|$ & 5.5 & $8 / 5 \cdot 51$ & $8 / 5 \hat{\xi}$ & $8 i \varepsilon+\frac{2}{2 !}$ & $9 ! / l !-7 \mid z / 2 !-\tau=$ & $\overline{\varepsilon / 5 \cdot 2}$ & 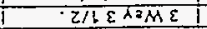 & $\bar{z}$ \\
\hline$z \cdot k 1$ & $z$ & & & & $8 / S \cdot \varepsilon$ & $8|\varepsilon-\varepsilon|$ & $196 / 6 !-71-9: 16-2$ & $9 / 5-z$ & Dand $6 ! 0 \% / 6 \times 2$ & $\bar{z}$ \\
\hline$\frac{2 \cdot 02 \pi-2 \cdot 41}{10}$ & $\frac{\infty}{\sigma z l}$ & $1 \cdot c Z>\sigma \sigma \cdot z \cdot H$ & $\bar{Q}$ & $8 / 6-1)$ & $8 / 5-1$ & $8 / \tau-\frac{2}{2}$ & $9 ! / 11-759 ! / 6-2$ & $7 ; 1-2$ & $z \times z$ & $\bar{z}$ \\
\hline & 1 & & & i & & $3^{*}-1$ & $1 \cdots$ & & & \\
\hline$\tau \cdot 4 i$ & $59 ! 1$ & 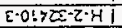 & 96 & & $z / !-z 1$ & $2|1-2|$ & $|\bar{\varepsilon} / \bar{s}: \bar{\varepsilon}| \bar{\varepsilon} / \Omega-1$ & $8 i \leq-1$ & xusig & 5 \\
\hline 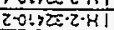 & $\frac{5961}{s .5+1}$ & 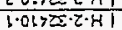 & $5.5 !$ & $!$ & $z / 1+z \mid$ & $z / t-z \mid$ & $|\tau / 5|-\varepsilon \mid \tau / \Omega \cdot 1$ & $8 / 6-1)$ & $1 \times b$ & $i$ \\
\hline $\begin{array}{c}\text { on } \\
\text { butmaso }\end{array}$ & 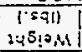 & $\begin{array}{c}\text { ON } \\
\text { Bu!sato }\end{array}$ & 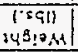 & s & $\exists$ & $a$ & ? & $\forall$ & $o \alpha_{1}$ & $92 ! 5$ \\
\hline \multicolumn{2}{|c|}{$\tan$} & \multicolumn{2}{|c|}{ 1e:402120H } & \multicolumn{5}{|c|}{ 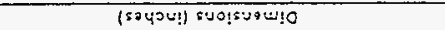 } & \multicolumn{2}{|c|}{ x>0:9 10:020005. } \\
\hline
\end{tabular}
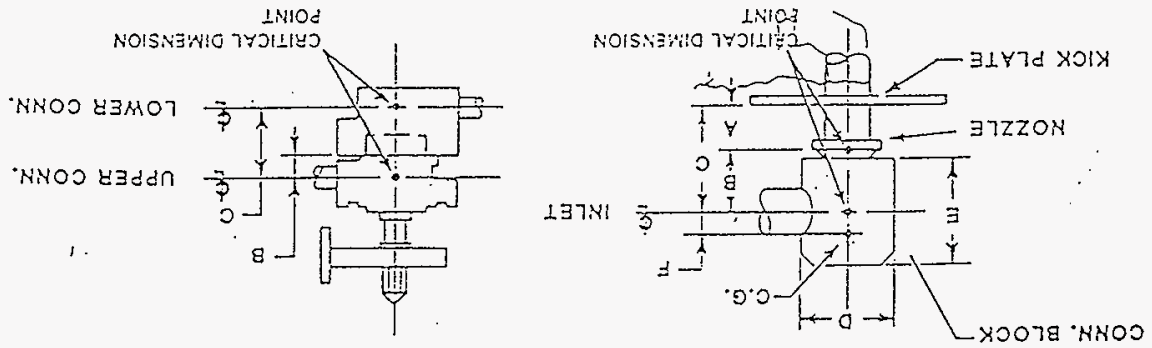

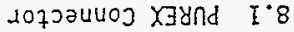

ษIYO NOIS $30 \quad 0.8$ 
WHC-SD-KM-DA-063 REVISION 0

\subsection{INTRODUCTION}

This analysis determines the capacities of the lifting bails shown in Drawing H-2-90161, Revision 1. The drawing details six different assemblies of bails in two groups. The grouping is based on materials. Three of the six bails are of carbon steel (CS); the material for the other three is stainless steel (SST). The bails vary in geometry within the group. In addition, this drawing also. includes two assemblies of bails by an Engineering Change Notice $\# 117198$ (ECN), Reference 8 and Appendix K. All bails are required to withstand the loads of support assemblies, equipment, or other attached loads. This analysis does not evaluate the supporting assemblies.

\subsection{DISCUSSION}

The lifting bails as designed are considered to be "below-the-hook" items and are associated with critical lifts, in accordance with the Hanford Hoisting and Rigging Manual (Reference 1). The allowable loads, therefore, have a factor of safety of 3 based on the yield strength and 5 based on the uTtimate strength. The ANSYS computer program was used to perform the structural analysis of the lifting bails and to determine their capacities. The lifted item may lie in the vertical piane or in the horizontal plane; therefore, it is necessary to determine the capacities of the bails in vertical and horizontal (1ateral) lifts.

Two load options for the vertical lift were used. These options are based on the varied locations of the attachment of the flat bar of the lifting bail to the supporting assembiy to be lifted. For a standard lifting bail, this attachment is considered to be within the bail. When the attachment falls beyond the bail, further analys is will be required.

Two sets of ANSYS analyses were performed for each of the Assembities 1, $3,5,15$, and 16 . Assemblies 2, 4, and 6 are identical to Assemblies 1, 3, and 5 , respectively, except for material. Hence, the capacities of Assemblies 2,4 , and 6 were determined by linear interpolation of the capacities of Assemblies 1, 3, and 5 .

The weld between the bail and the flat bar has been modified to satisfy the minimum size requirement (Reference 6 , Table 7.2). The capacities of the bails were determined by using the critical stress in the bail (rod), flat bar, or weld connections. The calculations indicated that the stress in the bail (rod) dictated the capacity of the bails. 


\subsection{SUMMARY OF RESULTS}

The capacities of the lifting bails are shown in the table below.

TABLE 1

DRAWING H-2-90161, REVISION 1

\begin{tabular}{|c|c|c|c|}
\hline Lifting Bail & Material & \multicolumn{2}{|c|}{ C A P A C I TY, L B S . } \\
Assembiy Number & Vertical Lift & Lateral Lift \\
\hline 1 & CS & 410 & 70 \\
\hline 2 & SST & 295 & 50 \\
\hline 3 & CS & 390 & 56 \\
\hline 4 & SST & 280 & 40 \\
\hline 5 & CS & 475 & 68 \\
\hline 6 & SST & 340 & 49 \\
\hline 15 & CS & 795 & 125 \\
\hline 16 & CS & 1490 & 260 \\
\hline
\end{tabular}

$C S=$ Carbon steel

SST = Stainless steel

\subsection{CONCLUSIONS}

The lifting bails as detailed in drawing H-2-90161, Revision I, are identified with their respective capacities in Table 1 , above. The calculations are shown in Appendices $A$ and $J$. All pertinent ANSYS runs. are. shown in Appendices B through 1 .

The capacities of the bails, as shown in Table 1, shall be compared to the reactions at the bails. The reaction varies with the location of the bail and the center of gravity of the supporting assembiy. The users of standard bails should determine the center of gravity of the supporting assembly and the lifting bail reaction. These data should be used to select an appropriate lifting bail assembiy, as shown in Table 1 .

PAGE 4 
Calculat wo w20-27.053 $\overline{B-9}$ of $B-19$

design Calculation WHC-SD-wH-DA-06.3, Revo

(1) Dräwing $\mathrm{H}-2-90 / 61$

(2) Doc. No.

(3) Page 10 of H1 152

(4) Building 200 Area (Gen.) (5) Rev. (6) Job No.

(7) subject Lifting Bail Capacity

(8) Originator M. A. ISLAM

Date 12.12 .89

(9) Checker T.C. Maske Date $7 / 6 / 90$

(10)

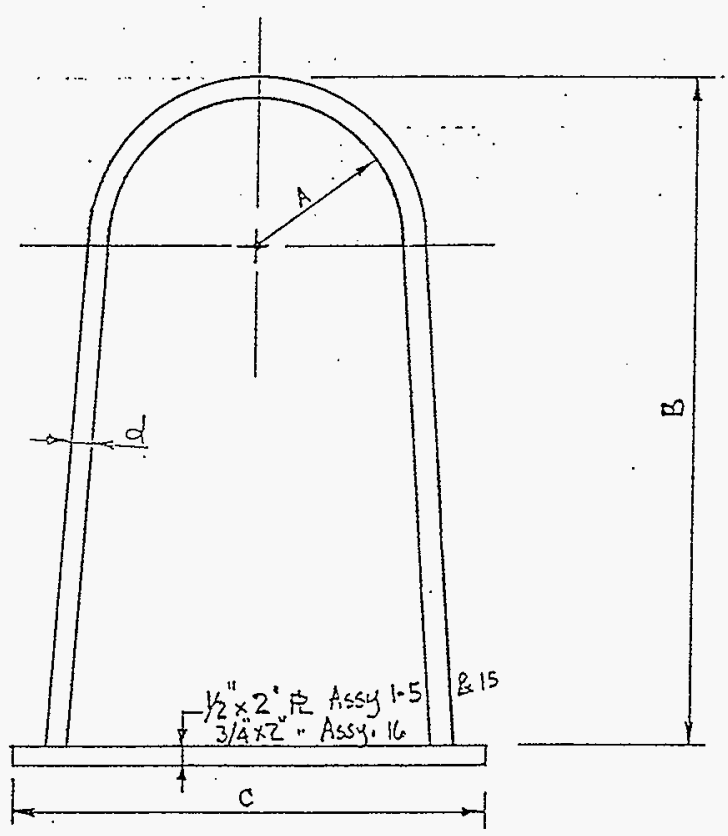

HNF-2479, Rev. 0

Page D-44

TYP. BAIL ELEY.

See REF. 7

Dug. H-290161 Rev1 and ECN 117198

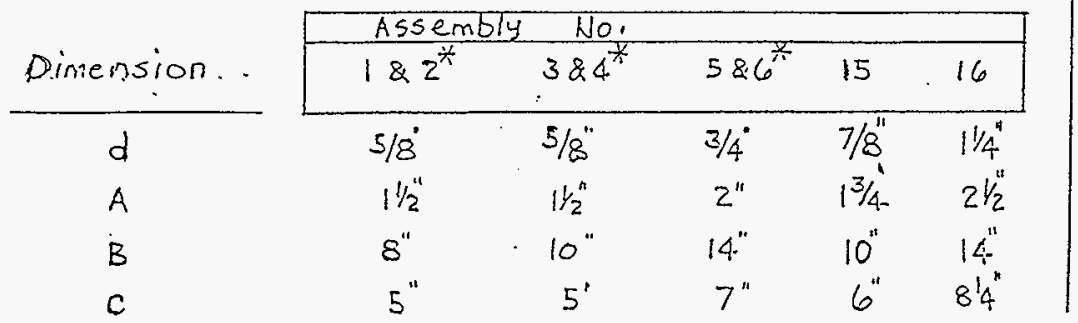

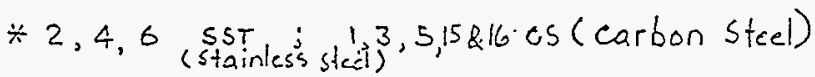


Calculation w320-27-053 DESIGN CALCULATION (2) Doc. No.

(1) Drawing $\mathrm{H}-2-9016 \mathrm{l}$

(4) Building 200 Area (Gen;) (5) Rev.

(7) Subject Lifting Bail Capacity

(8) Originator M.ATISLAM

(9) Checker

(10)

Allowable stresses

Impact Level II
$B-10$ of $B-19$

$W H C-S D-W W-D A-6 t 3, R U O$

(3) Page 12 of 152 (6) Job No.

Date $12 \cdot 12 \cdot 89$

Date $7 / 4 / 90$

bail \& Plate, allowable bending stress, $T_{b}$

$$
\sigma_{b}=\frac{1}{3}\left(y_{\text {eld }}\right) \text { or } \frac{1}{5} \text { (Ultimate) }\left.\right|_{1} ^{R E F \text {. }}
$$

Carbon steel (cs)

$$
\text { REF, 3 }
$$

$$
\text { REF } 5
$$

Yield stress, $F_{y}=36000$ Psifor A36 steel Ultimate stress, $F_{U}=58000 P_{s i}$

$\therefore F_{b}=\frac{1}{3} \times 36000=12000 P_{s i}$

or $=\frac{1}{5} \times 58000=11600$ Psi.

Use $\bar{T}_{6}=11600$. Psi

Stainless steel (SST)

Type $304 \mathrm{~K}: \quad F_{y}=\frac{25000}{30} \mathrm{P}_{s i}, F_{U}=70000 \mathrm{Psi}$

$$
\begin{aligned}
& \sigma_{b}=\frac{1}{5} \times 25000=8333 \cdot P_{s i}=10,000 \\
& \text { or }=\frac{1}{5} \times 75000=14000 P_{s i} \\
& \text { Use } \frac{\nabla_{b}=8335 P_{s i}}{10,000}
\end{aligned}
$$

Allowable stress in Weld

$$
\begin{aligned}
& \text { ( } \operatorname{REF} 3 \mid \text { shear Capacity }=\left(\frac{2}{3}\right) \text { (Tension Capacity) } \\
& \therefore f_{\omega}=\left(\frac{2}{3}\right)(11600)(\omega)^{\text {size } 6 f \text { could }}=7733(\omega) \mathrm{H} / \mathrm{in}(c s) \\
& f_{\omega}=(2 / 3)(8333)(\omega)=5555(\omega) W_{\text {in }} \text { (sST) }
\end{aligned}
$$


Calculation

Table LSIgn Convention for Stresses Resulting from Radial and Moment Loading on a Cylindrical Shell

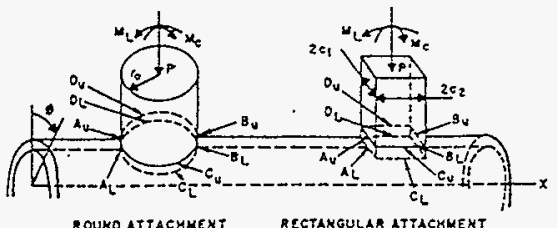

ROUNOATTACMHEXT RECTAKGULAR ATTACKMENT

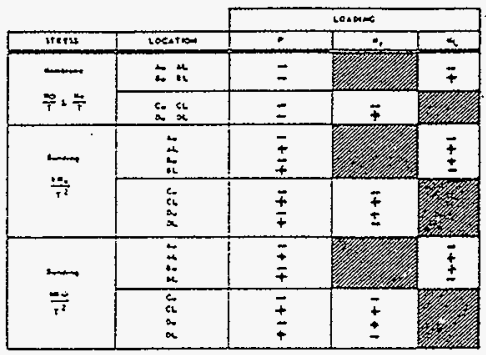

mic

tensile bending stresses result at $A$ and $C$ on the inside of the vessel, and $B$ and $D$ on the outside of the vessel. Similarly, compressive bending streses result at $A$ and $C$ on the outside and $B$ and $D$ on the inside.

In this manner Table 4 has been developed to show the signs of stresses resulting from various external loading conditions. These stresses are located in the vessel wall at its juncture with the at. tachment. Use of Table 4 permits one to use the nondimensional curves presented in the following procedure with a minimum of encumbency and concern for sign convention.

The numerous stress components can be readily accourated for if a scheme similar to that shown in Table 5 is adopted. In using this scheme it is to be noted that the Maximum Shear Theory has been used to determine equivalent stress intensities. Also it is to be noted that evaluation of stresses resulting from internal pressure has been omitted.

Test work conducted by PVRC has shown that streses attenuate rapidly at points removed from the attachment-to-shell juncture, the maximum stress usually being locsted at the juncture. However, in the general case of arbitrary loading, one has no assurance that the absolute maximum stress intensity will be located at one of the eight points considered in the above discussion. The maximum stress intensity could be located at some intermediate point around the juncture under an arbitrary load, of under a longitudinal moment with the circumstances outlined in para. 4.4 and
Appendix A.

\subsection{Parameters}

The results of Bijlaard's work have been plotted in terms of nondimensional geometric parameters by use of an electronic computer. Hence, the first step in this procedure is to evaluate the applicable geometric parameters $\gamma$ and 8 .

4.2.1 Stell Parameter $(\gamma)$. The shell parameter is given by the ratio of the shell mid-radius to shell thickness thus:

$$
y=R_{m} / T
$$

4.2.2 Attachment PARAMETER ( $\beta$ ). For cylindrical shells, either round or rectangular attachments may be considered in the following manner:

4.2.2.1 Round Attachment: For a round attachment the parameter $\beta$ is evaluated using the expression:

$$
\beta=\frac{0.875 r_{\prime \prime}}{R_{m}}
$$

4.2.2.2 Square Attachment: For a square attachment the parameter is evaluated by:

$$
\beta=\beta_{1}=\beta_{*}=\stackrel{c_{1}}{R_{4}}=\frac{c_{t}}{R_{n}}
$$

4.2.2.3 Rectangular Attachment Subject to Radial Load $(P)$ : For this case 3 is evaluated as follows:

$$
\beta_{1}=\frac{c_{1}}{R_{m}} \quad \beta_{z}=\frac{c_{z}}{R_{*}}
$$

If $\underset{\beta}{\beta_{1}}>1, \beta=$

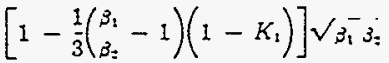

If $\underset{\beta_{1}}{\beta_{1}}<1, \beta=$

$$
\left[1-\frac{4}{3}\left(1-\frac{\beta_{2}}{\beta_{z}}\right)\left(1-K_{z}\right)\right] \sqrt{\beta_{1} \beta_{z}}
$$

where $K$ values are obtained from Table 6.

\subsubsection{Rectangular Attaci:ment Subject to Circum-} ferential Moment (Ka:

4.2.2.4.1: When considering membrane forces $\left(N_{t}\right): \beta=\sqrt{\beta_{1}}: \beta_{*}$. Then multiply values of $N_{t} /\left(M_{e} / R_{m}: \beta\right)$ so determined by $C_{c}$ from Table 7 (see para. 4.3).

4.2.2.4.2: When considering bending moment $\left(M_{1}\right): \beta=K, \mathfrak{V}_{\beta_{1}}^{*} \beta_{\text {: }}$ where $K$, is given in Table 7 .

4.2.2.5 Rectangular Attachment Subject to Langitudinal Moment $\left(M_{L}\right)$.

4.2.2.5.1: When considering membrane forces $\left(N_{1}\right): \beta=\sqrt[1]{\beta_{1} \beta_{:}:}$. Then multiplv values of 
Table 6-Radial Load (P)

$\begin{array}{lllll} & N . & N & M, & M, \\ K_{1} & 0.91 & 1.68 & 1.76 & 1.2 \\ K_{*} & 1.48 & 1.2 & 0.88 & 1.25\end{array}$

NOTE: Above holds approximately within limits $4 \geq$ $\beta_{1} / \beta_{0} \geq / / d$.

- calculated in para.4.2, entor Fig.3C or $4 \mathrm{C}$ and read off the dimensionless. membrane force $\left[N_{o i}: P: R_{m}\right)$.

Step 2. By the same procedure used in Step 1 . enter Fig. $1 \mathrm{C}$ or $2 \mathrm{C}-1$ and find the dimensionless bending moment $\left\{M_{\circ}, P\right\}$.

Step 3. Using applicable values of $P, R_{m}$, and $T$, find the circumfercntial membrane stress $\left(N_{4} / T\right)$ by:

$$
\stackrel{N_{*}}{T}=\left[\stackrel{N_{*}}{P_{i}}\right] \cdot\left[\frac{P}{R_{m}}\right]
$$

Step 4. By a procedure similar to that used in Step 3 , find the circumferential bending stress $\left(6 M, / T^{2}\right)$ thus:

$$
\frac{6 M}{T:}=\left[\frac{M_{*}}{P}\right] \cdot\left[\frac{6 P}{T^{*}}\right] .
$$

Step 5. Combine the circumferential membrane and bending stresses by use of the general stress equation (Section 2), together with the proper choice of sign (Table 4); i.e.:

$$
\sigma_{*}=K_{*} \frac{N_{*}}{T}=K_{b} \frac{6 M}{T^{*}}
$$

4.3.1.2 Longitudinal Stresses $\left(\sigma_{x}\right):$ Follow the 5 steps outlined in 4.3.1.1 except that $\left[N_{s} / P / R_{m}\right]$ is obtained using Fig. $3 \mathrm{C}$ or $f C_{\text {; }}$ and $\left\{M_{3} / P \mid\right.$, using Fig.1C-1. or 2C, It follows that:

$$
\begin{gathered}
\frac{N_{z}}{T}=\left[\frac{N_{z}}{P_{1} R_{m}}\right] \cdot\left[\frac{P}{R_{m} T}\right], \\
\frac{6 M_{I}}{T^{2}}=\left[\frac{M_{z}}{P}\right] \cdot\left[\frac{6 P}{T^{2}}\right] \text { and } \\
\sigma_{I}=K_{*} \frac{N_{z}}{T} \pm K_{0} \frac{6 M_{z}}{T^{2}}
\end{gathered}
$$

\subsubsection{Stresses ResultiNG FROM. CIRCUMFEREN-} TIAL MOBENT, $M$.

\subsubsection{Circumferential Stresses $\left(\sigma_{\oplus}\right)$ :}

Step 1. Using the applicable values of $\beta$ ard $\gamma$ calculated in para. 4.2, enter Fig. $3 A$ and read off the dimensionless membrane force $N_{0} /\left(M_{c} / R_{m}^{2} \beta\right)$.

\begin{tabular}{|c|c|c|c|c|c|c|}
\hline \multicolumn{7}{|c|}{ Tablo T-Circumforontial Moment $\left(H_{c}\right)$} \\
\hline \multirow{5}{*}{${ }^{3}{ }_{1}{ }^{3}=$} & & $K$, for $\theta$ & $K_{r}$ for $M$ & $K_{c}$ for $M_{s}$ & $C_{c}$ for $N_{*}$ & $C_{c}$ for $N_{z}$ \\
\hline & 15 & 1.09 & 1. 31 & 1.84 & 0.31 & 0.49 \\
\hline & 50 & 1.04 & 1.24 & 1.62 & 0.21 & 0.46 \\
\hline & 100 & 0.97 & 1.16 & 1.45 & 0.15 & 0.44 \\
\hline & 300 & 0.92 & 1.02 & 1.17 & 0.09 & 0.46 \\
\hline \multirow[t]{4}{*}{$\therefore$} & 15 & 1.00 & 1.09 & 1.36 & 0.64 & 0.75 \\
\hline & 50 & 0.98 & I. .08 & 1.31 & 0.57 & 0.75 \\
\hline & 100 & 0.94 & 1.04 & 1.26 & 0.51 & 0.76 \\
\hline & 300 & 0.95 & 0.99 & 1.13 & 0.39 & 0.77 \\
\hline \multirow[t]{3}{*}{2} & 15 & $(1.00)$ & $(1.20)$ & $(0.97)$ & $(1.7)$ & (1.3) \\
\hline & 100 & 1.19 & 1.10 & 0.95 & 1.43 & 1.12 \\
\hline & 300 & & (I.00) & $(0.90)$ & (1.3) & $(1.00)$ \\
\hline \multirow[t]{3}{*}{4} & 15 & $(1.00)$ & $(1.47)$ & (1.08) & (1.75) & (1.31) \\
\hline & 100 & 1.49 & 1.38 & 1.06 & 1.49 & 0.81 \\
\hline & 300 & $\ldots$ & $(1,27)$ & $(0.98)$ & (1.36) & $(0.74)$ \\
\hline
\end{tabular}

Step 2. By the same procedure used in Step 1, enter Fig. $1 \mathrm{~A}$ and find the dimensionless bending moment $M_{*} /\left(M_{d} / R_{m} \beta\right)$.

Step 3. Using applicable values of $M_{c}, R_{m}, \beta$

Nore: The values in parenthesis determined by an approximate solution.

$B_{2} / ?_{1}^{3}$

$\because$

$\therefore$

2

4
Table 8-Longitudinal Moment ( $\mathrm{MH}_{H}$ )

$\begin{array}{ccc}K_{L} \text { for } & K_{L} \text { for } M_{0} & K_{L} \text { for } M_{T} \\ 1.14 & 1.80 & 1.24 \\ 1.13 & 1.65 & 1.16 \\ 1.18 & 1.59 & 1.11 \\ 1.31 & 1.56 & 1.11 \\ (1.00) & (1.08) & (1.04) \\ 1.00 & 1.07 & 1.02 \\ (1.00) & (1.05) & (1.02) \\ \ldots 1.09 & (0.94) & (1.12) \\ \ldots 9 & 0.89 & 1.07 \\ 1.39 & (0.79) & (0.90) \\ 1.18 & 0.90 & 1.24 \\ \ldots & 0.81 & 1.12 \\ & (0.64) & (0.83)\end{array}$

$C_{6}$ for $N$
0.75
0.77
0.80
0.90
$(0.90)$
0.97
$(1.10)$
$(0.87)$
0.81
$(0.80)$
0.68
0.51
$(0.50)$

$C_{4}$ for $N_{6}$

0.77

0.80

0.90

0.97

$(1.10)$

0.81

0.80 )

0.51

$(0.50)$
(2)

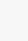




\section{Calculation w320-27-053}

2.

30

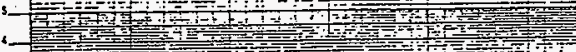

2.

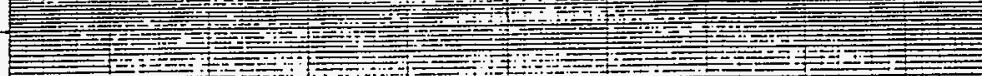
E

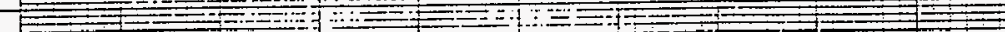

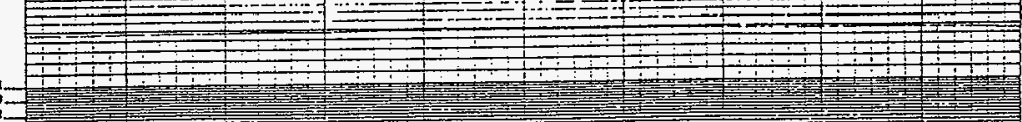

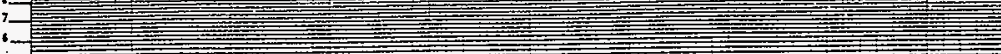

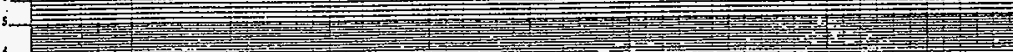

41,12

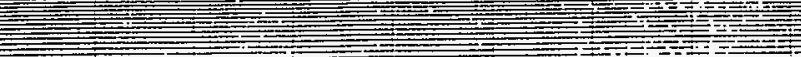

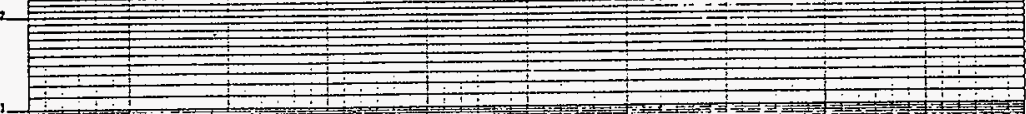

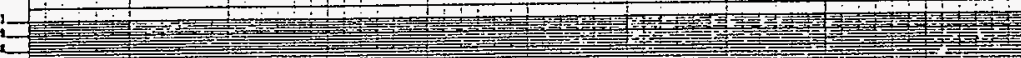

4

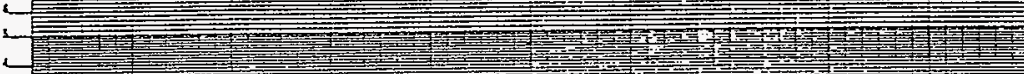

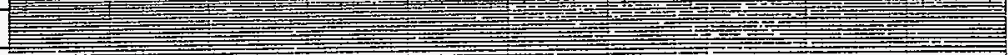

21

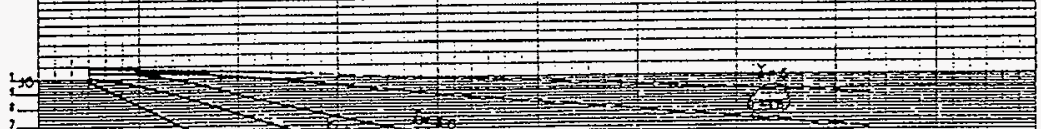

,

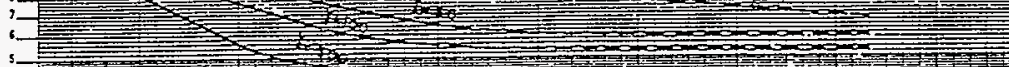

3023
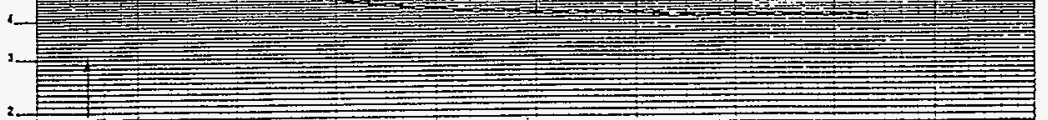

2.

E

E.je

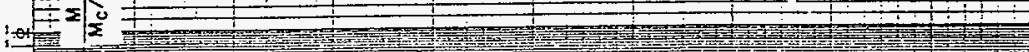

3

30

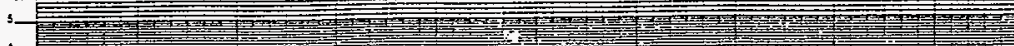

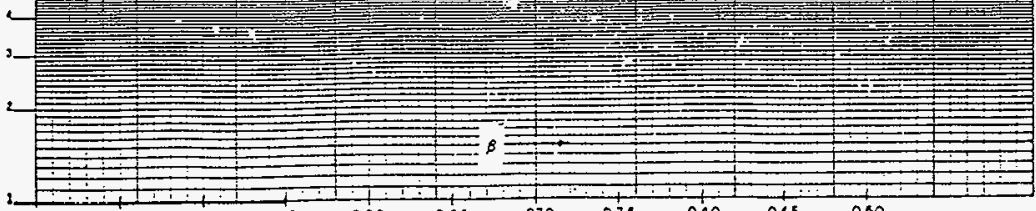

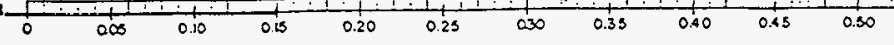

Fig. $2 A-M o m e n t M_{*} /\left(M_{1} / R_{m} 3\right)$ due to an external circurnterential momen: $M$. on a circular cylinder 


\section{Calculation ن $320-27-053$}

$B-14$

(1)

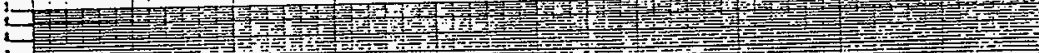

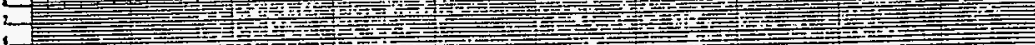

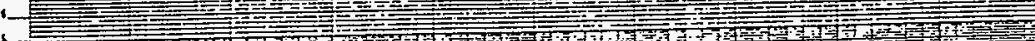

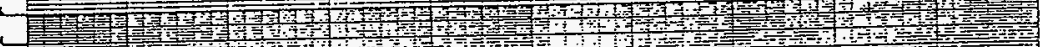
4.

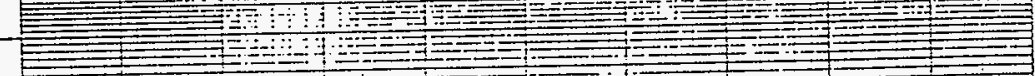

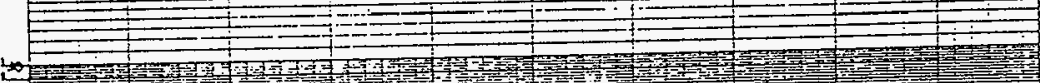

if

.

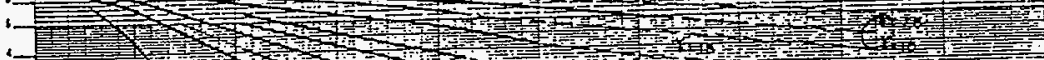
1

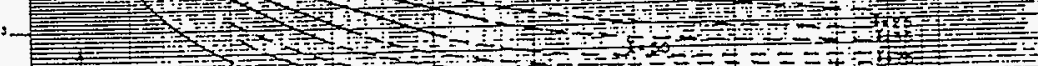

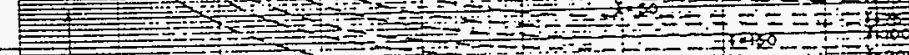

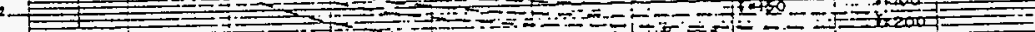

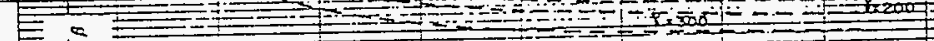

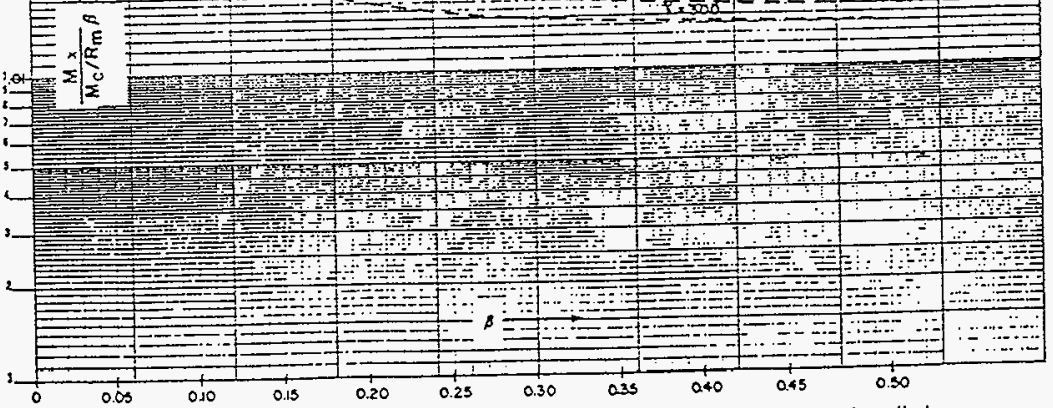

Fig. 2A-Moment $M_{1} /\left(M_{2} / R_{c} s\right)^{\circ}$. due to an external circumferentiai moment $M_{c}$ on a circular cylintior 


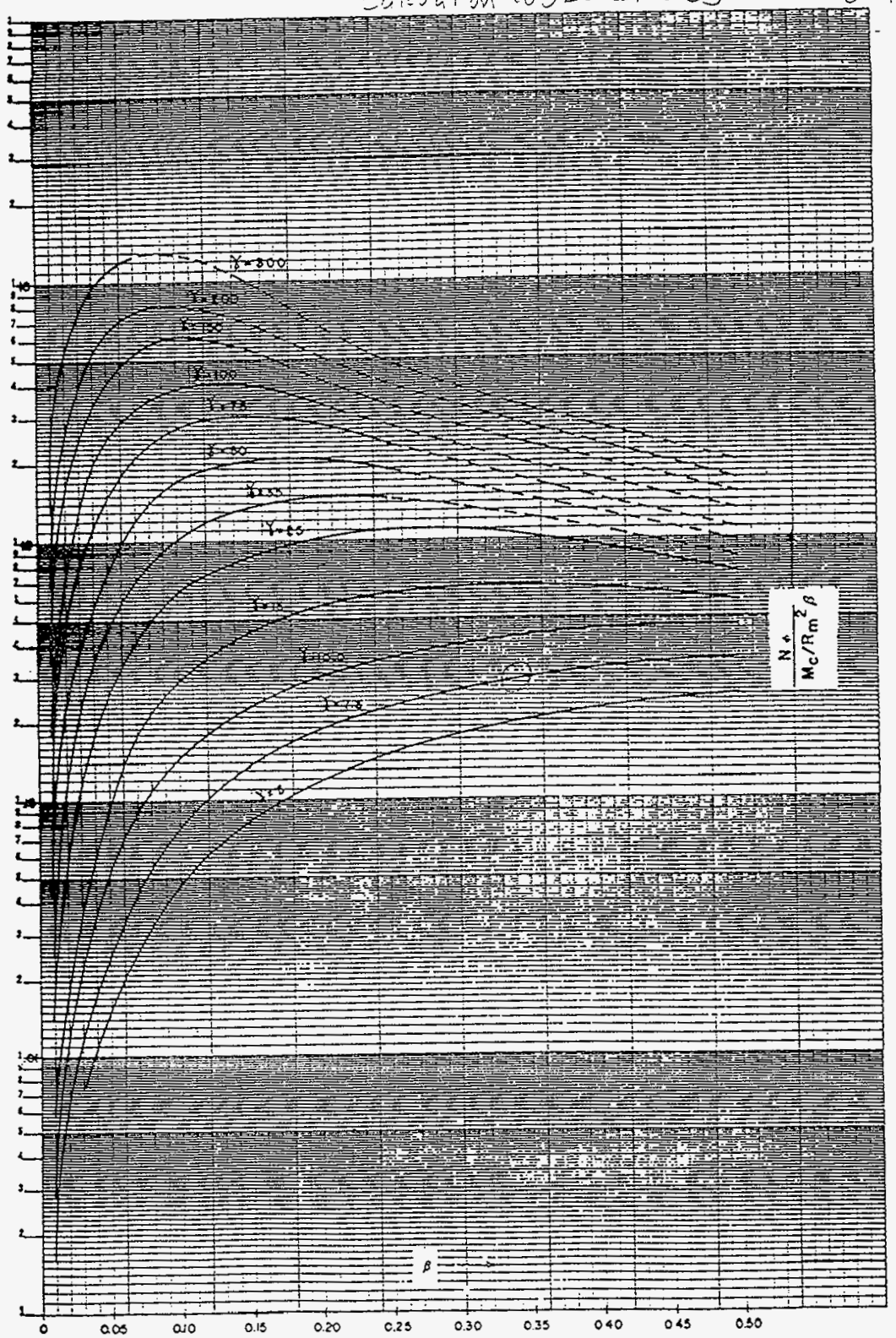

Fig. $3 A-M e m b r a n e$ force $N_{0} /\left(M_{1} / R_{n}: s\right)$ due to an external circumferential moment $M_{s}$ on a circular cylinder 


\section{Calculation w320-27-053 \\ $B-16$ of $B-19$}
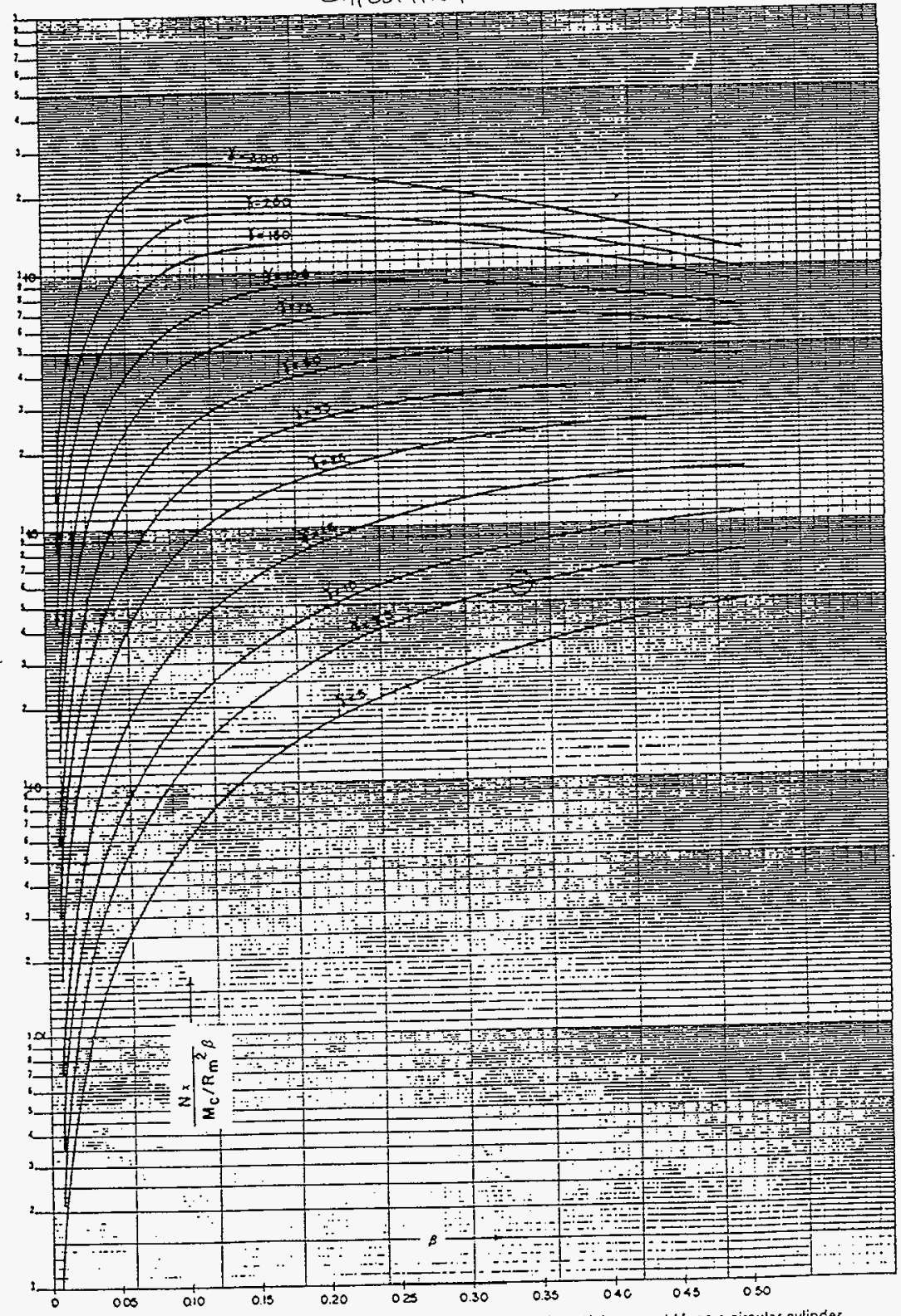

Fig. 4A-Membrane force $N_{s} /\left(M_{c} / R_{m}^{2} \beta\right)$ due to an external circumierential moment $M_{s}$ on a circular cytinder 


\section{Calcution w320-27.053}

$13-17$ of $18-19$
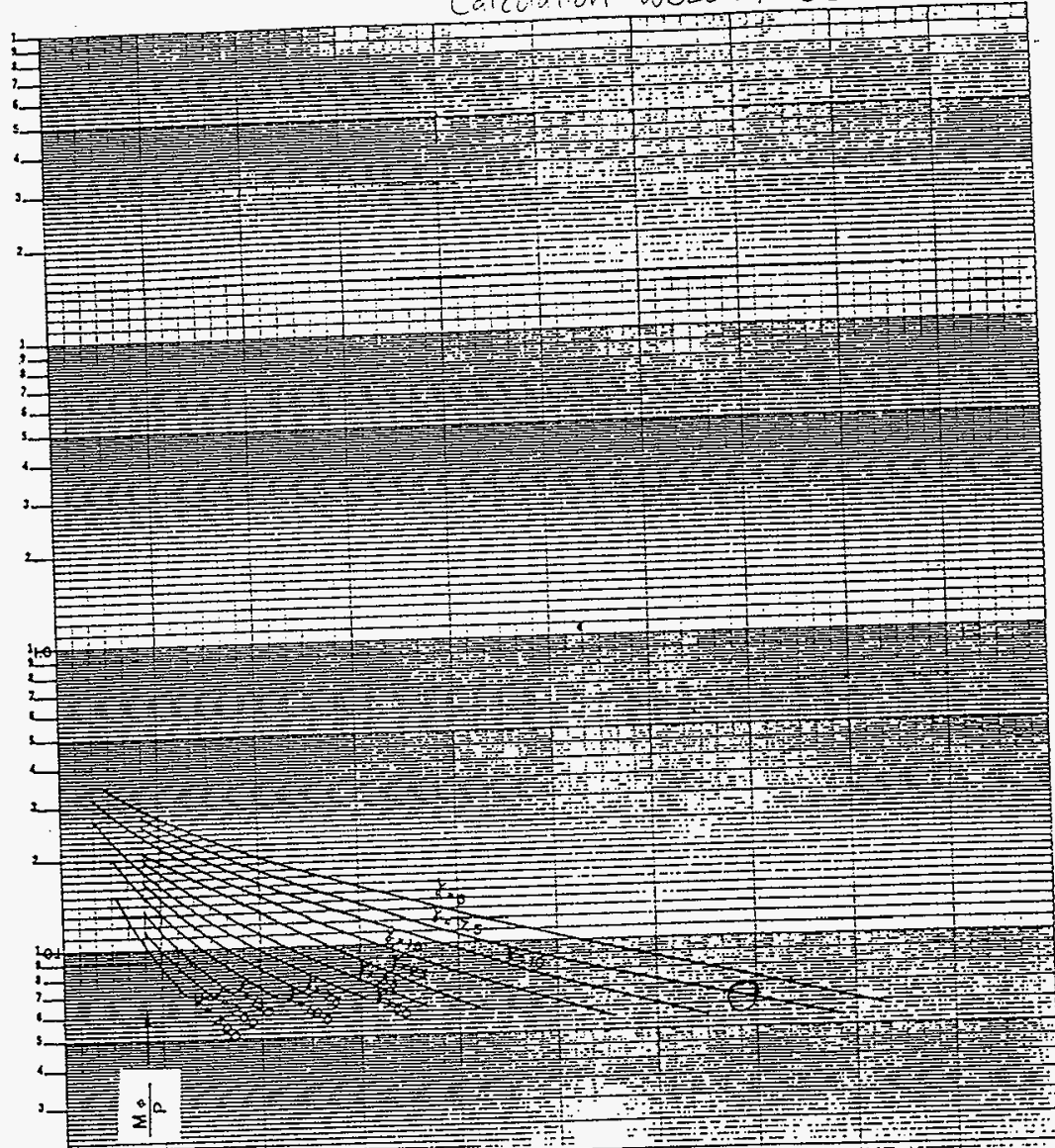

2.

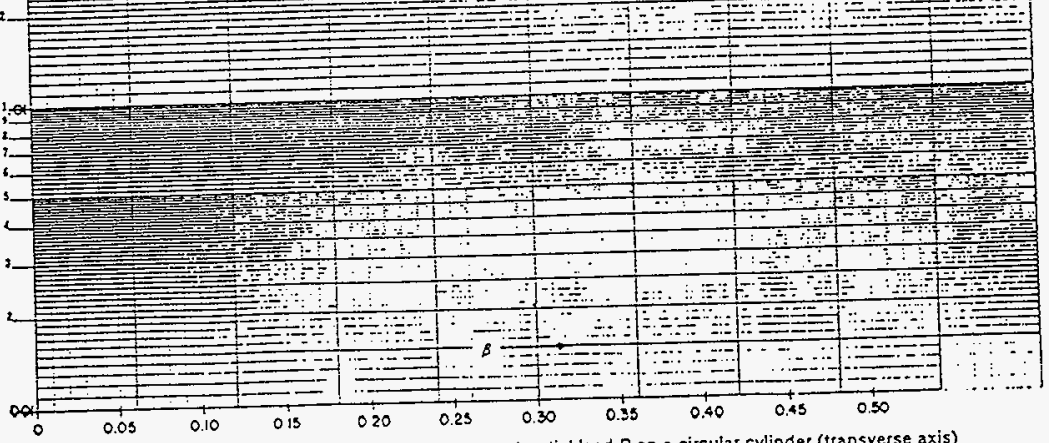

Fig. $1 C-$ Bending moment $M_{\odot} / P$ ove to an external radial load $P$ on a circular cylinder (transverse axis) 
$\leadsto 1$ 


\section{Calculation W320-27-053}

$B-19$ of $B-19$

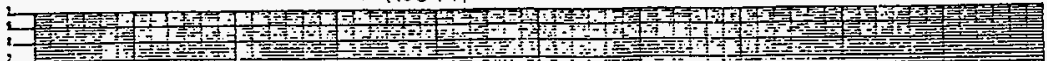
, 年 -

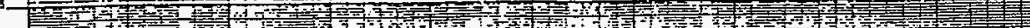
4 壁-

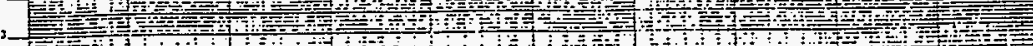
1

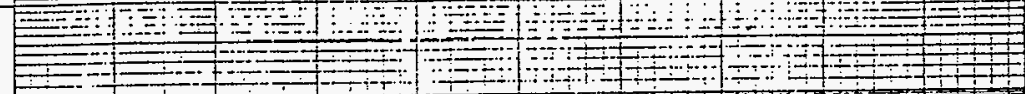

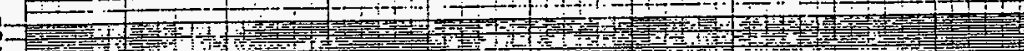

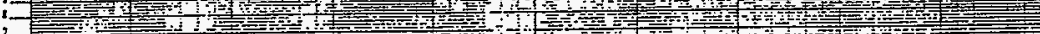

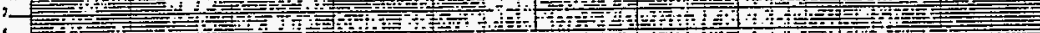
,

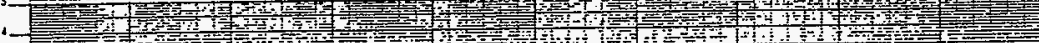

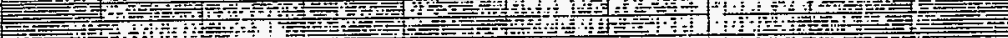

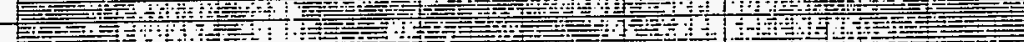

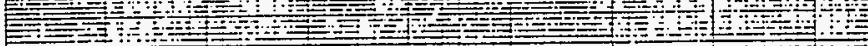

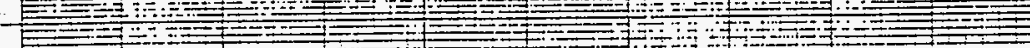

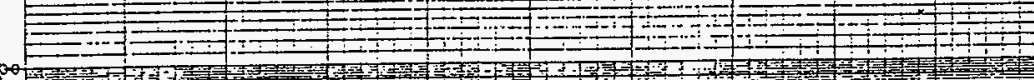

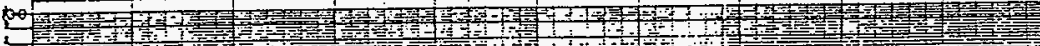

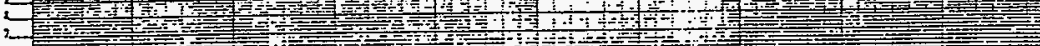

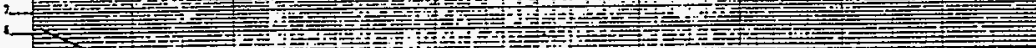

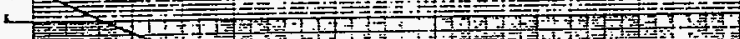

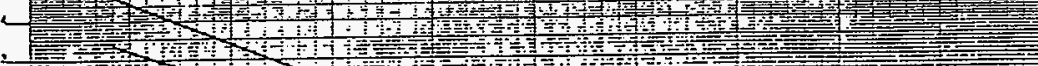
年

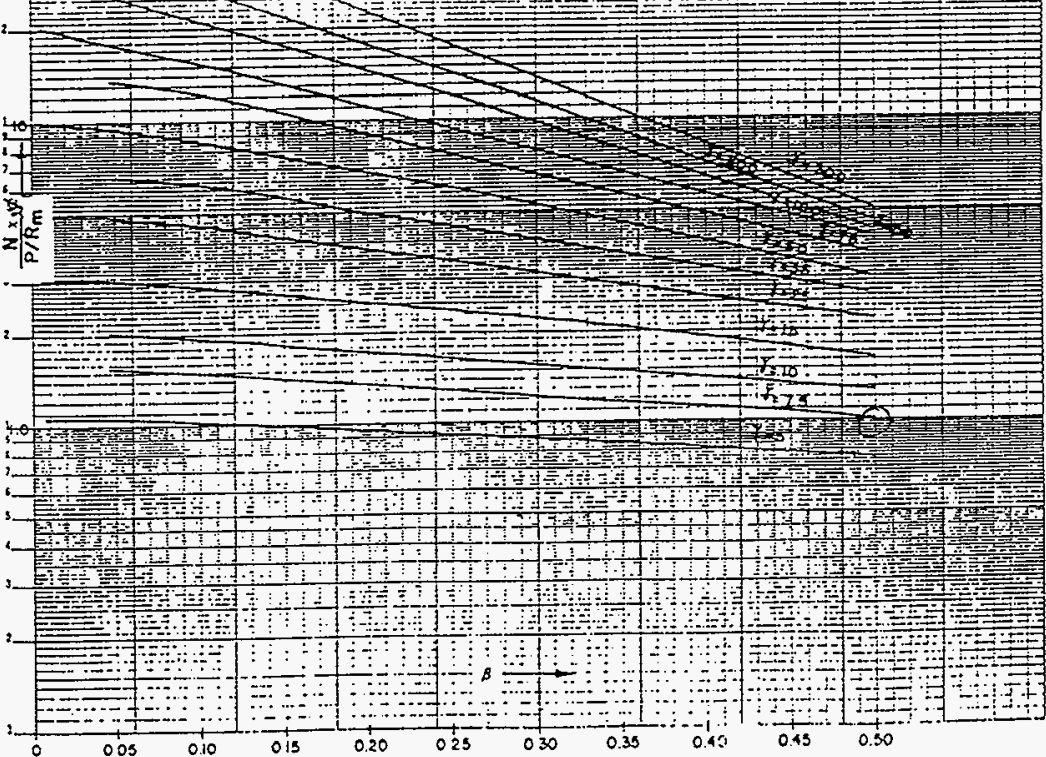

Fig. $4 \mathrm{C}$-Membrane force $N_{x}\left(P / R_{+1}\right)$ due to an external radial loao $P$ in a citcular cylinder (transverse axis) $\rightarrow$ Membrane Jorce $N\left(P / R_{-}\right)$óve to an external radial boso $R$ an a circular cylinder (longltud Inal axis? 
HNF-2479, Rev. 0

W320-27-54

System Curves for Portable Exhauster Installation

$E-i$ 
This sheet shows the status and description of the attached Design Analysis sheets.

Discipline: (27) Piping

WO/Job No.: ER4319M-320

Calculation No: W320-27-054

Project No. \& Name: W-320 Tank 241-C-106 Waste Retrieval

Calculation ltem: System Curves for Portable Exhauster Installation

These calculations apply to:

Dwg. No: See References

Rev. No.

Dwg. No.:

Rev. No.

Other (Study, CDR):

Rev. No.

The status of these calculations is:

I] Preliminary Calculations

[X] Final Calculations

[] Check Calculations (On Calculation Dated)

[] Void Calculation (Reason Voided)

Incorporated in Final Drawings?

[X] Yes [] No

This calculation verified by independent "check" calculations?

[] Yes [X] No

Original and Revised Calculation Approvals:

\begin{tabular}{|c|c|c|c|}
\hline & $\begin{array}{c}\text { Rev. } 0 \\
\text { Signature/Date }\end{array}$ & $\begin{array}{c}\text { Rev. } 1 \\
\text { Signature/Date }\end{array}$ & $\begin{array}{c}\text { Rev. } 2 \\
\text { Signature/Date }\end{array}$ \\
\hline Originator & Relle Vhttanese $2 / 18 / 98$ & . & \\
\hline Checked by & & & \\
\hline Approved by & & & \\
\hline $\begin{array}{l}\text { Checked Against } \\
\text { Approved Vendor Data }\end{array}$ & A & & \\
\hline
\end{tabular}

\begin{tabular}{|c|l|}
\hline $\begin{array}{c}\text { Design Analysis } \\
\text { Page No. }\end{array}$ & Objective, Design Inputs, References, Conclusions \\
\hline $1-2$ & Calculations \\
\hline $3-4$ & Appendix A - System Curves \\
\hline A-1 to A-5 & Appendix B - Pipe-Flo Model ANNULUS2 \\
\hline B-1 to B-11 & Appendix C - Pipe-Flo results of ANNULUS2 \\
\hline C-1 to C-13 & Appendix D - Pipe-Flo Model ANNULUS \\
\hline D-1 to D-20 & Appendix E - Pipe-Flo results of ANNUULUS \\
\hline E-1 to E-13 & Appendix F - Pipe-Flo Model ANNU-PEX \\
\hline F-1 to F-15 & Appendix G - Pipe-Flo results of ANNU-PEX \\
\hline G-1 to G-13 & Appendix H - References \\
\hline H-1 to H-2
\end{tabular}




\begin{tabular}{|c|c|c|c|c|c|c|c|c|c|c|}
\hline \multicolumn{10}{|c|}{$\begin{array}{l}\text { CALCULATION CROSS INDEX (Typical) } \\
\text { Subject Calculation No:: W320-27-054 }\end{array}$} & \multirow{3}{*}{$\begin{array}{l}\text { Page ii of } i i \\
\begin{array}{c}\text { Discipline manager's sinnature and } \\
\text { dale indicating evaluation } \\
\text { complete. }\end{array}\end{array}$} \\
\hline \multirow[t]{2}{*}{$\begin{array}{l}\text { Subject } \\
\text { Calculation } \\
\text { Revision } \\
\text { No. }\end{array}$} & \multirow[t]{2}{*}{$\begin{array}{l}\text { Superceded } \\
\text { by } \\
\text { Calculation } \\
\text { No. }\end{array}$} & \multicolumn{2}{|c|}{$\begin{array}{l}\text { These interiacing calculation/documents } \\
\text { provididinut to the subbiect calaculation, } \\
\text { and if revised may require revision of } \\
\text { the subject calculatation. }\end{array}$} & \multicolumn{2}{|c|}{$\begin{array}{l}\text { Results and conclusions of the subject } \\
\text { calculation are used in these interfacing } \\
\text { calculations andfor documents }\end{array}$} & \multicolumn{2}{|c|}{$\begin{array}{l}\text { Does the output } \\
\text { interface calculationt } \\
\text { documents require } \\
\text { revision? }\end{array}$} & \multicolumn{2}{|c|}{$\begin{array}{l}\text { Has the output } \\
\text { interfacecalculationt } \\
\text { documents been } \\
\text { revised? }\end{array}$} & \\
\hline & & Calculation/Document No. & $\begin{array}{c}\text { Revision } \\
\text { No. }\end{array}$ & Calculation/Document No. & $\begin{array}{l}\text { Revision } \\
\text { No. }\end{array}$ & Yes & No & res & No & \\
\hline 0 & NA & $\mathrm{H}-2-64307$, Sheet 1 & 4 & NA & & & - & & r & 1 \\
\hline & & $\mathrm{H}-2-77324$, Sheet 1 & 2 & & & & - & & - & \\
\hline & & $\mathrm{H}-2-77325$, Sheet 1 & 1 & & & & - & & - & \\
\hline & & H-2-77326, Sheet 1 & 2 & & & & - & & - & \\
\hline & & H-2-77326, Sheet 2 & 2 & & & & - & & - & D.L. $2=-\sigma^{7}=148$ \\
\hline & & H-2-77326, Sheet 3 & 2 & & & & - & & - & j \\
\hline & & H-2-818506, Sheet 1 & $\sigma^{1}$ & & & & - & & 2 & \\
\hline & & H-2-818506, Sheet 2 & $\theta^{1}$ & & & & - & & \llcorner & \\
\hline & & H-2-818507, Sheet 1 & 81 & & & & r & & - & \\
\hline & & H-2-818507, Sheet 2 & 01 & & & & - & & $e$ & \\
\hline & & H-2-818507, Sheet 4 & 01 & & & & $e$ & & - & 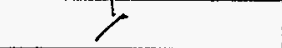 \\
\hline & & & & & & & & & & \\
\hline & & & & & & & & & & \\
\hline & & & & & & & & & & \\
\hline & & & & & & & & & & \\
\hline & & & & & & & & & & \\
\hline & & & & & & & & & & \\
\hline & & & & & & & & & & \\
\hline & & & & & & & & & & \\
\hline
\end{tabular}


Client: Numatec

Subject: System Curves for Portable Exhauster Installation

Location: 241-C/241-AY
WO/Job No:: ER4319N-320

Date: $2 / 18 / 98$

Checked: $3 / 2198$

Revised:
By: Kelly Hayase By: Kewi Cart

By:

\section{OB.JECTIVE:}

The objective of this calculation is to generate the system curves for the portable exhauster installation. There are three scenarios for installing the portable exhauster; exhaust the dome space for Tank 241-C-106, exhaust the dome space for Tank 241-AY-102, and exhaust the annulus for Tank 241-AY-102.

\section{DESIGN INPUTS:}

CRITERIA AND SOURCE:

1. HNF-SD-W320-FDC-001, Rev. 4

\section{GIVEN OR KNOWN DATA:}

1. The existing configuration of the annulus vent piping and under tank air distribution channels.

2. Test data of flow rate versus annulus vacuum pressure. (Ref. \#4)

\section{ASSUMPTIONS:}

1. The air shall be assumed to be $50^{\circ} \mathrm{F}$. This is consistent with the test data of flow rate versus annulus vacuum pressure. Note: higher air temperatures would result in lower pressure drops because of the lower air density, and vise versa.

\section{METHODS TO BE USED:}

The computer program Pipe-Flo (Ref. \#2) shall be used for this calculation. Pipe-Flo uses the DarcyWeisbach equation to calculate the pressure drop in a pipe. Refer to the Pipe-Flo manual for a more detailed discussion of the methods used by the program.

\section{REFERENCES/SOURCES:}

1. HNF-SD-W320-FDC-001, Rev. 4.

2. Pipe-Flo Computer Program Version 5.01, by Engineered Software Inc.

3. Crane Technical Paper No. 410, 1991.

4. CC:Mail message from Steve Shaw (1/26/98) discussing test data. (Appendix $\mathrm{H}-1$ )

5. HNF-SD-W320-ER-002, Rev. 0, "Project W-320 Thermal Evaluation" (Appendix H-2) 
Client: Numatec

Subject: System Curves for Portable Exhauster Installation
WOIJob No:: ER4319N-320

Date: $2 / 18 / 98$

Checked: $3 / 2 / 98$

By: Kelly Hayase

By: Ken clot

Revised: By:

6. Drawing Numbers:

H-2-64307, Sheet 1, Rev. 4 H-2-77324, Sheet 1, Rev. 2 H-2-77325, Sheet 1, Rev. 1 H-2-77326, Sheet 1, Rev. 2 H-2-77326, Sheet 2, Rev. 2 H-2-77326, Sheet 3, Rev. 2 H-2-818506, Sheet 1, Rev. 0 H-2-818506, Sheet 2, Rev. 0 H-2-818507, Sheet 1, Rev. 0 H-2-818507, Sheet 2, Rev. 0 H-2-818507, Sheet 4, Rev. 0

\section{CONCLUSIONS:}

1. Figure A-1, Appendix $A$ shows the annulus vacuum versus annulus air flow rate as determined from this analysis. The test data points from Reference \#4 are also included to validate the results of the analysis. Upon comparison, the Pipe-Flo model closely represents the actual tested conditions. The annulus vacuum versus the air flow rate as determined from HNF-SD-W320-ER-002 (Ref. \#5) was plotted for information only.

2. The system curve for the portable exhauster connected to the dome space of Tanks $241-\mathrm{C}-106$ and 241-AY-102 is given in Figure A-2, Appendix A.

3. The system curve for the portable exhauster connected to the annulus of Tank 241-AY-102 is given in Figure A-3, Appendix A. 


\section{DESIGN ANALYSIS}

Page No.: 3 of 4

Client: Numatec

Subject: System Curves for Portable Exhauster Installation

Location: 241-C/241-AY
WO/Job No.: ER4319/W-320

Date: $2 / 18 / 98$

Checked: $3 / 2 / 98$

By: Kelly Hayase

By: Kar: Clot

Revised:

\section{CALCULATIONS:}

Discussion of the Pipe-Flo analysis:

1. The following properties of air was used for the analysis:

$\begin{array}{ll}\text { Temperature: } & 50^{\circ} \mathrm{F} \\ \text { Density: } & 0.0779 \mathrm{lb} / \mathrm{ft}^{3} \\ \text { Viscosity: } & 0.0176 \mathrm{cpois}\end{array}$

2. The rectangular slots of the air distribution system under the tank was modeled as pipe based on the equivalent diameter, $D_{e}$ of the rectangular cross section as follows:

For $a(a \times b)$ rectangle: $D_{e}=2 a b /(a+b)$

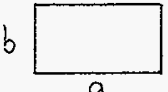

$$
\begin{aligned}
& \text { 3" } \times 1-1 / 2 " \text { rectangle: } \quad D_{e}=2(3)(1.5) /(3+1.5)=2 \text { in } \quad \text { Use 2" Sch } 40 \text { pipe } \\
& (d=2.067 \text { in) } \\
& 2 \text { " } \times 1-1 / 2 \text { " rectangle: } \quad D_{e}=2(2)(1.5) /(2+1.5)=1.71 \text { in } \\
& \text { Use 2" Sch } 160 \text { pipe } \\
& (\mathrm{d}=1.687 \mathrm{in}) \\
& 1-1 / 2^{\prime \prime} \times 1-1 / 2 \text { " rectangle: } \quad D_{\theta}=2(1.5)(1.5) /(1.5+1.5)=1.5 \mathrm{in} \\
& \text { Use 1-1/2" Sch } 80 \text { pipe } \\
& (d=1.5 \mathrm{in})
\end{aligned}
$$

3. The annulus was modeled as pipe based on the equivalent diameter, $D_{e}$ as follows:

For outer diameter $D_{0}$ and inner diameter $D_{i}: D_{6}=D_{0}-D_{i}$

$$
D_{\circ}=40^{\prime} \text { and } D_{i}=37.5^{\prime} \quad D_{e}=40-37.5=2.5 \mathrm{ft}=30 \text { in } \quad \begin{aligned}
& \text { Use 32" Sch } 40 \text { pipe } \\
& (d=30.624 \text { in })
\end{aligned}
$$

4. The air distribution system under the tank consists of three sections; an inner ring of 18 radial slots, a middle ring of 36 radial slots, and an outer ring of 72 radial slots. Therefore, for each inner slot, there are 2 middle slots and 4 outer slots. This pattern was modeled with pipe flow (Model name "ANNULUS2") to determine the pressure drop from the 1'-6" air distributor to the annulus for one of the 18 initial flow paths of the inner ring. The pressure drop was calculated for different flow rates of air and was multiplied to represent the pressure drop for the entire air distribution system.

5. The modeling of the remainder of the annulus vent piping was straight forward and did not require any simplifications. The four $6^{\prime \prime}$ drop legs to the $6^{\prime \prime}$ annulus nozzles are blocked and therefore not included in the analysis. 
Revision: 0

\section{DESIGN ANALYSIS}

Page No.: 4 of 4

Client: Numatec

Wo/Job No.: ER4319NW-320

Subject: System Curves for Portable Exhauster Installation

Date: $2 / 18 / 98$

Checked: $3 / 2 / 98$

By: Kelly Hayase,

Revised:

By: Ki:

Location: $241-\mathrm{C} / 241-\mathrm{AY}$

6. As determined from the analysis, there is no pressure drop resulting from air flow in the $1^{\prime}-6$ " air distributor or the annulus. The only pressure difference in the annulus is due to the $40 \mathrm{ft}$ change in elevation from the bottom of the annulus to the top.

7. Test data from Reference \# $4800 \mathrm{fpm}(984 \mathrm{cfm}) \quad$ 14" WG vacuum in annulus $850 \mathrm{fpm}(1045 \mathrm{cfm}) \quad 15^{\prime \prime}$ WG vacuum in annulus

8. The system curve for the portable exhauster connected to the dome space of Tanks 241-C-106 and 241-AY-102 was determined from the analysis of the portable exhauster connected to the annulus of Tank 241-AY-102. The pressure drop from the annulus to the portable exhauster skid intake from Pipe-Flo Model ANNU-PEX represents the pressure drop thru the riser and the flex duct. The pressure drop was added to the dome space vacuum to get the system curve for the portable exhauster connected to the dome space. Although the flex duct is $25 \mathrm{ft}$ longer connecting to the annulus than the dome space, this difference is not critical.

9. The 8 " ID flexible duct was modeled as 8 " Schedule 80 pipe (ID $=7.625^{\prime \prime}$ ) with a roughness factor equal to $0.018^{\prime \prime}$ (which is ten times that of steel). This was to account for the possible contraction of the duct ID under vacuum and the rough surface of the duct. 
ङ FLUOR DANIEL NORTHWEST INC.

\section{DESIGN ANALYSIS}

Calc. No.: W320-27-054

Revision: 0

Page No.: A-Oof A-5
Client: Numatec

Subject: System Curves for Portable Exhauster Installation
WO/Job No.: ER4319N-320

Date: $2 / 18 / 98$

Checked: $3 / 2 / 58$

Revised:
By: Kelly Hayase

By: Kri ceil

By:

\section{Appendix A System Curves}




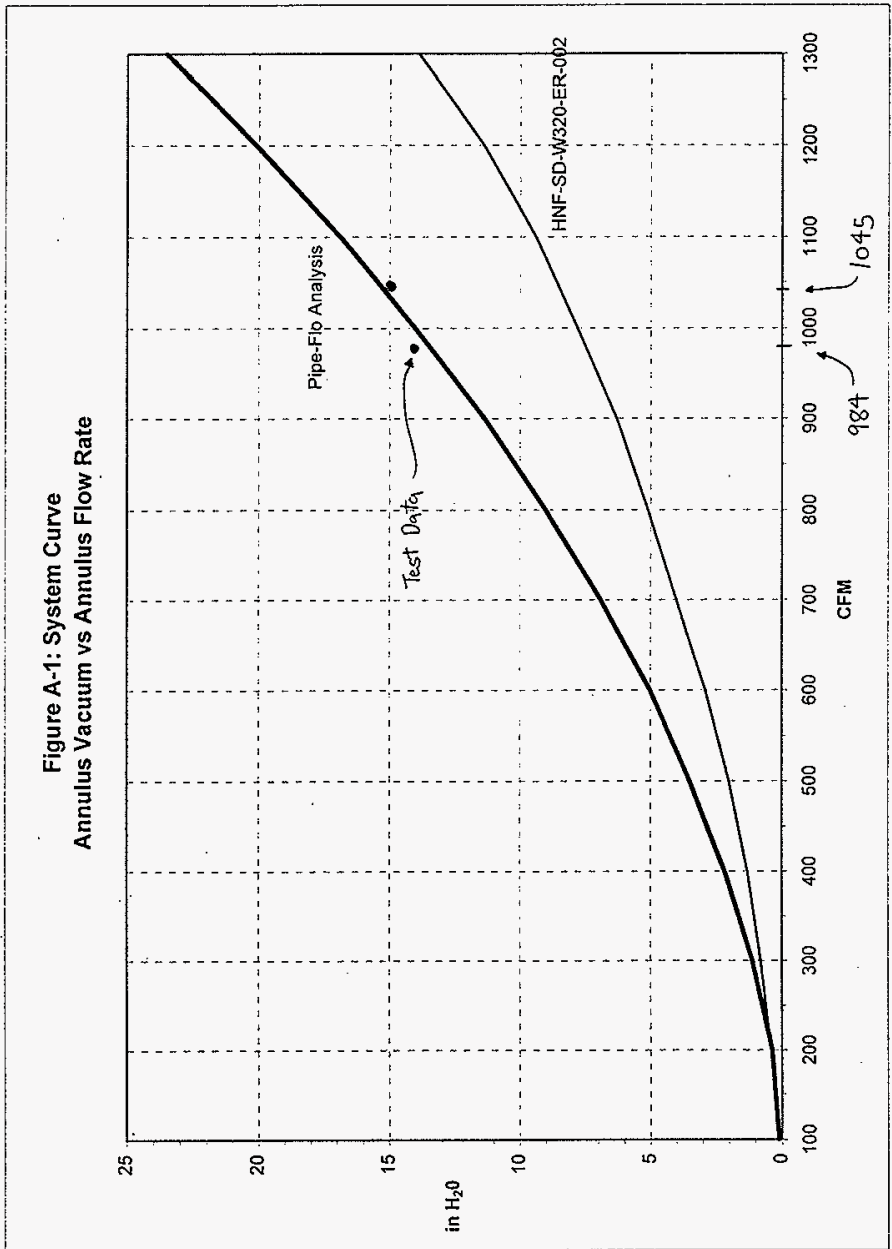

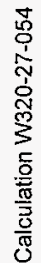

HNF-2479, Rev. 0 


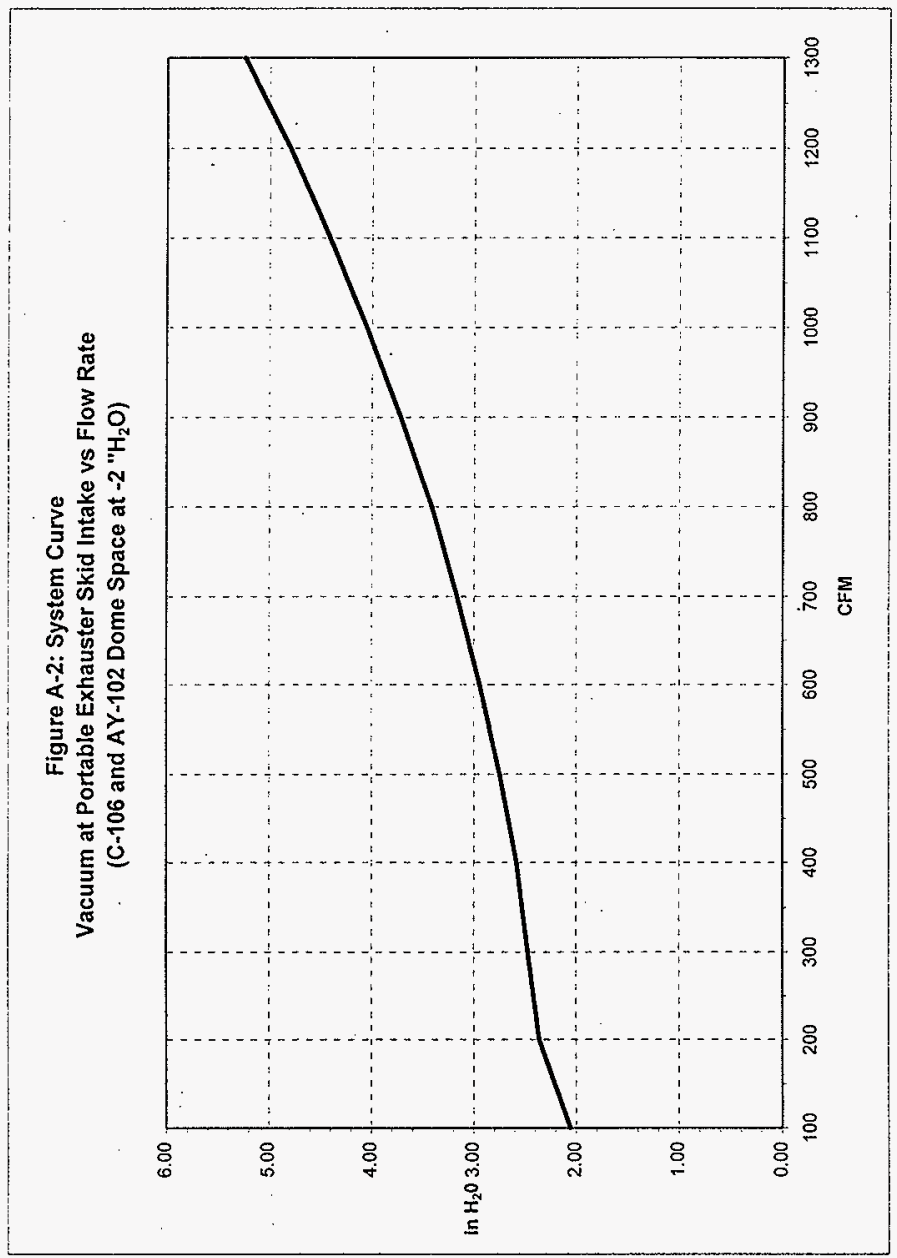

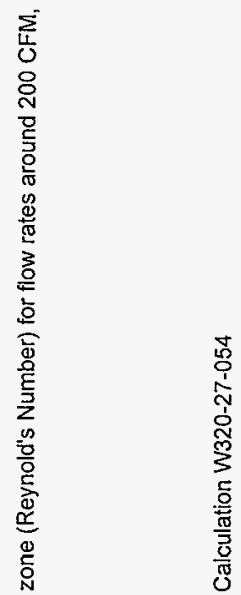




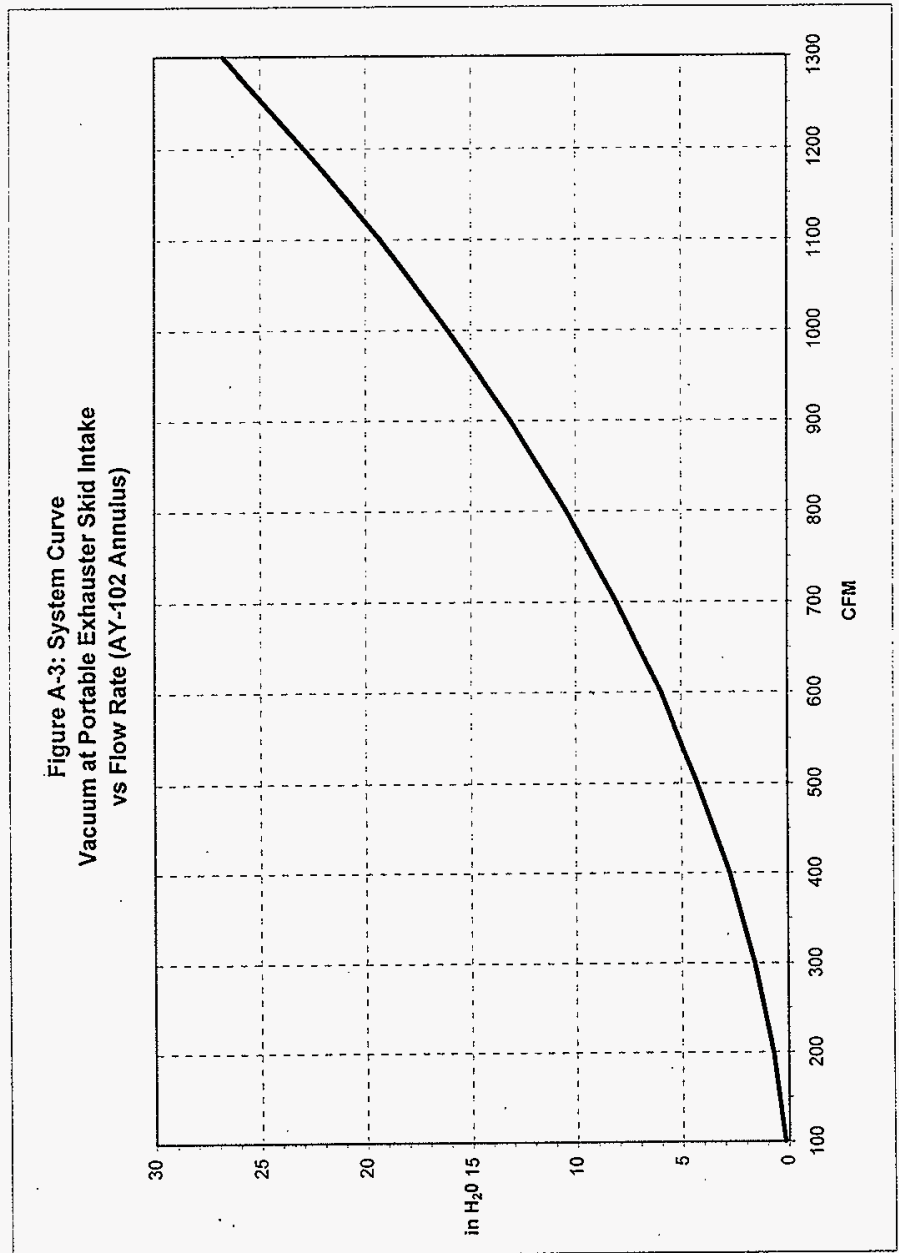

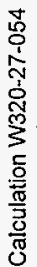




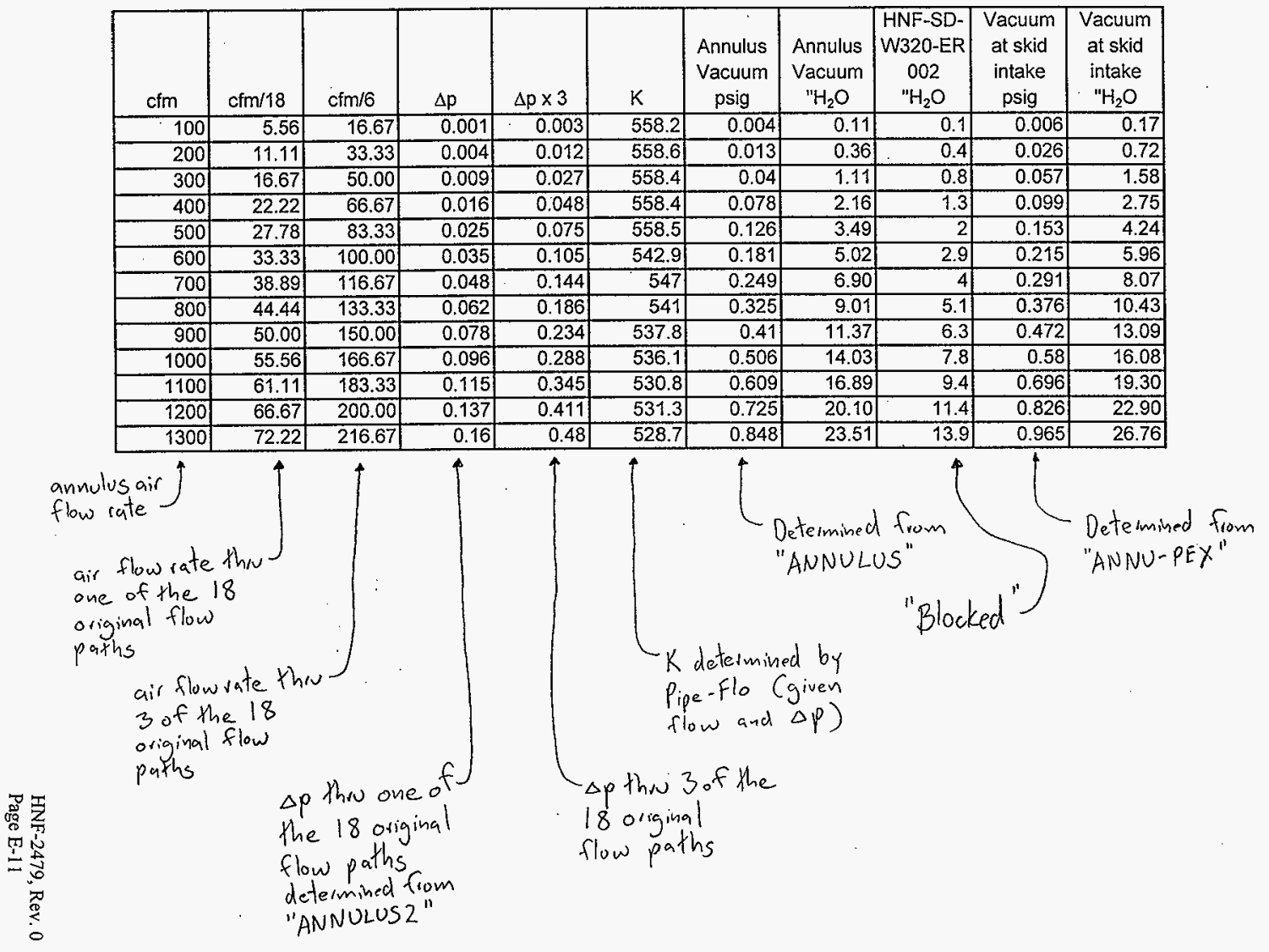




\begin{tabular}{|r|r|r|r|}
\hline scfm & $\begin{array}{c}\text { Tank } \\
\text { Vacuum } \\
\text { " } \mathrm{H}_{2} \mathrm{O}\end{array}$ & $\begin{array}{c}\Delta p \text { Thru } \\
\text { Hose }\end{array} \mathrm{H}_{2} \mathrm{O}$ & $\begin{array}{c}\text { Vacuum } \\
\text { at skid } \\
\text { intake } \\
\text { " } \mathrm{H}_{2} \mathrm{O}\end{array}$ \\
\hline 100 & 2 & 0.06 & 2.06 \\
\hline 200 & 2 & 0.36 & 2.36 \\
\hline 300 & 2 & 0.47 & 2.47 \\
\hline 400 & 2 & 0.58 & 2.58 \\
\hline 500 & 2 & 0.75 & 2.75 \\
\hline 600 & 2 & 0.94 & 2.94 \\
\hline 700 & 2 & 1.16 & 3.16 \\
\hline 800 & 2 & 1.41 & 3.41 \\
\hline 900 & 2 & 1.72 & 3.72 \\
\hline 1000 & 2 & 2.05 & 4.05 \\
\hline 1100 & 2 & 2.41 & 4.41 \\
\hline 1200 & 2 & 2.80 & 4.80 \\
\hline 1300 & 2 & 3.24 & 5.24 \\
\hline
\end{tabular}




\section{DESIGN ANALYSIS}

Page No: $B-O$ of $B-1 !$

Client: Numatec

Subject: System Curves for Portable Exhauster Installation

Location: $241-\mathrm{C} / 241-\mathrm{AY}$
Wolsob No.: ER4319N-320

Date: $2 / 18 / 98$

Checked: $3 / 2 / 18$

By: Kelly Hayase

By: Keiz

By:

Appendix B: Pipe-Flo Model ANNULUS2

HNF-2479, Rev. 0

Page E-I3 
:opedo a |ana|
oisd :ainsseid

w!o :ojed mol!

:dnau!7

:squatuturos

ZSก7กNNY :7s!|u!

we $9 \varepsilon: 6 \quad 86 / L L / Z 0$

MN lọueg jonıูy : : Kq

zjooloud

MN jolueg Lonj] :Kueduos

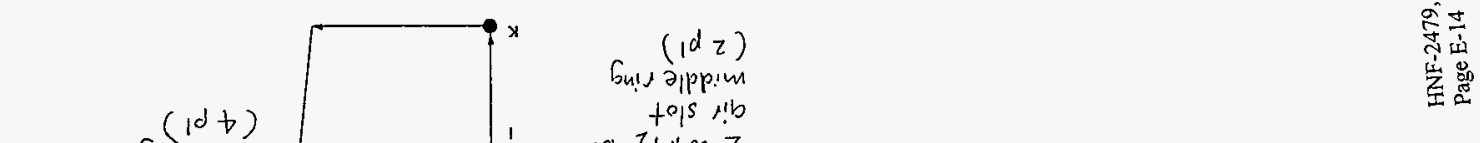

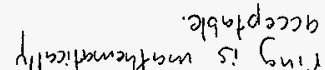
snonu! unos b fupnom s! bu!d argarayl oraz of 1yobo Ajoa:fbuayfum st thaubas

sint u! of mol me

Gu!l tatro teis jib

w

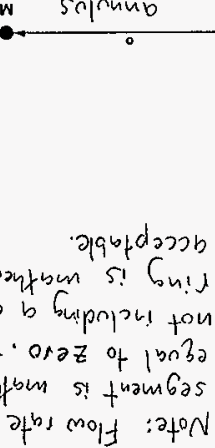

l $\quad d a z i x m_{n} z$

jotnq!:ts!p

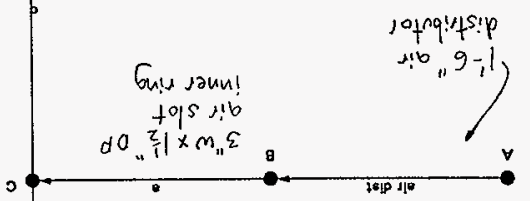

(1ds) to9s 1 ib 人 m 
y: Fluor Daniel
t: ,y: Fluor Daniel NW

ted: 01/26/98 9:46 am

file:

ecs: 3
System: ANNULUS2

rev: 01/29/98 10:30 am

SYSTEM REPORT

\author{
Pipes: 16 \\ Nodes: 13 \\ Pumps/Comps: 0
}

SYSTEM NODES

\section{ELEVATION}

$f t$

623

623

623

623

623

623

623

623

623

623

623

623

663.17
PIPELINES IN

air dist

a

b

c

d

e

$f$

g

h

i

k

I

n

0

\section{PIPELINES OUT}

air dist

a

b

c

d

e

f

h

i

k

I

m

n

$\circ$ 


$\begin{array}{llll}\text { PIPELINE } & \text { SPEC } & \text { FROM_NODE } & \text { TO } \\ \text { a } & 01 & \text { B } & \text { C } \\ \text { air dist } & 03 & \text { A } & \text { B } \\ \text { b } & 02 & \text { C } & \text { D } \\ \text { c } & 02 & \text { C } & \text { E } \\ \text { d } & 02 & \text { D } & \text { F } \\ \text { e } & 02 & \text { E } & \text { G } \\ f & 03 & \text { F } & \text { H } \\ \text { g } & 03 & \text { F } & \text { I } \\ \text { h } & 03 & \text { G } & \text { J } \\ \text { i } & 03 & \text { G } & \text { K } \\ \text { j } & 03 & \text { J } & \text { I } \\ \text { k } & 03 & \text { H } & \text { L } \\ \text { I } & 03 & \text { J } & \text { L } \\ \text { m } & 03 & \text { J } & \text { L } \\ \text { n } & 03 & \text { K } & \text { L } \\ \text { o } & 01 & \text { L } & \text { M }\end{array}$




\section{SPECIFICATIONS}

PIPE MATERIAL

Sch/Roughness

\section{Steel \\ $\operatorname{Sch} 40$ \\ 0.012 in}

Size for: $6 \mathrm{ft} / \mathrm{sec}$

\section{FLUID \\ Temp / Pres}

Air

$50^{\circ} \mathrm{F}$

0 psig

Air $50^{\circ} \mathrm{F}$ 0 psig

0.012 in

Size for: $6 \mathrm{ft} / \mathrm{sec}$

Steel

Sch 80

0.012 in

Size for: $6 \mathrm{ft} / \mathrm{sec}$

For concrete, Ref. $=5$
VALVE TABLE

Standard

Standaró

Standard

Standard

Standard

Standard
DESIGN LIMITS

Vel / Pres

$0-40 \mathrm{f} / \mathrm{sec}$

$-14.4-14.4 \mathrm{psig}$

$0-40 \mathrm{ft} / \mathrm{sec}$

$-14.4-14.4 \mathrm{psi} \mathrm{g}$

$0-40 \mathrm{ft} / \mathrm{sec}$

$-\$ 4.4-14.4$ psi g $50^{\circ} \mathrm{F}$

0 psig

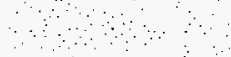


$B-5$ of $B-11$

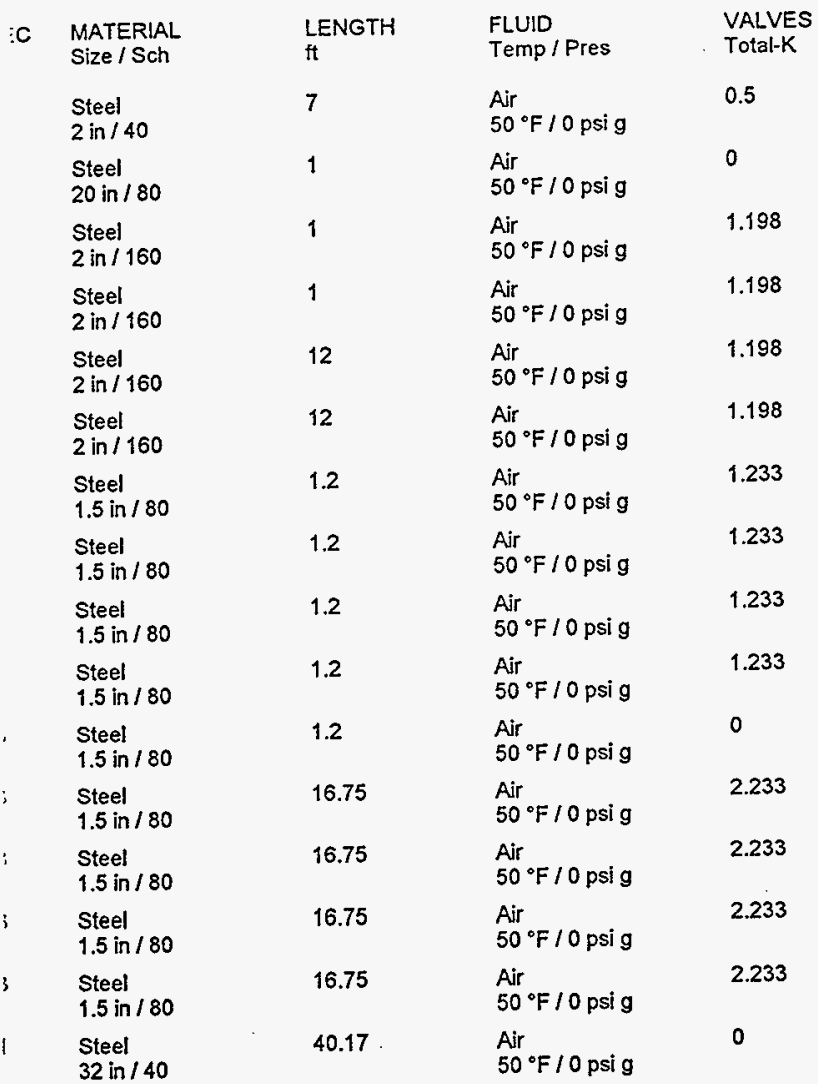




\section{PIPE MATERIALS LIST}

\begin{tabular}{|c|c|c|c|}
\hline PEC & $\begin{array}{l}\text { MATERIAL } \\
\text { Size/Sch }\end{array}$ & $\begin{array}{l}\text { LENGTH } \\
\mathrm{ft}\end{array}$ & VALVES \& FITTINGS \\
\hline 31 & $\begin{array}{l}\text { Steel } \\
2 \text { in / } 40\end{array}$ & 7 & 1-Entrance Sharp-Edged \\
\hline 33 & $\begin{array}{l}\text { Steel } \\
20 \text { in } / 80\end{array}$ & 1 & \\
\hline 32 & $\begin{array}{l}\text { Steel } \\
2 \text { in } / 160\end{array}$ & 1 & 1-Tee Flow Thru Branch \\
\hline 32 & $\begin{array}{l}\text { Steel } \\
2 \text { in / } 160\end{array}$ & 1 & 1-Tee Flow Thru Branch \\
\hline 32 & $\begin{array}{l}\text { Steel } \\
2 \text { in } / 160\end{array}$ & 12 & 1-Tee Flow Thru Branch \\
\hline 02 & $\begin{array}{l}\text { Steel } \\
2 \text { in / } 160\end{array}$ & 12 & 1-Tee Flow Thru Branch \\
\hline 03 & $\begin{array}{l}\text { Steel } \\
1.5 \mathrm{in} / 80\end{array}$ & 1.2 & 1-Tee Flow Thru Branch \\
\hline 03 & $\begin{array}{l}\text { Steel } \\
1.5 \mathrm{in} / 80\end{array}$ & 1.2 & 1-Tee Flow Thru Branch \\
\hline 03 & $\begin{array}{l}\text { Steel } \\
1.5 \mathrm{in} / 80\end{array}$ & 1.2 & 1-Tee Flow Thru Branch \\
\hline 03 & $\begin{array}{l}\text { Steel } \\
1.5 \mathrm{in} / 80\end{array}$ & 1.2 & 1-Tee Flow Thru Branch \\
\hline 03 & $\begin{array}{l}\text { Steel } \\
1.5 \mathrm{in} / 80\end{array}$ & 1.2 & \\
\hline 03 & $\begin{array}{l}\text { Steel } \\
1.5 \mathrm{in} / 80\end{array}$ & 16.75 & $\begin{array}{l}\text { 1-Tee Flow Thru Branch } \\
\text { 1-Exit Sharp-Edged }\end{array}$ \\
\hline
\end{tabular}

$\begin{array}{lll}\text { 03 Steel } & 16.75 & \begin{array}{l}\text { 1-Tee Flow Thru Branch } \\ \text { 1-Exut Sharp-Edged }\end{array}\end{array}$

$\begin{array}{llll}03 & \begin{array}{l}\text { Steel } \\ 1.5 \text { in } / 80\end{array} & 16.75 & \begin{array}{l}\text { 1-Tee Flow Thru Branch } \\ \text { 1-Exit Sharp-Edged }\end{array} \\ 03 & \begin{array}{l}\text { Steel } \\ 1.5 \text { in } 180\end{array} & 16.75 & \begin{array}{l}\text { 1-Tee Flow Thu Branch } \\ \text { 1-Exit Sharp-Edged }\end{array}\end{array}$

$\begin{array}{ll}01 \quad \text { Steel } & 40.17 \\ & 32 \text { in } / 40\end{array}$
Calculation W320-27-054
HNF-2479, Rev. 0
Page E-19 
160

2 in

$26 \mathrm{ft}$

40

2 in

$7 \mathrm{ft}$

32 in

$40.17 \mathrm{ft}$

80

$1.5 \mathrm{in}$

$73 \mathrm{ft}$

20 in

$1 \mathrm{ft}$

VALVE \& FITTING SUMMARY

MATERIAL

SCHEDULE VALVES \& FITTINGS

Steel

40

Size: 2 in

1-Entrance Sharp-Edged

Steel

160

Size: 2 in

4-Tee Flow Thru Branch

Steel

80

Size: 1.5 in

8-Tee Flow Thru Branch

4-Exit Sharp-Edged

Calculation w320-27-054

HNF-2479, Rev. 0 


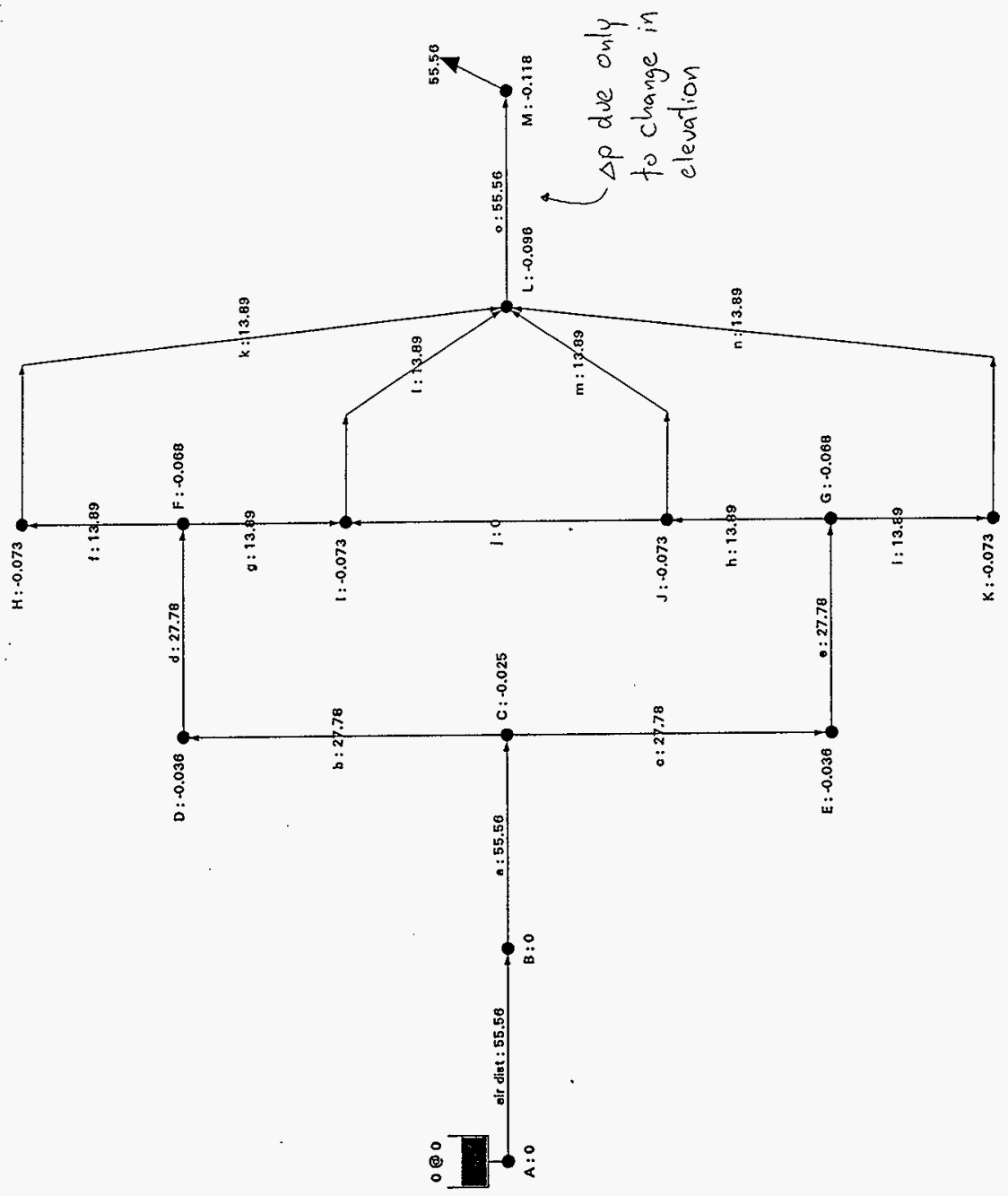

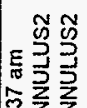

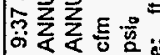

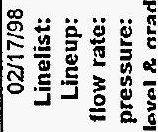

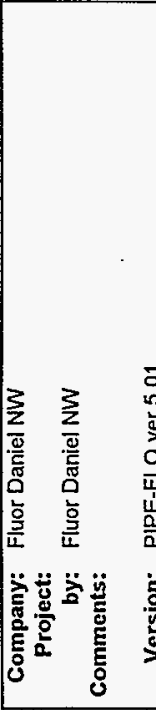

Calculation w320-27-054

HNF-2479, Rev. 0

Page E-21 
rates require constant fluid properties in all pipelines. Fluid properties in the first specification were used in this LINEUP SUMMARIES

\begin{tabular}{|c|c|c|c|c|}
\hline \multirow{4}{*}{$\gg$} & $\begin{array}{l}\text { DEMAND } \\
\text { cfm }\end{array}$ & NODE & \multicolumn{2}{|c|}{$\begin{array}{l}\text { DEMAND } \\
\mathrm{cfm}\end{array}$} \\
\hline & 55.56 & & & \\
\hline & \multicolumn{4}{|c|}{$\begin{array}{l}\text { Flows IN: } 0 \mathrm{cfm} \\
\text { Flows OUT: } 55.56 \mathrm{cfm}\end{array}$} \\
\hline & \multicolumn{4}{|c|}{ NET FLOWS OUT: $55.56 \mathrm{cfm}$} \\
\hline \multicolumn{5}{|c|}{ LINEUP SUMMARIES } \\
\hline & $\begin{array}{l}\text { FLOW } \\
\mathrm{cfm}\end{array}$ & $\begin{array}{l}\text { PRESSURE } \\
\text { SOURCE }\end{array}$ & $\begin{array}{l}\text { SET } \\
\text { psi g }\end{array}$ & $\begin{array}{l}\text { LEVEL } \\
\mathrm{ft}\end{array}$ \\
\hline$\ll$ & 55.56 & $A$ & 0 & 0 \\
\hline
\end{tabular}

Flows IN: $55.56 \mathrm{cfm}$ Flows OUT: $0 \mathrm{~cm}$

NET FL.OWS IN: $55.56 \mathrm{cfm}$ 


$\begin{array}{llll}\text { ELEVATION } & \begin{array}{l}\text { DEMAND } \\ \mathrm{ft}\end{array} & \begin{array}{l}\text { PRESSURE } \\ \mathrm{psig}\end{array} & \begin{array}{l}\text { HGRADE } \\ \mathrm{ft}\end{array} \\ 623 & & 0 \text { (source) } & 623 \\ 623 & & 0 & 623 \\ 623 & -0.025 & 576.8 \\ 623 & & -0.036 & 556.6 \\ 623 & & -0.036 & 556.6 \\ 623 & -0.068 & 496.5 \\ 623 & & -0.068 & 496.5 \\ 623 & & -0.073 & 487.6 \\ 623 & & -0.073 & 487.6 \\ 623 & & -0.073 & 487.6 \\ 623 & & -0.073 & 487.6 \\ 623 & & -0.096 & 445.7 \\ 663.17 & & -0.118 & 445.7\end{array}$

Calculation w320.27-054 


PIPELINE
adist
b
d
e
f
g
h
i
j
k
f
$\mathrm{m}$
n
0

FROM

B

A

C

C

D

E

$F$

F

G

G

$J$

H

I

J

K

L

\section{TO}

C

B

D

E

F

G

H

1

J

K

I

L

L

$L$

$L$

M
FLOW

55.56

55.56

27.78

27.78

27.78

27.78

13.89

13.89

13.89

13.89

0

13.89

13.89

13.89

13.89

55.56
VEL

ft'sec

39.77

0.528

29.85

29.85

29.85

29.85

18.88

18.88

18.88

18.88

0

18.88

18.88

18.88

18.88

0.181
$B-11$ of $B-11$

$\begin{array}{ll}\mathrm{dP} & \mathrm{HL} \\ \text { psig } & \mathrm{ft}\end{array}$

0.025

0

0.011

0.011

0.033

0.033

0.005

0.005

0.005

0.005

0

0.023

0.023

0.023

0.023

0.022 $\mathrm{ft}$

46.16

0

20.2

20.2

60.13

60.13

8.935

8.935

8.935

8.935

0

41.88

41.88

41.88

41.88

0 
ङ FLUOR DANIEL NORTHWEST INC.
Calc. No.: W320-27-054

Revision: 0

DESIGN ANALYSIS
Page No. $C-O$ of $C-13$
Client: Numatec

Subject: System Curves for Portable Exhauster Installation

Location: 241-C/241-AY
WO/Job No.: ER4319/W-320

Date: $2 / 18 / 98$ Checked: $3 / 2 / 98$

Revised:
By: Kelly Hayase,

By: Kan $\operatorname{Cec} R$

By:

Appendix C: Pipe-Flo results of ANNULUS2 for different flow rates used as input into Pipe-Flo Model ANNULUS 


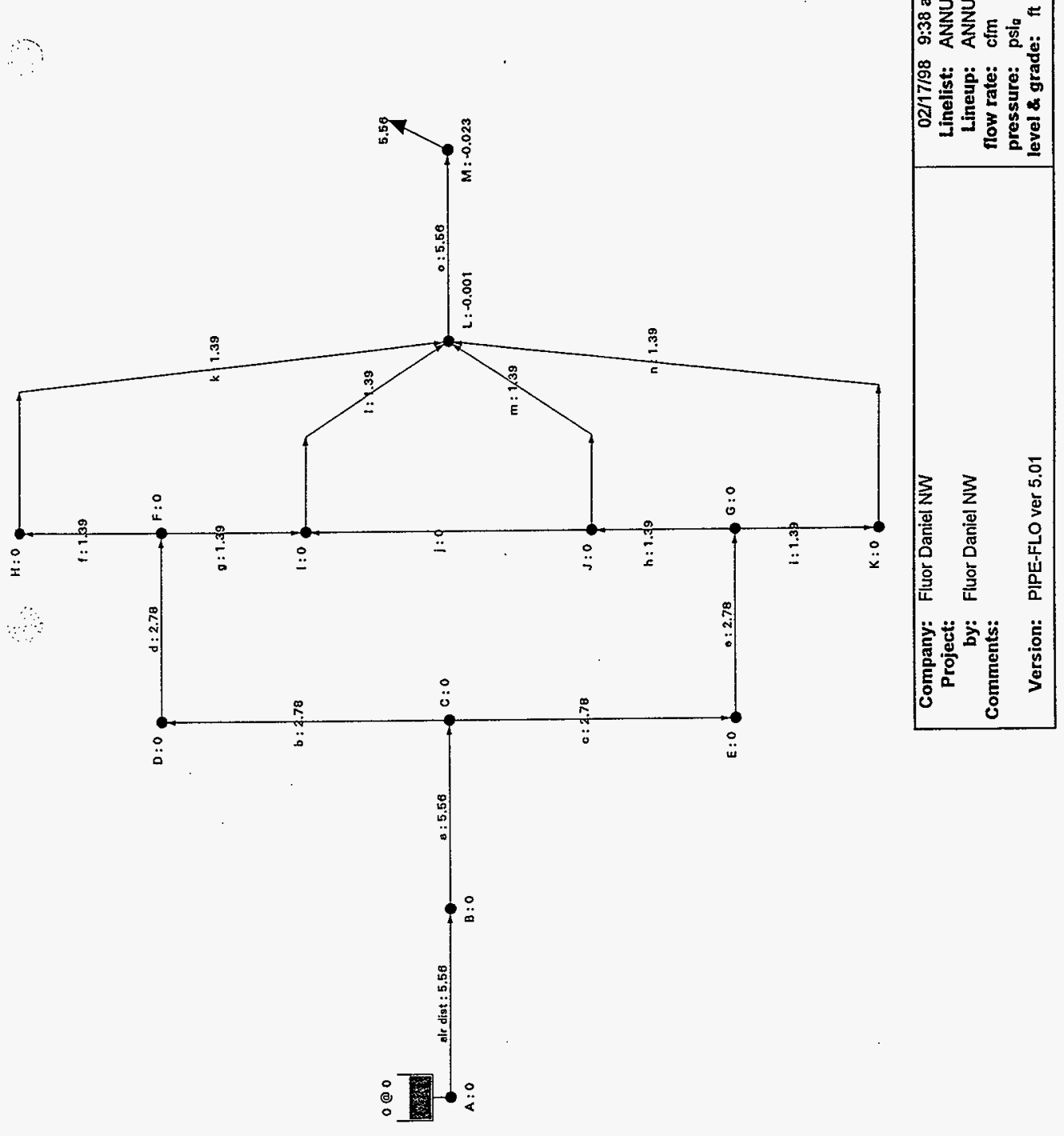

Calculation w320-27-054 


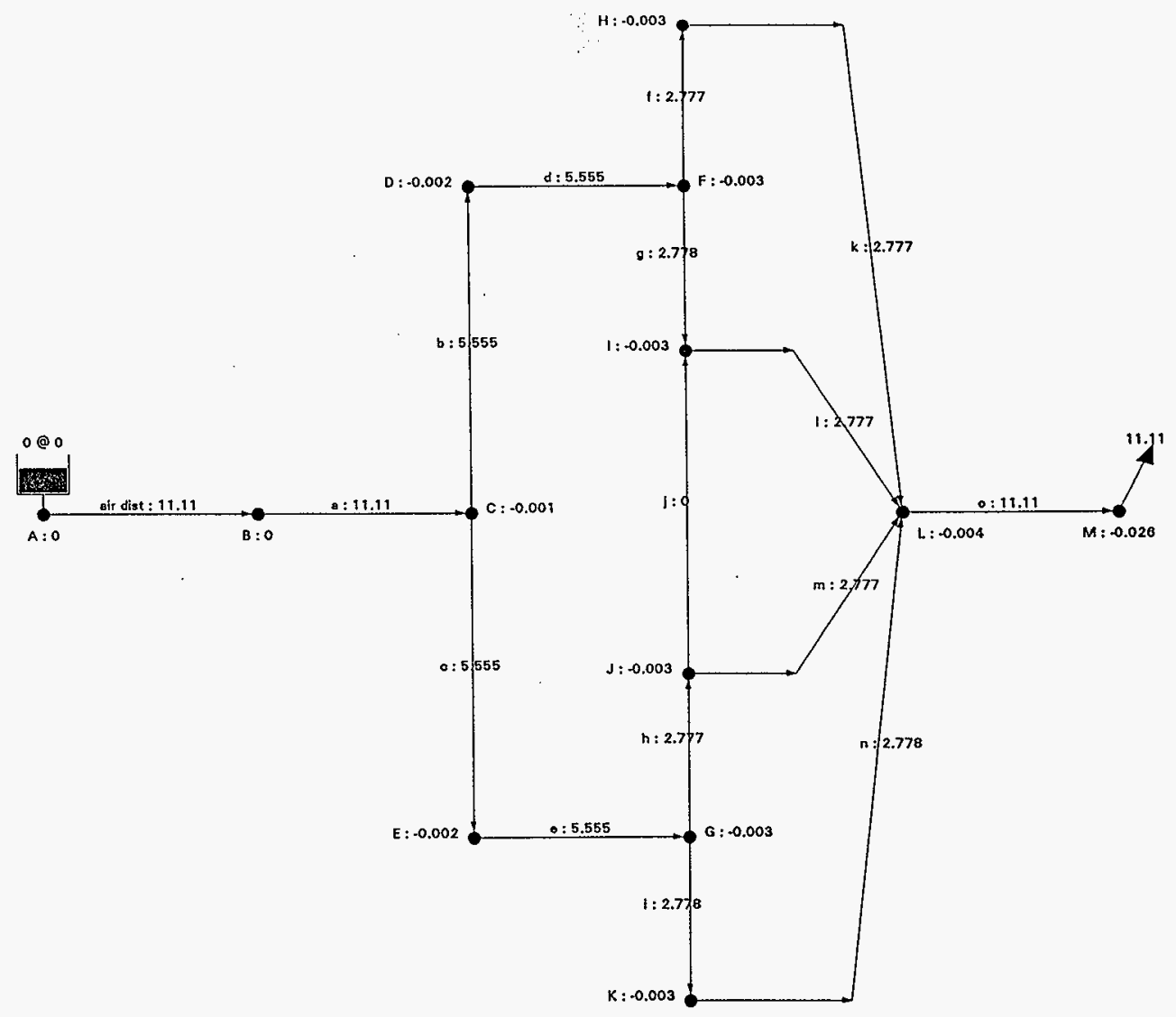

\section{Company: Fluor Daniel NW}

Project:

by: Fluor Daniel NW

Comments:

Version: PIPE-FLO ver 5.01
02/17/98 9:39 am Linelist: ANNULUS2

Lineup: ANNULUS2

flow rate: cfm

pressure: psig 


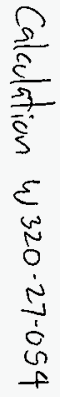

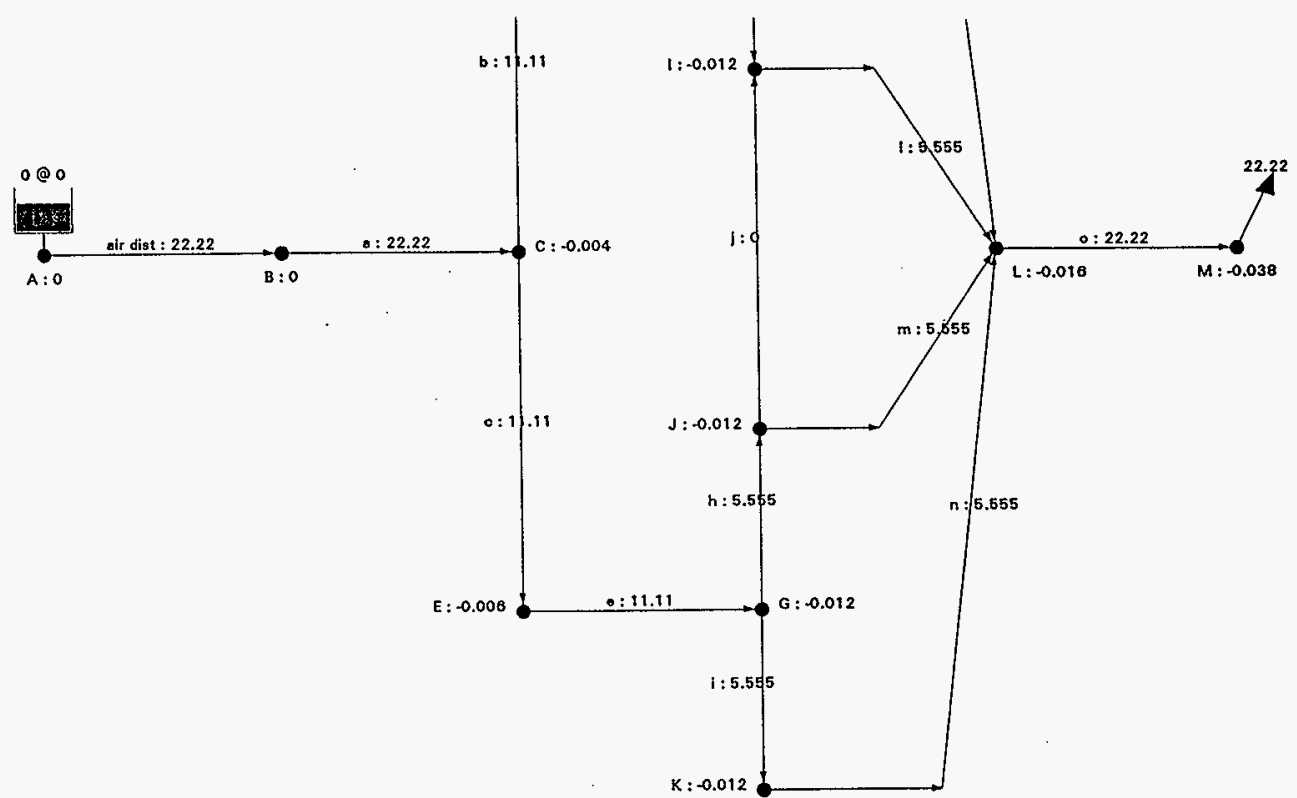

Company: Fluor Daniel NW
Project:

by: Fluor Daniel NW

Comments:

Version:

PIPE-FLO ver 5.01
02/17/98 9:39 am Linelist: ANNULUS2

Lineup: ANNULUS2

flow rate: cfm

pressure: psio

level \& grade: ft 


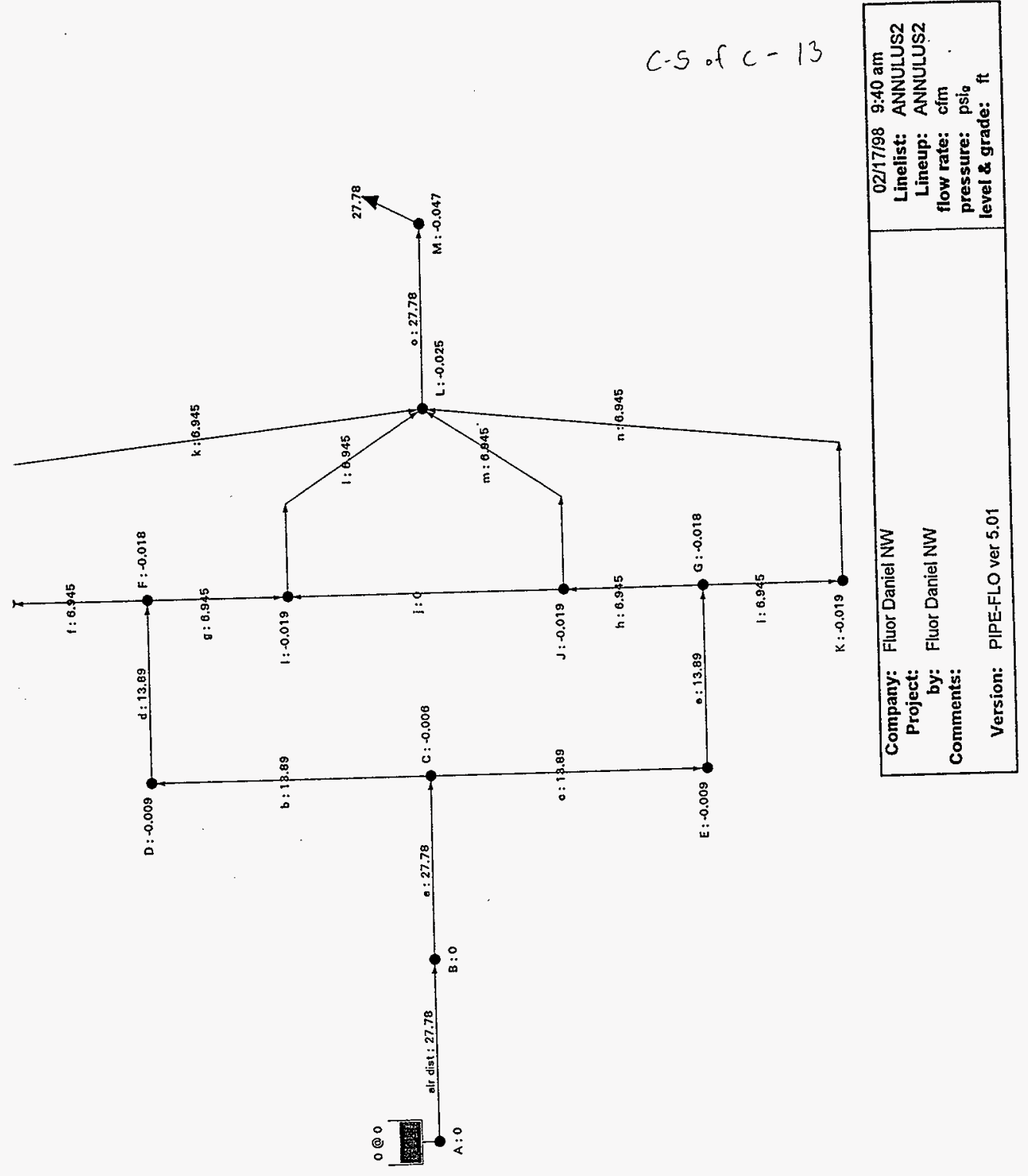

Calculation w320-27-054 


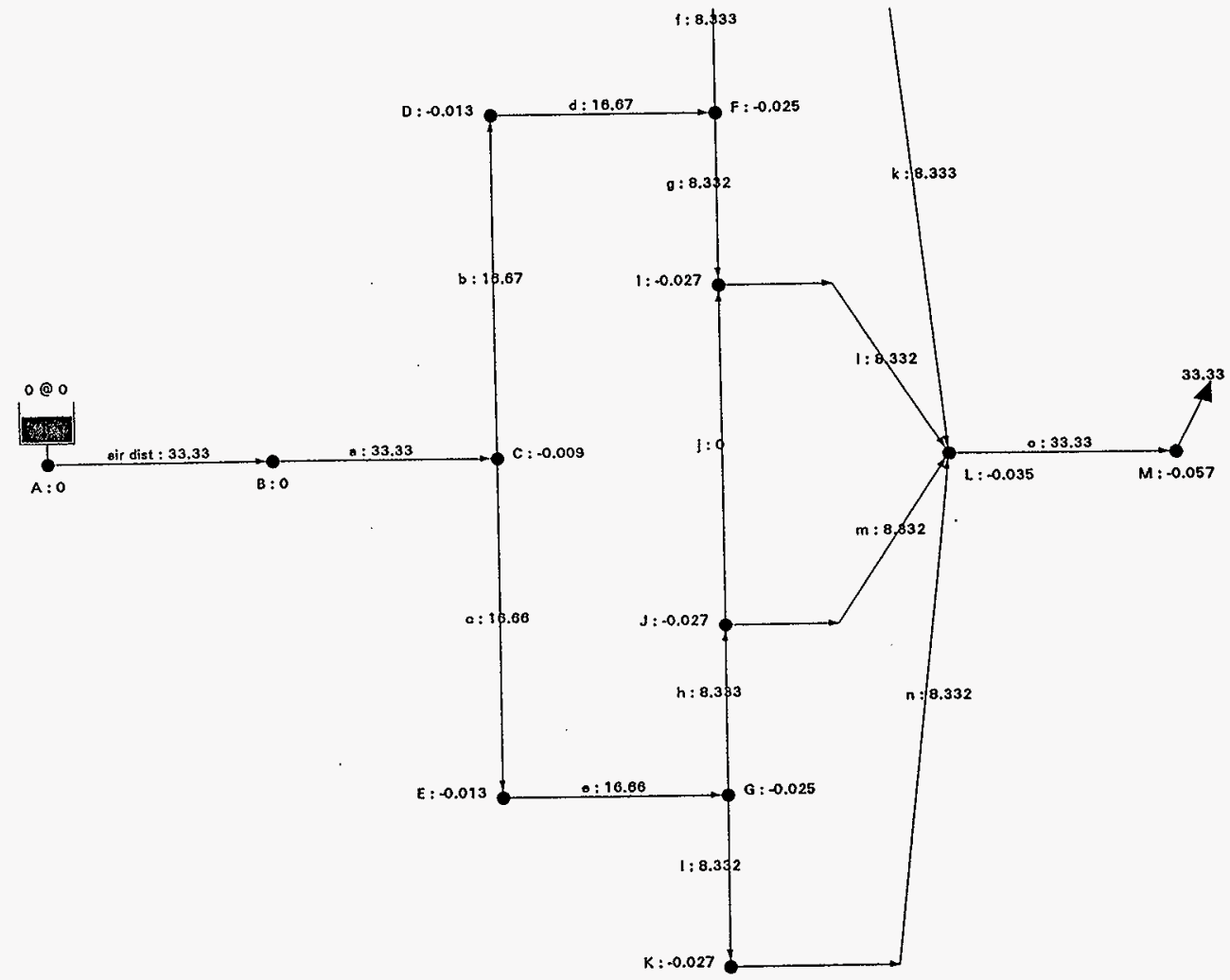

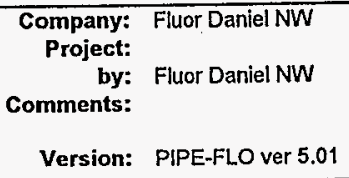

02/17/98 9:40 am

Linelist: ANNULUS2

Lineup: ANNULUS2

flow rate: cfm

pressure: psig

level \& grade: ft 


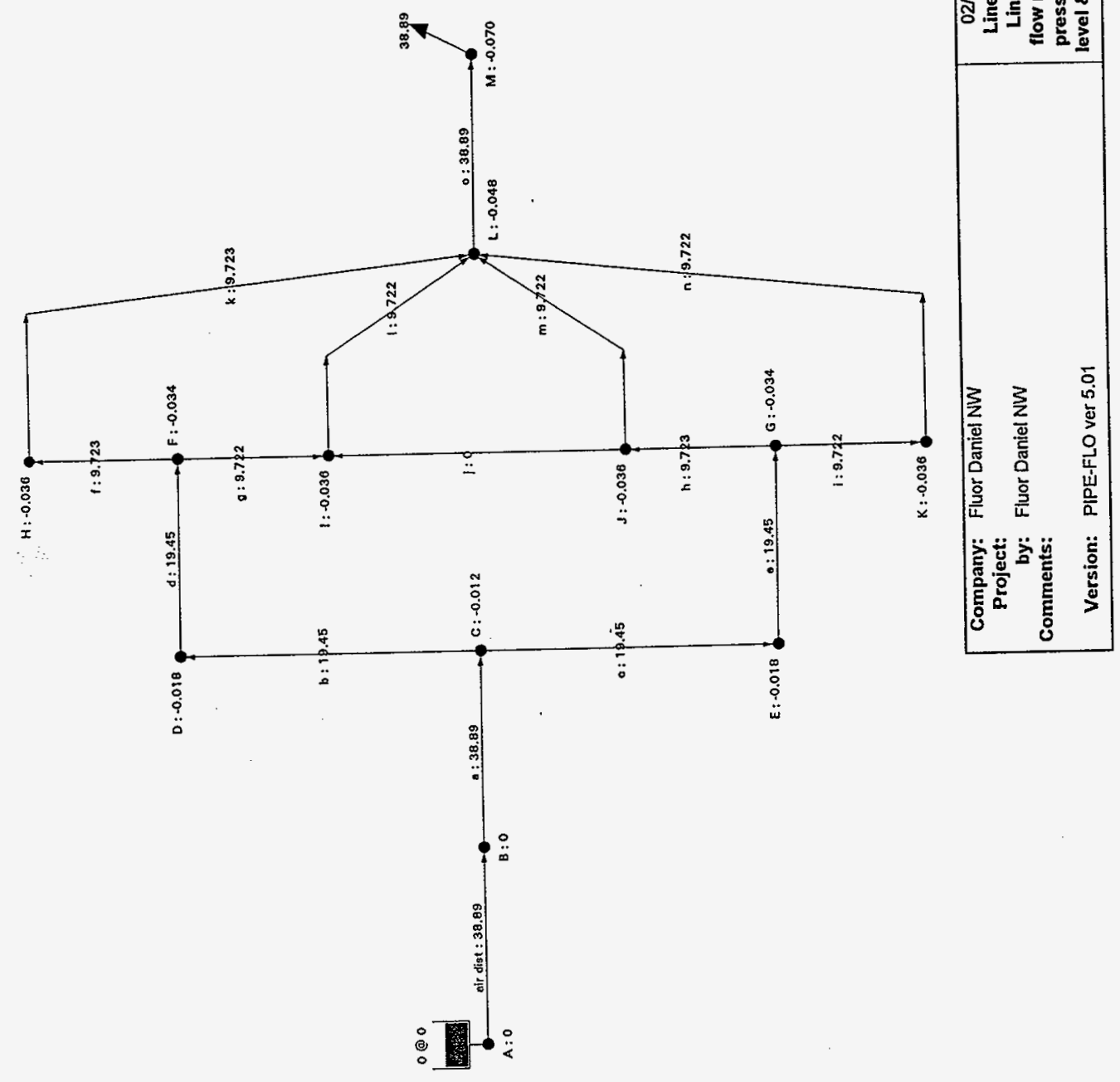

Calculation w320-27-054 


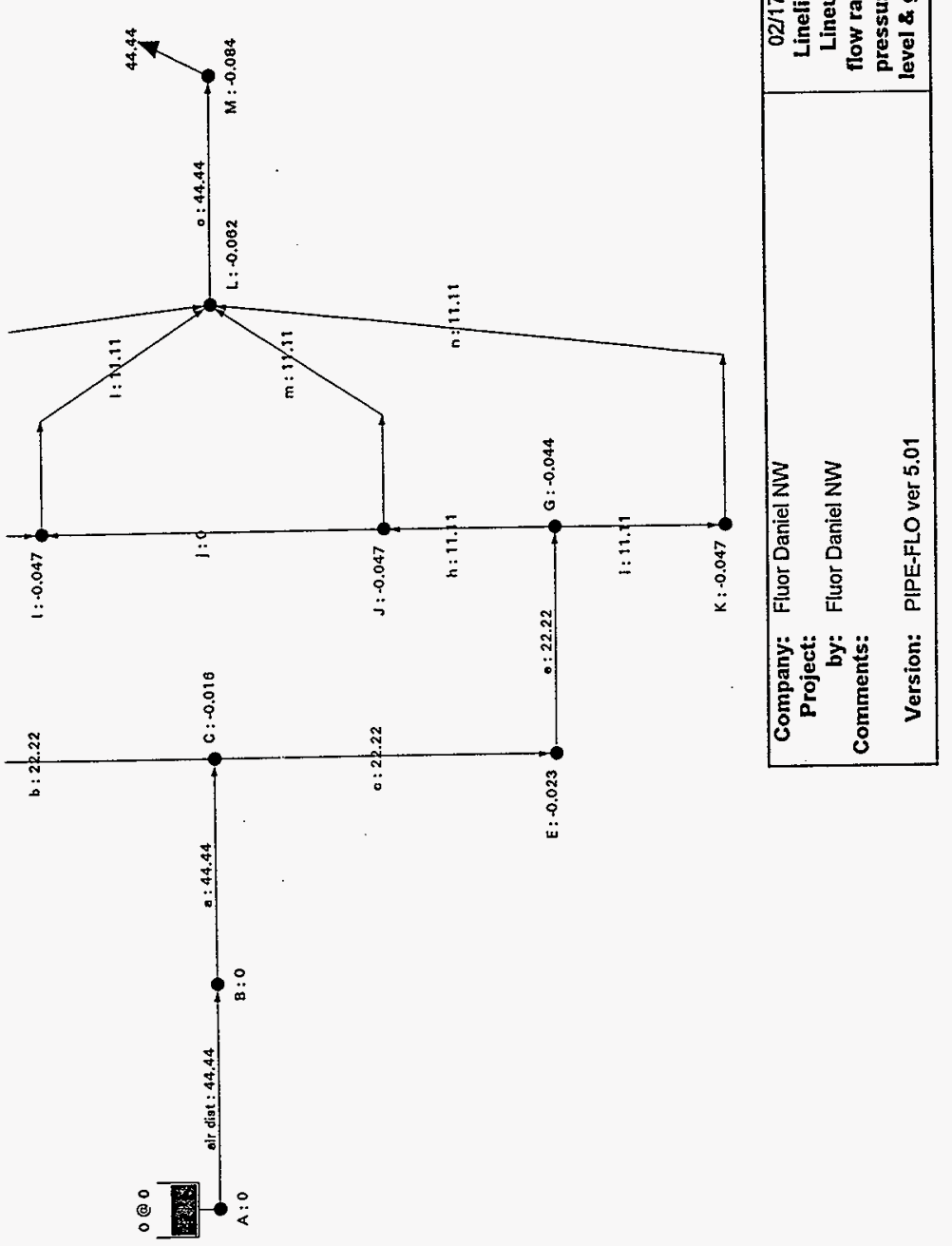

Calculation w320.27-054

HNF-2479, Rev. 0

Page $E 33 \quad E-33$ 


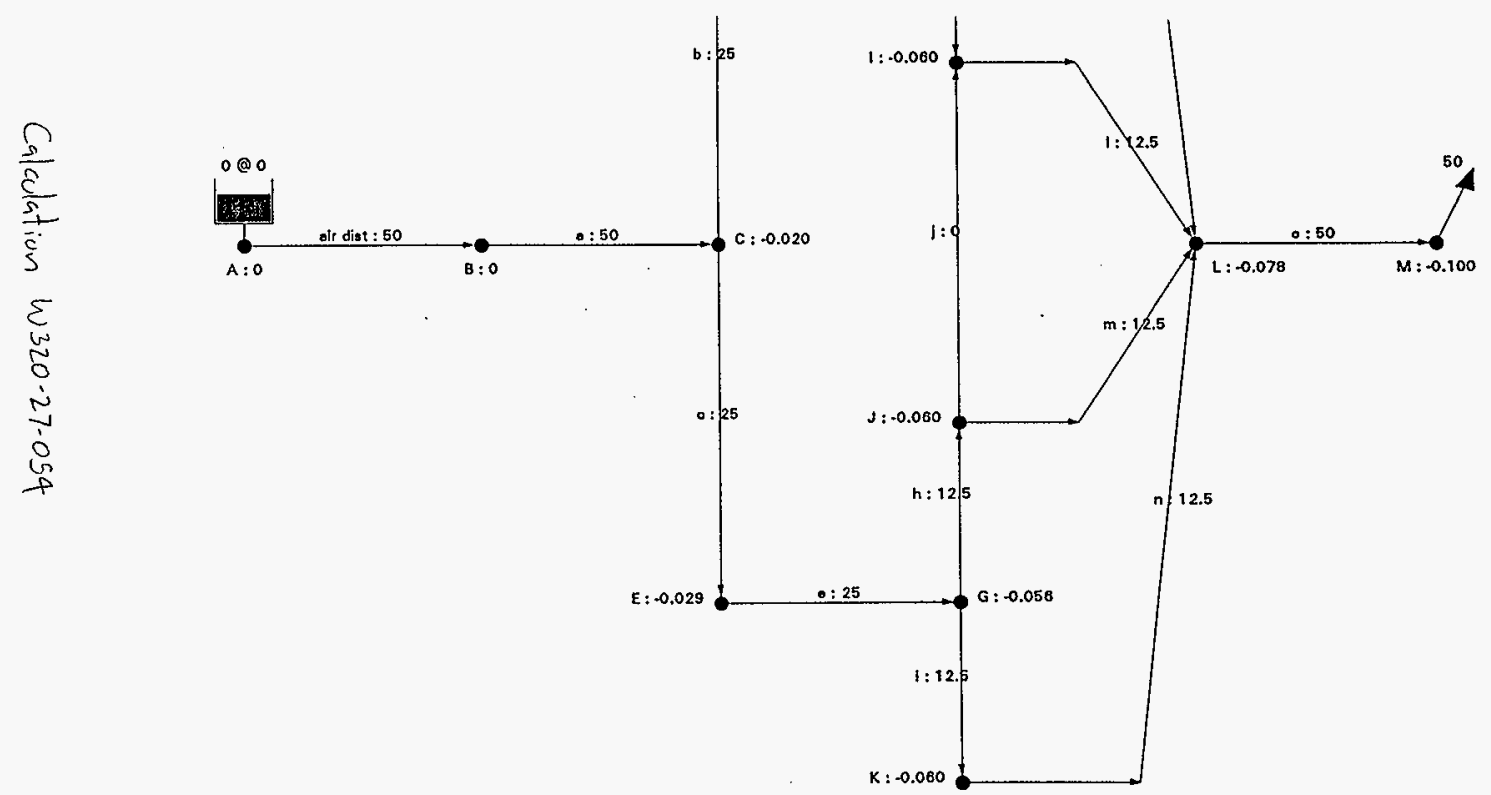

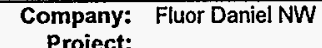

Project:

by: Fluor Daniel NW

Comments:

Version:
$02 / 17 / 98 \quad 9: 46$ am Linelist: ANNULUS2

Lineup: ANNULUS2

flow rate: cfm

pressure: psio

level \& grade: $f$ 


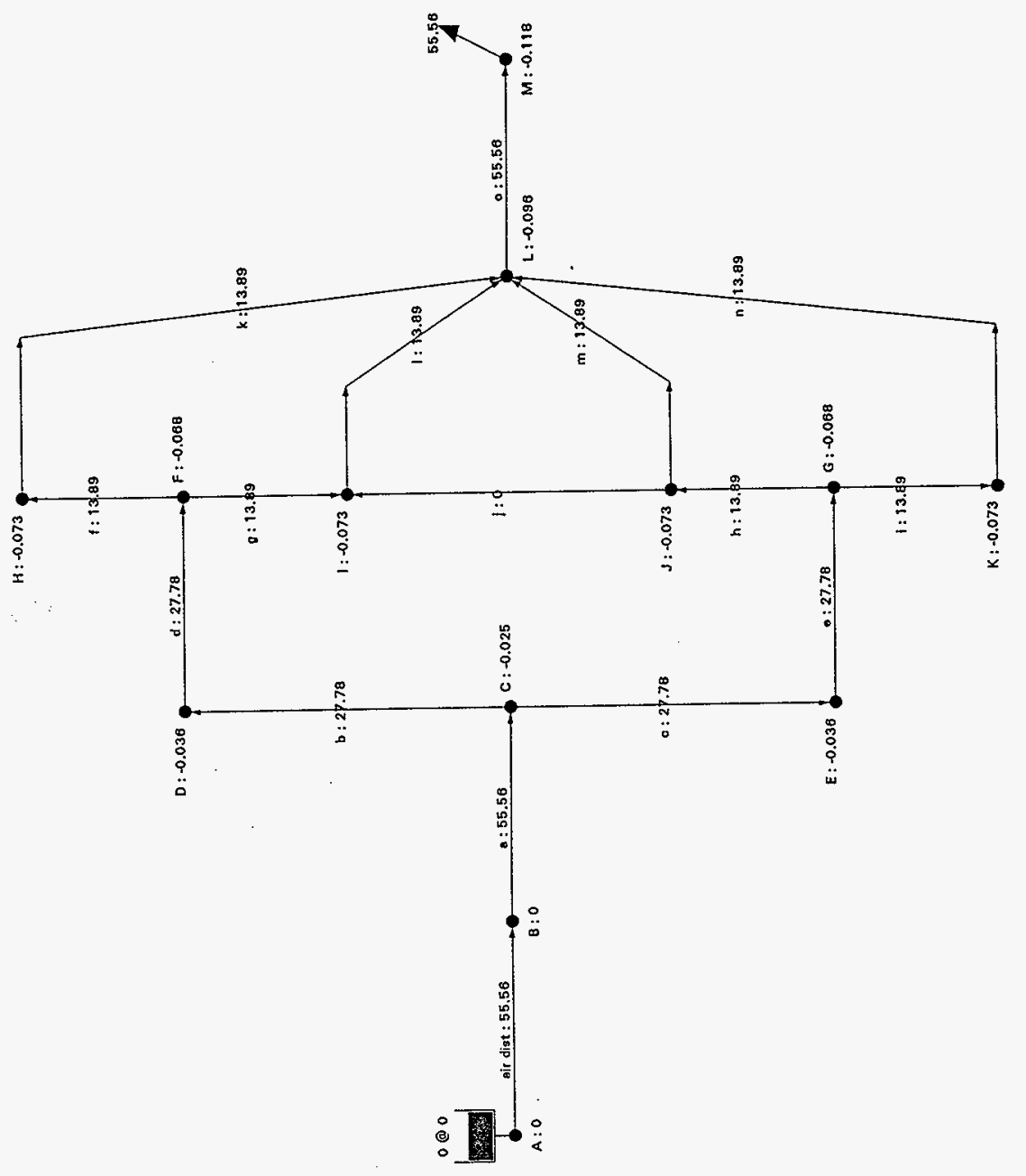

Calculation w320-27-054

HNF-2479, Rev. 0

Page 6-35 E-35 


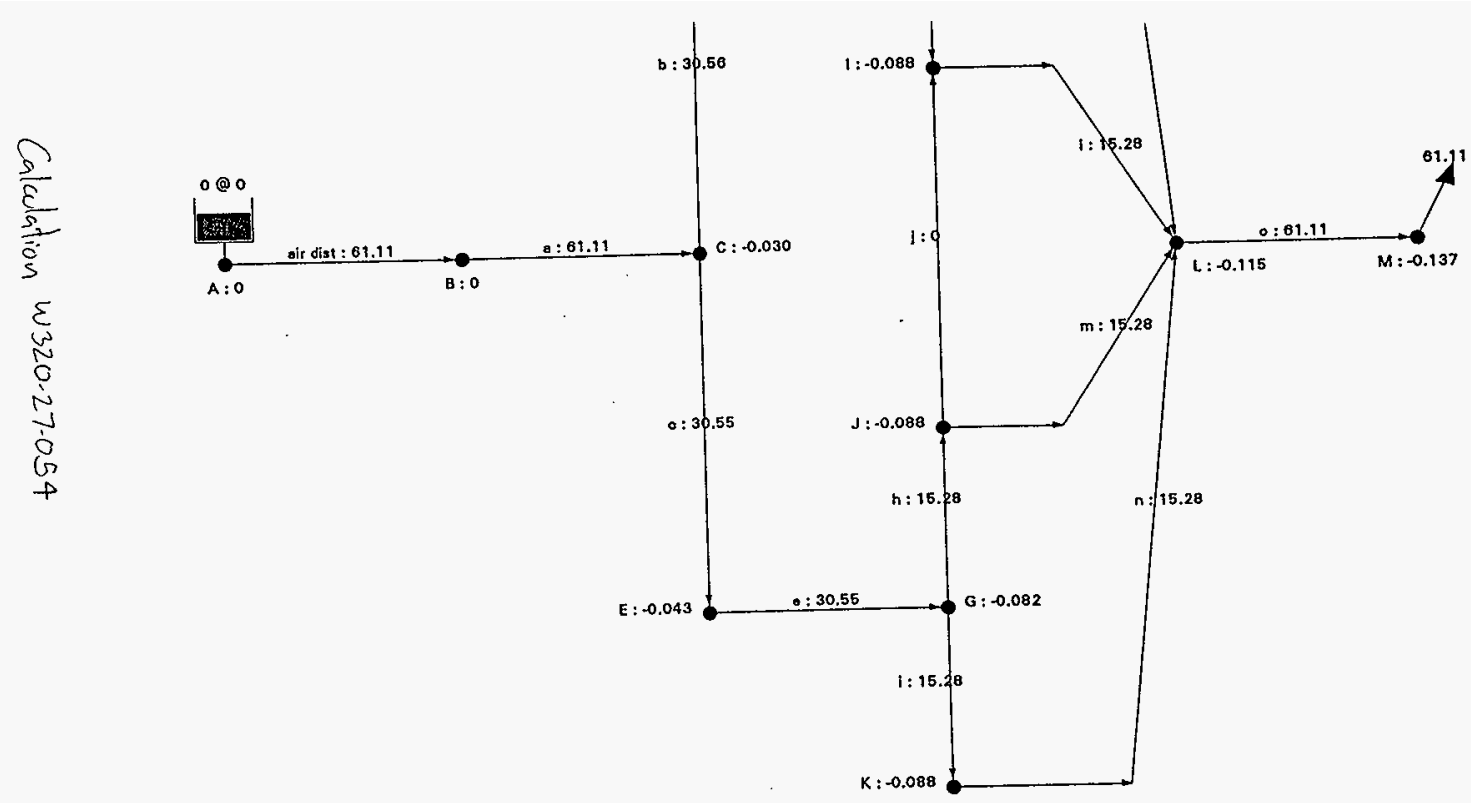

\begin{tabular}{|l|c|}
\hline $\begin{array}{l}\text { Company: Fluor Daniel NW } \\
\text { Project: } \\
\text { by: Fluor Daniel NW }\end{array}$ & $\begin{array}{c}02 / 17 / 98 \\
\text { Linelist: ANNULUS2 } \\
\text { Lineup: ANNULUS2 } \\
\text { flow rate: cfm } \\
\text { pressure: psio } \\
\text { level \& grade: } \mathrm{ft}\end{array}$ \\
\hline
\end{tabular}




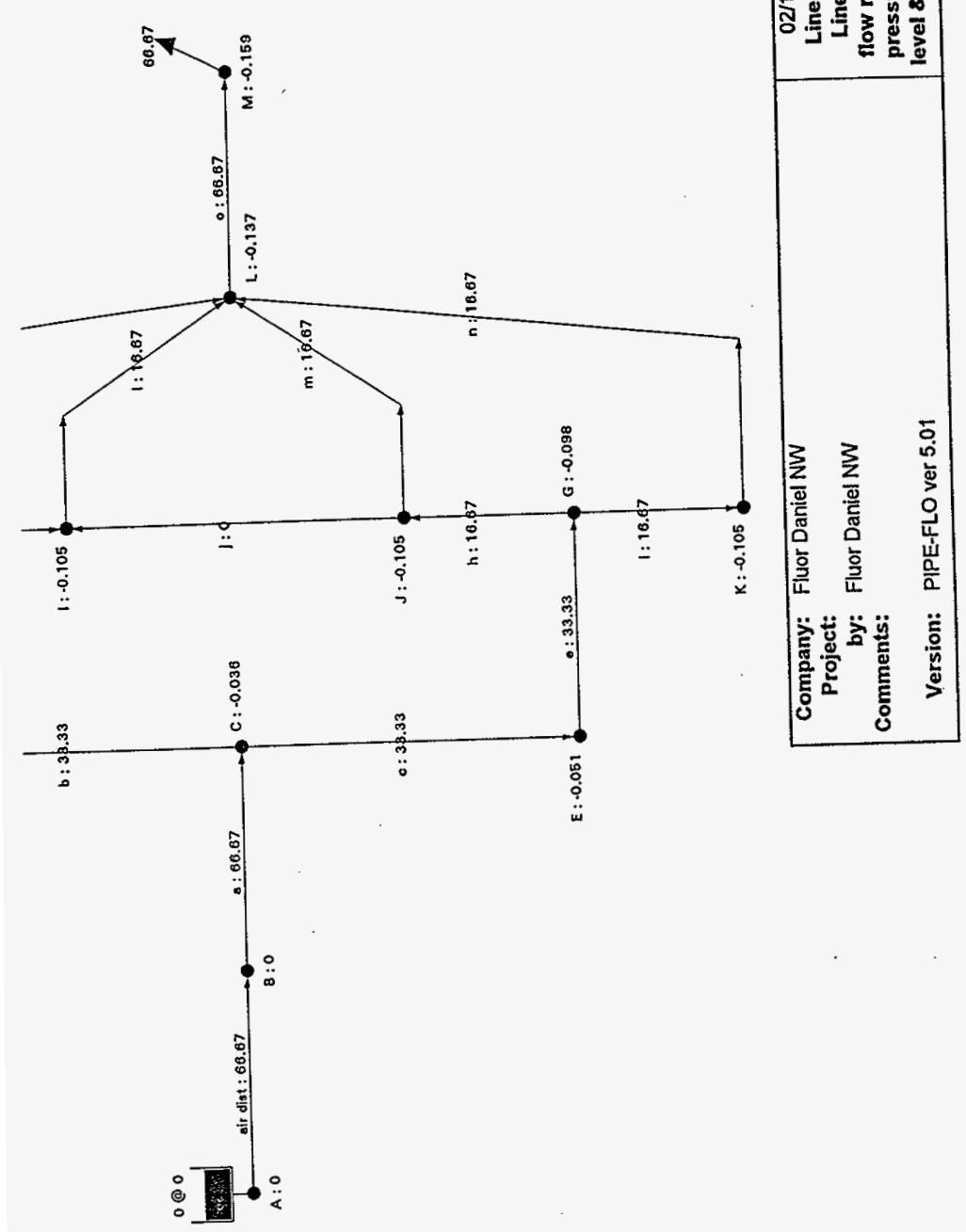

Calculation w320.27.054

HNF-2479, Rev. 0

Page E-37 E -37 


\section{$C-B$ of $C-B$}

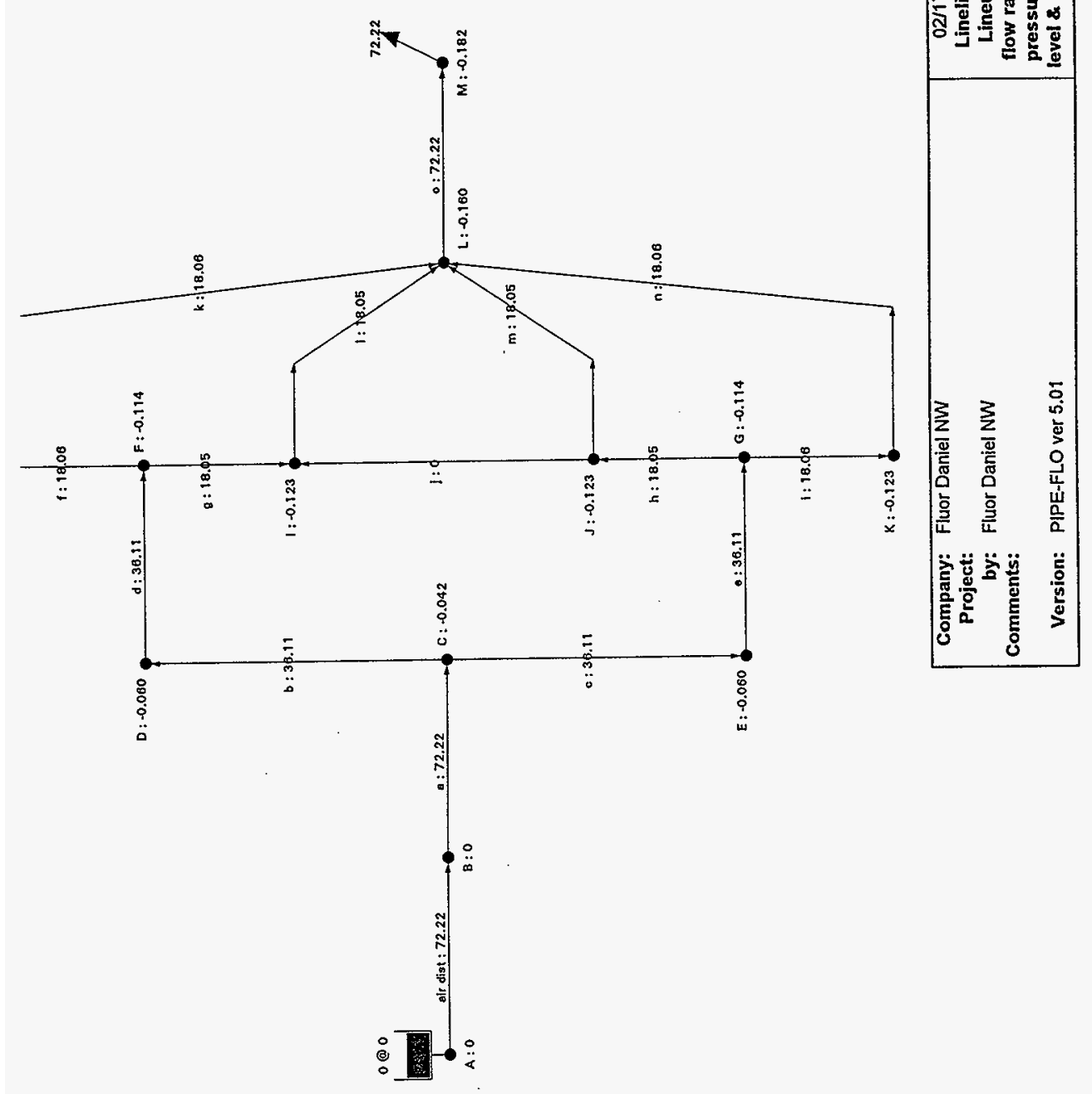

Calculation W320-27.054

HNF-2479, Rev, 0

Page E-38 $<-38$ 
ङ FLUOR DANIEL NORTHWEST INC.
Calc. No.: W320-27-054

Revișion: 0

DESIGN ANALYSIS

Page No.:D-Oof $D-20$
Client: Numatec

Subject: System Curves for Portable Exhauster Installation

Location: 241-C/241-AY
WO/Job No.: ER4319M-320

Date: $2 / 18 / 98$

Checked: $3 / 2 / 98$

By: Kelly Hayase,

By: Kri ces

Revised:

Appendix D: Pipe-Flo Model ANNULUS

HNF-2479, Rev. 0 
Pumps/Comps: 0

\section{SYSTEM NODES}

\begin{tabular}{|c|c|c|}
\hline $\begin{array}{l}\text { ELEVATION } \\
\mathrm{ft}\end{array}$ & PIPELINES IN & PIPELINES OUT \\
\hline 674.43 & $\mathrm{zl}$ & $z q$ \\
\hline 674.44 & $\mathbf{i}$ & n \\
\hline 674.8 & $\begin{array}{l}\mathrm{zk} \\
\mathrm{zq}\end{array}$ & $z r$ \\
\hline 677.33 & b & $\begin{array}{l}\mathrm{c} \\
\mathrm{m}\end{array}$ \\
\hline 677.35 & $\begin{array}{l}z j \\
z 0\end{array}$ & $z p$ \\
\hline 673.49 & $\begin{array}{l}z i \\
z n\end{array}$ & zo \\
\hline 673.37 & $c$ & $\begin{array}{l}d \\
d\end{array}$ \\
\hline 673.22 & $\begin{array}{l}\mathrm{zh} \\
\mathrm{zm}\end{array}$ & $\mathrm{zn}$ \\
\hline 672.69 & $f$ & j \\
\hline 672.79 & $\mathrm{zg}$ & $\mathrm{zm}$ \\
\hline 677.5 & $\mathbf{a}$ & $\begin{array}{l}b \\
g\end{array}$ \\
\hline 681.86 & & a \\
\hline 673.37 & d & $\mathrm{e}$ \\
\hline 673.07 & e & $\mathbf{f}$ \\
\hline 674.83 & $\mathbf{g}$ & $h$ \\
\hline 674.52 & $n$ & $\mathbf{i}$ \\
\hline 671.44 & $\mathbf{j}$ & $k$ \\
\hline 658.77 & $k$ & 0 \\
\hline 682.33 & zs & \\
\hline 671.62 & 1 & $\mathrm{p}$ \\
\hline 669.58 & $\mathrm{~m}$ & $q$ \\
\hline
\end{tabular}

Calalation w320-27.054 


\section{ELEVATION \\ ft}

\subsection{2}

623

623

623

663.17

663.17

663.17

663.17

663.17

663.17

669.17

669.5

669.5

671.5

670.5

668.5

677.5

\section{PIPELINES IN}

n

0

p

$\mathbf{s}$

t

u

zt

w

$x$

$z v$

y
$z w$

$z$

$z x$

za

$z b$

zc

$\mathrm{zd}$

ze

zf

$z p$ 


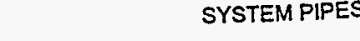

$\begin{array}{llll}\text { SPEC } & \text { FROM_NODE } & \text { TO_NODE } & \text { PUMPICOMP } \\ 01 & \text { In } & \text { I } & \end{array}$

$\begin{array}{lll}01 & \text { I } & \text { F } \\ 01 & \text { D-in } & \text { J } \\ 01 & \text { F } & \text { K } \\ 01 & \text { J } & \text { H in }\end{array}$

$01 \quad K \quad H$-in

$01 \quad 1$

01 L

$01 \quad M$

$01 \mathrm{H}$-in $\mathrm{N}$

$\begin{array}{lll}01 & N & P\end{array}$

$01 \quad F \quad$ D-in

$\begin{array}{lll}01 & B & R\end{array}$

$01 \quad 0$ S

$01 \quad P \quad S$

$01 \quad Q$

or $R$

$01 \quad T$

$\begin{array}{lll}01 & T & W \\ 01 & T & X\end{array}$

$01 \quad U \quad Z$

$\begin{array}{lll}01 & U & Z A \\ 01 & U & Z B\end{array}$

$01 \quad V \quad Z B$

$01 W \quad \mathrm{~W}$

$01 \quad X \quad Z O$

$01 \quad Y \quad$ ZE

$01 \quad Z \quad Z F$

$01 \quad Z A \quad Z G$

$01 \quad Z B \quad$ ZC

$\begin{array}{lll}01 & Z C & E\end{array}$

$\begin{array}{lll}01 & \text { ZD } & \text { D-out } \\ 01 & \text { ZE } & \text { C } \\ 01 & \text { ZF } & \text { A } \\ 01 & \text { ZG } & \text { G } \\ 01 & \text { H-out } & \text { E } \\ 01 & \text { G } & \text { D-out } \\ 01 & \text { E } & \text { ZH } \\ 01 & \text { D-out } & \end{array}$

Caladation W320.27-054 HNF-2479, Rev. 0 
PIPELINE

$z q$

$\therefore$ is

zt

zu

$2 V$

Zw

$z x$

\section{SPEC}

01

01

01

01

01

01

01

01
TO_NODE

C

$\mathrm{ZH}$

Out

w

$X$

$Y$

$Z$

ZA

\section{$02 / 17 / 98 \quad 9: 52 \mathrm{am}$}

$\begin{array}{ll}A & C \\ C & Z H \\ Z H & \text { Out } \\ V & W \\ W & X \\ X & Y \\ Y & Z \\ Z & Z A\end{array}$


Company: Fluor Daniel NW

Project:

by: Fluor Daniel NW

Created: 01/26/98 11:38 am

Design file:

Ipe Specs: 1

PIPELIST REPORT

02/17/98 9:52 am

System: ANNULUS

rev: 02/17/98 9:51 am

$D-6$ of $D-20$

Pipes: $\mathbf{5 0}$

Nodes: 38

Pumps/Comps: 0

\section{SPECIFICATIONS}

SPECIFICATION

$01 \operatorname{Sch} 40$

rev: 01/29/98 10:40 am
PIPE MATERIAL

Sch / Roughness

Steel

$\operatorname{Sch} 40$

0.0018 in

Size for: $6 \mathrm{ft} / \mathrm{sec}$
FLUID

Temp / Pres

Air

$50^{\circ} \mathrm{F}$

opsig
VALVE TABLE

Standard

Standard
DESIGN LIMITS

Vel / Pres

$0-40 \mathrm{ft} / \mathrm{sec}$

$-14.4-14.4$ psi g

HNF-2479, Rev. 0

Page E-45 


\begin{tabular}{|c|c|c|c|c|c|}
\hline PIPELINE & SPEC & $\begin{array}{l}\text { MATERIAL } \\
\text { Size/ Sch }\end{array}$ & $\begin{array}{l}\text { LENGTH } \\
\mathrm{ft}\end{array}$ & $\begin{array}{l}\text { FLUID } \\
\text { Temp/Pres }\end{array}$ & $\begin{array}{l}\text { VALVES } \\
\text { Total-K }\end{array}$ \\
\hline & 01 & $\begin{array}{l}\text { Steel } \\
12 \text { in / } 40\end{array}$ & 45 & $\begin{array}{l}\text { Air } \\
50^{\circ} \mathrm{F} / 0 \mathrm{psig}\end{array}$ & 0.9994 \\
\hline$b$ & 01 & $\begin{array}{l}\text { Steel } \\
14 \mathrm{in} / 40\end{array}$ & 31 & $\begin{array}{l}\text { Air } \\
50^{\circ} \mathrm{F} / 0 \mathrm{psig}\end{array}$ & 0.8908 \\
\hline c & 01 & $\begin{array}{l}\text { Steel } \\
14 \text { in } / 40\end{array}$ & 71 & $\begin{array}{l}\text { Air } \\
50^{\circ} \mathrm{F} / 0 \mathrm{psi} g\end{array}$ & 0.76 \\
\hline d & 01 & $\begin{array}{l}\text { Steel } \\
14 \mathrm{in} / 40\end{array}$ & 1 & $\begin{array}{l}\text { Air } \\
50^{\circ} \mathrm{F} / 0 \mathrm{psig}\end{array}$ & 0.1164 \\
\hline e & 01 & $\begin{array}{l}\text { Steel } \\
10 \mathrm{in} / 40\end{array}$ & 30 & $\begin{array}{l}\text { Air } \\
50^{\circ} \mathrm{F} / 0 \mathrm{psig}\end{array}$ & 1.429 \\
\hline$f$ & 01 & $\begin{array}{l}\text { Steel } \\
6 \mathrm{in} / 40\end{array}$ & 40 & $\begin{array}{l}\text { Air } \\
50^{\circ} \mathrm{F} / 0 \mathrm{psig}\end{array}$ & 0.1478 \\
\hline $\mathbf{g}$ & 01 & $\begin{array}{l}\text { Steel } \\
14 \mathrm{in} / 40\end{array}$ & 9 & $\begin{array}{l}\text { Air } \\
50^{\circ} \mathrm{F} / 0 \mathrm{psig}\end{array}$ & 1.388 \\
\hline$h$ & 01 & $\begin{array}{l}\text { Steel } \\
10 \mathrm{in} / 40\end{array}$ & 17 & $\begin{array}{l}\text { Air } \\
50^{\circ} \mathrm{F} 10 \mathrm{psig}\end{array}$ & 0.1047 \\
\hline $\mathbf{i}$ & 01 & $\begin{array}{l}\text { Steel } \\
8 \text { in } / 40\end{array}$ & 13 & $\begin{array}{l}\text { Air } \\
50^{\circ} \mathrm{F} / 0 \text { psig }\end{array}$ & 0.1396 \\
\hline j & 01 & $\begin{array}{l}\text { Steel } \\
6 \mathrm{in} / 40\end{array}$ & 1.25 & $\begin{array}{l}\text { Air } \\
50^{\circ} \mathrm{F} / 0 \text { psi g }\end{array}$ & 2.599 \\
\hline$k$ & 01 & $\begin{array}{l}\text { Steel } \\
3 \mathrm{in} / 40\end{array}$ & 12.67 & $\begin{array}{l}\text { Air } \\
50^{\circ} \mathrm{F} / 0 \mathrm{psig}\end{array}$ & 0.05435 \\
\hline 1 & 01 & $\begin{array}{l}\text { Steel } \\
3 \text { in } / 40\end{array}$ & 1.75 & $\begin{array}{l}\text { Air } \\
50^{\circ} \mathrm{F} / 0 \mathrm{psig}\end{array}$ & 1.094 \\
\hline$m$ & 01 & $\begin{array}{l}\text { Steel } \\
3 \text { in / } 40\end{array}$ & 7.75 & $\begin{array}{l}\text { Air } \\
50^{\circ} \mathrm{F} / 0 \mathrm{psig}\end{array}$ & 1.094 \\
\hline $\mathrm{n}$ & 01 & $\begin{array}{l}\text { Steel } \\
3 \text { in } / 40\end{array}$ & 3.5 & $\begin{array}{l}\text { Air } \\
50^{\circ} \mathrm{F} / 0 \mathrm{psig}\end{array}$ & 1.094 \\
\hline 0 & 01 & $\begin{array}{l}\text { Steel } \\
4 \mathrm{in} / 40\end{array}$ & 85 & $\begin{array}{l}\text { Air } \\
50^{\circ} \mathrm{F} / 0 \mathrm{psig}\end{array}$ & 1.913 \\
\hline$p$ & 01 & $\begin{array}{l}\text { Steel } \\
4 \text { in / } 40\end{array}$ & 98 & $\begin{array}{l}\text { Air } \\
50^{\circ} \mathrm{F} / 0_{\mathrm{psi}} \mathrm{g}\end{array}$ & 1.913 \\
\hline$q$ & 01 & $\begin{array}{l}\text { Steel } \\
4 \mathrm{in} / 40\end{array}$ & 96 & $\begin{array}{l}\mathrm{Air} \\
50^{\circ} \mathrm{F} / 0 \mathrm{psig}\end{array}$ & 1.913 \\
\hline$r$ & 01 & $\begin{array}{l}\text { Steel } \\
4 \text { in } / 40\end{array}$ & 97 & $\begin{array}{l}\text { Air } \\
50^{\circ} \mathrm{F} / 0 \mathrm{psig}\end{array}$ & 1.913 \\
\hline s & 01 & $\begin{array}{l}\text { Steel } \\
20 \mathrm{in} / 40\end{array}$ & 1 & $\begin{array}{l}\text { Air } \\
50^{\circ} \mathrm{F} / 0 \mathrm{psig}\end{array}$ & 0 \\
\hline$t$ & 01 & $\begin{array}{l}\text { Steel } \\
20 \text { in } / 40\end{array}$ & 1 & $\begin{array}{l}\text { Air } \\
50^{\circ} \mathrm{F} / 0 \text { psi g }\end{array}$ & 0 \\
\hline u & 01 & $\begin{array}{l}\text { Steel } \\
8 \text { in } / 40\end{array}$ & 1 & $\begin{array}{l}\text { Air } \\
50^{\circ} \mathrm{F} / 0 \text { psig }\end{array}$ & 536.1 \\
\hline$v$ & 01 & $\begin{array}{l}\text { Steel } \\
8 \text { in } / 40\end{array}$ & 1 & $\begin{array}{l}\text { Air } \\
50^{\circ} \mathrm{F} / 0 \mathrm{psig}\end{array}$ & 536.1 \\
\hline$w$ & 01 & $\begin{array}{l}\text { Steel } \\
8 \mathrm{in} / 40\end{array}$ & 1 & $\begin{array}{l}\text { Air } \\
50^{\circ} \mathrm{F} / 0 \mathrm{psig}\end{array}$ & 536.1 \\
\hline$x$ & 01 & $\begin{array}{l}\text { Steel } \\
8 \text { in } 140\end{array}$ & 1 & $\begin{array}{l}\text { Air } \\
50^{\circ} \mathrm{F} / 0 \mathrm{psig}\end{array}$ & 536.1 \\
\hline
\end{tabular}




\begin{tabular}{|c|c|c|c|c|c|}
\hline \multirow[b]{2}{*}{ PIPELINE } & \multicolumn{3}{|c|}{ PIPELIST } & \multicolumn{2}{|c|}{$02 / 17 / 98 \quad 9: 36 \mathrm{am}$} \\
\hline & SPEC & $\begin{array}{l}\text { MATERIAL } \\
\text { Size / Sch }\end{array}$ & $\begin{array}{l}\text { LENGTH } \\
\mathrm{ft}\end{array}$ & $\begin{array}{l}\text { FLUID } \\
\text { Temp / Pres }\end{array}$ & $\begin{array}{l}\text { VALVES } \\
\text { Total-K }\end{array}$ \\
\hline a & 01 & $\begin{array}{l}\text { Steel } \\
2 \text { in } / 40\end{array}$ & 7 & $\begin{array}{l}\text { Air } \\
50^{\circ} \mathrm{F} / 0 \mathrm{psig}\end{array}$ & 0.5 \\
\hline air dist & 03 & $\begin{array}{l}\text { Steel } \\
20 \text { in } / 80\end{array}$ & 1 & $\begin{array}{l}\text { Air } \\
50^{\circ} \mathrm{F} / 0 \mathrm{psig}\end{array}$ & 0 \\
\hline b & 02 & $\begin{array}{l}\text { Steel } \\
2 \text { in / } 160\end{array}$ & 1 & $\begin{array}{l}\text { Air } \\
50^{\circ} \mathrm{F} / 0 \mathrm{psig}\end{array}$ & 1.198 \\
\hline$c$ & 02 & $\begin{array}{l}\text { Steel } \\
2 \text { in } / 160\end{array}$ & 1 & $\begin{array}{l}\text { Air } \\
50^{\circ} \mathrm{F} / 0 \mathrm{psig}\end{array}$ & 1.198 \\
\hline d & 02 & $\begin{array}{l}\text { Steel } \\
2 \text { in } / 160\end{array}$ & 12 & $\begin{array}{l}\text { Air } \\
50^{\circ} \mathrm{F} / 0 \mathrm{psig}\end{array}$ & 1.198 \\
\hline e & 02 & $\begin{array}{l}\text { Steel } \\
2 \text { in } / 160\end{array}$ & 12 & $\begin{array}{l}\text { Air } \\
50^{\circ} \mathrm{F} / 0 \mathrm{psig}\end{array}$ & 1.198 \\
\hline$f$ & 03 & $\begin{array}{l}\text { Steel } \\
1.5 \mathrm{in} / 80\end{array}$ & 1.2 & $\begin{array}{l}\text { Air } \\
50^{\circ} \mathrm{F} / 0 \mathrm{psig}\end{array}$ & 1.233 \\
\hline g & 03 & $\begin{array}{l}\text { Steel } \\
1.5 \mathrm{in} / 80\end{array}$ & 1.2 & $\begin{array}{l}\text { Air } \\
50^{\circ} \mathrm{F} / 0 \text { psig }\end{array}$ & 1.233 \\
\hline h & 03 & $\begin{array}{l}\text { Steel } \\
1.5 \text { in / } 80\end{array}$ & 1.2 & $\begin{array}{l}\text { Air } \\
50^{\circ} \mathrm{F} / 0 \mathrm{psig}\end{array}$ & 1.233 \\
\hline $\mathbf{i}$ & 03 & $\begin{array}{l}\text { Steel } \\
1.5 \text { in } / 80\end{array}$ & 1.2 & $\begin{array}{l}\text { Air } \\
50^{\circ} \mathrm{F} / 0 \mathrm{psig}\end{array}$ & 1.233 \\
\hline j & 03 & $\begin{array}{l}\text { Stee! } \\
1.5 \mathrm{in} / 80\end{array}$ & 1.2 & $\begin{array}{l}\text { Air } \\
50^{\circ} \mathrm{F} / 0 \mathrm{psig}\end{array}$ & 0 \\
\hline k & 03 & $\begin{array}{l}\text { Steel } \\
1.5 \mathrm{in} / 80\end{array}$ & 16.75 & $\begin{array}{l}\text { Air } \\
50^{\circ} \mathrm{F} / 0 \mathrm{psig}\end{array}$ & 2.233 \\
\hline 1 & 03 & $\begin{array}{l}\text { Steel } \\
1.5 \mathrm{in} / 80\end{array}$ & 16.75 & $\begin{array}{l}\text { Air } \\
50^{\circ} \mathrm{F} / 0 \mathrm{psig}\end{array}$ & 2.233 \\
\hline$m$ & 03 & $\begin{array}{l}\text { Steel } \\
1.5 \mathrm{in} / 80\end{array}$ & 16.75 & $\begin{array}{l}\text { Air } \\
50^{\circ} \mathrm{F} / 0 \mathrm{psig}\end{array}$ & 2.233 \\
\hline $\mathbf{n}$ & 03 & $\begin{array}{l}\text { Steel } \\
1.5 \mathrm{in} / 80\end{array}$ & 16.75 & $\begin{array}{l}\text { Air } \\
50^{\circ} \mathrm{F} / 0 \mathrm{psig}\end{array}$ & 2,233 \\
\hline 0 & 01 & $\begin{array}{l}\text { Steel } \\
32 \mathrm{in} / 40\end{array}$ & 40.17 & $\begin{array}{l}\text { Air } \\
50^{\circ} \mathrm{F} / 0 \mathrm{psig}\end{array}$ & 0 \\
\hline
\end{tabular}


Company: Fluor Daniel NW

Project:

by: Fluor Daniel NW

Created: 01/26/98 9:46 am

Design file:

Pipe Specs: 3
MATERIALS REPORT

9.36 am

rystem: ANNULUS2 $01 / 29 / 98$ 10:30 am $B-6$ of $B-11$

Pipes: 16

Nodes: 13

Pumps/Comps: 0

\begin{tabular}{|c|c|c|c|c|}
\hline \multirow[b]{2}{*}{ PIPELINE } & \multicolumn{4}{|c|}{ PIPE MATERIALS LIST } \\
\hline & SPEC & $\begin{array}{l}\text { MATERIAL } \\
\text { Size/ Sch }\end{array}$ & $\begin{array}{l}\text { LENGTH } \\
\mathrm{ft}\end{array}$ & VALVES \& FITTINGS \\
\hline a & 01 & $\begin{array}{l}\text { Steel } \\
2 \text { in } / 40\end{array}$ & 7 & 1-Entrance Sharp-Edged \\
\hline air dist & 03 & $\begin{array}{l}\text { Steel } \\
20 \mathrm{in} / 80\end{array}$ & 1 & \\
\hline$b$ & 02 & $\begin{array}{l}\text { Steel } \\
2 \text { in } / 160\end{array}$ & 1 & 1-Tee Flow Thru Branch \\
\hline c & 02 & $\begin{array}{l}\text { Steel } \\
2 \text { in } / 160\end{array}$ & 1 & 1-Tee Flow Thru Branch \\
\hline d & 02 & $\begin{array}{l}\text { Stee! } \\
2 \text { in } / 160\end{array}$ & 12 & 1-Tee Flow Thru Branch \\
\hline e & 02 & $\begin{array}{l}\text { Steel } \\
2 \text { in } / 160\end{array}$ & 12 & 1-Tee Flow Thru Branch \\
\hline$f$ & 03 & $\begin{array}{l}\text { Steel } \\
1.5 \mathrm{in} / 80\end{array}$ & 1.2 & 1-Tee Flow Thru Branch \\
\hline$g$ & 03 & $\begin{array}{l}\text { Steel } \\
1.5 \mathrm{in} / 80\end{array}$ & 1.2 & 1-Tee Flow Thru Branch \\
\hline h & 03 & $\begin{array}{l}\text { Steel } \\
1.5 \mathrm{in} / 80\end{array}$ & 1.2 & 1-Tee Flow Thru Branch \\
\hline $\mathbf{i}$ & 03 & $\begin{array}{l}\text { Steel } \\
1.5 \mathrm{in} / 80\end{array}$ & 1.2 & 1-Tee Flow Thru Branch \\
\hline $\mathbf{j}$ & 03 & $\begin{array}{l}\text { Steel } \\
1.5 \mathrm{in} / 80\end{array}$ & 1.2 & \\
\hline k & 03 & $\begin{array}{l}\text { Steel } \\
1.5 \mathrm{in} / 80\end{array}$ & 16.75 & $\begin{array}{l}\text { 1-Tee Flow Thru Branch } \\
\text { 1-Exit Sharp-Edged }\end{array}$ \\
\hline 1 & 03 & $\begin{array}{l}\text { Steel } \\
1.5 \mathrm{in} / 80\end{array}$ & 16.75 & $\begin{array}{l}\text { 1-Tee Flow Thru Branch } \\
\text { 1-Exit Sharp-Edged }\end{array}$ \\
\hline $\mathrm{m}$ & 03 & $\begin{array}{l}\text { Steel } \\
1.5 \mathrm{in} / 80\end{array}$ & 16.75 & $\begin{array}{l}\text { 1-Tee Flow Thru Branch } \\
\text { 1-Exit Sharp-Edged }\end{array}$ \\
\hline$n$ & 03 & $\begin{array}{l}\text { Steel } \\
1.5 \mathrm{in} / 80\end{array}$ & 16.75 & $\begin{array}{l}\text { 1-Tee Flow Thru Branch } \\
\text { 1-Exit Sharp-Edged }\end{array}$ \\
\hline 0 & 01 & $\begin{array}{l}\text { Steel } \\
32 \text { in } / 40\end{array}$ & 40.17 & \\
\hline
\end{tabular}

PIPE MATERIALS LIST

$\mathrm{ft}$
$\mathrm{ft}$

Pipe Specs: 3 
PIPE SUMMARY

\section{PIPE MATERIAL}

Steel

Steel

Steel

\section{SCHEDULE}

160

40

80
SIZE

1.5 in

20 in

2 in

2 in

32 in ENGTH

$26 \mathrm{ft}$

$7 \mathrm{ft}$

$40.17 \mathrm{ft}$

$73 \mathrm{ft}$

$1 \mathrm{ft}$

VALVE \& FITTING SUMMARY

SPECIFICATION

011

022

033
MATERIAL

Steel

Size: 2 in

Steel

Size: 2 in

Steel

Size: 1.5 in
SCHEDULE VALVES \& FITTINGS

40

160

4-Tee Flow Thru Branch

80

8-Tee Flow Thru Branch

4-Exit Sharp-Edged 


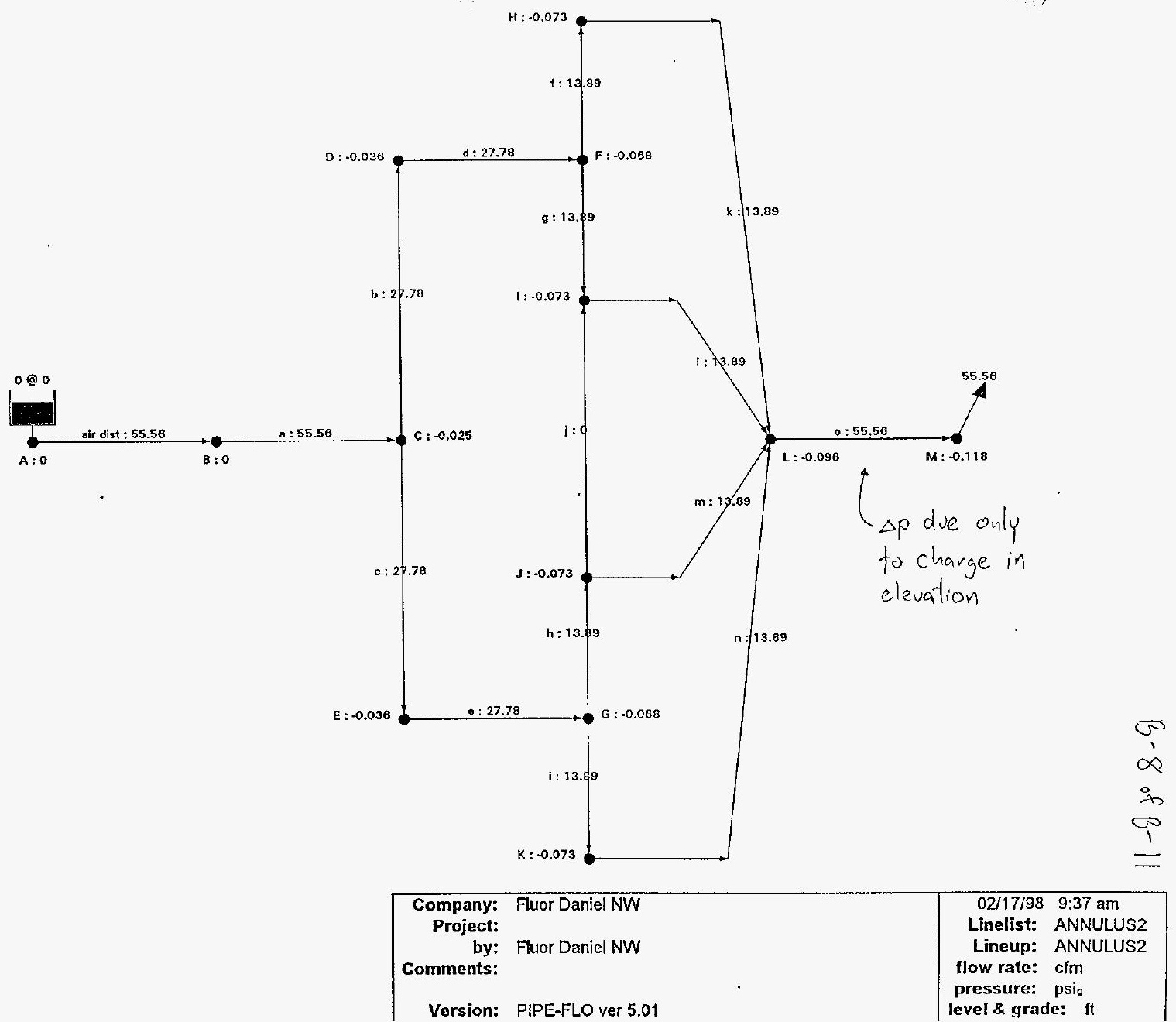


Company: Fluor Daniel NW

Project:

by: Fluor Daniel NW

rev: 02/17/98 9:36 am $B-9$ of $B-11$

System: ANNULUS2

rev: 01/29/98 10:30 am

Deviation: $0.00456 \%$

after: 6 iterations

Volumetric flow rates require constant fluid properties in all pipelines. Fluid properties in the first specification were used in this calculation.

LINEUP SUMMARIES

NODE

DEMAND NODE

DEMAND

$\mathrm{cfm}$

$\mathrm{cfm}$

M

$\gg \quad 55.56$

Flows IN: $0 \mathrm{~cm}$

Flows OUT: $55.56 \mathrm{cfm}$

NET FLOWS OUT: $55.56 \mathrm{cfm}$

LINEUP SUMMARIES

PIPELINE

FLOW

PRESSURE

SOURCE

SET

cfm

A

psig

LEVEL

air dist

« 55.56

0

0

Flows IN: $55.56 \mathrm{cfm}$

Flows OUT: $0 \mathrm{cfm}$

NET FLOWS IN: $55.56 \mathrm{cfm}$ 
NODE

A

B

C

D

E

F

G

H

1

J

K

L

M
ELEVATION

$\mathrm{ft}$

623

623

623

623

623

623

623

623

623

623

623

623

663.17
DEMAND
$\mathrm{cfm}$

0 (source)

0

$-0.025$

$-0.036$

$-0.036$

$-0.068$

$-0.068$

$-0.073$

$-0.073$

$-0.073$

$-0.073$

$-0.096$

$-0.118$
H GRADE

ft

623

623

576.8

556.6

556.6

496.5

496.5

487.6

487.6

487.6

487.6

445.7

445.7 
ט2/1//48 y:3/ am

PIPELINE

\section{FROM}

TO

FLOW

$\mathrm{cfm}$

VEL

ftsec

55.56

55.56

A

C

8

39.77

0.528

27.78

27.78

C

D

29.85

27.78

27.78

E

13.89

13.89

13.89

13.89

0

13.89

13.89

13.89

13.89

55.56

29.85

29.85

29.85

18.88

18.88

18.88

18.88

0

18.88

18.88

18.88

18.88

0.181

M

$B-11$ of $B-11$

HL

ft

46.16

0

20.2

20.2

60.13

60.13

8.935

8.935

8.935

8.935

0

41.88

41.88

41.88

41.88

0 


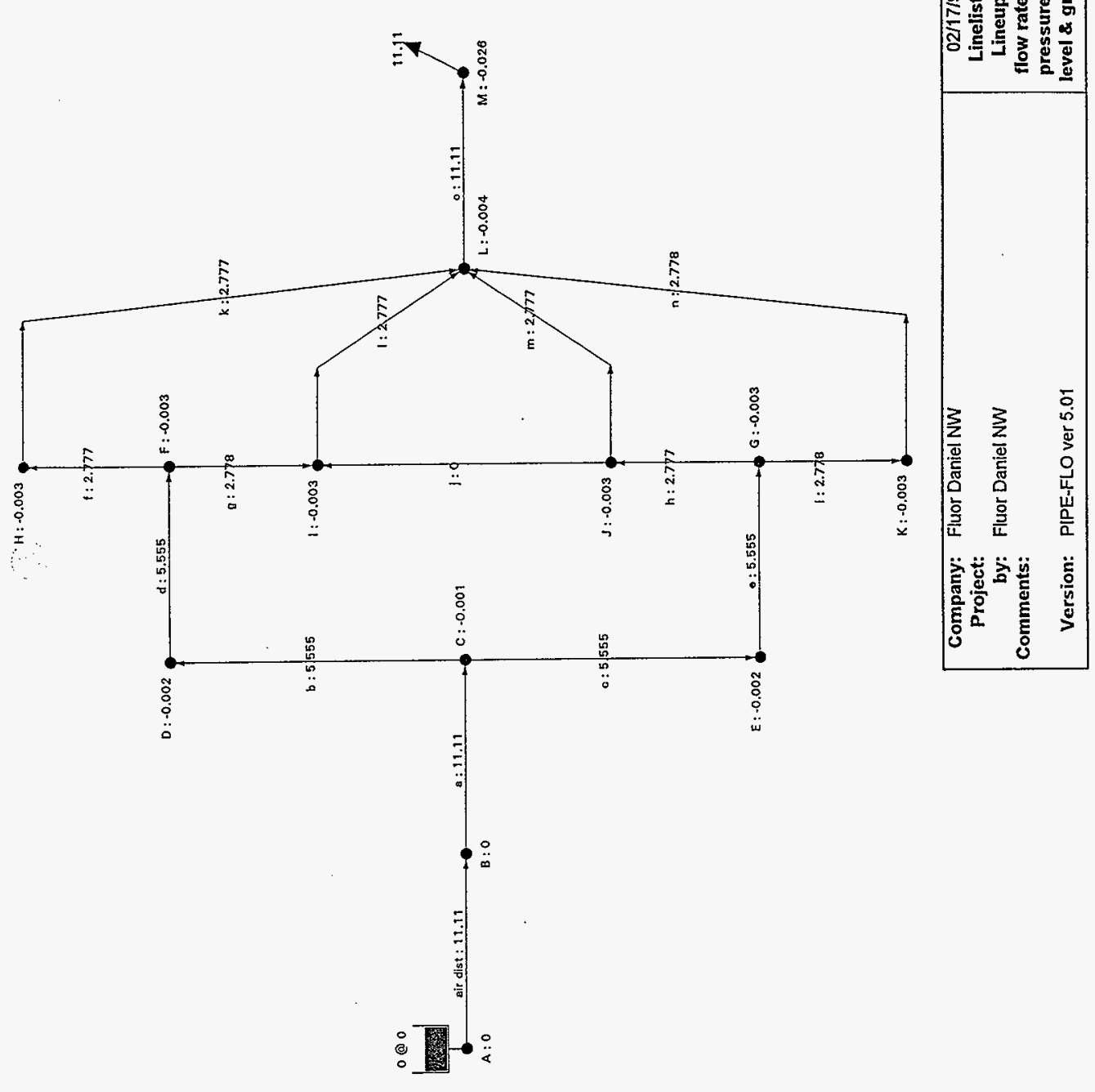

Calculation w320-27-054 


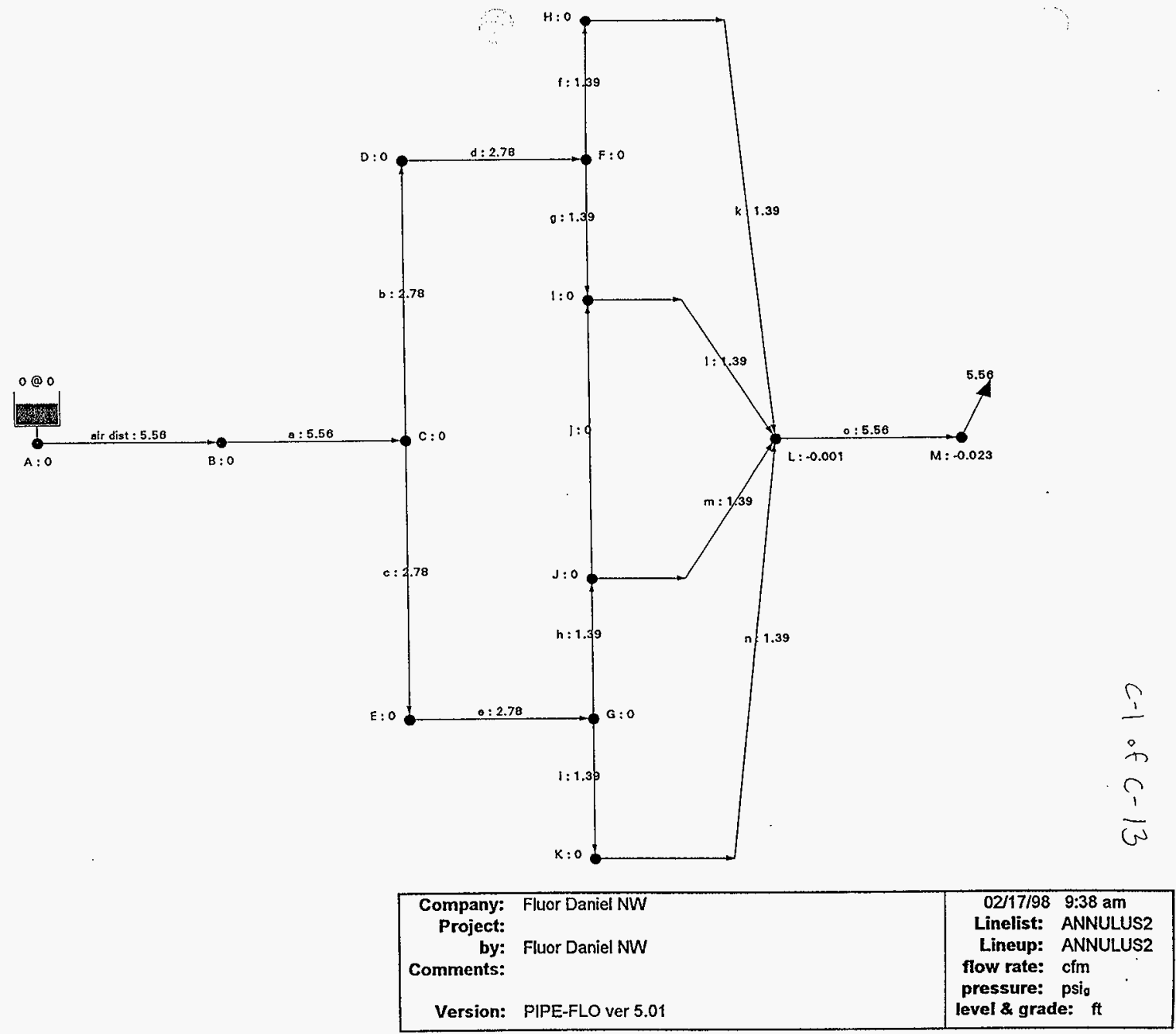




\section{DESIGN ANALYSIS}

Revision: 0

Page No. $C-O$ of $C-13$

Client: Numatec

WO/Job No: : ER4319N-320

Subject: System Curves for Portable Exhauster Installation

Date: $2 / 18 / 98$

checked: $3 / 2 / 98$

By: Kelly Hayase,

Location: 241-C/241-AY

Revised:

By: Kan cerl

By:

Appendix C: Pipe-Flo results of ANNULUS2 for different flow rates used as input into Pipe-Flo Model ANNULUS 
PIPELINE

$z$

za

$z b$

zo

$z d$

ze

$z f$

$\mathrm{zg}$

$z h$

zi

zj

$z k$

zl

$z m$

$z n$

zo

$2 p$

$\mathrm{zq}$

$\mathrm{zr}$

zs

zt

zu

iv
SPEC MATERIAL

Size / Sch

01 Steel

8 in 140

01 Steel

8 in $/ 40$

01 Steel

4 in $/ 40$

01 Steel

$4 \mathrm{in} / 40$

01 Steel

4 in $/ 40$

01 Steel

4 in $/ 40$

01 Steel

4 in $/ 40$

01 Steel

4 in $/ 40$

01 Steel

6 in 140

01 Steel

6 in $/ 40$

01 Stee!

6 in $/ 40$

01 Steel

6 in $/ 40$

01 Steel

6 in $/ 40$

01 Steel

$6 \mathrm{in} / 40$

01 Steel

8 in $/ 40$

01 Steel

12 in $/ 40$

01 Steel

12 in $/ 40$

01 Steel

12 in $/ 40$

01 Steel

8 in $/ 40$

01 Steel

8 in 140

01 Steel

16 in $/ 40$

01 Steel

32 in $/ 40$

01 Steel

32 in $/ 40$

01 Steel

32 in $/ 40$
LENGTH

it

1

1

6

6.33

6.33

8.33

7.33

5.33

12

12

12

14

12

20

50

53

47

27

51

21

15

40

40

40

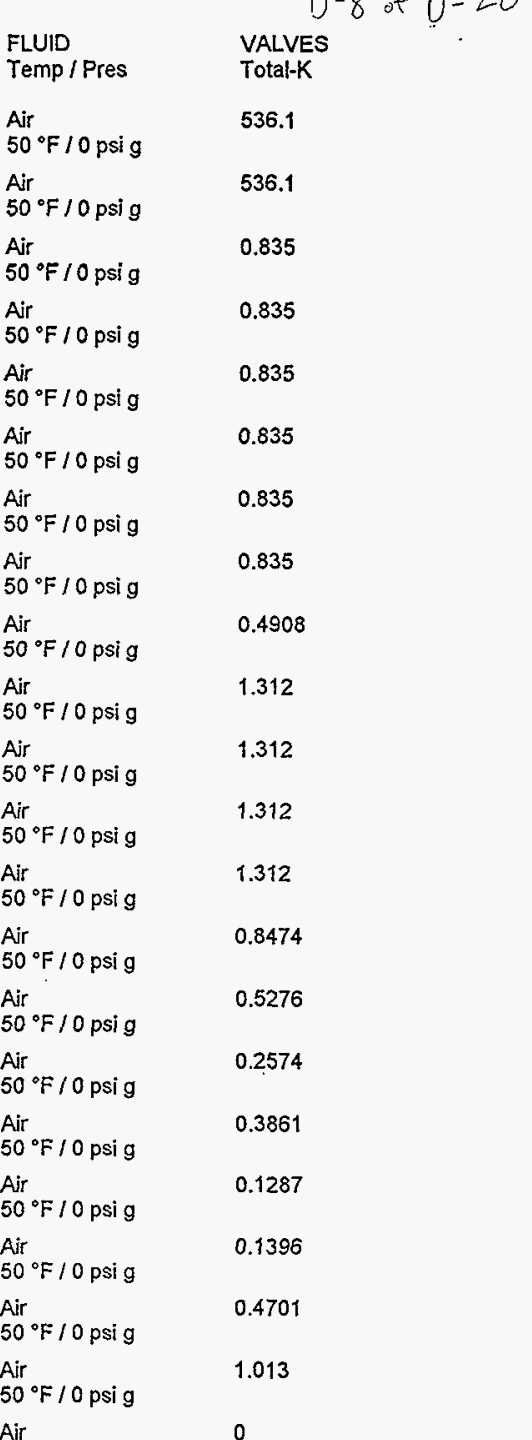

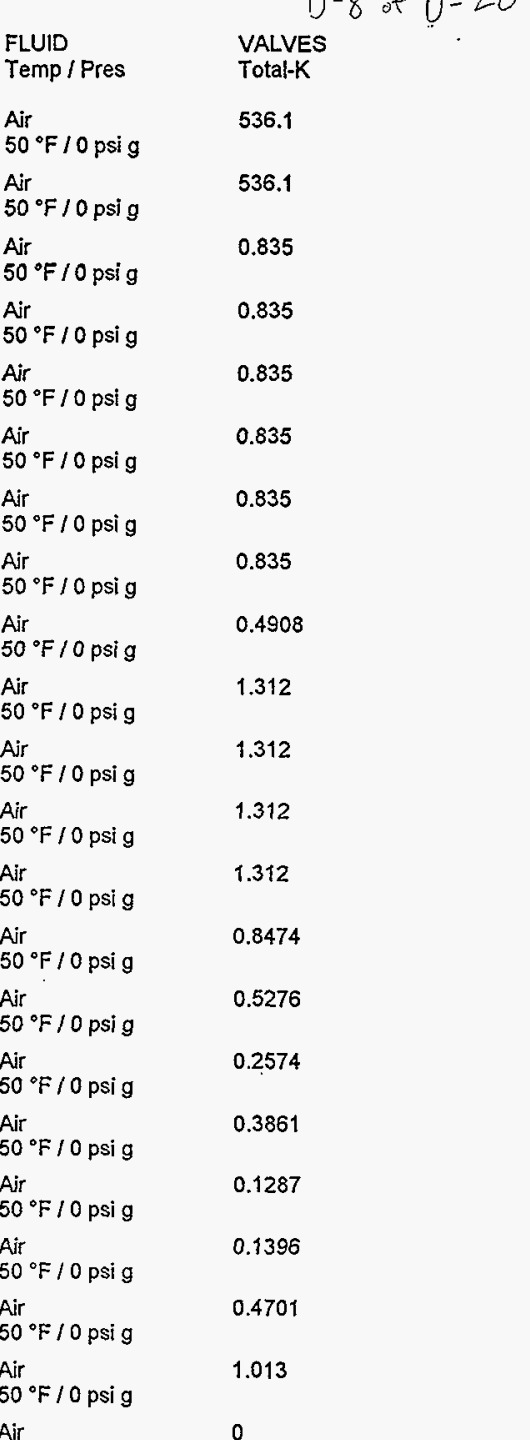

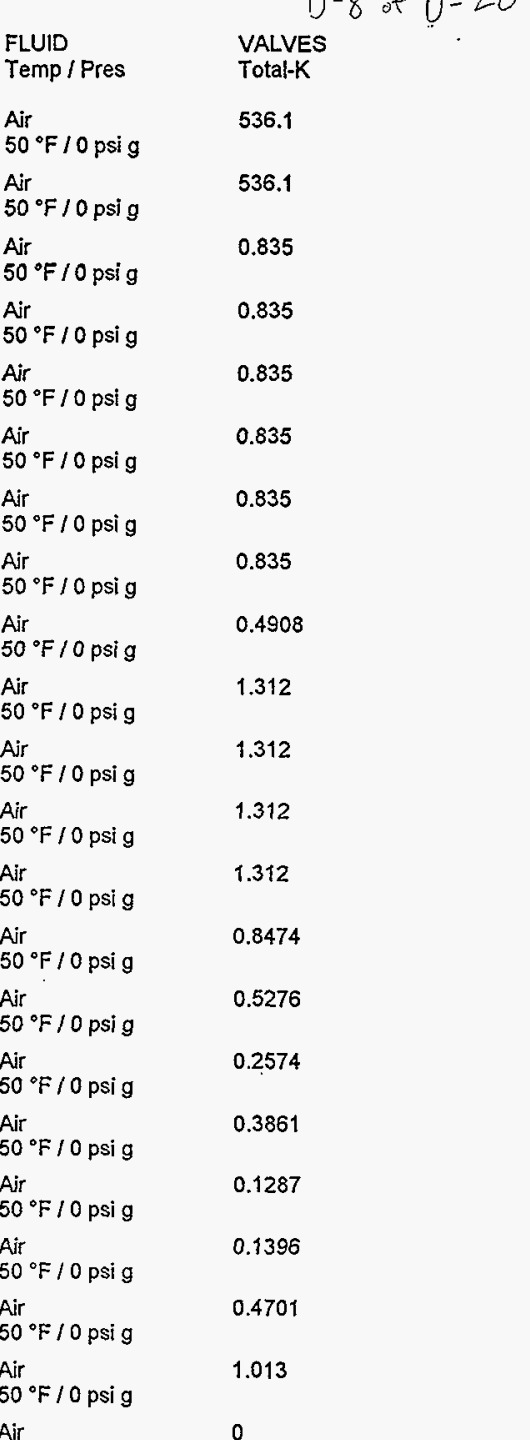

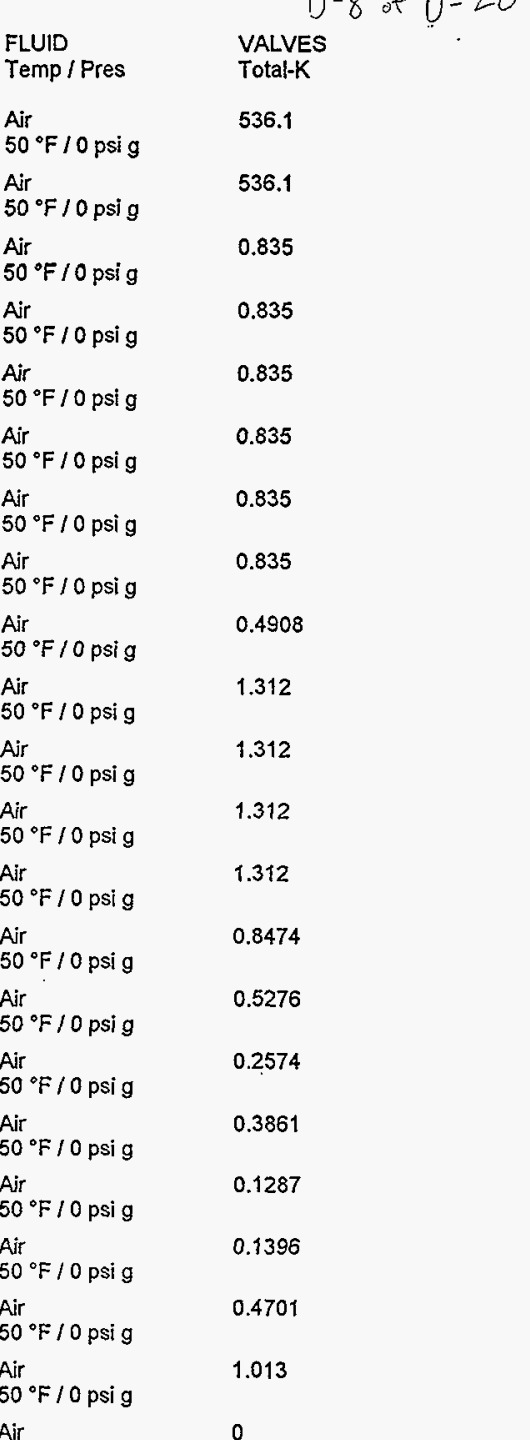

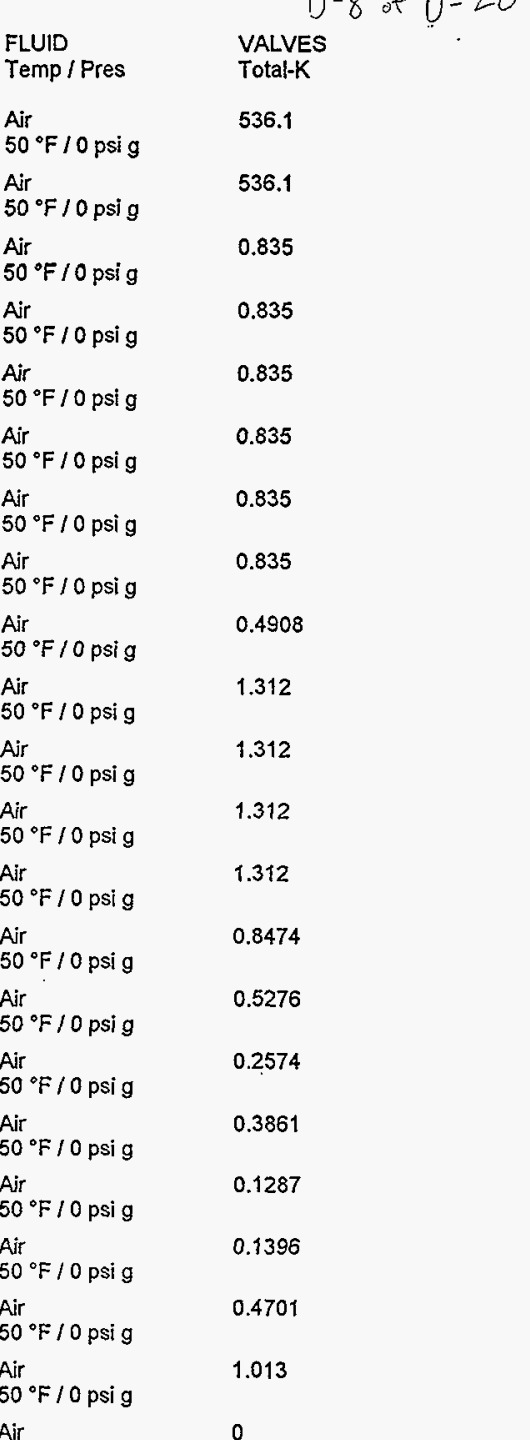

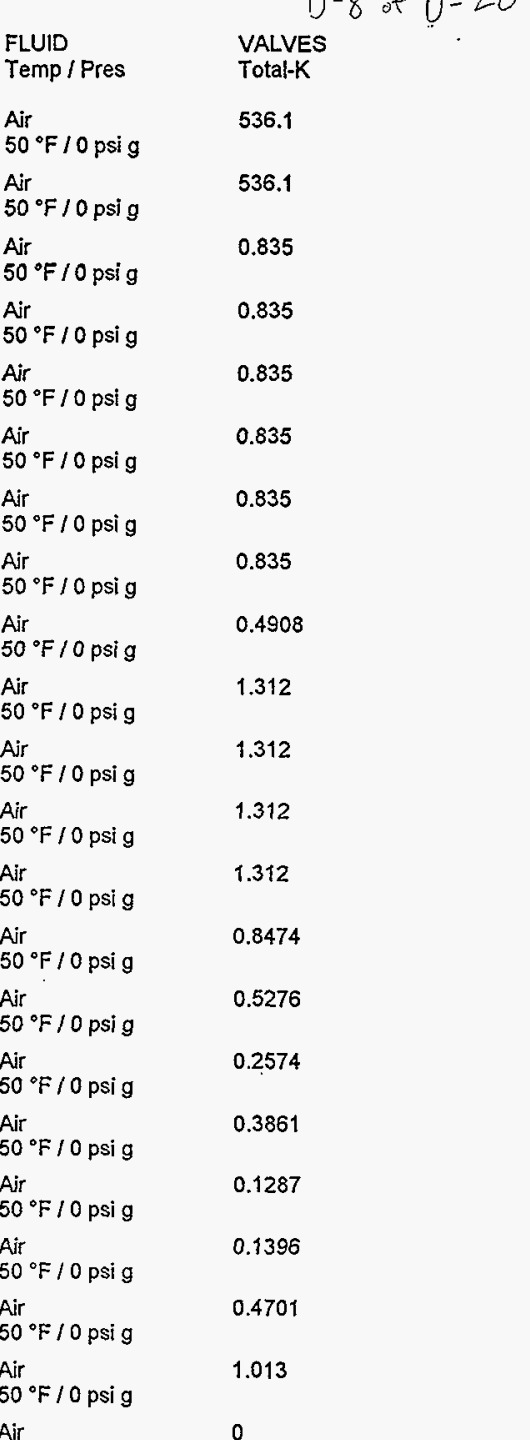

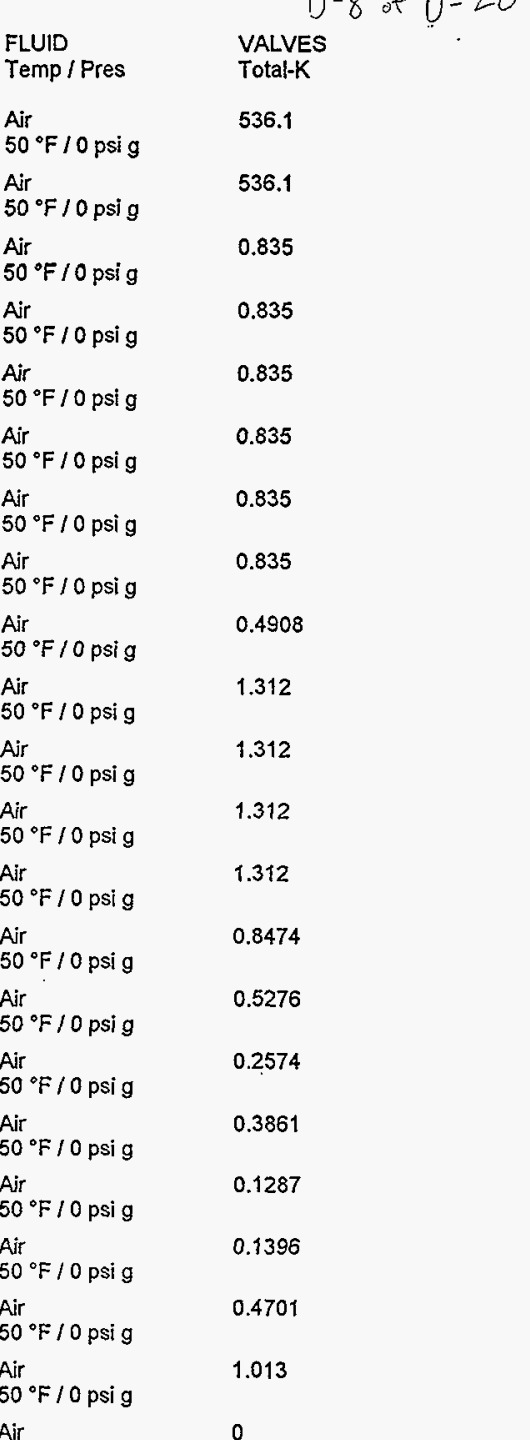

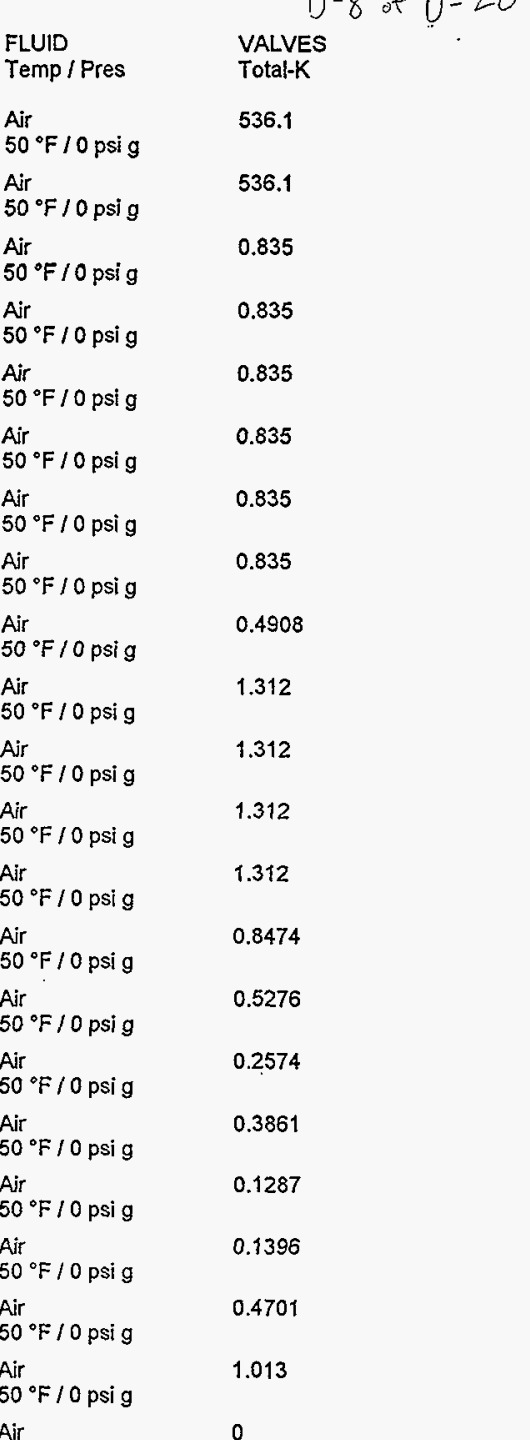

Air

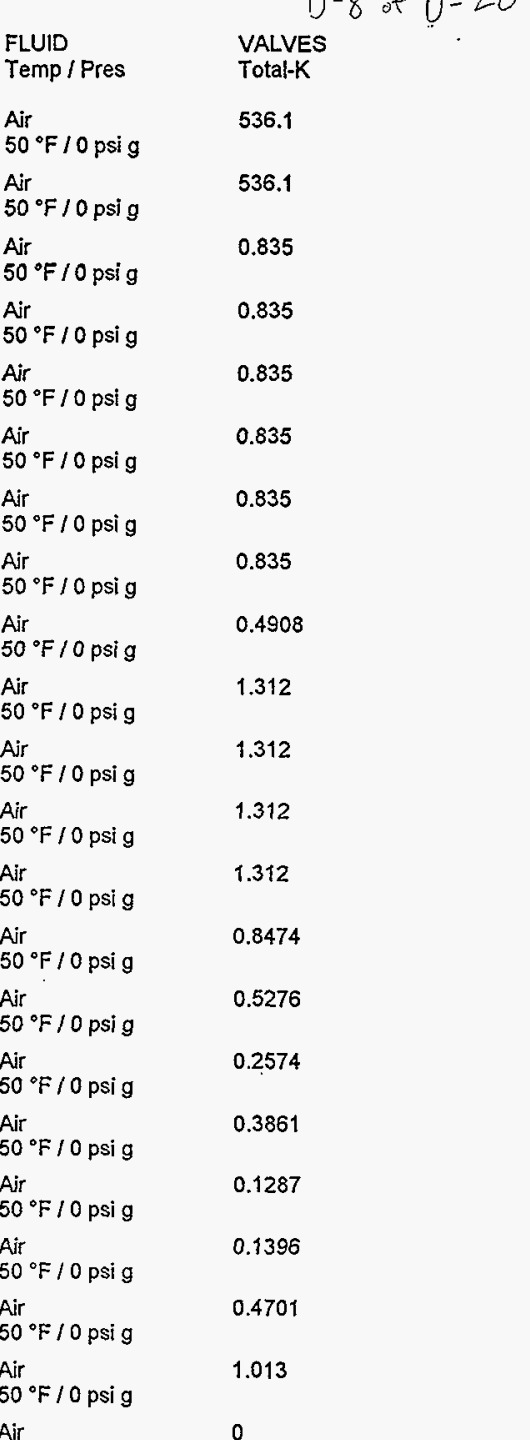

Air

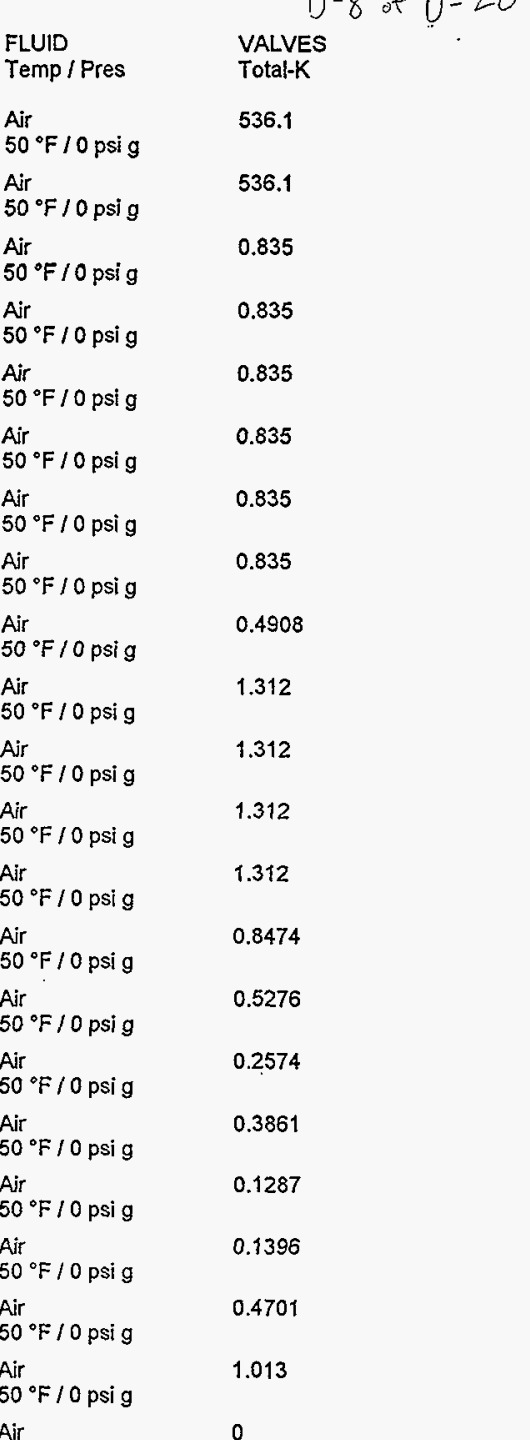

Air

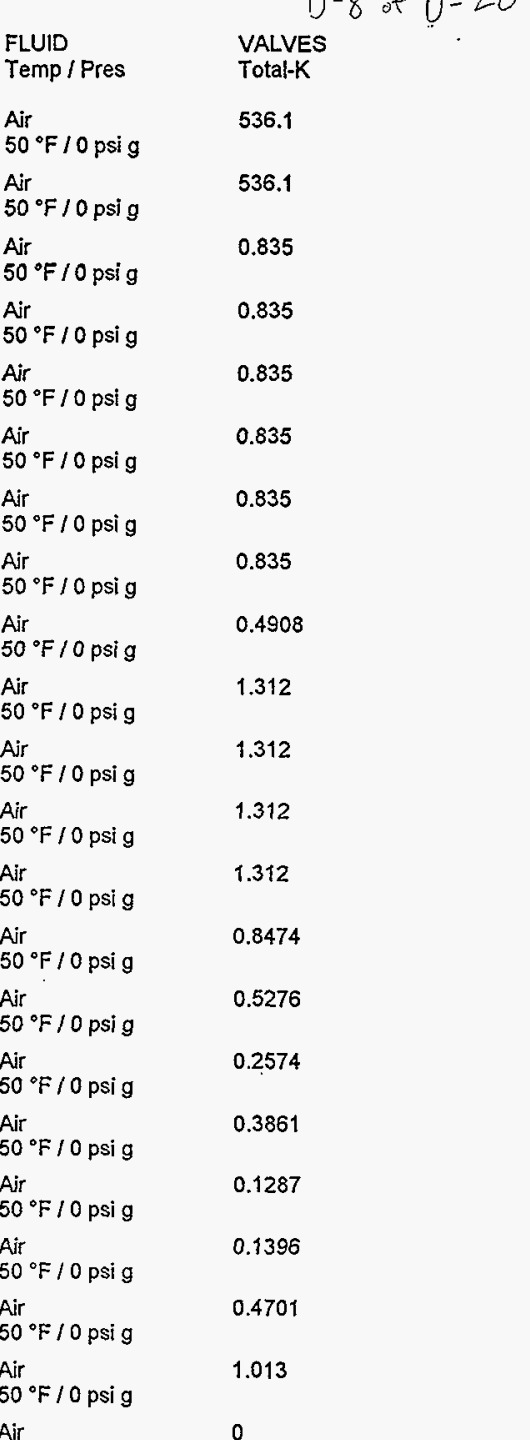

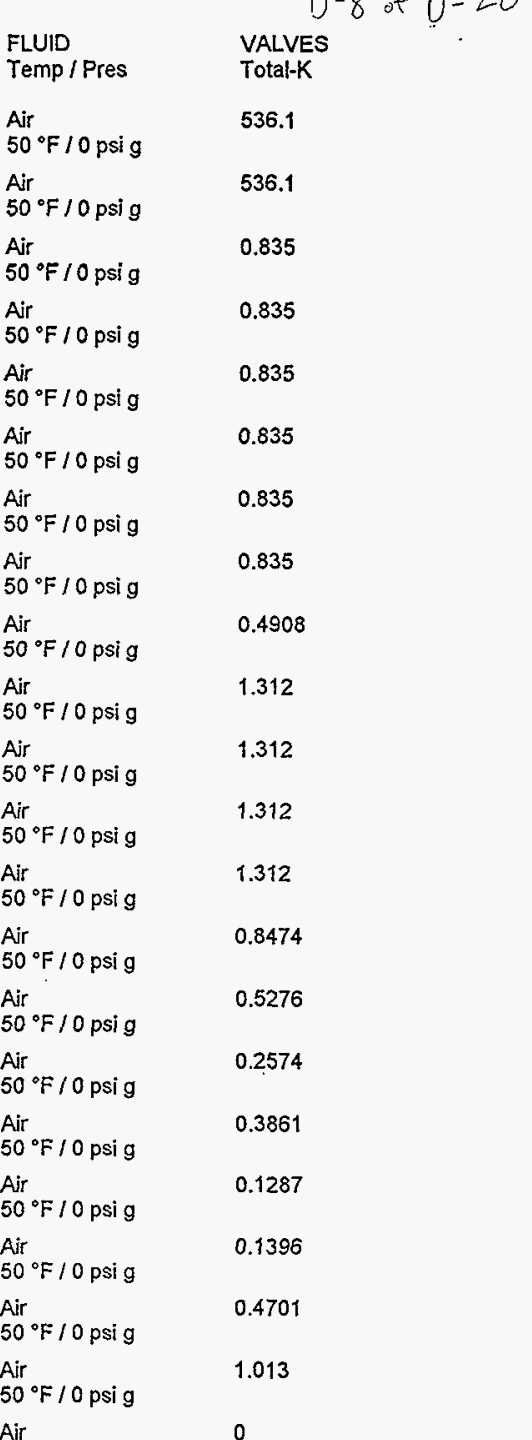

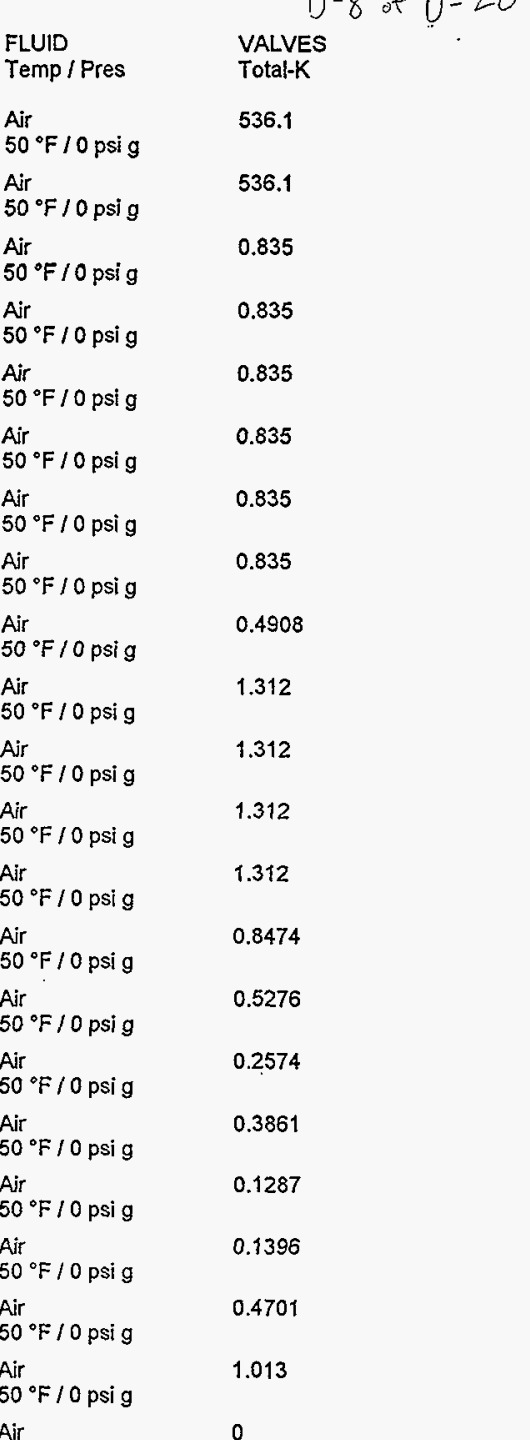

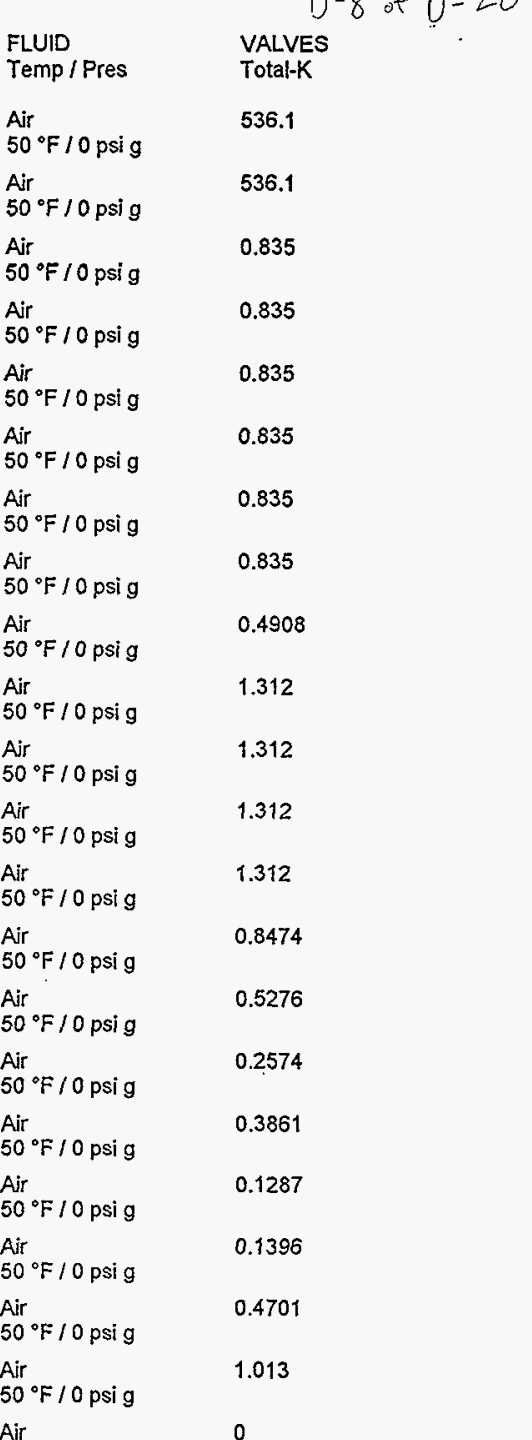

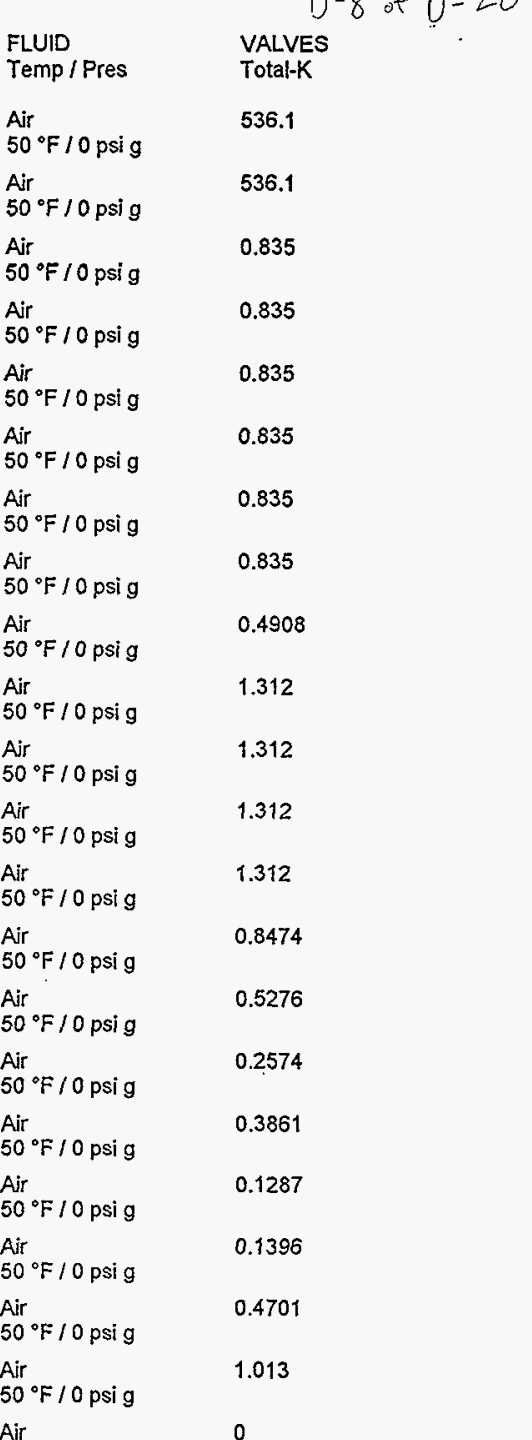

Air

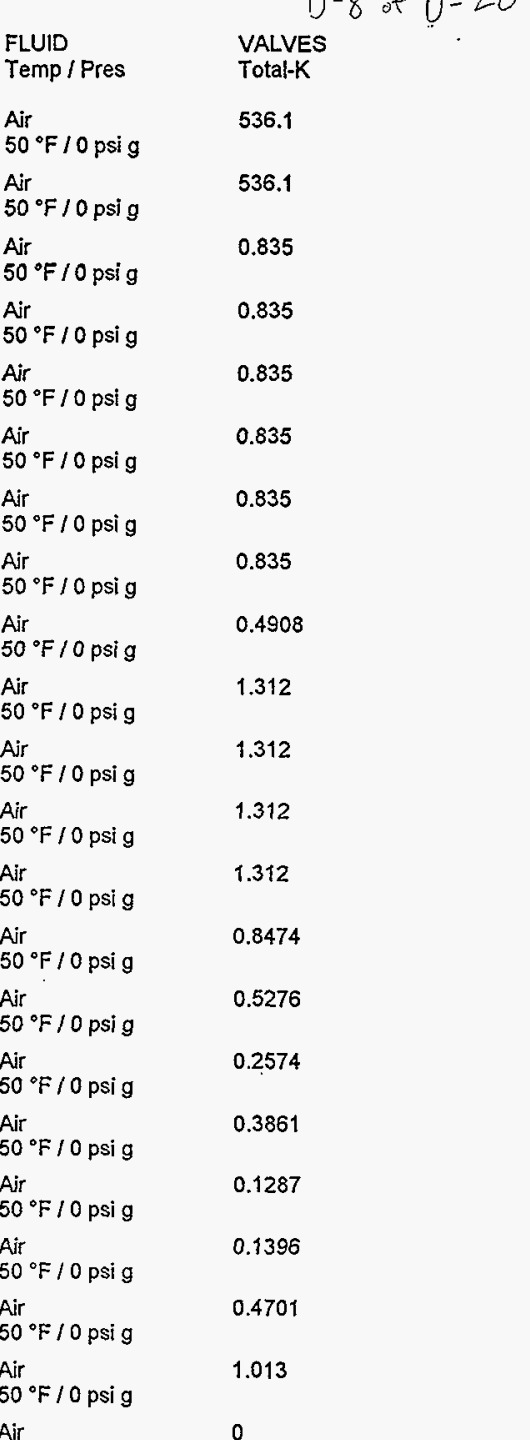

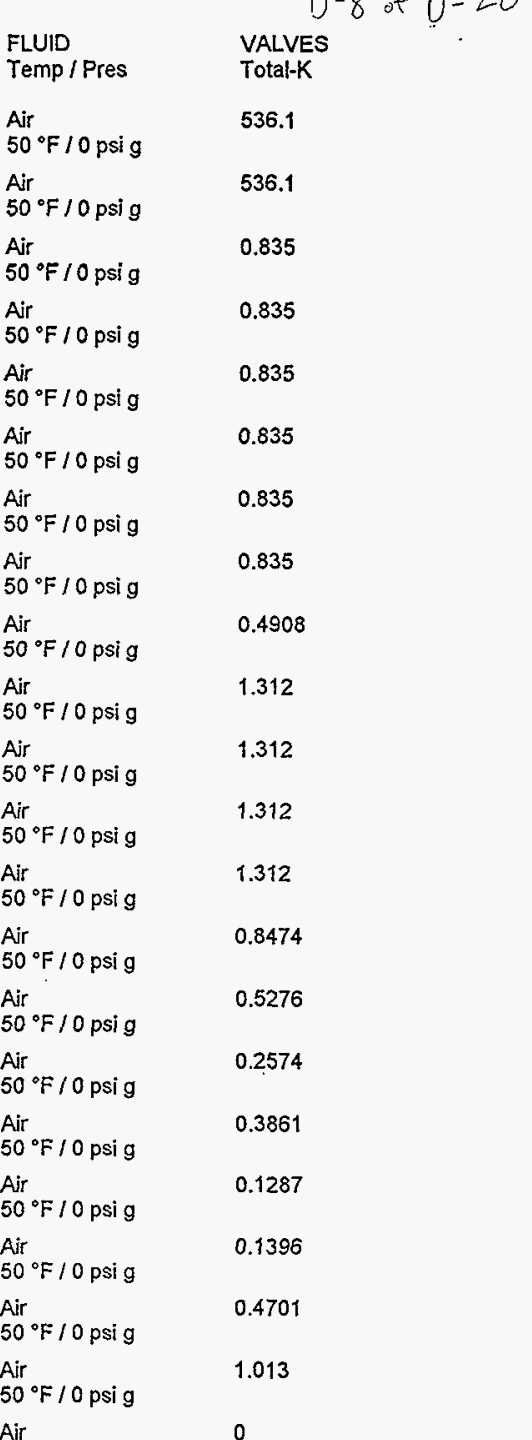

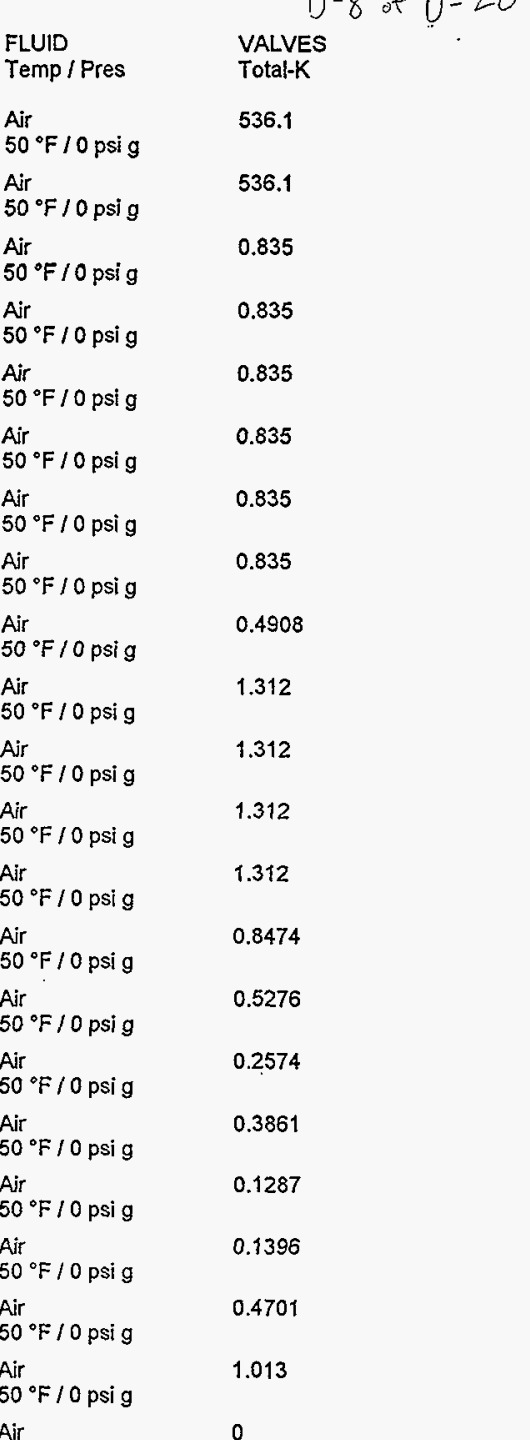

Air

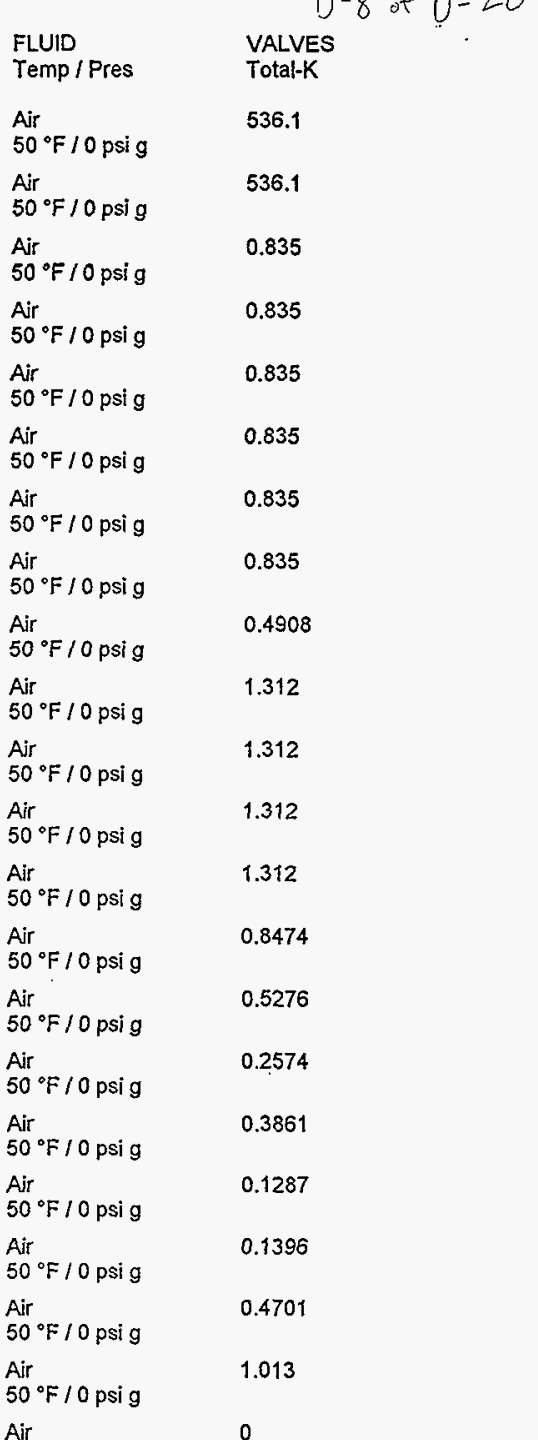

Air

\begin{tabular}{ll} 
FLUID & \multicolumn{1}{c}{ VALVES } \\
Temp / Pres & Total-K \\
Air & \\
$50^{\circ} \mathrm{F} / 0 \mathrm{psig}$ & 536.1 \\
Air & \\
$50^{\circ} \mathrm{F} / 0 \mathrm{psig}$ & 536.1 \\
Air & \\
$50^{\circ} \mathrm{F} / 0 \mathrm{psig}$ & 0.835 \\
Air & \\
$50^{\circ} \mathrm{F} / 0 \mathrm{psig}$ & 0.835 \\
Air & \\
$50^{\circ} \mathrm{F} / 0 \mathrm{psig}$ & 0.835 \\
Air & \\
$50^{\circ} \mathrm{F} / 0 \mathrm{psig}$ & 0.835 \\
Air & \\
$50^{\circ} \mathrm{F} / 0 \mathrm{psig}$ & 0.835 \\
Air & \\
$50^{\circ} \mathrm{F} / 0 \mathrm{psig}$ & 0.835 \\
Air & \\
$50^{\circ} \mathrm{F} / 0 \mathrm{psig}$ & 0.4908 \\
Air \\
$50^{\circ} \mathrm{F} / 0 \mathrm{psig}$
\end{tabular}

Air

\begin{tabular}{ll} 
FLUID & \multicolumn{1}{c}{ VALVES } \\
Temp / Pres & Total-K \\
Air & \\
$50^{\circ} \mathrm{F} / 0 \mathrm{psig}$ & 536.1 \\
Air & \\
$50^{\circ} \mathrm{F} / 0 \mathrm{psig}$ & 536.1 \\
Air & \\
$50^{\circ} \mathrm{F} / 0 \mathrm{psig}$ & 0.835 \\
Air & \\
$50^{\circ} \mathrm{F} / 0 \mathrm{psig}$ & 0.835 \\
Air & \\
$50^{\circ} \mathrm{F} / 0 \mathrm{psig}$ & 0.835 \\
Air & \\
$50^{\circ} \mathrm{F} / 0 \mathrm{psig}$ & 0.835 \\
Air & \\
$50^{\circ} \mathrm{F} / 0 \mathrm{psig}$ & 0.835 \\
Air & \\
$50^{\circ} \mathrm{F} / 0 \mathrm{psig}$ & 0.835 \\
Air & \\
$50^{\circ} \mathrm{F} / 0 \mathrm{psig}$ & 0.4908 \\
Air \\
$50^{\circ} \mathrm{F} / 0 \mathrm{psig}$
\end{tabular}

Air

\begin{tabular}{ll} 
FLUID & \multicolumn{1}{c}{ VALVES } \\
Temp / Pres & Total-K \\
Air & \\
$50^{\circ} \mathrm{F} / 0 \mathrm{psig}$ & 536.1 \\
Air & \\
$50^{\circ} \mathrm{F} / 0 \mathrm{psig}$ & 536.1 \\
Air & \\
$50^{\circ} \mathrm{F} / 0 \mathrm{psig}$ & 0.835 \\
Air & \\
$50^{\circ} \mathrm{F} / 0 \mathrm{psig}$ & 0.835 \\
Air & \\
$50^{\circ} \mathrm{F} / 0 \mathrm{psig}$ & 0.835 \\
Air & \\
$50^{\circ} \mathrm{F} / 0 \mathrm{psig}$ & 0.835 \\
Air & \\
$50^{\circ} \mathrm{F} / 0 \mathrm{psig}$ & 0.835 \\
Air & \\
$50^{\circ} \mathrm{F} / 0 \mathrm{psig}$ & 0.835 \\
Air & \\
$50^{\circ} \mathrm{F} / 0 \mathrm{psig}$ & 0.4908 \\
Air \\
$50^{\circ} \mathrm{F} / 0 \mathrm{psig}$
\end{tabular}

Air

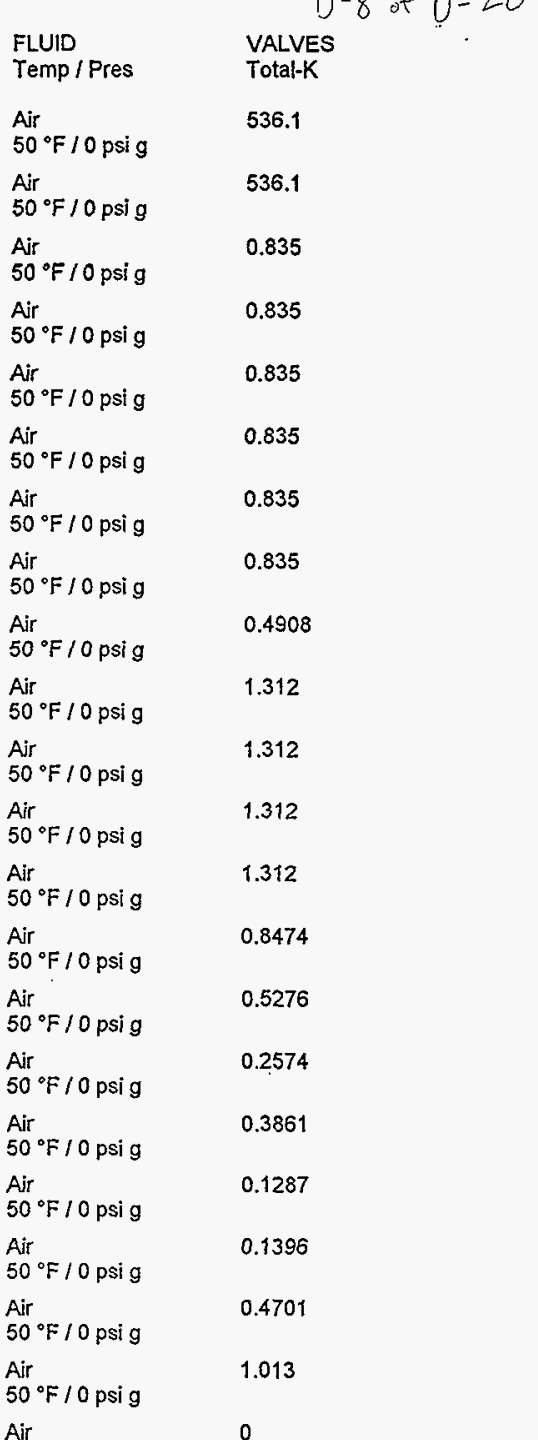

Air

\begin{tabular}{ll} 
FLUID & \multicolumn{1}{c}{ VALVES } \\
Temp / Pres & Total-K \\
Air & \\
$50^{\circ} \mathrm{F} / 0 \mathrm{psig}$ & 536.1 \\
Air & \\
$50^{\circ} \mathrm{F} / 0 \mathrm{psig}$ & 536.1 \\
Air & \\
$50^{\circ} \mathrm{F} / 0 \mathrm{psig}$ & 0.835 \\
Air & \\
$50^{\circ} \mathrm{F} / 0 \mathrm{psig}$ & 0.835 \\
Air & \\
$50^{\circ} \mathrm{F} / 0 \mathrm{psig}$ & 0.835 \\
Air & \\
$50^{\circ} \mathrm{F} / 0 \mathrm{psig}$ & 0.835 \\
Air & \\
$50^{\circ} \mathrm{F} / 0 \mathrm{psig}$ & 0.835 \\
Air & \\
$50^{\circ} \mathrm{F} / 0 \mathrm{psig}$ & 0.835 \\
Air & \\
$50^{\circ} \mathrm{F} / 0 \mathrm{psig}$ & 0.4908 \\
Air \\
$50^{\circ} \mathrm{F} / 0 \mathrm{psig}$
\end{tabular}

Air

\begin{tabular}{ll} 
FLUID & \multicolumn{1}{c}{ VALVES } \\
Temp / Pres & Total-K \\
Air & \\
$50^{\circ} \mathrm{F} / 0 \mathrm{psig}$ & 536.1 \\
Air & \\
$50^{\circ} \mathrm{F} / 0 \mathrm{psig}$ & 536.1 \\
Air & \\
$50^{\circ} \mathrm{F} / 0 \mathrm{psig}$ & 0.835 \\
Air & \\
$50^{\circ} \mathrm{F} / 0 \mathrm{psig}$ & 0.835 \\
Air & \\
$50^{\circ} \mathrm{F} / 0 \mathrm{psig}$ & 0.835 \\
Air & \\
$50^{\circ} \mathrm{F} / 0 \mathrm{psig}$ & 0.835 \\
Air & \\
$50^{\circ} \mathrm{F} / 0 \mathrm{psig}$ & 0.835 \\
Air & \\
$50^{\circ} \mathrm{F} / 0 \mathrm{psig}$ & 0.835 \\
Air & \\
$50^{\circ} \mathrm{F} / 0 \mathrm{psig}$ & 0.4908 \\
Air \\
$50^{\circ} \mathrm{F} / 0 \mathrm{psig}$
\end{tabular}

Air

\begin{tabular}{ll} 
FLUID & \multicolumn{1}{c}{ VALVES } \\
Temp / Pres & Total-K \\
Air & \\
$50^{\circ} \mathrm{F} / 0 \mathrm{psig}$ & 536.1 \\
Air & \\
$50^{\circ} \mathrm{F} / 0 \mathrm{psig}$ & 536.1 \\
Air & \\
$50^{\circ} \mathrm{F} / 0 \mathrm{psig}$ & 0.835 \\
Air & \\
$50^{\circ} \mathrm{F} / 0 \mathrm{psig}$ & 0.835 \\
Air & \\
$50^{\circ} \mathrm{F} / 0 \mathrm{psig}$ & 0.835 \\
Air & \\
$50^{\circ} \mathrm{F} / 0 \mathrm{psig}$ & 0.835 \\
Air & \\
$50^{\circ} \mathrm{F} / 0 \mathrm{psig}$ & 0.835 \\
Air & \\
$50^{\circ} \mathrm{F} / 0 \mathrm{psig}$ & 0.835 \\
Air & \\
$50^{\circ} \mathrm{F} / 0 \mathrm{psig}$ & 0.4908 \\
Air \\
$50^{\circ} \mathrm{F} / 0 \mathrm{psig}$
\end{tabular}

Air

\begin{tabular}{ll} 
FLUID & \multicolumn{1}{c}{ VALVES } \\
Temp / Pres & Total-K \\
Air & \\
$50^{\circ} \mathrm{F} / 0 \mathrm{psig}$ & 536.1 \\
Air & \\
$50^{\circ} \mathrm{F} / 0 \mathrm{psig}$ & 536.1 \\
Air & \\
$50^{\circ} \mathrm{F} / 0 \mathrm{psig}$ & 0.835 \\
Air & \\
$50^{\circ} \mathrm{F} / 0 \mathrm{psig}$ & 0.835 \\
Air & \\
$50^{\circ} \mathrm{F} / 0 \mathrm{psig}$ & 0.835 \\
Air & \\
$50^{\circ} \mathrm{F} / 0 \mathrm{psig}$ & 0.835 \\
Air & \\
$50^{\circ} \mathrm{F} / 0 \mathrm{psig}$ & 0.835 \\
Air & \\
$50^{\circ} \mathrm{F} / 0 \mathrm{psig}$ & 0.835 \\
Air & \\
$50^{\circ} \mathrm{F} / 0 \mathrm{psig}$ & 0.4908 \\
Air \\
$50^{\circ} \mathrm{F} / 0 \mathrm{psig}$
\end{tabular}

Air

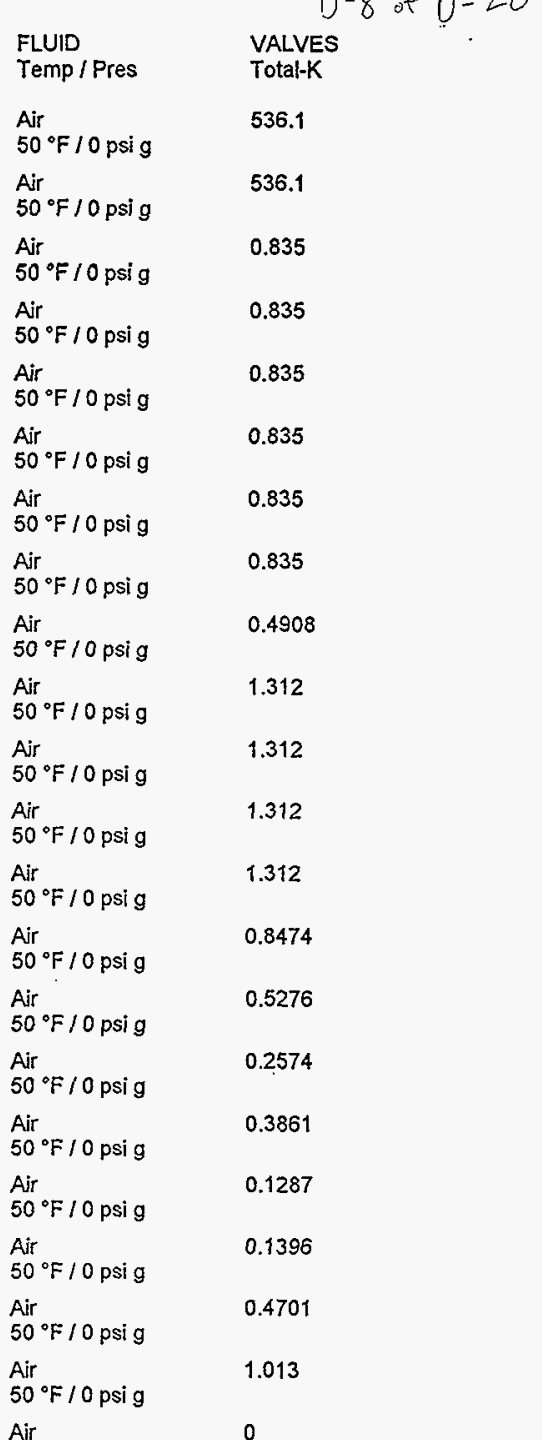

Air

\begin{tabular}{ll} 
FLUID & \multicolumn{1}{c}{ VALVES } \\
Temp / Pres & Total-K \\
Air & \\
$50^{\circ} \mathrm{F} / 0 \mathrm{psig}$ & 536.1 \\
Air & \\
$50^{\circ} \mathrm{F} / 0 \mathrm{psig}$ & 536.1 \\
Air & \\
$50^{\circ} \mathrm{F} / 0 \mathrm{psig}$ & 0.835 \\
Air & \\
$50^{\circ} \mathrm{F} / 0 \mathrm{psig}$ & 0.835 \\
Air & \\
$50^{\circ} \mathrm{F} / 0 \mathrm{psig}$ & 0.835 \\
Air & \\
$50^{\circ} \mathrm{F} / 0 \mathrm{psig}$ & 0.835 \\
Air & \\
$50^{\circ} \mathrm{F} / 0 \mathrm{psig}$ & 0.835 \\
Air & \\
$50^{\circ} \mathrm{F} / 0 \mathrm{psig}$ & 0.835 \\
Air & \\
$50^{\circ} \mathrm{F} / 0 \mathrm{psig}$ & 0.4908 \\
Air \\
$50^{\circ} \mathrm{F} / 0 \mathrm{psig}$
\end{tabular}

Air 0

$50^{\circ} \mathrm{F} / 0 \mathrm{psig}$

Air

$50^{\circ} \mathrm{F} / 0 \mathrm{psig}$

Air

$50^{\circ} \mathrm{F} / 0 \mathrm{psig}$
$0-8$ of $0-20$

VALVES

536.1

536.1

0.835

0.835

0.835

0.835

0.835

0.835

0.4908

1.312

1.312

1.312

1.312

0.8474

0.5276

0.2574

0.3861

0.1287

0.1396

0.4701

1.013

0

HNF-2479, Rev. 0
Page E-57 


\begin{tabular}{|c|c|c|c|c|c|}
\hline PIPELINE & SPEC & $\begin{array}{l}\text { MATERIAL } \\
\text { Size / Sch }\end{array}$ & $\begin{array}{l}\text { LENGTH } \\
\mathrm{ft}\end{array}$ & $\begin{array}{l}\text { FLUID } \\
\text { Temp / Pres }\end{array}$ & $\begin{array}{l}\text { VALVES } \\
\text { Total-K }\end{array}$ \\
\hline$w$ & 01 & $\begin{array}{l}\text { Steel } \\
32 \text { in / } 40\end{array}$ & 40 & $\begin{array}{l}\text { Air } \\
50^{\circ} \mathrm{F} / 0 \mathrm{psig}\end{array}$ & 0 \\
\hline$\alpha x$ & 01 & $\begin{array}{l}\text { Steel } \\
32 \text { in } / 40\end{array}$ & 40 & $\begin{array}{l}\text { Air } \\
50^{\circ} \mathrm{F} / 0 \mathrm{psig}\end{array}$ & 0 \\
\hline
\end{tabular}


Company: Fluor Daniel NW

Project:

by: Fluor Daniel NW

Created: 01/26/98 11:38 am

Design file:

'ipe Specs: 1
02/17/98 9:52 am

System: ANNULUS

rev: 02/17/98 9:51 am
MATERIALS REPORT

.
Pipes: 50

Nodes: 38

Pumps/Comps: 0

PIPE MATERIALS LIST

\section{PIPELINE}

a

b

$c$

d

e

g

h

j

k

m

01

Steel

3 in $/ 40$

Steel

Steel

01

Steel

6 in 140

01

Steel

Steel

01 Steel

8 in 140

01 Steel

6 in $/ 40$

01 Steel

3 in 140

01 Steel

3 in $/ 40$

\section{LENGTH VALVES \& FITTINGS}

$\mathrm{ft}$

$14 \mathrm{in} / 40$

14 in $/ 40$

$10 \mathrm{in} / 40$

14 in $/ 40$

10 in $/ 40$

PIPE-FLO ver 5.01
45

31

71

3-Elbow Long - r/d $1.5 @ 90^{\circ}$ 1-Butterfly Valve

1-Tee Flow Thru Branch

1-Elbow Long-r/d $1.5 @ 45^{\circ}$

4-Elbow Long - r/d $1.5 @ 45^{\circ}$

1-Tee Flow Thru Run

1-Reducer Contraction $14 \times 10$

1-Elbow Long - r/d $1.5 @ 45^{\circ}$

1-Tee Flow Thru Run

1-Reducer Contraction $10 \times 6$

40

1-Elbow Long - r/d $1.5 @ 45^{\circ}$

2-Elbow Long-r/d $1.5 @ 45^{\circ}$

1 -Tee Flow Thru Branch

1-Reducer Contraction $14 \times 10$

1-Tee Flow Thru Run

17

1-Reducer Contraction $10 \times 8$

1-Elbow Long - r/d $1.5 @ 45^{\circ}$

1-Elbow Long - r/d $1.5 @ 90^{\circ}$

1-Reducer Contraction $6 \times 3$

12.67

1-Reducer Enlargement $4 \times 3$

1.75

1-Tee Flow Thru Branch

1-Reducer Enlargement $4 \times 3$

$7.75 \quad$ 1-Tee Flow Thru Branch

1-Reducer Enlargement $4 \times 3$
Calculation w320-27.054 
PIPELINE

$n$

0

$p$

$q$

$r$

s

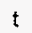

u

y

w

$x$

$y$

$z$

za

$\mathrm{zb}$

zc

$z d$
SPEC MATERIAL

Size / Sch

01 Steel

3 in 140

01 Steel

4 in $/ 40$

01 Steel

$4 \mathrm{in} / 40$

01 Steel

4 in $/ 40$

01 Steel

4 in 140

01

Steel

20 in 140

01 Steel

20 in $/ 40$

01

Steel

8 in 140

01

Steel

8 in $/ 40$

01

Steel

8 in $/ 40$

01

Steel

$8 \mathrm{in} / 40$

01 Steel

8 in 140

01

Steel

8 in 140

01 Steel

4 in $/ 40$

01 Steel

4 in $/ 40$

01

Steel

4 in $/ 40$

01 Steel

\section{LENGTH VALVES \& FITTINGS}

ft

3.5

85

98

96

97

1

1

1

1

1

1

1

1

6

6.33

6.33

8.33
1-Tee Flow Thru Branch

1-Reducer Enlargement $4 \times 3$

4-Elbow Long - $r / d 1.5 @ 90^{\circ}$ 1 -Exit Sharp-Edged

4-Elbow Long - r/d $1.5 @ 90^{\circ}$ 1-Exit Sharp-Edged

4-Elbow Long - r/d $1.5 @ 90^{\circ}$ 1-Exit Sharp-Edged

4-Elbow Long - r/d $1.5 @ 90^{\circ}$ 1-Exit Sharp-Edged

1.Fixed K 536.1

1-Fixed K 536.1

1-Fixed $K 536.1$

1-Fixed K 536.1

1-Fixed K 536.1

1-Fixed K 536.1

1-Entrance Sharp-Edged

1-Reducer Contraction $8 \times 4$

1-Reducer Enlargement $6 \times 4$

1-Entrance Sharp-Edged

1 -Reducer Contraction $8 \times 4$

1-Reducer Enlargement $6 \times 4$

1-Entrance Sharp-Edged

1-Reducer Contraction $8 \times 4$

1-Reducer Enlargement $6 \times 4$

1-Entrance Sharp-Edged
HNF-2479, Rev. 0

Page E-60 


\section{PIPELINE}

SPEC

MATERIAL

Size / Sch

4 in $/ 40$

ze

$z f$

$\mathrm{zg}$

zh

zi

zj

$\therefore \mathrm{k}$

zl

$\mathrm{zm}$

zn

zo

$z p$

$z q$

zr
01 Steel

4 in $/ 40$

Steel

4 in $/ 40$

Steel

6 in $/ 40$

01 Steel

6 in $/ 40$

01 Steel

6 in $/ 40$

01 Steel

6 in 140

01 Steel

6 in $/ 40$

01

Steel

6 in $/ 40$

01 Steel

8 in 140

01 Steel

12 in $/ 40$

01 Steel

12 in $/ 40$

01 Steel

12 in $/ 40$

01 Steel

8 in $/ 40$

01 Steel

8 in $/ 40$

\section{LENGTH VALVES \& FITTINGS}

$\mathrm{ft}$

1-Reducer Contraction $8 \times 4$ 1-Reducer Enlargement $6 \times 4$

7.33

12

12

12

14

12

20

50

53

47

27

51

21

1-Entrance Sharp-Edged

1-Reducer Contraction $8 \times 4$

i-Reducer Enlargement $6 \times 4$

1-Entrance Sharp-Edged 1-Reducer Contraction $8 \times 4$ 1-Reducer Enlargement $6 \times 4$

2-Elbow Long - r/d $1.5 @ 90^{\circ}$ 1 -Reducer Enlargement $8 \times 6$

2-Elbow Long-r/d $1.5 @ 90^{\circ}$ 1-Tee Flow Thru Branch

2-Elbow Long - r/d $1.5 @ 90^{\circ}$ 1-Tee Flow Thru Branch

2-Elbow Long - $r / d 1.5 @ 90^{\circ}$ 1-Tee Flow Thru Branch

2-Elbow Long - $r / d 1.5 @ 90^{\circ}$ 1-Tee Flow Thru Branch

3-Elbow Long - $r / d 1.5 @ 90^{\circ}$

1-Elbow Long - r/d $1.5 @ 45^{\circ}$

1-Reducer Enlargement $8 \times 6$

1-Elbow Long - r/d 1.5 @ 90

1-Elbow Long-r/d $1.5 @ 45^{\circ}$

1-Reducer Enlargement $12 \times 8$

2-Elbow Long - r/d $1.5 @ 45^{\circ}$

3-Elbow Long - $r / d 1.5 @ 45^{\circ}$

1-Elbow Long - r/d 1.5 @ $45^{\circ}$

1-Elbow Long - $r / d 1.5 @ 45^{\circ}$

2-Elbow Long - r/d $1.5 @ 45^{\circ}$

i-Reducer Enlargement $12 \times 8$ 


\section{PIPELINE}

ZS

zt

ZU

zN

ZW

$z X$
SPEC MATERIAL

Size / Sch

01 Steel

16 in $/ 40$

\section{LENGTH VALVES \& FITTINGS} ff

15

Steel

32 in $/ 40$

Steel

32 in $/ 40$

01 Steel

32 in 140

01 Steel

32 in $/ 40$

01 Steel

32 in 140
1-Reducer Enlargement $16 \times 12$ 1-Elbow Long- $/ \mathrm{d} 1.5 @ 90^{\circ}$ 1-Tee Flow Thru Branch 
PIPE SUMMARY

PIPE MATERIAL

Steel

SCHEDULE

40
$02 / 17 / 98 \quad 9: 52 \mathrm{am}$

LENGTH

$D-14$ of $0-20$
$25.67 \mathrm{ft}$

$415.65 \mathrm{ft}$

$123.25 \mathrm{ft}$

$141 \mathrm{ft}$

$47 \mathrm{ft}$

$172 \mathrm{ft}$

12 in

$1\} 2 \mathrm{ft}$

16 in

$15 \mathrm{ft}$

20 in

$2 \mathrm{ft}$

32 in

VALVE \& FITTING SUMMARY

SPECIFICATION

$01 \operatorname{Sch} 40$
MATERIAL

Stee!

Size: 3 in

Size: 4 in

Size: 6 in

Size: 8 in

Size: 10 in

Size: 12 in

Size: 14 in
SCHEDULE VALVES \& FITTINGS

40
4-Reducer Enlargement $4 \times 3$

3-Tee Flow Thru Branch

16-Elbow Long - r/d $1.5 @ 90^{\circ}$

4-Exit Sharp-Edged

6-Entrance Sharp-Edged

6-Reducer Contraction $8 \times 4$

6-Reducer Enlargement $6 \times 4$

2-Elbow Long - r/d 1.5@45

14-Elbow Long-r/d $1.5 @ 90^{\circ}$

1-Reducer Contraction $6 \times 3$

2-Reducer Enlargement $8 \times 6$

4-Tee Flow Thru Branch

5-Elbow Long - r/d $1.5 @ 45^{\circ}$

6-Fixed K 536.1

1-Elbow Long - rid $1.5 @ 90^{\circ}$

2-Reducer Enlargement $12 \times 8$

1-Elbow Long - r/d $1.5 @ 45^{\circ}$

1-Tee Flow Thru Run

1-Reducer Contraction $10 \times 6$

1-Reducer Contraction $10 \times 8$

3-Elbow Long-r/d $1.5 @ 90^{\circ}$

1-Butterfly Valve

6-Elbow Long - $\mathrm{r} / \mathrm{d} 1.5 @ 45^{\circ}$

2-Tee Flow Thru Branch

7-Elbow Long-r/d $1.5 @ 45^{\circ}$

Calculation w 320.27 .054
HNF-2479, Rev. 0 Page E 63 
MATERIAL

Size: 14 in

Size: 16 in
2-Tee Flow Thru Run

2-Reducer Contraction $14 \times 10$

1-Reducer Enlargement $16 \times 12$

1-Elbow Long - r/d $1.5 @ 90^{\circ}$

1-Tee Flow Thru Branch 
iystem: ANNULUS

rev: 02/17/88 9:51 am

Deviation: $0.00167 \%$

after: 13 iterations

Volumetric flow rates require constant fluid properties in all pipelines. Fluid properties in the first specification were used in this calculation.

\section{LINEUP SUMMARIES}

NODE

DEMAND

cfm

NODE

>> 1000

Out

Flows IN: $0 \mathrm{cfm}$

Flows OUT: $1000 \mathrm{cfm}$

NET FLOWS OUT: $1000 \mathrm{cfm}$

LINEUP SUMMARIES

\section{PIPELINE}

a

\section{FLOW}

$\mathrm{cfm}$

$\ll \quad 1000$

\section{PRESSURE \\ SOURCE}

In

\section{SET \\ psig}

0

DEMAND

$\mathrm{cfm}$

Flows $\mathbb{N}: 1000 \mathrm{cfm}$

Flows OUT: $0 \mathrm{cfm}$

NET FLOWS IN: $1000 \mathrm{cfm}$

HNF-2479, Rev. 0

Page E-66 
NODE

1

B

$C$

D-in

D-out

E

$F$

G

$H$-in

H-out

1

In

$J$

K

L

M

N

0

Out

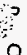

Q

$R$

$S$

T

u

v

w

$x$

$Y$

$Z$

ZA

$Z B$

$\mathrm{ZC}$

$\mathrm{ZD}$

ZE

ZF

ZG

$\mathrm{ZH}$

ELEVATION
$\mathrm{ft}$

674.43

674.44

674.8

677.33

677.35

673.49

673.37

673.22

672.69

672.79

677.5

681.86

673.37

673.07

674.83

674.52

671.44

658.77

682.33

671.62

669.58

670.92

623

623

623

663.17

663.17

663.17

663.17

663.17

663.17

669.17

669.5

669.5

671.5

670.5

668.5

677.5

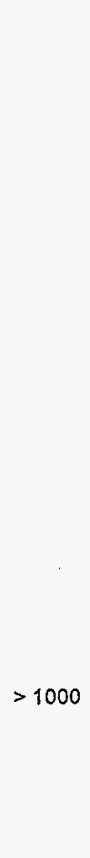

$>1000$
PRESSURE

psig

$-0.525$

$-0.004$

$-0.526$

$-0.007$

$-0.528$

$-0.525$

$-0.006$

$-0.524$

$-0.014$

$-0.523$

$-0.005$

0 (source)

$-0.006$

$-0.007$

$-0.003$

$-0.004$

$-0.023$

$-0.078$

$-0.534$

$-0.075$

$-0.089$

$-0.078$

$-0.196$

$-0.196$

$-0.196$

$-0.506$

$-0.506$

$-0.506$

$-0.506$

$-0.506$

$-0.506$

$-0.519$

$-0.519$

$-0.520$

$-0.522$

$-0.521$

$-0.519$

$-0.530$
HGRADE ft

$-295.7$

666.8

$-297.6$

665.1

$-300$

$-297.6$

662.5

$-296.5$

647.7

$-294.2$

569

681.9

662.4

660.3

668.5

668

628.8

515.4

$-305.6$

533.8

504.4

526.6

260

260

260

$-272.6$

$-272.6$

$-272.6$

$-272.6$

$-272.6$

$-272.6$

$-291.2$

$-291.2$

$-292$

$-294.1$

$-292.3$

$-290.6$

$-302$

HNF-2479, Rev. 0

Page E-67

PIPE-FLO ver 5.01

Calculation w320.27.054

pg 2 
PIPELINE

FROM

In

1

D-in

$F$

J

K

I

L

$M$

$H$-in

$N$

$F$

D-in

B

O

$P$

Q

R

S

S

$T$

T

T

U

U

U

V

w

$X$

$Y$

$Z$

ZA

ZB

ZC

ZD

ZE

$\mathrm{ZF}$

ZG

H-out

G

E
TO

1

D-in

$F$

$\jmath$

K

$\mathrm{H}$-in

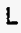

M

B

N

o

$P$

Q

R

$S$

$S$

$s$

$S$

$T$

U

V

W

$X$

$Y$

$z$

ZA

ZB

ZC

ZD

ZE

ZF

$Z G$

H-out

G

E

D-out

C

A

G

E

D-out $\begin{array}{llll}\text { FLOW } & \text { VEL } & \mathrm{dP} & \mathrm{HL} \\ \mathrm{cfm} & \mathrm{ft} / \mathrm{sec} & \mathrm{psig} & \mathrm{ft}\end{array}$

1000

749.9

510

257.4

257.4

257.4

250.1

250.1

250.1

257.4

257.4

252.6

239.9

250.1

257.4

252.6

239.9

250.1

500

500

166.7

166.7

166.7

166.7

166.7

166.7

166.4

164.6

168.5

168.8

165.3

166.5

166.4

164.6

168.5

168.8

165.3

166.5

166.4

330.9

499.4
21.46

13.32

9.056

4.571

7.841

21.4

4.441

7.619

12.01

21.4

- 83.64

- 82.08

* 77.95

- 81.27

- 48.57

- 47.67

- 45.27

- 47.19

4.321

4.321

8.003

8.003

8.003

8.003

8.003

8.003

31.39

31.06

31.79

31.86

31.18

31.42

13.83

13.69

14.01

14.04

13.74

13.84

7.988

7.103

10.72
0.005

5.35

5.89

2.37

12.86

3.916

2.635

0.045

2.121

12.61

0.484

0.502

1.249

18.83

113.5

128.7

160.7

140.2

255.3

273.7

244.3

266.5

0.004

0.004

532.7

532.7

532.7

532.7

532.7

532.7

18.58

18.51

19.37

21.44

19.61

17.96

3.025

5.597

5.392

5.137

2.254

1.105 


\section{LINEUP PIPELINES}

\section{PIPELINE}

$z$

$z q$

2r

zs

$2 t$

zu

zv

$z w$

ZX
FROM

D-out

A

C

$\mathrm{ZH}$

$\checkmark$

w

$\times$

$z$

ZA
$\mathrm{ZH}$

$\mathrm{C}$

$\mathrm{ZH}$

Out

w

$X$

$\leftrightarrow \quad Y$

$\leftrightarrow Z$
$02 / 17 / 989: 54 \mathrm{am}$

$$
D-20 \text { of } D-20
$$

$\begin{array}{lll}\text { VEL } & d P & H L \\ \text { ftsec } & \text { psig } & \mathrm{ft}\end{array}$

FLOW
668.2

166.5

331.8

1000

0.306

2.385

0.596

1.572

0.163
14.34

7.995

15.93

13.59

0

0.008

0.002

0.005

0 psig

ft

2.05

1.907

4.378

3.529

0

0

0

0

0

HNF-2479, Rev. 0

Page E-69 
$\Im$ FLUOR DANIEL

NORTHWEST INC.
Calc. No.: W320-27-054

Revision: 0

Page No: E- Oof E-13
Client: Numatec

Subject: System Curves for Portable Exhauster Installation

Location: 241-C/241-AY

\section{DESIGN ANALYSIS}

WO/Job No.: ER4319M-320

Date: $2 / 18 / 98$ Checked: $3 / 2 / 98$

Revised:
By: Kelly Hayase

By: hoin cened

By:

Appendix E: Pipe-Flo results of ANNULUS used to generate the system curve 


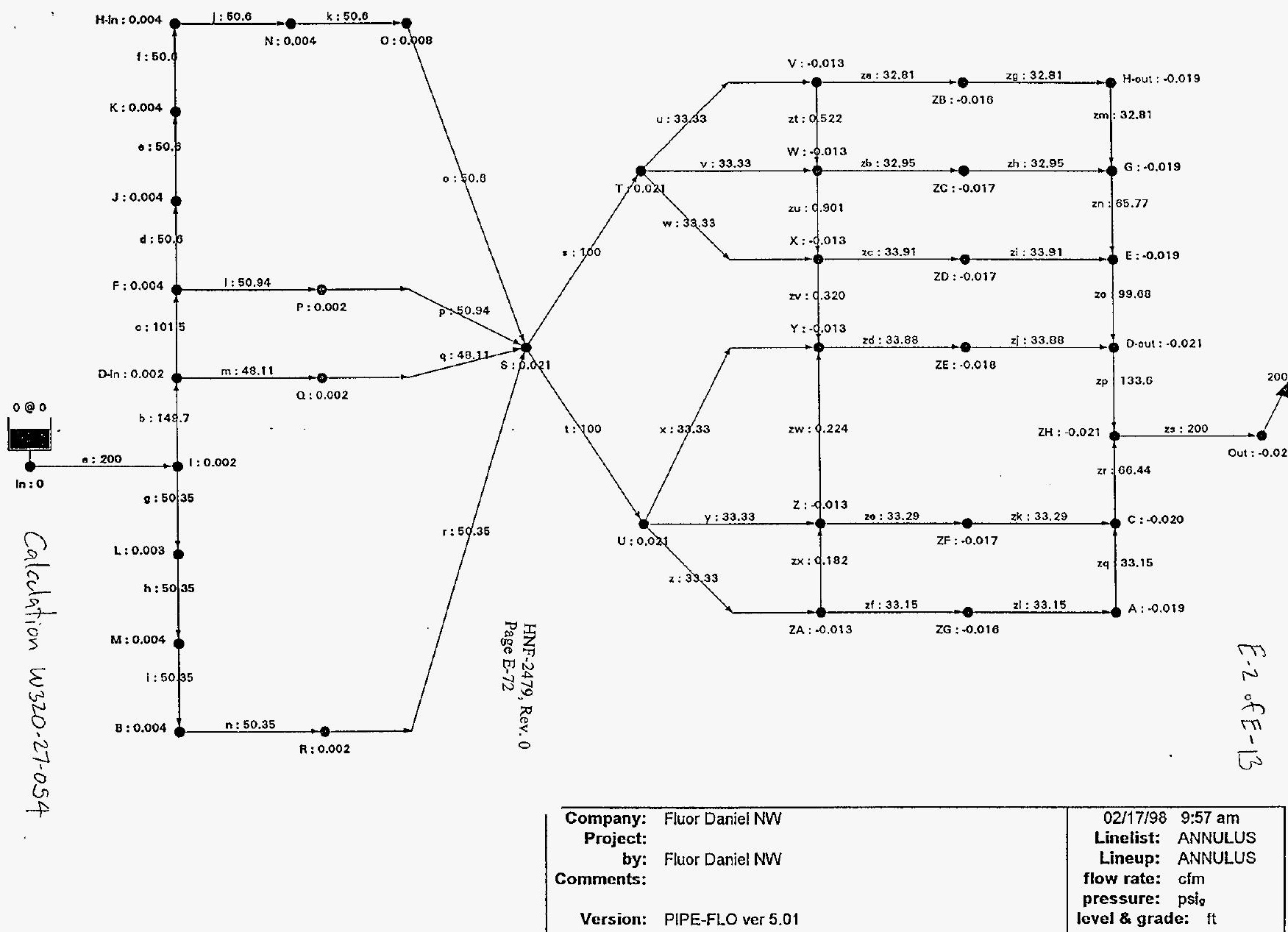




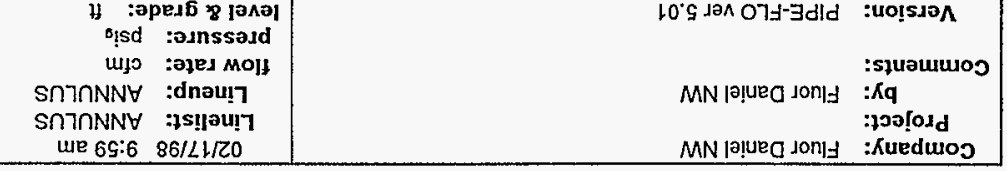

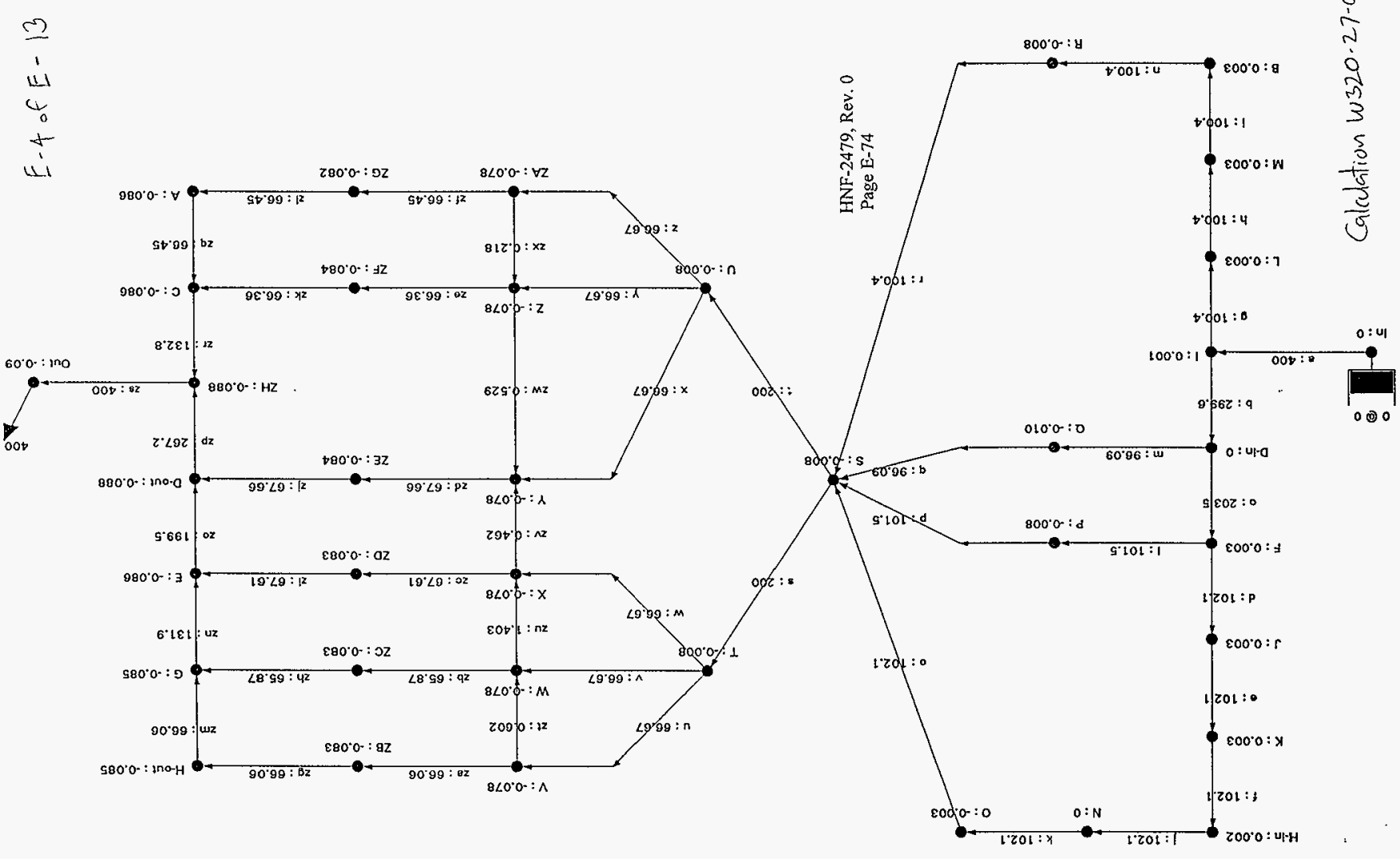




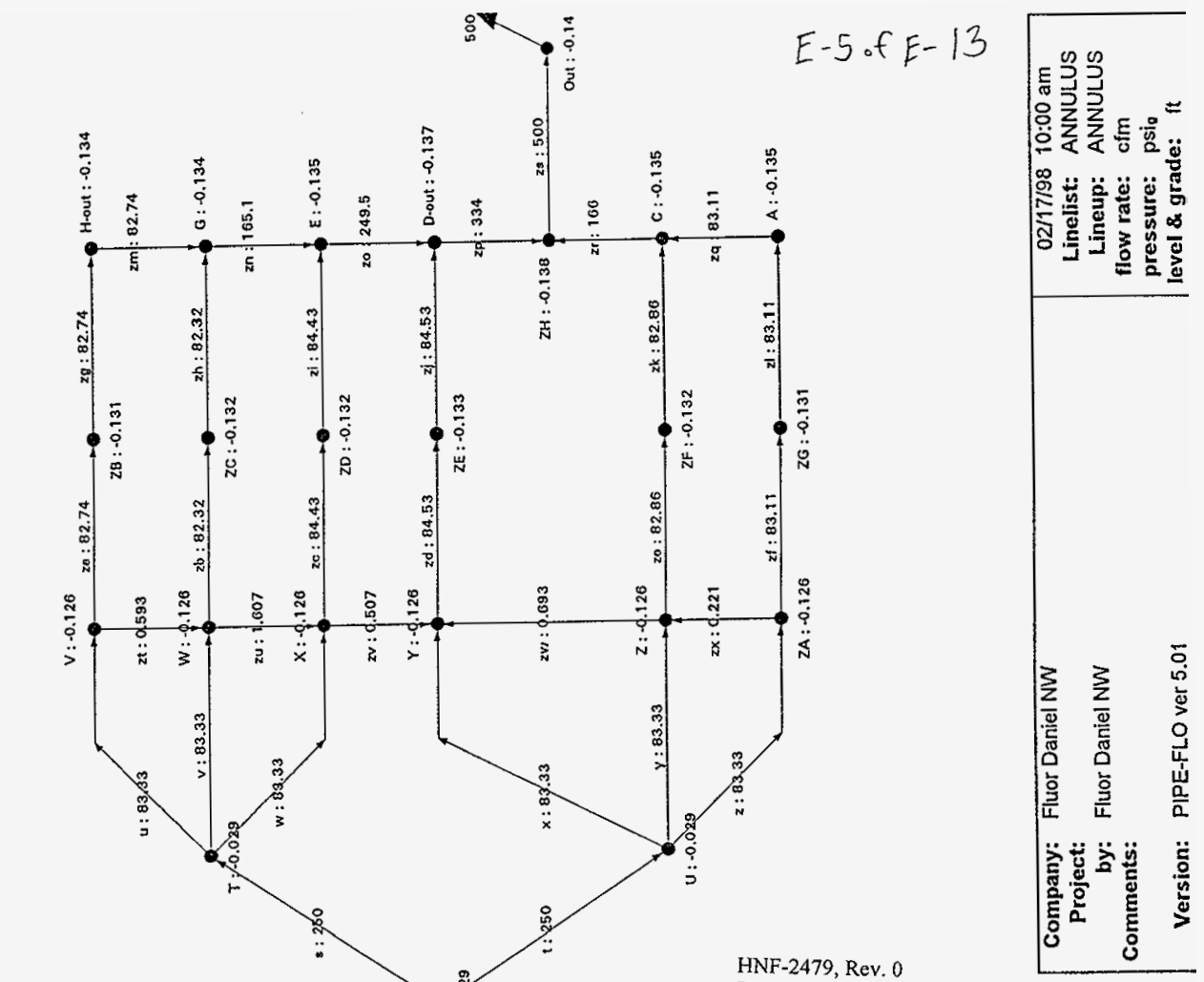

H.

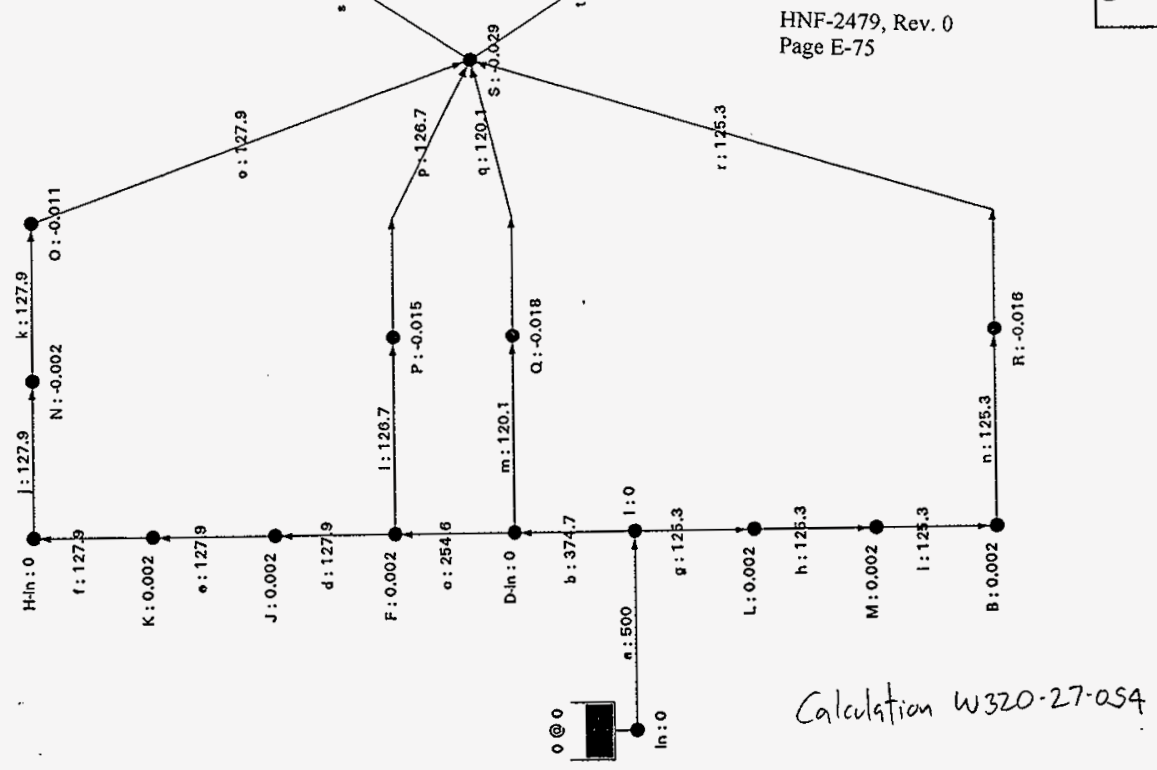




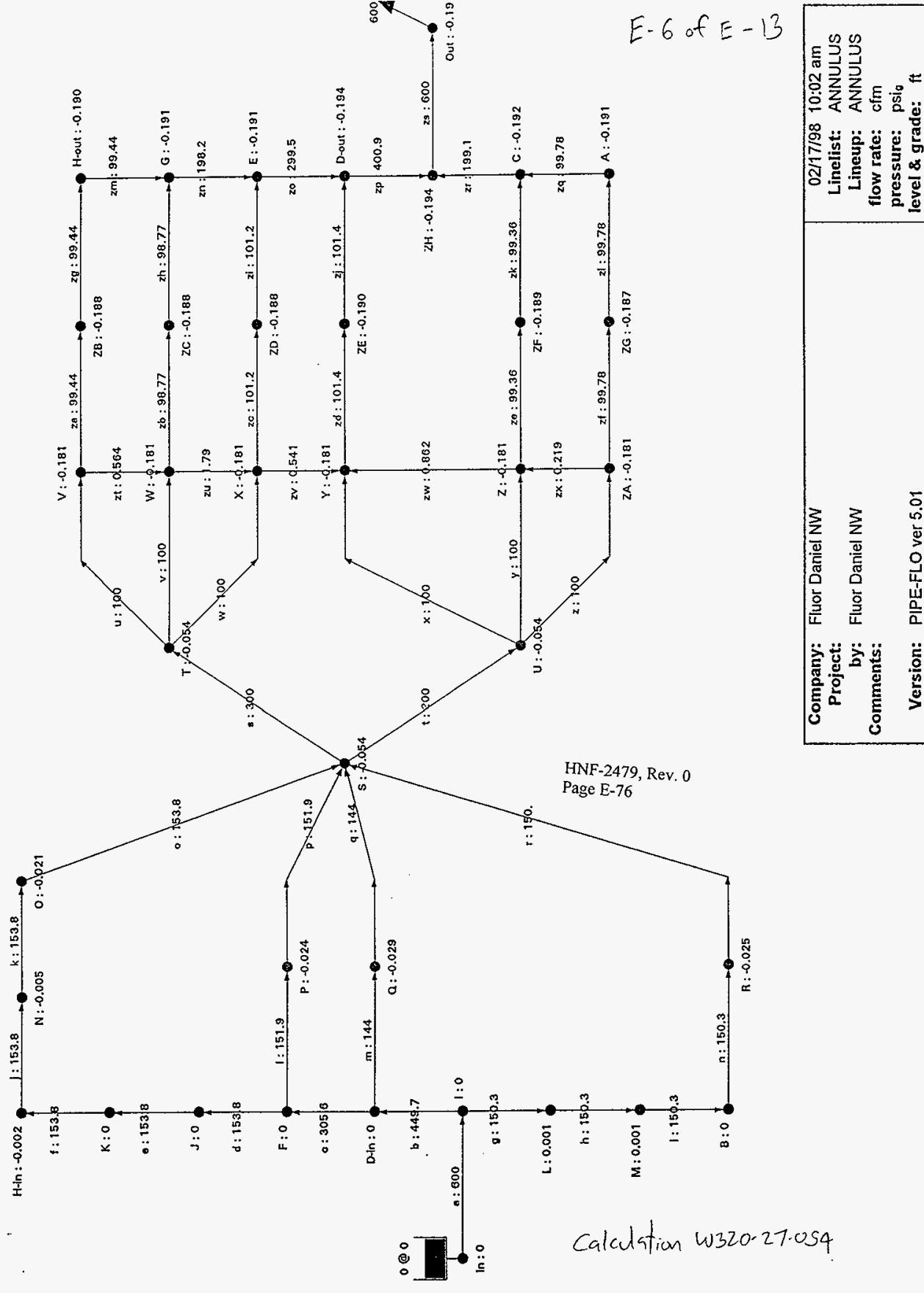



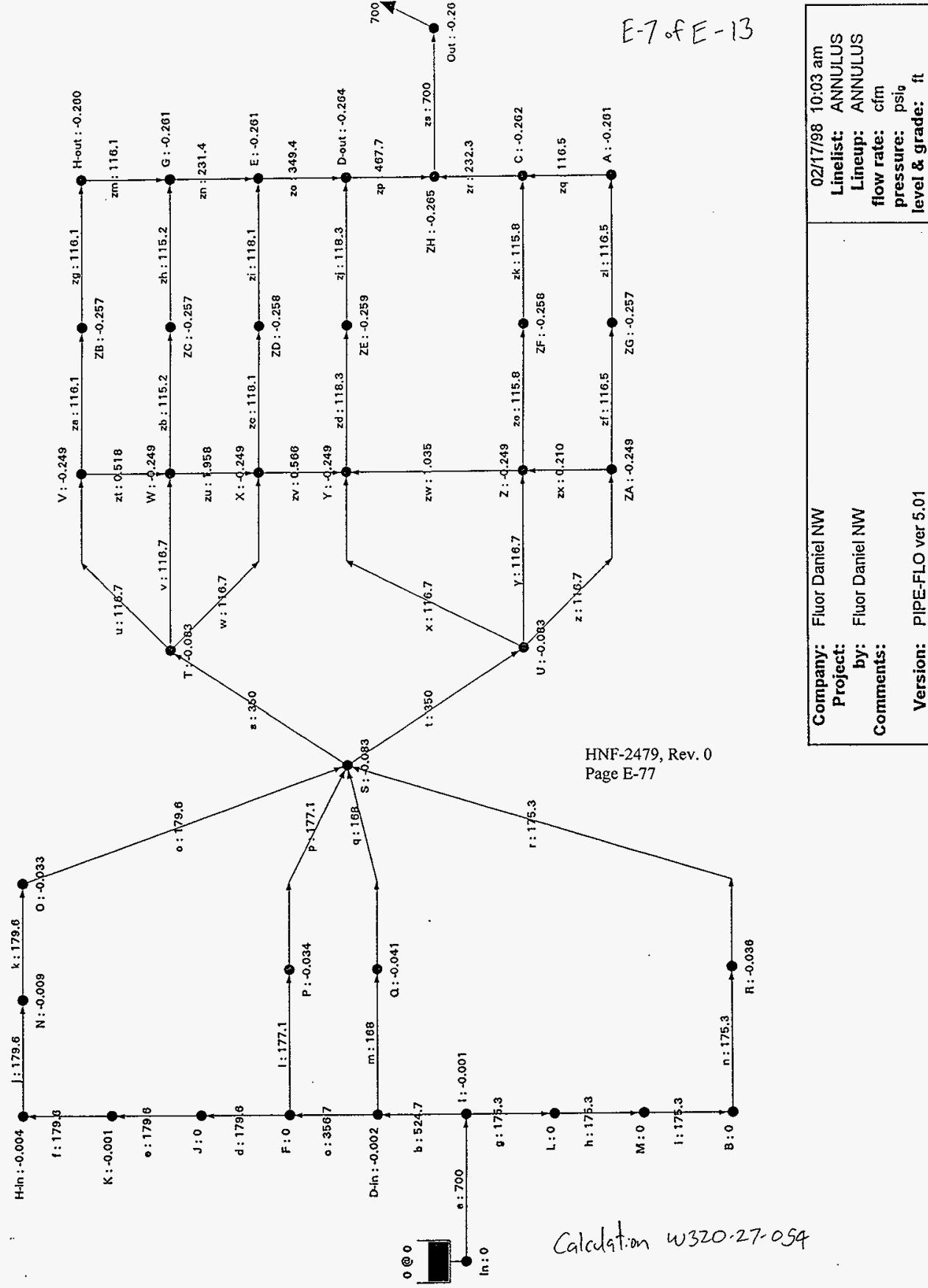


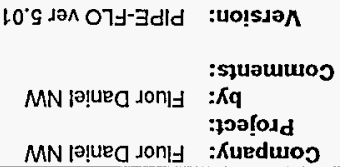

n

I

U1)

4

$\infty$

(i)

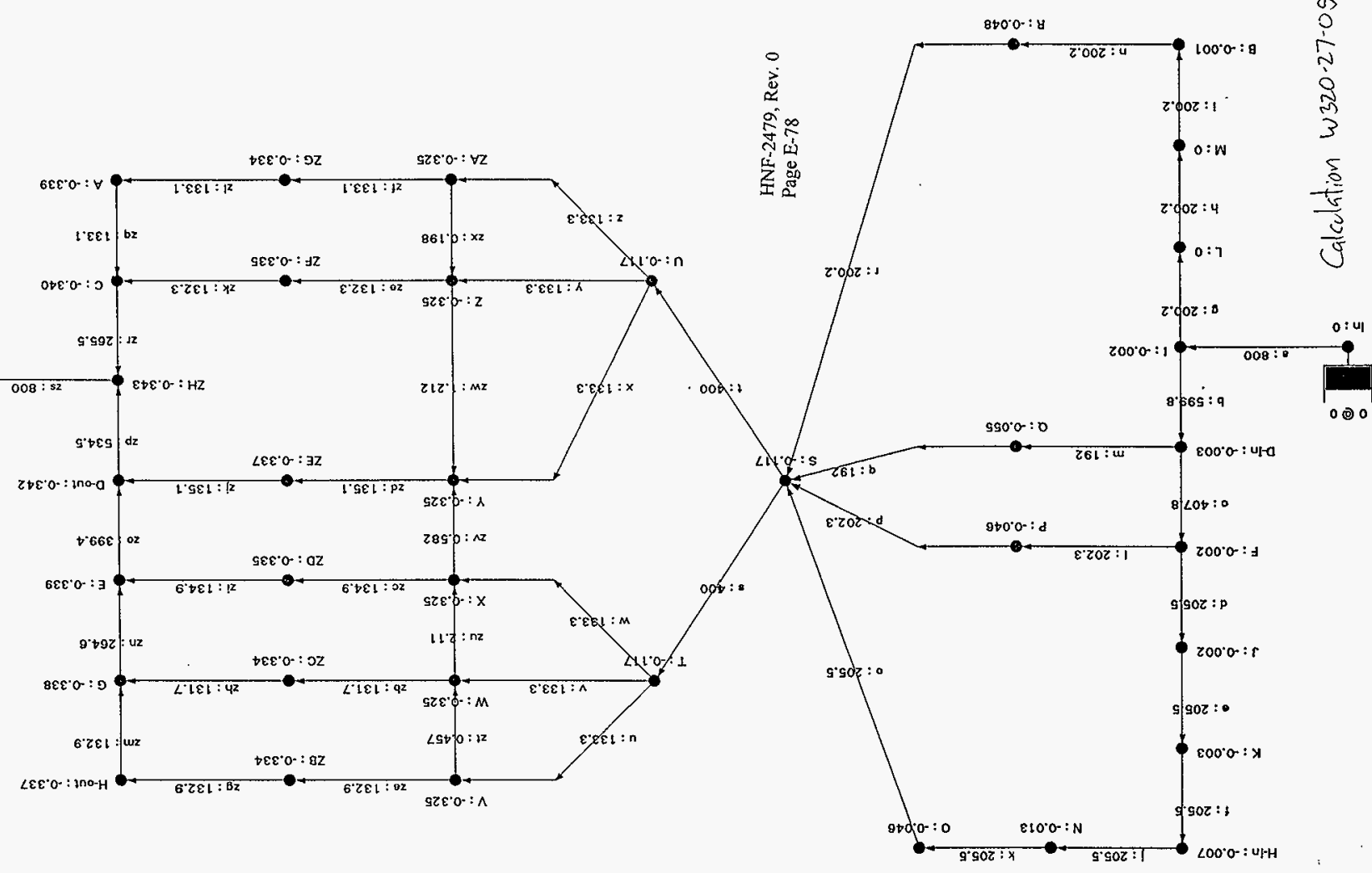



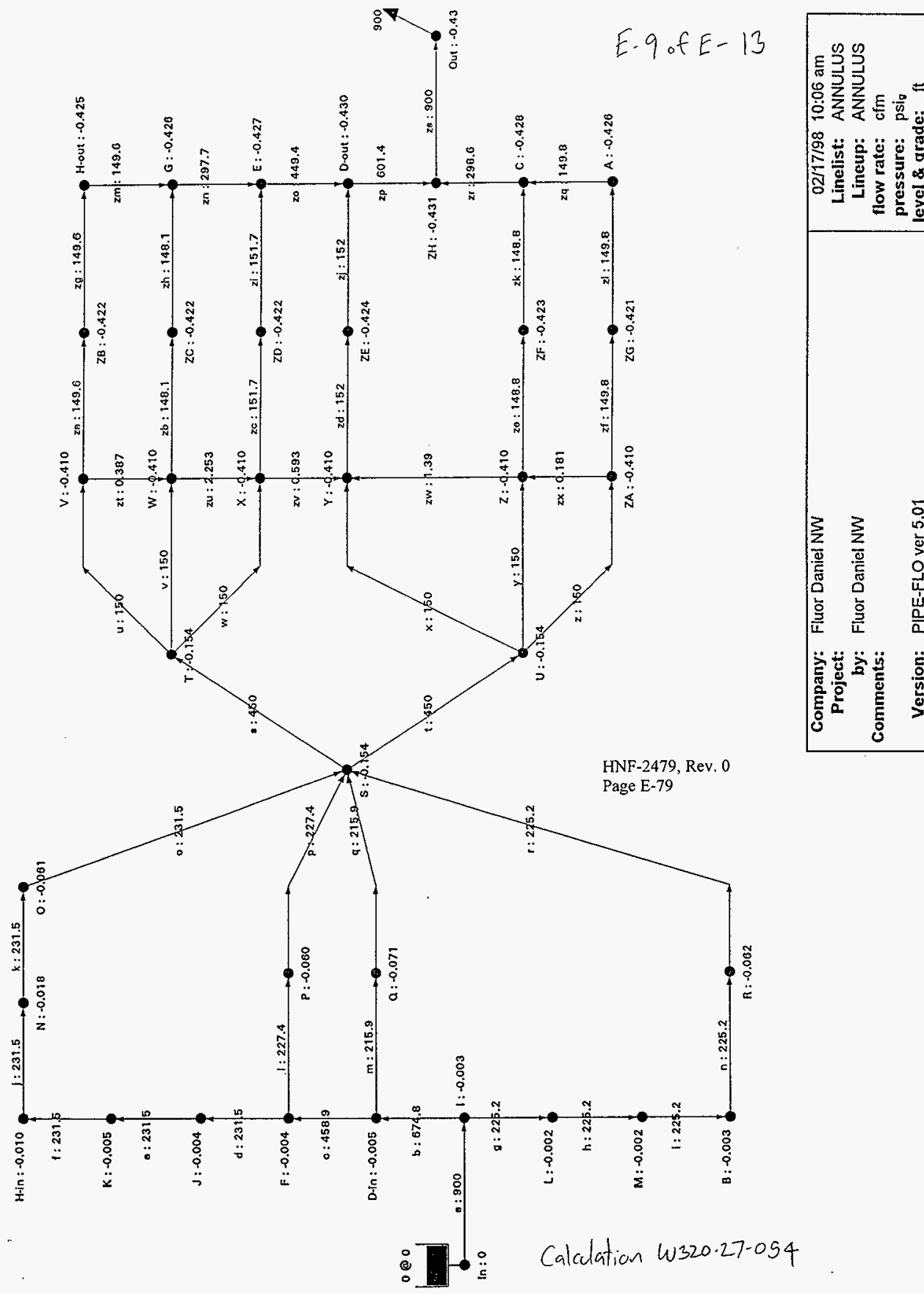


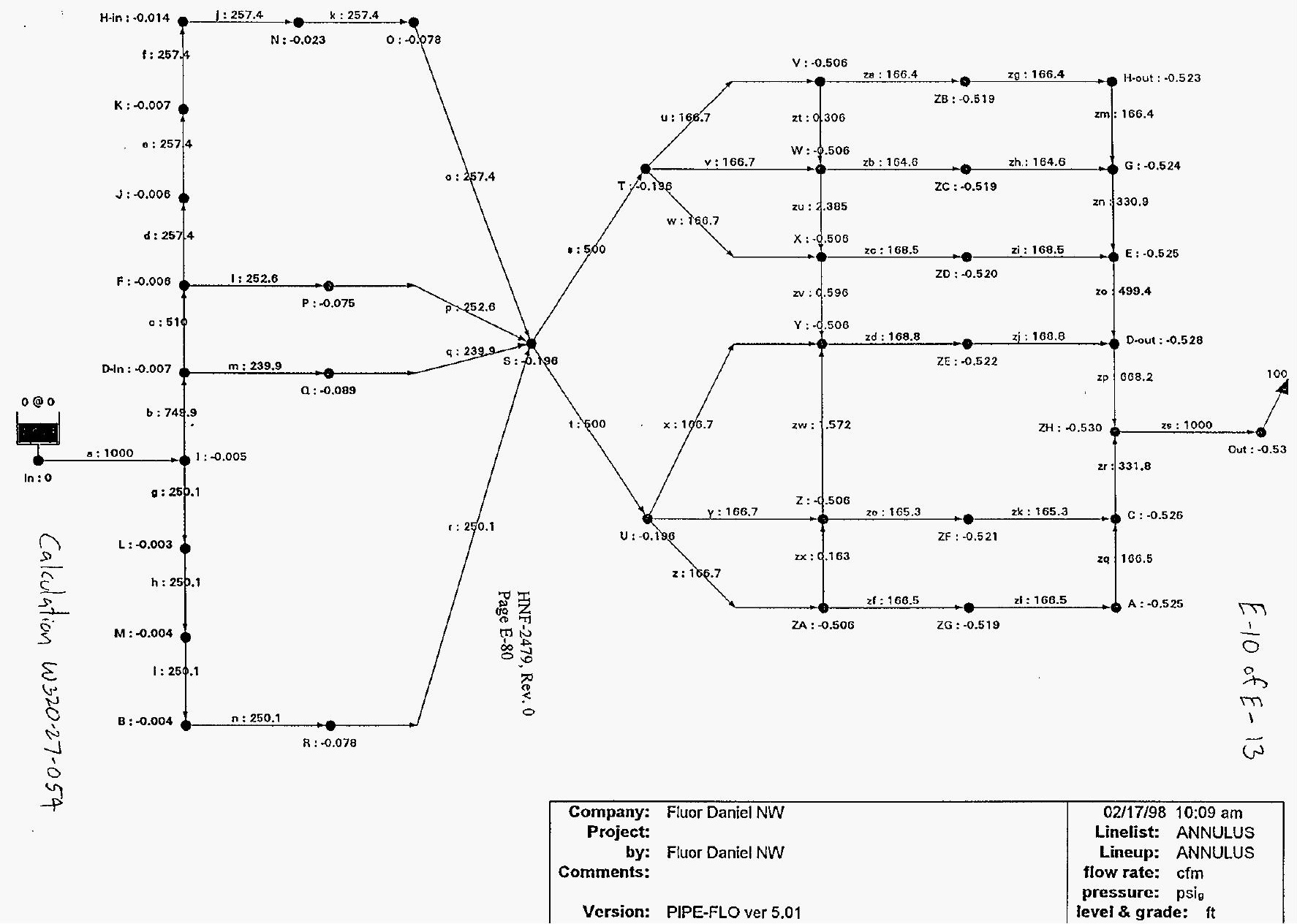




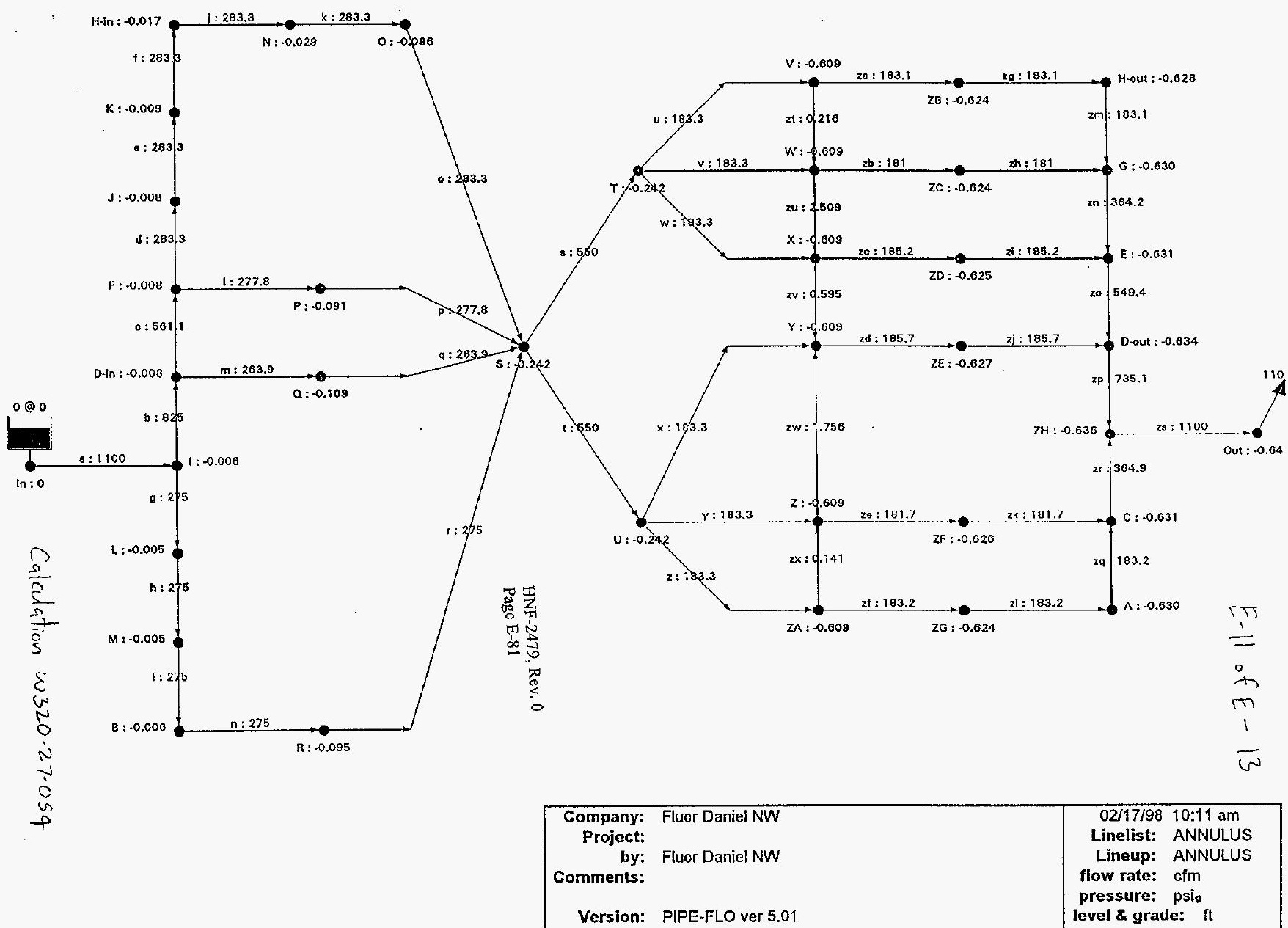




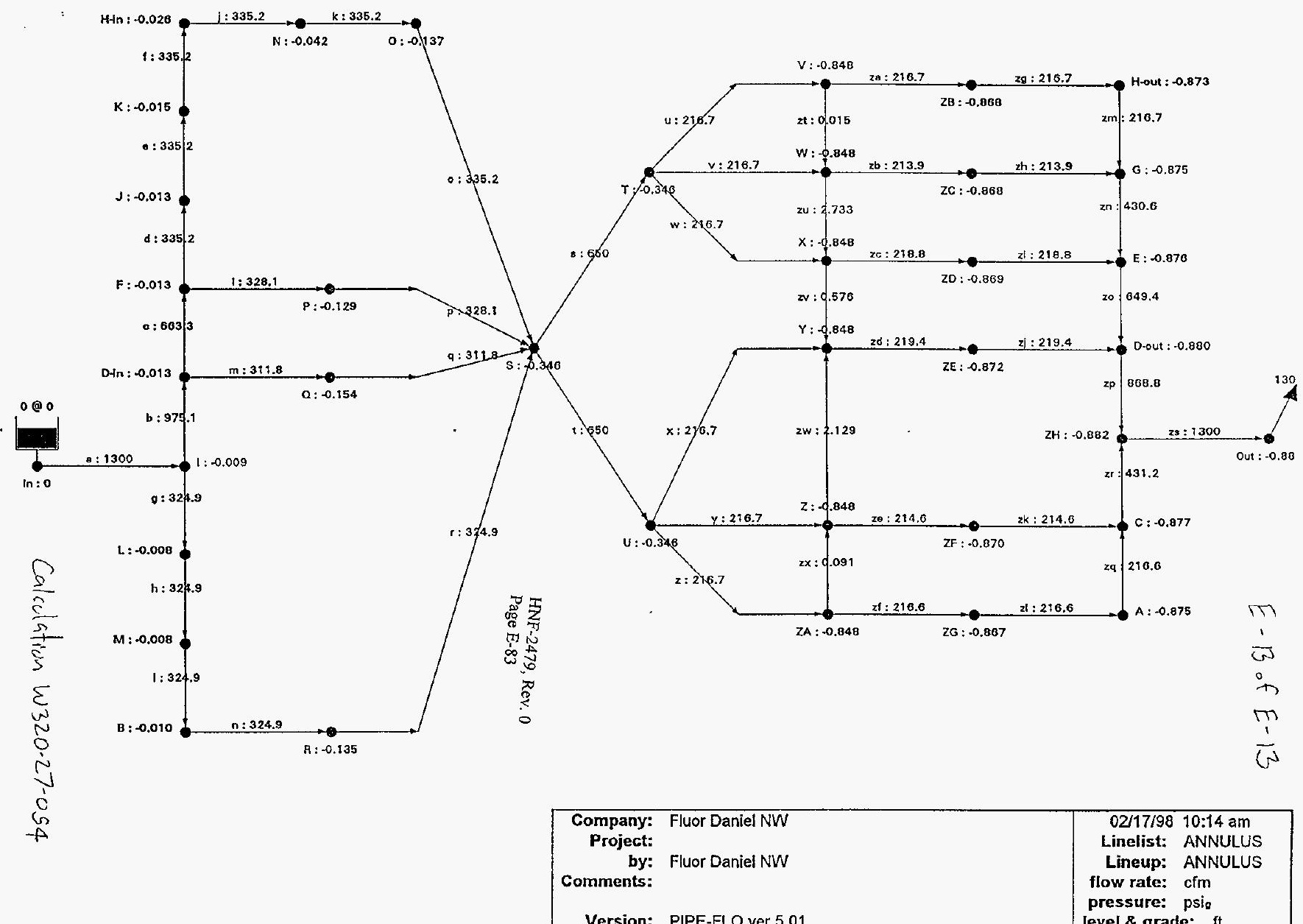




\section{DESIGN ANALYSIS}

Page No: F-Oof F- 15

Client: Numatec

Subject: System Curves for Portable Exhauster Installation

Location: 241-C/241-AY
Wo/Job No.: ER4319N-320

Date: $2 / 18 / 98 \quad$ By: Kelly Hayase/

Checked: $3 / 2 / 98$ By: Lain Cest

Revised:

By:

Appendix F: Pipe-Flo Model ANNU-PEX 


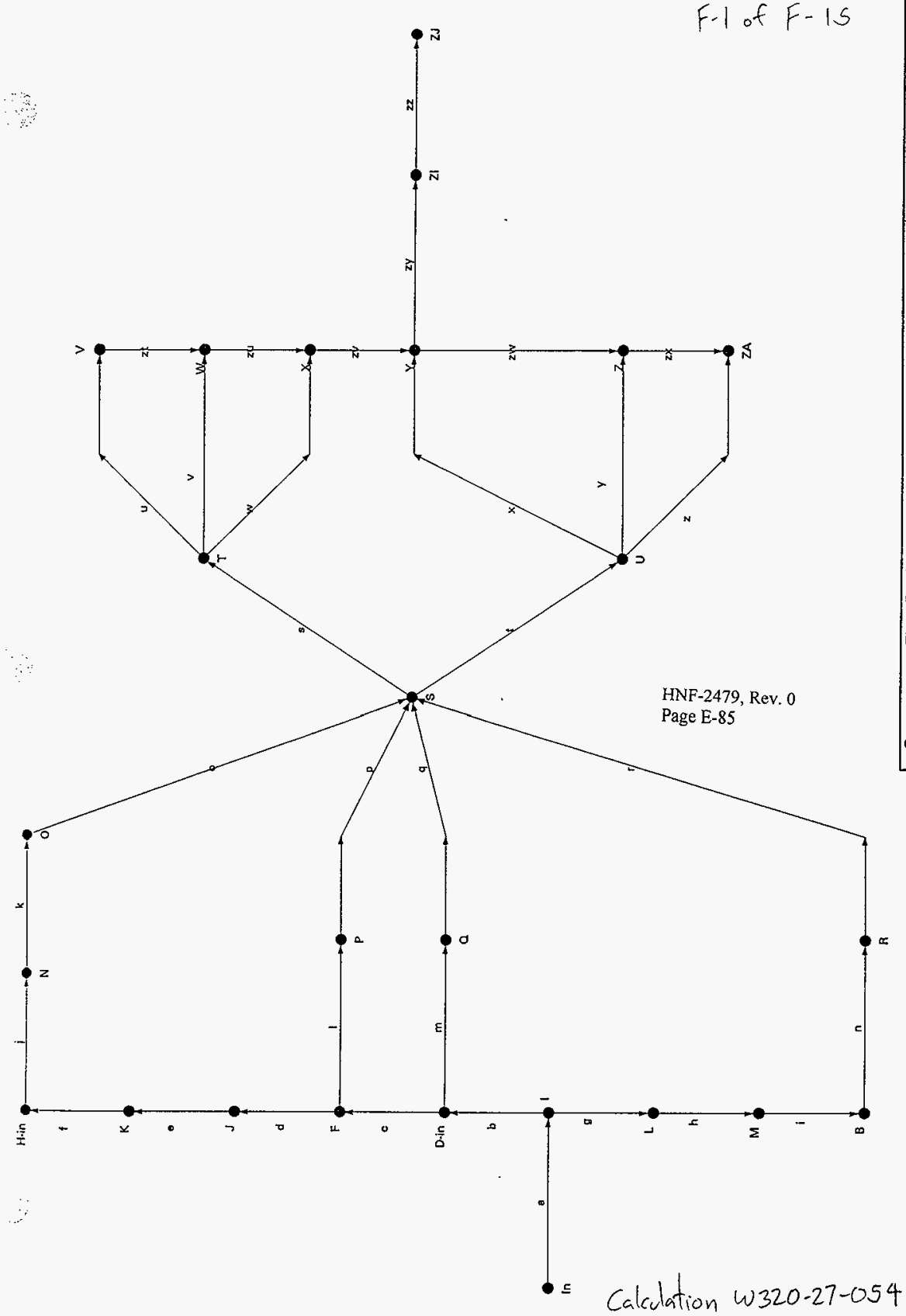


Company: Fluor Daniel NW

Project:

by: Fluor Daniel NW

Created: 01/26/98 11:38 am

Design file:

Pipe Specs: 1
02/18/98 2:03 pm

System: ANNU-PEX F-2 of F-15

SYSTEM REPORT rev: 02/18/98 2:02 pm

Pipes: 33

Nodes: 26

Pumps/Comps: 1

SYSTEM NODES

\section{NODE}

B

D-in

F

$H-$ in

I

In

了

K

$\mathbf{L}$

M

N

o

$\mathrm{P}$

Q

R

S

$T$

U

v

\section{ELEVATION \\ $\mathrm{ft}$}

\subsection{4}

677.33

673.37

672.69

677.5

681.86

673.37

673.07

674.83

674.52

671.44

658.77

671.62

669.58

670.92

623

623

623

663.17

\section{PIPELINES IN}

PIPELINES OUT

n

$c$

m

d

f

a

b

$g$

a

e

f

$\mathrm{h}$

$\mathrm{h}$

j

k

k

o

p

m.

q

$\mathrm{n}$

$r$

o

$\mathrm{p}$

q

s

s

$u$
$v$
$w$

$t$

$x$

y

$z$

$\mathrm{zt}$

HNF-2479, Rev. 0

Page E-86 


$\begin{array}{llll}\text { NODE } & \begin{array}{lll}\text { ELEVATION } \\ \mathrm{ft}\end{array} & \mathrm{PIPELINES} \mathrm{IN} & \text { PIPELINES OUT } \\ \mathrm{W} & 663.17 & \mathrm{v} & \mathrm{zu} \\ \mathrm{X} & 663.17 & \mathrm{zt} & \mathrm{zV} \\ \mathrm{Y} & \mathrm{w} & \mathrm{zu} \\ \mathrm{Z} & 663.17 & \mathrm{x} & \mathrm{zy} \\ \mathrm{Z} & 663.17 & \mathrm{zV} & \mathrm{zx} \\ \mathrm{ZA} & \mathrm{y} & \\ \mathrm{ZI} & 663.17 & \mathrm{zW} & \\ \mathrm{ZJ} & 680 & \mathrm{zx} & \mathrm{zz}\end{array}$

HNF-2479, Rev. 0

Page E-87 


\section{PIPELINE}

a

b

c

d

e

f

g

h

i

j

k

1

m

n

0

$p$

q

r

s

t

u

$v$

w

$x$

$y$

$z$

zt

zu

zv

$z W$

$z X$

$z y$

$z z$

\section{SPEC FROM_NODE}

01

01

01

01

01

01

01

01

01

01

01

01

01

01

01

01

01

01

01

01

01

01

01

01

01

01

01

01

01

01

01

01

$<01>$

\section{TO_NODE}

\section{PUMPICOMP}

1

D-in

F

$J$

K

$\mathrm{H}$-in

L

M

B

N

O

$P$

Q

$R$

$S$

$S$

s

$S$

$T$

u

V

w

$X$

$Y$

$\mathrm{Z}$

ZA

w

$\mathrm{X}$

$Y$

Z

ZA

ZI

ZJ 
Company: Fluor Daniel NW

Project:

by: Fluor Daniel NW

Created: 01/26/98 11:38 am

Design file:

Pipe Specs: 1
PIPELIST REPORT

02/18/98 2:03 pm

System: ANNU-PEX F. 5 of F-15 rev: 02/18/98 2:02 pm

Pipes: 33

Nodes: 26

Pumps/Comps: 1

\section{SPECIFICATIONS}

SPECIFICATION

PIPE MATERIAL.

Sch / Roughness

FLUID

Temp / Pres

VALVE TABLE

Air

Steel

$01 \operatorname{Sch} 40$

rev: 01/29/98 11:21 am

$\operatorname{Sch} 40$

0.0018 in

$50^{\circ} \mathrm{F}$

0 psig

Size for: $6 \mathrm{ft} / \mathrm{sec}$
Standard

Standard
DESIGN LIMITS Vel / Pres

$0-40 \mathrm{ft} / \mathrm{sec}$

$-14.4-14.4$ psi g

HNF-2479, Rev. 0

Page E-89 
$F-6$ of $F-15$

PIPELINE

a

b

c

d

e

f

g

h

i

$$
\text { j }
$$

$k$

1

$\mathrm{m}$

n

$\circ$

$p$

$q$

$r$

$$
s
$$

t

u

v

w

; $\mathrm{x}$
SPEC MATERIAL

Size / Sch

01 Steel

12 in $/ 40$

01 Steel

$14 \mathrm{in} / 40$

01 Steel

14 in $/ 40$

01 Steel

14 in $/ 40$

01 Steel

10 in $/ 40$

01 Steel

6 in 140

01 Steel

14 in $/ 40$

01 Steel

$10 \mathrm{in} / 40$

01 Steel

8 in $/ 40$

01 Steel

$$
6 \text { in } / 40
$$

01 Steel

3 in $/ 40$

01 Steel

$$
3 \text { in } / 40
$$

01 Steel

$$
3 \text { in } / 40
$$

01 Steel

$$
3 \text { in } / 40
$$

01 Steel

$$
4 \text { in } 140
$$

01 Steel

$$
4 \text { in } / 40
$$

01 Steel

$$
4 \text { in } / 40
$$

01 Steel

$$
4 \text { in } / 40
$$

01 Steel

$$
20 \text { in } / 40
$$

01 Steel

$$
20 \text { in } / 40
$$

01 Steel

$$
8 \text { in } / 40
$$

01 Steel

$$
8 \text { in } / 40
$$

01 Steel

$$
8 \text { in } 140
$$

01 Steel

$$
8 \mathrm{in} / 40
$$

\section{LENGTH \\ ft}

45

31

71

1

30

40

9

17

13

1.25

12.67

1.75

7.75

3.5

85

98

96

97

i

1

1

1

1

1
FLUID

Temp / Pres

Air $\quad 0.9994$

$50^{\circ} \mathrm{F} / 0$ psig

Air

$50^{\circ} \mathrm{F} / 0 \mathrm{psig}$

Air

$50^{\circ} \mathrm{F} / 0$ psig

Air

$50^{\circ} \mathrm{F} / 0$ psig

Air

$50^{\circ} \mathrm{F} / 0$ psig

Air

$50^{\circ} \mathrm{F} / 0 \mathrm{psig}$

Air

$50^{\circ} \mathrm{F} / 0$ psig

Air

$50^{\circ} \mathrm{F} / 0$ psig

Air

$50^{\circ} \mathrm{F} / 0 \mathrm{psig}$

Air

$50^{\circ} \mathrm{F} / 0$ psig

Air

$50^{\circ} \mathrm{F} / 0$ psi g

Air

$50^{\circ} \mathrm{F} / 0$ psig

Air

$50^{\circ} \mathrm{F} / 0 \mathrm{psig}$

Air

$50^{\circ} \mathrm{F} / 0$ psi g

Air

$50^{\circ} \mathrm{F} / 0$ psig

Air

$50^{\circ} \mathrm{F} / 0$ psi g

Air

$50^{\circ} \mathrm{F} / 0$ psi g

Air

$50^{\circ} \mathrm{F} / 0$ psi g

Air

$50^{\circ} \mathrm{F} / 0$ psi g

Air

$50^{\circ} \mathrm{F} / 0$ psig

Air

$50^{\circ} \mathrm{F} / 0$ psi g

Air

$50^{\circ} \mathrm{F} / 0 \mathrm{psig}$

Air

$50^{\circ} \mathrm{F} / 0$ psig

Air

$50^{\circ} \mathrm{F} / 0$ psi g
VALVES

Total-K

0.8908

0.76

0.1164

1.429

0.1478

1.388

0.1047

0.1396

2.599

0.05435

1.094

1.094

1.094

1.913

1.913

1.913

1.913

$$
0
$$

0

536.1

536.1

536.1

536.1

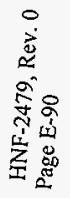




\begin{tabular}{|c|c|c|c|c|c|}
\hline PIPELINE & SPEC & $\begin{array}{l}\text { MATERIAL } \\
\text { Size / Sch }\end{array}$ & $\begin{array}{l}\text { LENGTH } \\
\mathrm{ft}\end{array}$ & $\begin{array}{l}\text { FLUID } \\
\text { Temp / Pres }\end{array}$ & $\begin{array}{l}\text { VALVES } \\
\text { Total-K }\end{array}$ \\
\hline$y$ & 01 & $\begin{array}{l}\text { Steel } \\
8 \text { in } / 40\end{array}$ & 1 & $\begin{array}{l}\text { Air } \\
50^{\circ} \mathrm{F} / 0 \mathrm{psig}\end{array}$ & 536.1 \\
\hline$z$ & 01 & $\begin{array}{l}\text { Steel } \\
8 \text { in } / 40\end{array}$ & 1 & $\begin{array}{l}\text { Air } \\
50^{\circ} \mathrm{F} / 0 \mathrm{psig}\end{array}$ & 536.1 \\
\hline$z t$ & 01 & $\begin{array}{l}\text { Steel } \\
32 \text { in } / 40\end{array}$ & 40 & $\begin{array}{l}\text { Air } \\
50^{\circ} \mathrm{F} / 0 \mathrm{psig}\end{array}$ & 0 \\
\hline $\mathrm{zu}$ & 01 & $\begin{array}{l}\text { Steel } \\
32 \text { in } / 40\end{array}$ & 40 & $\begin{array}{l}\text { Air } \\
50^{\circ} \mathrm{F} / 0 \mathrm{psig}\end{array}$ & 0 \\
\hline$z V$ & 01 & $\begin{array}{l}\text { Steel } \\
32 \text { in } / 40\end{array}$ & 40 & $\begin{array}{l}\text { Air } \\
50^{\circ} \mathrm{F} / 0 \mathrm{psig}\end{array}$ & 0 \\
\hline$z w$ & 01 & $\begin{array}{l}\text { Steel } \\
32 \text { in / } 40\end{array}$ & 40 & $\begin{array}{l}\text { Air } \\
50^{\circ} \mathrm{F} / 0 \mathrm{psig}\end{array}$ & 0 \\
\hline$z x$ & 01 & $\begin{array}{l}\text { Steel } \\
32 \text { in } / 40\end{array}$ & 40 & $\begin{array}{l}\text { Air } \\
50^{\circ} \mathrm{F} / 0 \mathrm{psig}\end{array}$ & 0 \\
\hline$z y$ & 01 & $\begin{array}{l}\text { Steel } \\
12 \text { in / } 40\end{array}$ & 20 & $\begin{array}{l}\text { Air } \\
50^{\circ} \mathrm{F} / 0 \mathrm{psig}\end{array}$ & 1 \\
\hline$z z$ & $\langle 01\rangle$ & $\begin{array}{l}\text { Steel } \\
8 \text { in } / 80 \\
\text { roughness: } 0.018 \text { in }\end{array}$ & 45 & $\begin{array}{l}\text { Air } \\
50^{\circ} \mathrm{F} / 0 \mathrm{psig}\end{array}$ & 0.699 \\
\hline
\end{tabular}

HNF-2479, Rev. 0 Page E-91 
Company: Fluor Daniel NW

Project:

by: Fluor Daniel NW

Created: 01/26/98 11:38 am

Design file:

Pipe Specs: 1
MATERIALS REPORT

$2: 03 \mathrm{pm}$

System: ANNU-PEX

rev: 02/18/98 2:02 pm F. 8 of F.15

Pipes: 33

Nodes: 26

Pumps/Comps: 1

PIPE MATERIALS LIST

PIPELINE

a

b

c

d

e

g

h

i

j

k

I

m

01

Steel

3 in 140

Steel

6 in $/ 40$

01 Steel

01 Steel

01 Steel

8 in 140

01 Steel

6 in 140

Steel

3 in 140

01

Steel

3 in $/ 40$

\section{LENGTH VALVES \& FITTINGS \\ $\mathrm{ft}$}

1

Steel
10 in $/ 40$

14 in / 40

10 in $/ 40$

7.75
45

31

71

30

1.75

3-Elbow Long - r/d $1.5 @ 90^{\circ}$

1-Butterfly Valve

1-Tee Flow Thru Branch

1-Elbow Long - r/d $1.5 @ 45^{\circ}$

4-Elbow Long - $r / d 1.5 @ 45^{\circ}$

1-Tee Flow Thru Run

1-Reducer Contraction $14 \times 10$

1-Elbow Long - $r / d 1.5 @ 45^{\circ}$ 1-Tee Flow Thru Run 1-Reducer Contraction $10 \times 6$

1-Elbow Long-r/d $1.5 @ 45^{\circ}$

2-Elbow Long - r/d $1.5 @ 45^{\circ}$ 1-Tee Flow Thru Branch 1-Reducer Contraction $14 \times 10$ 1-Tee Flow Thru Run

1-Reducer Contraction $10 \times 8$

1-Elbow Long - r/d $1.5 @ 45^{\circ}$

1-Elbow Long - r/d $1.5 @ 90^{\circ}$ 1-Reducer Contraction $6 \times 3$

12.67

1-Reducer Enlargement $4 \times 3$

1-Tee Flow Thru Branch

1-Reducer Enlargement $4 \times 3$

1-Tee Flow Thru Branch

1-Reducer Enlargement $4 X$ :
HNF-2479, Rev. 0

Page E-92 
PIPELINE

n

o

p

9

$r$

s

$\mathrm{t}$

u

v

w

$\mathrm{x}$

y

z

zt

zu

$2 v$

zw

$z x$

zy
SPEC MATERIAL

Size / Sch

01 Steel

3 in $/ 40$

01 Steel

4 in $/ 40$

01

Steel

4 in $/ 40$

01 Steel

4 in $/ 40$

01 Steel

4 in $/ 40$

01 Steel

20 in $/ 40$

01 Steel

20 in $/ 40$

01 Steel

8 in $/ 40$

01 Steel

8 in $/ 40$

01 Steel

8 in $/ 40$

01 Steel

8 in $/ 40$

01 Steel

8 in $/ 40$

01 Steel

8 in $/ 40$

01 Steel

32 in / 40

01

Steel

32 in $/ 40$

01

Steel

32 in $/ 40$

01 Steel

32 in $/ 40$

01 Steel

32 in $/ 40$

01

Steel

12 in $/ 40$
LENGTH VALVES \& FITTINGS

$\mathrm{ft}$

3.5

85

98

96

97

1

1

1

1

1

1

1

1

40

40

40

40

40

20
1-Tee Flow Thru Branch

1-Reducer Enlargement $4 \times 3$

4-Elbow Long - r/d $1.5 @ 90^{\circ}$ 1-Exit Sharp-Edged

4-Elbow Long - r/d $1.5 @ 90^{\circ}$ 1-Exit Sharp-Edged

4-Elbow Long - r/d $1.5 @ 90^{\circ}$ 1-Exit Sharp-Edged

4-Elbow Long - r/d $1.5 @ 90^{\circ}$

1-Exit Sharp-Edged 
PIPELINE

$Z Z$

\section{SPEC MATERIAL}

Size / Sch

<01> Steel

8 in $/ 80$
LENGTH VALVES \& FITTINGS

ft

45

1-Elbow Long - r/d $1.5 @ 90^{\circ}$

1-Entrance Sharp-Edged

HNF-2479, Rev. 0

Page E-94 
PIPE SUMMARY

PIPE MATERIAL

Steel

Steel

SPECIFICATION

01 Sch40

Size: 3 in

Size: 4 in

Size: 6 in

Size: 8 in

Size: 10 in

Size: 12 in

Size: 14 in

\section{SIZE}

40

80
3 in

4 in

6 in

8 in

10 in

12 in

14 in

20 in

32 in

8 in
LENGTH

$F-11$ of $F-15$
VALVE \& FITTING SUMMARY

SCHEDULE

40
$25.67 \mathrm{ft}$

$376 \mathrm{ft}$

$41.25 \mathrm{ft}$

$19 \mathrm{ft}$

$47 \mathrm{ft}$

$65 \mathrm{ft}$

$112 \mathrm{ft}$

$2 \mathrm{ft}$

$200 \mathrm{ft}$

$45 \mathrm{ft}$
VALVES \& FITTINGS

4-Reducer Enlargement $4 \times 3$

3-Tee Flow Thru Branch

16-Elbow Long - r/d $1.5 @ 90^{\circ}$

4-Exit Sharp-Edged

1-Elbow Long - $r / d 1.5 @ 45^{\circ}$

1-Elbow Long - r/d $1.5 @ 90^{\circ}$

1-Reducer Contraction $6 \times 3$

1-Elbow Long - $r / d 1.5 @ 45^{\circ}$

6-Fixed K 536.1

1-Elbow Long - r/d $1.5 @ 90^{\circ}$

1-Entrance Sharp-Edged

1-Elbow Long - $r / d 1.5 @ 45^{\circ}$

1-Tee Flow Thru Run

1-Reducer Contraction $10 \times 6$

1-Reducer Contraction $10 \times 8$

3-Elbow Long - $r / d 1.5 @ 90^{\circ}$

1-Butterfly Valve

1-Exit Sharp-Edged

2-Tee Flow Thru Branch

7-Elbow Long-r/d $1.5 @ 45^{\circ}$

2-Tee Flow Thru Run

2-Reducer Contraction $14 \times 10$
HNF-2479, Rev. 0

Page E-95 


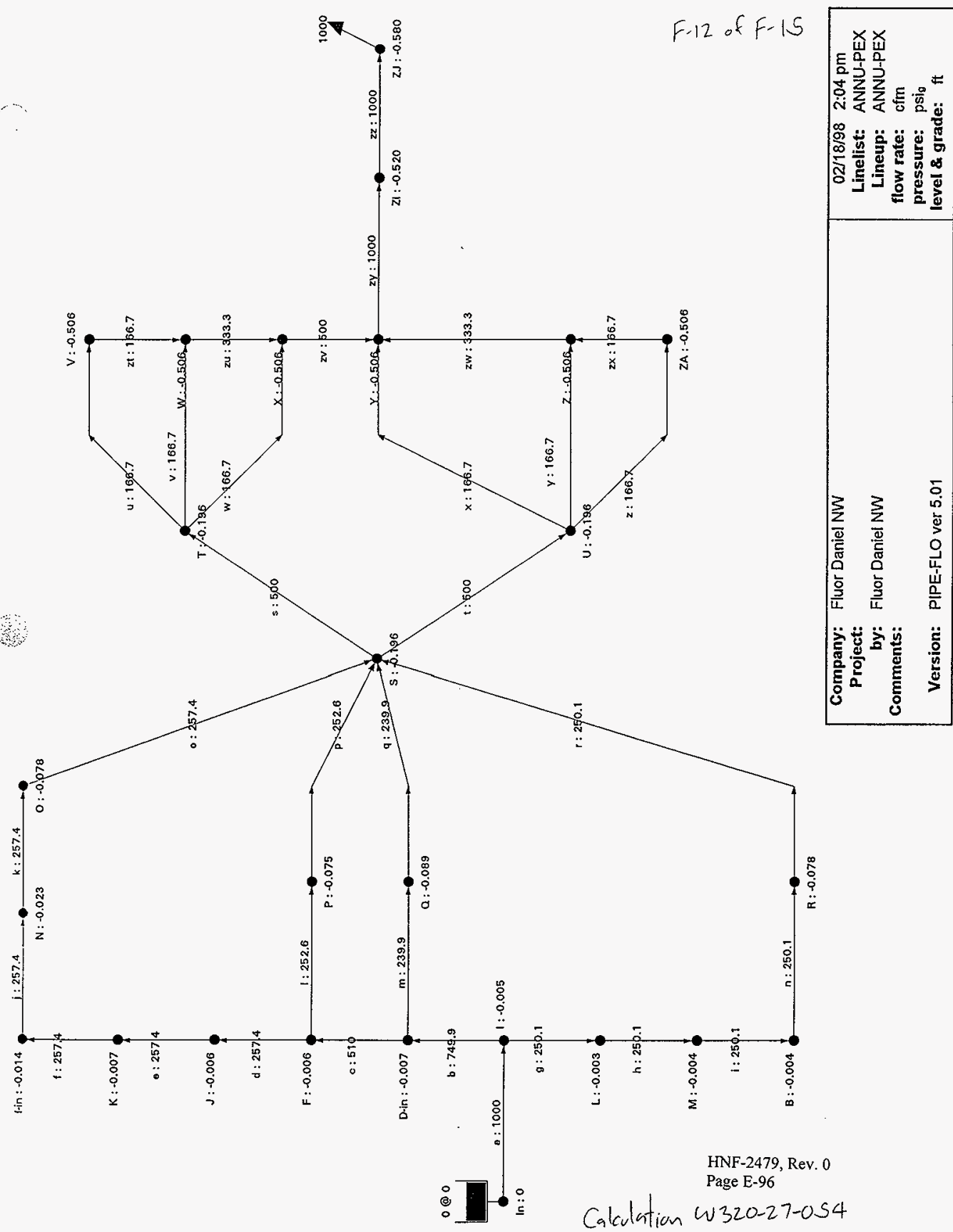


Company: Fluor Daniel NW

Project:

by: Fluor Daniel NW

System: ANNU-PEX

rev: 02/18/98 2:02 pm
02/18/98 2:04 pm

Lineup: ANNU-PEX $02 / 18 / 98$ 2:04 pm $F-13$ of $F-15$

Volumetric flow rates require constant fluid properties in all pipelines. Fluid properties in the first specification were used in this calculation.

LINEUP SUMMARIES

NODE

DEMAND

NODE

$\mathrm{cfm}$

Deviation: $8.7 \mathrm{e}-005 \%$

after: 16 iterations

ZJ

$\gg 1000$

Flows IN: $0 \mathrm{cfm}$

Flows OUT: $1000 \mathrm{cfm}$

NET FLOWS OUT: $1000 \mathrm{cfm}$

LINEUP SUMMARIES

PIPELINE

FLOW

PRESSURE

cfm

SOURCE

SET

psi $g$

LEVEL

DEMAND

$\mathrm{cfm}$

a

$\ll 1000$

In

0

0

Flows IN: $1000 \mathrm{cfm}$

Flows OUT: $0 \mathrm{cfm}$

NET FLOWS IN: $1000 \mathrm{cfm}$

HNF-2479, Rev. 0

Page E-97 
טटाาช/צช 2:U4 pm

\section{NODE}

B

D-in

$F$

$\mathrm{H}$-in

I

In

J

K

L

M

N

O

$P$

Q

R

$S$

$T$

u

v

W

$X$

$Y$

$Z$

ZA

Zl

ZJ

\section{ELEVATION}

ft

674.44

677.33

673.37

672.69

677.5

681.86

673.37

673.07

674.83

674.52

671.44

658.77

671.62

669.58

670.92

623

623

623

663.17

663.17

663.17

663.17

663.17

663.17

680

683
DEMAND

cfm

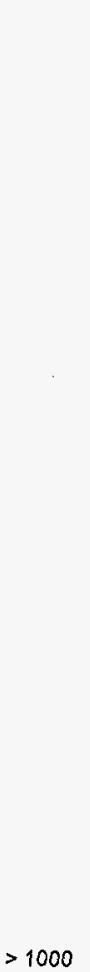

PRESSURE

psi $\mathbf{g}$

$-0.004$

$-0.007$

$-0.006$

$-0.014$

$-0.005$

0 (source)

$-0.006$

$-0.007$

$-0.003$

$-0.004$

$-0.023$

$-0.078$

$-0.075$

$-0.089$

$-0.078$

$-0.196$

$-0.196$

$-0.196$

$-0.506$

$-0.506$

$-0.506$

$-0.506$

$-0.506$

$-0.506$

$-0.520$

$-0.580$
F.14 of F-15

H GRADE

$\mathrm{ft}$

666.8

665.1

662.5

647.7

669

681.9

662.4

660.3

668.5

668

628.8

515.4

533.8

504.4

526.6

260

260

260

$-272.6$

$-272.6$

$-272.6$

$-272.7$

$-272.6$

$-272.6$

$-282.3$

$-389.5$

HNF-2479, Rev. 0

Page E-98 


FROM
In
I - -in
F
J
K
I
L
M
H-in

TO

FLOW

VEL $\quad d P$

$\mathrm{cfm}$

$\mathrm{ft} / \mathrm{sec}$

psig

HL

$1 \quad 1000$

21.46

0.005

12.86

D-in

749.9

13.32

0.002

3.916

$F \quad 510$

9.056

0

2.635

J 257.4

4.571

0

0.045

257.4

7.841

0

2.121

$H$-in

257.4

21.4

0.007

12.61

$L$

250.1

4.441

(0.001)

0.484

250.1

7.619

0

0.502

250.1

12.01

0

1.249

257.4

21.4

0.010

18.83

$N$

257.4

* 83.64

0.054

113.5

$F$

252.6

- 82.08

0.069

128.7

D-in

239.9

* 77.95

0.083

160.7

B

$\mathrm{R}$

250.1

* 81.27

0.074

140.2

257.4

* 48.57

0.119

255.3

$P$

252.6

* 47.67

0.122

273.7

239.9

* 45.27

0.107

244.3

$\mathrm{R}$

250.1

- 47.19

0.118

266.5

500

4.321

0

0.004

500

166.7

4.321

0

0.004

V

$T$

166.7

166.7

166.7

166.7

166.7

166.7

333.3

500

333.3

166.7

1000

8.003

0.310

532.7

8.003

0.310

532.7

8.003

0.310

532.7

8.003

0.310

532.7

8.003

0.310

532.7

8.003

0.310

532.7

0.544

0

0.002

1.087

0

0.008

1.631

0

0.016

1.087

0

0.008

0.544

0

0.002

ZI

ZJ

21.46

0.014

9.686

1000

* 52.61

0.060

107.2

HNF-2479, Rev. 0

PageE-99 
FLUOR DANIEL

Talc. No.: W320-27-054

NORTHWEST INC.

Revision: 0

DESIGN ANALYSIS

Page No: $G-O$ of $G-13$

Client: Numatec

Subject: System Curves for Portable Exhauster Installation

Location: 241-C/241-AY
Wo/Job No: ER 4319/N-320

Date: $2 / 18 / 98$

Checked: $3 / 2 / 98$

Revised:
By: Kelly Hayase,

By: Loin Cert

By:

Appendix G: Pipe-Flo results of ANNU-PEX used to generate the system curve

HNF-2479, Rev. 0

Page E-100

FDNW CALCULATION SHEET

ANNUPEX.WPD 


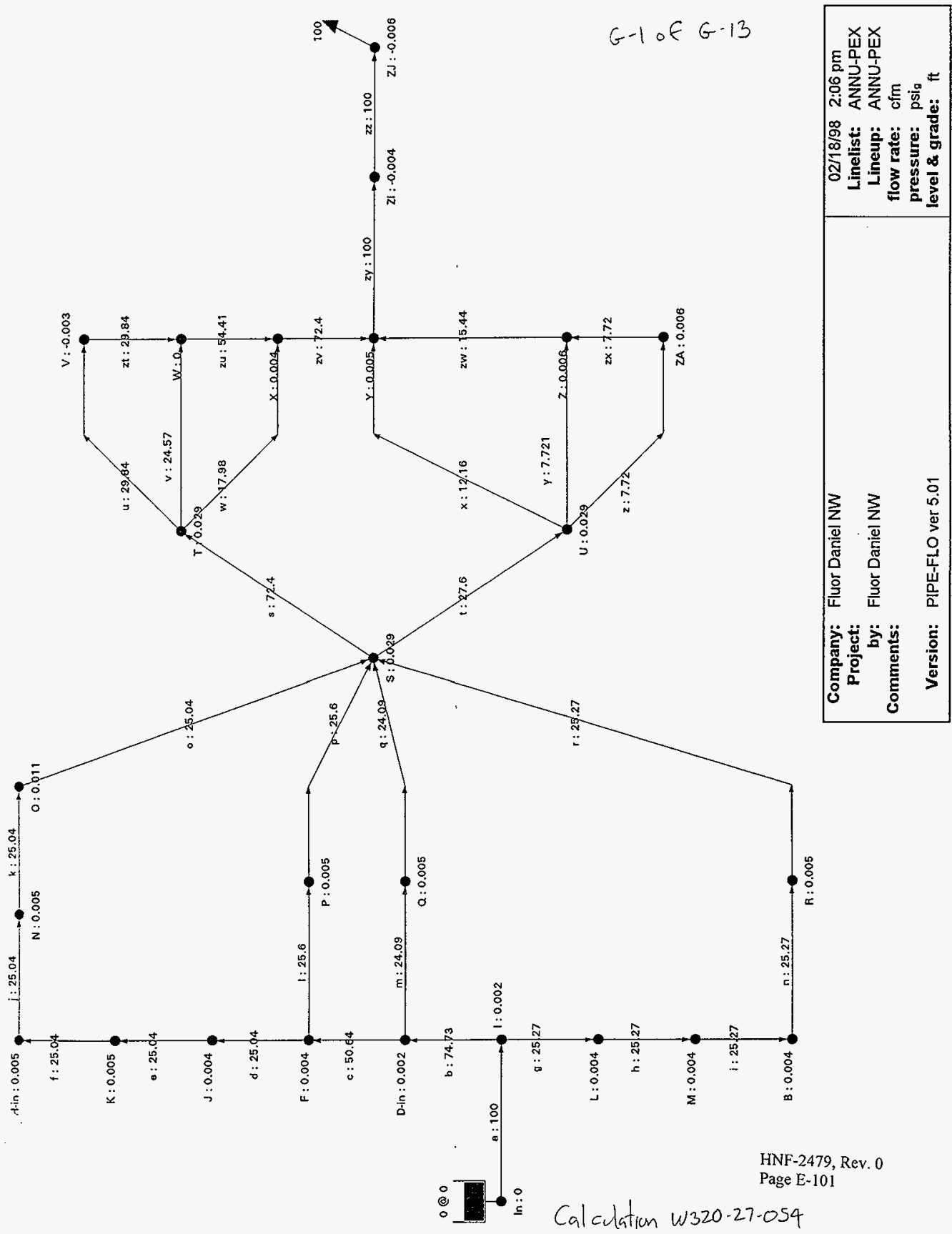




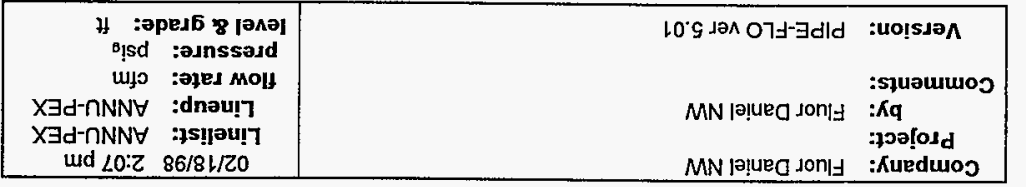

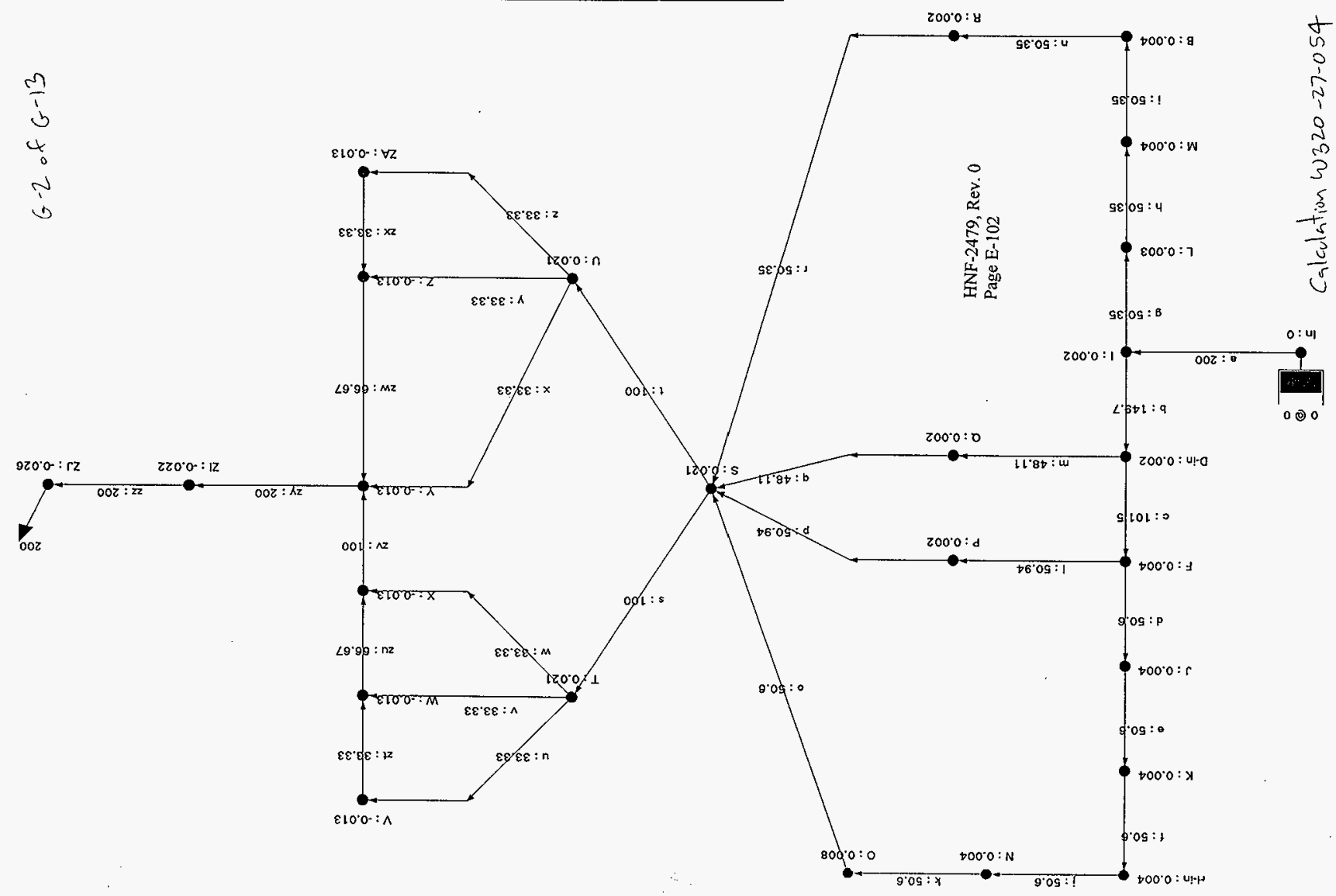




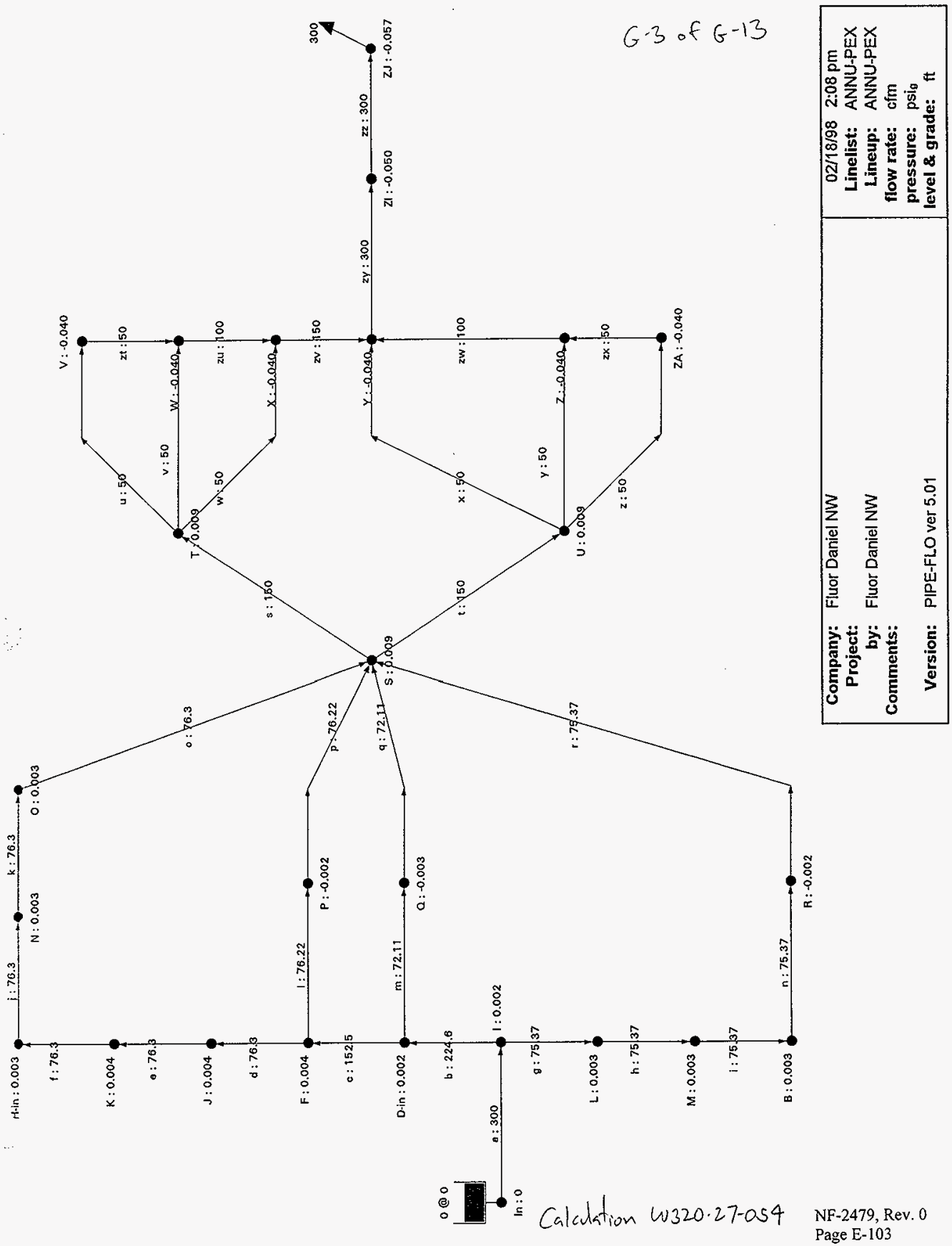




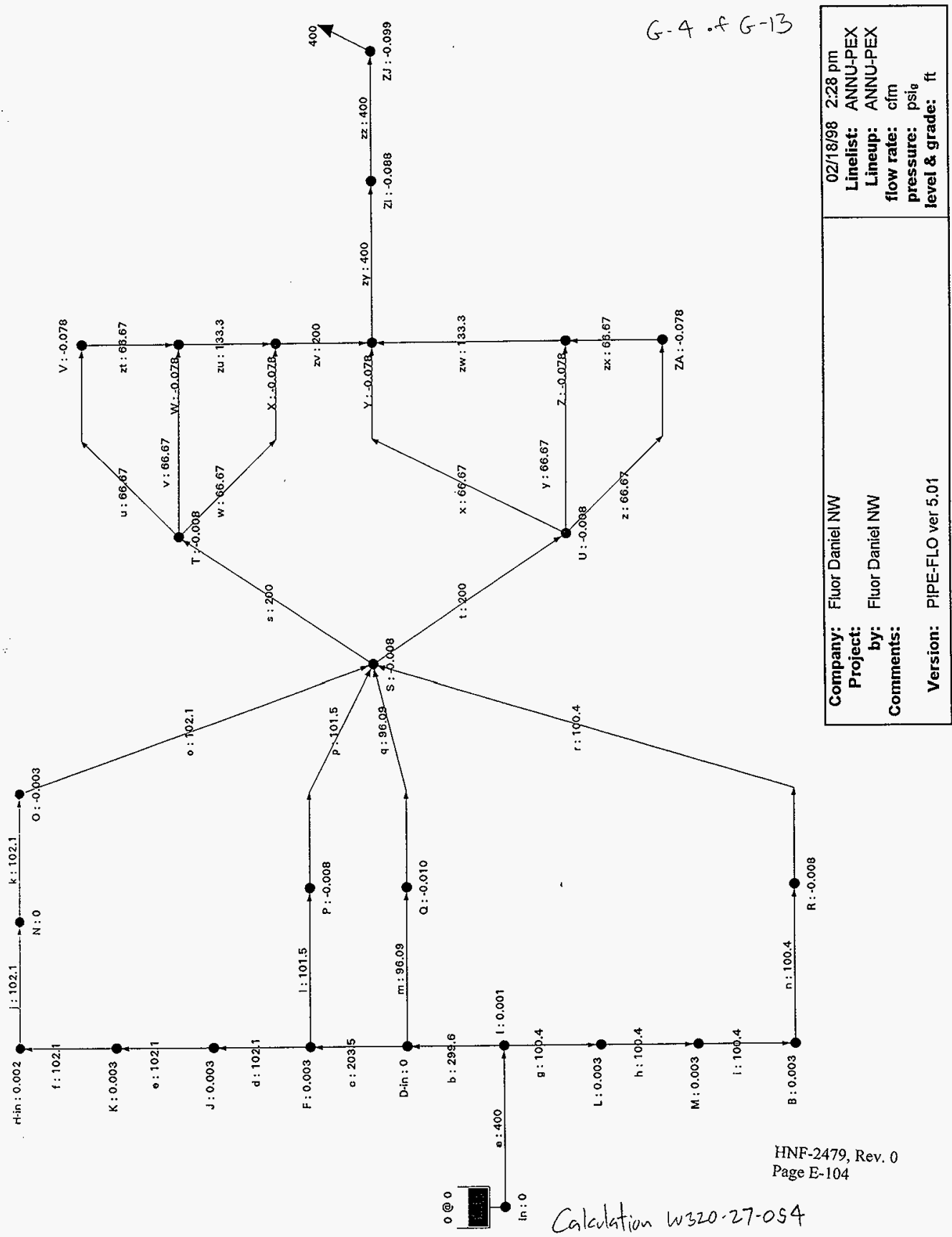




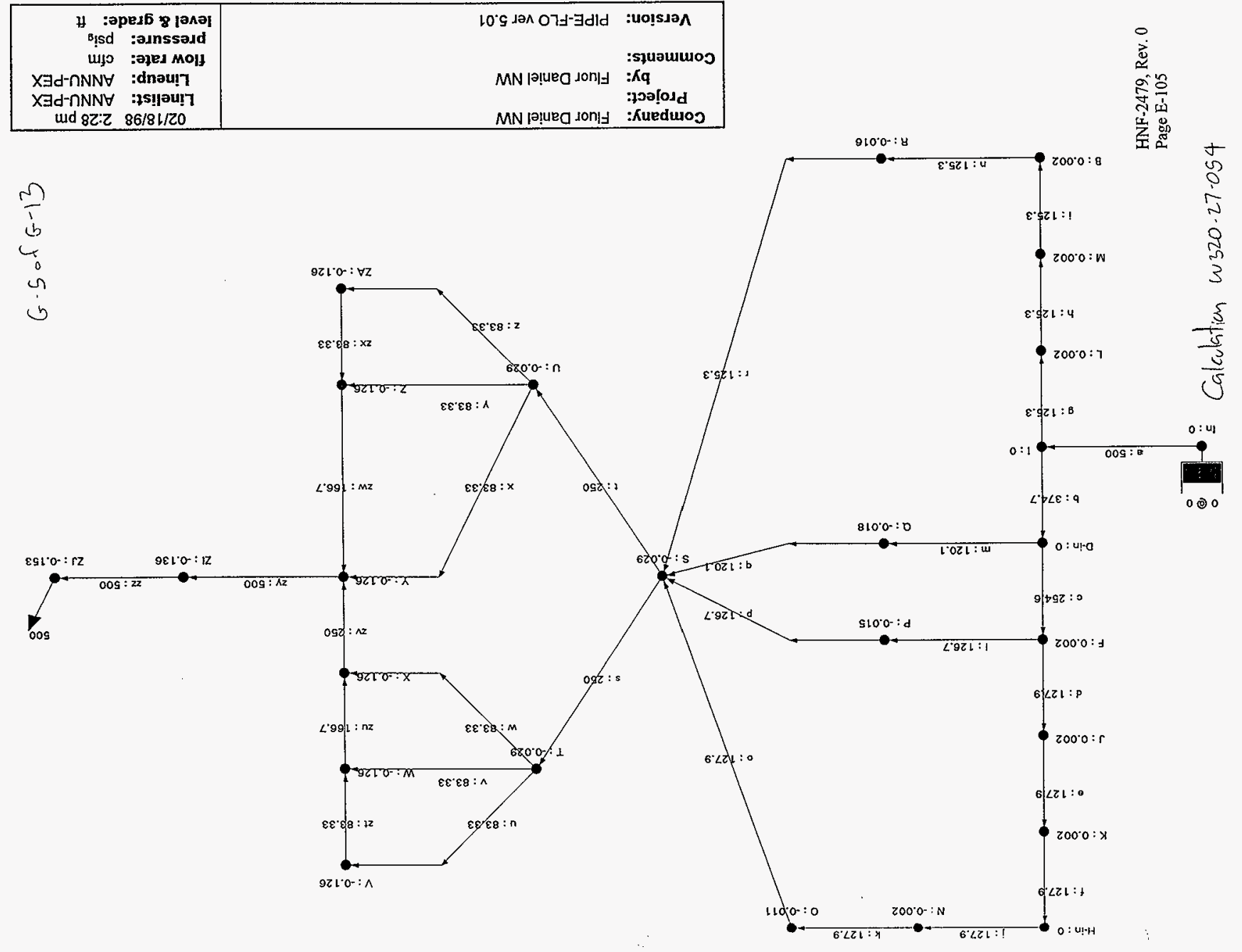




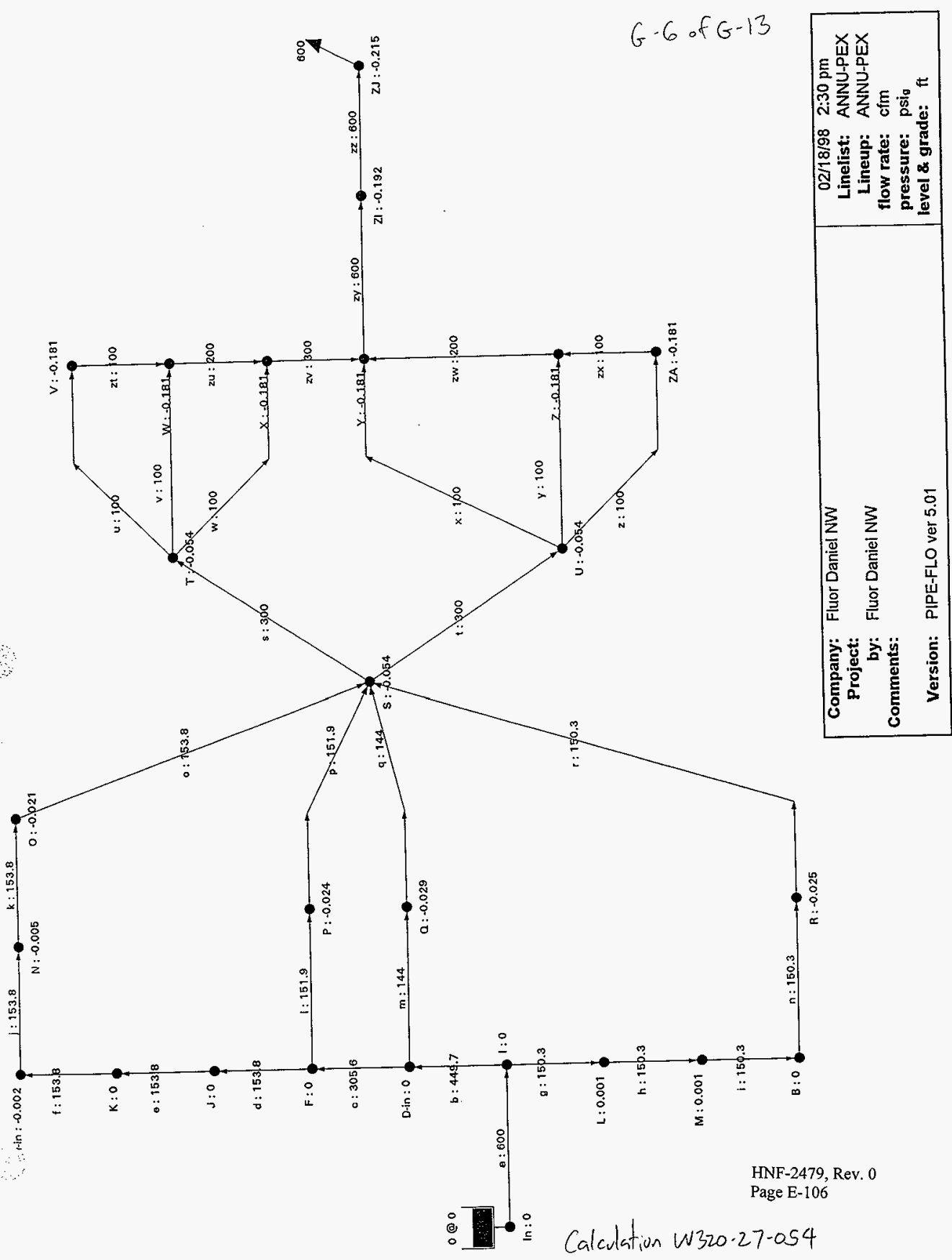




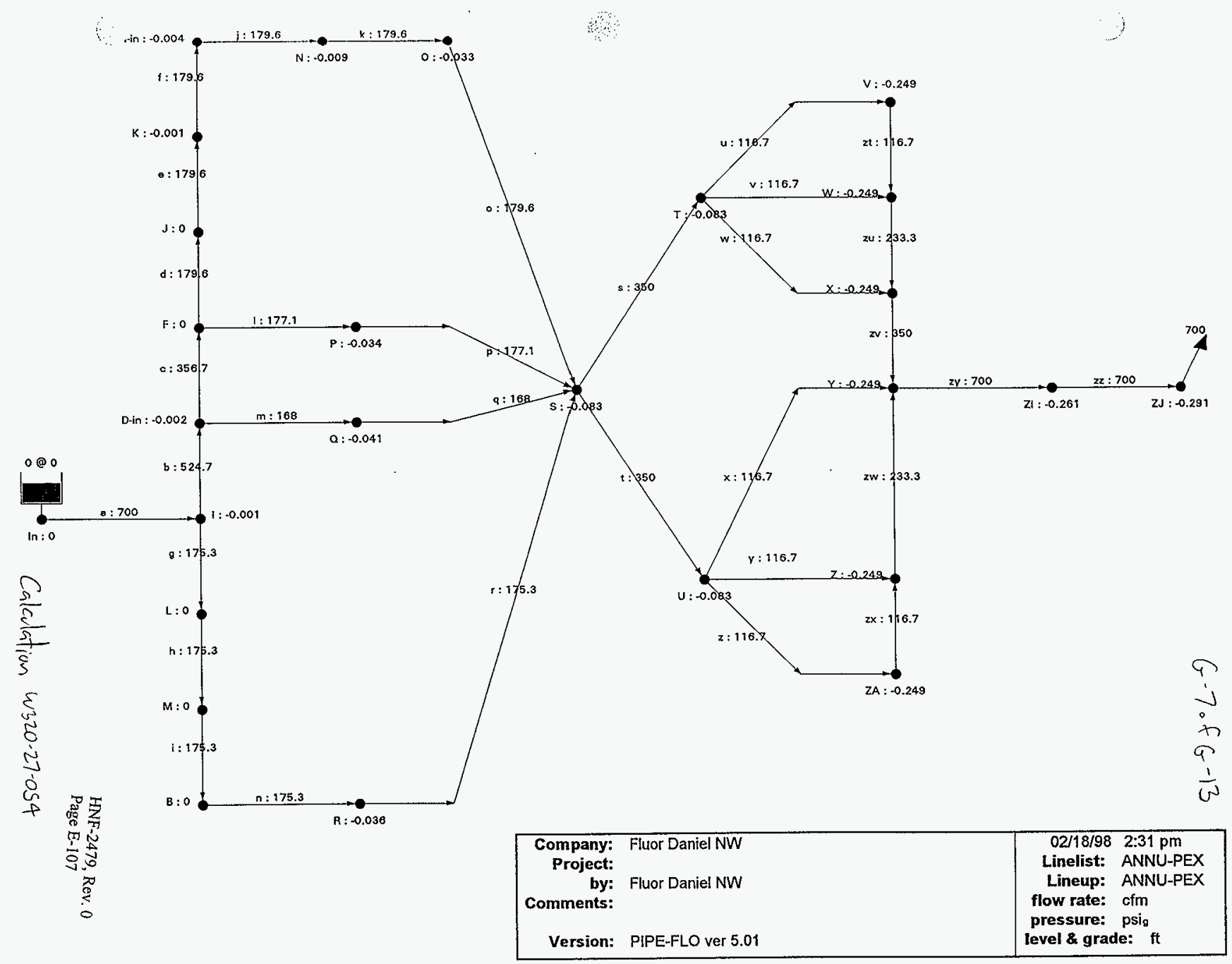




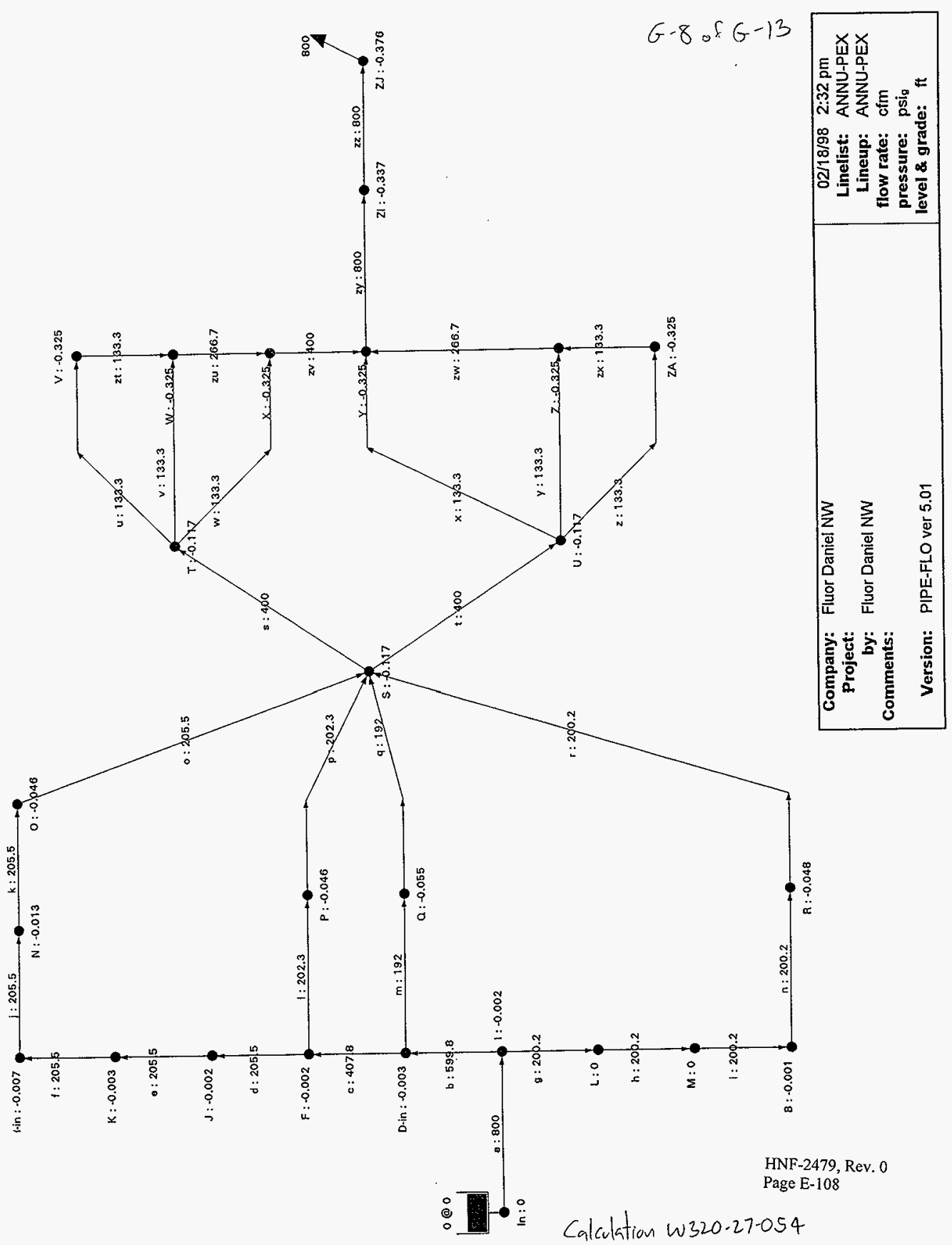




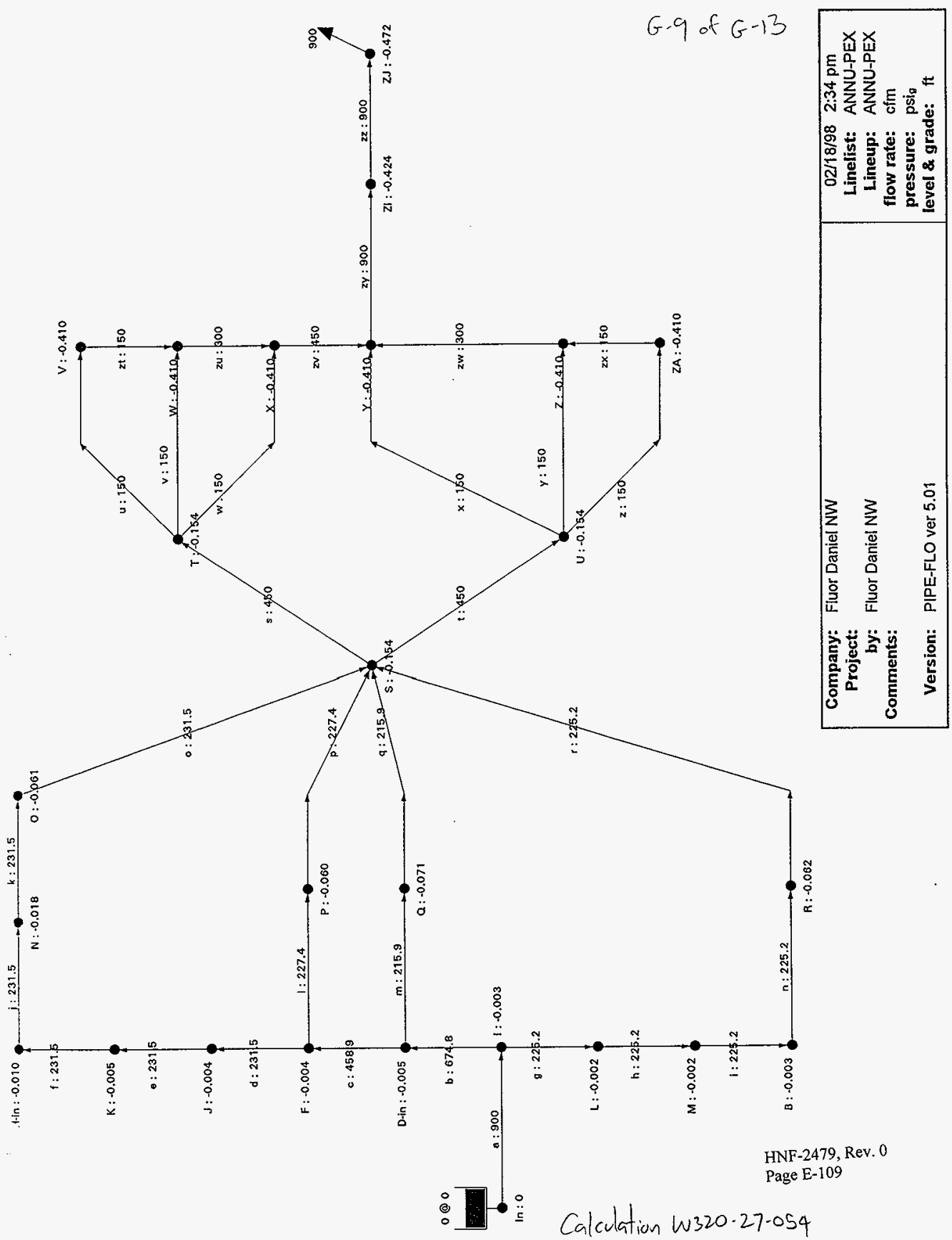




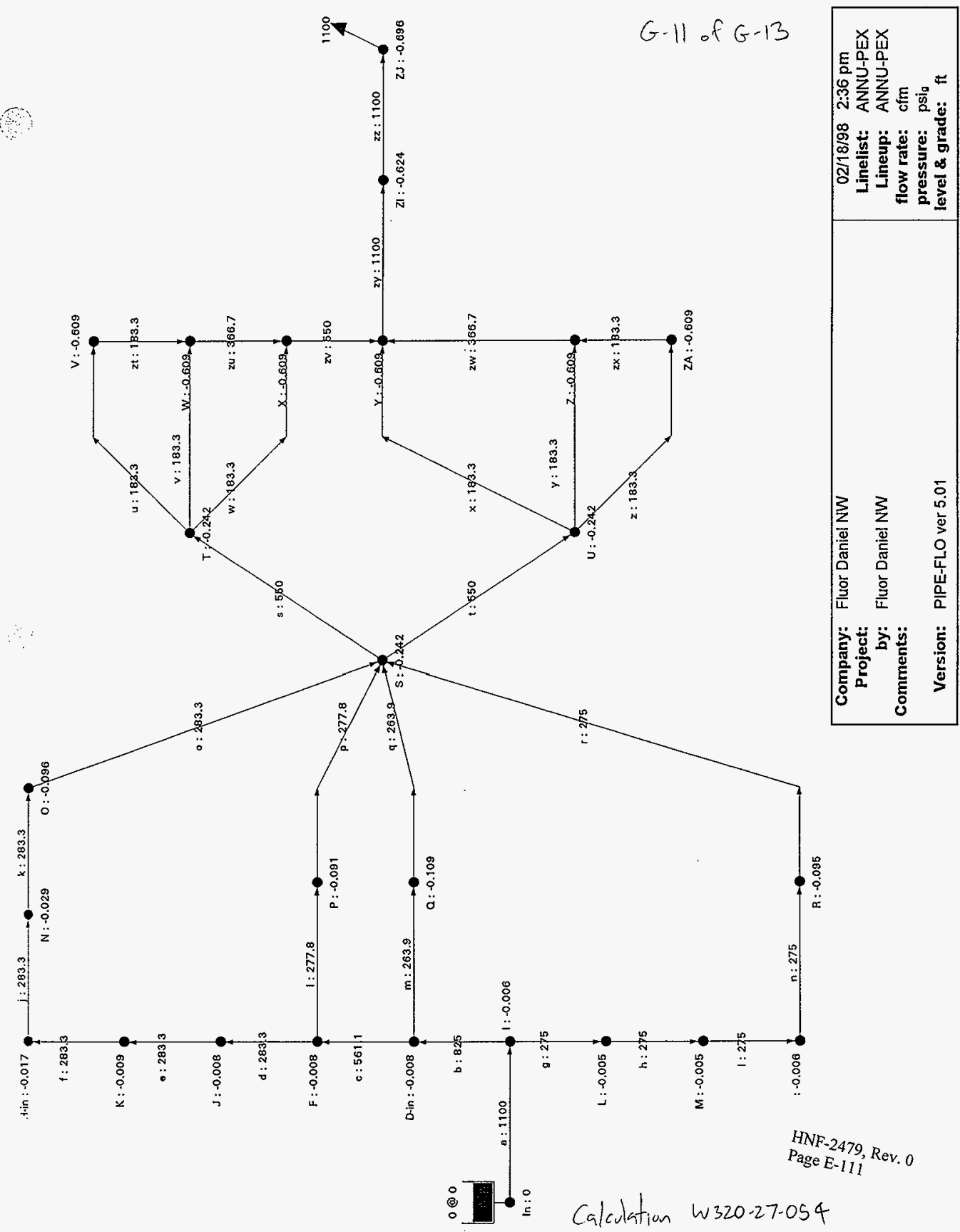




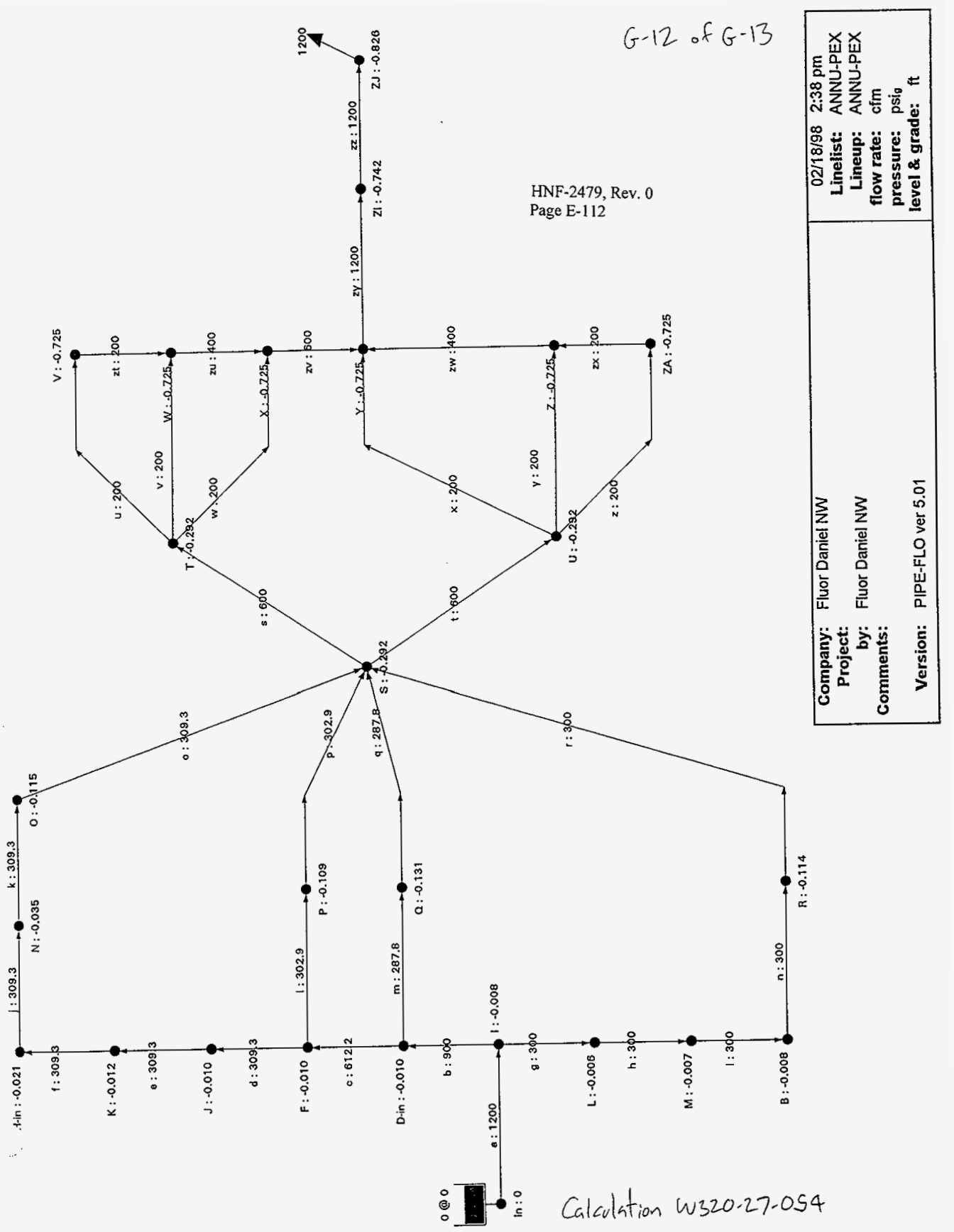




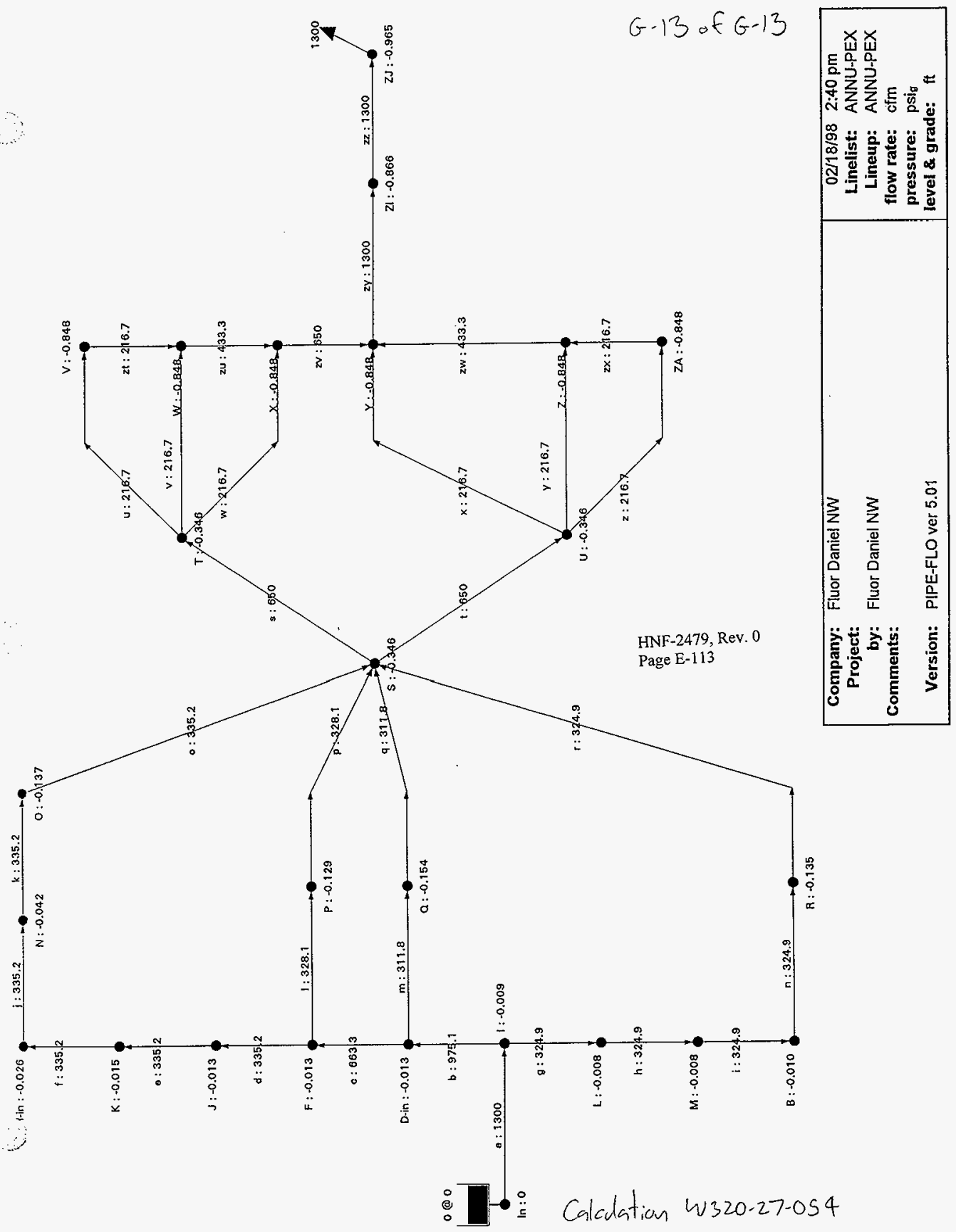


Appendix H: References 
Author: Steven W (Steve) Shaw at HANFORD12E

\section{Date: $1 / 26 / 98$ 6:56 AM}

mo: John W Bailey at HANFORD1OC

TO: Owen D Nelson at HANFORD2IE

TO: William J (Bill) Powell at HANFORD04E

TO: Ryan A Dodd at HANFORDO5E

TO: Joseph $M$ Jones at HANFORD05E

TO: Ronald $L$ legg at HANFORDI1B

TO: Daniel G (Dan) Baide at HANFORD04A

TO: Jack $W$ Lentsch at HANFORD24E

TO: Mark $M$ Jennings at HANFORD11C

TO: Kenneth $J$ Anderson at HANFORDIOA

TO: Jeffrey $E$ Andrews at HANFORDO $4 E$

Subject: 102-AY ANNULUS VENT SYSTEM TESTING

Just to keep everybody up to speed, and to apologize again for calling on Saturday:

Friday night, after resheaving the fan, we were able to close $T-V-1$ all the way, and got several good data points for the system curve.

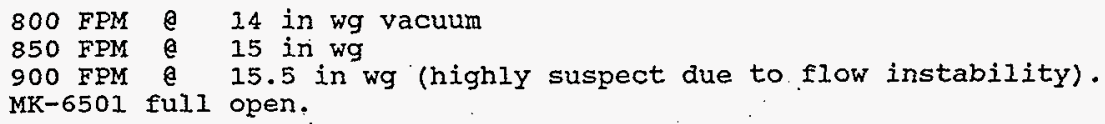

However, due to an ommision in the OTP, we were not able to operate the radial inlet damper to the fan. At this point 1000 FPM flow velocities through the annulus will not be obtainable. What we would hope to obtain by operation of the radial inlet damper would be to stabilize the flow at something less then 900 FPM.

The HOPE is that by closing the radial inlet damper, we will change the velocity profile/inlet path into the fan, and achieve a stable flow velocity. However, by closing the damper, it must be assumed that we will take a pressure loss with a corresponding decrease in flow. 
Figure 2-11. Floor Volumetric Flow ys. Annulus Yacuum or System Pressure Drop-6-Inch Annulus Inlet Lines Blocked and Unblocked.

-

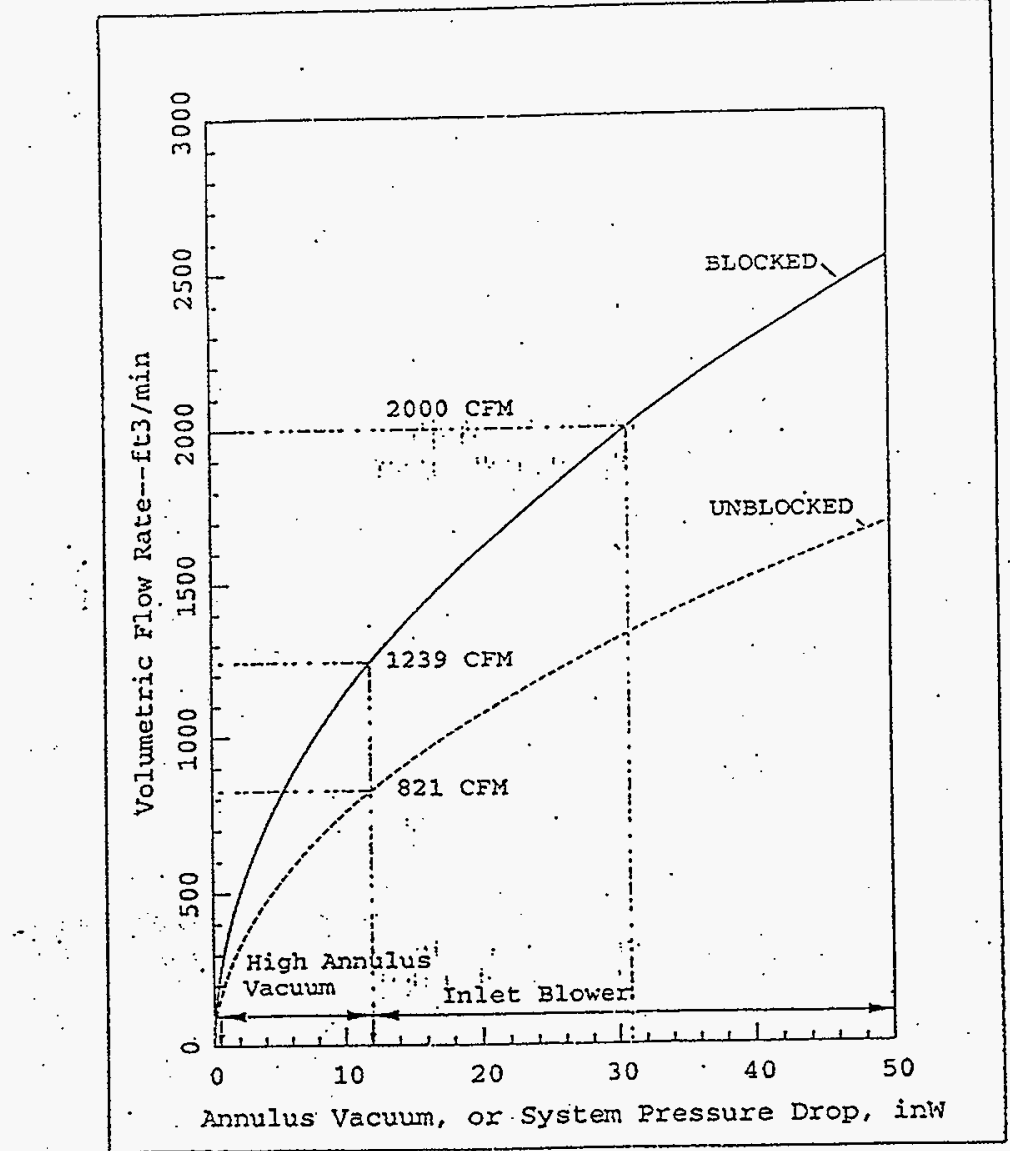

Calculation W320-27-054

HNF. 2479 , ReV.O. Page $E-116$. 
HNF-2479, Rev. 0

W320-27-055

Nozzle Plate \& Encasement Plate Analysis 


\begin{tabular}{|lcccc|}
\hline $\begin{array}{l}\text { Fluor Daniel } \\
\text { NORTHWEST, INC }\end{array}$ & CALCULATION IDENTIFICATION AND INDE & Page & i of & iii \\
Date & $7 / 17 / 98$ & \\
\hline
\end{tabular}

This sheet shows the status and description of the attached Design Analysis sheets.

Discipline 27,Piping and Vessels WO/Job No:W320 Calculation No.

W320-27-055

Project No. \& Name Project W-320, Waste Retrieval for Tank 241-C-106

Calculation Item Nozzle Plate \& Encasement Plate Analysis.

These calculations apply to:

Dwg. No. $\quad \mathrm{H}-2-818522 \& \mathrm{H}-2-818523$

Rev. No.

Dwg. No. H-2-818542 \& $\mathrm{H}-2-818543$

Rev. No.

Other (Study, CDR)

The status of these calculations is:

- Preliminary Calculations

$x \quad$ Final Calculations

- Check Calculations (On Calculation Dated

- Void Calculation (Reason Voided

Incorporated in Final Drawings?

This calculation verified by independent "check" calculation?

Original and Revised Calculation Approvals:

\begin{tabular}{|c|c|c|c|}
\hline & $\begin{array}{c}\text { Rev. } 0 \\
\text { Signature / Date }\end{array}$ & $\begin{array}{c}\text { Rev. } 1 \\
\text { Signature / Date }\end{array}$ & $\begin{array}{c}\text { Rev. } 2 \\
\text { Signature / Date }\end{array}$ \\
\hline Originator & MM Ahmed 1 \& & & \\
\hline Checked by & $\begin{array}{l}\text { Sargo } \\
\text { Sean Fargo }\end{array}$ & & \\
\hline Approved by & & & \\
\hline $\begin{array}{l}\text { Checked Against } \\
\text { Approved Vendor Data }\end{array}$ & N. Aluves $\frac{}{7.23 .98}$ & & \\
\hline
\end{tabular}

Design Analysis

\begin{tabular}{c}
\hline Page No. \\
\hline$i$ \\
\hline$i i$ \\
\hline$i i i$ \\
\hline 1 \\
\hline 2 \\
\hline 3 \\
\hline$\frac{4-7}{8-11}$ \\
\hline $12-13$ \\
\hline Appdx-A \\
\hline
\end{tabular}

\section{INDEX \\ $\overline{\text { Description }}$}

Calculation Identification and Index

Calculation Cross Index

Design Verification Screening Criteria

Objective, Introduction, Design Criteria, Design inputs

Design methodology

Calculations, References and Conclusion

Process, Encasement \& Jumper piping load consolidation

Nozzle Kick Off Plate Analysis

Encasement pipe Plate Analysis

Reference Material 


\begin{tabular}{|c|c|c|c|c|c|c|c|c|c|c|}
\hline \multicolumn{10}{|c|}{$\begin{array}{l}\text { CALCULATION CROSS INDEX (Typical) } \\
\text { Subject Calculation No. W320-27-055 }\end{array}$} & Page ii of iii \\
\hline \multirow{2}{*}{$\begin{array}{c}\text { Subject } \\
\text { Calculation } \\
\text { Revision } \\
\text { No. }\end{array}$} & \multirow{2}{*}{$\begin{array}{c}\text { Superceded } \\
\text { by Calculation } \\
\text { No. }\end{array}$} & \multicolumn{2}{|c|}{$\begin{array}{l}\text { These interfacing calculation/documents provide } \\
\text { input to the subject calculation, and if revised } \\
\text { may require revision of the subject calculation. }\end{array}$} & \multicolumn{2}{|c|}{$\begin{array}{c}\text { Results and conclusions of the subject } \\
\text { calculation are used in these interfacing } \\
\text { calculations and/or documents. }\end{array}$} & \multicolumn{2}{|c|}{$\begin{array}{c}\text { Does the output } \\
\text { interface calculation } \\
\text { documents require } \\
\text { revision? }\end{array}$} & \multicolumn{2}{|c|}{$\begin{array}{c}\text { Has the output } \\
\text { interface calculation' } \\
\text { documents been } \\
\text { revised? }\end{array}$} & \multirow[t]{2}{*}{$\begin{array}{l}\text { Discipline manager's signature and } \\
\text { date indicating evaluation is } \\
\text { complete }\end{array}$} \\
\hline & & Calcuallion/Document No. & \begin{tabular}{|c|}
$\begin{array}{c}\text { Revision. } \\
\text { No. }\end{array}$ \\
\end{tabular} & Calcualtion/Document No. & \begin{tabular}{|c|} 
Revision. \\
No. \\
\end{tabular} & Yes & No & Yes & No & \\
\hline 0 & NA & Dwg.\# H-2-818522 & 1 & NA & & & $x$ & & $x$ & 1 \\
\hline 0 & NA & Dwg\# H-2-818523 & 1 & NA & & & $x$ & & $x$ & \multirow{3}{*}{ Damy L Enams $7 / 23 \mid \varepsilon$} \\
\hline 0 & NA & Dwg\# H-2-818542 & 2 & NA & & & $x$ & & $x$ & \\
\hline 0 & NA & Dwg\# H-2-818543 & 2 & NA & & & $x$ & & $x$ & \\
\hline 0 & NA & Calc\# W320-27-013 & 3 & NA & & & $x$ & & $x$ & 1 \\
\hline 0 & NA & Calc\# W320-27-014 & 2 & NA & & & $x$ & & $x$ & \\
\hline 0 & NA & Calc\# W320-27-016 & 1 & NA & & & $x$ & & $x$ & \\
\hline 0 & NA & Calc\# W320-27-029 & 3 & NA & & & $x$ & & $x$ & 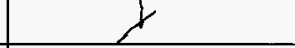 \\
\hline & & & & & & & & & & \\
\hline & & & & & & & & & & \\
\hline & & & & & & & & & & \\
\hline & & & & & & & & & & \\
\hline & & & & & & & & & & \\
\hline & & & & & & & & & & \\
\hline & & & & & & & & & & \\
\hline & & & & & & & & & & \\
\hline & & & & & & & & & & \\
\hline & & & & & & & & & & \\
\hline
\end{tabular}




\section{DESIGN VERIFICATION SCREENING CRITERIA}

Project/Document No. W320-27.055

When the design or design change affects hardware, independent design verification must be performed if one or more of the following questions must be answered affirmatively (YES).

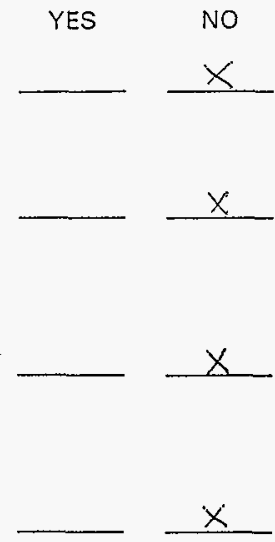

1. Does the design or design change involved meet the established criteria to be considered Safety Class?

2. Does this design or design change cause or permit changes to Safety Class instrument or alarm setpoints outside of previously approved operational limits?

3. Does this design or design change significantly affect the nuclear or environmental safety consequences of a malfunction or failure of the structure, system, or component?

4. Does this design or design change involve or change design that has previously undergone formal design verification?

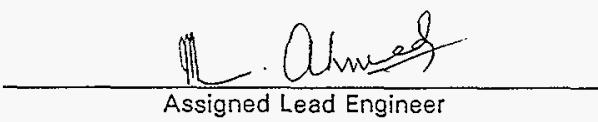

$\frac{7.17 .98}{\text { Date }}$

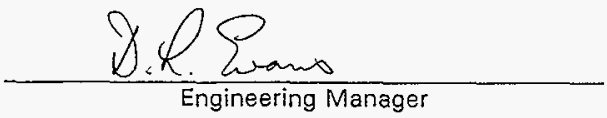

$\frac{7 \cdot 23 \cdot 98}{\text { Date }}$

Original Design Package Distribution:

Project Manager

Engineering Manager

Technical Document Control
Design Change Distribution:

Attach to Design Change Notice 


\title{
DESIGN ANALYSIS
}

\author{
$\begin{array}{ll}\text { Client } & \text { Numatec Hanford Inc } \\ \text { Subject } & \text { Project W-320, Waste retrieval for Tank 241-C-106 }\end{array}$ \\ Subject \\ Nozzle Plate \& Encasement Plate Analysis \\ Location $200 \mathrm{~W}$.
}

WO/Job No.
Date:July 17,98
Checked $7 / 90198$
Revised

Filename:W320plts

By: M. M. Ahmed ha/

By: S. Fargo SAY

By:

\section{OBJECTIVE:}

The objective of this calculation is two fold:

Analyze the nozzle kick off plates located inside of the pit wall for primary process pipe and jumper pipe loads.

Analyze the encasement pipe cover plates located outside of the pit wall for encasement pipe loads.

To meet the requirements of ASME code B31.3 allowable stresses.

\section{INTRODUCTION:}

The transfer lines passing through pit (pump \& sluice) walls penetrations have plates connected to piping on either side of the pit wall as detailed on drawings (Ref:7).

Nozzle plate located inside the pit, is a standard size-4 Purex nozzle kick off plate $\left(3 / 8 " X 13^{\prime \prime} \times 13^{\prime \prime}\right\}$ is welded to primary \& jumper pipe on one side and encasement pipe on other side.

Encasement pipe plate 3/8"X14"X14" (Ref: Dwg H-2-818523) is welded to encasement pipe on the out side of the pit wall.

\section{DESIGN CRITERIA:}

1. Project W-320, Tank 241-C-106 Sluicing, Functional Design Criteria: WHC-SD-W320-FDC-001, Rev-5.

2. ASME code B31.3-1993, Chemical and Petroleum Refinery Piping.

\section{DESIGN INPUTS:}

Design Pressure:

Design Temperature

Safety Class:

Process Pipe

Encasement pipe

Jumpers

\author{
$325 \mathrm{psi}$ \\ $180^{\circ} \mathrm{F}$ \\ Safety Significant. \\ General Service. \\ General Service.
}

\section{DESIGN METHODOLOGY:}

\section{LOAD COMBINATION:}

The nozzle plate is subjected to loads from process primary pipe on one side and jumper piping loads from other side. The process pipe loads are obtained from calculation: W320-27-0013, Process pipe stress analysis (Ref:2). The jumper piping loads are obtained from calculations W320-27-016 for C-Farm jumper nozzles U6 \& U9(Ref:4) and W320-27-029 for AY-Farm jumper nozzles U2 \& U11(Ref:5). 


\section{DESIGN ANALYSIS}
Client Numatec Hanford Inc
WO/Jab No.
Subject Project W-320, Waste retrieval for Tank 241-C-106
Date:July 17,98
Nozzle Plate \& Encasement Plate Analysis
Location $200 \mathrm{~W}$.
Checked $7 / 19 / 48$
Revised

Filename: W320plt

By: M. M. Ahmed the

By: S. Fargo Sefe

By:

The sustain $(G R+P)$ and thermal loads are combined together algebraically for each nozzle (U2, U6, U9 \& U11) separately

The seismic loads (process \& jumper pipe loads) for each nozzles are combined absolutely. The nozzle loads for each nozzle are tabulated on Excel spread sheets and documented on pages 4 thru 7 of this calculation.

\section{NOZZLE PLATE ANALYSIS:}

The nozzle plate, since welded to encasement pipe on one side and process pipe on the other side, is treated as an integral pipe enclosure plate. Further the plate is not attached to any structure. As such the plate is considered to be pipe integral attachment and governed by the piping code B31.3 criteria for allowable stresses.

Review of summation of loads (as listed on pages 4 thru 7) indicates that nozzle-U2 plate is subjected to much higher loads compared to other nozzles. Since nozzle plate design is typical for all the nozzles, the plate is evaluated for nozzle U2 loads as a worst case.

The bending stress in the plate is computed using the methodology specified in Formulas for Stress \& Strain by Roark and Young (Ref:6) for annular plate subjected to axisymmetric loading. The plate bending stress is calculated using Table-24, Case-1f formula for axial load, Case-2f for internal design pressure and Case-24 for bending moment (trunnion) loadings.

The plate bending stress so obtained for all three loadings are summed to get total plate stress. Two separate cases, one for sustained (GR+P) \& thermal loads and second case for seismic loads are performed individualiy.

\section{ENCASEMENT PLATE ANALYSIS:}

The encasement pipe plate is square plate with circular opening for encasement pipe. The Table-26, Case-1 formula for rectangular plate with all edges simply supported (bearing against concrete wall) and subjected to a load at center as specified in reference- 6 is used to compute the plate bending stress.

As in the case of nozzle plate, two separate loading cases (thermal \& seismic) are evaluated. The encasement pipe loads (thermal \& seismic) are soil frictional forces exerted on pipe when pipe translates due to thermal and seismic moments. These loads are calculated by multiplying unit friction forces (thermal and seismic) obtained from Ref:3 and length of the straight run of the pipe from pit wall to the first bend (See succeeding pages for documentation).

\section{ALLOWABLE STRESSES:}

ASME code B31.3 (Ref:!) criteria for allowable stresses as outlined below is used to check actual plate stresses.

$S_{h}=S_{c}=20,000 p s i$ for ASTM 240 SST plate from Appendix-A, Table-1A 


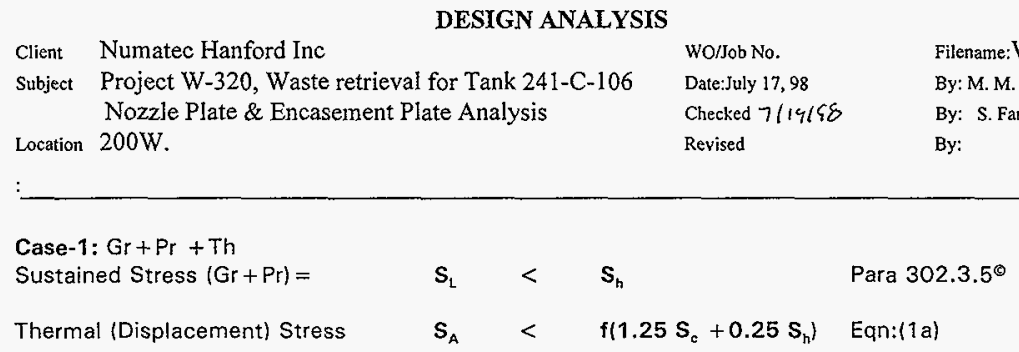

Adding above two cases together: $f=1$ for less than 7000 cycles during the life of plant and $S_{h}=S_{c}$ $\mathrm{GR}+\mathrm{Pr}+\mathrm{Th}$

Case-2: Seismic (Occasional)

$$
S_{L}+S_{A}<2.5 S_{h}=50,000 p s i
$$

Occasional Stress

$$
\mathrm{S}_{\text {occ }}<1.33 \mathrm{~S}_{\mathrm{h}}=26,600 \text { psi } \quad \text { Para } 302.3 .6
$$

\section{CALCULATIONS:}

The analysis of nozzle plate is documented on pages 8 thru 11

The analysis of encasement pipe plate is documented on pages 12 thru 13

\section{REFERENCES:}

1. ASME Code B31.3-1993, Chemical Plant and Petroleum Refinery Piping.

2. Project W-320 Calculation no: W320-27-013, Rev-3 "Process Pipe Stress Analysis".

3. Project W-320 Calculation no: W320-27-014, Rev-2 "Encasement Pipe Stress Analysis".

4. Project W-320 Calculation no: W320-27-016, Rev-1 "C-Farm Jumper Stress Analysis".

5. Project W-320 Calculation no: W320-27-029, Rev-0 "Miscellaneous Jumper pipe Stress AnalysisAY Farm.

6. Roark and Young, Formulas for Stress and Strain. Fifth Edition.

$$
\begin{aligned}
& \text { 7. Project W-320 Drawings: H-2-818522 Rev-1 } \\
& \text { H-2-818523 Rev-1 } \\
& \mathrm{H}-2-818542 \text { Rev-2 } \\
& \text { H-2-818543 Rev-2 }
\end{aligned}
$$

\section{CONCLUSION:}

As evident from the succeeding analysis, the stresses in nozzle plate as well as encasement plate have met the requirements of ASME Code B31.3 for sustain, thermal and seismic loadings exerted by the piping system. 
FLUOR DANIEL
NORTHWEST INC.

Client: Numatec hanford Inc.

Subject: Project W-320, Waste Retrieval for Tank 241-C-106

Nozzle Plate \& Encasement Plate Analysis

Location: 241-AP
Calc no:W320-27-055

Rev no: 0

Page no:4 of 13

File name: W320U2

Date: 7-17-98

By: M. M. Ahmed ha

Chk'd:7/19/58 By: S. Fargo 5

Revised:
By:

\section{PIT WALL PIPING LOAD CONSOLIDATION SUMMARY}

\begin{tabular}{|c|c|c|c|c|c|c|c|c|}
\hline $\begin{array}{l}\text { NOZZLEILOCATION } \\
\text { PIPE ORIENTATION }\end{array}$ & $\begin{array}{l}\text { LOAD } \\
\text { CASES }\end{array}$ & $\begin{array}{l}\mathrm{Fx} \\
\mathrm{lb}\end{array}$ & $\begin{array}{l}\text { Fy } \\
\mathrm{Ib}\end{array}$ & $\begin{array}{l}\mathrm{Fz} \\
\mathrm{lb}\end{array}$ & $\begin{array}{l}M x \\
f t-l b\end{array}$ & $\begin{array}{l}\text { My } \\
\mathrm{ft}-\mathrm{lb}\end{array}$ & $\begin{array}{c}\mathrm{Mz} \\
\mathrm{ft}-\mathrm{Ib}\end{array}$ & $\begin{array}{l}\text { REF } \\
\text { CALC NO }\end{array}$ \\
\hline \multirow{6}{*}{$\begin{array}{l}\text { Nozzl-U2/241-AY-02E } \\
\text { Sluice Pit } \\
\text { AutoPipe Orientation }\end{array}$} & $\mathrm{GR}+\mathrm{P}+\mathrm{TH}$ & \multirow[t]{2}{*}{ LATERAL } & \multirow[t]{2}{*}{ VERTICA } & \multirow{2}{*}{$\overline{A X I A L}$} & \multirow[b]{2}{*}{-81} & \multirow[b]{2}{*}{2783} & \multirow[b]{2}{*}{387} & \multirow{6}{*}{$\begin{array}{l}\text { Ref:2 } \\
\text { Autopipe: } \\
\text { TRAN-SP } \\
\text { Node-A167 } \\
\text { Ref:5 } \\
\text { AutoPipe: } \\
\text { AY02E-R2 } \\
\text { Node-B12 }\end{array}$} \\
\hline & $\begin{array}{l}\text { Primary } \\
\text { Pipe } \\
\text { Jumper } \\
\text { Pipe }\end{array}$ & & & & & & & \\
\hline & \begin{tabular}{l|} 
Total \\
$\mathrm{GR}+\mathrm{P}+\mathrm{TH}$
\end{tabular} & -508 & 798 & 812 & 530 & 2720 & 384 & \\
\hline & Seismic & & & & & & & \\
\hline & $\begin{array}{l}\text { Primary } \\
\text { Pipe } \\
\text { Jumper } \\
\text { Pipe }\end{array}$ & 102 & 86 & 125 & 94 & 53 & 68 & \\
\hline & $\begin{array}{l}\text { Total } \\
\text { Seismic }\end{array}$ & 102 & 86 & 125 & 94 & 53 & 68 & \\
\hline \multirow{2}{*}{\multicolumn{8}{|c|}{$\begin{array}{l}\text { Encasement Pipe Loads: } \\
\text { Encasemnet pipe is subjected to soil frictional force along the pipe axis when pipe translates } \\
\text { due to thermal or seismic movements. These frictional forces are calculated by the product } \\
\text { of the length of straigth pipe run from pitwall to first bend and the friction force per unit length } \\
\text { obtained from Encasement pipe stress Analysis Calculation no:W320-27-014 Rev-2 (Ref:3) } \\
L=10 \text { feet }=120 \text { inches } \quad f(\text { thermal) }=23.18 \mathrm{lbs} / \text { inch } \quad f(\text { seismic) }=24.48 \mathrm{lbs} / \text { inch } \\
\mathrm{Fa} \text { (thermal) }=120 \times 23.18=2856 \mathrm{lbs} \\
\mathrm{Fa} \text { ( seismic) }=120 \times 24.48=2938 \mathrm{lbs}\end{array}$}} & \\
\hline & & & & & & & & Ref:3 \\
\hline
\end{tabular}


FLUOR DANIEL

NORTHWEST INC.

Client: Numatec hanford Inc.

Subject: Project W-320, Waste Retrieval for Tank 241-C-106

Transfer line \& Jumper pipe Connecting Plate Analysis

Location: 241-AP
Calc no:W320-27-055

Rev no: 0

Page no:5 of 13

File name: w320U6

Date: $7-17-98$

Chk'd: $7 / 19198$

Revised:
By: M. M. Ahmed a By: S. Fargo SAE 8y:

PIT WALL PIPING LOAD CONSOLIDATION SUMMARY

\begin{tabular}{|c|c|c|c|c|c|c|c|c|}
\hline $\begin{array}{l}\text { NOZZIE/LOCATION } \\
\text { PIPE ORIENTATION }\end{array}$ & $\begin{array}{l}\text { LOAD } \\
\text { CASES }\end{array}$ & $\overline{F x}$ & Fy & $\overline{F z}$ & $\overline{M x}$ & My & $\mathrm{Mz}$ & $\begin{array}{l}\text { REF } \\
\text { CALC NO }\end{array}$ \\
\hline \multirow{6}{*}{$\begin{array}{l}\text { Nozzle-U6/241-C-06C } \\
\text { Sluice Pit } \\
\text { AutoPipe orientation }\end{array}$} & $\mathrm{GR}+\mathrm{P}+\mathrm{TH}$ & $\overline{A X I A L}$ & VERTICA & LATERAL & & & & \multirow{6}{*}{$\begin{array}{l}\text { Ref:2 } \\
\text { Autopipe: } \\
\text { TRAN-SP } \\
\text { NOde-A00 } \\
\text { Ref:4 } \\
\text { AutoPipe: } \\
\text { MA-J6A } \\
\text { Node-A00 } \\
\\
\text { Ref:2 } \\
\text { Autopipe: } \\
\text { TRAN-SP } \\
\text { Ref:4 } \\
\text { AutoPipe: } \\
\text { MA-J6A }\end{array}$} \\
\hline & $\begin{array}{l}\text { Primary } \\
\text { Pipe } \\
\text { Jumper } \\
\text { Pipe }\end{array}$ & $\begin{array}{r}378 \\
-723\end{array}$ & $\begin{array}{l}-45 \\
205\end{array}$ & 2407 & 24 & $\begin{array}{l}-288 \\
-581\end{array}$ & $\begin{array}{c}36 \\
-82\end{array}$ & \\
\hline & $\begin{array}{l}\text { Total } \\
\mathrm{GR}+\mathrm{P}+\mathrm{TH}\end{array}$ & -345 & 160 & 2437 & -96 & -869 & -46 & \\
\hline & Seismic & & & & & & & \\
\hline & $\begin{array}{l}\text { Primary } \\
\text { Pipe } \\
\text { Jumper } \\
\text { Pipe }\end{array}$ & 264 & 0 & 207 & 0 & $\begin{array}{r}452 \\
6\end{array}$ & & \\
\hline & $\begin{array}{l}\text { Total } \\
\text { Seismic }\end{array}$ & 276 & 1 & 6 & 5 & 6 & 2 & \\
\hline \multirow{2}{*}{\multicolumn{8}{|c|}{$\begin{array}{l}\text { Encasement Pipe Loads: } \\
\text { Encasemnet pipe is subjected to soil frictional force along the pipe axis when pipe translates } \\
\text { due to thermal or seismic movements. These frictional forces are calculated by the product } \\
\text { of the length of straigth pipe run from pitwall to first bend and the friction force per unit length } \\
\text { obtained from Encasement pipe stress Analysis Calculation no:W320-27-014 Rev-2 (Ref:3) } \\
L=16.8 \text { feet }=201.6 \text { inches } \quad f(\text { thermal) }=23.18 \mathrm{lbs} / \mathrm{inch} \quad \mathrm{f}(\text { seismic) }=24.48 \mathrm{lbs} / \text { inch } \\
\text { Fa (thermal) }=201.6 \times 23.18=4673 \mathrm{lbs} \\
\text { Fa ( seismic) }=201.6 \times 24.48=4935 \mathrm{lbs}\end{array}$}} & \\
\hline & & & & & & & & Ref:3 \\
\hline
\end{tabular}




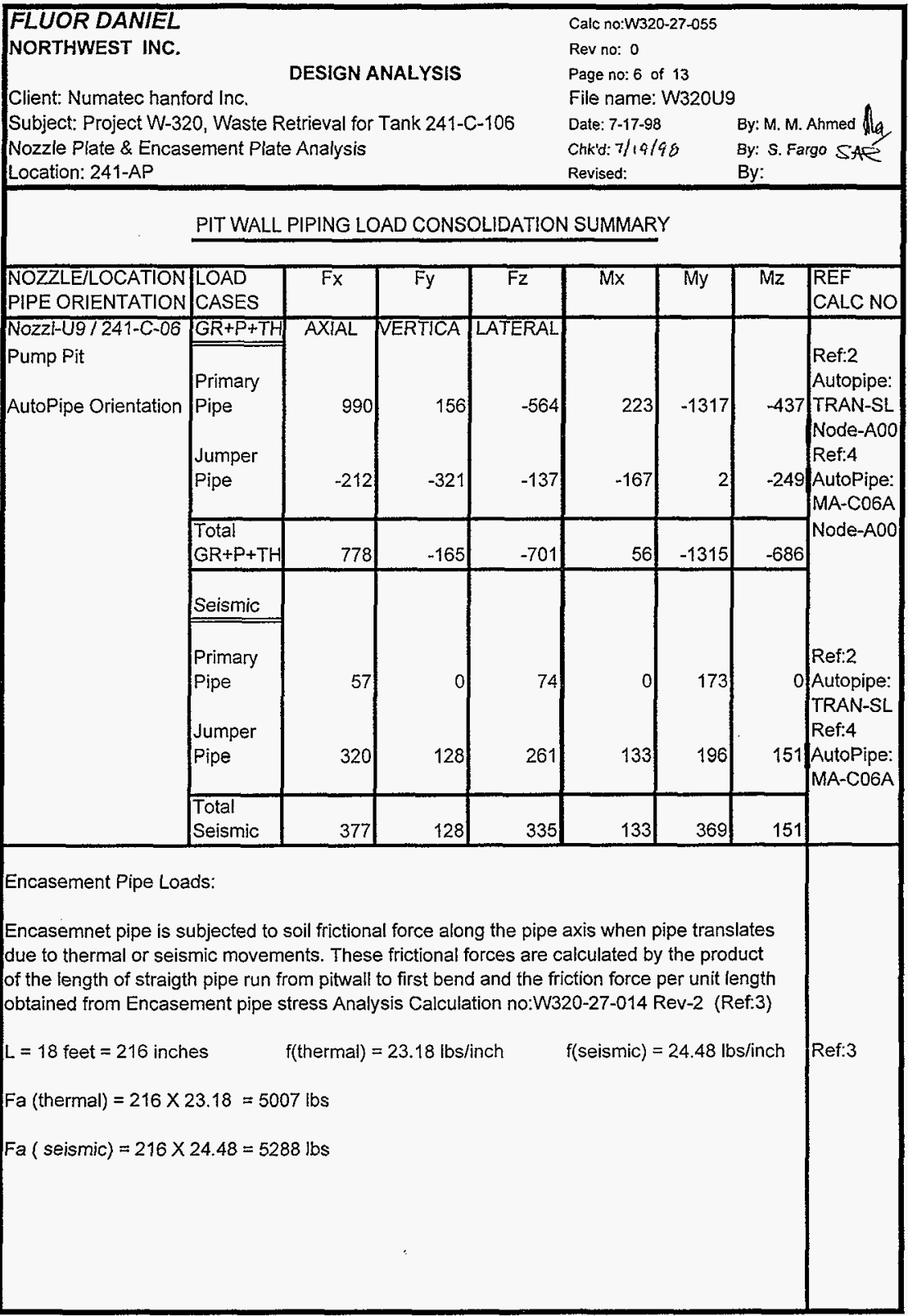


FLUOR DANIEL NORTHWEST INC.

\section{DESIGN ANALYSIS}

Client: Numatec hanford inc.

Subject: Project W-320, Waste Retrieval for Tank 241-C-106

Transfer line \& Jumper pipe Connecting Plate Analysis

Location: 241-AP
Calc no:W320-27-055

Rev no: 0

Page no: 7 of 13

File name: U11

Date: 7-17-98

Chk'd: 7/19/48

Revised:
By: M. M. Ahmed By: S. Fargo sAP By:

\section{PIT WALL PIPING LOAD CONSOLIDATION SUMMARY}

\begin{tabular}{|c|c|c|c|c|c|c|c|c|}
\hline $\begin{array}{l}\text { NOZZLE/LOCATION } \\
\text { PIPE ORIENTATION }\end{array}$ & $\begin{array}{l}\text { LOAD } \\
\text { CASES }\end{array}$ & $F x$ & Fy & $\overline{F z}$ & $\overline{M x}$ & My & $\overline{M z}$ & $\begin{array}{l}\text { REF } \\
\text { CALC NO }\end{array}$ \\
\hline \multirow{6}{*}{$\begin{array}{l}\text { Nozzl-U11/241-AY-02A } \\
\text { PUMP PIT } \\
\text { Autopipe Orientation }\end{array}$} & $\mathrm{GR}+\mathrm{P}+\mathrm{TH}$ & $\overline{A X \mid A L}$ & VERTICA & LATERAL & & & & \multirow{6}{*}{$\begin{array}{l}\text { Ref:2 } \\
\text { Autopipe: } \\
\text { TRAN-SL } \\
\text { Node-A171 } \\
\text { Ref:5 } \\
\text { AutoPipe: } \\
\text { AY02A1R2 } \\
\text { Node-A00 } \\
\\
\\
\text { Ref:2 } \\
\text { Autopipe: } \\
\text { TRAN-SL } \\
\text { Ref:4 } \\
\text { AutoPipe: } \\
\text { AY02A2R2 } \\
\text { Node-A00 } \\
\end{array}$} \\
\hline & $\begin{array}{l}\text { Primary } \\
\text { Pipe } \\
\text { Jumper } \\
\text { Pipe }\end{array}$ & -530 & $\begin{array}{r}-78 \\
-390\end{array}$ & 305 & 35 & -1060 & -112 & \\
\hline & $\begin{array}{l}\text { Total } \\
\mathrm{GR}+\mathrm{P}+\mathrm{TH}\end{array}$ & -478 & -468 & 242 & 26 & -1040 & 71 & \\
\hline & Seismic & & & & & & & \\
\hline & $\begin{array}{l}\text { Primary } \\
\text { Pipe } \\
\text { Jumper } \\
\text { Pipe }\end{array}$ & 90 & 102 & 205 & 27 & 200 & 209 & \\
\hline & $\begin{array}{l}\text { Total } \\
\text { Seismic }\end{array}$ & 90 & 102 & 205 & 27 & 206 & 209 & \\
\hline
\end{tabular}

Encasement Pipe Loads:

Encasemnet pipe is subjected to soil frictional force along the pipe axis when pipe translates due to thermal or seismic movements. These frictional forces are calculated by the product of the length of straigth pipe run from pitwall to first bend and the friction force per unit length obtained from Encasement pipe stress Analysis Calculation no:W320-27-014 Rev-2 (Ref:3)

$$
\begin{aligned}
& \mathrm{L}=11.5 \text { feet }=138 \text { inches } \quad \mathrm{f}(\text { thermal })=23.18 \mathrm{lbs} / \mathrm{inch} \quad \mathrm{f}(\text { seismic })=24.48 \mathrm{lbs} / \mathrm{inch} \\
& \mathrm{Fa} \text { (thermal) }=138 \times 23.18=3199 \mathrm{lbs} \\
& \mathrm{Fa} \text { ( seismic) }=138 \times 24.48=3378 \mathrm{lbs}
\end{aligned}
$$


FLUOR DANIEL

NORTHWEST
DESIGN ANALYSIS
Calc. No. W320-27-055

Revision 0

Page No. 8 of 13

Client:_Numatec Hanford Inc Wo/Job No. W-320

Subject: Project W-320 Waste Retrieval for Tank 241-C-Date: July 17, 1998 Nozzle Plate \& Encasement Plate Analysis

Location: 200W

Checked: I/ia/68

Revised:
File: $W 320 \cup 2$

By: M.M. Ahmed

By: S. Fargo Sor

By:

\section{NOZZLEE KICK OFF PLATE ANALYSIS:}

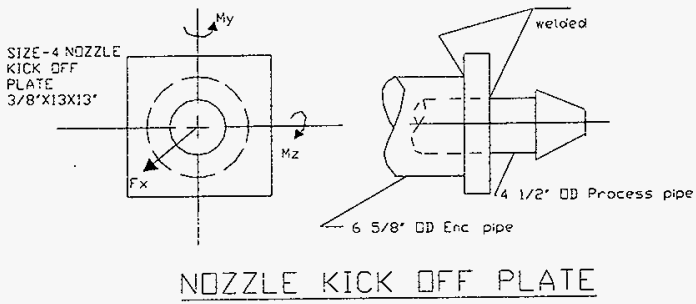

$$
\begin{aligned}
& a \equiv \frac{6.625}{2} \cdot \text { in } \quad a=3.313 \cdot \text { in } \\
& \mathrm{b}=\frac{4.5}{2} \cdot \text { in } \quad \mathrm{b}=2.25 \cdot \text { in } \\
& \frac{\mathrm{b}}{\mathrm{a}}=0.679 \\
& t=0.375 \cdot \mathrm{in}
\end{aligned}
$$

\section{Load Case-1: (Sustained+Thermal)}

As evident from preceeding pages, the Nozzle-U2 located in the 241-AY-02E Sluice Pit is subjected to highest $G R+P+T H$ loads compared to other nozzles. As such following analysis considers Nozzle-U2 loads.

AXIAL LOADING Table-24, Case-1f (Ref:6)

Annular plate with a concentrated load applied @ center, outer edge (Enc.pipe) $\mathrm{F}_{\mathrm{X}}=812 \cdot \mathrm{lb}$ fixed and inner edge (Process Pipe) guided.

$$
\mathrm{K}_{\mathrm{mrb}} \equiv 0.147 \quad \text { Prorating for } \mathrm{b} / \mathrm{a}=0.68
$$

$\mathrm{W}=\frac{\mathrm{F} X}{2 \cdot \pi \cdot \mathrm{b}} \quad \mathrm{W}=57.437 \cdot \frac{\mathrm{lb}}{\mathrm{in}} \quad \mathrm{M}=\mathrm{K}_{\mathrm{mrb}} \cdot \mathrm{W} \cdot \mathrm{a} \quad \mathrm{M}=27.968 \cdot \mathrm{lb}$

$\sigma_{\text {axial }}=\frac{6 \cdot M}{t^{2}} \quad \sigma_{\text {axial }}=1193.316 \cdot \frac{\mathrm{lb}}{\mathrm{in}^{2}}$ 
FLUOR DANIEL

NORTHWEST
Calc. No. W320-27-055

Revision 0

Page No. 9 of 13

Client: Numatec Hanford inc

DESIGN ANALYSIS

Wo/Job No. W-320

Subject: Project W-320 Waste Retrieval for Tank 241-C-Date: July 17, 1998 Nozzle Plate \& Encasement Plate Analysis

Location: $200 \mathrm{~W}$

Checked: $\underline{7} / 21 / G \varepsilon_{2}$

Revised:
File: W320U2

By: M.M. Ahmed ha

By: S. Fargo SAP

By:

\section{PRESSURE LOADING:}

Table-24, Case-2f (Ref:6): Annular plate subjected to internal design pressure of 325 psi, end conditions being same as above.

$\mathrm{q} \equiv 325 \cdot \frac{\mathrm{lb}}{\mathrm{in}^{2}} \quad \mathrm{~K}_{\mathrm{mrb}} \equiv 0.0175 \quad \mathrm{M} \equiv \mathrm{K}_{\mathrm{mrb}} \cdot \mathrm{q} \cdot \mathrm{a}^{2} \quad \mathrm{M}=62.407 \cdot \mathrm{lb}$

$\sigma_{\text {pressure }}=\frac{6 \cdot \mathrm{M}}{t^{2}} \quad \sigma_{\text {pressure }}=2662.698 \cdot \frac{\mathrm{lb}}{\mathrm{in}^{2}}$

MOMENT LOADING:

Table-24, Case-21 (Ret:6) Central couple on a plate with a fixed edge (trunnion loading)

$M_{y} \equiv 2720 \cdot f \cdot \cdot 16 \quad M_{z} \equiv 384 \cdot f \cdot-16$

$M_{r}=\left(M_{y}^{2}+M_{z}^{2}\right)^{0.5} \quad M_{r}=32963.666 \cdot \mathrm{in} \cdot 1 \mathrm{~b}$

$\beta=0.523 \quad \alpha \equiv 0.02 \quad$ prorating for $b / a=0.68$

$\sigma_{\text {moment }}=\frac{\beta \cdot M_{\mathrm{r}}}{\mathrm{t}^{2} \cdot \mathrm{a}} \quad \sigma_{\text {moment }}=37009.973 \cdot \frac{\mathrm{lb}}{\mathrm{in}^{2}}$

TOTAL PLATE STRESS DUE TO SUSTAINED \& THERMAL LOADS:

$\sigma_{\text {total }}=\sigma_{\text {axial }}+\sigma_{\text {pressure }}+\sigma_{\text {moment }}$

$\sigma_{\text {total }}=40865.987 \cdot \frac{\mathrm{lb}}{\mathrm{in}^{2}}$ 
FLUOR DANIEL

NORTHWEST
Calc. No. W320-27-055

Revision 0

Page No. 10 of 13

Client: Numatec Hanford inc

DESIGN ANALYSIS

WO/Job No. W-320

Subject: Project W-320 Waste Retrieval for Tank 241-C-Date: July 17, 1998

Nozzle Plate \& Encasement Plate Analysis

Location: 200W

Checked: $1 / 2,155$

Revised:

File: W320U2

By: M.M. Ahmed ha,

By: S. Fargo SAP

By:

Allowable Stresses per ASME Code B31.3(Ref:1): $\quad f=1 \quad S_{h}=20000 \cdot \frac{\mathrm{Ib}}{\mathrm{in}^{2}} \quad \mathrm{~S}_{\mathrm{C}} \equiv 20000 \cdot \frac{\mathrm{Jb}}{\mathrm{in}^{2}}$

For Sustained loads(GR+P) "SI": $\quad \mathrm{S}_{\mathrm{L}} \equiv \mathrm{S}_{\mathrm{h}} \quad$ Para 302.3.5(c)

For Thermal loads: $\quad \mathrm{S}_{\mathrm{a}} \equiv \mathrm{f} \cdot\left(1.25 \cdot \mathrm{S}_{\mathrm{c}}+0.25 \cdot \mathrm{s}_{\mathrm{h}}\right) \quad$ Eqn: (1a) $\quad \mathrm{S}_{\mathrm{a}}=30000 \cdot \frac{\mathrm{lb}}{\mathrm{in}^{2}}$

Allowable Stress for $\mathrm{GR}+\mathrm{P}+\mathrm{TH}$ loads:

$$
\mathrm{S}_{\mathrm{L}}+\mathrm{S}_{\mathrm{a}}=50000 \cdot \frac{\mathrm{lb}}{\mathrm{in}^{2}}>\sigma_{\text {total }}=40865.987 \cdot \frac{\mathrm{lb}}{\mathrm{in}^{2}}
$$

\section{SEISMIC LOAD CASE:}

Seismic loads at nozzle U- 9 are critical

$F_{x}=377 \cdot 16$

$M_{y} \equiv 369 \cdot f t \cdot 1 b$

$\mathrm{M}_{\mathrm{z}}=151 \cdot \mathrm{ft} \cdot \mathrm{lb}$

$M_{r}=\left(M_{y}{ }^{2}+M_{z}\right)^{0.5}$

$M_{r}=4784.405 \cdot \mathrm{in} \cdot 16$ 
FLUOR DANIEL

NORTHWEST
DESIGN ANALYSIS
Calc. No. W320-27-055

Revision 0

Page No. 11 of 13

Client: Numatec Hanford Inc

Wo/Job No. W-320

Subject: Project W-320 Waste Retrieval for Tank 241-C-Date: July 17,1998

Nozzle Plate \& Encasement Plate Analysis

Location: 200W

Checked: $7 / 2, / 98$

Revised:

File: W320U2

By: M.M. Ahmed

By: S. Fargo SAR

By:

Annular plate with a concentrated load applied @ center, outer edge (Enc.pipe)

AXIAL LOADING fixed and inner edge (Process Pipe) guided.

Table-24, Case-1f (Ref:6)

$$
\mathrm{K}_{\mathrm{mrb}}=0.147 \quad \text { Prorating for } \mathrm{b} / \mathrm{a}=0.68
$$

$\mathrm{w} \equiv \frac{\mathrm{F}_{\mathrm{x}}}{2 \cdot \pi \cdot \mathrm{b}} \quad \mathrm{w}=26.667 \cdot \frac{\mathrm{lb}}{\mathrm{in}} \quad \mathrm{M}=\mathrm{K}_{\mathrm{mrb}} \cdot \mathrm{w} \cdot \mathrm{a} \quad \mathrm{M}=12.985 \cdot \mathrm{lb}$

$\sigma_{\text {axial }}=\frac{6 \cdot \mathrm{M}}{t^{2}} \quad \sigma_{\text {axial }}=554.04 \cdot \frac{\mathrm{lb}}{\mathrm{in}^{2}}$

\section{MOMENT LOADING:}

Table-24, Case-21 (Ref:6)

Central couple on a plate with a fixed edge (trunnion loading)

$\beta=0.523$

$\alpha \mathbf{0} 0.02$

prorating for $b / a=0.68$

$\sigma_{\text {moment }}=\frac{\beta \cdot M_{r}}{t^{2} \cdot a}$

$\sigma_{\text {moment }}=5371.693 \cdot \frac{\mathrm{lb}}{\mathrm{in}^{2}}$

Total Plate seismic stress:

$\sigma_{\text {seismic }}=\sigma_{\text {axial }}+\sigma_{\text {moment }}$

$\sigma_{\text {seismic }}=5925.733 \cdot \frac{\mathrm{lb}}{\mathrm{in}^{2}}$

$$
\mathrm{S}_{\text {occ }}=1.33 \cdot \mathrm{S}_{\mathbf{h}}
$$$$
S_{o c c}=26600 \cdot \frac{\mathrm{lb}}{\mathrm{in}^{2}}
$$

Ref:1 
FLUOR DANIEL

NORTHWEST
DESIGN ANALYSIS
Calc. No. W320-27-055

Revision 0

Page No. 12 of 13

Client: _Numatec Hanford Inc

Wo/Job No. W-320

Subject: Project W-320 Waste Retrieval for Tank 241-C-Date: July 17, 1998 Nozzle Plate \& Encasement Plate Analysis

Location: 200W
Checked: $2 / 21 / 48$

Revised:
File: W320U2

By: M.M. Ahmed la

By: S. Fargo S

By:

\section{ENCASEMENT PLATE ANALYSIS:}

Table-26, Case-1a: Rectangular plate simply supported on all four edges and load applied uniformly.

Critical encasement pipe load is at Nozzle-U9:

$\mathrm{F}_{\text {thermal }}=5007 \cdot \mathrm{lb}$

$\mathrm{F}_{\text {seismic }}=5288 \cdot \mathrm{lb}$

6 5/8*CD ENC. PIPE
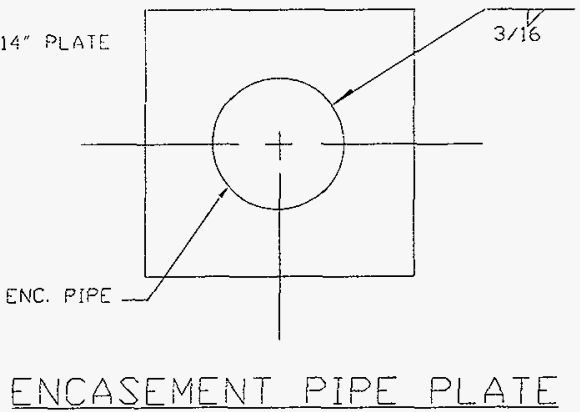
$a \equiv 14 \cdot$ in
$t=0.375 \cdot$ in
$b=14 \cdot$ in
$\frac{\mathrm{a}}{\mathrm{b}}=1$
$\beta=0.2874$ 
FLUOR DANIEL

NORTHWEST

\section{DESIGN ANALYSIS}

Calc. No. W320-27-055

Revision 0

Page No. 13 of 13

Client: Numatec Hanford Inc

WO/Jab No. W-320

Subject: Project W-320 Waste Retrieval for Tank 241.C-Date: July 17,1998 Nozzle Plate \& Encasement Plate Analysis

Location: 200W
Checked: $7 / 2+198$

Revised:
File: W320U2

By: M.M. Ahmed la

By: S. Fargo SAE

By:
$\mathrm{q}_{\mathrm{t}}=\frac{\mathrm{F}_{\text {thermal }}}{\mathrm{a} \cdot \mathrm{b}}$

$\mathrm{q}_{\mathrm{s}}=\frac{\mathrm{F} \text { seismic }}{\mathrm{a} \cdot \mathrm{b}}$

Thermal Stress:

$\sigma_{t}=\frac{\beta \cdot q_{t} \cdot b^{2}}{t^{2}}$

$$
\sigma_{t}=10232.973 \cdot \frac{\mathrm{lb}}{\mathrm{in}^{2}}
$$

$$
\mathrm{q}_{\mathrm{t}}=25.546 \cdot \frac{\mathrm{lb}}{\mathrm{in}^{2}}
$$

$q_{s}=26.98 \cdot \frac{\mathrm{lb}}{\mathrm{in}^{2}}$

Seismic Stress:

$$
\begin{aligned}
& \sigma_{\mathrm{s}} \equiv \frac{\beta \cdot q_{\mathrm{s}} \cdot \mathrm{b}^{2}}{\mathrm{t}^{2}} \\
& \sigma_{\mathrm{s}}=10807.262 \cdot \frac{\mathrm{lb}}{\mathrm{in}^{2}} \quad<\quad \mathrm{S}_{\text {occ }}=26600 \cdot \frac{\mathrm{lb}}{\mathrm{in}^{2}}
\end{aligned}
$$




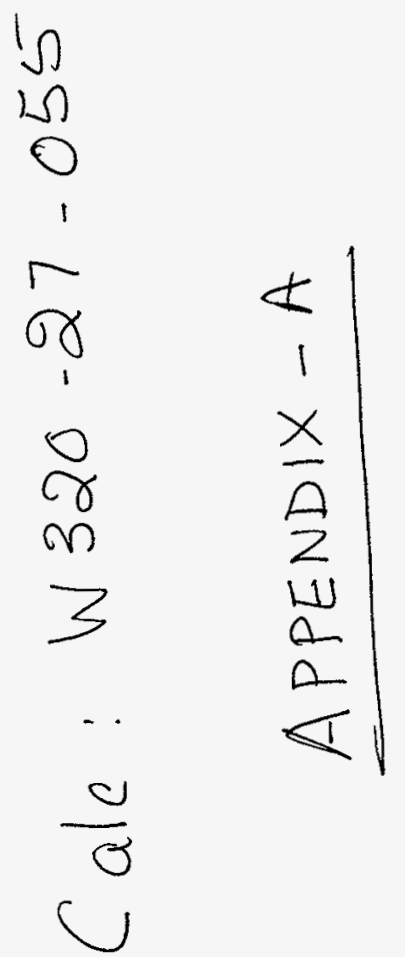

HNF-2479, Rev. 0

Page F-17 
TRAN-SP PROJECT U-320 09705/96 SUPERMATE LINE PROCESS PIPE REV. 2 AUtOPIPE+4.60 RESULT PAGE 109

SUPPORT FORCES

Point/ Connect/ Load

\section{LOCA L}

Supp. ID Type Combination Dirn Force Deform

\begin{tabular}{|c|c|c|c|c|c|c|}
\hline RESP & back & . & 0.000 & $\begin{array}{l}X \\
y \\
Z\end{array}$ & & $\begin{array}{l}0.000 \\
0.000 \\
0.000\end{array}$ \\
\hline TOTAL & back & 79 & 0.000 & $\begin{array}{l}x \\
y \\
z\end{array}$ & 79 & $\begin{array}{l}0.240 \\
0.000 \\
0.096\end{array}$ \\
\hline
\end{tabular}

TRAN-SP PROJECT $4-320$ ES-330-M3, $44, M 5, M 6$ ICF Kai

ICF Kaiser Hanford Company

RESTRAINT. REACTIONS

Point Load FORCES (lb ) MOMENTS ( $\mathrm{ft}-l \mathrm{~b}$ )

name combination $X \quad Y \quad Z$ Result $X \quad Y \quad z$ Result

A00 Anchor

$N O Z-G \quad$ GR

NOE- 6 P1

C-OGC RESP

Sluice Put TOTA

Guide

GR

T1
P1
SUM
RESP

TOTAL.

$\mathrm{A} 02$

Incl ined

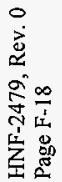

$$
\text { Tid }
$$

SU,

RESP

TOTAL.

R04

Inclined

GR

P1

RESP

IOTAL

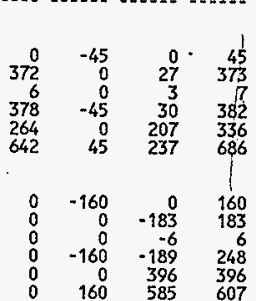

Y.....................

Guide

GR

T1

SUM

RESP

TOTAL

$\begin{array}{rrrr}24 & 0 & 36 & 443 \\ 0 & -294 & 0 & 294 \\ 0 & 6 & 0 & 16 \\ 24 & -288 & 36 & 291 \\ 0 & 452 & 0 & 452 \\ 24 & 740 & 36 & 741\end{array}$

$$
\begin{array}{rrrr}
0 & -69 & 0 & 69 \\
0 & 0 & 0 & 0 \\
0 & 0 & 0 & 0 \\
0 & -69 & 0 & 69 \\
0 & 0 & 0 & 0 \\
0 & 69 & 0 & 69
\end{array}
$$

$$
\begin{aligned}
& 0 \\
& 0 \\
& 0 \\
& 0 \\
& 0 \\
& 0
\end{aligned}
$$




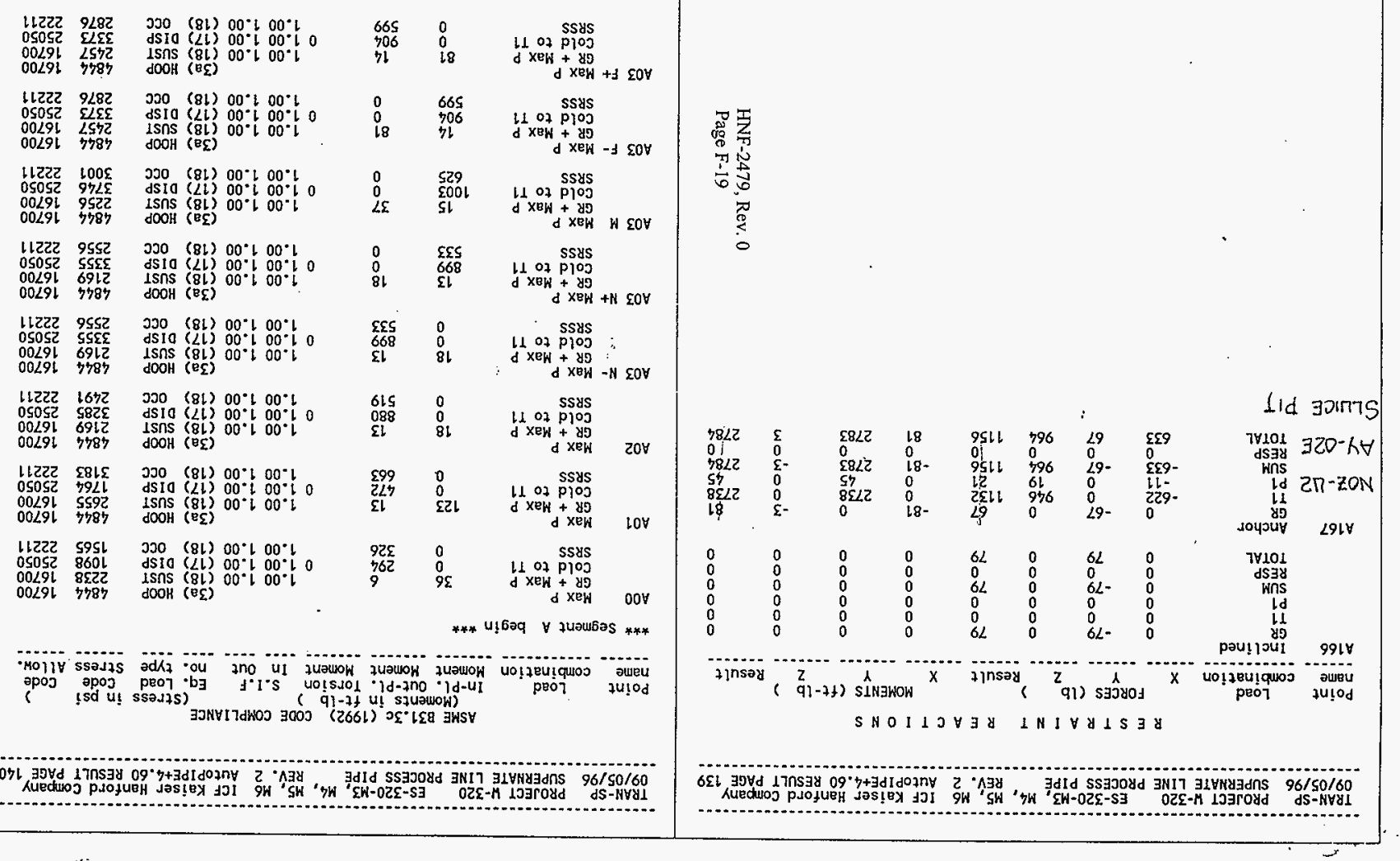




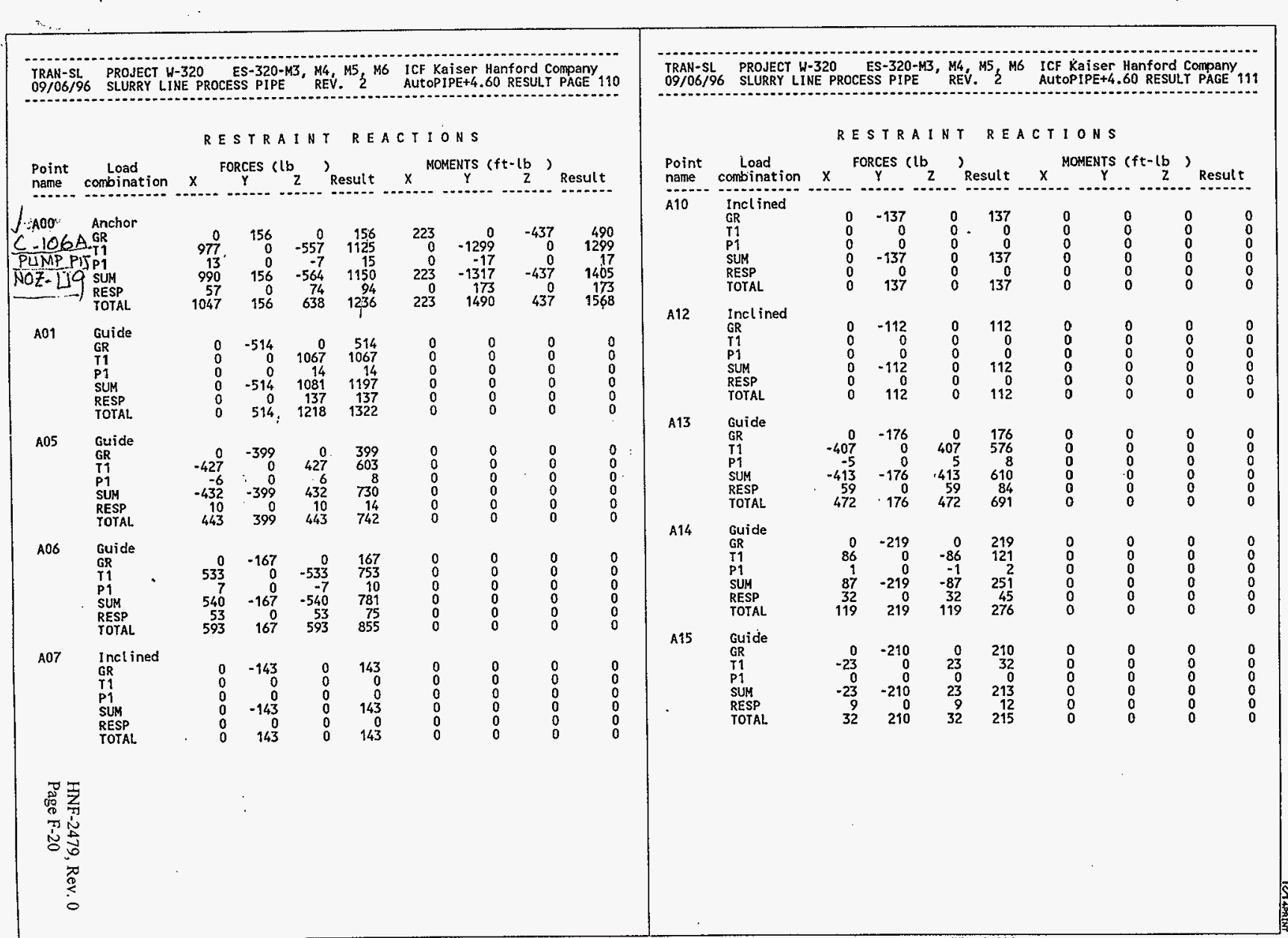




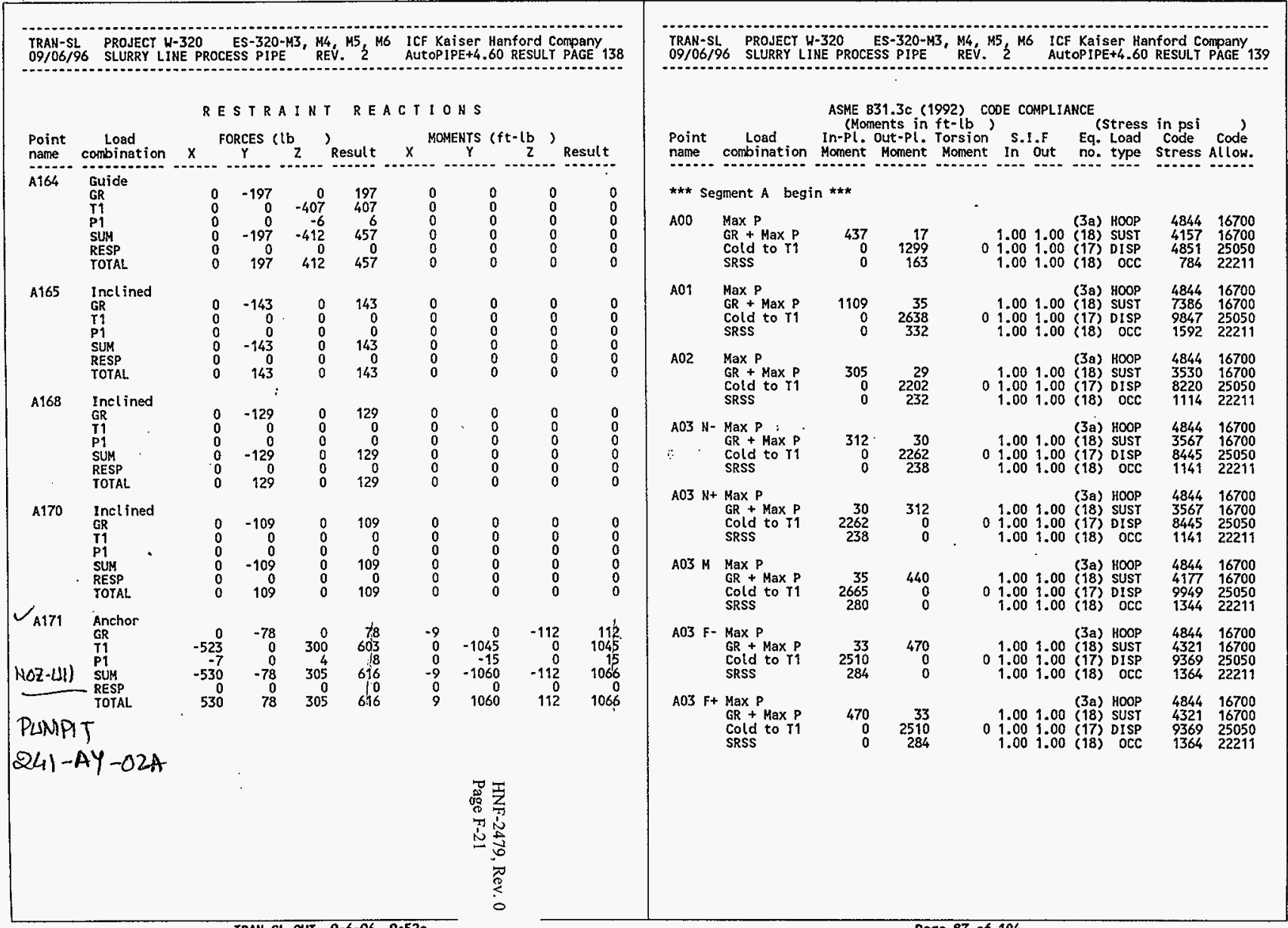




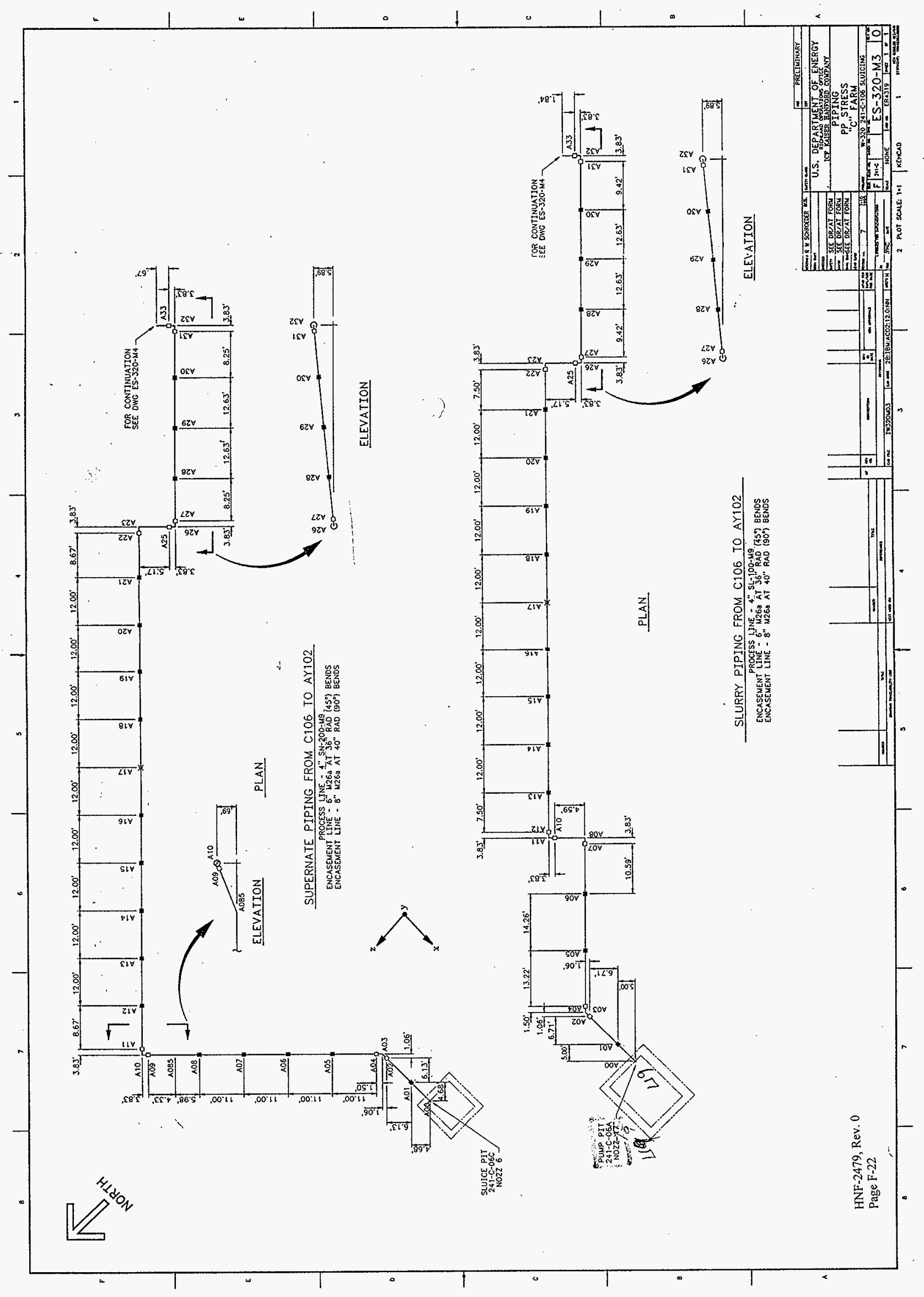




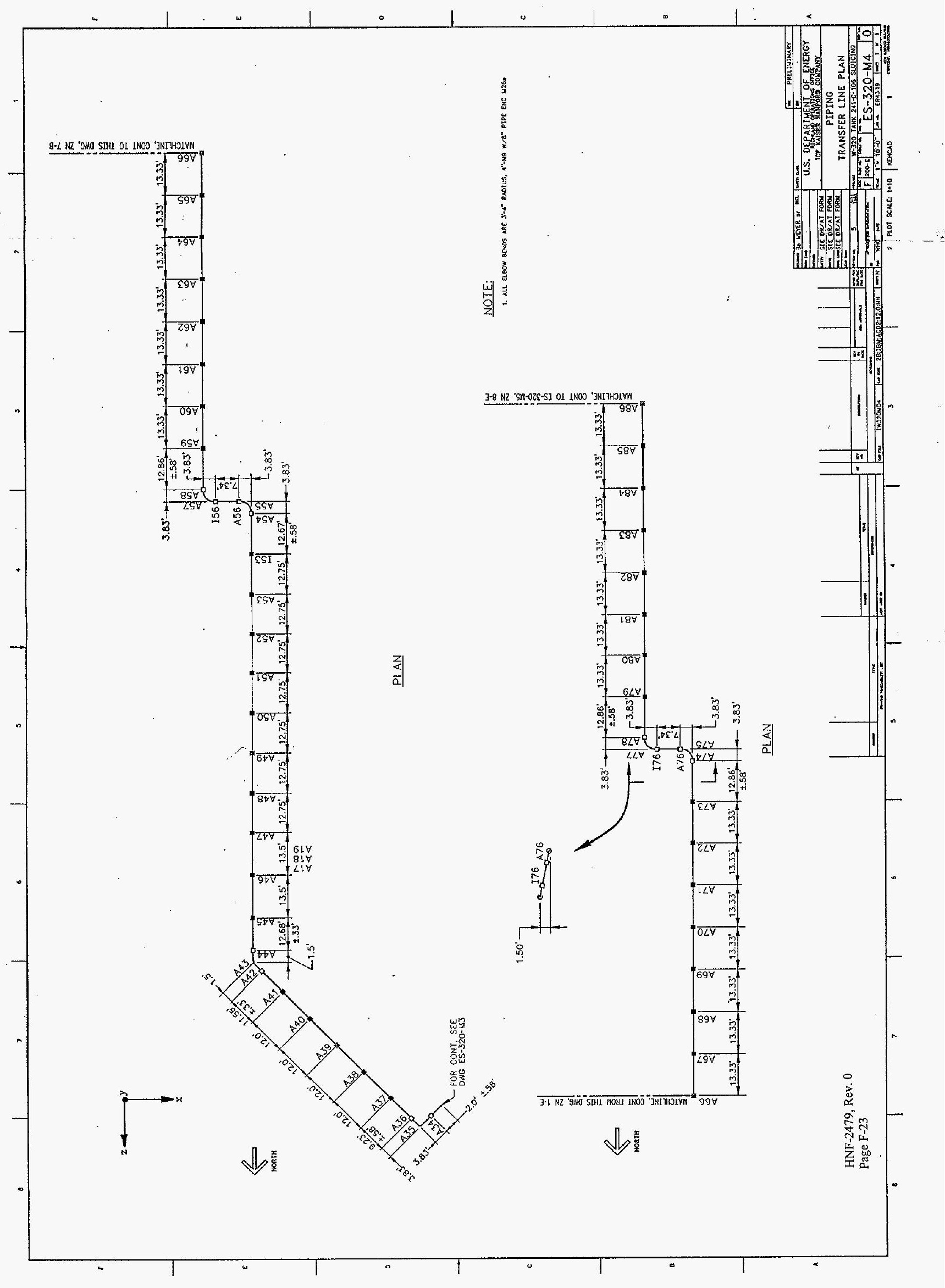




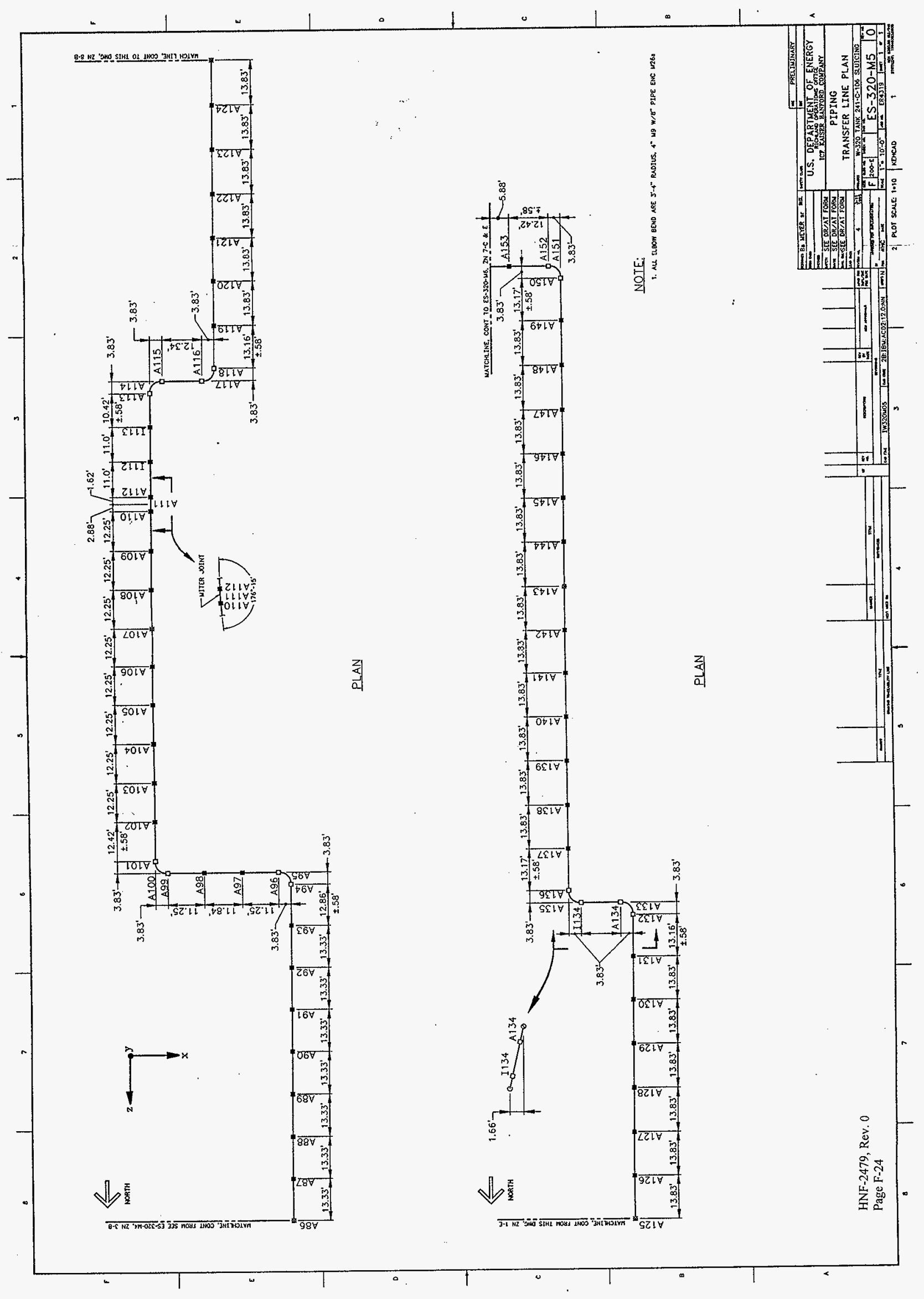




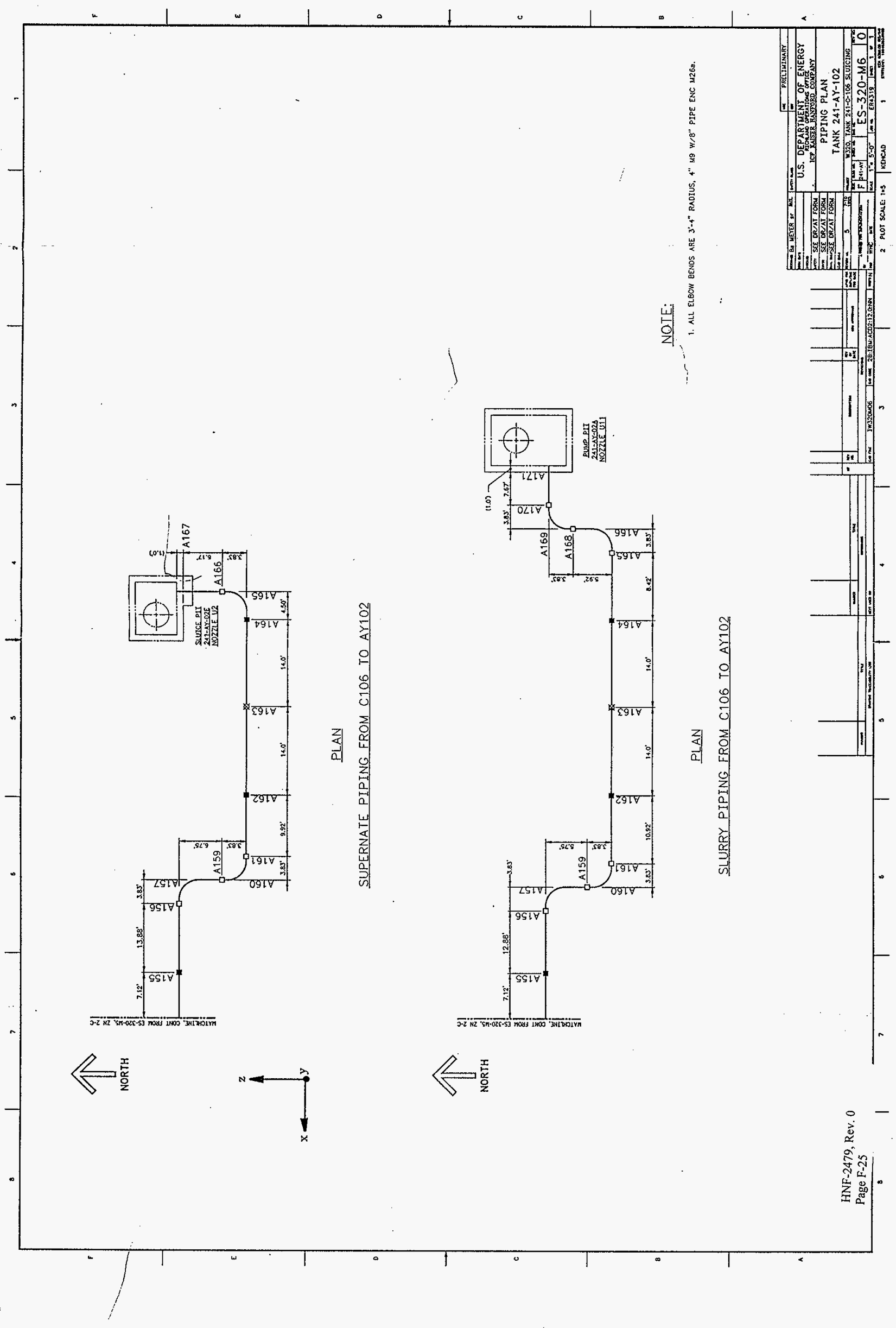


ICF KAISER

HANFORD COMPANY

\section{DESIGN ANALYSIS}

Client WESTINGHOUSE HANFORD COMPANY

SUbject AYY FARM- JUMPER STRESS ANALYSIS

PROJECT W-320 WASTE RETRIEVAL FOR TANK C-106

Location C TANK FARM - 200W.
WO/Job No.ER4319

Date $8 / 31 / 95$

Checked $9 / 11 / 95$

Revised
Calo No. W320-27-029

Revision No. 03

Page No. 10 of 10

Filename:AYO2E.WP

By: M. M. Ahmed

By: M. K. Pal

By:

Rev 3 By: K. Hayase $11 / 26 / 97$

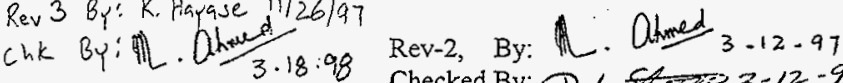

Checked By: D. L. Stowe 3-12-97

PROJECT W-320: JUMPER ASSY FOR SLUICE PIT

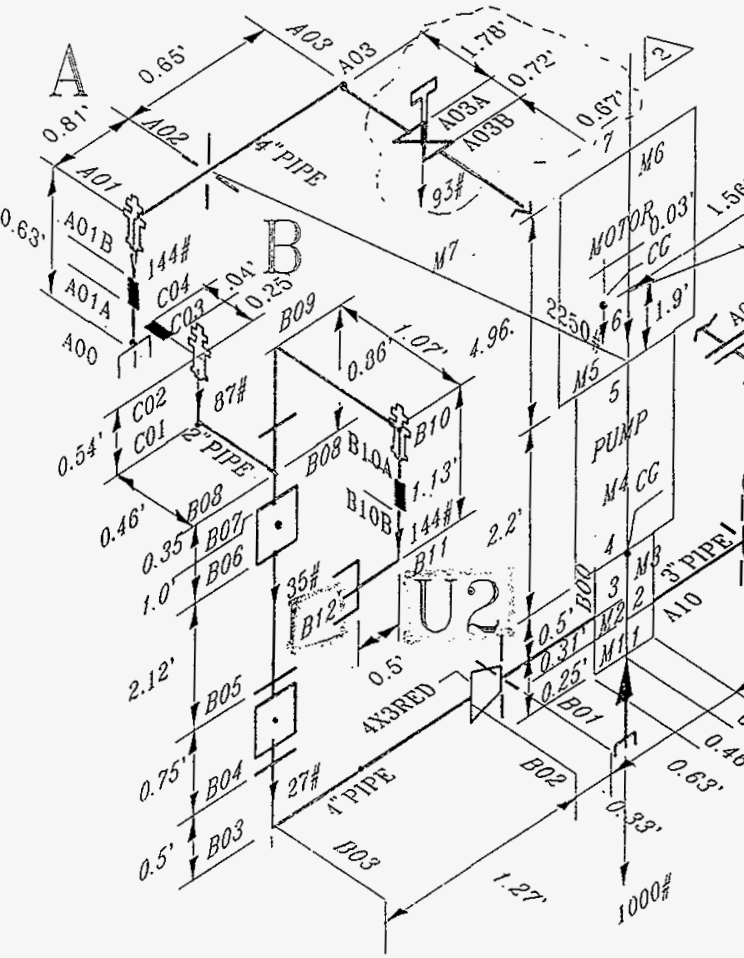

PREPARED BY: M. M. AHMED

CHECKED BY: D. L. STONE

REF: ECN $W-320-380$

ECN W-320-587

DWG: B503AR2 REV-2

AUTOCAD: AYO2E

AUTOPIPE: AYO2E-R2

Valve at A03A should be closes to AO4, however, the overall length between $A 03+A 07$ is correct, thesefore of as is.

HNF-2479, Rev. 0
Page F-26 should be $271 \%$, thelefore ok as is. 


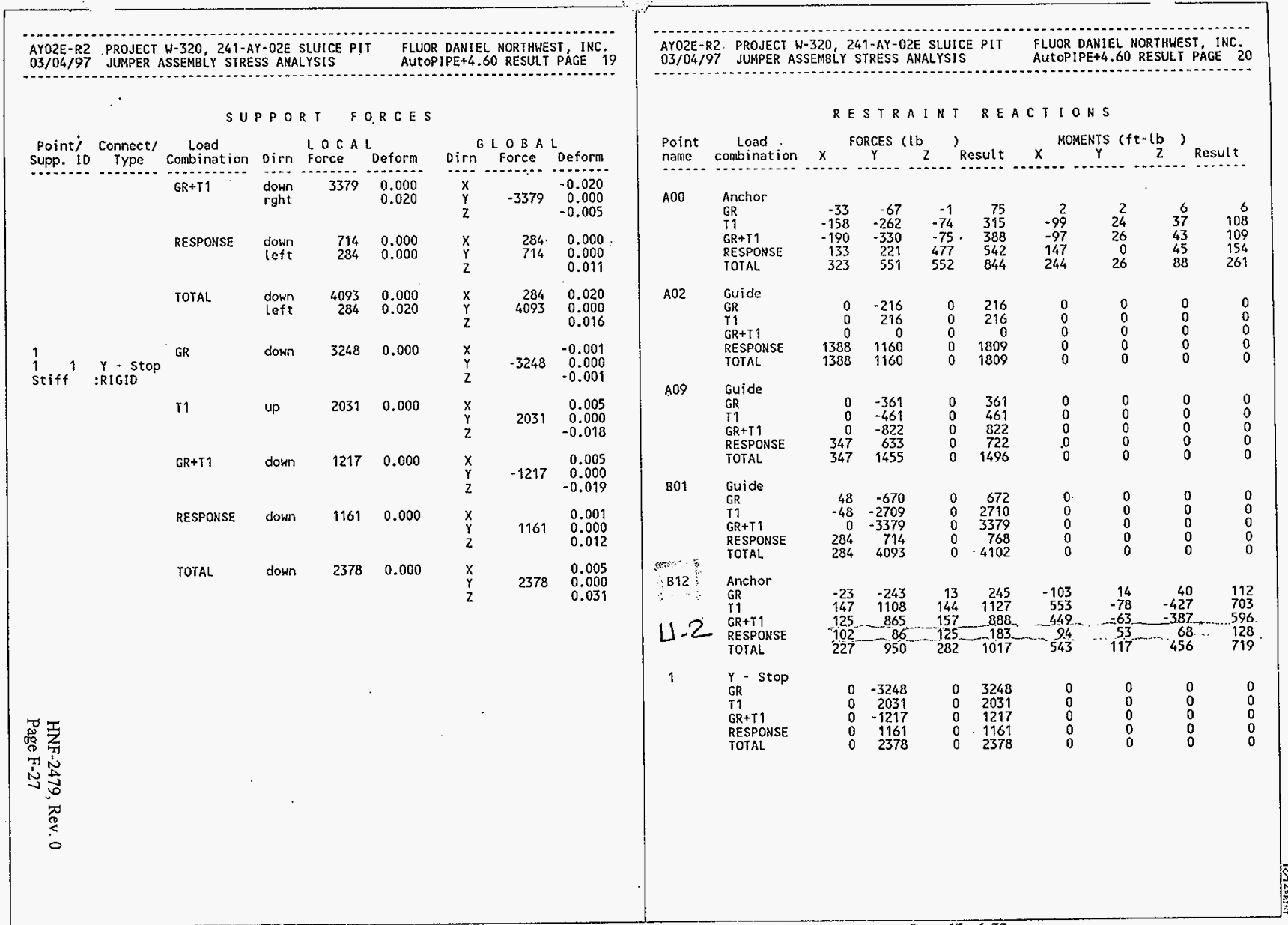




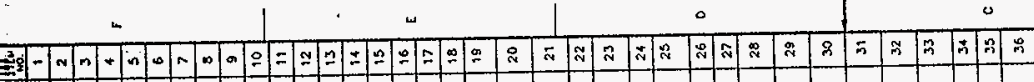

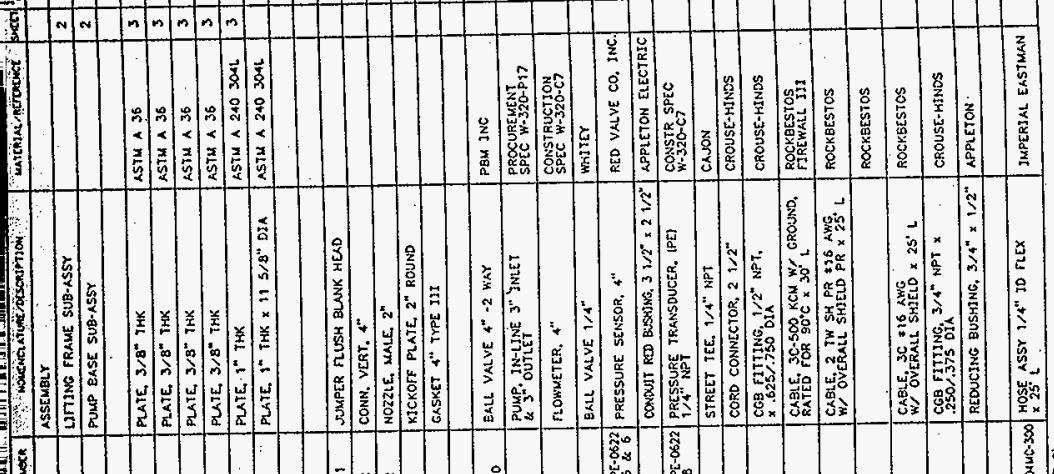
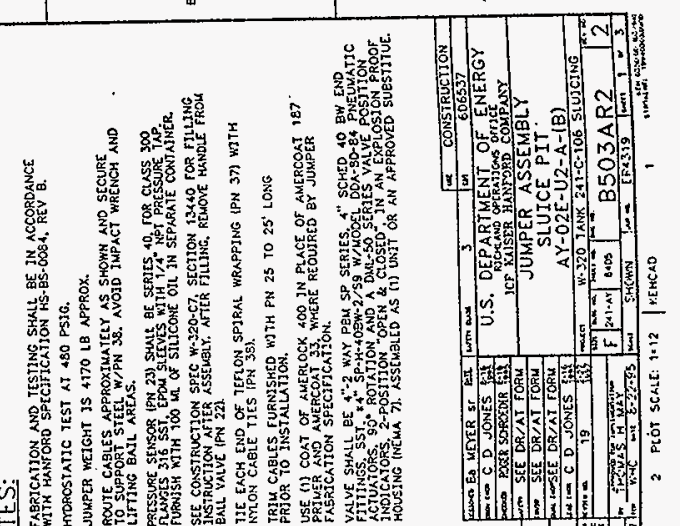

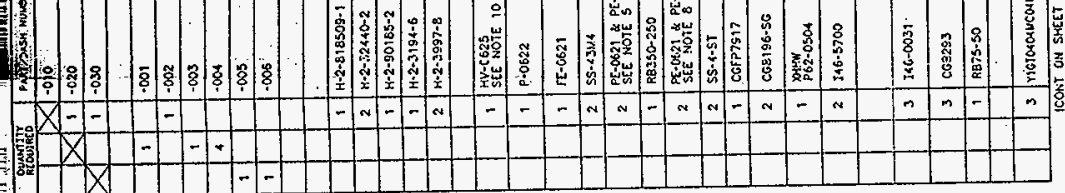

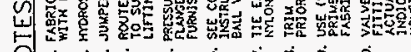
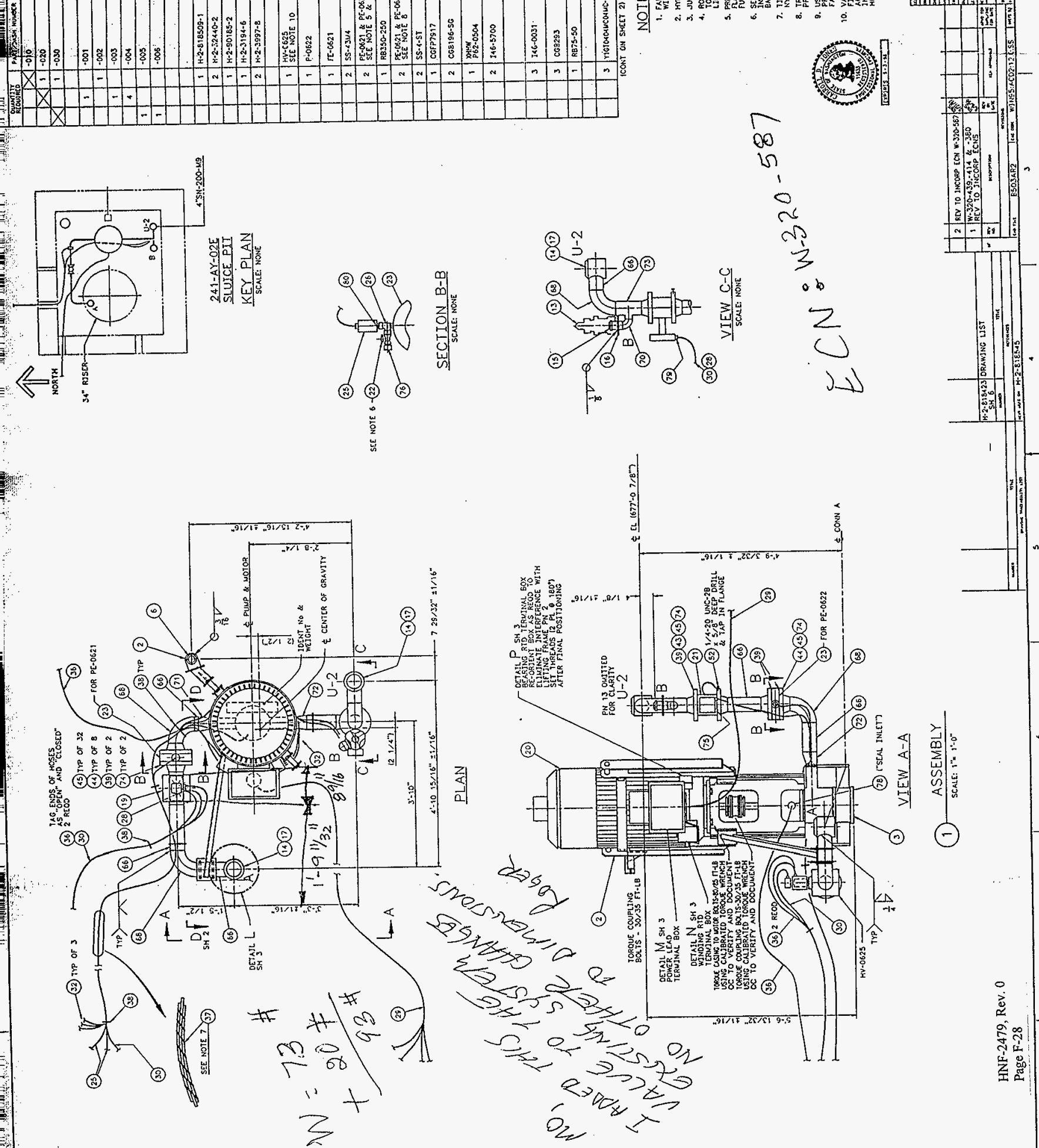


MA-J6A W320- C-FARM JUMPER STRESS ANALYSIS ICF KAISER HANFORD COMPAHY
$09 / 11 / 95$
JUMPER C-06C-6-A

\section{SUPPORT FORCES}

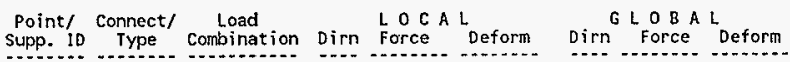

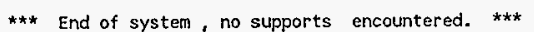

\section{MA-J6A W320- C-FARM JUMPER STRESS ANALYSIS ICF KAISER HANFORD COMPANY \\ MA-J6A WB20- C-FARM JUMPER STRESS ANALYSIS \\ AUTOPIPE+4.60 RESULT PAGE

-

\section{RESTRAINT REACIIONS}

Point Load FORCES ( $\mathrm{lb}$ ) MOMENTS ( $\mathrm{ft}-\mathrm{lb}$ )

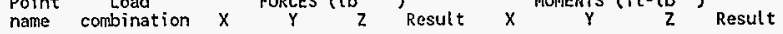

A00 Anchor

$\begin{array}{lrrrr}\text { Anchor } & & & \\ \text { GR } & -447 & -222 & 29 & 224 \\ \text { T1 } & 9 & 1 & -2062 & 2153 \\ \text { R1 } & 1 & 0 & 1 & 12 \\ \text { R2 } & 0 & 0 & 0 & 1 \\ \text { R3 } & -441 & 205 & -2034 & 2091 \\ \text { GR+T1 } & 10 & 1 & 8 & 13 \\ \text { SE IS } & 451 & 206 & 2042 & 2101\end{array}$

$\begin{array}{rrr}55 & 7 & 38 \\ 76 & -588 & -60 \\ 4 & 5 & 3 \\ 0 & 1 & 0 \\ 0 & 0 & 0 \\ 131 & -581 & -22 \\ 4 & 6 & 4 \\ 135 & 586 & 26\end{array}$

A11

$\begin{array}{lrrrrrrrr}\text { Anchor } & & & & & & & & \\ \text { GR } & -6 & -208 & -29 & 210 & -27 & 0 & 12 & 30 \\ \text { I1 } & 447 & -427 & 2062 & 2153 & 458 & 8 & -175 & 491 \\ \text { R1 } & 10 & 1 & 7 & 12 & 3 & 1 & 0 & 3 \\ \text { R2 } & 1 & 0 & 1 & 1 & 0 & 0 & 0 & 0 \\ \text { R3 } & 0 & 0 & 0 & 0 & 0 & 0 & 0 & 0 \\ \text { GR+T1 } & 441 & -635 & 2034 & 2175 & 431 & 7 & -163 & 461 \\ \text { SEIS } & 11 & 1 & 8 & 14 & 3 & 2 & 0 & 3 \\ \text { TOTAL } & 452 & 636 & 2042 & 2186 & 434 & 9 & 164 & 464\end{array}$



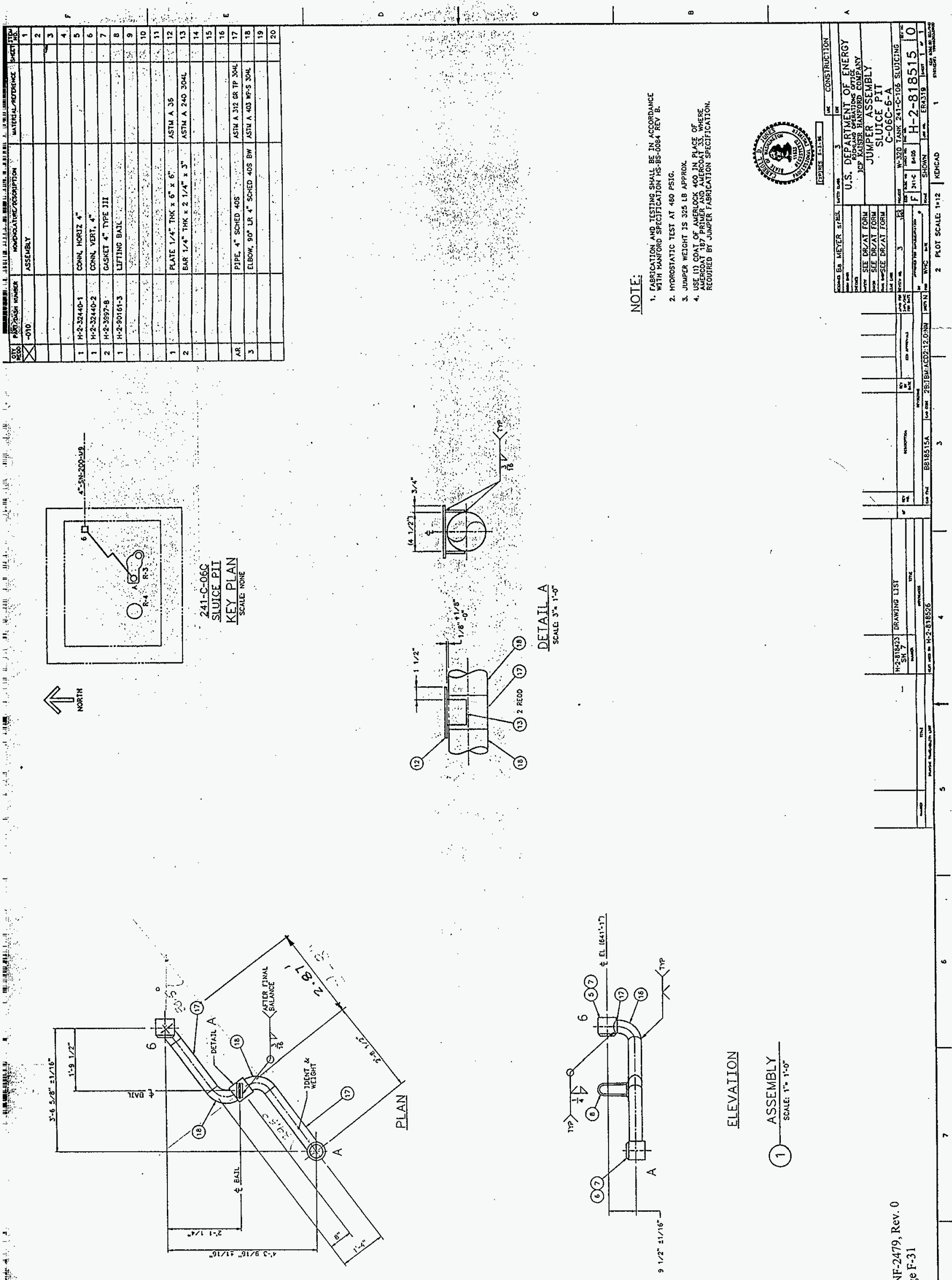

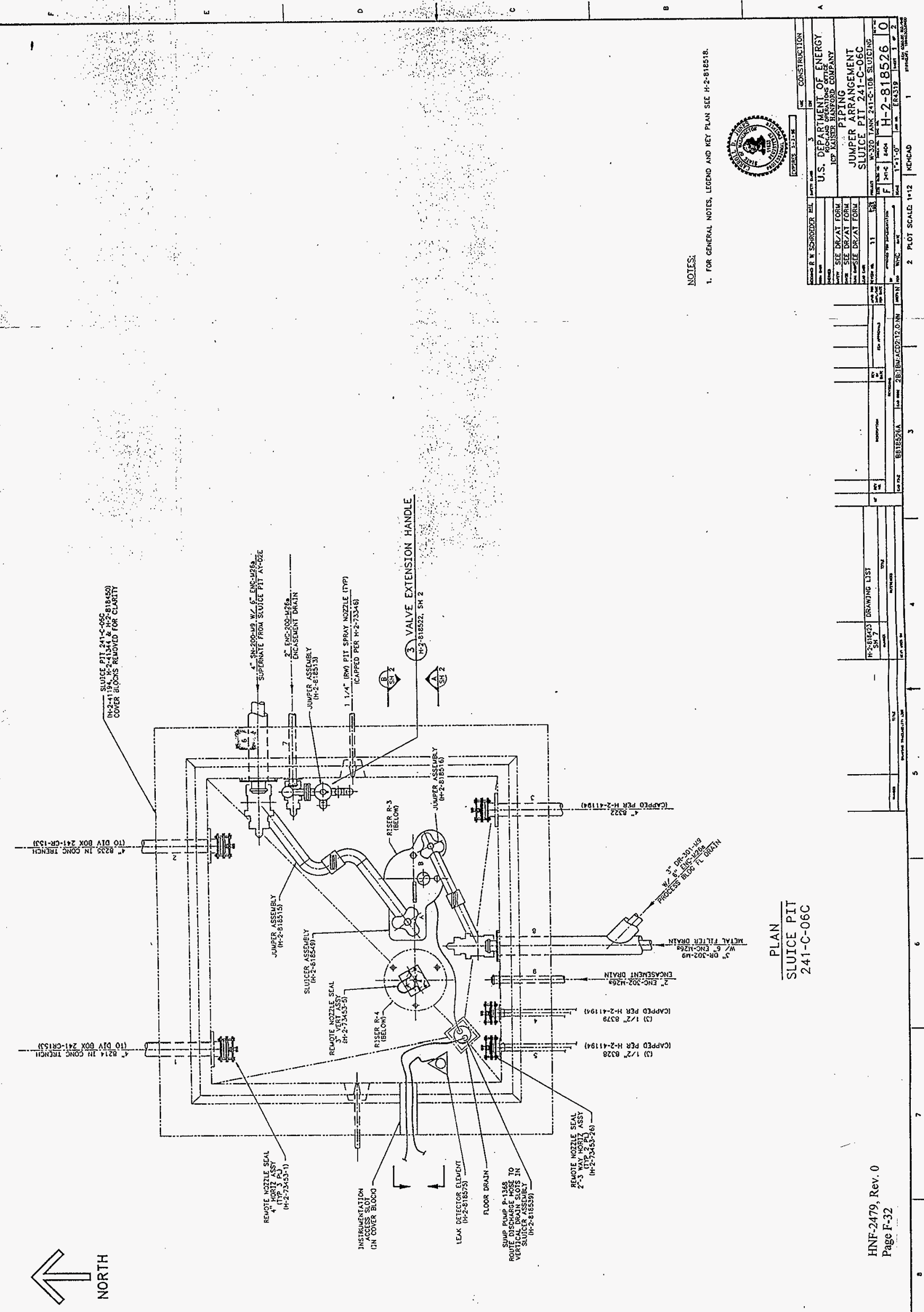

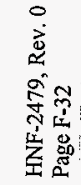




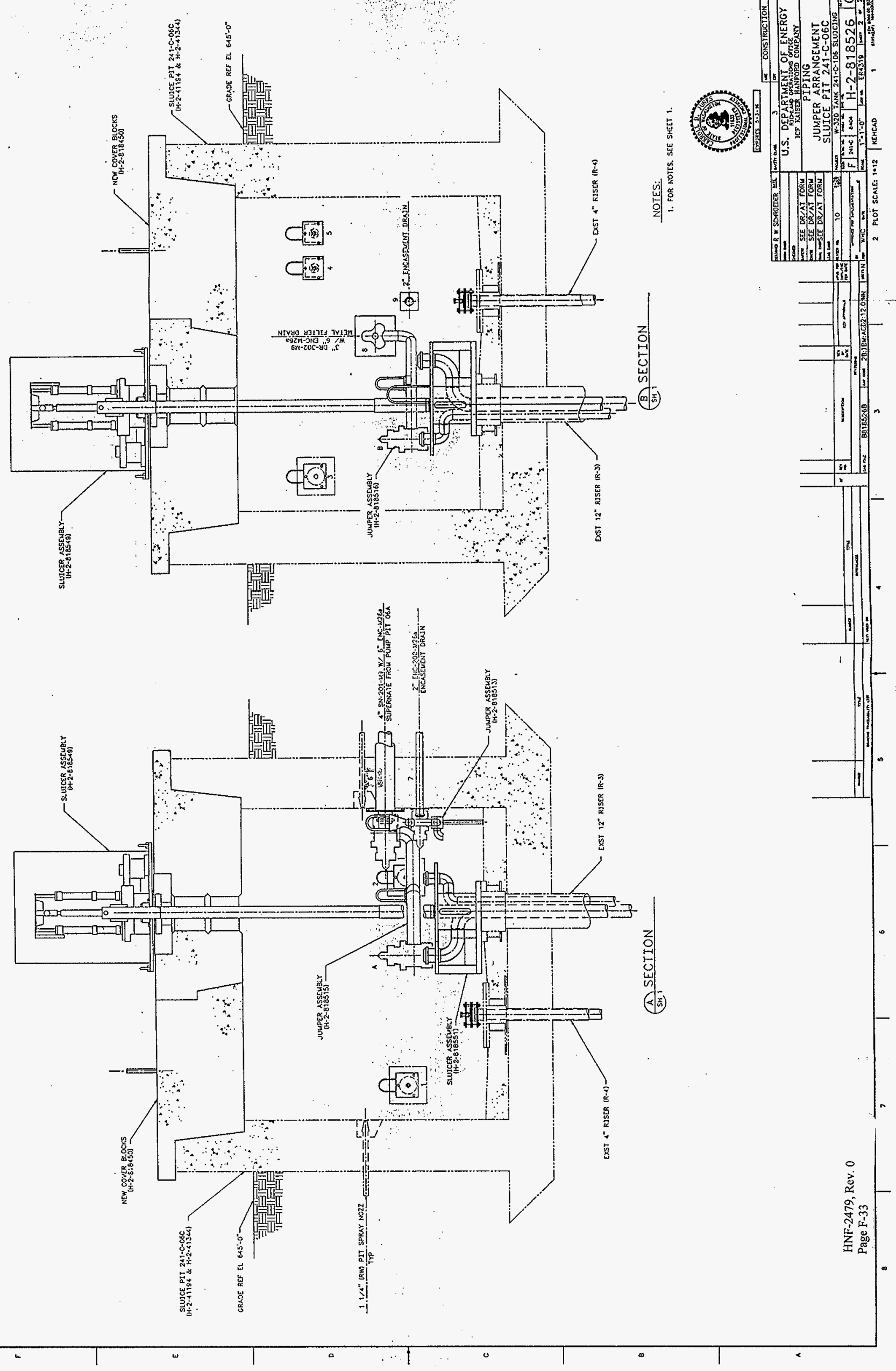


Client WESTINGHOUSE HANFORD COMPANY subject AY FARM - JUMPER STRESS ANALYSIS PROJECT W-320 WASTE RETRIEVAL for TANK 241-C-106 Location C TANK FARM - 200 W. AREA
Wo/sob No. ER4319

Date 9-11-95

Checked $9 / 11 / 95$

Revised / /
Filename:CO6A.WP By: M.M. Ahmed By: M.K. Pal By:

Rev-1: By: Ohined 6.28 .96

Checked By: PC- $7-1-96$

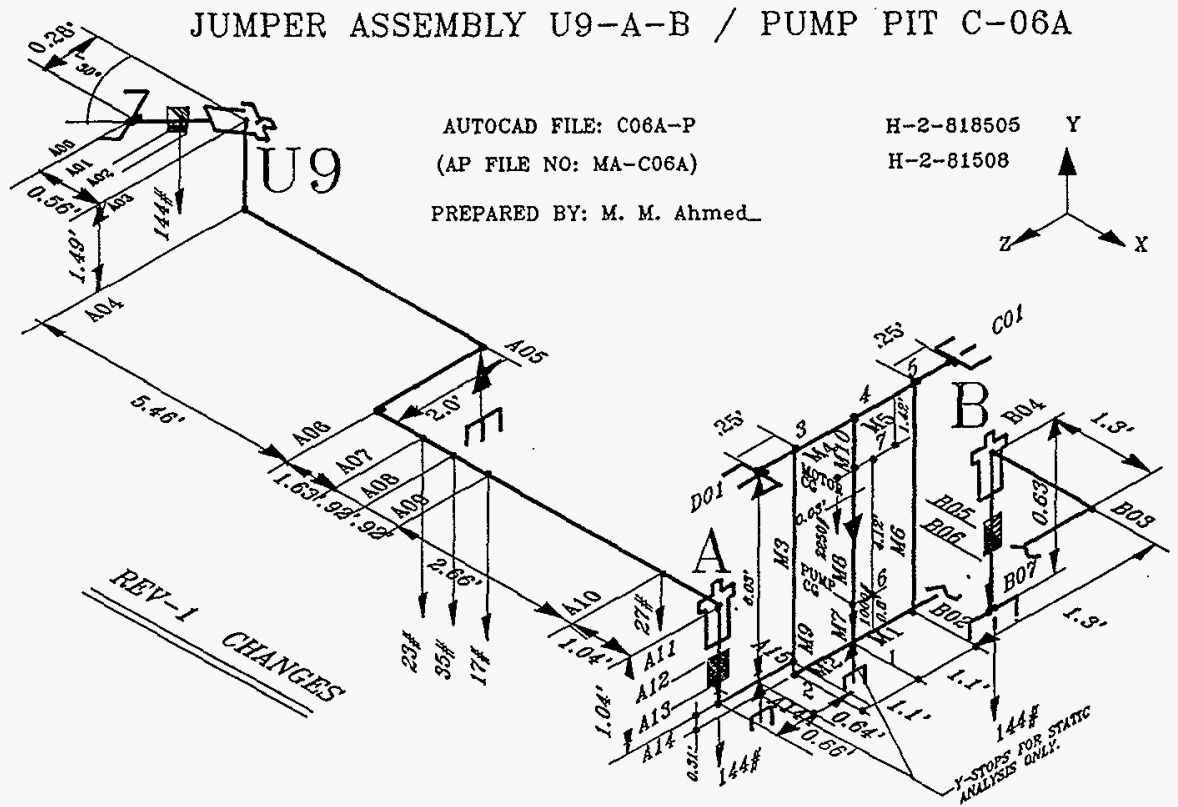

REF - 4 


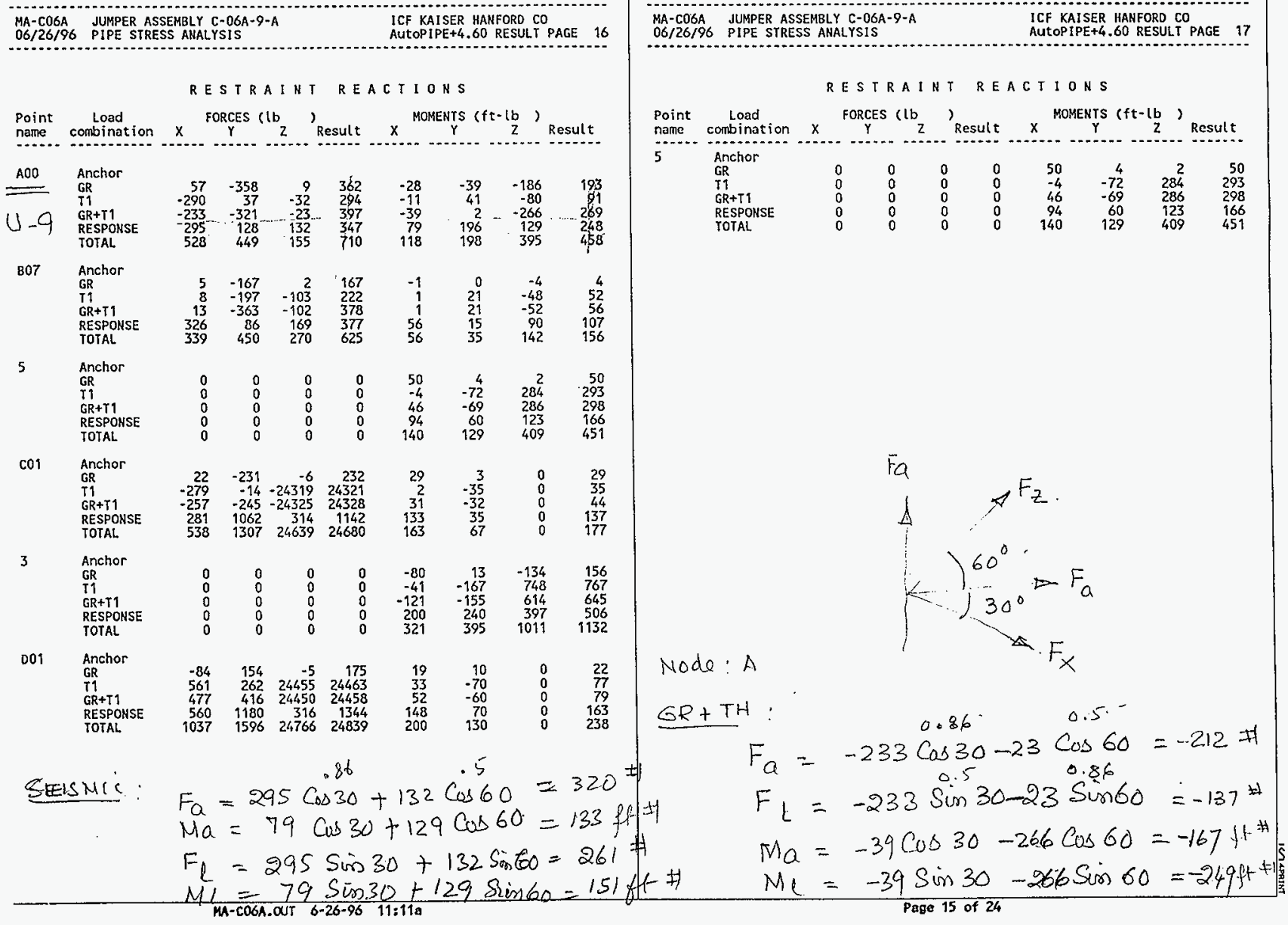

$\begin{array}{rrrr}50 & 4 & 2 & 50 \\ -4 & -72 & 284 & 293 \\ 46 & -69 & 286 & 298 \\ 94 & 60 & 123 & 166 \\ 140 & 129 & 409 & 451\end{array}$




\section{ICF KAISER}

HANFORD COMPANY

\section{DESIGN ANALYSIS}

Client WESTINGHOUSE HANFORD COMPANY WO/Job No.ER4319

Subject AY FARM- JUMPER STRESS ANRLYSIS

PROJECT W-320 WASTE RETRIEVAL FOR TANK C-106 Checked 9/11/95

Location C TANK FARM - 200W.
Date $8 / 31 / 95$

Revised
Calc No. W320-27-029

Revision No. $O$

Page No. 9 of 10

Filename:AYO2E.WP

By: M. M. Ahmed

By: M. K. Pal

By:

Rev-2, By: A. Qhed $3-12.97$

Checked By: DL-12-97

JUMPER ASSEMBLY PUMP PIT: AY-02A-U11-A

$\checkmark$

DWG: $H-2-818501$

ACAD FILE: AYO2A1

APIPE FILE: AYO2A1R2'

\& AYO2A2R2

PREPARED BY:

$M M$ AHMEO

CHECKED BY:

OL. STONE

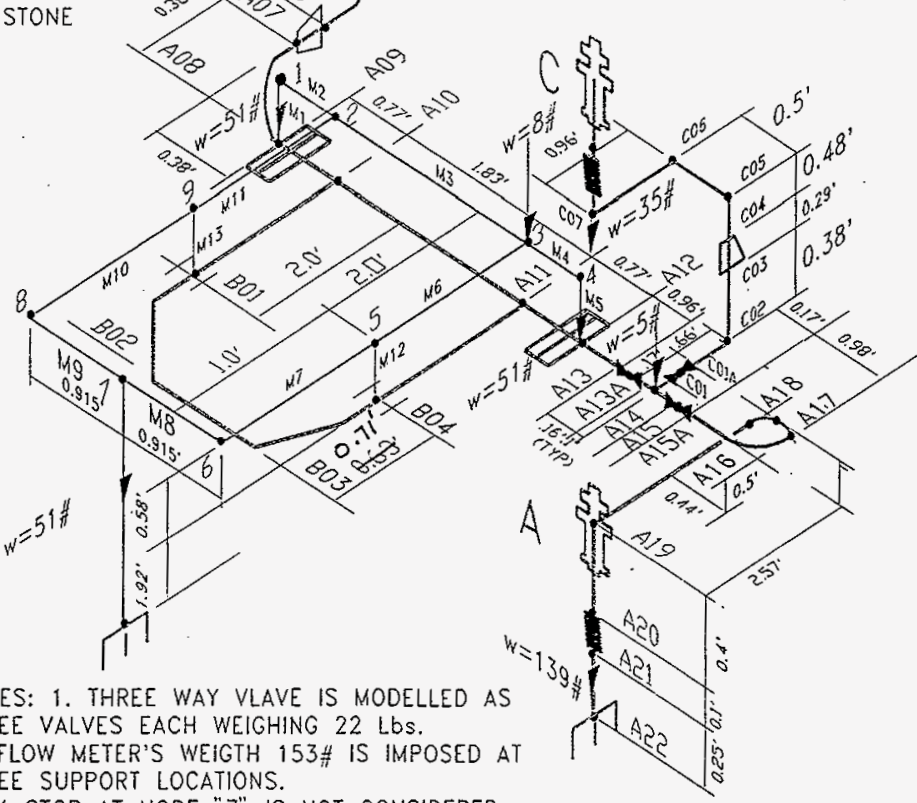

NOTES: 1. THREE WAY VLAVE IS MOOELLED AS

THREE VALVES EACH WEIGHING 22 LbS.

2. FLOW METER'S WEIGTH $153 \#$ IS IMPOSED AT

THREE SUPPORT LOCATIONS.

3. $Y$-STOP AT NODE " 7 " IS NOT CONSIDERED

FOR DYNAMIC ANALYSIS.

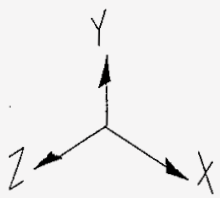

HNF-2479, Rev. 0

Page F-36 

AYO2A1R2 PROJECT W-320: TANK 241-C-106 SLUICING FLUOR DANIEL NORTHWEST INC. $03 / 12 / 97$ AY-02A-U11-A JUMPER HYDRO STATIC ANAL. AUTOPIPE+4.60 RESULT PAGE

\section{SUPPORT FORCES}

Point/ Connect/ Point/ Connect/ Load
Supp. ID Type Combination Dirn Force A Leform Dirn G Force Deform

\begin{tabular}{|c|c|c|c|c|c|c|c|c|}
\hline \multirow[t]{3}{*}{$\begin{array}{l}\text { B01 } \\
\text { Bo1 } 1 \\
\text { Stiff }\end{array}$} & $\begin{array}{l}9 \\
\text { Guide } \\
\text { :RIGIO }\end{array}$ & $G R$ & $\begin{array}{l}\text { down } \\
\text { rght } \\
\text { forw }\end{array}$ & 26 & $\begin{array}{l}0.000 \\
0.013 \\
0.008\end{array}$ & $\begin{array}{l}x \\
y \\
z\end{array}$ & -26 & $\begin{array}{r}-0.013 \\
0.000 \\
0.008\end{array}$ \\
\hline & & 11 & $\begin{array}{l}\text { down } \\
\text { left } \\
\text { fork }\end{array}$ & 1 & $\begin{array}{l}0.000 \\
0.003 \\
0.001\end{array}$ & $\begin{array}{l}x \\
y \\
z\end{array}$ & -1 & $\begin{array}{l}0.003 \\
0.000 \\
0.001\end{array}$ \\
\hline & & $G R+I 1$ & $\begin{array}{l}\text { down } \\
\text { rght } \\
\text { forw }\end{array}$ & 26 & $\begin{array}{l}0.000 \\
0.010 \\
0.009\end{array}$ & $\begin{array}{l}x \\
y \\
z\end{array}$ & -26 & $\begin{array}{r}-0.010 \\
0.000 \\
0.009\end{array}$ \\
\hline \multirow[t]{3}{*}{$\begin{array}{l}804 \\
\text { B04 } 1 \\
\text { stiff }\end{array}$} & $\begin{array}{l}5 \\
\text { Guide } \\
\text { :RIGID }\end{array}$ & $G R$ & $\begin{array}{l}\text { down } \\
\text { left } \\
\text { back }\end{array}$ & 47 & $\begin{array}{l}0.000 \\
0.014 \\
0.008\end{array}$ & $\begin{array}{l}X \\
y \\
Z\end{array}$ & -47 & $\begin{array}{r}-0.014 \\
0.000 \\
0.008\end{array}$ \\
\hline & & $\mathrm{T} 1$ & $\begin{array}{l}\text { down } \\
\text { rght } \\
\text { back }\end{array}$ & 1 & $\begin{array}{l}0.000 \\
0.003 \\
0.001\end{array}$ & $\begin{array}{l}X \\
Y \\
Z\end{array}$ & -1 & $\begin{array}{l}0.003 \\
0.000 \\
0.001\end{array}$ \\
\hline & & $\mathrm{GR}+\mathrm{I} 1$ & $\begin{array}{l}\text { down } \\
\text { left } \\
\text { back }\end{array}$ & 48 & $\begin{array}{l}0.000 \\
0.010 \\
0.009\end{array}$ & $\begin{array}{l}x \\
y \\
z\end{array}$ & -48 & $\begin{array}{r}-0.010 \\
0.000 \\
0.009\end{array}$ \\
\hline \multirow[t]{3}{*}{$\begin{array}{l}7 \\
\text { Stiff }\end{array}$} & $\begin{array}{l}Y \text { - Stop } \\
\text { :RIGID }\end{array}$ & $G R$ & $\begin{array}{l}\text { down } \\
-2 \\
+x\end{array}$ & 146 & $\begin{array}{l}0.000 \\
0.028 \\
0.016\end{array}$ & $\begin{array}{l}X \\
Y \\
Z\end{array}$ & -146 & $\begin{array}{r}0.016 \\
0.000 \\
-0.028\end{array}$ \\
\hline & & 11 & $\begin{array}{l}\text { down } \\
+z \\
+x\end{array}$ & 2 & $\begin{array}{l}0.000 \\
0.013 \\
0.033\end{array}$ & $\begin{array}{l}x \\
y \\
z\end{array}$ & -2 & $\begin{array}{l}0.033 \\
0.000 \\
0.013\end{array}$ \\
\hline & & $\mathrm{GR}+\mathrm{T} 1$ & $\begin{array}{l}\text { down } \\
-z \\
+X\end{array}$ & 147 & $\begin{array}{l}0.000 \\
0.016 \\
0.049\end{array}$ & $\begin{array}{l}X \\
y \\
Z\end{array}$ & -147 & $\begin{array}{r}0.049 \\
0.000 \\
-0.016\end{array}$ \\
\hline
\end{tabular}
03/12/97 AY-02A-UI1-A JUKPER HYDRO STATIC ANAL. AUTOPIPE +4.60 RESULT PAGE 11

\section{RESTRAINT REACTIONS}

Point Load $\quad$ FORCES (tb ${ }_{Z}$ ) Result $X$ MOMENTS ( $f t-l b$ ) Result

AOD

$\therefore \rightarrow-G$

LI-II T1

AY $-02 A$

GR+T1

A22 Anchor

PBMP PIT GR

$\mathrm{GR}$
$\mathrm{GR}+\mathrm{T} 1$

B01

Guide

GR

GR+T1

B04

Guide

GR

$T 1$
$G R+T 1$

7

$Y$ - stop

GR

GR+T

$\begin{array}{rr}19 & -424 \\ -82 & 33 \\ -63 & -390 \\ -19 & -531 \\ 82 & -32 \\ 63 & -563 \\ & \\ 0 & -26 \\ 0 & -1 \\ 0 & -26 \\ & \\ 0 & -47 \\ 0 & -1 \\ 0 & -48 \\ & \\ 0 & -146 \\ 0 & -2 \\ 0 & -147\end{array}$

0
-52
-52
-
0
52
52
0
0
0
0
0
0
0
0

44
02
9
332
02
69
.
26
1
26

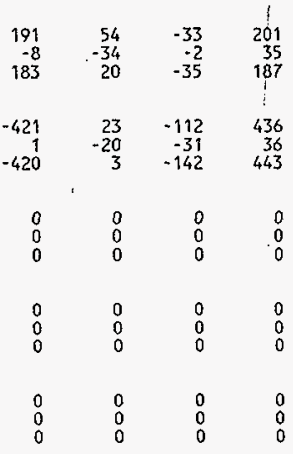




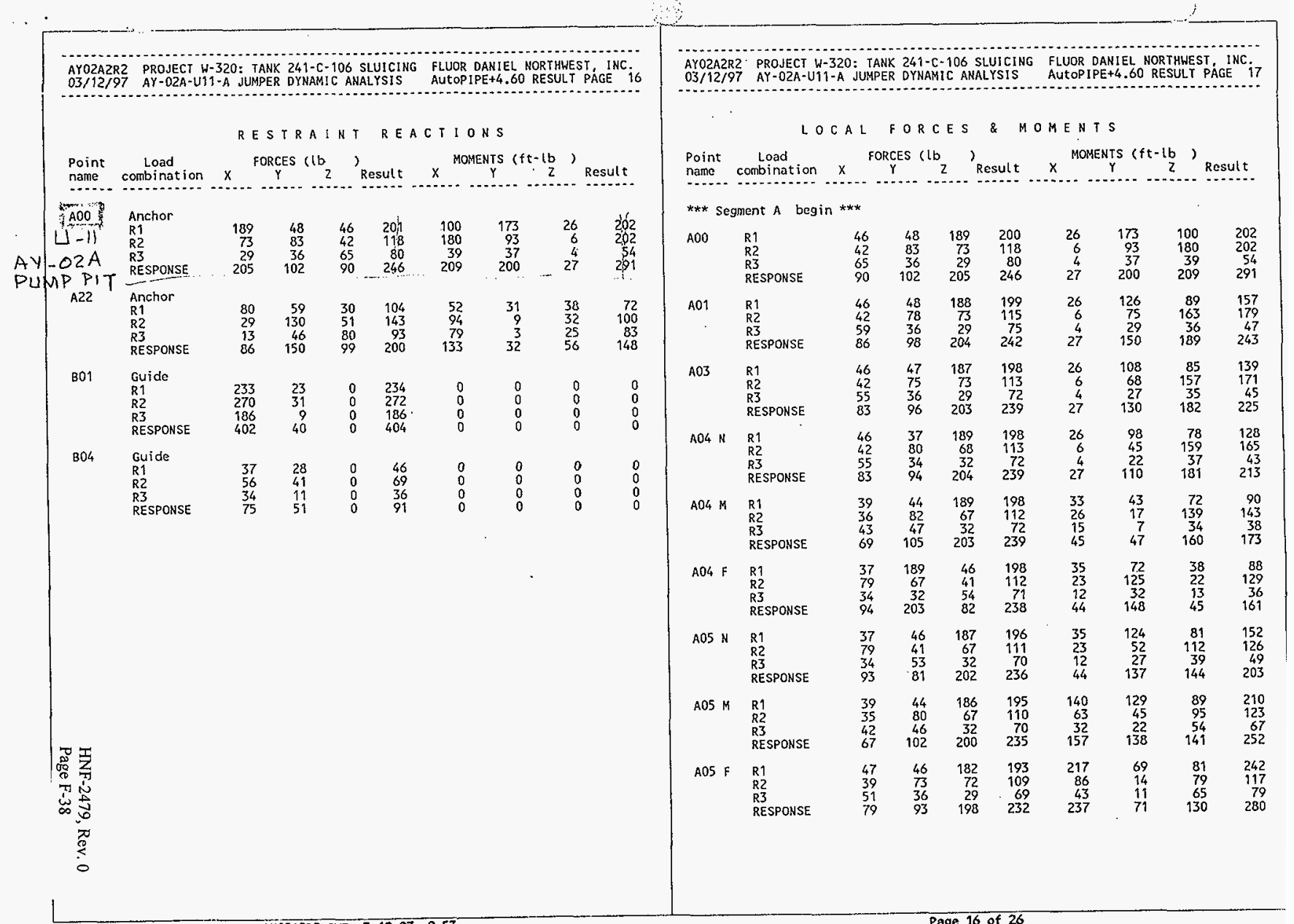




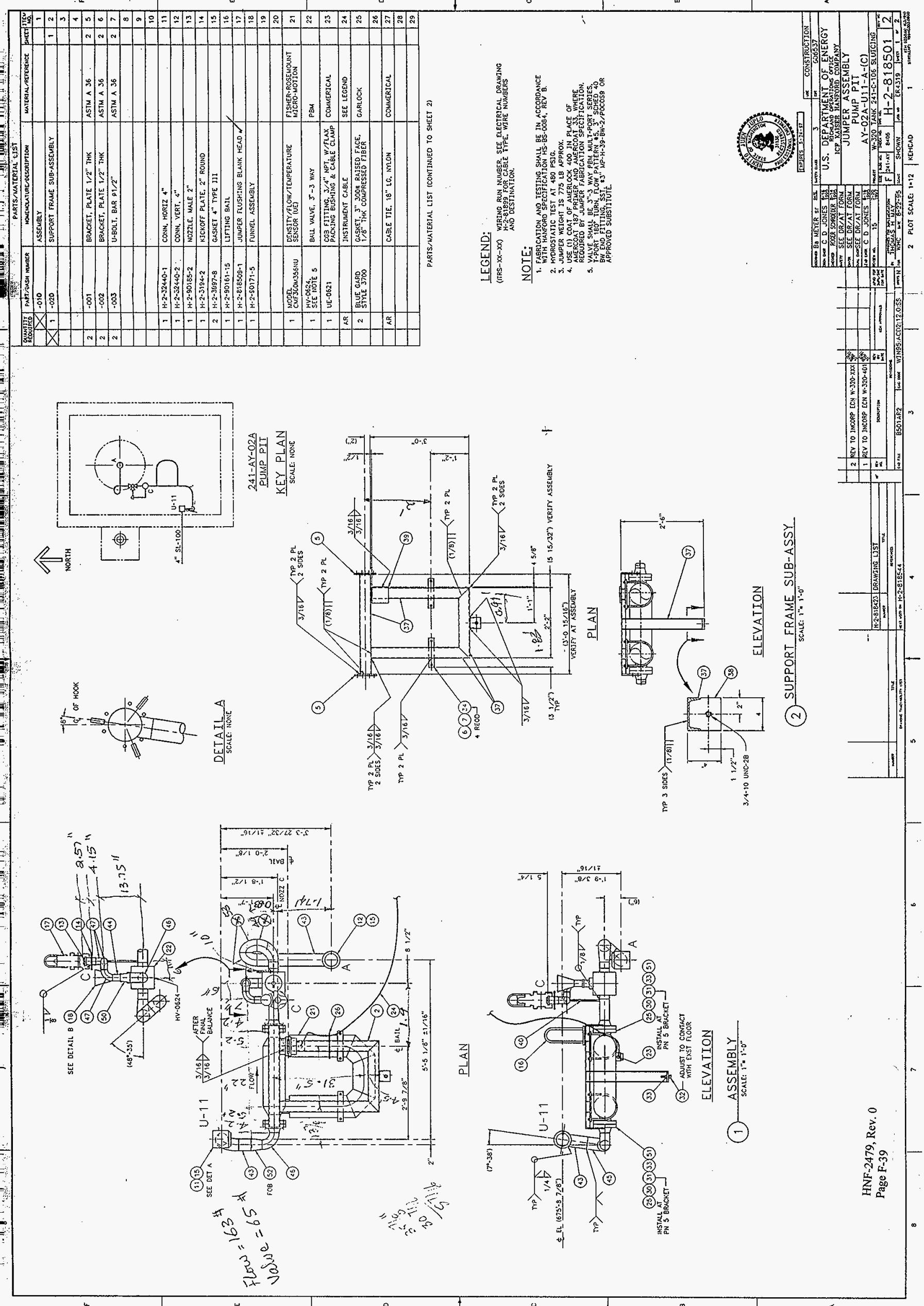




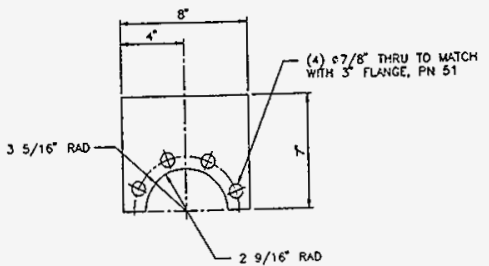

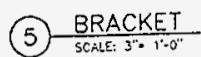

$\sqrt{\frac{110}{g^{2}}}$

(6) $\frac{B R A C K E T}{\operatorname{SGALE}: 3^{*} \cdot 1 \cdot 0^{\circ}}$

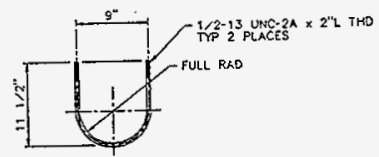

(7) $\frac{U-B O L T}{\text { SCAEE } 11 / 2^{2} \times 10^{n}}$

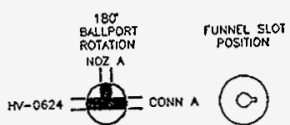

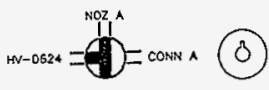

$$
\begin{aligned}
& \text { N-2062 }=\text { conn A }
\end{aligned}
$$
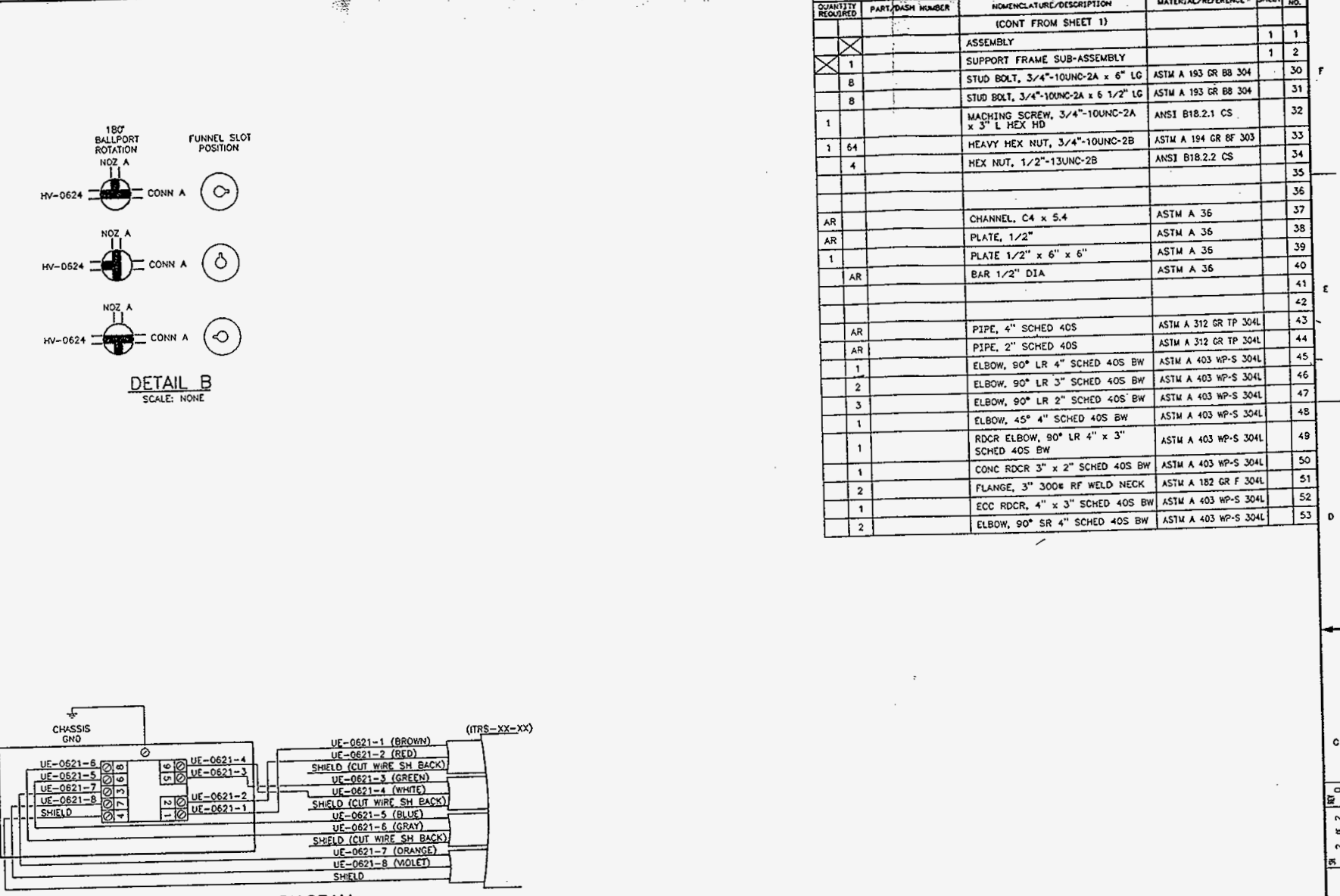

WIRING CONNECTION DIAGRAM

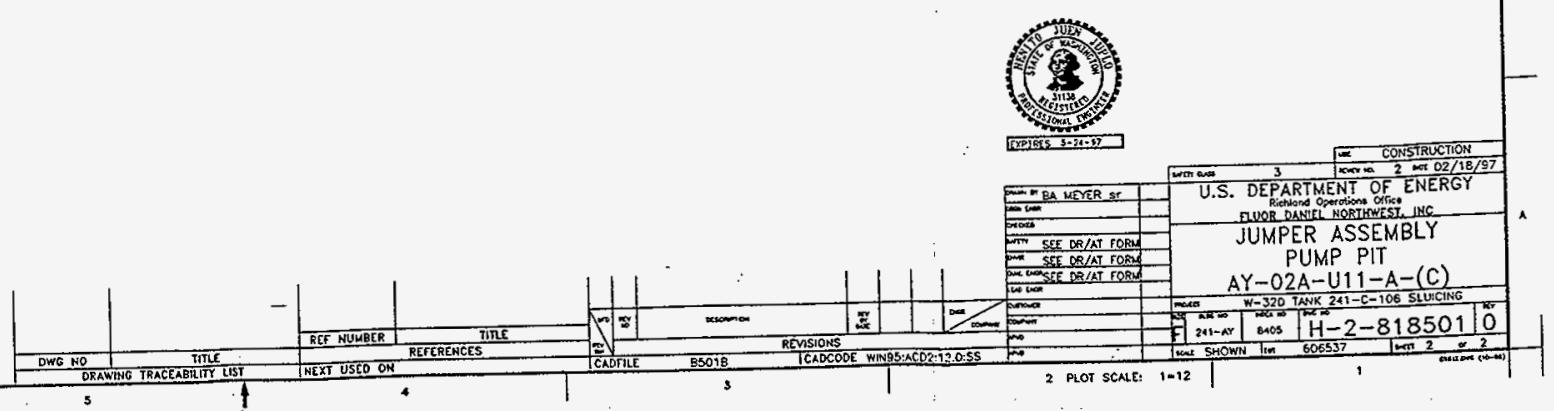




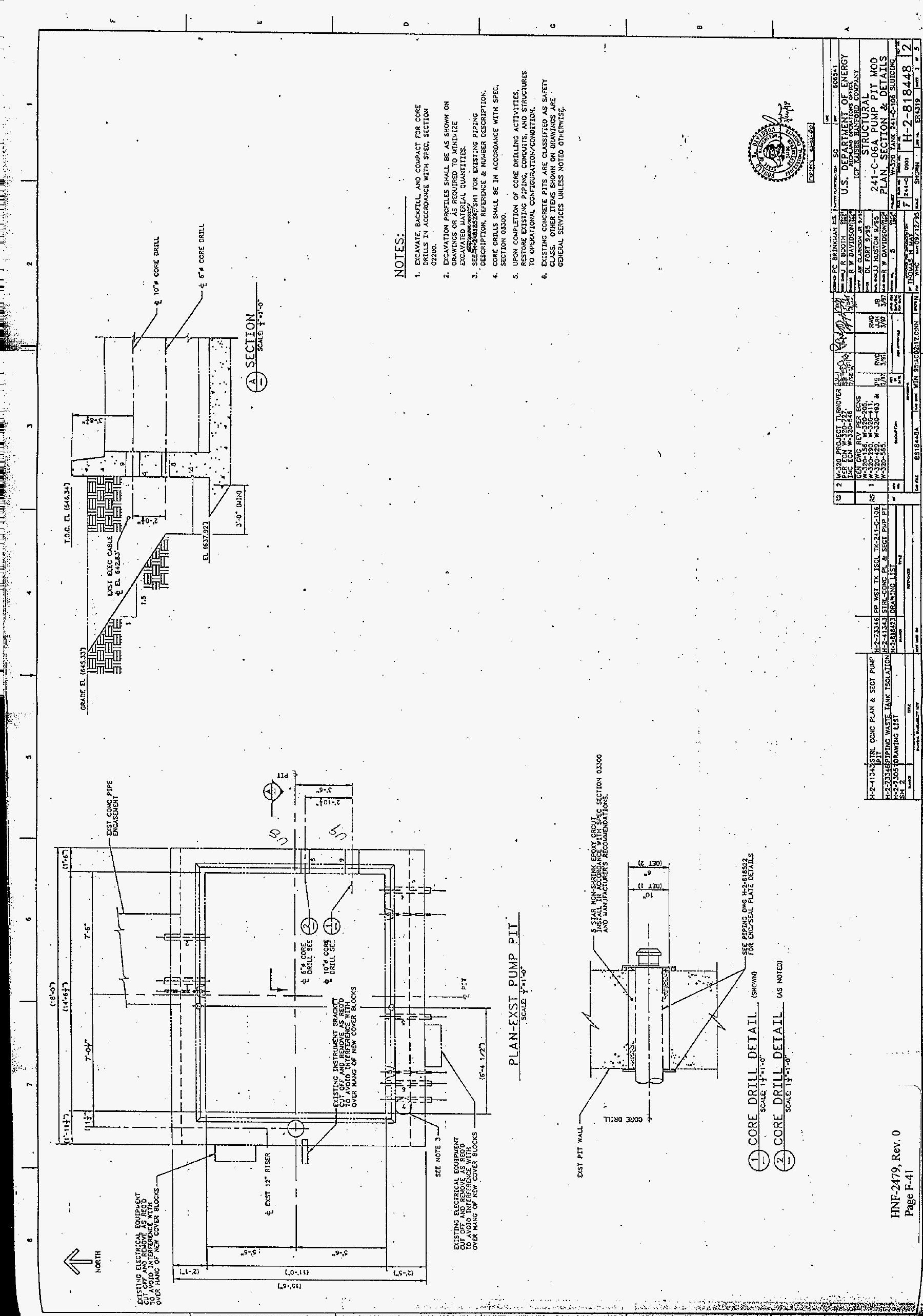




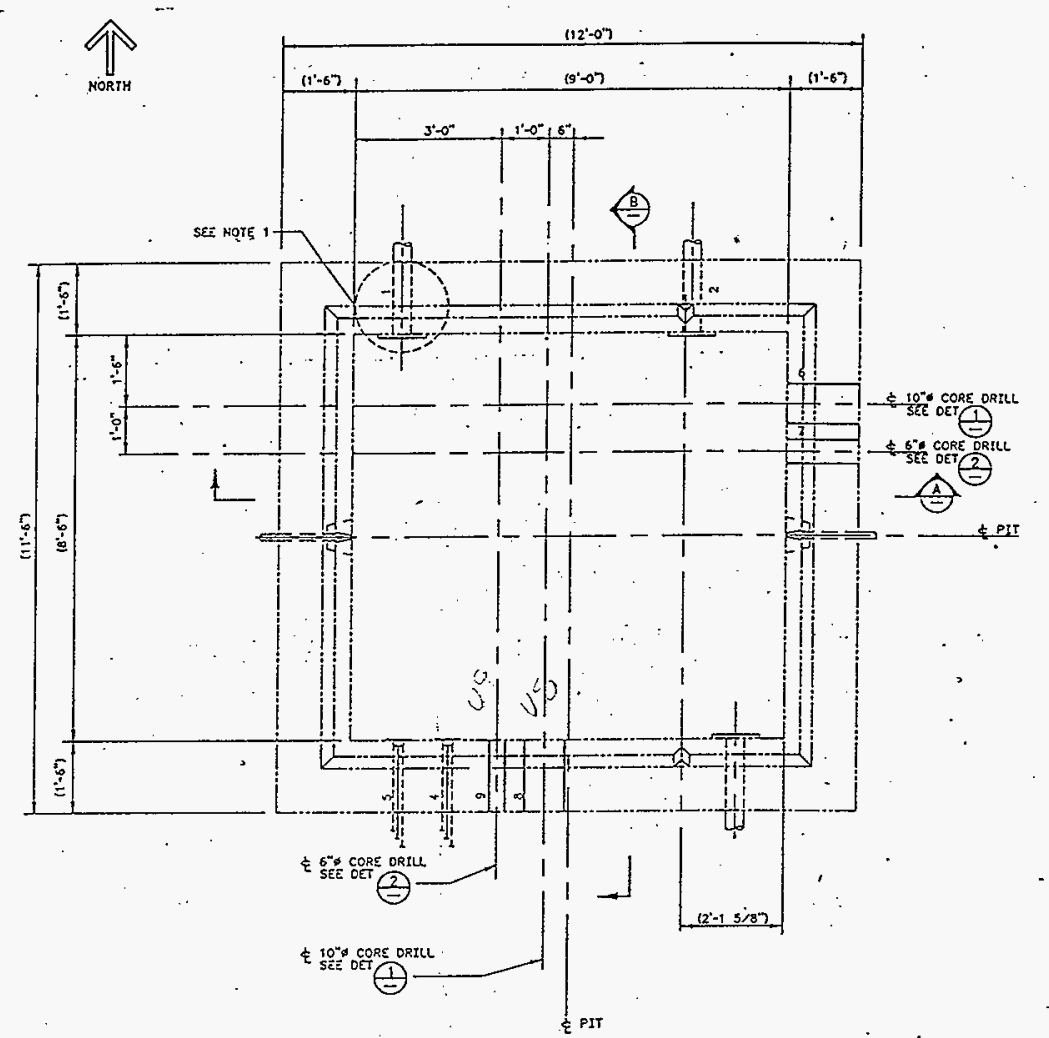

$\frac{\text { PLAN-EXST SLUICE PIT }}{\text { SCALE }}$
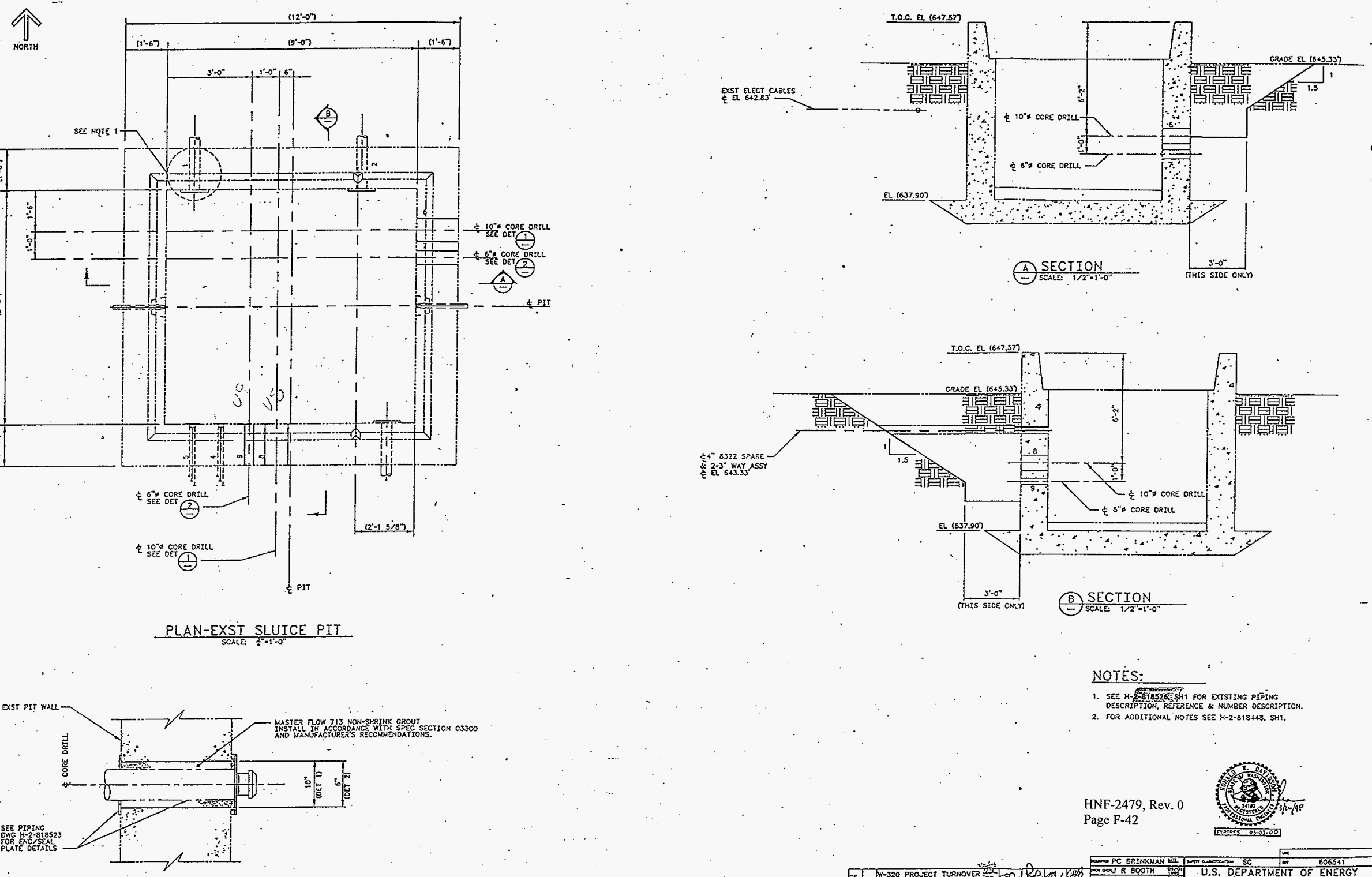

(1) CORE DRILL DETAIL (SNOWN) (3) CORE DRILL DETAIL us могео
NOTES:

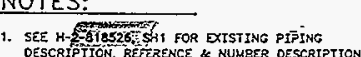

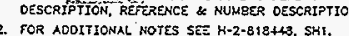

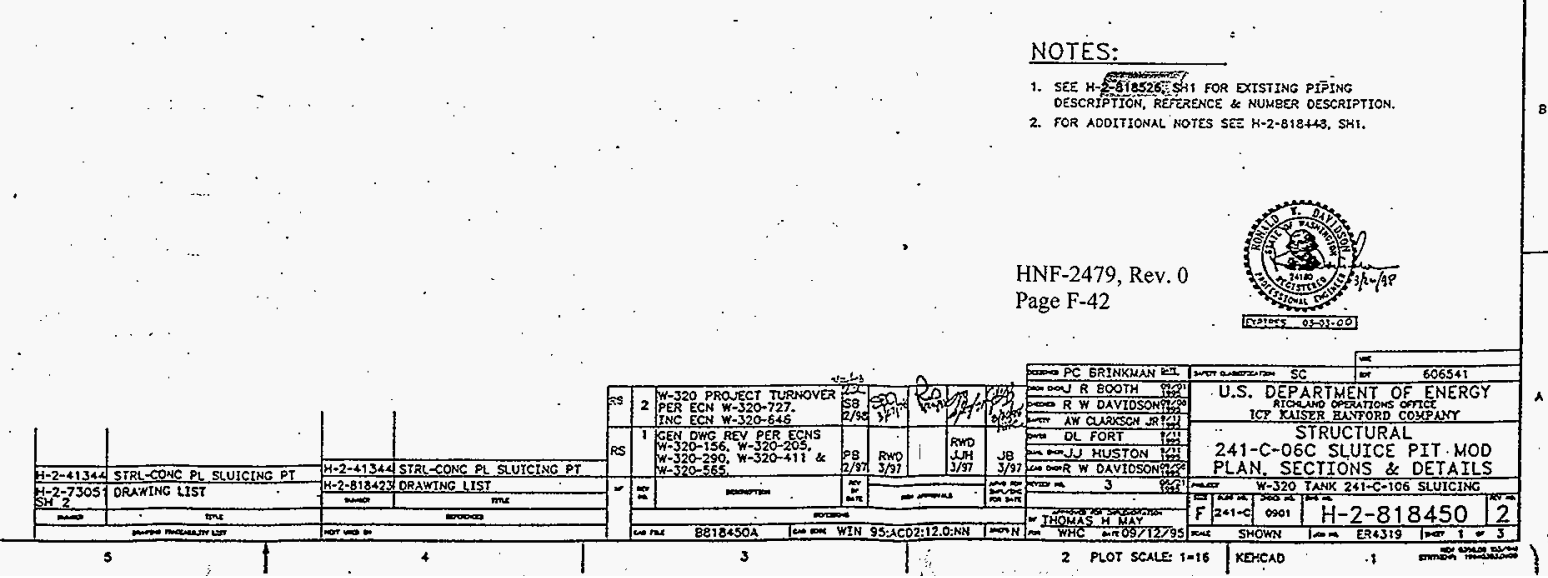



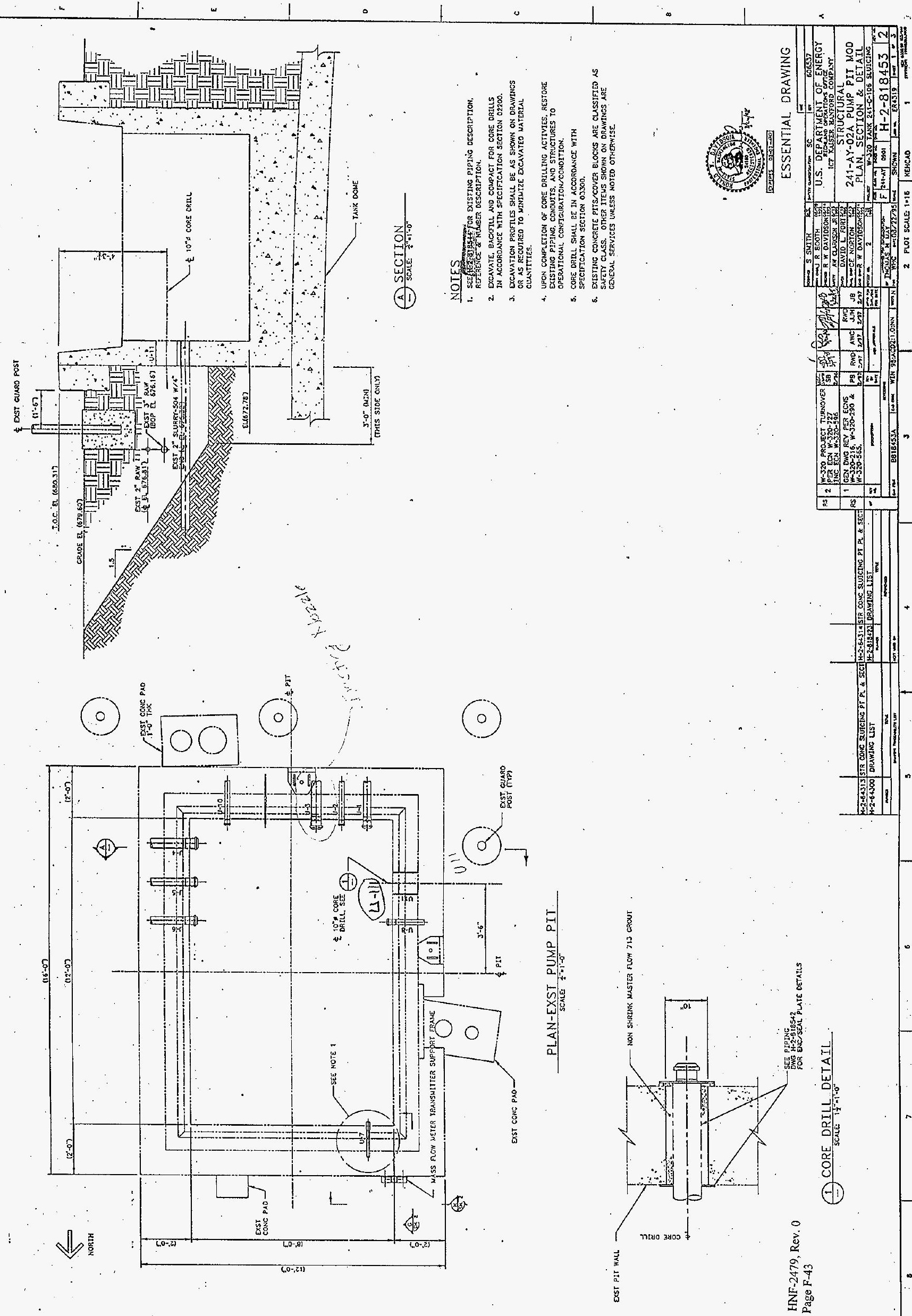


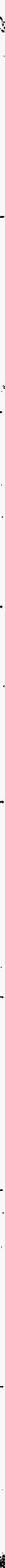



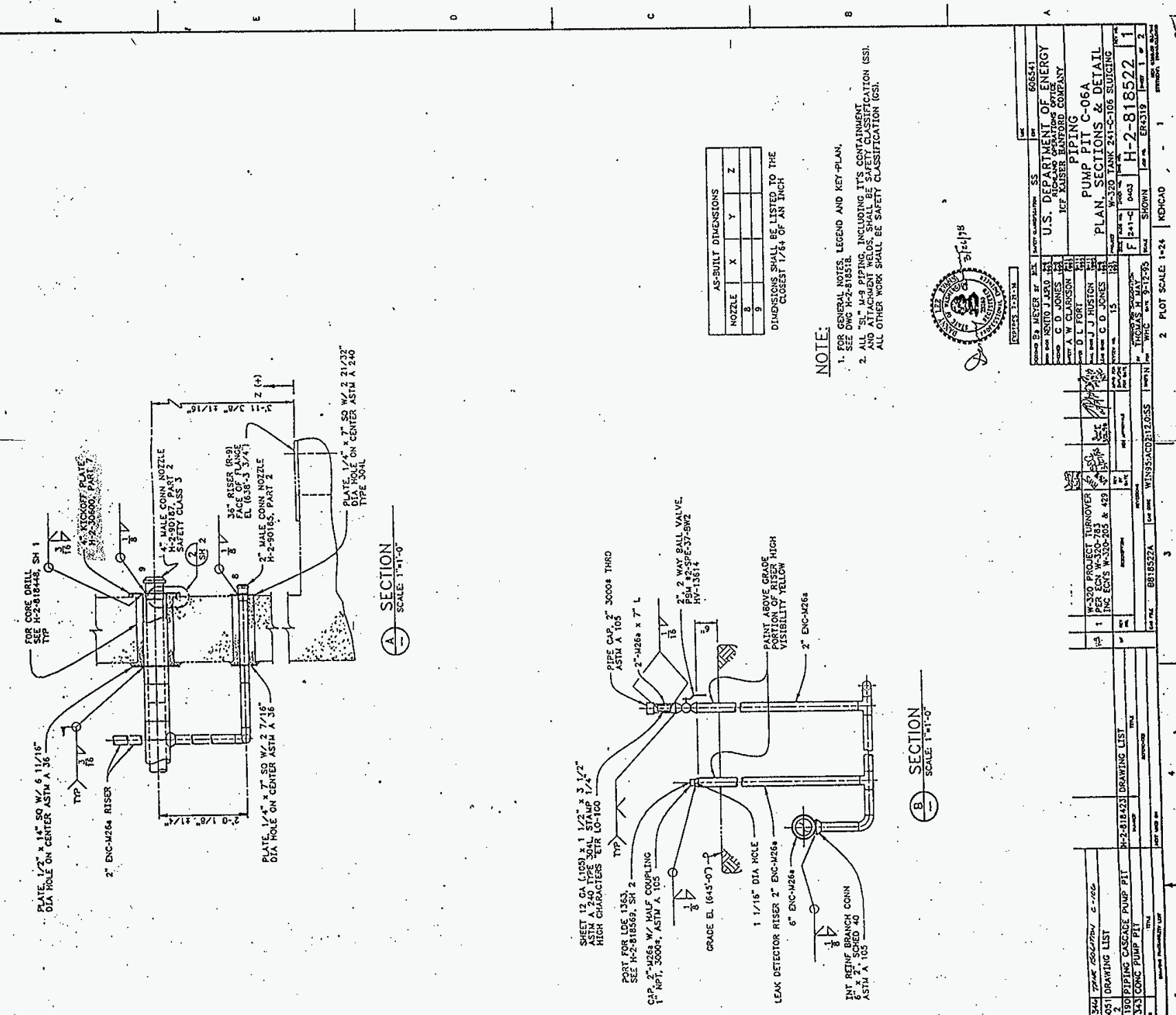

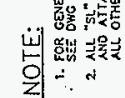
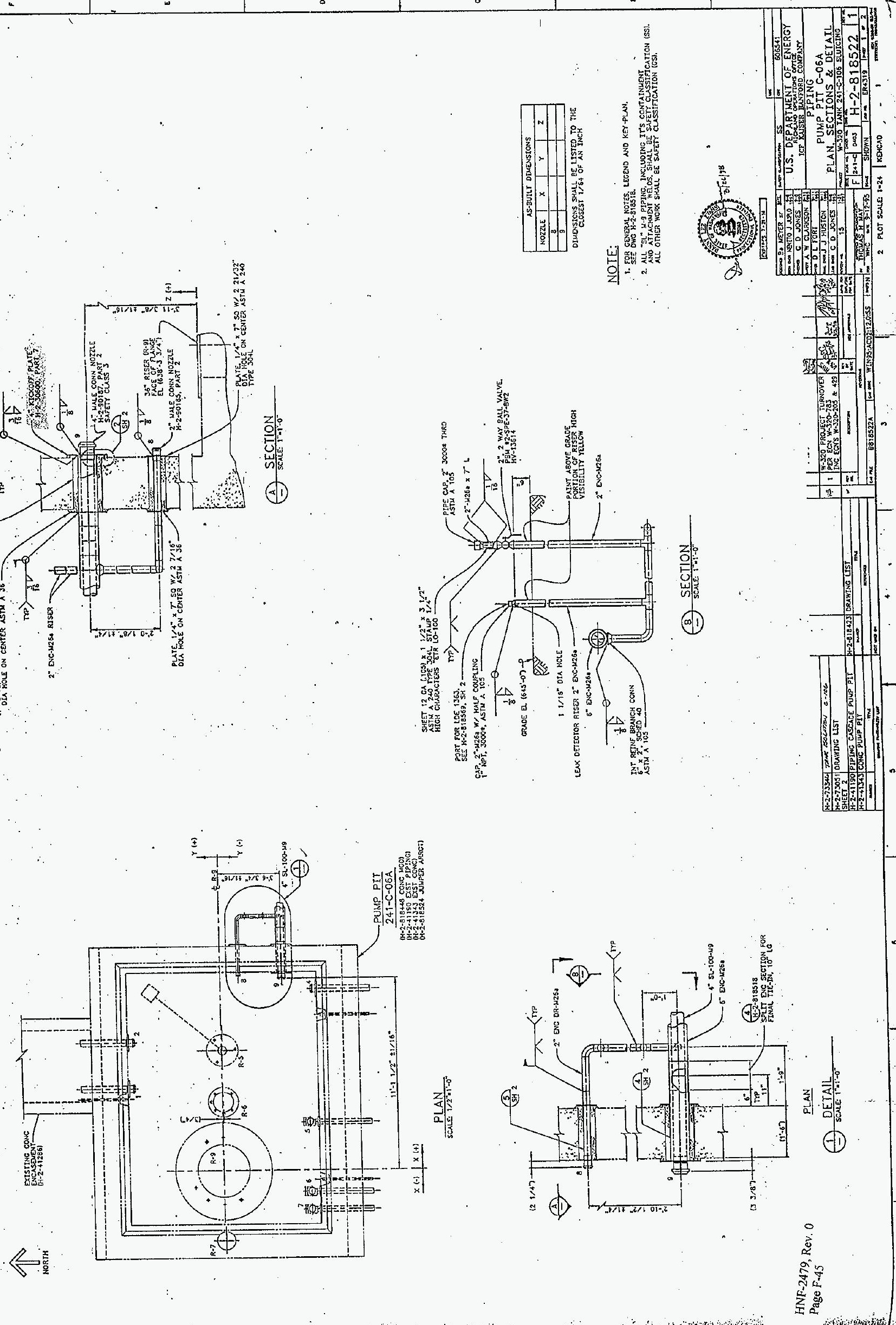


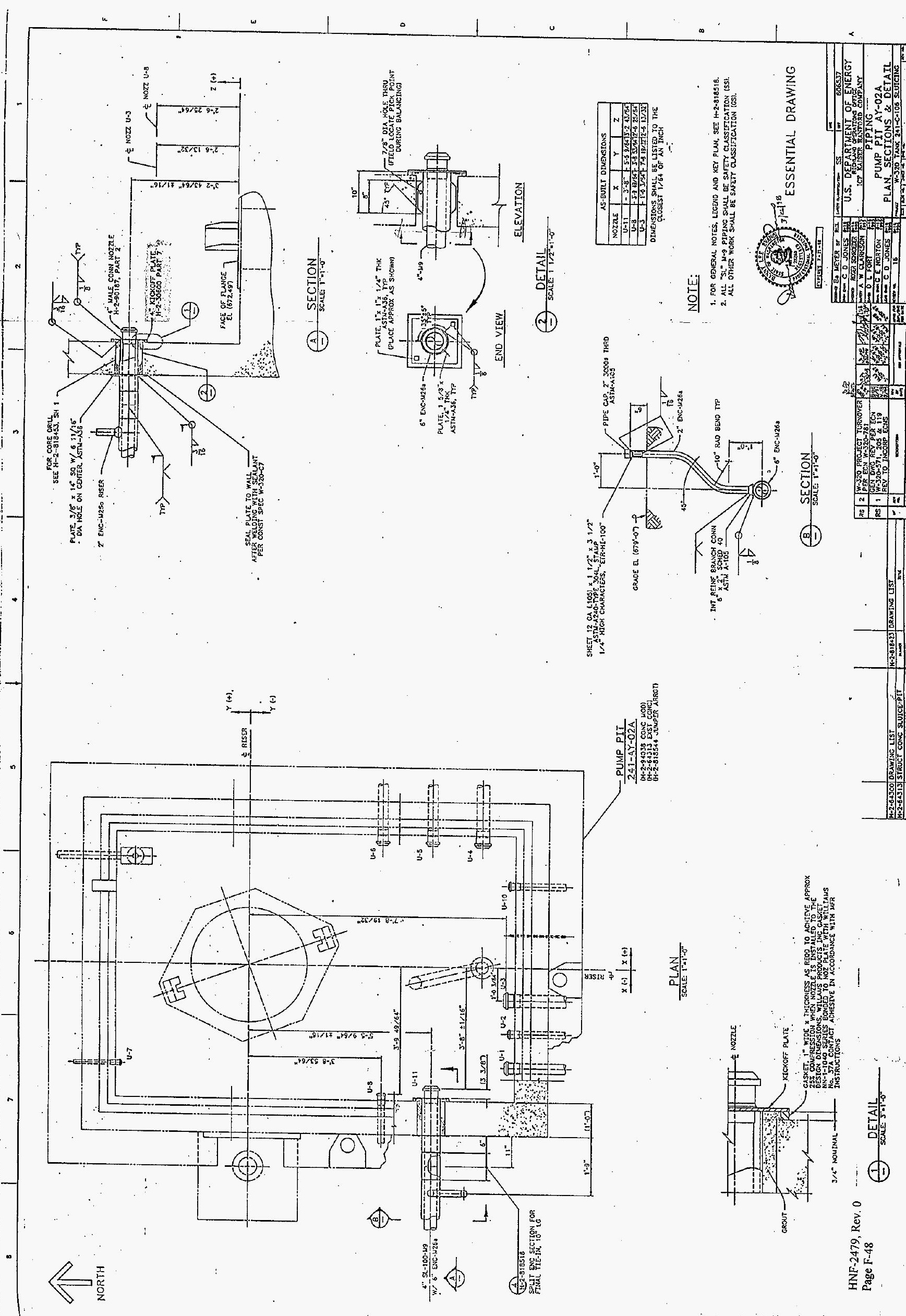




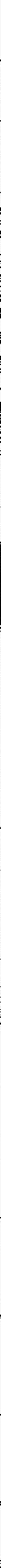




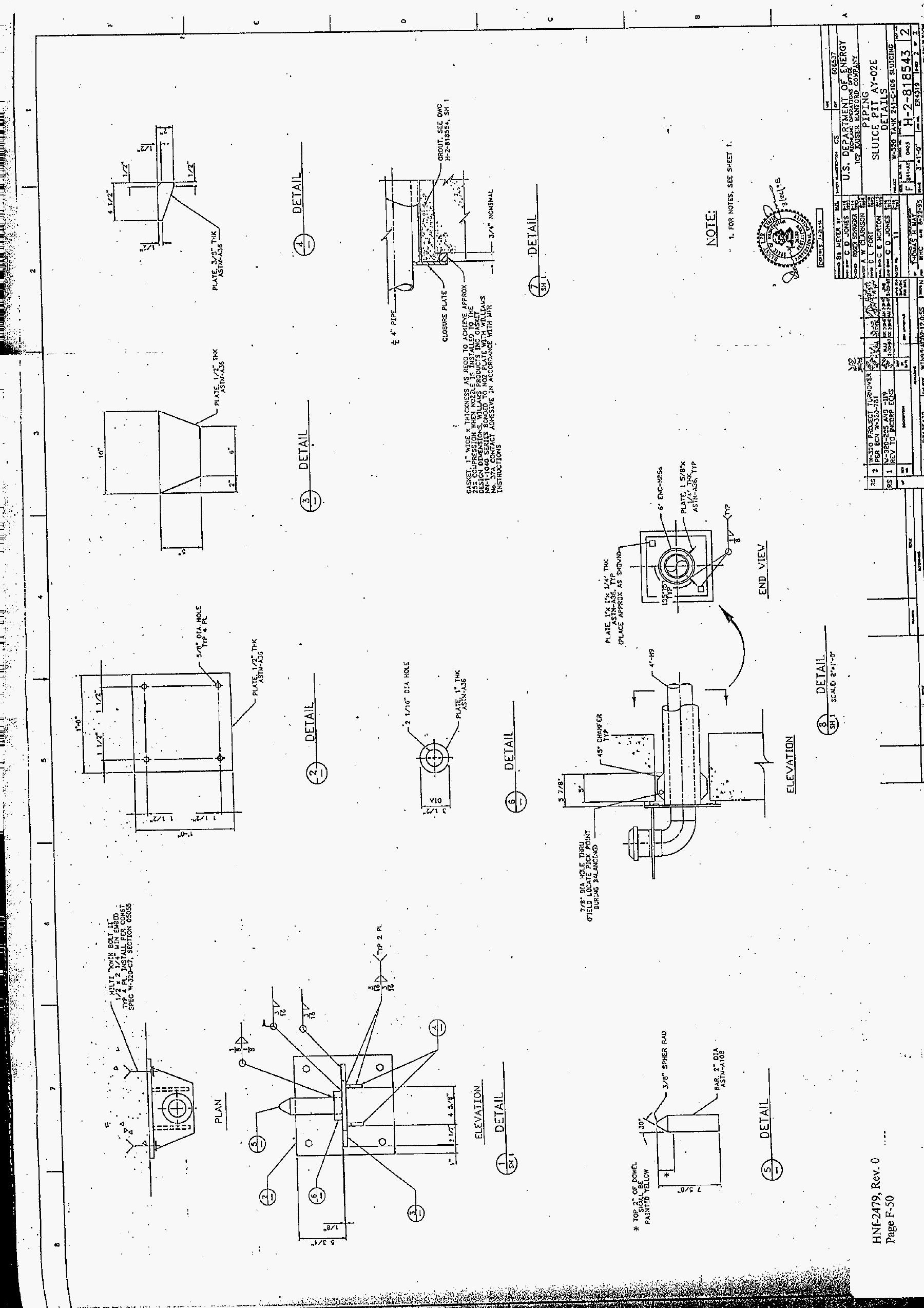





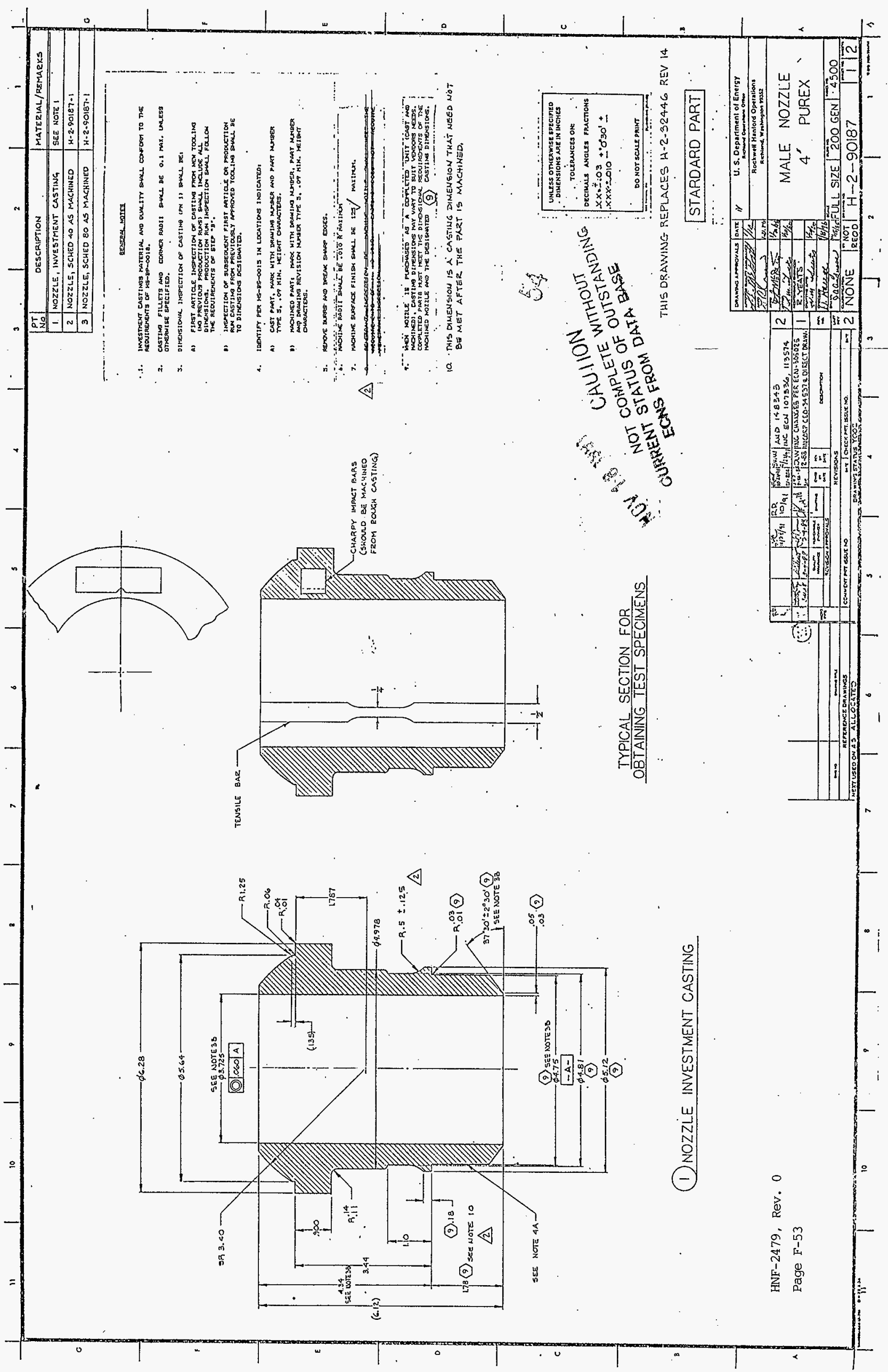




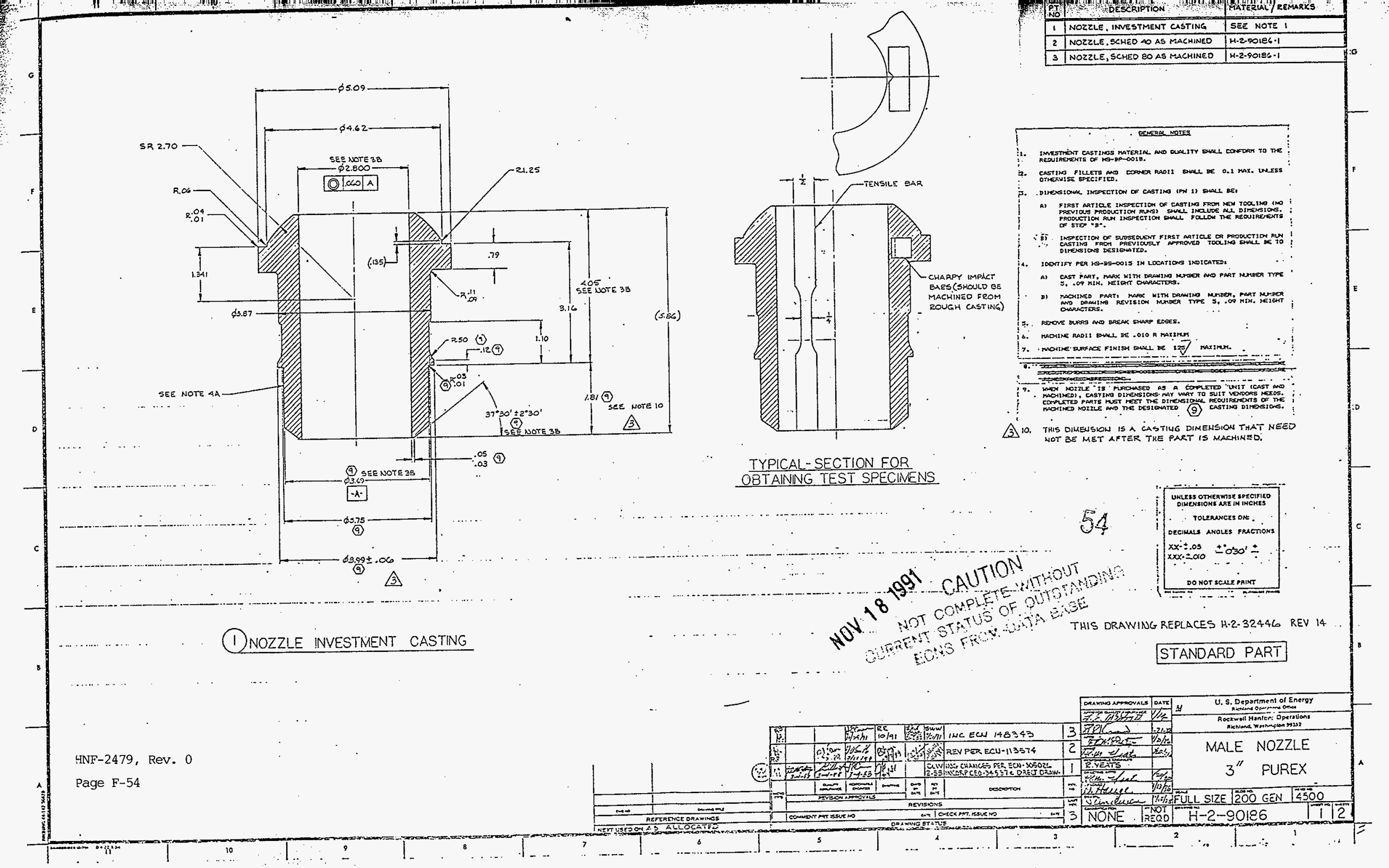




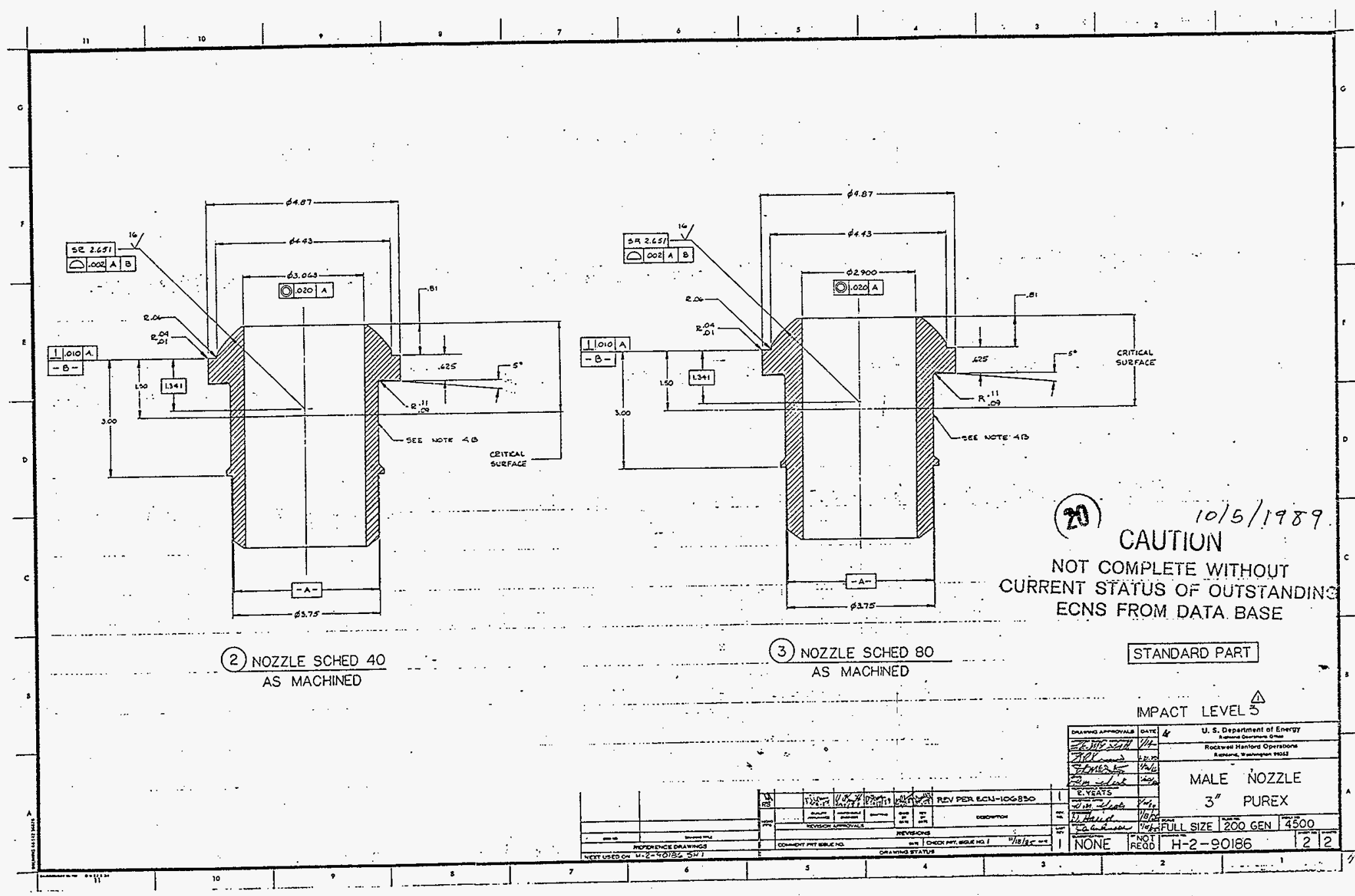

HNF-2479, Rev. 0 


\section{DISTRIBUTION SHEET}

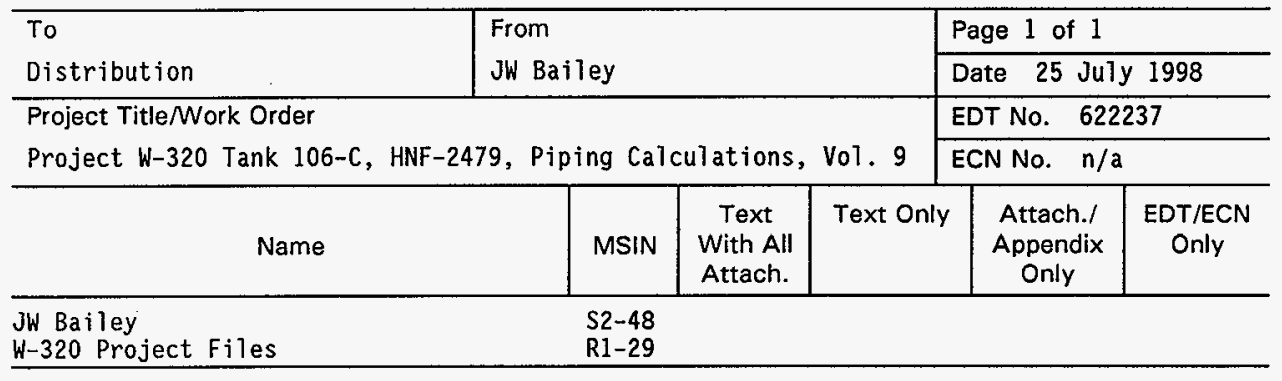

